\title{
A INTERPRETAÇÃO DAS CONVENÇÕES CONTRA DUPLA TRIBUTAÇÃO INTERNACIONAL À LUZ DA TEORIA DA ARGUMENTAÇÃO JURÍDICA
}

\author{
Tese de Doutorado
}

Orientador:

Prof. Dr. Heleno Taveira Torres

Faculdade de Direito da Universidade de São Paulo

São Paulo 


\title{
A INTERPRETAÇÃO DAS CONVENÇÕES CONTRA DUPLA TRIBUTAÇÃO INTERNACIONAL À LUZ DA TEORIA DA ARGUMENTAÇÃO JURÍDICA
}

\author{
Tese apresentada ao Programa de Pós- \\ Graduação, nível Doutorado Direto, da \\ Faculdade de Direito da Universidade de São \\ Paulo, como requisito para obtenção do título \\ de Doutor em Direito. \\ Orientador: Heleno Taveira Torres
}

Faculdade de Direito da Universidade de São Paulo

São Paulo

2010 


\section{Banca Examinadora}

\begin{tabular}{c}
\hline $\begin{array}{c}\text { Prof. Dr. Heleno Taveira Tôrres } \\
\text { Orientador }\end{array}$ \\
\hline Examinador \\
\hline Examinador \\
\hline Examinador \\
\hline
\end{tabular}

Examinador 
Para Jussara e Fernando

Para Alan e Isabel

Para tio Zezé e vovô Pedro (in memoriam) 


\section{AGRADECIMENTOS}

Em agradecimentos deste tipo, qualquer individualização é arriscada, e, ultimamente, minha memória anda traiçoeira. Por isso, já deixo de antemão um pedido de desculpas aos que, eventualmente, eu me esquecer de mencionar. Porém, para não dizer apenas "obrigado a todos, por tudo", o que seria demasiado simplista para descrever a gratidão que tenho em relação a todos que permaneceram próximos e que participaram comigo desta jornada, deixo aqui meu mais sincero e honesto "MUITO OBRIGADO" a Deus e a meus pais, Jussara e Fernando, por acreditarem no meu potencial e investirem em mim até que eu conseguisse andar por minhas próprias pernas; ao Alan, pelo amor, companheirismo e incentivo incondicionais, e também pela paciência e compreensão nas minhas ausências; à Isabel, meu tesouro particular e meu maior projeto, que agora retomo em tempo integral, pelo exercício tão precoce das virtudes da paciência, amor e compreensão nas muitas vezes em que estive ausente; aos meus fiéis escudeiros Laura, Pedro Fernando, vovó Hermínia, tias Adriana e Irma, Jurema e Cristina, por cuidarem tão bem do meu tesouro enquanto eu não pude; ao querido tio Eduardo pelo carinho, disponibilidade e, principalmente, pela boa vontade em revisar meu texto; à querida tia Juscenira, pela valiosa ajuda com a bibliografia desde o início, e também pela disponibilidade, minuciosidade, carinho e boa vontade em revisar minhas incontáveis notas de rodapé; à Marilete e à Cidinha, pelo carinho e pela amizade, e especialmente pelas preciosas dicas da voz da experiência; aos queridos tios Guilherme e Simara, ao Aírton e aos amigos de São Paulo e de Belo Horizonte, pela confiança e incentivo constantes; à Fundação de Amparo à Pesquisa do Estado de São Paulo - FAPESP, pelo auxílio financeiro imprescindível; ao meu orientador, querido Professor Heleno Torres, rigoroso, mas sempre amável, com quem muito aprendi, não apenas sobre Direito Tributário, mas principalmente sobre a importância de batalhar pelos nossos objetivos; aos demais professores e funcionários da Faculdade de Direito da USP e aos meus queridos colegas e amigos que fiz no Largo de São Francisco, e em especial, à Renata La Guardia, grande amiga que o doutorado me deu; aos mestres Sacha Calmon, Misabel Derzi e Igor Mauler Santiago, aos demais professores e amigos da UFMG, sem cujas lições eu jamais teria chegado até aqui e, por fim, também agradeço aos membros da banca examinadora, pela disponibilidade de avaliar meu trabalho. 


\section{SUMÁRIO}

INTRODUÇÃO 11

1. INTERPRETAÇÃO DAS NORMAS JURÍDICAS. .20

1.1. HERMENÊUTICA, INTERPRETAÇÃO E APLICAÇ̃̃o 20

1.2. TEORIAS DA INTERPRETAÇ̃̃o AO LONGO DA HISTÓRIA - DA ESCOLA DA EXEGESE À TEORIA DA ARGUMENTAÇ̃̃o 29

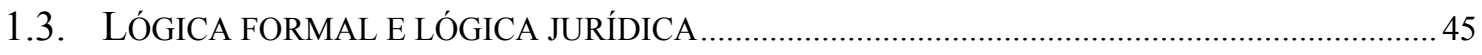

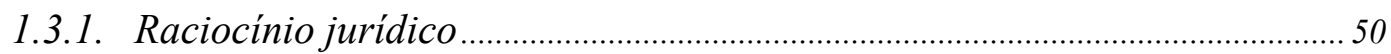

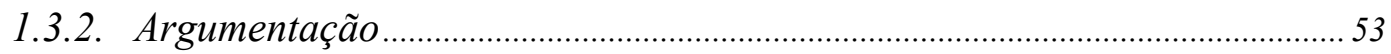

1.4. OBJETO DA INTERPRETAÇÃO JURÍDICA - DA NORMA GERAL E ABSTRATA À NORMA INDIVIDUAL E CONCRETA .56

1.5. LUGARES ESPECÍFICOS DA INTERPRETAÇÃO E DA ARGUMENTAÇÃO JURÍDICA - AS NORMAS INTERPRETATIVAS DO DIREITO TRIBUTÁRIO BRASILEIRO 60

1.5.1. Antinomias 64

1.5.2. Lacunas 69

1.5.2.1. Analogia .73

1.5.2.2. Equidade 76

1.5.3. Expressões vagas, ambíguas e confusas... .79

1.6. MÉTOdOS HERMENÊUTICOS . 81

1.6.1. Quanto ao contexto no qual a norma se insere: 81

1.6.1.1. Interpretação textual (literal, gramatical) 81

1.6.1.2. Interpretação sistemática (lógica). 82

1.6.2. Quanto aos intérpretes da norma: .84

1.6.2.1. Interpretação autêntica 84

1.6.2.2. Interpretação judicial (ou interpretação positiva) 86

1.6.2.3. Interpretação doutrinária (dogmática ou privada) 87

1.7. AGENTES INTERPRETATIVOS 89

2. A TEORIA DA ARGUMENTAÇÃO JURÍDICA .94

2.1. INTERPRETAR É DECIDIR: OS MOTIVOS QUE NOS LEVARAM A ESTUDAR A TEORIA DA ARGUMENTAÇÃO JURÍDICA 
2.2. AS ORIGENS - S PENSAMENTOS QUE INFLUENCIARAM A TEORIA DA ARGUMENTAÇÃO JURÍDICA DE ROBERT ALEXY ………………………………………........ 96

2.2.1. Teorias Metaéticas: do Naturalismo à teoria de Baier...................................... 97

2.2.2. Filosofia Analítica - Habermas e a Escola de Erlangen ............................... 103

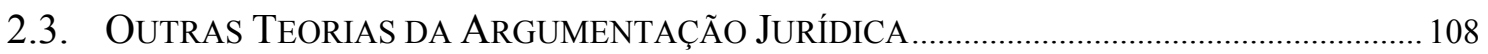

2.3.1. A Teoria da Argumentação de Chaïm Perelman ............................................. 108

2.3.2. A teoria da argumentação de Stephen E. Toulmin ......................................... 115

2.3.3. A teoria da argumentação de Neil MacCormick ............................................ 118

2.4. A TEORIA DE Robert AleXY - EA TEORIA DO Discurso RACIONAL À TEORIA DA

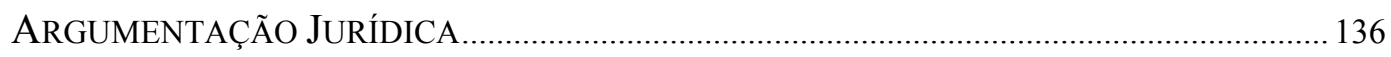

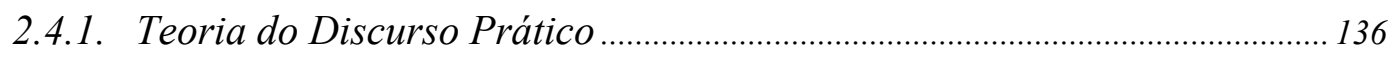

2.4.1.1. Perspectivas de análise das regras do discurso racional .............. 137

2.4.1.2. As regras e formas do discurso prático geral ..................................... 139

2.4.1.3. Os limites do discurso prático geral .......................................................... 148

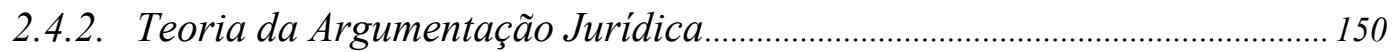

2.4.2.1. Características gerais do discurso jurídico .......................................... 150

2.4.2.2. Características gerais da argumentação jurídica ........................... 153

2.4.2.3. Regras de justificação interna e de justificação externa ................. 154

2.4.2.4. Relações entre o discurso jurídico e o discurso prático geral .... 169

2.5. PRINCÍPIOS E REGRAS - LIMITES DO DISCURSO JURÍDICO 171

\section{PRINCÍPIOS GERAIS DA INTERPRETAÇÃO JURÍDICA, EM ESPECIAL} DAS NORMAS DO DIREITO TRIBUTÁRIO INTERNACIONAL ............................174

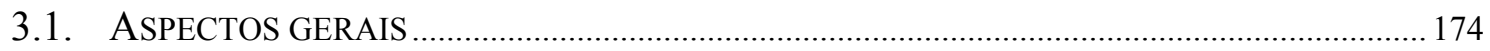

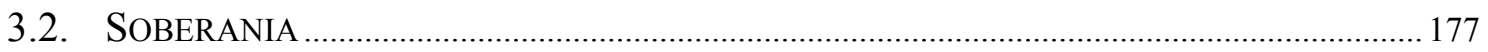

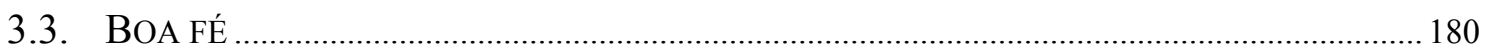

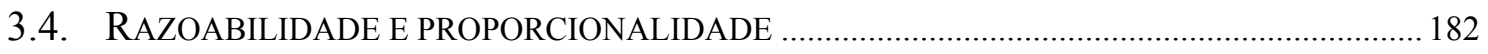

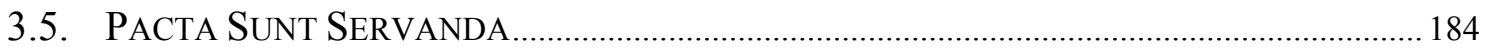

3.6. ISONOMIA (IGUALDADE TRIBUTÁRIA) E NÃO-DISCRIMINAÇÃO........................................ 186 3.6.1. Relações entre o princípio da igualdade e outros princípios tributários. 192 3.6.2. Instrumentos e meios para atingir a isonomia tributária.............................. 195

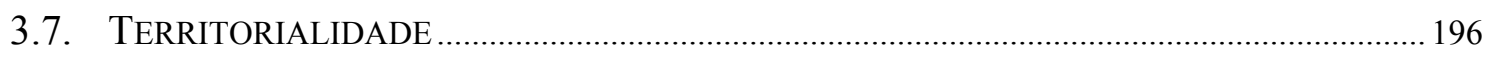

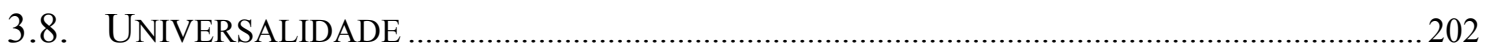

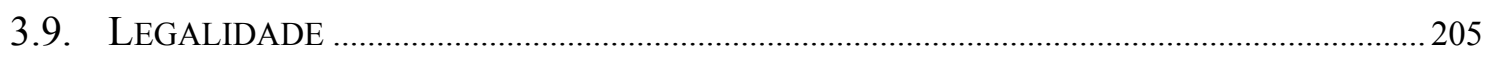


3.10. CAPACIDADE CONTRIBUTIVA

3.11. PRINCÍPIO DA NÃO-SURPRESA DO CONTRIBUINTE: IRRETROATIVIDADE E ANTERIORIDADE

3.12. VEDAÇÃO AO CONFISCO

4. AS CONVENÇÕES CONTRA A DUPLA TRIBUTAÇÃO INTERNACIONAL.227

4.1. O DiREITO TRIBUTÁRIO INTERNACIONAL E O DiREITO TRIBUTÁRIO INTERNO ........227 4.1.1. Monismo x Dualismo: ainda seria importante esta dicotomia?.................. 231

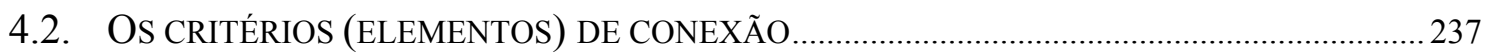

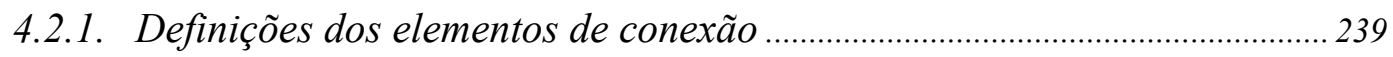

4.2.2. Classificação dos elementos de conexão............................................................. 243

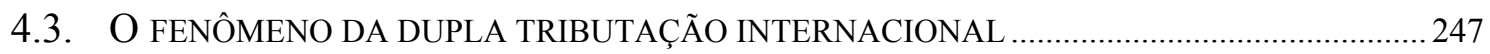

4.4. CELEBRAÇÃo de TRATAdos INTERNACIONAIS NO DiREITO BRASILEIRO....................2252

4.5. OS TRATADOS INTERNACIONAIS EM MATÉRIA TRIBUTÁRIA E SUA HIERARQUIA NO ORDENAMENTO JURÍDICO BRASILEIRO

4.6. O DIREITO TRIBUTÁRIO INTERNACIONAL E AS CONVENÇÕES CONTRA A DUPLA TRIBUTAÇÃO INTERNACIONAL

4.6.1. Surgimento e evolução das convenções contra a dupla tributação internacional

4.6.2. Características e objetivos das convenções contra a dupla tributação.... 274

4.7. A NATUREZA JURÍDICA DAS NORMAS CONSTANTES DAS CONVENÇÕES CONTRA DUPLA TRIBUTAÇÃO

4.8. A VANTAGEM DAS CONVENÇÕES CONTRA A BITRIBUTAÇÃO INTERNACIONAL EM FACE DOS MÉTODOS UNILATERAIS PARA EVITAR A DUPLA TRIBUTAÇÃO INTERNACIONAL

4.9. OS PRINCIPAIS MODELOS DE CONVENÇÃO CONTRA A BITRIBUTAÇÃO

INTERNACIONAL

4.9.1. O Modelo da OCDE. 285

4.9.2. O Modelo da ONU 287

4.9.3. O U.S. Model.. 290

4.9.4. O Modelo do Pacto Andino 292

\section{O MÉTODO CLÁSSICO DE INTERPRETAÇÃO DAS CONVENÇÕES}


5.1. A ConVEnÇão de Viena sobre o Direito dos Tratados - Aspectos gerais e APLICAÇÃO AOS TRATADOS INTERNACIONAIS EM GERAL

5.2. APLICAÇÃO DA CONVENÇÃO DE VIENA NA INTERPRETAÇÃO DAS CONVENÇÕES CONTRA A DUPLA TRIBUTAÇÃO INTERNACIONAL

5.3. APLICABILIDADE ÀS CONVENÇÕES BRASILEIRAS INDEPENDENTE DE RATIFICAÇÃO297

5.3.1. O artigo 31 da CVDT-Regra geral de interpretação 298

5.3.1.1. A "boa fé" 300

5.3.1.2. O "sentido comum" e o "sentido especial" dos termos de um tratado internacional 302

5.3.1.3. "Objetivos e finalidade". 305

5.3.1.4. A noção de "Contexto" e o conceito de "tratado" segundo o artigo 31 da Convenção de Viena 308

5.3.1.5. "Acordos formais" e "práticas posteriores" - demais elementos de interpretação autêntica. 312

5.3.2. O artigo 32 da CVDT-Meios suplementares de interpretação. 315

5.3.3. O artigo 33 da CVDT - Interpretação de tratados autenticados em dois ou mais idiomas.

5.4. A INTERPRETAÇÃO DE CONVENÇÕES DE BITRIBUTAÇÃO SEGUNDO AS RECOMENDAÇÕES DA OCDE 322

5.4.1. Os comentários ao Modelo da OCDE: status e importância para a interpretação

5.4.2. A "regra geral" de interpretação segundo o Modelo da OCDE - artigo $3(2)$

5.4.2.1. Escopo de aplicação - regra geral ou regra específica?

5.4.2.2. O alcance da expressão "Law" 332

5.4.2.3. A qual Direito interno deve-se recorrer? 335

5.4.2.4. O contexto no Modelo da OCDE e o reenvio ao Direito interno dos Estados contratantes..................................................................................... 340

5.4.3. As expressões autônomas 345

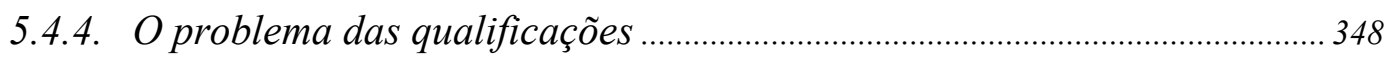

5.4.4.1. Qualificação pela Lex Fori................................................................... 357

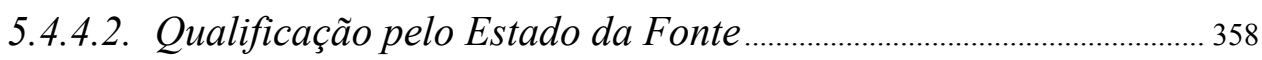

5.4.4.3. $O$ "New Approach" da OCDE ………………………………………...... 359

5.4.4.4. Qualificação autônoma 361 
5.4.4.5. Qualificação pelo Estado de Residência

5.4.4.6. A teoria das competências qualificatórias exclusivas .363

5.4.5. Métodos de solução de conflitos interpretativos. 366

5.4.5.1. O Procedimento Amigável 366

5.4.5.2. Arbitragem 376

5.5. DEMAIS QUESTÕES RELEVANTES PARA A INTERPRETAÇÃO DAS CONVENÇÕES CONTRA A BITRIBUTAÇÃO 378

5.5.1. A questão da tradução: convenções firmadas em mais de um idioma e as versões traduzidas - a necessidade de uma linguagem fiscal internacional 378

5.5.2. Interpretação das convenções contra a bitributação e a sua finalidade de prevenção e combate à evasão fiscal. 385

5.5.2.1. Cláusulas antiabuso específicas 390

5.5.2.2. Demais dispositivos antiabuso (dispersos nas demais normas das convenções). 394

6.1 A VERIFICAÇÃO EMPÍRICA DA INTERPRETAÇÃO DA RECEITA FEDERAL DO BRASIL ACERCA DOS TRATADOS DE DUPLA TRIBUTAÇÃO 398

6.2. A AÇÃo Direta de INCONSTITUCIONALIDADE N. 2.588 433

6.3. A DENÚNCIA DO ACORDO BRASIL-ALEMANHA 438 


\title{
INTRODUÇÃ̃O
}

\section{"El significado es en el ojo de quien mira."}

\author{
Joseph Raz
}

A clássica figura da justiça, de olhos vendados, segurando em uma das mãos uma balança e na outra uma espada, simboliza os três ideais perseguidos pelas instituições judiciárias: a imparcialidade, representada pela venda nos olhos, a isonomia, ilustrada por meio da figura da balança, e a determinação na aplicação de suas decisões, simbolizada pela espada. Estes três ideais do Direito e da justiça dependem fundamentalmente da correta interpretação e aplicação das normas jurídicas que integram o ordenamento, e, por isso, o tema da interpretação tem sido, há muito tempo, objeto de discussões acaloradas dentre os estudiosos do Direito.

Sabe-se que o ser humano é, em sua essência, um agente interpretativo, uma vez que, a todo momento, em qualquer lugar, as pessoas instintivamente interpretam as sensações, os estímulos e as mensagens que o mundo lhes envia. O próprio caráter social da humanidade faz com que as pessoas interajam entre si e com o mundo a sua volta, e para que tal interação seja racional, é necessária a interpretação. Assim, é correto dizer, em uma acepção filosófica, que absolutamente tudo que existe no mundo é, foi, ou será objeto de interpretação.

Entretanto, este caráter universal da interpretação é normalmente deixado de lado pela maioria das pessoas, sendo que a noção mais comum que se tem do ato de interpretar é diretamente ligada à interpretação de um texto, no sentido de compreender a mensagem contida sua redação. E, de fato, os textos escritos devem ser interpretados. Contudo, a interpretação é algo muito maior do que simplesmente ler um texto escrito e compreender o significado das palavras que o integram.

$\mathrm{O}$ ato de interpretar envolve muito mais do que conhecimentos linguísticos, sendo também relacionado com a forma como se desenvolve o raciocínio. Em exemplo bastante simples, é possível perceber que, um indivíduo brasileiro que vê uma placa de trânsito " $\mathrm{X}$ " poderá interpretá-la de forma totalmente diferente de como a interpretaria, por 
exemplo, um indivíduo japonês. Isso permite afirmar que o ato de interpretar não é estático, e possui muito mais facetas do que se pode imaginar.

Outro aspecto relevante da interpretação, e, neste ponto já adentramos o campo da interpretação jurídica, é que, por mais que se deva e que se tente ser o mais imparcial (isso é um dever para os juízes), o ato de interpretar sempre vem carregado com os préconceitos e com as impressões do intérprete em relação ao mundo que o cerca. Isto porque, todo e qualquer ser humano, necessariamente, possui uma história, vivenciou experiências, possui formação cultural de maior ou menor grau, recebeu alguma forma de educação (não apenas educação formal ou acadêmica), e vive em algum tipo de sociedade. Todos estes fatores influenciam o intérprete durante a atividade hermenêutica.

A aplicação do Direito, em qualquer hipótese, pressupõe a interpretação de suas normas. Na prática, estes dois atos - de interpretação e de aplicação - na maioria das vezes se realizam por meio de uma única ação. Dizemos na maioria das vezes porque deixamos ressalvada a possibilidade de interpretar uma norma sem aplicá-la no sentido formal da aplicação do Direito, ou seja, sem emitir uma decisão de mérito a partir de seu mandamento. Assim, interpretação e aplicação são atividades distintas, mas que estão sempre juntas, como os dois lados de uma moeda. Entretanto, para fins didáticos, é útil separar a interpretação e a aplicação do direito como se fossem etapas distintas e subsequentes.

Outro ponto bastante relevante, que por algum tempo foi desconsiderado em virtude da equivocada aplicação do brocardo in claris cessat interpretatio, como veremos adiante, corresponde à noção de que toda e qualquer norma jurídica deve ser interpretada, e não apenas aquelas consideradas obscuras, vagas ou ambíguas, até porque o próprio conceito de obscuridade e ambiguidade pode variar. Em outras palavras, mesmo as normas aparentemente claras devem ser interpretadas com o devido cuidado antes de serem aplicadas.

Revela-se, desta forma, o motivo pelo qual a doutrina especializada superou a noção subjacente ao referido brocardo, a qual há algum tempo já não é mais aceita, eis que sua utilização prática pode levar a desvios de aplicação da norma que poderiam ser facilmente identificados mediante a devida interpretação. De fato, como já mencionamos, não é possível aplicar o conteúdo de uma norma sem a sua devida compreensão prévia, o que se dá por meio da interpretação. 
Em vista disso, não parecem restar dúvidas de que ao intérprete do Direito incumbe a tarefa de determinar o sentido e o alcance da norma em face das situações concretas que devem ser por ela reguladas.

Para compreender como se desenvolve o processo de interpretação das normas jurídicas e como se formam as decisões daí decorrentes, faz-se necessária, inicialmente, uma abstração do âmbito puramente jurídico e um retorno à análise da interpretação geral.

Inicialmente, é necessário distinguir os conceitos de interpretação, hermenêutica e aplicação do direito. A Hermenêutica é a ciência (ou arte, como preferem alguns) que estuda o processo e os métodos pelos quais se desenvolve a interpretação. Esta, como já mencionamos, relaciona-se com a atribuição de sentido às coisas e fatos, neles inclusos as palavras e o texto normativo. Já a aplicação das normas jurídicas constitui um ato complexo, que inclui a interpretação e deve considerar também todas as circunstâncias que podem influir na subsunção do fato ao enunciado normativo. Para a aplicação, é necessário, pois, um encadeamento lógico e harmônico entre a estrutura interna da norma jurídica e o ambiente ao qual ela se aplica. Desta forma, relacionando os três conceitos, afirma-se que por meio da Hermenêutica são elaborados os enunciados, os quais serão interpretados juridicamente e em seguida aplicados aos casos concretos.

Como mencionamos, a interpretação e a aplicação de normas jurídicas pressupõem um encadeamento lógico entre ideias e proposições. Mas a lógica que se aplica ao direito não é a lógica formal, aquela válida, por exemplo, para as ciências exatas. Ao direito se aplica a lógica jurídica, que se diferencia da lógica formal por ter suas proposições sujeitas ao critério de correção ou incorreção em relação ao ordenamento, e, não, ao critério de verdade, aplicável à lógica formal. Considerando isso, percebe-se que o modo de aplicação do critério de correção consiste no emprego da argumentação. São, pois, os argumentos jurídicos que formam as provas dialéticas que, com sua força de convencimento variável, prestam-se à comprovação da correção de uma proposição jurídica e ao convencimento de um auditório, seja este um júri, uma banca examinadora, uma sala de aula de um curso de Direito ou o próprio juiz. Assim, em direito não se fala em uma única solução correta para um caso, mas, sim, em uma solução correta em face dos argumentos e das provas apresentadas, considerando o direito aplicável.

Embora o raciocínio jurídico e a argumentação jurídica estejam presentes em todas as formas de manifestação do direito, é nas sentenças e decisões judiciais que ambos podem ser percebidos e compreendidos com mais clareza, e é por isso que aqui utilizamos 
as decisões judiciais como meio de trabalho. E, neste ponto, passamos à análise da argumentação jurídica, cujo conceito, em linhas gerais, corresponde à arte de persuadir e convencer mediante a exposição lógica dos argumentos.

A realização do Direito depende essencialmente dos juízos valor que são efetuados pelos órgãos julgadores. Tais juízos valorativos, por sua vez, são sujeitos à influência, basicamente, de três fatores extremamente importantes: a história pessoal do julgador, sua personalidade e os argumentos expostos pelas partes. Neste estudo não adentraremos o campo dos aspectos psicológicos que influenciam a interpretação das normas jurídicas, já que isto, por si só, seria matéria suficiente para outra tese. Limitar-nosemos, desta forma, aos aspectos objetivos da interpretação e da argumentação jurídicas.

Mesmo quando não se trata de decidir um caso jurídico, a todo tempo interpreta-se a legislação e escolhas são realizadas. É que, quando se interpreta algo, especialmente uma norma jurídica, diversos são os resultados possíveis, mas sempre haverá um que será mais adequado. Por isso é correto afirmar que interpretar é decidir: interpretam-se os fatos e as normas e elege-se o resultado mais adequado em detrimento de vários outros possíveis. Este ato de escolha depende da argumentação.

Desta forma, evidencia-se a importância que a argumentação tem para a interpretação e para a aplicação do direito. São diversas as teorias da argumentação jurídica, porém decidimos adotar a teoria da argumentação jurídica elaborada por Robert Alexy, que tem como fundamento a busca pela racionalidade nas decisões jurídicas como forma de verificar a sua justificação. Para chegar à estrutura final da teoria de Alexy, realizamos um estudo do discurso prático geral até chegar no discurso jurídico, o qual constitui uma espécie do primeiro. E, como veremos adiante, as regras da teoria da argumentação jurídica surgem justamente em virtude das necessidades decorrentes das limitações que se aplicam à teoria geral do discurso.

É possível encontrar referências a diversos filósofos na teoria de Alexy, porém os que mais se destacam, no que tange à filosofia da linguagem, são Dworkin, Habermas e Perelman. Este último, especialmente, por ser, provavelmente, o grande precursor das teorias da argumentação jurídica, também é objeto de análise no presente trabalho. De fato, muito dos conceitos e das estruturas propostas por Perelman são facilmente identificáveis na teoria de Alexy, que poderia ser qualificada, grosso modo, como uma refinação das ideias inicialmente apresentadas por Perelman. 
A título de comparação, analisamos também as teorias de Toulmin e de MacCormick, este último contemporâneo de Alexy. De Toulmin, Alexy herda a noção do discurso jurídico dialógico, como um debate onde há a proposição e a refutação de pretensões. E, em relação a MacCormick, embora não seja possível afirmar que se trate de uma influência, é possível notar uma certa semelhança entre a proposta de MacCormick de aplicação do raciocínio dedutivo para alguns casos e a noção de justificação interna das proposições jurídicas, introduzida por Alexy.

Assim, de modo bastante objetivo, é possível afirmar que a teoria da argumentação de Alexy propõe a análise da racionalidade das decisões jurídicas sob duas perspectivas: primeiro, pela justificação interna das assertivas, pela qual se avalia a coesão lógica dos argumentos, ou seja, a coerência da relação entre as premissas normativas e fáticas; e, segundo, pela justificação externa, que remonta à fundamentação das premissas que levam o aplicador do direito a interpretar uma norma de uma forma, e não de oura, ou seja, a justificação externa relaciona-se com o fundamento da escolha de uma dentre as várias interpretações possíveis para as normas e para os fatos.

Durante a aplicação do direito, o operador transita constantemente entre as esferas do discurso jurídico e do discurso prático geral. Isto porque o discurso jurídico encontra seu campo de aplicação a partir das limitações existentes em relação ao discurso prático, e vice-versa. Assim, a racionalidade do discurso jurídico e da Ciência do Direito não está na segurança definitiva de suas proposições, até porque, nem mesmo para as ciências exatas ou naturais se pode afirmar que tal grau de segurança exista. A racionalidade do direito reside, em verdade, no cumprimento de uma série de condições, critérios e regras que tornam a sua aplicação ordenada e impedem o arbítrio e os excessos da discricionariedade. O requisito da racionalidade é, pois, a segurança e a certeza em relação aos procedimentos, e não em relação ao resultado em si.

Outra contribuição extremamente relevante da doutrina de Alexy é a sua distinção entre princípios e regras. É bem verdade que esta distinção não é originalmente sua, sendo possível encontrar registros desta diferença desde a obra de Dworkin. Mas é igualmente verdade que a distinção proposta por Alexy hoje venha a ser, talvez, a mais difundida. Assim, segundo Alexy, os princípios são informadores dos valores que o legislador perseguia ao elaborar as regras jurídicas, implicando a conclusão de que toda regra jurídica é baseada num princípio, e que nestes a pretensão de correção e de justiça do direito é mais visível. Eles refletem, desta forma, os valores que são caros à sociedade. 
Além disso, os princípios não estão sujeitos aos critérios de exclusão, e eles não podem ser aplicados por mera subsunção, como ocorre com as regras. E, no caso de conflito de princípios, trata-se de atribuir maior ou menor "peso" a um princípio em detrimento do outro. O desempate entre princípios é, desta forma, qualitativo, ou seja, um princípio prevalece sobre o outro em virtude dos objetivos perseguidos no caso concreto. Os princípios são utilizados, ainda, com a finalidade de desempatar uma situação em que haja a concorrência de regras. Já as regras constituem a concretização dos princípios, e, quando uma regra é aplicável a um caso, significa que nenhuma outra pode se aplicar à mesma situação, segundo o critério de exclusividade. Outra diferença é que, em relação às regras, havendo um conflito, não se ponderam os valores, simplesmente exclui-se a aplicação de uma ou de outra.

Após estas considerações sobre a interpretação do direito em geral, retornamos à interpretação das normas tributárias, especialmente aquelas presentes nos tratados de bitributação. Dizemos que ocorre dupla tributação internacional quando dois ou mais Estados soberanos submetem uma mesma pessoa (física ou jurídica), em concomitante período de tempo, ao pagamento de impostos comparáveis em razão de um mesmo fato gerador. O fenômeno da bitributação internacional compreende, assim, aspectos interpretativos, aspectos tributários e o caráter internacional da situação fática. Assim, princípios que se aplicam, neste caso, são todos aqueles pertinentes à Hermenêutica geral, ao Direito Internacional e também ao Direito Tributário Internacional e interno, dentre os quais podemos mencionar, exemplificativamente, o princípio da soberania, a boa fé, o pacta sunt servanda, a isonomia, a legalidade, a universalidade e a irretroatividade.

Durante a aplicação das normas jurídicas em geral, e assim também para aquelas introduzidas pelos tratados de bitributação, todo intérprete e/ou aplicador do Direito acaba sofrendo influência do seu background cultural durante o processo de interpretação. A grande diferença é que, na interpretação jurídica, essa influência é limitada pelo dever de imparcialidade e de obediência ao Direito, em decorrência da legalidade. Isto significa que o juiz deve abstrair o máximo possível de suas noções anteriores sobre os fatos da vida para se concentrar na narrativa dos fatos apresentada pelas partes.

Conduzindo-nos, agora, para o objeto específico do presente estudo, partimos para a análise das convenções de bitributação e para o estudo da interpretação de suas normas, inicialmente pelo "método clássico", ou seja, pelos critérios propostos pela 
Convenção de Viena e pela Organização para Cooperação e Desenvolvimento Econômico - OCDE, até chegar à aplicação da teoria da argumentação jurídica de Alexy. No entanto, antes de tratarmos da interpretação especificamente, é necessário estabelecer o panorama geral das convenções de bitributação.

As normas das convenções contra a bitributação não visam regular diretamente a tributação dos rendimentos transnacionais. Elas, na verdade, possuem a função de indicar a ordem jurídica competente para tributar o rendimento transnacional, podendo delimitar alguns aspectos da regra matriz de incidência (como as alíquotas), mas nunca instituir uma nova regra matriz. Em outras palavras, as normas das convenções de bitributação operam, primordialmente, atribuindo a competência tributária exclusivamente a um dos Estados pactuantes, o qual, então, tributará do rendimento de acordo com a sua legislação doméstica, cabendo ao outro Estado isentar o rendimento, ou, então, deferindo a competência concomitantemente a ambos, com previsão, nesse último caso, de mecanismos de isenção ou crédito para mitigar o concurso de imposições daí decorrente.

São múltiplas as finalidades pretendidas pelos tratados de bitributação. Dentre elas, citam-se a distribuição proporcional das receitas tributárias entre os Estados contratantes, a promoção e o incremento de investimento estrangeiro, a remoção de obstáculos fiscais ao comércio, a prevenção e combate à discriminação e à evasão fisscal, e ainda o incentivo à cooperação internacional para fiscalização tributária e troca de informações entre os signatários.

No entanto, tais objetivos nem sempre são atingidos. A realização das finalidades das convenções contra dupla tributação perpassa a superação de uma série de dificuldades, dentre elas, a ausência de harmonia tributária entre os sistemas, a multiplicidade de idiomas, expressões e institutos, e as distintas qualificações recebidas pelos rendimentos nos variados ordenamentos. Somente mediante a superação destes obstáculos, o que é realizado através da interpretação e da argumentação jurídicas, é que os países signatários podem se beneficiar de suas disposições, em última análise, fomentando o desenvolvimento econômico.

Expostas as suas características gerais, passamos ao tema da interpretação. Como mencionamos anteriormente, o "método clássico" consiste no recurso às diretivas presentes na Convenção de Viena sobre o Direito dos Tratados, normas cogentes de Direito Internacional, portanto, obrigatórias até mesmo para aqueles que, embora sejam signatários da convenção, ainda não a ratificaram, como é o caso do Brasil, e também na 
aplicação das recomendações contidas, principalmente, nos comentários ao Modelo da OCDE, os quais, por sua vez, não são vinculantes nem mesmo para os membros da organização, embora sejam uma importante fonte de informações sobre as interpretações dos países e de recomendações feitas por especialistas.

A Convenção de Viena regula a interpretação dos tratados internacionais em seus artigos 31 a 33. No artigo 31 encontra-se positivada a regra geral de interpretação, segundo a qual as cláusulas de um acordo internacional devem ser interpretadas a partir de seu texto e do sentido comum atribuído aos seus termos e expressões, dentro do contexto do tratado, aplicando-se o princípio da boa fé e considerando os objetivos e finalidades do tratado. $\mathrm{O}$ artigo 32 trata dos meios suplementares de interpretação, que são aplicáveis quando os resultados da interpretação a partir da aplicação da regra geral do artigo 31 não forem satisfatórios. E, por fim, o artigo 33 disciplina a interpretação dos tratados firmados em dois ou mais idiomas.

Por sua vez, os Comentários ao Modelo da OCDE contém recomendações feitas por especialistas sobre como devem ser interpretadas as cláusulas das convenções elaboradas com base no modelo da referida organização. Destaca-se a norma do artigo 3(2) do Modelo, que alguns consideram como regra geral de interpretação, apesar das críticas, a qual dispõe, em linhas gerais, que os termos e expressões não definidos no acordo deverão ser interpretados segundo a legislação interna de cada tratado, desde que o contexto não imponha interpretação diversa. Assim, embora não sejam vinculantes, os comentários são uma excelente fonte de interpretação autêntica para os tratados que tenham por base o Modelo da OCDE, o que, de fato, engloba a maioria das convenções deste tipo.

A interpretação segundo o método clássico apresenta, entretanto, uma série de problemas e deixa diversas questões importantes sem solução satisfatória. Dentre os problemas mais comuns, destacam-se a questão da interpretação estática ou da interpretação dinâmica, o recurso ao direito interno, o problema das qualificações, o uso de expressões autônomas, a questão da tradução de tratados e ainda a aplicação das convenções com finalidade de combate à evasão fiscal internacional.

É em virtude destes inconvenientes encontrados no método clássico que propomos o recurso à teoria da argumentação jurídica como método para interpretar e aplicar as convenções contra a bitributação, bem como para permitir que, na prática, as decisões relativas à aplicação de tais tratados sejam devidamente fundamentadas segundo a lógica jurídica. 
Para demonstrar a validade e a viabilidade de nossa proposta, analisaremos, sob a perspectiva da teoria da argumentação jurídica de Alexy, um acórdão paradigma no tema da interpretação e aplicação dos tratados de bitributação no Brasil, e verificaremos, também quanto a esse acórdão, o grau de justificação e de racionalidade da decisão. Analisaremos, ainda, a evolução da Ação Direta de Inconstitucionalidade n. 2.588, que tem influência direta na aplicação dos acordos de bitributação no Brasil. E, por fim, descrevemos em linhas gerais, a partir do exemplo da denúncia do acordo BrasilAlemanha, os efeitos que a interpretação inadequada das cláusulas de um tratado de bitributação pode gerar. 


\section{INTERPRETAÇÃO DAS NORMAS JURÍDICAS}

\subsection{Hermenêutica, interpretação e aplicação}

A hermenêutica, a interpretação e a aplicação das normas jurídicas institutos afins, mas não se pode afirmar que sejam sinônimos.

Pela concepção clássica, "interpretar" corresponde a explicar, fornecer o sentido verdadeiro de um termo ou expressão, de um gesto ou uma atitude, enfim, de um objeto qualquer ${ }^{2}$. Segundo ensina Riccardo Guastini ${ }^{3}$, o termo “interpretação" refere-se tanto à atividade interpretativa quanto ao produto desta atividade. Já conforme Eros Roberto Grau, o ato de interpretar vai além de simplesmente compreender o sentido de um objeto, sendo também uma forma de evidenciar este objeto, numa verdadeira operação de mediação em que se transforma uma expressão em outra com o objetivo de facilitar a compreensão deste objeto por meio da linguagem utilizada ${ }^{4} 5$

Nessa mesma linha, Rolando Tamayo y Salmorán explica que a compreensão do significado de uma expressão começa pela análise de seus usos paradigmáticos e da

\footnotetext{
1 "En latín, la palabra [interpretativo] indicaba, al parecer, una negociación para pasar luego a significar la explicación del asunto como una intervención negociadora... el interpres era el intermediario encargado de una negociación $y$, por ende, capaz de lograr un entendimiento entre las partes... de ahí... traductor... mediador entre partes... que no se entienden..." TAMAYO Y SALMORÁN, Rolando. Interpretación Constitucional - La falacia de la interpretación cualitativa. In: VÁZQUEZ, Rodolfo (coord.) Interpretación jurídica y decisión judicial. Cidade do México: Fontamara, 2003. p. 90. (Série Doctrina Jurídica Contemporánea).

2 MAXIMILIANO, Carlos. Hermenêutica e Aplicação do Direito. 18 ed. Rio de Janeiro: Forense, 1999. p. 09.

3 “El vocablo 'interpretación', como en general los vocablos con el mismo sufijo, puede denotar bien una actividad - la actividad interpretativa - bien el resultado o producto de esa actividad. Por ejemplo, 'las disposiciones legales sobre la interpretación' son disposiciones que disciplinan la actividad interpretativa; por el contrario, una 'interpretación restrictiva' es el resultado de una cierta técnica interpretativa. El resultado o producto de la actividad interpretativa no es otra cosa mas que el 'significado' del objeto interpretado." GUASTINI, Riccardo. La Interpretación: objetos, conceptos y teorías. In: VÁZQUEZ, Rodolfo (coord.) Interpretación jurídica y decisión judicial. Cidade do México: Fontamara, 2003. p. 19. (Série Doctrina Jurídica Contemporánea)

${ }^{4}$ GRAU, Eros Roberto. O direito posto e o direito pressuposto. São Paulo: Malheiros, 2002. p. 207.

${ }^{5}$ Sobre o papel da linguagem na formação do Direito: COÊLHO, Sacha Calmon Navarro. Teoria Geral do Tributo e da Exoneração Tributária. 3. ed. Belo Horizonte: Del Rey, 2000. p. 40. CARVALHO, Paulo de Barros. Curso de Direito Tributário. 16. ed., São Paulo: Saraiva, 2004. p. 108.
} 
recuperação de sua etimologia, o que, no caso da interpretação, especialmente na interpretação jurídica, revela-se como uma estratégia particularmente útil ${ }^{6}$.

A definição de "interpretar", contudo, pode variar dependendo do objeto que é interpretado. Se o que se está interpretando é um ato ou comportamento humano, “interpretar" pode ser concebido como elaborar suposições acerca dos objetivos, razões ou intenções do sujeito ou de outro agente, podendo significar também o ato de conferir um sentido ou valor à ação em questão. Especificamente no âmbito jurídico, interpretar um fato significa incluir este fato dentro de certa classificação, subsumi-lo a uma norma ou mesmo qualificar este fato segundo um esquema de qualificação que permita a aplicação posterior de uma norma jurídica, como por exemplo, qualificar o ato de tirar intencionalmente a vida de uma pessoa como homicídio doloso, para a posterior aplicação da sanção penal ${ }^{7}$.

Sob outra perspectiva, é possível interpretar um acontecimento histórico, e aqui o termo "interpretar" pode ganhar o sentido de estabelecer a relação de causa e efeito entre os fatos. "Interpretar" também pode consistir na atividade de atribuir significado a um determinado texto ${ }^{8}$ ou mesmo a um fragmento de linguagem que não esteja posto na forma de texto escrito. Nesse sentido, Joseph Raz lembra que somente existe significado no mundo onde houve a introdução de significado pelos seres humanos ${ }^{9}$.

Como se observa, tudo pode ser interpretado, a qualquer tempo. Na realidade, a cada momento, o ser humano interpreta o mundo à sua volta, e é a partir da sua interpretação (aqui tida como sinônimo de resultado do ato de interpretar) que toma desde as suas decisões quotidianas, instintivas e corriqueiras até as decisões que podem influenciar os rumos de uma nação inteira. Assim, quando uma pessoa abre os olhos pela

${ }^{6}$ TAMAYO Y SALMORÁN, Rolando. Interpretación Constitucional: La falacia de la interpretación cualitativa. In: VÁZQUEZ, Rodolfo (coord.) Interpretación jurídica y decisión judicial. Cidade do México: Fontamara, 2003. p. 90. (Série Doctrina Jurídica Contemporánea).

${ }^{7}$ GUASTINI, Riccardo. La Interpretación: objetos, conceptos y teorías. In: VÁZQUEZ, Rodolfo (coord.) Interpretación jurídica y decisión judicial. Cidade do México: Fontamara, 2003. p. 20. (Série Doctrina Jurídica Contemporánea).

${ }^{8}$ Paulo de Barros Carvalho define que o texto ocupa o suporte físico, a base material para produzir-se a representação mental na consciência do homem (significação) e, também, termo da relação semântica com os objetos significados. Em outras palavras, o texto é o ponto de partida para a formação das significações. CARVALHO, Paulo de Barros. Direito Tributário: Fundamentos Jurídicos da Incidência. 3. ed., rev. e atual. São Paulo: Saraiva, 2004. p. 17.

${ }^{9}$ RAZ, Joseph. Por qué interpretar? In: VÁZQUEZ, Rodolfo (coord.) Interpretación jurídica y decisión judicial. Cidade do México: Fontamara, 2003. p. 46. (Série Doctrina Jurídica Contemporánea). 
manhã e vê que o dia já está claro, ela interpreta este fato e entende que a noite já acabou, e assim toma a decisão de levantar-se da cama. É desta forma que a interpretação pauta a vida e o existir humano, desde o início dos tempos. Da mesma forma, um representante de um Estado interpreta o lançamento de uma bomba contra seu território como um ato hostil, impondo a tomada das providencias cabíveis.

Entretanto, é necessário esclarecer que "interpretar" não corresponde ao ato de buscar as intenções do autor. Nesse sentido, Guastini ensina que uma coisa é indagar o significado das palavras de um texto (que não necessariamente precisa estar na forma escrita), outra coisa é tentar compreender as intenções do autor. Interpretar parte do que o próprio texto coloca à disposição do intérprete, e a vontade do autor (ou do legislador, se se tratar de um texto jurídico), não necessariamente precisa estar explícita no texto. São, portanto, duas ações distintas, que não se entrelaçam, embora possam ser complementares, dependendo da situação. Por exemplo, dizer que a palavra "homem" significa "indivíduo humano do sexo masculino" é diferente de perguntar se a frase "cuidado com o que faz", dita por um indivíduo qualquer, constitui uma advertência ou uma ameaça ${ }^{10}$.

Tradicionalmente, tem-se que a interpretação jurídica corresponde a uma espécie do gênero interpretação textual (embora não apenas de textos na forma escrita), sendo que quando se fala em interpretação jurídica, o objeto a que se refere são as normas jurídicas (escritas e não escritas, princípios e regras) e as fontes do Direito (a lei, as decisões judiciais, os costumes, apenas para citar alguns exemplos).

A interpretação jurídica possui a particularidade de ser eminentemente prática, quase sempre voltada para a aplicação imediata da norma jurídica, embora também seja possível a interpretação apenas com fins doutrinários, sem o fim imediato de aplicação da norma. Além disso, quando se interpreta uma norma jurídica com finalidade de aplicação, existe ainda a necessidade de sempre se considerar os fatores tempo e espaço, já que estes são inerentes a qualquer disposição normativa. Considerando estas características, Rolando Tamayo y Salmorán explica que a interpretação jurídica pode corresponder a duas hipóteses: (i) atribuição de significado jurídico a certos fatos ou comportamentos humanos os quais se constituem em fatos jurídicos, na medida em que são juridicamente considerados, ou seja, juridicamente interpretados, e; (ii) atribuição de um significado

${ }^{10}$ GUASTINI, Riccardo. La Interpretación: objetos, conceptos y teorías. In: VÁZQUEZ, Rodolfo (coord.) Interpretación jurídica y decisión judicial. Série Doctrina Jurídica Contemporánea. Cidade do México: Fontamara, 2003. p. 20. (Série Doctrina Jurídica Contemporánea). 
jurídico, no sentido técnico do termo, a objetos conhecidos dentro do ambiente jurídico, como por exemplo, as "fontes" do direito".

Em sentido estrito, e sob uma perspectiva tradicional (e já ultrapassada), interpretar uma norma jurídica significava esclarecer o seu conteúdo, o seu significado e também o seu escopo de aplicação, desde que houvesse dúvidas acerca destes aspectos. Foi a partir desta noção restritiva de interpretação jurídica que surgiu o brocardo "in claris cessat interpretatio", cuja ideia geral é: se o texto for claro, ele não deve ser interpretado. E, um texto será claro quando todas as interpretações possíveis que dele se poderiam extrair conduzem ao mesmo resultado ${ }^{12}$. Porém, mesmo a mais breve digressão sobre a clareza de textos ou de termos leva à conclusão de que, se as circunstâncias variarem, um texto que aparentemente é claro pode deixar de sê-lo imediatamente. Nesse sentido, Maria Helena Diniz ensina que uma mesma norma jurídica pode ser clara em sua aplicação aos casos mais imediatos, mas pode ser duvidosa se aplicada a outras relações que a ela possam ser subsumidas, porém às quais não há referência direta ${ }^{13}$.

Na realidade, essa noção restritiva de interpretação jurídica teve espaço durante certo tempo porque as disposições normativas jurídicas podem, de fato, ser estruturadas de modo que a sua leitura seja fácil e incontroversa, acarretando a equivocada impressão de que seria desnecessária a interpretação ${ }^{14}$. Segundo esse entendimento, a interpretação somente seria necessária, pois, com relação às disposições cuja formulação fosse indireta,

11 TAMAYO Y SALMORÁN, Rolando. Interpretación Constitucional - La falacia de la interpretación cualitativa. In: VÁZQUEZ, Rodolfo (coord) Interpretación jurídica y decisión judicial. Cidade do México: Fontamara, 2003. p. 94-95. (Série Doctrina Jurídica Contemporánea).

${ }^{12}$ PERELMAN, Chaïm. Ética e Direito. Trad. Maria Ermantina de Almeida Prado Galvão. 2. ed. São Paulo: Martins Fontes, 2005. p. 623.

${ }^{13}$ DINIZ, Maria Helena. Compêndio de introdução à ciência do direito. São Paulo: Saraiva, 1991, p. 381.

${ }^{14}$ Nesse sentido, Perelman explica: “A concepção tradicional afirma clara non sunt interpretanda, o que é claro não deve ser interpretado, como se tal clareza pudesse impor-se antes de qualquer interpretação, o que é uma concepção inspirada em Descartes. A esta se opõe a reflexão de Locke, segundo a qual, em direito, essa pretensa clareza resulta mais de uma falta de imaginação, do fato de não se ter pensado em todas as situações que permitiriam revelar a ambigüidade ou a obscuridade da regra. É por isso que, em vez de dizer que a regra é clara em si própria, ou seja, sejam quais forem as situações às quais é aplicável, o que supõe que as examinamos todas, é mais prudente e mais justo dizer que ela é clara neste ou naquele caso de aplicação, pois as diversas interpretações razoáveis que dela se poderiam fornecer não dão azo a nenhuma divergência. (...) Toda vez que o sentido claro de um texto contradiz a finalidade da instituição, à qual se supõe que ele serve, ou colide com a equidade, ou conduz a conseqüencias socialmente inadmissíveis, procurar-se-á interpretá-lo; o texto deixará de ser claro, pois que, conforme o valor privilegiado (a segurança, a equidade, o bem comum), esta ou aquela interpretação prevalecera definitivamente." PERELMAN, Chaïm. Ética e Direito. Trad. Maria Ermantina de Almeida Prado Galvão. 2. ed. São Paulo: Martins Fontes, 2005. pp. 546-547, 623. 
obscura, indeterminada, ou de alguma forma complexa a ponto de surgirem dúvidas que impedissem a sua aplicação imediata e incontroversa aos fatos a que se destinassem.

Outro aspecto que justificava o princípio "in claris cessat interpretatio" referese aos próprios fatos jurídicos aos quais a norma será aplicada. Se os fatos são incontroversos e simples, então a aplicação da norma é a mediante subsunção direta e evidente, não sendo necessária nenhuma justificativa para a aplicação da norma jurídica, o que implicaria a desnecessidade de sua interpretação. Porém, quando se trata de fatos que por sua natureza ou complexidade tornam a aplicação da norma controvertida, duvidosa ou obscura, a aplicação desta norma somente seria possível por meio da argumentação jurídica, ou seja, mediante a exposição dos motivos que justificassem a sua aplicação, e isto somente seria possível através da interpretação. A decisão sobre a aplicação da norma estaria, neste caso, condicionada à interpretação e à argumentação.

Porém, os próprios fundamentos do conceito restritivo e tradicional de interpretação demonstram que esta noção carrega em si uma enorme contradição. Ora, como seria possível saber se uma norma é clara ou obscura, ou saber se um fato é simples ou complexo, senão por meio da própria interpretação destes? Isto significa que a interpretação sempre precede o juízo de valor. Além disso, o que é claro e evidente para um intérprete pode não ser para outro. Portanto, vê-se que somente a partir da interpretação é que seria possível tal classificação ${ }^{15}$, de forma que o brocardo "in claris cessat interpretatio", atualmente, perdeu todo o seu sentido, sendo útil apenas para referências históricas.

Outrossim, se a definição restritiva de interpretação fosse realmente correta, seria imperioso considerar que o texto legislativo é a norma jurídica em si, o que, como sabemos, não é verdade, já que um mesmo fragmento de texto legislativo, uma mesma

\footnotetext{
15 “Se podría añadir que la misma distinción entre texto 'claros' y textos 'oscuros' es discutible. En el sentido de que claridad y oscuridad, bien visto, no son cualidades intrínsecas de un texto, precedentes a la interpretación: son, ellas mismas, fruto de la interpretación, entendida en un sentido amplio como adscripción de un significado a un texto. Esto es así por dos razones. Antes que nada, porque sólo después de haber interpretado un texto se podría decir si es claro u oscuro. Por otra parte, sobre todo porque sobre la misma claridad u oscuridad del texto puede existir controversia: un texto puede resultar claro para alguno y oscuro para otros. Entonces, la claridad, más que excluir toda controversia, puede también ella ser objeto de controversia. Adicionando el argumento, se puede decir que un texto es claro sólo si, y en el sentido de que, sobre su significado los intérpretes concuerden. Pero esto quiere decir, apunto, que la supuesta claridad no es una propiedad del texto, sino el fruto de una decisión interpretativa (o de más decisiones interpretativas concordes)." GUASTINI, Riccardo. La Interpretación: objetos, conceptos y teorías. In: VÁZQUEZ, Rodolfo (coord) Interpretación jurídica y decisión judicial. Cidade do México: Fontamara, 2003. p. 25. (Série Doctrina Jurídica Contemporánea).
} 
disposição, podem conter diversas normas, e, ao mesmo tempo, uma norma jurídica não necessariamente precisa estar expressa num texto legislativo, podendo estar simplesmente consubstanciada num princípio ou até mesmo numa regra costumeira não escrita. Enfim, por todos os motivos acima, atualmente o conceito restritivo de interpretação encontra-se superado.

Efetivamente, com a evolução dos estudos doutrinários no campo da hermenêutica jurídica, e notadamente a partir dos estudos formulados por Kelsen ${ }^{16}$, $\operatorname{Hart}^{17}$ e Gadamer ${ }^{18}$, percebeu-se que o ato de interpretar o Direito engloba muito mais do que a simples ação de fornecer o sentido de normas jurídicas "obscuras" ou "controversas". Superou-se também o entendimento de que a interpretação jurídica seria um método por meio do qual seria possível apreender o verdadeiro e único sentido das normas legais ${ }^{19}$.

De fato, a moderna e bem mais abrangente concepção de interpretação demonstrou que qualquer decisão em torno de uma norma jurídica, seja ela simples ou complexa, sobre quaisquer que sejam os fatos, constitui uma interpretação jurídica. $O$ fato de a aplicação de uma norma jurídica ser considerada fácil e simples não significava mais que não houve interpretação, mas demonstrava apenas que os fatos se apresentaram com mais exatidão à luz do que estava disposto na norma, de modo que a sua interpretação e

\footnotetext{
${ }^{16}$ Kelsen nega a ética, a moral e a justiça como valores absolutos, de forma que pudessem ser acolhidos pelas normas jurídicas. Sua teoria, baseada numa estrutura piramidal, partia do pressuposto de que as normas devem ser interpretadas sempre à luz da norma fundamental, que se encontrava no topo da pirâmide e que fornecia o fundamento de validade para todas as demais normas do ordenamento jurídico. Outro aspecto relevante da teoria de Kelsen consiste na atribuição de um caráter de indeterminação ao resultado da interpretação das normas jurídicas, já que, para ele, o ato de interpretar uma norma jurídica está relacionado com a ideia de que a norma geral e abstrata constitui uma moldura a partir da qual a interpretação pode levar a diversas normas individuais e concretas, que são, elas próprias, o resultado da interpretação. KELSEN, Hans. Teoria Pura do Direito. Trad. João Baptista Machado. São Paulo: Martins Fontes, 1999, p. 42.
}

${ }^{17}$ Em linhas gerais, Hart, baseado em sua teoria da indeterminação da linguagem, entende que toda norma jurídica, em algum momento de sua aplicação, é indeterminada. Isto se deve à própria generalidade dos conceitos utilizados nas normas gerais e abstratas, os quais são necessários para a sua aplicabilidade geral. Por isso, durante a aplicação norma, existe uma certa margem de ponderação que é suprida pela interpretação feita pelo aplicador. HART, Herbert L. A. O Conceito de Direito. Trad. Antônio de Oliveira Sette-Câmara. São Paulo: Martins Fontes, 2009, pp. 161-199.

${ }^{18}$ Gadamer entende que as ciências humanas não são apreensíveis através dos métodos aplicáveis às ciências exatas. Para ele, as ciências humanas são compreendidas por meio da linguagem, ou seja, pela dialética. Por isso, o intérprete e o objeto da interpretação são próximos, não existindo o distanciamento entre ambos que haveria se fosse utilizado o método. Além disso, o intérprete traz consigo os pré-conceitos e todo um background cultural que influencia na sua interpretação da norma, de modo que interpretação e aplicação da norma tornam-se concomitantes. GADAMER, Hans-Georg. Verdade e Método I: Traços de uma hermenêutica filosófica. Trad. Flávio Paulo Meurer. 10. ed. Petrópolis: Ed. Vozes, 2008, p. 37 e seguintes.

${ }^{19}$ ROCHA, Sérgio André. Interpretação dos Tratados contra a Bitributação da Renda. Rio de Janeiro: Lumen Juris, 2008, p. 64. 
aplicação foram simplificadas. Concluiu-se, pois, que a interpretação não necessariamente precisa ser um processo difícil ou complicado.

O ponto de partida da interpretação será o texto da disposição normativa, de modo que podemos designar como "disposição" qualquer enunciado de linguagem oriundo de uma fonte do Direito. A norma é, pois, extraída a partir da interpretação das disposições normativas, constituindo o verdadeiro resultado da interpretação jurídica.

Desta forma, em seu sentido mais amplo, é possível dizer até mesmo que a interpretação jurídica engloba a sistematização, a integração e a solução de antinomias, o preenchimento de lacunas legais e o esclarecimento de expressões obscuras e ambíguas.

Em alguns casos, a interpretação pode ser tomada como manipulação do sentido de uma norma jurídica com propósitos elusivos. E, em outros, o termo "interpretação" pode ser utilizado, equivocadamente, como sinônimo de "aplicação", especialmente como referência à interpretação judicial.

Em termos de normas jurídicas, e, portanto, de interpretação e aplicação destas, a distinção entre os conceitos de interpretação e de aplicação nem sempre é clara, até por que, na prática, ambas se desenvolvem concomitantemente, embora acreditemos que seja possível interpretar uma norma sem efetivamente aplicá-la naquele momento. É nesse sentido a lição de Oswaldo Aranha Bandeira de Mello:

“A interpretação da lei pode-se fazer pela interpretação tão-somente. É a obra doutrinária dos juristas, já ressaltada. Mas ela se leva a efeito, principalmente, para sua aplicação. Aliás, a própria obra doutrinária dos juristas tem esse objetivo, embora de maneira indireta e mediata, pois serve como subsídios esclarecedores aos que vão aplicar o direito. (...)

Não se confunde, portanto, interpretação com a aplicação do direito. A aplicação pressupõe sempre a interpretação. Mas a recíproca não é verdadeira, pois esta pode permanecer no puro plano da exegese, como obra de doutrina, ante a razão em que assentam os ensinamentos do intérprete sobre o sentido da lei e a convicção com que os desenvolve, sem cogitação de qualquer caso concreto. Revela-se especialmente nas lições dos professores, nas monografias, tratados, manuais e comentários dos juristas. A aplicação do direito efetiva-se pelos particulares nas suas relações jurídicas e pelos órgãos 
do Estado-poder. Estes podem ser o Legislativo, o Executivo e o Judiciário, efetivando-o. "20

Precisamente, a distinção entre interpretação e aplicação reside no fato de que a interpretação corresponde à aplicação dos princípios hermenêuticos para a descoberta do significado da letra da lei, enquanto a aplicação consiste no enquadramento dos fatos jurídicos aos dizeres da norma, promovendo a incidência desta mediante a interpretação previamente realizada. Nesse sentido, vale citar a magistral lição de Kelsen:

“Quando o Direito é aplicado por um órgão jurídico, este necessita de fixar o sentido das normas que vai aplicar, tem de interpretar estas normas. A interpretação é, portanto, uma operação mental que acompanha o processo da aplicação do Direito no seu progredir de um escalão superior para um escalão inferior. Na hipótese em que geralmente se pensa quando se fala de interpretação, na hipótese da interpretação da lei, deve responder-se à questão de saber qual o conteúdo que se há de dar à norma individual de uma sentença judicial ou de uma resolução administrativa, norma essa a deduzir da norma geral da lei na sua aplicação a um caso concreto. ",21

Mais especificamente, a distinção entre interpretação e aplicação concerne aos sujeitos e ao objeto de cada uma. Quanto aos sujeitos, a interpretação pode ser realizada por qualquer pessoa, já a aplicação somente pode ser realizada pelos aplicadores da norma investido de poderes para tanto, como, por exemplo, juízes, desembargadores, ministros e árbitros. A rigor, qualquer cidadão comum, e regra geral, os advogados, podem interpretar uma norma jurídica e até mesmo postular perante os órgãos competentes a sua aplicação, mas não podem propriamente aplicá-la.

E, quanto ao objeto, tem-se que a interpretação parte dos textos normativos (não somente na forma escrita), já o objeto da aplicação consiste na norma jurídica em sentido estrito, ou seja, o conteúdo de sentido dos textos normativos. Além disso, a aplicação é mais abrangente, englobando a interpretação, a qualificação e a decisão proferida pelo aplicador. Desta forma, evidencia-se que se trata de institutos distintos,

\footnotetext{
${ }^{20}$ MELlo, Osvaldo Aranha Bandeira de. Princípios Gerais de Direito Administrativo. 3. ed., v. 1 Introdução. São Paulo: Malheiros, 2007, p. 407- 402.

${ }^{21}$ KELSEN, Hans. Teoria Pura do Direito. Trad. João Baptista Machado. São Paulo: Martins Fontes, 1999 , p. 245 .
} 
embora não seja possível, na prática, separar seus momentos de ocorrência, já que a aplicação sempre pressupõe a interpretação. ${ }^{22}$

Diante de todas estas características, é possível concluir que a interpretação corresponde a uma técnica, ou como dizem alguns autores, corresponde à arte de compreender os sentidos dos objetos. Desta forma, a interpretação jurídica deverá ser realizada sempre em observância aos princípios da justiça, especialmente a imparcialidade, isonomia, razoabilidade, vedação à arbitrariedade e aos excessos, e equidade.

Embora sejam campos filosóficos afins, a interpretação e a Hermenêutica possuem naturezas distintas. A Hermenêutica consiste na ciência da interpretação, e a Hermenêutica jurídica corresponde, deste modo, à ciência da interpretação das normas jurídicas, englobando as diversas técnicas e os vários métodos e os princípios interpretativos. Oswaldo Aranha Bandeira de Mello conceitua Hermenêutica jurídica como a "teoria relativa à apuração dos sentidos dos textos legais", e seu objeto compreende a "sistematização teórica dos princípios a serem utilizados na descoberta do significado dos textos legais ${ }^{\text {,23 }}$. Dito de outra forma, a Hermenêutica jurídica tem como objeto a própria Lei, e seu objetivo é encontrar os seus possíveis sentidos e sistematizar os processos que permitem a sua aplicação. A Hermenêutica é, desta forma, um meio para permitir a aplicação das normas.

O estudo da Hermenêutica é sistematizado em três escolas principais: (i) a Escola Jurídico-Exegética, que prioriza a interpretação segundo a vontade do legislador, seguindo uma linha teleológica e exaltando o texto da lei; (ii) a Escola JurídicoSociológica, segundo a qual o Direito deve ser interpretado e visto como uma forma de atender e regular as necessidades sociais, devendo, desta forma, prevalecer sempre o interesse social; e, (iii) a Escola do Direito-Livre, que prega a conciliação do Direito com as necessidades sócio-políticas, porém concedendo ampla discricionariedade ao intérprete e ao aplicador do Direito, permitindo-lhes, até mesmo, deixar de aplicar uma lei quando, em sua opinião, esta tiver caído em desuso.

\footnotetext{
${ }^{22}$ GUASTINI, Riccardo. La Interpretación: objetos, conceptos y teorías. In: VÁZQUEZ, Rodolfo (coord.) Interpretación jurídica y decisión judicial. Cidade do México: Fontamara, 2003. p. 26-27 (Série Doctrina Jurídica Contemporánea).

23 MELlo, Osvaldo Aranha Bandeira de. Princípios Gerais de Direito Administrativo. 3. ed., v. 1 Introdução. São Paulo: Malheiros, 2007, p. 402-403.
} 
Todas as escolas de pensamento acima citadas possuem deficiências que não permitem uma interpretação satisfatória das normas jurídicas. Efetivamente, não se pode confiar simplesmente na vontade do legislador, eis que a lei, depois de promulgada, tornase uma entidade autônoma sujeita às mais diversas interpretações. Além disso, a lei é feita para durar no tempo, e a vontade do legislador, bem como as circunstancias em que se deu a elaboração da norma, à época, podem não ser compatíveis com as circunstâncias em que, futuramente, se dará a sua aplicação. Igualmente, o interesse social não pode prevalecer a qualquer custo, sob pena de, cedendo margem à arbitrariedade, ferir-se a segurança jurídica e os principais pilares de sustentação do Estado Democrático de Direito. Este mesmo efeito de violação ao princípio da segurança jurídica surge quando se confere excessiva discricionariedade ao aplicador do Direito. Por isso é que, atualmente, não se adota nenhuma delas isoladamente.

Em vista de todos os aspectos acima explicados, objetivamente, e adotando uma perspectiva mais pragmática em relação às normas jurídicas, é possível concluir que a diferença básica entre Hermenêutica e interpretação reside no fato de que esta possui caráter concreto, visando à aplicação, enquanto que aquela é abstrata, não necessariamente voltada à aplicação prática da norma jurídica com o objetivo de resolver um caso concreto.

Assim, é possível perceber que a interpretação pode ser considerada uma forma de aplicação da Hermenêutica. Por sua vez, a aplicação da norma jurídica difere da Hermenêutica e da interpretação por requerer um raciocínio muito mais complexo, englobando não apenas a norma em si, mas todas as circunstâncias que podem influir na subsunção do fato ao enunciado normativo, como, por exemplo, o tempo, o espaço e os destinatários da norma. $\mathrm{Na}$ aplicação, é necessário, pois, um encadeamento lógico e harmônico entre a estrutura interna da norma jurídica e o ambiente ao qual ela se aplica. Resumindo: por meio da Hermenêutica é possível estabelecer os enunciados que serão interpretados juridicamente e em seguida aplicados aos casos concretos.

\subsection{Teorias da interpretação ao longo da história - da Escola da Exegese à Teoria da Argumentação}

Existem diversas teorias dedicadas ao tema da interpretação jurídica. Seguindo uma linha de evolução cronológica, desde o século XIX, nos parágrafos a seguir 
discorreremos brevemente acerca das principais, indicando em linhas gerais suas mais relevantes características.

As primeiras análises desenvolvidas sobre o tema da interpretação jurídica foram realizadas pela chamada Escola da Exegese, linha doutrinária que teve suas origens em fins do século XVIII e início do século XIX, na Franca pós-revolucionária, em franca reação ao absolutismo do ancièn règime. Esta linha de pensamento desenvolveu-se concomitantemente à evolução da codificação francesa, baseando-se no racionalismo jurídico e proclamando a onipotência do texto da $1 \mathrm{ei}^{24}$, de modo que seria até mesmo dispensável a interpretação das normas codificadas, as quais seriam claras o suficiente para sua imediata aplicação. Esse extremo apego ao texto da lei demonstrava a evidente reação dos estudiosos do Direito ao arbítrio e discricionariedade exacerbados observados durante o período absolutista imediatamente anterior.

A tradição exegética se baseava numa teoria formalista, também denominada de cognoscitiva, que priorizava os métodos literal e gramatical de interpretação, partindo da noção de que as palavras teriam significados naturais próprios, cabendo ao intérprete apenas verificar empiricamente o significado objetivo. Nessa época surgiu e teve aplicação o brocardo in claris cessat interpretatio, revelando um caráter essencialmente formal e pragmático que literalmente dispensava a interpretação de prescrições consideradas claras. Isto implicava um caráter descritivo aos enunciados jurídicos que constituem o objeto da interpretação, tornando-os, portanto, passíveis de subsunção aos critérios de verdade ou falsidade, como num silogismo lógico. Em outras palavras, pela Escola da Exegese, a ação de interpretar corresponderia simplesmente a inserir fatos dentro de normas, as quais, por sua vez, estariam inseridas dentro de um sistema jurídico lógico e completo, sem lacunas ou antinomias.

\footnotetext{
24 “A tese fundamental da Escola é a de que o Direito por excelência é o revelado pelas leis, que são normas gerais escritas emanadas pelo Estado, constitutivas de direito e instauradoras de faculdades e obrigações, sendo o Direito um sistema de conceitos bem articulados e coerentes, não apresentando senão lacunas aparentes. O verdadeiro jurista, pensam seus adeptos, deve partir do Direito Positivo, sem procurar fora da lei respostas que nas leis mesmas seja possível e necessário encontrar. Surge, assim, a idéia de uma Dogmática Jurídica conceitual, ou de uma Jurisprudência conceituai, como objeto primordial do jurista. Ao jurisconsulto cabe, como sua tarefa por excelência, a análise cuidadosa e metódica dos textos, desenvolvida no tríplice plano gramatical, lógico e sistemático. Da interpretação dos preceitos, dos quais é necessário partir, e de sua ordenação lógica, inferem-se os institutos jurídicos, que reúnem as regras segundo diferentes centros de interesses e uma ratio juris específica. (...) O objeto de estudo do jurista é, porém, em última análise, sempre a regra de Direito, quer isoladamente, quer no seu confronto com outras regras complementares, na unidade coerente e cerrada de seus comandos, sob o enlace dedutivo de princípios ou preceitos normativos fundamentais." REALE, Miguel. Filosofia do Direito. São Paulo: Saraiva, 2002. p. 416.
} 
Outro fundamento desta Teoria Formalista seguida pela Escola da Exegese, também decorrente do "significado natural" dos termos e expressões, consiste na presunção da existência de apenas uma resposta verdadeira para cada questão jurídica. Assim, pela doutrina exegética, a única fonte do Direito era a Lei, cujos termos possuíam um significado natural que dispensava a interpretação, sendo que, apenas mediante autorização expressa dela própria é que o intérprete poderia recorrer a outras fontes para aplicá-la. Dito de outra forma, o que a Escola Exegética pregava era que a interpretação legal era algo prescindível e desnecessário, já que as normas jurídicas se inseriam dentro de um sistema completo e acabado ${ }^{25}$.

A Escola da Exegese e seu pensamento formalista tiveram espaço entre os juspositivistas do século XIX, embora hodiernamente já se encontrem ambos totalmente superados, uma vez que, como se sabe, o argumento de que as palavras possuem significado próprio, como se a relação entre estas e a realidade fosse algo natural, não é válido. De fato, as palavras somente possuem os significados que são conhecidos porque o homem, o intérprete, assim determinou. Portanto, não se trata de algo natural, mas, sim, de um fruto da linguagem humana, e, desta forma, não há como se sustentar a aplicação de critérios de verdade ou falsidade, e, sim, de correção ou incorreção, de adequação ou de inadequação, em conformidade com parâmetros que também são fixados pelo homem através da linguagem. E, como resultado da superação desta teoria, restou ultrapassada também a ideia de coesão do ordenamento jurídico, tomando espaço a noção de que uma mesma questão jurídica pode ter diversas respostas corretas, a depender da interpretação que lhe for dada.

Na mesma época em que na França se desenvolviam e tinham destaque a linha exegética, na Alemanha surgiu um movimento de caráter oposto, liderado por Savigny, denominado de Escola Histórica, que se fundamentava no argumento de que o Direito deveria refletir o espírito do povo. Em outras palavras, o Direito era concebido como fruto da evolução histórica espontânea de cada povo:

"O Direito deve ser a expressão do espírito do povo, e este, dizia Savigny, manifesta-se especialmente através de regras de caráter consuetudinário, que cabe ao legislador interpretar: - os costumes devem exprimir-se em leis,

${ }^{25}$ FIÚZA, Cezar. Direito Civil - Atualidades. Belo Horizonte: Del Rey, 2003. p. 37. 
porque somente são leis verdadeiras as que traduzem as aspirações autênticas do povo ${ }^{, 26}$.

Em outras palavras, pela Escola Histórica, o dever do Poder Legislativo seria elaborar o Direito segundo os costumes do povo para diminuir as incertezas que lhe são inerentes ${ }^{27}$. Daí a importância da Academia, e, por consequência, da Hermenêutica, para a concretização da dogmática jurídica.

A evolução da Escola Histórica levou a um cientificismo, passando de uma concepção histórica e costumeira para uma concepção formalista e científica do Direito. A dogmática jurídica teve grande impulso com a Escola Histórica, como uma forma de garantir certeza jurídica aos textos legais ambíguos e vagos fruto do costume popular. E desse formalismo exacerbado surgiram as teorias jurídicas que fundamentaram 0 positivismo que imperou durante o século XX.

O formalismo também presente na Escola Histórica forneceu as bases para a elaboração dos conceitos e teorias gerais que mais tarde informaram o Positivismo, movimento que sofreu influência da teoria sociológica de Augusto Comte e encontrou sua expressão máxima nos estudos e teorias elaborados por Hans Kelsen ${ }^{28}$, notadamente em sua obra Teoria Pura do Direito.

O Positivismo Jurídico pregava que o Direito deveria ser posto pelo Estado independentemente de valores morais, ocorrendo uma verdadeira cisão entre a justiça e a moral $^{29}$. Além disso, Kelsen entendida que todo sistema de normas jurídicas é

\footnotetext{
${ }^{26}$ REALE, Miguel. Filosofia do Direito. São Paulo: Saraiva, 2002. p. 423.

${ }^{27}$ FIÚZA, Cezar. Direito Civil - Atualidades. Belo Horizonte: Del Rey, 2003. p. 38.

28 "Do ponto de vista kelseniano, direito e moral pertencem a dois sistemas normativos distintos, separação essa que já está presente na obra de Immanuel KANT. Com efeito, para KANT a legalidade se constitui pela simples conformidade da ação com a legislação externa. É dentro dessa definição de legalidade que se fundamenta o direito. Este se refere ao mundo dos deveres externos, impostos por uma legislação jurídica, em que não se exige que a idéia interna do dever (moral) seja o motivo determinante da vontade. $O$ direito considera as relações externas de uma pessoa no que diz respeito aos efeitos que venham a causar no mundo exterior (jurídico). É o conjunto de condições nas quais a vontade de um concorda com a de outro segundo uma lei de liberdade. Dai extrai-se o princípio geral de direito, a saber: "Aja de tal modo que o livre exercício do teu arbitrio possa estar em conformidade com a liberdade de todos segundo uma lei universal". Então, toda ação que não é um obstáculo ao acordo do arbitrio de todos com a liberdade de todos segundo uma lei universal é considerada justa." CELLA, José Renato Gaziero. A Teoria da Argumentação Jurídica como proposta de uma racionalidade possivel frente à postura cética do positivismo jurídico contemporâneo. Disserção de mestrado. Universidade Federal do Estado do Paraná. 2001, p. 60.
}

29 "Enquanto a moral é uma coação interna ao indivíduo (a moral é autônoma), o direito encontra-se na legalidade exterior das ações com a força coativa da lei (o direito é heterônomo). Trata-se da regulamentação coativa das liberdades externas a fim de assegurar a ordem social, sem qualquer intenção moral, pois o direito 
hierarquizado e dinâmico, sendo a hierarquia estabelecida a partir da norma fundamental, que constitui o pressuposto de validade para todas as demais normas do sistema, enquanto o dinamismo decorreria da possibilidade de dedução de normas inferiores a partir de normas superiores.

Desta forma, Kelsen concebe o Direito numa estrutura piramidal, de modo que a norma fundamental está no topo e, abaixo (e com fundamento nela), vêm todas as demais normas jurídicas, ou seja, a norma fundamental estaria positivada na constituição, que ocupa, portanto, o topo da pirâmide, e na base da pirâmide estariam localizadas as normas individuais e concretas ${ }^{30}$.

O positivismo kelseniano colocava-se numa postura cética em relação aos fatos da vida. O Direito, para os positivistas, visava regulamentar os fatos da vida social, os quais seriam tornados o mais abstratos possível para que pudesse haver a dissociação entre estes e os valores morais a eles inerentes. Ademais, na ideologia positivista a dogmática jurídica assumiu com mais veemência o papel de elaborar os conceitos gerais destinados a limitar o Direito a um campo de atuação próprio. Como resultado disso, a jurisprudência da época passou a ser denominada de Jurisprudência dos Conceitos, exatamente em virtude de suas fundamentações se remeterem aos conceitos e teorias elaborados pela dogmática.

deve estar separado desta (que diz respeito aos deveres internos). O direito puro se obtém do mundo exterior, assim como a moral pura se obtém do foro íntimo: 'Numa acepção puramente kantiana, a heteronomia só pode ser determinada pela oposição à noção de autonomia, qualidade que a vontade tem de ser lei para si mesma. A vontade jurídica é heterônoma porque busca a lei que deve determiná-la num outro lugar: na vontade anônima dos costumes ou na vontade institucionalizada dos órgãos estatais. No âmbito legal obedecemos a regras que foram postas por outros ou pela sociedade, ou seja, não é pelo conteúdo que o Direito se distingue da moral, mas pela maneira de se tornar obrigatório. É pela diversidade da legislação que une um e outro impulso à lei, que determinamos se estamos no âmbito da legalidade ou da moralidade. $O$ Direito como liberdade externa gera a responsabilidade frente aos outros, que podenós o cumprimento das obrigações.' Como consequência dessa concepção de direito puro teremos o positivismo jurídico, que é uma convenção de direito fundada na força e não na consciência ética." CELLA, José Renato Gaziero. A Teoria da Argumentação Jurídica como proposta de uma racionalidade possível frente à postura cética do positivismo jurídico contemporâneo. Dissertação de mestrado. Universidade Federal do Estado do Paraná. 2001, p. 61. BOITEUX, Elza Antônia Pereira Cunha. O significado perdido da função de julgar. São Paulo, 1990. Tese (Doutorado em Direito). Universidade de São Paulo, p. 31-32.

30 "Se se concebe o Direito como uma ordem de coerção, a fórmula com a qual traduzimos a norma fundamental de uma ordem jurídica estadual significa: a coação de um indivíduo por outro deve ser praticada pela forma e sob os pressupostos fixados pela primeira Constituição histórica. A norma fundamental delega na primeira Constituição histórica a determinação do processo pelo qual se devem estabelecer as normas estatuidoras de atos de coação. Uma norma, para ser interpretada objetivamente como norma jurídica, tem de ser o sentido subjetivo de um ato posto por este processo - pelo processo conforme à norma fundamental - e tem de estatuir um ato de coação ou estar em essencial ligação com uma norma que o estatua. Com a norma fundamental, portanto, pressupõe-se a definição nela contida do Direito como norma coercitiva." KELSEN, Hans. Teoria Pura do Direito. Trad. João Baptista Machado. São Paulo: Martins Fontes, 1999, pág. 42. 
A interpretação, segundo a teoria positivista de Kelsen, consistiria numa operação mental que se desenvolve junto com o ato de aplicação do Direito, sob a forma de um silogismo realizado entre os escalões da norma jurídica. Efetivamente, Kelsen concebe a interpretação como a determinação cognoscitiva do sentido de um objeto. Desta forma, a interpretação jurídica seria correspondente ao conhecimento, dentro da moldura da norma jurídica, das várias possibilidades de sentidos atribuíveis a um objeto, o que implicaria a conclusão de que uma sentença judicial não seria um exemplo de uma norma individual e concreta obtida a partir da aplicação da norma geral e abstrata, mas sim a evidência de uma dentre as várias normas individuais e concretas que podem ser obtidas a partir desta mesma norma geral e abstrata. Esta ideia acaba minimizando a capacidade decisória dos juízes, que ficariam reduzidos a meros instrumentos de escolha de uma dentre as diversas interpretações possíveis. Ou seja, quando um juiz aplicasse uma norma jurídica, seu objetivo e sua função não consistiriam em dizer o sentido correto daquela norma, mas, sim, ele apenas realizaria a tarefa de escolher, dentre as várias interpretações possíveis daquela norma, a mais adequada aos fatos que compõem o caso sob julgamento. Como se vê, a interpretação, na teoria positivista, não corresponde a um ato de apreensão, mas uma escolha do juiz a partir do que o direito lhe oferece.

Assim, considerando a existência de vários níveis hierárquicos aplicáveis às normas jurídicas que compõem o ordenamento, a interpretação jurídica deveria ser realizada tendo em conta os diversos âmbitos de aplicação da norma, bem como considerando as outras normas jurídicas que the servem de fundamento. Outro aspecto relativo à interpretação no positivismo é que esta se desenvolve em dois níveis: o público, em que a interpretação é realizada pelas autoridades públicas e assim, é classificada de autêntica, e privado, em que a interpretação é feita pelos particulares em seus casos concretos, ocasião em que se denomina de interpretação privada. O legislador poderia, propositadamente, deixar um pequeno espaço na norma jurídica dentro do qual, durante a interpretação, o aplicador da norma poderia utilizar um pouco de discricionariedade para melhor aplicá-la ao caso, no que se chama de indeterminação relativa intencional da norma. Isto não significava, porém, que os valores morais do juiz devessem ser considerados na interpretação das normas e na elaboração de sua decisão. Como já dissemos acima, no positivismo, o direito e a moral são duas entidades dissociadas e distantes. Assim, independentemente de maior ou menor grau de indeterminação, a interpretação das normas jurídicas no positivismo sempre era realizada segundo a moldura 
posta pelo direito. Por fim, segundo a doutrina positivista, ao intérprete caberia tãosomente conhecer e compreender a lei de modo abstrato, independentemente do caso concreto, e a sua interpretação não seria capaz, de forma alguma, de criar o direito.

O Ceticismo ou Relativismo foi uma linha que também se desenvolveu nessa época (século XX), e baseava-se no fundamento de que a interpretação é uma atividade de valoração e decisão sobre conceitos elaborados com base na linguagem e na vontade humana, e não uma atividade de conhecimento de algo pré-existente. Os céticos se identificavam com os adeptos do Realismo Jurídico $^{31}$, corrente doutrinária surgida nos Estados Unidos a partir das ideias propostas pelo Juiz da Suprema Corte Americana Oliver Wendell Holmes, o qual propunha uma desclassificação do tradicionalismo jurídico dos tribunais para ceder lugar a uma interpretação evolutiva do Direito, mais adaptada às mudanças da consciência social. O Realismo Jurídico teve sua expressão mais radical pelos pensamentos de Jerome Frank, também juiz norte americano, que defendia a inexistência de Direito objetivo - para ele, o Direito seria uma permanente criação do juiz por meio de cada decisão proferida. Assim, o princípio da certeza do direito perdia seu fundamento, pois não é possível prever um comportamento humano. Assim, para os realistas, a certeza do direito nada mais seria do que uma forma infantil de aceitação do princípio da autoridade.

Outra tese defendida pelos adeptos do Ceticismo, com maior destaque para os estudiosos do Realismo Jurídico ${ }^{32}$, nos Estados Unidos, é a de que as lacunas e antinomias do sistema jurídico seriam supridas e resolvidas através da interpretação pelos juízes dos enunciados normativos existentes, a partir dos princípios e valores morais e culturais, de

${ }^{31}$ CELLA, José Renato Gaziero. A Teoria da Argumentação Jurídica como proposta de uma racionalidade possivel frente à postura cética do positivismo jurídico contemporâneo. Dissertação de mestrado. Universidade Federal do Estado do Paraná. 2001, pp. 93-96.

32 "O realismo jurídico sustenta que, para entender a natureza e funcionamento do Direito, deve-se realizar uma investigação empírica das atividades dos operadores do Direito. Para eles, as regras jurídicas não desempenham papel crucial nas decisões jurídicas. Revelam uma atitude cética em relação ao papel que as regras exercem na administração do Direito - este é determinado pelos juizes. De forma consciente ou não, eles atacam o princípio da legalidade, que postula que as decisões jurídicas são decorrentes de regras objetivas e neutras. Hart rebate os argumentos realistas, demonstrando que o Direito não é meramente aquilo que os juizes decidem, mas existem muitos casos classificados pelo núcleo de significado das regras jurídicas. É a noção de textura aberta da linguagem que possibilita que Hart desenvolva uma teoria intermediária entre as duas tendências opostas. Para Hart, o juiz deve aplicar o Direito nos casos claros e, nos casos de penumbra, a atividade do juiz é criativa e construtiva." STRUCHINER, Noel. Uma Análise da Textura Aberta da Linguagem e sua Aplicação ao Direito. Extrato da dissertação. Revista CEJ, Brasília, n.17,abr. jun.2002 p. 120. Disponível em http://daleth.cjf.jus.br/revista/numero17/prodacad2.pfd. Acesso em $\underline{10 \text { dez.2009. }}$. 
forma que a interpretação dos juízes efetivamente criasse normas jurídicas. Como consequência, o Poder Judiciário acabaria assumindo, neste aspecto, as funções do Poder Legislativo, e a jurisprudência dessa fase ficou conhecida como a Jurisprudência dos Interesses $^{33}$, a qual teve o mérito de introduzir a consideração de princípios e valores na interpretação das normas jurídicas.

Num meio-termo entre o formalismo da Escola da Exegese e o Ceticismo está a teoria de interpretação que Guastini ${ }^{34}$ denomina de Teoria Intermediária, que, em linhas gerais, sustenta que a atividade interpretativa pode assumir tanto o caráter de conhecimento defendido pela Escola da Exegese quanto o caráter de valoração preconizado pelo Ceticismo, a depender da situação de fato. Um dos fundamentos dessa teoria consiste na indeterminação dos termos jurídicos, numa expressa referência à textura aberta da linguagem ${ }^{35}$ já analisada por Hart, que se baseia na incompletude essencial das expressões.

Assim, Guastini ${ }^{36}$ explica que em um enunciado normativo é possível identificar um núcleo essencial "luminoso" e uma zona de penumbra. O núcleo do enunciado se identifica com aqueles casos denominados de "fáceis", envolvendo as situações "claras", enquanto os casos ditos "difíceis"37 seriam aqueles que durante o

\footnotetext{
33 “A Jurisprudência dos Interesses partia de duas idéias preponderantes. A primeira era a de que o juiz estaria obrigado a obedecer ao Direito positivo. Sua função consistia em proceder ao ajuste de interesses, do mesmo modo que o legislador. A disputa das partes apresenta um conflito de interesses. O juiz valora esses interesses e busca a valoração do legislador. Esta deverá prevalecer sobre aquela, se houver conflito. A segunda idéia era a de que, havendo lacunas na Lei, o juiz deveria desenvolver critérios axiológicos, os mesmos de que partiu o legislador, para conjugar os interesses em pauta com base naqueles valores. Assim, o juiz sempre ficará restrito aos valores embutidos na vontade do legislador." FIÚZA, Cezar. Direito Civil Atualidades. Belo Horizonte: Del Rey, 2003. pp. 43-44.

${ }^{34}$ GUASTINI, Riccardo. La Interpretación: objetos, conceptos y teorías. In: VÁZQUEZ, Rodolfo (coord.) Interpretación jurídica y decisión judicial. Cidade do México: Fontamara, 2003. p. 33. (Série Doctrina Jurídica Contemporánea).

35 "Hart diz que a textura aberta da linguagem é uma propriedade tanto de termos quanto de sentenças e regras, e faz com que estas apresentem sempre a possibilidade da existência de uma "penumbra de dúvida", na qual não se sabe com clareza se a regra deve ou não ser aplicada." STRUCHINER, Noel. Uma Análise da Textura Aberta da Linguagem e sua Aplicação ao Direito. Extrato da dissertação. Revista CEJ, Brasília, n. 17, abr. jun. 2002. pág. 120. Disponível em http://daleth.cjf.jus.br/revista/numero17/prodacad2.pfd. Acesso em 10 dez.2009.
}

${ }^{36}$ GUASTINI, Riccardo. La Interpretación: objetos, conceptos y teorías. In: VÁZQUEZ, Rodolfo (coord.) Interpretación jurídica y decisión judicial. Cidade do México: Fontamara, 2003. p. 33 (Série Doctrina Jurídica Contemporánea).

${ }^{37} \mathrm{O}$ conceito de "casos difíceis" foi inicialmente proposto por Dworkin, e corresponde às ações judiciais que não podem ser subsumidas a uma regra de direito clara, estabelecida de antemão por alguma instituição, nos quais o juiz teria o poder discricionário para decidir o caso de uma maneira ou de outra, porque mesmo nos casos em que nenhuma regra aparentemente regule o caso, ainda permanece o dever de julgar. DWORKIN, Ronald. Levando os direitos a sério. Trad. Nelson Boeira. 2. ed. São Paulo: Martins Fontes, 2007, p. 127. 
processo de subsunção cairiam na zona de penumbra ${ }^{38}$. Desta forma, ao analisar casos "fáceis", o juiz apenas interpreta e aplica as normas jurídicas de forma descritiva, subsumindo os fatos às categorias descritas nas normas sem exercer um juízo de valor. Já com relação aos casos "difíceis" 39 , o juiz interpreta construtivamente a norma, exercendo um juízo de valor e atuando discricionariamente sobre os fatos e elegendo entre os possíveis significados dos termos gerais antes de realizar a operação de subsunção dos fatos às categorias presentes nos enunciados jurídicos. Desta maneira, na primeira hipótese (caso "fácil"), a interpretação limita-se à análise do "núcleo essencial" e corresponde ao descobrimento do significado, mediante a simples operação designada pela fórmula "o texto T significa o significado S". No segundo caso (caso de “penumbra"), porém, não é possível simplesmente "descobrir" o significado do enunciado, é necessário "atribuir" o significado $\mathrm{S}$ ao texto $\mathrm{T}$ por meio da interpretação construtiva, na qual verifica-se a influência do background cultural do intérprete e cujo resultado final fica sujeito aos critérios de correção ou incorreção. Esta modalidade, a interpretação construtiva, esteve presente notadamente na fase da jurisprudência dos valores, em que a cultura passou a ser uma referência básica para a aplicação do Direito.

Com a evolução dos estudos sobre o Direito e sobre a interpretação das normas jurídicas e com o maior questionamento dos fundamentos das teorias desenvolvidas até então, os filósofos do Direito passaram rejeitar a ideia presente no Formalismo de que as palavras possuem um significado natural, adotando uma postura mais aproximada do Ceticismo e do Realismo Jurídico no sentido de que as palavras possuem a pluralidade de significados que lhe é atribuída pela vontade humana expressa pela linguagem. Desta forma, os enunciados normativos passaram a ser vistos como sujeitos a critérios de

\footnotetext{
${ }^{38}$ Manuel Atienza analisa a diferença e cita exemplos de casos fáceis e difíceis, estabelecendo também a distinção entre estes e os chamados "casos trágicos". Segundo o autor, os casos trágicos são aqueles em que não é possível encontrar nenhuma solução jurídica sem sacrificar algum elemento essencial de um valor considerado como fundamental sob o ponto de vista jurídico e/ou moral. ATIENZA, Manuel. Los Límites de la Interpretación Constitucional: De Nuevo sobre los Casos Trágicos. In: VÁZQUEZ, Rodolfo (coord.) Interpretación jurídica y decisión judicial. Cidade do México: Fontamara, 2003. p. 195-197 (Série Doctrina Jurídica Contemporánea).

${ }^{39}$ Especificamente quanto aos casos difíceis, Alexy destaca que "a tese de que a Ciência do Direito e a jurisprudência não podem prescindir de valorações não significa que não haja casos em que não exista nenhuma dúvida sobre como se deve decidir, seja por causa das normas vigentes ou pressupostas, seja por referencia a enunciados da dogmática ou a precedentes. Pode-se inclusive aceitar que esses casos são mais numerosos que os casos claros." ALEXY, Robert. Teoria da Argumentação Jurídica: A Teoria do Discurso Racional como Teoria da Justificação Jurídica. Trad. Zilda Hutchinson Schild Silva. Introd. à ed. brasileira Claudia Toledo. São Paulo: Landy, 2005. p. 39.
} 
correção ou incorreção, e não de verdade ou falsidade, como pretendia o pensamento formalista da Escola da Exegese e, de certo modo, o Positivismo.

De fato, as teorias e os pensamentos céticos e realistas foram responsáveis por quebrar o paradigma da utilização da lógica formal para a ciência jurídica, pensamento este que fazia parte do positivismo. Este rompimento foi um dos fatores da crise do positivismo. Outro fator que influenciou a crise do positivismo foi a exacerbada separação entre direito e moral presente na noção, posta por Kelsen, de que toda norma jurídica seria Direito, independente de buscar o ideal da justiça. De fato, durante o período pós-guerra, Kelsen foi muito criticado em virtude desta ideia, tendo em vista que afirmar que toda norma jurídica, independente de seu conteúdo moral, seria direito, era o mesmo que legitimar regimes totalitários ${ }^{40}$, cujas normas jurídicas tinham o único fim de manter o regime e a ordem instalada sem perseguir os ideais da justiça e sem se submeter aos seus princípios.

Além disso, a partir da noção de que a interpretação judicial é capaz de construir o Direito, começou a ter maior aceitação a ideia de que o Direito não se submete à lógica formal, a aplicação das normas jurídicas não segue um silogismo exato. A aplicação das normas jurídicas passou a ser vista sob a ótica da lógica jurídica com suas provas dialéticas e com a teoria da argumentação. Nesse sentido, destacando a relação entre a argumentação e fundamentação com a interpretação, Joseph Raz afirma que como o sucesso das interpretações é medido pelo quanto se consegue iluminar o significado de seus objetos, a interpretação tem que estar fundamentada por razões bem constituídas que demonstrem como tais significados foram encontrados ${ }^{41}$.

A separação entre o Direito e a moral passou a ser questionada também sob o prisma do jusnaturalismo, que voltou à tona quando os jusfilósofos passaram a perceber que mesmo as decisões judiciais mais simples sobre os casos mais singelos sempre possuíam alguma carga de moral e de justiça inata, pois o juiz sempre realiza um juízo de

\footnotetext{
40 “Apesar de Kelsen não rechaçar a contribuição da análise sociológica, psicológica, histórica e cultural para o Direito, de uma leitura simplista de seu pensamento se aproveitaram vários regimes ditatoriais, inclusive o brasileiro de 1964, para legitimar normas absurdas, que privavam o cidadão de seus direitos fundamentais. Tentaram, e em algum grau conseguiram, transformar os cursos jurídicos em escolinhas de leis. E tentaram, também conseguindo em certo grau, reduzir a Justiça a mera aplicadora cega e literal de normas escritas, utilizando-se de métodos arcaicos de interpretação positivista." FIÚZA, Cezar. Direito Civil - Atualidades. Belo Horizonte: Del Rey, 2003. pp. 43-44.

${ }^{41}$ RAZ, Joseph. Por qué interpretar? In: VÁZQUEZ, Rodolfo (coord.) Interpretación jurídica y decisión judicial. Cidade do México: Fontamara, 2003. p. 46. (Série Doctrina Jurídica Contemporánea).
} 
valor sobre os fatos que compõem um caso e sempre busca o fim mais justo para solucionar o caso.

Em face da crise do positivismo começaram a surgir novas teorias e novas propostas, que configuram um novo movimento chamado de Pós-Positivismo. Em linhas gerais, o pós-positivismo surge já em meados do século XX como uma superação dos ideais positivistas, no sentido de que reintroduz a noção de justiça e legitimidade, por meio dos princípios, no Direito. Além disso, o pós-positivismo prega que o Direito deve ser visto como forma de composição dos interesses, sempre buscando a segurança jurídica. Assim, na fase pós-positivista os princípios passaram a pautar a interpretação e a aplicação das normas jurídicas, uma vez que já se sabia que a lógica formal não era a mais adequada para a aplicação do Direito. Dentre os principais autores pós-positivistas, destacam-se Ronald Dworkin, Jürgen Habermas e Chaïm Perelman, sendo que este último foi o precursor da teoria da argumentação jurídica.

A teoria desenvolvida por Jürgen Habermas em sua obra intitulada de Agir Comunicativo e Razão Descentralizada ${ }^{42}$ era fundada na percepção de que existe uma intenção comunicativa como finalidade de qualquer forma de linguagem, e, por isso passou a ser chamada de "teoria do agir comunicativo". Sabendo que a finalidade da linguagem é estabelecer uma comunicação entre dois agentes, implica-se a conclusão de que existe uma racionalidade inerente a essa linguagem, tendo em vista que, caso o discurso não fosse racional, não haveria entendimento, e, desta forma, não haveria comunicação. Desta forma é possível afirmar que a razão é comunicativa, e se a razão é o que pauta o agir humano, logo a ação também é comunicativa. Então, qualquer ação racional humana visa comunicar algo a alguém. Daí parte-se para a noção de persuasão por meio da argumentação, sem a necessidade do uso da força. Assim, a aplicação do Direito seria legitimada não em virtude de valores morais, mas em virtude de argumentos racionalmente construídos pela linguagem humana no sentido de explicar a correção de determinada pretensão. Percebese, então, que com a doutrina de Habermas começam a ser estabelecidas as bases do convencimento mediante argumentação que serão mais profundamente analisados pelos filósofos dedicados à Teoria da Argumentação Jurídica que seria posteriormente formulada.

${ }^{42}$ HABERMAS, Jürgen. Agir Comunicativo e Razão Descentralizada. Trad. Lucia Aragão. Rio de Janeiro: Tempo Brasileiro, 2002. 
Por sua vez, segundo a teoria formulada por Ronald Dworkin em Levando os direitos a sério a questão central do positivismo a ser superada era o fato de que o direito não pode ser reduzido a simples estruturas normativas desprovidas de valores morais. $\mathrm{O}$ direito, conforme Dworkin, era constituído de regras e princípios, estes refletindo aos valores que inspiram todo o sistema sendo, portanto, bem mais abrangentes do que aquelas. Os princípios, desta forma, inspiram o padrão que deve ser seguido pela sociedade na busca da justiça e dos ideais morais a ela relativos, e por isso, permanecem válidos até que haja uma mudança na moral, no ethos da sociedade. Assim, Dworkin entende que o processo de interpretação e aplicação do direito deve ser pautado pelos princípios jurídicos.

Começaram a ser plantadas, então, as bases da moderna Teoria da Argumentação Jurídica, tendência que passou a ser bastante difundida já a partir de 1950 . Os principais autores que se dedicaram à Teoria da Argumentação foram Theodor Viehweg, Chaïm Perelman, Stephen Edelston Toulmin, e, dentre os mais recentes, Neil MacCormick e Robert Alexy, sendo ponto comum a todos a definitiva superação da utilização da lógica formal dedutiva à ciência jurídica, cedendo lugar à aplicação da lógica jurídica fundada na dialética e na retórica para a interpretação e aplicação do direito mediante a argumentação.

A teoria desenvolvida por Viehweg em sua obra "Tópica e Jurisprudência"43, parte do princípio de que os casos concretos devem ser o ponto central para a busca da justiça mediante aplicação do Direito. Em outras palavras, seu modo de pensar era baseado no problema jurídico que compunha cada caso, de modo que as teorias jurídicas somente deveriam ser analisadas em face do caso concreto, e não abstratamente. Viehweg entendia que, diante de um caso concreto, o intérprete teria uma gama de soluções possíveis previstas no sistema jurídico, e a escolha da melhor solução dependeria do resultado do raciocínio retórico.

Perelman ${ }^{44}$, por sua vez, entende que a interpretação das normas jurídicas deveria obedecer à lógica das provas dialéticas ${ }^{45}$ e atender aos critérios de razoabilidade e

\footnotetext{
${ }^{43}$ VIEHWEG, Theodor. Tópica e Jurisprudência. Trad. da 5. ed., alemã, rev. e ampl. Kelly Susane Alflen da Silva. Porto Alegre: Sergio Antonio Fabris Editor, 2008.

${ }^{44}$ PERELMAN, Chaïm. Ética e Direito. Trad. Maria Ermantina de Almeida Prado Galvão. 2. ed. São Paulo: Martins Fontes, 2005. p. 469 e seguintes. PERELMAN, Chaïm. OLBRECHTS-TYTECA, Lucie. Tratado da Argumentação: A nova Retórica. Trad. Maria Ermantina de Almeida Prado Galvão. 2. ed. São Paulo: Martins Fontes, 2005. p. 15 e seguintes.
} 
equidade, mas sempre com vistas à manutenção da segurança jurídica. A teoria de Perelman, denominada de Nova Retórica, era baseada, deste modo, na diferença existente entre o raciocínio jurídico, que para ele somente poderia ser apreendido em sua completado nas sentenças judiciais, e o raciocínio lógico formal, de inspiração cartesiana ${ }^{46}$. O raciocínio jurídico não visa buscar uma única solução verdadeira para o problema (como ocorreria se se utilizasse a lógica formal), mas, sim, apresentar a solução mais adequada ao caso em face das suas características, do Direito aplicável e dos princípios de justiça, da boa fé e da segurança jurídica. Não se visa, desta forma, um resultado único que exclua, mediante critérios de verdade ou falsidade, todas as demais alternativas possíveis. O que se pretende é o convencimento das partes (auditório) de que a solução dada pelo juiz para o caso é a mais adequada. O convencimento das partes deve, entretanto, ser espontâneo, deve partir delas próprias, como se elas mesmas chegassem à mesma conclusão que o juiz, sem a necessidade de coação. De fato, para Perelman, a única argumentação válida é aquela em que não há coação nem coerção, ou seja, a verdadeira argumentação retórica deve levar o auditório a concluir por si só pela adequação do entendimento exposto pelo juiz, ou vice versa. Assim, a argumentação em Perelman sempre possui a finalidade de convencer alguém, sejam as partes, o juiz, ou um júri, e por isso sua teoria foi chamada de Nova Retórica. Entretanto, o próprio Perelman reconhece que, na prática do Direito, é extremamente difícil que uma sentença seja capaz de convencer ambas as partes envolvidas num litígio, já que, necessariamente, para uma delas a decisão dada será desfavorável. Por isso é que as sentenças judiciais são impostas às partes, fazendo lei entre elas. E, assim, Perelman revela o grande desafio do Direito: convencer até mesmo aquele para o qual a sentença é desfavorável, apenas mediante a argumentação, ou seja, sem uso de coerção, de que a solução jurídica apresentada foi a mais adequada para o caso. Assim, a relevância da obra de Perelman, conforme destacado pelo Professor Manuel Atienza:

\footnotetext{
45 "Nem é demais observar que a interpretação das regras jurídicas envolve sempre um processo de estimativas, e, por conseguinte, a aplicação de método dialético que correlacione os elementos fático e normativo”. REALE, Miguel. Filosofia do Direito. São Paulo: Saraiva, 2002. p. 183.

46 “(...) Perelman considera a argumentação como um processo em que todos os seus elementos interagem constantemente, e nisso ela se distingue também da concepção dedutiva e unitária do raciocínio de Descartes e da tradição racionalista. Descartes via no raciocínio um 'encadeamento' de ideias, de tal maneira que a cadeia das proposições não pode ser mais ólida que o mais frágil dos aneis; basta que se rompa um dos anéis para que a certeza da conclusão se desvaneça. Ao contrário, Perelman considera que a estrutura do discurso argumentativo assemelha-se à de um tecido: a solidez deste é muito superior à de cada fio que constitui a trama (Perelman, 1969). Uma conseqüência disto é a impossibilidade de separar radicalmente cada um dos elementos que compõe a argumentação." ATIENZA, Manuel. As razões do Direito: teorias da argumentação jurídica. Trad. Maria Cristina Gumarães Cupertino. 3. ed. São Paulo: Landy, 2006. p. 62.
} 
"reside essencialmente em seu objetivo de reabilitar a razão prática, ou seja, introduzir algum tipo de racionalidade na discussão de questões concernentes à moral, ao Direito, à política, etc., que venha a significar algo assim como uma via intermediária entre a razão teórica (a das ciências lógicoexperimentais) e a pura e simples irracionalidade. ${ }^{, 47}$

Outro filósofo de grande importância para o desenvolvimento da interpretação das normas jurídicas e da teoria da argumentação, apesar de não ser filósofo do Direito, foi Hans-Georg Gadamer. Em resumo, observa-se que o pensamento de Gadamer era fundado em três premissas: (a) nas ciências do espírito (ciências humanas como a sociologia, a filosofia e a própria ciência jurídica), a verdade não se alcança através de um método, mas sim através da dialética, e suas proposições não ficam sujeitas à avaliação de verdadeiro ou falso, mas sim de correto ou incorreto à luz do contexto48; (b) durante o processo hermenêutico, o intérprete não se distancia do objeto interpretado, na verdade, ele interpreta aquele objeto com base no conjunto de suas experiências anteriores e à luz de seus pré-conceitos; (c) a interpretação e a aplicação da norma são como dois lados da mesma moeda, não se separam e nem constituem fases sucessivas de um procedimento. Assim, supera-se a noção de que a aplicação seria um momento posterior à interpretação da norma ${ }^{49}$.

Para Gadamer, os métodos hermenêuticos (métodos literal, sistemático, autêntico, histórico, teleológico, etc.), são apenas representativos dos diversos elementos que influenciam o intérprete. Além disso, ele rejeitava a idéia de que o intérprete somente poderia conhecer o objeto através do método. Na verdade, em relação às ciências humanas (denominadas por ele de "ciências do espírito"), ele entende que o intérprete e o objeto são, na verdade, próximos, sendo que o intérprete analisa o objeto a partir de suas précompressões e de seus pré-conceitos da vida. Ou seja, todo o background histórico-

47 ATIENZA, Manuel. As razões do Direito: teorias da argumentação jurídica. Trad. Maria Cristina Gumarães Cupertino. 3. ed. São Paulo: Landy, 2006. p. 95.

${ }^{48}$ Nesse sentido, Riccardo Guastini ensina que quem descreve as interpretações de outros, quaisquer que sejam tais interpretações, cumpre um ato lingüístico descritivo: aos enunciados do discurso descritivo se atribuem valores de verdadeiro e falso. Pelo contrario, quem interpreta um texto - de qualquer modo que o interprete - desenvolve um ato de linguagem totalmente diferente: o ato lingüístico chamado de interpretação. Aos enunciados do discurso interpretativo não se pode atribuir valores de veracidade. GUASTINI, Riccardo. La Interpretación: objetos, conceptos y teorías. In: VÁZQUEZ, Rodolfo (compág.) Interpretación jurídica y decisión judicial. Série Doctrina Jurídica Contemporánea. Cidade do México: Fontamara, 2003. pp. 29-30.

${ }^{49}$ Veremos, mais adiante, que para fins didáticos é possível considerar a aplicação da norma como uma fase sucessiva à sua interpretação, embora, na realidade, ambas ocorram concomitantemente. 


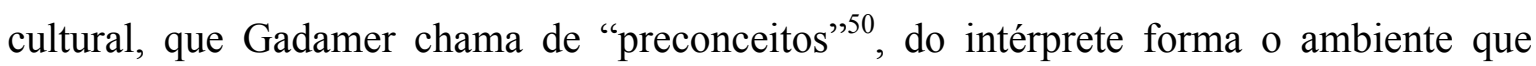
circunda e influencia a interpretação, a qual, segundo Gadamer, não ocorre segundo um único método, mas sim mediante a utilização da linguagem ${ }^{51}$ (dialética). Sendo assim, para as ciências do espírito, o resultado da interpretação corresponderia à compreensão do objeto dentro do contexto histórico-cultural do intérprete, e isso ocorre através da linguagem, da dialética, e não por meio de um método.

A crítica de Gadamer não implica, contudo, que os métodos hermenêuticos não tenham sua utilidade. De fato, embora lhes seja negado o caráter de meios para que se desenvolva o processo interpretativo, reconhece-se que tais métodos refletem os diversos aspectos e elementos que influenciam a interpretação, embora não sejam capazes de garantir a "correção" 52 do resultado. Assim, o método literal ou gramatical reflete o elemento textual, o método histórico reflete o ambiente histórico do objeto e do intérprete.

Partindo de uma outra perspectiva, Stephen E. Toulmin, em sua obra Os usos do argumento $^{53}$, introduz a noção de lógica como uma teoria da fundamentação das proposições e da expressão argumentativa ${ }^{54}$, e propõe que a argumentação jurídica é algo muito mais próximo de um debate do que de um esforço de convencimento dirigido a um auditório. Em outras palavras, a argumentação, para ele, corresponde à atividade total de propor pretensões, questioná-las, apresentar razões e contra-razões, criticá-las e apresentar réplicas a estas críticas ${ }^{55}$. Pela definição acima é possível perceber os quatro elementos que

50 GADAMER, Hans-Georg. Verdade e Método I: Traços de uma hermenêutica filosófica. Trad. Flávio Paulo Meurer. 10. ed. Petrópolis: Ed. Vozes, 2008, pp. 369-385.

51 “143. Neste estudo, será de importância fundamental o recurso à Teoria da Linguagem como meio de acesso aos conteúdos espirituais. Procedemos, muitas vezes a respeito da linguagem, como procedemos com referência ao ar, do qual só nos apercebemos quando dele sentimos falta. Tudo quanto o homem sabe, sabe através de palavras e símbolos, através da linguagem. Procurar a raiz de uma realidade muitas vezes é procurar a raiz de um vocábulo. A etimologia das palavras é manancial precioso de verdades a respeito dos fenômenos, mesmo porque as palavras raramente surgem por acaso, mas são antes postas em função de algo que se impõe inicialmente ao espírito. Nem mesmo os povos selvagens ou primitivos usam as palavras sem qualquer motivação. Nós, no Brasil, para citar só um exemplo, temos a prova maravilhosa da precisão extraordinária com que nossos indígenas davam nomes aos lugares. Ainda hoje, podemos saber qual a característica de uma região, pela precisão das palavras empregadas pelos indígenas em sua toponímia espontânea e poética.” REALE, Miguel. Filosofia do Direito. São Paulo: Saraiva, 2002. pp. 370/371.

52 Até porque, se considerarmos a perspectiva de Kelsen, nem caberia falar em “correção"da interpretação, já que, segundo o Autor, diversos resultados são possíveis e corretos, dependendo das circunstâncias.

${ }^{53}$ TOULMIN, Stephen Edelston. The uses of Argument. New York: Cambridge University Press, 2003.

${ }^{54}$ TOULMIN, Stephen Edelston. The uses of Argument. New York: Cambridge University Press, 2003. p. 6 e seguintes. 
formam o "debate" que caracteriza a argumentação: as pretensões, as razões, as garantias e os respaldos, os quais são dispostos como uma cadeia justificativa da argumentação.

Desafiando a tendência de rejeitar totalmente a lógica formal dedutiva que vinha se firmando até então, Neil MacCormick publicou em 1978 a obra Legal Reasoning and Legal Theory, traduzido para o vernáculo como Argumentação Jurídica e Teoria do Direito, na qual expôs sua teoria baseado na premissa de que a argumentação jurídica seria uma ramificação da argumentação prática, consistente na aplicação da razão por parte dos seres humanos para decidir como se comportar em uma situação em que devam realizar uma escolha ${ }^{56}$, enquanto as normas seriam formulações relativamente concretas de princípios mais abstratos ${ }^{57}$. O Autor defende veementemente que uma forma de raciocínio dedutivo é essencial para a argumentação jurídica, mas que o raciocínio dedutivo nem de longe esgota as possibilidades da argumentação, a qual possui também importantes elementos não-dedutivos que demonstram o paralelismo entre a argumentação jurídica e a argumentação moral. O raciocínio dedutivo que está presente na argumentação jurídica é bastante simples, podendo ser expresso na fórmula $\mathrm{N}+\mathrm{F}+\mathrm{C}$, em que $\mathrm{N}$ são as normas, $\mathrm{F}$ representa os fatos e C é a conclusão a que se chega. Em certos aspectos, a teoria de MacCormick aproxima-se da Teoria Intermediária explicada por Guastini anteriormente, especialmente quanto aos exemplos de casos ditos fáceis, em que há a subsunção direta pelo raciocínio dedutivo (como na fórmula acima) e para os difíceis, em que o raciocínio deve ser mais elaborado. MacCormick entende, ainda, que as decisões jurídicas devem ser lógicas e justas, apresentando, ao mesmo tempo, o raciocínio dedutivo e a argumentação jurídica.

Por fim, chegamos à Teoria da Argumentação Jurídica de Robert Alexy, que constitui o marco teórico da presente tese. A obra de Alexy, denominada de Teoria da Argumentação Jurídica - a teoria do discurso racional como teoria da fundamentação jurídica, também foi publicada originalmente na Alemanha em 1978 (sendo, portanto, contemporânea à obra de MacCormick), e se desenvolve no contexto do Racionalismo

\footnotetext{
55 ATIENZA, Manuel. As razões do Direito: teorias da argumentação jurídica. Trad. Maria Cristina Gumarães Cupertino. 3. ed. São Paulo: Landy, 2006. p. 94.

${ }^{56}$ MACCORMICK, Neil. Argumentação Jurídica e Teoria do Direito. Trad. Waldéa Barcellos. São Paulo: Martins Fontes, 2006. p. IX.

${ }^{57}$ MACCORMICK, Neil. Argumentação Jurídica e Teoria do Direito. Trad. Waldéa Barcellos. São Paulo: Martins Fontes, 2006. p. XI.
} 
europeu, sob influência da teoria da ação comunicativa de Habermas e da teoria da argumentação de Perelman, em torno da questão da fundamentação racional das decisões judiciais e da exigência dessa mesma racionalidade na argumentação que legitima tais decisões. Alexy destaca que a racionalidade, no Direito, está relacionada com a correção das assertivas que compõem o discurso jurídico, tanto sob o aspecto formal, pelo qual se verifica a racionalidade procedimental discursiva por meio da aplicação das regras da lógica do discurso, quanto sob a perspectiva material, que implica a análise do conteúdo cultural e moral das normas jurídicas, em face da finalidade primordial de promoção da justiça $^{58}$. Assim, no discurso jurídico não se exige que as assertivas sejam verdadeiras, mas sim que sejam corretas em face do ordenamento vigente. Em outras palavras, o discurso jurídico é baseado em argumentos de correção, os quais são associados aos argumentos empíricos (questões de fato) e aos argumentos dogmáticos. Desta forma, Alexy destaca a necessidade de integração entre o discurso jurídico e o discurso prático racional geral, e, tomando como parâmetro as regras e princípios do próprio sistema jurídico, sistematiza a estrutura da argumentação jurídica em formas e regras de justificação interna, que demonstram a coesão lógica do silogismo jurídico, e de regras de justificação externa, que remetem à justificação das próprias premissas do silogismo. Evidenciando a influência de Dworkin, Alexy entende que os princípios são mais genéricos e abstratos que as regras, e não prescrevem condutas, mas sim, remetem à necessidade de realização de valores morais. Já as regras são propositadamente restritas, pois visam a prescrever e regulamentar condutas humanas de forma direta. Assim, os princípios são informadores das regras.

\subsection{Lógica formal e lógica jurídica}

A lógica formal é aquela que independe da matéria corpórea para o desenvolvimento do raciocínio, sendo abstrata e geral, o que possibilita a sua aplicação nas mais diversas áreas. Assim, a lógica formal se identifica com as ciências exatas, como a matemática e a física, cujo raciocínio é eminentemente abstrato ${ }^{59}$, independente de análise de fatos. Perelman, citando Church, explica que a lógica formal relaciona-se com a análise de sentenças ou de proposições e das provas com atenção à forma em abstração à matéria.

\footnotetext{
58 ALEXY, Robert. Teoria da Argumentação Jurídica: A Teoria do Discurso Racional como Teoria da Justificação Jurídica. Trad. Zilda Hutchinson Schild Silva. Introd. à ed. brasileira Claudia Toledo. São Paulo: Landy, 2005. pp. 15-19.

${ }^{59}$ PERELMAN, Chaïm. Ética e Direito. Trad. Maria Ermantina de Almeida Prado Galvão. 2. ed. São Paulo: Martins Fontes, 2005. p. 469.
} 
Sob esta perspectiva, a lógica deixa de ser uma disciplina filosófica e passa a ser uma ciência rigorosa, especificamente dedicada ao estudo da estrutura dos sistemas logísticos ou de cálculos não interpretados ${ }^{60}$.

Porém, esta visão da lógica estritamente relacionada com as ciências exatas não permite, em princípio, que ela se aplique também para outras importantes ciências ditas não-exatas, precisamente as ciências humanas e, dentre estas, especialmente o Direito. Isto porque a lógica jurídica e o raciocínio jurídico são fundados em argumentos, os quais não podem ser demonstrados por meio de proposições sujeitas a critérios de correção ou incorreção, ao contrário da lógica formal, que necessita de provas demonstrativas, sujeitas a critérios de verdade ou falsidade, levando a uma única resposta correta $^{61}$.

Por outro lado, os argumentos jurídicos estão sujeitos a critérios de força, com base num referencial fático. É nesse sentido que Perelman explica que "o estudo dos argumentos, que nem o direito nem as ciências humanas nem a filosofia podem dispensar, não se prende a uma teoria de demonstração rigorosa, concebida a exemplo de um cálculo mecanizável, mas a uma teoria da argumentação "62. Perelman, ainda, que a lógica jurídica não foi ignorada nem mesmo por Aristóteles, que é considerado o criador da lógica formal. De fato, o Organon de Aristóteles contempla, além das obras que examinam as provas analíticas da lógica forma, obras dedicadas ao estudo da argumentação e das provas dialéticas $^{63}$.

Uma parte da doutrina entende que a lógica jurídica nada mais seria do que um ramo da lógica formal dedicada ao exame, sob o aspecto formal, das operações e processos mentais do jurista, bem como os respectivos produtos destas operações. Entretanto, uma corrente oposta defende que a lógica jurídica é estruturada de modo diverso da lógica

\footnotetext{
${ }^{60}$ PERELMAN, Chaïm. Ética e Direito. Trad. Maria Ermantina de Almeida Prado Galvão. 2. ed. São Paulo: Martins Fontes, 2005. p. 470. CHURCH, A. Introduction to Mathematical Logic. Princeton, 1956. pág. 48. v. 1. No mesmo sentido, ATIENZA, Manuel. As razões do Direito: teorias da argumentação jurídica. Trad. Maria Cristina Gumarães Cupertino. 3. ed. São Paulo: Landy, 2006. pp. 74-75.

${ }^{61}$ Nesse sentido, v. FAZZALARI, Elio. Conoscenza e Valori: Saggi. 2. ed. Torino: G. Giappichelli Editore, 2004.

${ }^{62}$ PERELMAN, Chaïm. Ética e Direito. Trad. Maria Ermantina de Almeida Prado Galvão. 2. ed. São Paulo: Martins Fontes, 2005. p. 471. PERELMAN, Chaïm. OLBRECHTS-TYTECA, Lucie. Tratado da Argumentação: a Nova Retórica. São Paulo: Martins Fontes, 2005. § 1.

${ }^{63}$ PERELMAN, Chaïm. Ética e Direito. Trad. Maria Ermantina de Almeida Prado Galvão. 2. ed. São Paulo: Martins Fontes, 2005. p. 471.
} 
formal, partindo dos exemplos fornecidos pelos casos concretos para demonstrar o raciocínio jurídico, que, segundo Atienza, consiste na conciliação de valores de equidade e segurança jurídica a procura de uma solução que seja não apenas de acordo com a lei, como também equitativa, razoável e aceitável ${ }^{64}$. Perelman, analisando criticamente estas duas linhas e seus respectivos conceitos, questiona-se se seria correto falar em lógica jurídica como um simples ramo da lógica formal, ou até mesmo se seria correto falar em "lógica jurídica" propriamente dita. De fato, este Autor critica a noção de lógica jurídica como um ramo da lógica formal, entendendo que a lógica jurídica apresenta particularidades específicas que a tornam distinta da lógica formal baseada em silogismos.

A ideia da existência de uma lógica jurídica apartada da lógica formal poderá ser melhor compreendida se traçarmos um paralelo entre ambas, partindo das diferenças conceituais entre as duas. De fato, é possível compreender a lógica jurídica em sentido estrito se aceitarmos a noção da existência de uma lógica formal dedicada exclusivamente ao exame das provas demonstrativas ou analíticas e obrigatórias, excluindo-se o exame das provas dialéticas, em contraponto a uma lógica não-formal dedicada ao estudo da argumentação, das provas dialéticas e dos conjuntos de raciocínios que permitem apoiar, criticar ou combater uma tese jurídica e também permitem fundamentar uma decisão.

Segundo a lógica formal, diante de provas formalmente corretas, não se contesta a verdade das premissas, impondo-se uma única conclusão correta, excluindo-se ou rejeitando-se todas as outras conclusões. Por outro lado, de acordo com a lógica jurídica, fundamentada em argumentos cuja força de convencimento é variável, nunca se pode dizer que a argumentação em um dado sentido exclui a argumentação em outro. $\mathrm{Na}$ verdade, a conclusão dependerá de quem interpreta a norma em questão, eis que um argumento que pode ser bastante persuasivo para um intérprete pode não o ser para outro. Ou seja, ao contrário do que ocorre na lógica formal, em que se emprega o raciocínio analítico, na lógica jurídica a prova argumentativa nunca exclui a argumentação em sentido oposto ${ }^{65}$.

Ainda comparando a lógica formal à lógica jurídica, seria possível afirmar que a argumentação desta corresponde à demonstração daquela, porém utilizando provas

\footnotetext{
${ }^{64}$ ATIENZA, Manuel. As razões do Direito: teorias da argumentação jurídica. Trad. Maria Cristina Gumarães Cupertino. 3. ed. São Paulo: Landy, 2006. p. 77.

${ }^{65}$ PERELMAN, Chaïm. Ética e Direito. Trad. Maria Ermantina de Almeida Prado Galvão. 2. ed. São Paulo: Martins Fontes, 2005. p. 492.
} 
dialéticas, e não provas analíticas ou demonstrativas. Outra diferença reside no fato de que, enquanto pela lógica formal a demonstração é absolutamente impessoal, a argumentação necessariamente se dirige a um auditório (um júri, um juiz) que se pretende convencer. Por isso é essencial conhecer de antemão este auditório, o que retira da argumentação o caráter de impessoalidade. Isso significa que o raciocínio jurídico, seguindo a lógica jurídica, sempre terá, mesmo que mínimo, um grau de pessoalidade.

Efetivamente, quando um juiz aplica uma norma, não se trata de uma mera operação de subsunção, ou de um simples silogismo, que recairiam na lógica formal. A aplicação de uma norma jurídica pressupõe muitos outros atos, já que, antes de aplicar a norma, o juiz deve primeiro avaliar os fatos e verificar (e com isso já se está exercendo um juízo de valor) se eles são, realmente, subsumíveis àquela norma. Em outras palavras, trata-se de avaliar previamente os fatos (e aí se encontra a pessoalidade da operação, revelada no juízo de valor), para só depois aplicar o Direito e decidir qual será a lei mais adequada; isso por si só já ultrapassa o silogismo ${ }^{66}$. A reconstrução da história e a valoração dos fatos que antecede a aplicação da norma dependerá necessariamente dos argumentos dialéticos apresentados pelas partes envolvidas no caso, argumentos estes que formam as provas dialéticas cuja força de convencimento é variável. Observa-se, pois, que o fato utilizar provas dialéticas consiste numa das principais diferenças entre a lógica formal e a lógica jurídica.

Outra distinção consiste em que, na lógica jurídica não existe a obrigação de estabelecer provas para todas as assertivas, e isso ocorre precisamente porque no Direito existem presunções que dispensam a produção probatória para determinados fatos. $\mathrm{Na}$ verdade, não é que ocorra uma dispensa total de prova. No caso das presunções, ocorre uma inversão do ônus da prova ${ }^{67}$. Dito de outra forma, significa que, enquanto na lógica formal todas as assertivas necessitam ser provadas, na lógica jurídica, os fatos presumidos

\footnotetext{
${ }^{66}$ Nesse sentido, Miguel Reale destaca que apenas na aparência é que há um silogismo nas sentenças: "Nunca será demais acentuar que a sentença só na aparência é um silogismo, pão sendo redutível a simples dedução formal, assim como a interpretação do Direito não é mero trabalho de Lógica formal, mas possui antes natureza dialética, implicando conexões fático-normativas segundo valores”. REALE, Miguel. Filosofia do Direito. São Paulo: Saraiva, 2002. p. 283.

67 Sobre as presunções legais, Perelman explica que "quando se trata de presunções legais, em geral nenhuma prova contrária é admitida; mas, em certos casos, a presunção não tem outro efeito senão deslocar o ônus da prova. É isso, de qualquer modo, que se passa com todas as presunções que são próprias do magistrado." PERELMAN, Chaïm. Ética e Direito. Trad. Maria Ermantina de Almeida Prado Galvão. 2. ed. São Paulo: Martins Fontes, 2005. p. 485.
} 
(como por exemplo, a presunção de inocência do Direito Penal) invertem o ônus da prova, cabendo ao acusador provar que o réu é culpado, e não este provar que é inocente.

Considerando as diferenças e semelhanças acima descritas, citamos o conceito de lógica jurídica precisamente sintetizado por Perelman:

"A lógica jurídica é uma lógica que permite levar a seu termo uma controvérsia, em que os argumentos são confrontados, em que, em cada etapa, o pró e o contra não são postos em pé de igualdade, pois as presunções intervêm em favor da tese ou da antítese, incumbindo o ônus da prova a quem se propõe derrubar essa presunção. Esse vaivém de argumentos e de contraargumentos terminará com a decisão do juiz, que decidirá quais argumentos devem prevalecer. A sentença assim emitida, com sua ratio deciendi, fará jurisprudência e se inserirá na ordem jurídica que contribui para elaborar. Bastará, no futuro, para justificar uma decisão, referir-se aos precedentes, devendo aqueles que lutam por uma reforma de jurisprudência fornecer as razões que deveriam, em sua opinião, prevalecer sobre aquelas que forma admitidas anteriormente. "68

Sendo assim, torna-se possível afirmar que a lógica jurídica seria adstrita à análise e compreensão dos argumentos jurídicos, sendo uma verdadeira lógica da argumentação, que dispensa provas analíticas e utiliza no lugar destas as chamadas provas dialéticas com o objetivo de convencer ou persuadir o auditório com a finalidade de dirimir com sua decisão uma disputa jurídica ${ }^{69}$.

A partir daí, revela-se a importância do papel desempenhado pela lógica jurídica durante o processo de escolha da norma aplicável a um caso concreto, principalmente quando a norma geral é ambígua, ou mesmo quando há conflito ou concorrência de normas. Trata-se de subsumir fatos à letra da norma, e, partindo deste ponto, extrair as consequências jurídicas pertinentes, por meio do raciocínio argumentativo. Por exemplo: durante a qualificação de um rendimento, a decisão do intérprete/aplicador do Direito, seja ele um Juiz togado ou uma autoridade administrativa,

\footnotetext{
${ }^{68}$ PERELMAN, Chaïm. Ética e Direito. Trad. Maria Ermantina de Almeida Prado Galvão. 2. ed. São Paulo: Martins Fontes, 2005. p. 504-505.

${ }^{69}$ PERELMAN, Chaïm. Ética e Direito. Trad. Maria Ermantina de Almeida Prado Galvão. 2. ed. São Paulo: Martins Fontes, 2005. p. 500.
} 
será pautada pelo raciocínio jurídico desenvolvido a partir dos argumentos que o intérprete encontrar durante o exame dos fatos e sua subsunção às normas.

Outro aspecto importante a ser considerado consiste no fato de que a lógica jurídica deve servir também para resolver questões relacionadas com as antinomias e lacunas do sistema jurídico, bem como para dirimir controvérsias relativas à interpretação literal e restritiva da norma em contraponto à interpretação teleológica da mesma. Para tanto, a lógica jurídica permite o recurso a enunciados que não estejam expressamente positivados, como é o caso dos princípios legais, e também o recurso à analogia, à teleologia e aos precedentes jurisprudências com o objetivo de fornecer fundamentos para uma decisão. Estes recursos integram as provas dialéticas que compõem os argumentos elaborados pela autoridade julgadora durante a fundamentação de uma decisão.

Em vista de todas estas características, é possível concluir, por fim, que somente por meio da lógica jurídica, ou seja, pela lógica argumentativa, é possível compreender a racionalidade das decisões jurídicas dentro do contexto do ordenamento jurídico.

\subsubsection{Raciocínio jurídico}

O raciocínio jurídico necessita da lógica jurídica para ser desenvolvido. Por seguir a lógica jurídica, as conclusões derivadas do raciocínio jurídico não estão sujeitas aos critérios de verdade ou falsidade, mas, sim de correção/incorreção ou adequação/inadequação. Os meios ideais de manifestação do raciocínio jurídico são as sentenças ou decisões proferidas pelos juízes ${ }^{70}$. É necessário notar, entretanto, que outros operadores do Direito, especialmente doutrinadores e advogados, também desenvolvem raciocínios jurídicos durante o exercício de suas funções, embora seus resultados não sejam vinculantes como as decisões e sentenças proferidas pelos juízes. Para Perelman, contudo, o raciocínio jurídico desenvolvido por operadores do Direito que não sejam os juízes constituiria, na verdade, uma forma de argumentação destinada a instruir o raciocínio jurídico, o qual, na opinião do autor belga, somente pode ser desenvolvido pelos juízes. Dito de outra maneira, o raciocínio desenvolvido por juristas em geral forneceria as razões e os fundamentos que exerceriam influência na decisão do juiz, esta sim, apta a

${ }^{70}$ PERELMAN, Chaïm. Ética e Direito. Trad. Maria Ermantina de Almeida Prado Galvão. 2. ed. São Paulo: Martins Fontes, 2005. p. 480. 
fornecer todo o conjunto de elementos que caracterizam o raciocínio jurídico. Em vista disso, verifica-se que a definição de raciocínio jurídico proposta por Perelman aproxima-se bastante do que poderia ser denominado de raciocínio judiciário, sendo, desta forma, uma concepção restritiva do termo. De fato, reconhecemos que é mais fácil visualizar todas as etapas do raciocínio jurídico numa sentença, mas entendemos que isso não significa, de forma alguma, que num artigo de doutrina ou num parecer elaborado por um advogado não haja sido desenvolvido o raciocínio jurídico. A única diferença é a força vinculante da primeira em contrapartida ao caráter de recomendação dos dois últimos, o que não afeta a existência de raciocínio jurídico em ambas as situações.

De toda forma, independentemente de quem o desenvolva, em termos de estrutura, o raciocínio jurídico se assemelha à estrutura do raciocínio prático. Em outras palavras, uma sentença judicial compreenderá, necessariamente, duas partes: a primeira, na qual o juiz expõe as razões e fundamentos que motivaram e justificaram sua decisão, e a segunda, que conterá a decisão propriamente dita.

Seria incorreto, no entanto, afirmar que a estrutura do raciocínio jurídico consiste num silogismo, em que a verdade da conclusão pode ser verificada com base na conformidade com as premissas adotadas. Se isso fosse possível, estaríamos eliminando justamente o que difere o raciocínio jurídico do raciocínio prático, ou seja, o fator “decisão" do juiz. Isto porque o caráter jurídico do raciocínio não está na dedução correta de uma conclusão a partir de premissas, mas, sim, no raciocínio anterior que permitiu o estabelecimento destas mesmas premissas pelo juiz, no juízo de valor realizado pelo juiz, com base na razoabilidade e na equidade, ao interpretar os fatos apresentados. Esse juízo de valor é, justamente, a característica que distingue o raciocínio jurídico do raciocínio prático, e é, ao mesmo tempo, o motivo que justifica a necessidade de um ser humano - o juiz - para o desenvolvimento do raciocínio jurídico. Este mesmo juízo de valor constitui, ainda, o motivo pelo qual uma decisão judicial nunca pode ser considerada absolutamente isenta, uma vez que o raciocínio do juiz para adotar as premissas que fundamentarão sua decisão é influenciado por fatores externos ao Direito.

Assim como os argumentos apresentados pelas partes litigantes ao juiz no decorrer do processo, as razões que fundamentam a decisão manifestada na sentença constituem argumentos que, ao contrário das premissas da lógica formal, não possuem poder de coerção, e, por isso, não podem obrigar uma única conclusão. Cada intérprete poderá obter conclusões diferentes a partir de argumentos idênticos. Não se trata de dizer 
se uma decisão é verdadeira ou falsa, mas sim de examinar a sua adequação e correção em face do Direito aplicável e em virtude dos fatos apresentados. Conclui-se, assim, que ao contrário das premissas, que são obrigatórias, os argumentos possuem força variável de convencimento. Por estes motivos, observa-se que, diferentemente do raciocínio lógico puro, o raciocínio jurídico não se restringe a uma simples operação de dedução lógica que se limitaria a aplicar normas gerais e abstratas a casos individuais e concretos.

O raciocínio jurídico está sujeito a alguns princípios. O primeiro deles é chamado de Princípio da Inércia do Judiciário ${ }^{71}$, segundo o qual somente é possível alterar o estado das coisas mediante a devida fundamentação. Ou seja, quem pretende modificar uma situação, deve apresentar os argumentos que forneçam razões suficientes para tal alteração.

Outro princípio que se verifica no raciocínio jurídico é o Princípio da Competência, segundo o qual somente uma Corte competente para resolver o caso em questão é que poderá proferir decisão que seja legitimamente vinculante para ambas as partes, visando à garantia da máxima imparcialidade (mesmo que esta nunca seja absoluta, como já mencionamos). Logicamente, segundo este princípio, as partes tem o direito de rejeitar uma decisão proferida por juiz incompetente.

Além disso, aplica-se ao raciocínio jurídico o Princípio da Fundamentação ${ }^{72}$, pelo qual toda e qualquer decisão judicial deve ser motivada e fundamentada, devendo o magistrado indicar claramente os motivos, razões e fundamentos de fato e de direito que lhe conduziram proferir a decisão, qualquer que seja o seu teor. Acompanhando o dever de fundamentar as decisões está o princípio da equidade, corolário da igualdade e da isonomia, que impõe o tratamento adequado de cada matéria segundo as suas particularidades e evitando a discriminação.

Observa-se ainda que o raciocínio jurídico, mesmo sendo adstrito aos moldes da lei, não constitui uma simples operação de dedução a partir de premissas estabelecidas, ou seja, não é uma mera dedução que se ateria a aplicar regras gerais a casos

\footnotetext{
${ }^{71} \mathrm{O}$ princípio da inércia proposto por Perelman será mais detidamente analisado adiante, no Capítulo 2.

72 O princípio da fundamentação será mais detidamente analisado junto com a teoria da argumentação jurídica de Alexy, adiante, no Capítulo 2.
} 
particulares $^{73}$. Isto se deve à sujeição do raciocínio jurídico aos princípios acima enumerados.

Por fim, cumpre destacar que o raciocínio jurídico apresenta em sua estrutura elementos que informam como deve ser a conduta do juiz em face dos fatos. Tais elementos são os chamados modais deônticos (é permitido/ é proibido/ é obrigatório), os quais se encontram na estrutura das normas gerais e abstratas, as quais são analisadas em item a seguir, dedicado ao objeto da interpretação jurídica.

\subsubsection{Argumentação}

Argumentação e retórica são dois conceitos que estão sempre juntos. Na verdade, a argumentação é o meio de manifestação da retórica, que é a arte de persuadir, de convencer. Esta ação de persuadir é realizada através da exposição lógica dos argumentos, cuja definição habermasiana, citada por Alexy, corresponde à "fundamentação que nos motiva a reconhecer a pretensão de validade de uma afirmação, ordem ou valoração"74. Dito de outra forma, a argumentação é baseada nas provas dialéticas, as quais correspondem justamente aos argumentos utilizados tanto num discurso quanto numa discussão (debate).

A argumentação assume ainda maior importância se imaginarmos que a ação de aplicar o Direito não é um ato mecânico sujeito às regras da lógica formal. A realização do Direito depende essencialmente dos juízos valor que são efetuados pelos órgãos julgadores. Tais juízos de valor, por sua vez, são sujeitos à influência, basicamente, de três fatores extremamente importantes: a história pessoal do julgador, sua personalidade e os argumentos expostos pelas partes.

Os dois primeiros fatores são relevantes porque, desde que se estabeleceu um Estado de Direito, determinando-se que as disputas entre os cidadãos devem ser solucionadas por um órgão judicante independente, personalizado nos juízes e tribunais, a história pessoal e a personalidade dos juízes necessariamente influenciam a interpretação

\footnotetext{
${ }^{73}$ PERELMAN, Chaïm. Ética e Direito. Trad. Maria Ermantina de Almeida Prado Galvão. 2. ed. São Paulo: Martins Fontes, 2005. p. 489. ATIENZA, Manuel. As razões do Direito: teorias da argumentação jurídica. Trad. Maria Cristina Gumarães Cupertino. 3. ed. São Paulo: Landy, 2006. pp. 59-92.

74 ALEXY, Robert. Teoria da Argumentação Jurídica: A Teoria do Discurso Racional como Teoria da Justificação Jurídica. Trad. Zilda Hutchinson Schild Silva. Introd. à ed. brasileira Claudia Toledo. São Paulo: Landy, 2005. p. 127.
} 
destes sobre os fatos jurídicos e sobre a lei. Entretanto, em virtude do imperativo da imparcialidade da justiça, a influência destes fatores é limitada pela materialidade dos fatos, à qual o juiz deve se restringir. $\mathrm{O}$ juiz deve interpretar os fatos a partir da narrativa das partes, e para formar sua decisão deverá interpretar os argumentos por elas fornecidos. Nestas duas etapas haverá a influência de sua história pessoal e de suas convicções particulares, por mais que se tente manter a abstração. Em outras palavras, isso significa que a imparcialidade e a abstração na realização do Direito nunca são absolutas, embora sejam ideais que devam ser constantemente perseguidos, sob pena de cairmos no arbítrio e violarmos as regras mais básicas do Estado democrático de Direito ${ }^{75}$.

Considerando isso, é correto afirmar que "se a lógica é vinculada à verdade e à maneira pela qual esta pode ser corretamente deduzida das premissas para a conclusão, a argumentação diz respeito à prática, às decisões e à maneira de justificá-las”, uma vez que, como já mencionamos anteriormente, a argumentação é baseada nas provas dialéticas, as quais, por sua vez, são fruto da linguagem encadeada com o intuito de persuadir.

Se as questões jurídicas e o exercício da função judiciária pudessem ser resolvidos apenas por meio da lógica formal, em meros silogismos, há de se convir que não seriam necessários juízes, pois neste caso, a jurisdição (em seu sentido de “dizer o direito") seria equivalente a um cálculo matemático, podendo ser resolvida mecanicamente, até mesmo por uma máquina. Mas, como a resolução das questões jurídicas ultrapassa o raciocínio silogístico, requerendo recurso às provas dialéticas e à argumentação, a jurisdição somente pode ser realizada por juízes capazes de avaliar e julgar ponderar os fatos e argumentos apresentados pelas partes, avaliando os valores postos em jogo de forma equilibrada e decidindo a questão conforme os princípios da justiça e da equidade. Isto é o que pode ser chamado de "julgar", ou seja, escolher, dentre as teorias apresentadas pelas partes, sustentadas por seus respectivos argumentos, a solução adequada para o caso, utilizando a razoabilidade, o bom senso e a equidade.

\footnotetext{
${ }^{75}$ No mesmo sentido é a opinião de Perelman: "Numa concepção assim, em que a intervenção do juiz não é mecânica nem arbitrária, o papel e a personalidade deste são essenciais. Não se pode pensar em eliminar o juiz, pois ele é que está no centro do debate judiciário. É nessa perspectiva que a teoria da argumentação adquire a importância que lhe concedemos. Pois é uma argumentação que, o mais das vezes, será determinante para estabelecer a convicção do juiz, é ela que lhe permitirá motivar sua decisão. (...) A personalidade dos juízes desempenha um papel essencial na administração da justiça, e são necessários, num Estado bem-governado, juízes competentes e imparciais.” PERELMAN, Chaïm. Ética e Direito. Trad. Maria Ermantina de Almeida Prado Galvão. 2. ed. São Paulo: Martins Fontes, 2005. pp. 514-516.
} 
Pode parecer que a argumentação relaciona-se somente com as alegações das partes perante o juiz, nas peças processuais apresentadas e em suas razões. Entretanto, as decisões e as sentenças também são lugares onde a argumentação é útil e necessária. Qualquer sentença ou decisão judicial é dividida em três partes: o relato dos fatos, a fundamentação legal e a decisão. É especificamente na parte da fundamentação legal, ou, numa acepção mais ampla, na parte da motivação, é que se encontra a argumentação.

A motivação de uma sentença pode corresponder tanto às razões objetivas e legais que motivaram o julgamento, quanto os motivos psicológicos que levaram o juiz a seguir determinada linha e decidir em determinado sentido. Assim, a motivação pode ser o fundamento, a legitimação ou a justificação de uma decisão. Desta forma, a sentença motivada representa uma tentativa de persuasão das partes que se associa ao dever de fundamentação das decisões judiciais e administrativas. Uma exposição de motivos bem redigida impede a arbitrariedade e possibilita uma representação fiel do raciocínio jurídico e permite que as partes conheçam com clareza as operações mentais que conduziram o juiz à sua decisão ${ }^{76}$.

Outra utilidade especialmente relevante da argumentação nas decisões judiciais relaciona-se com os casos em que existe lacuna legal ou antinomias, em que o juiz, em seu dever de jamais se furtar ao julgamento, deve convencer as partes de que a solução da antinomia ou preenchimento da lacuna legal mediante o recurso aos princípios legais foi realizado de forma adequada, por meio da interpretação dos dispositivos legais, e desta forma permitiu uma decisão justa e fundada na equidade.

No âmbito internacional, especificamente para a Corte Internacional de Justiça, a argumentação e a motivação das decisões assumem ainda maior relevância e tem uma repercussão muito maior. Isto porque as decisões proferidas por tribunais internacionais como a CIJ têm como destinatários Estados soberanos e como auditório organizações internacionais, como a própria ONU, que deixaria de legitimar o tribunal caso a motivação da decisão não fosse suficientemente convincente. Aí está a argumentação. Da mesma forma, os Estados que submetem suas disputas internacionais à CIJ também deixariam de

\footnotetext{
76 “Em direito, nenhum poder - seja o poder discricionário da administração pública, juíza da oportunidade e do interesse geral, seja o do juiz da causa, sejam os poderes de decisão da maioria de uma assembléia geral, ou de um conselho de administração ou de um particular a quem, por convenção, é confiada uma tarefa de apreciação ou de distribuição - pode exercer-se de forma arbitrária, ou seja, desarrazoada." PERELMAN, Chaïm. Ética e Direito. Trad. Maria Ermantina de Almeida Prado Galvão. 2. ed. São Paulo: Martins Fontes, 2005. p. 566.
} 
legitimá-lo caso a motivação da decisão fosse inadequada, mesmo que contrária aos seus interesses.

Como se vê, a argumentação jurídica não se restringe apenas às razões de fato e de direito apresentadas pelas partes litigantes, mas também está presente nas decisões judiciais, em sua motivação, atuando como uma justificativa do raciocínio jurídico adotado pelo julgador. É nesse sentido que Perelman ressalta que:

“motivar uma sentença é justificá-la, não é fundamentá-la de um modo impessoal e, por assim dizer, demonstrativo. É persuadir um auditório, que se deve conhecer, de que a decisão é conforme às suas exigências. Mas estas podem variar com o auditório: ora são puramente formais e legalistas, ora são atinentes às consequências; trata-se de mostrar que estas são oportunas, equitativas, razoáveis, aceitáveis. O mais das vezes, elas concernem aos dois aspectos, conciliam as exigências da lei, o espirito do sistema, com a apreciação das consequências. "77

Isto porque, o Direito é, "simultaneamente, ato de autoridade e obra da razão e

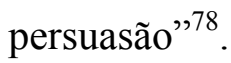

\subsection{Objeto da interpretação jurídica - da norma geral e abstrata à norma individual e concreta}

Quando se indaga sobre o objeto da interpretação jurídica, a resposta que imediatamente ocorre é: "normas jurídicas", incluindo-se nesta categoria geral as chamadas normas de conduta, as normas de estrutura e as normas de competência ${ }^{79}$. Segundo o grande mestre Norberto Bobbio, a norma jurídica é determinada através da sanção, e esta se determina por meio de aspectos de exterioridade e de institucionalização. Então, segundo Bobbio, a norma jurídica é "aquela cuja execução é garantida por uma sanção externa e institucionalizada" ${ }^{, 80}$.

\footnotetext{
77 PERELMAN, Chaïm. Trad. Maria Ermantina de Almeida Prado Galvão. 2. ed.. São Paulo: Martins Fontes, 2005. pp. 569-570.

${ }^{78}$ PERELMAN, Chaïm. Ética e Direito. Trad. Maria Ermantina de Almeida Prado Galvão. 2. ed. São Paulo: Martins Fontes, 2005. p. 570.

${ }^{79}$ BOBBIO, Norberto. Teoria do Ordenamento Jurídico. Trad. Maria Celeste Cordeiro Leite dos Santos. Rev. Claudio de Cicco. 6. ed. Brasília: Editora Universidade de Brasília, 1995. p. 33.
} 
Entretanto, esta noção não considera a necessária separação entre o texto do enunciado normativo (substrato no qual se insere a norma, por exemplo, um texto legislativo), e a norma jurídica nele contida. Nesse sentido, Sacha Calmon destaca que " $a$ norma - produto do universo legislado - se não confunde com seus veículos, os 'entes positivos' (leis, decretos-leis, etc.). Tampouco se confunde com as proposições jurídicas que a ciência do direito produz ao descrever a norma, sob a forma, quase sempre de juízos hipotéticos" ${ }^{\prime \prime 1}$. E, por isso, somente é correta se for tomada em uma acepção, digamos, ampla, do conceito de norma jurídica.

Para compreender o real objeto da interpretação jurídica é necessário, pois, estabelecer a distinção entre enunciado normativo, texto legislativo e norma jurídica.

Segundo Paulo de Barros Carvalho ${ }^{82}$, o texto consiste o suporte físico, a base material a partir da qual se produz a representação mental na consciência do homem (a significação). O texto é, pois, o ponto de partida para a construção das significações no processo que denominamos de interpretação. Desta forma, é necessário compreender o texto enquanto instância material, ou seja, o texto stricto sensu (linguagem escrita, linguagem verbal), com sua natureza essencialmente física, sendo igualmente relevante compreender o seu conteúdo, o que é possível pela análise do contexto83, ou seja, do texto em sua acepção lata, bem como dos elementos que lhe são exteriores, mas que a ele estão relacionados ${ }^{84}$. Obviamente, o texto a que nos referimos não é somente aquele que se apresenta na forma de linguagem escrita. O texto pode ser também verbal, gráfico, ou mesmo simbólico.

${ }^{80}$ BOBBIO, Norberto. Teoria do Ordenamento Jurídico. Trad. Maria Celeste Cordeiro Leite dos Santos. Rev. Claudio de Cicco. 6. ed. Brasília: Editora Universidade de Brasília, 1995. p. 23.

${ }^{81}$ COÊLHO, Sacha Calmon Navarro. Teoria Geral do Tributo e da Exoneração Tributária. 3. ed. Belo Horizonte: Del Rey, 2000. p. 88.

82 “(...) podemos mencionar o texto segundo um ponto de vista interno, elegendo como foco temático a organização que faz dele uma totalidade de sentido, operando como objeto de significação no fato comunicacional que se dá entre emissor e receptor da mensagem, e outro corte metodológico que centraliza suas atenções no texto enquanto instrumento da comunicação entre dois sujeitos, tomado, agora, como objeto cultural, e, por conseguinte, inserido no processo histórico-social, onde atuam determinadas formações ideológicas." CARVALHO, Paulo de Barros. Direito Tributário: Fundamentos Jurídicos da Incidência. 3. ed., rev. e atual. São Paulo: Saraiva, 2004. p. 18.

${ }^{83}$ Paulo de Barros Carvalho esclarece não há texto sem contexto, uma vez que a compreensão da mensagem pressupõe necessariamente uma série de associações linguísticas e extralinguísticas. Por isso é que referimo-nos ao contexto como texto em sentido lato. CARVALHO, Paulo de Barros. Direito Tributário: Fundamentos Jurídicos da Incidência. 3. Ed., rev. e atual. São Paulo: Saraiva, 2004. p. 18.

${ }^{84}$ CARVAlHO, Paulo de Barros. Direito Tributário: Fundamentos Jurídicos da Incidência. 3. ed., rev. e atual. São Paulo: Saraiva, 2004. p. 19. 
O enunciado normativo (que Paulo de Barros Carvalho denomina de "enunciado prescritivo"), geralmente expresso na forma de texto escrito, consiste na fórmula adotada pelo legislador para prescrever a norma jurídica. Assim, os enunciados normativos são as frases ou orações que compõem o texto legislativo e obedecem à estrutura proposição-hipótese (antecedente), seguida de proposição-tese (consequente), sendo a segunda modalizada pela primeira através de elementos que Von Wright denominou de modais deônticos. Os modais deônticos são elementos da lógica deôntica que determinam que, em vista de um fato hipotético, uma conduta será permitida, obrigatória ou proibida ${ }^{85}$. Por exemplo: “dada a ocorrência do fato A (antecedente), deve ser a consequência B (consequente)". A ligação estabelecida entre antecedente e consequente é realizada pelo que se denomina de modal deôntico, que corresponde ao "dever ser" $" 86$, mencionado para uma norma jurídica hipotética genérica. Citando novamente a esclarecedora lição de Paulo de Barros Carvalho:

“(os enunciados) se apresentam como frases, digamos assim soltas, com estruturas atômicas, plenas de sentido, uma vez que a expressão sem sentido não pode aspirar à dignidade de enunciado. Entretanto, sem encerrar uma unidade completa de significação deôntica, na medida em que permanecem na expectativa de juntar-se a outras unidades da mesma índole. Com efeito, terão de conjugar-se a outros enunciados, consoante específica estrutura lógicomolecular, para formar normas jurídicas, esta sim, expressões completas de significação deôntico-jurídica. ${ }^{\text {} 87}$

Analisando a norma jurídica como uma estrutura modalizada, Norberto Bobbio, com a mestria que lhe é peculiar, ensina que "a regulamentação consiste em

\footnotetext{
${ }^{85}$ Sobre a lógica deôntica, Perelman explica que ela nada tem de jurídico, já que pode ser aplicada a quaisquer enunciados que comportem elementos prescritivos, e não apenas aos enunciados jurídicos. $\mathrm{O}$ modal deôntico estabelece a ligação entre o antecedente e o consequente da norma jurídica. PERELMAN, Chaïm. Ética e Direito. Trad. Maria Ermantina de Almeida Prado Galvão. 2. ed. São Paulo: Martins Fontes, 2005. p. 491.

${ }^{86} \mathrm{O}$ modal deôntico estabelece a ligação entre o antecedente e o consequente da norma jurídica. Ele pode ser de três tipos, indicando condutas obrigatórias, permitidas ou proibidas. CARVALHO, Paulo de Barros. Direito Tributário: Fundamentos Jurídicos da Incidência. 3. ed., rev. e atual. São Paulo: Saraiva, 2004. pp. 26-30.

${ }^{87}$ CARVAlHO, Paulo de Barros. Direito Tributário: Fundamentos Jurídicos da Incidência. 3. ed., rev. e atual. São Paulo: Saraiva, 2004. pp. 60-61.
} 
qualificar uma ação através de uma das três modalidades normativas (ou deônticas) do obrigatório, do proibido e do permitido", 88

Como se vê, a norma jurídica pode ser extraída do enunciado normativo, mas não se confunde com ele. Quando se interpreta genericamente o enunciado normativo, extrai-se a norma geral e abstrata, que é a prescrição legislativa dirigida à generalidade de seus destinatários, a um conjunto indeterminado de sujeitos. Esta conclusão também pode ser extraída da obra de Maximiliano, segundo o qual:

"As leis positivas são formuladas em termos gerais; fixam regras, consolidam princípios, estabelecem normas, em linguagem clara e precisa, porém ampla, sem descer a minúcias. É tarefa primordial do executor a pesquisa da relação entre o texto abstrato e o caso concreto, entre a norma jurídica e o fato social, isto é, aplicar o Direito. Para conseguir, se faz mister um trabalho preliminar: descobrir e fixar o sentido verdadeiro da regra positiva; e logo depois, o respectivo alcance, a sua extensão. Em resumo, o executor extrai da norma tudo o que na mesma se contém: é o que se chama interpretar, isto é, determinar o sentido e o alcance das expressões do Direito „89

A tipificação de fatos ou ações no antecedente da norma confere a ela o caráter abstrato, enquanto a conduta especificada no tempo e no espaço lhe confere a concretude. Desta forma, quando se interpreta e se aplica a norma geral e abstrata ao caso concreto, dirigida a destinatários específicos, identifica-se a norma individual e concreta. Paulo de Barros Carvalho exemplifica: "pois bem, no caso das normas gerais, o antecedente o suposto anuncia a previsão de acontecimentos futuros, segundo a fórmula: 'se ocorrer o fato $F$ '. Diferente da regra individual e concreta: 'dado que ocorreu o fato $F$ '. ,90

Dados estes conceitos, é correto afirmar que o objeto da interpretação jurídica é a norma geral e abstrata ou mesmo a norma individual e abstrata. O processo de interpretação tem seu início a partir do enunciado normativo consubstanciado no texto legal e dos fatos do mundo real tal como se apresentam ao intérprete, e o resultado da

${ }^{88}$ BOBBIO, Norberto. Teoria do Ordenamento Jurídico. Trad. Maria Celeste Cordeiro Leite dos Santos. Rev. Claudio de Cicco. 6. ed. Brasília: Editora Universidade de Brasília, 1995. pp. 31-32.

${ }^{89}$ MAXIMILIANO, Carlos. Hermenêutica e aplicação do direito. Rio de Janeiro: Forense, 1994. p. 1

90 CARVAlHO, Paulo de Barros. Direito Tributário: Fundamentos Jurídicos da Incidência. 3. ed., rev. e atual. São Paulo: Saraiva, 2004. p. 37. 
interpretação fornecerá, a partir da conjugação destes, a norma individual e concreta que será aplicável para regular o caso apresentado.

\subsection{Lugares específicos da interpretação e da argumentação jurídica - as normas interpretativas do Direito Tributário brasileiro}

A interpretação e a argumentação jurídicas possuem aplicação geral em todo o ordenamento. Porém, em algumas situações específicas, sua importância e utilidade ficam mais evidentes, como é o caso das antinomias jurídicas, as lacunas legais e as expressões dúbias, vagas, ambíguas e confusas. Estas são as situações em que o juiz deve decidir socorrendo-se às analogias, aos princípios gerais do Direito, aos costumes e à equidade, pois, como se sabe, o juiz tem o dever de julgar em qualquer hipótese, não podendo se abster de decidir um caso em virtude da ausência de lei regulando o fato ${ }^{91}$.

Os lugares da argumentação jurídica não foram ignorados pelo legislador complementar brasileiro. O Código Tributário Nacional prevê, em seus artigos 107 a 112 as regras de interpretação e integração ${ }^{92}$ do Direito Tributário. Neste ponto, importa esclarecer que a integração difere da interpretação porque consiste num procedimento em que se faz necessário suprir lacunas para interpretar e aplicar a norma jurídica.

O artigo $107^{93}$ possui natureza de norma programática, cujo objetivo consiste apenas em determinar que a interpretação da legislação tributária deverá ser realizada conforme o disposto nos artigos 107 a 112. Não há maiores questionamento, portanto, quanto à norma inserida no artigo 107.

\footnotetext{
${ }^{91}$ Assim se encontra previsto na Lei de Introdução Código Civil Brasileiro: "Art. 4o Quando a lei for omissa, o juiz decidirá o caso de acordo com a analogia, os costumes e os princípios gerais de direito.", e também no Código de Processo Civil brasileiro: "Art. 126. O juiz não se exime de sentenciar ou despachar alegando lacuna ou obscuridade da lei. No julgamento da lide caber-lhe-á aplicar as normas legais; não as havendo, recorrerá à analogia, aos costumes e aos princípios gerais de direito. (Redação dada pela Lei $n^{o}$ 5.925, de 1'.10.1973). Art. 127. O juiz só decidirá por equidade nos casos previstos em lei.".

92 "Nos sistemas que adotam a sentença do juiz como o veículo por excelência de revelação do Direito, o processo de integração praticamente não existe, eis que a maneira de aplicar os princípios jurídicos aos casos concretos, levando em conta as peculiaridades de cada caso, constitui, por assim dizer, o próprio processo de aplicação do Direito à vida, dai as coleções de "precedentes" estudados minuciosamente para verificar se se adaptam ao case que está em exame, favorecendo a criação do Direito, numa elaboração interminável. (O Common Law é praticado pela Inglaterra e pelos povos que colonizou ou criou, como, v.g., a Nova Zelândia, a Austrália e os EUA)." COÊLHO, Sacha Calmon Navarro. Curso de Direito Tributário Brasileiro. 8. ed., rev. e atual. de acordo com o Código Civil de 2002. Rio de Janeiro: Forense, 2005. p. 685.
}

93 "Art. 107. A legislação tributária será interpretada conforme o disposto neste Capitulo." 
Já o artigo $108^{94}$ trata especificamente da hipótese de lacunas legais, um dos "lugares da argumentação", segundo a nomenclatura proposta por Perelman, e, por isso, será analisado em item próprio, a seguir.

Embora não mencionem diretamente em seu texto outros supostos lugares da argumentação jurídica, pela oportunidade e relação com o tema do presente item, discorreremos brevemente aqui sobre as normas contidas nos artigos 119 a 112 do CTN.

A norma do artigo $109^{95}$ revela que a inspiração do legislador foi a máxima de que os princípios não são capazes de criar regras de conduta, mas sim de informar os valores, os quais, a seu turno, estarão presentes em tais normas. A partir deste pensamento, o objetivo perseguido foi o de evitar ou combater o abuso das formas de direito privado, especialmente no que tange à realização de negócios jurídicos sem causa ${ }^{96}$ com o fim de fugir da incidência tributária. Um exemplo simples seria a constituição de uma sociedade em que um dos sócios entra com um imóvel e o outro com dinheiro na integralização dos respectivos capitais, e em seguida dissolve-se a sociedade, e o sócio que havia entrado com o dinheiro fica com o imóvel, e vice versa. Evidentemente, o objetivo das partes era realizar um contrato de compra e venda de imóvel, mas com o fim de elidir a incidência do imposto sobre transmissão de bens inter vivos, realizaram outro negócio jurídico - a

\footnotetext{
94 “Art. 108. Na ausência de disposição expressa, a autoridade competente para aplicar a legislação tributária utilizará sucessivamente, na ordem indicada:

I - a analogia;

II - os princípios gerais de direito tributário;

III - os princípios gerais de direito público;

IV - a equidade.

$\S 1^{\circ} \mathrm{O}$ emprego da analogia não poderá resultar na exigência de tributo não previsto em lei.

$\S 2^{\circ}$ O emprego da equidade não poderá resultar na dispensa do pagamento de tributo devido."
}

95 “Art. 109. Os princípios gerais de direito privado utilizam-se para pesquisa da definição, do conteúdo e do alcance de seus institutos, conceitos e formas, mas não para definição dos respectivos efeitos tributários."

96 Sobre a causa nos negócios jurídicos, Heleno Torres ensina: "E nessa tarefa de identificação dos elementos fundamentais do tratamento jurídico aplicado a algum fato ou instituto jurídico, urge analisar a "causa" do ato ou do negócio jurídico, como medida adequada de identificação, qualificação $e$ interpretação do conteúdo juridicizado. A causa é um dos elementos essenciais (gerais) do ato ou negócio jurídico, nas palavras de Antônio Junqueira de Azevedo, umas das circunstancias negociais, que, juntamente com o objeto e a forma, constituem a existência do negócio. A importância e utilidade do conceito de "causa" é perfeita. Como já se dessome, a "causa" oferece individualidade ao negócio jurídico. Nas palavras de Antônio Junqueira de Azevedo, com ênfase: 'É indispensável o exame da causa'. Por isso, ao conferir tal individualidade ao ato ou negócio jurídico, revela-se como um importante e inadaptável elemento para o procedimento de interpretação, especialmente par aos fins de aplicação de normas de Direito Tributário, que tomam o negócio jurídico como "fato" para fins de subsunção deste à hipótese normativa de um dado imposto." TORRES, Heleno Taveira. Juros sobre o capital próprio - autonomia privada nos investimentos societários e suas implicações em matéria tributária. In: Revista Internacional de Direito Tributário. Associação Brasileira de Direito Tributário. Belo Horizonte: Del Rey, 2006. p. 64. V. 4. 
constituição da sociedade -, o qual era desprovido de causa jurídica, ou seja, as partes não tinham nenhuma intenção de constituir uma pessoa jurídica para fins comerciais, mas, sim, visavam escapar da incidência do imposto que seria aplicável caso realizassem o negócio jurídico correto, ou seja, a compra e venda do imóvel.

A seu turno, o artigo $110^{97}$ impõe, antes de tudo, o princípio da interpretação das normas jurídicas conforme a Constituição, o que, em nossa opinião, nem precisaria estar previsto, uma vez que as normas jurídicas devem ser interpretadas dentro do contexto do sistema que lhes confere validade. Portanto, mesmo que não houvesse tal disposição, seria natural presumir que a interpretação das normas do Direito Tributário deve ser feita em consonância com a Constituição, inclusive com as constituições dos Estados e leis orgânicas dos municípios, dentro da esfera dos tributos de suas respectivas competências ${ }^{98}$.

Outro objetivo do artigo 110 consiste na proteção do sistema de repartição de competências mediante a proibição de alteração dos conceitos e institutos de Direito Privado utilizados na Constituição Federal, nas Constituições dos Estados ou nas leis orgânicas dos municípios nas regras que estabelecem e limitam as competências tributárias. Isto implica que conceitos como "salário", "bem imóvel”, "contrato de compra e venda", quando utilizados em dispositivos que contenham normas de determinação e limitação das competências tributárias, devem ser interpretados estritamente segundo o sentido que lhes é atribuído pelo Direito Privado, evitando, assim, o arbítrio legislativo ${ }^{99}$.

97 “Art. 110. A lei tributária não pode alterar a definição, o conteúdo e o alcance de institutos, conceitos e formas de direito privado, utilizados, expressa ou implicitamente, pela Constituição Federal, pelas Constituições dos Estados, ou pelas Leis Orgânicas do Distrito Federal ou dos Municípios, para definir ou limitar competências tributárias."

${ }^{98}$ ENTERRIA, Eduardo Garcia. Hermenêutica e Supremacia Constitucional: El principio de la interpretación conforme a la Constitución de todo el Ordenamiento. In: Revista de Direito Público. n. 77, jan. fev. mar. 1986. Ano XIX. São Paulo: Revista dos Tribunais, 1986.

99 Neste ponto, importa citar a lição de Alfredo Augusto Becker sobre a proibição de modificação dos conceitos, institutos e formas do direito tributário: "Da fenomenologia jurídica acima indicada decorre o seguinte: uma definição, qualquer que seja a lei que a tenha enunciado, deve valer para todo o direito; salvo se o legislador expressamente limitou, estendeu ou alterou aquela definição ou excluiu a sua aplicação num determinado setor do direito; mas para que tal alteração ou limitação ou exclusão aconteça é indispensável a existência de regra jurídica que tenha disciplinado tal limitação, extensão, alteração ou exclusão. Portanto, quando o legislador tributário fala de venda, de mútuo, de empreitada, de locação, de sociedade, de comunhão, de incorporação, de comerciante, de empréstimo, etc., deve-se aceitar que tais expressões têm dentro do Direito Tributário o mesmo significado que possuem no outro ramo do direito, onde originalmente entraram no mundo jurídico. Lá, por ocasião de sua entrada no mundo jurídico, é que houve uma deformação ou transfiguração de uma realidade pré-jurídica (exemplo: conceito de Economia Politica, instituto da Ciência das Finanças Públicas." BECKER, Alfredo Augusto. Teoria Geral do Direito Tributário. 2. ed., São Paulo: Saraiva, 1972. p. 111. No mesmo sentido é a lição de Ferreiro Lapatza: "La negativa a admitir 'criterios especiales de interpretacion' en Derecho Financiero es hoy ampliamente 
Em seguida, o artigo $111^{100}$ utiliza o enunciado "interpreta-se literalmente a legislação tributária que disponha sobre..." a fim de determinar que a interpretação dos fatos previstos no artigo deverá ser restritiva, o que não significa, contudo, que somente possa ser utilizado o método gramatical de interpretação. De fato, como se trata de benefícios fiscais e dispensa do cumprimento de obrigações acessórias, a interpretação deve ser restritiva em virtude do princípio da generalidade e da igualdade no Direito Tributário. Vale ressaltar, neste ponto, que todos os demais métodos hermenêuticos, especialmente a interpretação sistemática, são igualmente aplicáveis em Direito Tributário, o que a norma do artigo $111 \mathrm{fez}$ foi simplesmente estabelecer uma hipótese em que a interpretação deve ser o mais restritiva possível.

Finalizando o capítulo dedicado às normas de interpretação e integração do Direito Tributário, o artigo $112^{101}$ consagra o princípio da interpretação mais favorável ao contribuinte no caso da definição de infrações e da respectiva cominação de penalidades tributárias. Com efeito, a norma deste artigo é dirigida, em primeiro lugar, às autoridades fiscais encarregadas de aplicar a norma tributária penal, e apenas em segundo lugar, ao juiz. Caso esta ordem de destinatários fosse observada na prática, não haveria tantos processos penais tributários pendentes no judiciário, ou, os que eventualmente lá chegassem, teriam solução bem mais rápida.

Após esta breve explicação das normas de interpretação do Direito Tributário brasileiro, convém explicar que nossa análise dos lugares da argumentação jurídica não

compartida por la doctrina. La justificación de esta rotunda negativa debe arrancar, a nuestro parecer, de una consideración general que ya hemos recogido en lecciones anteriores. El Derecho Financiero, hemos dicho, ya, no es un conjunto de normas aisladas, sino un conjunto de normas que se 'funden' a un mismo nivel con la totalidad del ordenamiento. Esto quiere decir que al buscar las normas aplicables a una relación jurídicofinanciera debemos ter siempre presente el ordenamiento jurídico en su totalidad.” LAPATZA, J. J. Ferrero. La interpretación en el derecho financiero: especial referencia al derecho tributario. In: Revista de Direito Tributário. Jan. fev. mar. 1990. ano 14. v. 51, p. 7.

100 “Art. 111. Interpreta-se literalmente a legislação tributária que disponha sobre:

I - suspensão ou exclusão do crédito tributário;

II - outorga de isenção;

III - dispensa do cumprimento de obrigações tributárias acessórias. ”

101 “Art. 112. A lei tributária que define infrações, ou lhe comina penalidades, interpreta-se da maneira mais favorável ao acusado, em caso de dúvida quanto:

I - à capitulação legal do fato;

II - à natureza ou às circunstâncias materiais do fato, ou à natureza ou extensão dos seus efeitos;

III - à autoria, imputabilidade, ou punibilidade;

IV - à natureza da penalidade aplicável, ou à sua graduação." 
será restrita aos citados artigos, englobando todos aqueles que a doutrina hermenêutica menciona, para a interpretação das normas jurídicas em geral.

\subsubsection{Antinomias}

As antinomias jurídicas resultam não de uma contradição resultante da afirmação simultânea de proposições contrárias, mas, sim, da incompatibilidade entre as normas referentes a um mesmo objeto, sendo, desta forma, uma contradição de ordem prática, e não de ordem teórica. "O Direito não tolera antinomias"102. Assim, em uma situação em que existe uma antinomia, trata-se de um fato jurídico que é regulado, ao mesmo tempo, por normas contrárias ou contraditórias entre si, o que torna a sua aplicação concomitante inviável, devendo o juiz escolher uma delas.

Mas quando é que duas normas serão incompatíveis entre si? Bobbio elabora um esquema lógico de onde é possível extrair hipóteses que esclarecem as situações onde há antinomias. Confira-se o esquema abaixo:

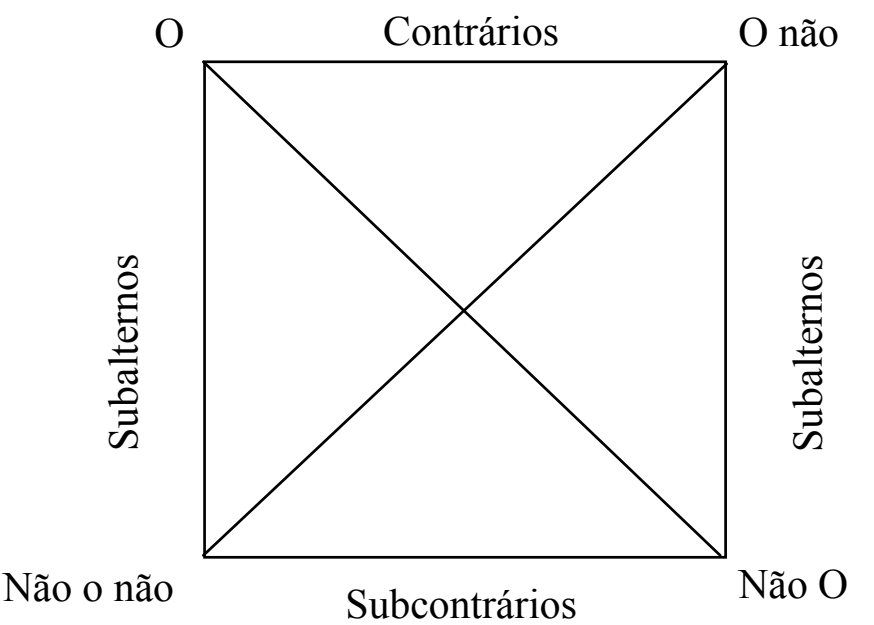

$\mathrm{O}=$ obrigatório

O não $=$ proibido

Não $\mathrm{O}=$ permitido negativo

Não O não = permitido positivo

Analisando o quadro esquemático acima, que tomamos da doutrina de Bobbio $^{103}$, é possível concluir pela existência de três hipóteses em que duas normas podem ser incompatíveis entre si: (i) uma norma ordena que algo deve ser feito e a outra proíbe aquela mesma ação; (ii) uma norma ordena fazer algo e a outra permite não fazer esta

${ }^{102}$ BOBBIO, Norberto. Teoria do Ordenamento Jurídico. Trad. Maria Celeste Cordeiro Leite dos Santos. Rev. Claudio de Cicco. 6. ed. Brasília: Editora Universidade de Brasília, 1995. p. 81.

${ }^{103}$ BOBBIO, Norberto. Teoria do Ordenamento Jurídico. Trad. Maria Celeste Cordeiro Leite dos Santos. Rev. Claudio de Cicco. 6. ed. Brasília: Editora Universidade de Brasília, 1995. p. 82. 
mesma coisa. Nesta hipótese, as normas são contraditórias entre si; (iii) uma norma proíbe determinada ação e outra permite a mesma ação. No primeiro caso, temos uma situação de contrariedade entre normas; já no segundo e no terceiro, as normas são contraditórias entre si.

Neste ponto, vale destacar a diferença entre antinomia e contradição: antinomias dizem respeito ao caráter de incompatibilidade de normas aplicáveis a um mesmo fato, enquanto a contradição consiste na negação de uma norma pela outra, como se uma estabelecesse um preceito verdadeiro e outra dispusesse uma falsa assertiva a respeito do mesmo fato. As contradições podem, dessa forma, ser puramente formais, já as antinomias pressupõem a interpretação ${ }^{104}$.

Dito de outra maneira, haverá uma antinomia na situação em que, ao mesmo tempo, uma norma obriga e outra pró́be, uma obriga e a outra permite, ou uma proíbe e a outra permite o mesmo comportamento, desde que ambas as normas sejam pertencentes ao mesmo ordenamento (pois devem ter o mesmo fundamento de validade ${ }^{105}$ ), devendo haver também coincidência quanto ao âmbito de validade de tais normas. Quanto a este último requisito, é importante lembrar que o âmbito de validade das normas é divido em quatro aspectos: temporal, espacial, pessoal e material.

Então, considerando os aspectos do âmbito de validade, é possível determinar 3 categorias de antinomias.

1) Antinomias do tipo Total-Total: ocorrem quando o âmbito de validade é totalmente incompatível. Por exemplo, a norma "É proibida a permanência de homens no alojamento feminino entre 20:00 e 8:00" é totalmente incompatível com a norma "É permitida a permanência de homens em qualquer horário no alojamento feminino".

2) Antinomias do tipo Parcial-Parcial: ocorrem quando a incompatibilidade afeta apenas parte do âmbito de validade das normas. Por exemplo, existirá

\footnotetext{
${ }^{104}$ Sobre as antinomias jurídicas, Perelman entende que, em Direito, ocorrem apenas as antinomias formais, e esclarece que "uma contradição puramente formal, ou seja, literal, não basta para ocasionar uma antinomia, pois o juiz, ao interpretar os textos, pode dar aos mesmos signos um sentido diferente ou outro campo de aplicação, de modo que se evite o conflito de normas; ele pode também descartar a aplicação de uma das normas, seja porque ela se opõe a uma lei superior, seja porque ele a considera tacitamente abrogada por uma lei posterior." PERELMAN, Chaïm. Ética e Direito. Trad. Maria Ermantina de Almeida Prado Galvão. 2. ed. São Paulo: Martins Fontes, 2005. pp. 633. 639.

${ }^{105}$ Sobre a validade das normas jurídicas, v. BECKER, Alfredo Augusto. Teoria Geral do Direito Tributário. 2. ed. São Paulo: Saraiva, 1972. pp. 79-81.
} 
antinomia parcial entre as normas "É proibido o acesso de pessoas não identificadas após às 19:00" e "É proibido o acesso de pessoas não identificadas". A incompatibilidade, neste caso, reside no âmbito pessoal da norma, ou seja, enquanto uma proíbe apenas o acesso de pessoas não identificadas após as 19:00, a outra proíbe o acesso de quaisquer pessoas em qualquer horário.

3) Antinomias do tipo Total-Parcial: ocorrem quando o âmbito de validade de uma norma é mais restrito que o da outra, mas é, ao mesmo tempo, igual em parte ao âmbito da outra. Neste caso, a primeira norma não poderá ser aplicada em nenhum caso se estiver em conflito com a segunda, já a segunda, por possuir um escopo de aplicação mais largo, poderá ser aplicada, em algumas hipóteses, sem colidir com a primeira. Por exemplo: "É proibida a utilização de câmeras fotográficas dentro do museu" é totalmente incompatível com a norma "É proibida a utilização de câmeras fotográficas dentro do museu, exceto por jornalistas e pesquisadores cadastrados". O âmbito de aplicação da segunda é maior que o da primeira, já que permite que jornalistas e pesquisadores cadastrados utilizem câmeras dentro do museu. Outro exemplo: "É proibida a utilização de aparelhos eletrônicos após o fechamento das portas e durante o voo" representa uma antinomia do tipo total-parcial com a norma "É proibida a utilização de aparelhos eletrônicos que possuam tecnologia de transmissão sem fio após o fechamento das portas do avião". Ou seja, no primeiro caso, ficam proibidos todos os aparelhos eletrônicos durante o voo, já no segundo após o fechamento das portas do avião é possível utilizar aparelhos eletrônicos, desde que estes não utilizem tecnologia de transmissão sem fio. ${ }^{106}$

Os exemplos e as categorias acima explicados ilustram as situações em que se trata das antinomias próprias, ou seja, as verdadeiras antinomias jurídicas. Porém é possível, ainda, a existência de antinomias que decorrem da incompatibilidade não das normas em si, mas dos valores que as informam. Esta é a categoria das antinomias

${ }^{106}$ BOBBIO, Norberto. Teoria do Ordenamento Jurídico. Trad. Maria Celeste Cordeiro Leite dos Santos. Rev. Claudio de Cicco. 6. ed. Brasília: Editora Universidade de Brasília, 1995. pp. 82-90. 
impróprias, como seria o caso em que uma norma cujo objetivo seja garantir a liberdade do indivíduo entre em conflito com outra que vise garantir a segurança e a ordem pública.

Tal como ocorre no caso das antinomias verdadeiras, as antinomias impróprias podem ser classificadas em três grupos:

1) Antinomias de princípios: ocorrem quando, apesar de as normas jurídicas não conterem mandamentos incompatíveis entre si, há incompatibilidade dos princípios que as informam, ou nos valores que visam proteger. Nestes casos, geralmente o juiz recorre à equidade ou a sobreprincípios para resolver a questão, ponderando qual dos bens jurídicos requer mais proteção naquele momento.

2) Antinomias de avaliação: que se verificam quando, por exemplo, uma norma atribui uma sanção leve a um delito grave, enquanto outra atribui uma sanção rigorosa a um delito leve. Aqui, a aparente antinomia (aparente porque, como vimos, não há incompatibilidade entre as normas) aproxima-se mais da injustiça. A característica comum entre as duas é que ambas requerem uma correção, porém por motivos distintos, já que na antinomia é necessário corrigir uma incerteza, enquanto a desigualdade é a razão pela qual uma injustiça deve ser eliminada.

3) Antinomias teleológicas: ocorrem quando há uma oposição entre a norma que determina o meio para se alcançar um fim, e a norma que estabelece o fim propriamente dito, de forma que se seguirmos o meio previsto na primeira, não atingiremos o fim previsto na segunda, e vice-versa. Nesta situação, verifica-se muitas vezes que nem se trata de antinomia, mas sim de lacuna.

Uma vez compreendidas as hipóteses possíveis para as antinomias jurídica, tanto as autênticas quanto as impróprias, é interessante notar que o problema possui, ainda, outros quatro aspectos que devem ser analisados. O primeiro deles diz respeito a não ser imprescindível que duas normas do direito positivo sejam simultaneamente inaplicáveis. É necessário apenas que duas normas incompatíveis sejam prescritas simultaneamente e sejam igualmente válidas para solucionar uma mesma questão, sendo, contudo, possível, que ambas as normas incompatíveis tenham sua origem em um único e mesmo texto. 
O segundo aspecto é referente à relação entre as ordens jurídicas interna e internacional. Por exemplo, se uma norma do Direito internacional somente for aplicável enquanto não viole a ordem pública internacional, qual seria a fonte do Direito internacional de onde emanariam as regras legítimas para determinar o que constituiria tal violação?

O terceiro ponto diz respeito à possibilidade de aplicação simultânea de duas normas tais como enunciadas. Este tipo de antinomia é de relativa simplicidade, já que, como se sabe, as normas jurídicas não são aplicadas tal como enunciadas, mas, sim, da forma como forem interpretadas. Neste caso, é possível perceber que a interpretação pode ter duas fases, a primeira, em que o aplicador lê superficialmente as duas normas e conclui pela possibilidade de sua aplicação simultânea, e a segunda, esta voltada à solução da antinomia supostamente criada pela primeira, em que o aplicador interpreta ambas as normas com vistas a determinar qual das duas será aplicável ao caso concreto.

Por fim, o quarto aspecto relaciona-se com a zona de penumbra existente entre a ocorrência de uma antinomia e a violação de um dispositivo de lei por uma autoridade hierarquicamente subordinada. Isso ocorre, por exemplo, quando tribunais independentes são concomitantemente competentes para julgar uma mesma questão, sob perspectivas opostas. Por exemplo, uma questão relativa à violação de um tratado cujas normas ocupam posição hierárquica equivalente às normas constitucionais pode ser julgada tanto por uma Corte internacional quanto pela Suprema Corte de um país. E, neste caso, ambos os tribunais examinarão a questão sob perspectivas distintas, podendo levar a conclusões incompatíveis entre si.

Como se vê a partir dos quatro aspectos mencionados acima, a questão das antinomias tem sua origem e seu fim na própria interpretação. Isto porque uma antinomia jamais é puramente formal, toda antinomia é fruto da interpretação equivocada de um preceito jurídico, e a sua solução será obtida a partir de uma nova interpretação que se baseie, ora nos critérios tradicionais de solução de antinomias (critério da hierarquia: lex superior derrogat inferior, critério cronológico: lex posteriori derrogat lex priori e critério da especialidade: lex specialis derrogat lex generalis $)^{107}$. Estes critérios são aplicáveis

\footnotetext{
${ }^{107}$ Tais critérios encontram-se previstos na Lei de Introdução ao Código Civil: “Art. $2^{\circ}$. Não se destinando à vigência temporária, a lei terá vigor até que outra a modifique ou revogue, $\S 1^{\circ}$. A lei posterior revoga a anterior quando expressamente o declare, quando seja com ela incompativel ou quando regule inteiramente a matéria de que tratava a lei anterior, $\S 2^{\circ}$. A lei nova, que estabeleça disposições gerais ou especiais a par
} 
apenas às antinomias solúveis, ou seja, aquelas meramente aparentes. Já para as antinomias reais, envolvendo normas contemporâneas, de mesmo nível hierárquico e gerais, ou então contemporâneas, de mesmo nível e individuais, a solução não é atingível mediante tais critérios, é imprescindível o recurso à teoria da argumentação e os princípios gerais da justiça e equidade para eliminar uma das normas, eliminar as duas, ou então, manter as duas, eliminando-se, ao invés disso, a incompatibilidade existente entre elas.

\subsubsection{Lacunas}

A interpretação jurídica também desempenha relevante papel na solução das lacunas normativas. A noção de lacuna jurídica está estritamente associada à ideia de completude (ou incompletude) do ordenamento. Como ensina Bobbio, quando é possível demonstrar que "nem a proibição nem a permissão de um certo comportamento são dedutíveis do sistema, da forma que foi colocado, é preciso dizer que o sistema é incompleto e que o ordenamento jurídico tem uma lacuna". 108

As noções de coerência e de completude do sistema são muito bem explicadas por Bobbio:

"Portanto, o nexo entre coerência e completude está em que a coerência significa a exclusão de toda a situação na qual pertençam ao sistema ambas as normas que se contradizem; a completude significa a exclusão de toda a situação na qual não pertençam ao sistema nenhuma das normas que se contradizem. Diremos 'incoerente' um sistema no qual existem tanto a norma que proíbe um certo comportamento quanto aquela que o permite; 'incompleto', um sistema no qual não existem nem a norma que proíbe um certo comportamento nem aquela que o permite. "109

Assim, dizemos que existe uma lacuna quando a norma é incompleta, quando os fatos escapam às definições nela previstas e, se fosse apenas pela lógica formal,

das já existentes, não revoga (salvo se houver incompatibilidade) nem a modifica a lei anterior, $\S 3^{\circ}$. Salvo disposição em contrário, a lei revogada não se restaura por ter a lei revogadora perdido a vigência."

${ }^{108}$ BOBBIO, Norberto. Teoria do Ordenamento Jurídico. Trad. Maria Celeste Cordeiro Leite dos Santos. Rev. Claudio de Cicco. 6. ed. Brasília: Editora Universidade de Brasília, 1995. p. 115. Confira-se também: BIANCO, João Francisco. Transparência Fiscal Internacional. São Paulo: Dialética, 2007, pp. 95-98.

${ }^{109}$ BOBBIO, Norberto. Teoria do Ordenamento Jurídico. Trad. Maria Celeste Cordeiro Leite dos Santos. Rev. Claudio de Cicco. 6. ed. Brasília: Editora Universidade de Brasília, 1995. p. 116. 
restariam sem solução. Alguns autores entendem que a lacuna legal ocorre quando uma matéria não é regida pela lei, ou quando algum aspecto material de um fato jurídico não se encontra regulamentado pela norma jurídica ${ }^{110}$.

Entretanto, é necessário destacar que a ausência de tipificação expressa no texto da lei não constitui, a rigor, uma lacuna, já que existem diplomas normativos que não enumeram taxativamente todas as situações em que devem ser aplicados, utilizando, em vez de listas taxativas, termos genéricos que permitem uma aplicação mais extensa mediante a interpretação judicial. Apenas em situações específicas, como no Direito Penal, e em alguns casos, no Direito Tributário, a ausência de menção expressa do fato na norma constitui uma lacuna. E, mesmo nestes casos, às vezes pode nem se tratar de lacuna, mas, sim, de opção legislativa de deixar de fora da lei certos fatos.

As lacunas jurídicas são divididas em dois grupos, as lacunas próprias e as lacunas impróprias. A primeira é aquela que se revela dentro do próprio sistema jurídico, já a segunda é oriunda da comparação do sistema jurídico real com um sistema ideal. Em face destas características, Bobbio estabelece de modo bastante objetivo a distinção entre ambas, ensinando que:

"num sistema em que cada caso não-regulamentado faz parte da norma geral exclusiva (como é geralmente um código penal, que não admite extensão analógica) não pode haver outra coisa além de lacunas impróprias. O caso não regulamentado não é uma lacuna do sistema porque só pode pertencer à norma geral exclusiva, mas, quando muito, é uma lacuna que diz respeito a como deveria ser o sistema. Temos a lacuna própria somente onde, ao lado da norma geral exclusiva, existe também a norma geral inclusiva, e o caso nãoregulamentado pode ser encaixado tanto numa quanto na outra. O que têm em comum os dois tipos de lacunas é que designam um caso não-regulamentado pelas leis vigentes num dado ordenamento jurídico. O que as distingue é a forma pela qual podem ser eliminadas: a lacuna imprópria somente através da formulação de novas normas, e a própria, mediante as leis vigentes. As

\footnotetext{
110 MELlo, Osvaldo Aranha Bandeira de. Princípios Gerais de Direito Administrativo. 3. ed., v. 1 Introdução. São Paulo: Malheiros, 2007, pp. 408-409. EZQUIAGA, Francisco Javier. Argumentos Interpretativos y Postulado del Legislador Racional. In: VÁZQUEZ, Rodolfo (coord.) Interpretación jurídica $y$ decisión judicial. Cidade do México: Fontamara, 2003. pp. 163-164. (Série Doctrina Jurídica Contemporánea).
} 
lacunas impróprias são completáveis somente pelo legislador; as lacunas próprias são completáveis por obra do intérprete." 111

$\mathrm{Na}$ verdade, afora os casos em que é essencial uma enumeração taxativa dos fatos abrangidos pela lei (como no caso da tipificação criminal), entendemos que a lacuna jurídica surge quando é realizada uma interpretação muito literal e restritiva do texto da norma. Assim, a argumentação serve justamente para auxiliar na tarefa de interpretar a norma jurídica incompleta, tarefa que a lógica formal isoladamente não consegue cumprir, auxiliando o aplicador do Direito, neste caso, durante o recurso à analogia, aos princípios do direito, aos costumes e à equidade, como determina o artigo $4^{\circ}$ da Lei de Introdução ao Código Civil.

A necessidade de suprimir lacunas, evidenciando a necessidade de completude do sistema, deriva de dois princípios: primeiro, do princípio pelo qual o juiz não pode fugir do seu dever de julgar, em qualquer caso; e, em segundo lugar, o princípio de que todo caso deve ser julgado mediante aplicação de uma norma oriunda do ordenamento jurídico.

Assim, muitas vezes é necessário criar a norma jurídica através da interpretação e da aplicação dos princípios jurídicos. A diferença é que a eficácia desta norma, como se sabe, não será ampla, mas, sim, restrita às partes envolvidas na disputa.

Se por um lado é possível eliminar uma lacuna e preencher o espaço com uma norma jurídica fruto da interpretação judicial, a interpretação, isoladamente, não será capaz de resolver os vazios normativos, ou lacunas impróprias. Estes se diferenciam das lacunas próprias porque, conforme já ressaltado por Bobbio ${ }^{112}$, somente podem ser preenchidos pelo legislador. Um exemplo de "vazio" legislativo, citado por Perelman ${ }^{113}$, é a

${ }^{111}$ BOBBIO, Norberto. Teoria do Ordenamento Jurídico. Trad. Maria Celeste Cordeiro Leite dos Santos. Rev. Claudio de Cicco. 6. ed. Brasília: Editora Universidade de Brasília, 1995. pp. 143-144.

112 BOBBIO, Norberto. Teoria do Ordenamento Jurídico. Trad. Maria Celeste Cordeiro Leite dos Santos. Rev. Claudio de Cicco. 6. ed. Brasília: Editora Universidade de Brasília, 1995. pp. 143-144.

113 Para esclarecer o conceito de "vazio" legal, Perelman cita o seguinte exemplo: "Vamos esclarecer nosso pensamento com um exemplo concreto, que constitui um caso indiscutido e 'vazio' de uma legislação. Sabese que em Israel, atualmente, continuando uma situação anterior à criação do Estado, todas as questões relativas ao estado das pessoas são da alçada de tribunais religiosos, competentes em virtude da religião dos interessados. Não existe registro civil, e os funcionários e tribunais civis são incompetentes na matéria, salvo para as questões que podem ser evocadas à Corte Suprema. Daí resulta não existir nenhuma autoridade civil que seja qualificada para solucionar as questões relativas ao casamento e ao divórcio das pessoas, das quais nenhum tribunal religioso deseja ocupar-se, por exemplo, casamento ou divórcio de incréus, casamento entre pessoas de religião (sic) diferentes que não são tolerados por nenhuma das religiões conhecidas, etc. Trata-se nitidamente de um 'vazio' do direito israelense, que nenhum juiz israelense poderia preencher, pois não poderia modificar o próprio espírito de uma legislação, que se 
inexistência de registro civil em Israel. As anotações referentes ao estado civil das pessoas são de incumbência de tribunais religiosos, cuja competência é definida de acordo com a religião da pessoa. Assim, por exemplo, se uma pessoa se declarar ateia, ela não poderá ter registro civil, simplesmente porque não haverá tribunal religioso competente para tal ato. $\mathrm{E}$ um juiz de Direito nada poderia fazer a respeito, já que inexiste a norma jurídica definindo que os registros de estado civil devam ser realizados em cartórios. É necessário que o legislador supra este vazio legislativo, criando a norma por inteiro. Este exemplo permite diferenciar claramente o 'vazio' das 'lacunas'. Haveria uma lacuna, e não um vazio, se, por exemplo, se a norma que regulamenta o registro civil restringisse esse direito apenas aos cidadãos nascidos em Israel e filhos de pais israelenses, deixando de regulamentar os casos de indivíduos nascidos em Israel mas que sejam filhos de pais de outras nacionalidades. Este seria um clássico exemplo de lacuna legal, que poderia ser corrigido pelo juiz mediante a lógica e a interpretação jurídicas que, exigindo a aplicação dos princípios de isonomia, dignidade da pessoa humana e equidade, indubitavelmente permitiriam extensão do direito de obtenção do registro civil a tais indivíduos. Como se percebe a partir dos dois exemplos acima, enquanto diante de uma lacuna, o juiz pode utilizar a interpretação e a lógica jurídica para preenchê-la, em face de um vazio legislativo, o juiz nada pode fazer.

Agora, trazendo a análise para o Direito Tributário nacional, observa-se que o legislador tributário tratou das lacunas no artigo 108 do Código Tributário Nacional. Nele, o legislador complementar determinou que a supressão de uma lacuna legal se dará mediante interpretação e integração mediante recurso à analogia, aos princípios gerais de Direito Tributário e de Direito Público, e também segundo a equidade. Foram estabelecidos, desta forma, os limites aplicáveis à interpretação do Direito Tributário, com evidente inspiração no respeito ao princípio da legalidade formal e material, e também da isonomia tributária, especialmente quando tomamos em consideração os enunciados prescritos nos dois parágrafos do artigo 108.

Assim, analisaremos nos itens a seguir dois dos recursos previstos pelo legislador para a nortear a integração do Direito Tributário e suprir as lacunas eventualmente constatadas. Esclarecemos, porém, que a análise dos princípios de Direito Tributário e do Direito Público, por ser mais extensa, será realizada em capítulo separado.

exprime pela inexistência de certas instituições, tal como o registro civil.” PERELMAN, Chaïm. Ética e Direito. Trad. Maria Ermantina de Almeida Prado Galvão. 2. ed. São Paulo: Martins Fontes, 2005. p. 647. 


\subsubsection{Analogia}

A analogia consiste no principal motivo pelo qual os ordenamentos jurídicos tendem a se expandir além dos casos expressamente regulamentados em suas normas positivadas. Isto porque a analogia corresponde, precisamente, ao "procedimento pelo qual se atribui a um caso não-regulamentado a mesma disciplina de um caso regulamentado semelhante" ${ }^{\text {114 }}$. Ou, nos dizeres de Oswaldo Aranha Bandeira de Mello, a analogia corresponde a um "método de aplicação da lei aos casos por ela não regulados nos quais há identidade de razão a justificar a sujeição de hipótese ao seu preceito, ante a semelhança de situações que as unifica, por traço comum entre o objeto de consideração da lei e o outro por ela não cogitado. ${ }^{115 ", ~ E m ~ o u t r a s ~ p a l a v r a s, ~ a ~ a n a l o g i a ~ t e m ~ o ~ o b j e t i v o ~ d e ~}$ integrar as normas legais mediante aplicação da norma jurídica a um fato concreto que não se encontrava nela previsto, mas que possua características semelhantes ${ }^{116}$ ao fato descrito na sua hipótese de incidência.

A semelhança fática que deve ser constatada para a aplicação da analogia pode ser compreendida mediante a formulação de um silogismo, no qual a premissa menor exprime uma relação de semelhança, e não de identidade. Por exemplo: se os homens são seres vivos e têm direito à vida, e animais são seres vivos, logo, animais têm direito à vida. Entretanto, não é a constatação de qualquer semelhança que permitirá a aplicação da analogia. A semelhança deve ser relevante para os fins do direito que se pretende aplicar. Assim, no exemplo acima, se a semelhança fosse somente o fato de que tanto homens

${ }^{114}$ BOBBIO, Norberto. Teoria do Ordenamento Jurídico. Trad. Maria Celeste Cordeiro Leite dos Santos. Rev. Claudio de Cicco. 6. ed. Brasília: Editora Universidade de Brasília, 1995. p. 151.

115 MELlo, Osvaldo Aranha Bandeira de. Princípios Gerais de Direito Administrativo. 3. ed., vol. 1 Introdução. São Paulo: Malheiros, 2007, p. 414.

${ }^{116}$ Embora a semelhança fática seja o fundamento para a aplicação da analogia, o Direito não estabelece os critérios que devam ser obedecidos para se constatar uma situação de semelhança. Assim, a observação fática da semelhança fica a cargo do intérprete e do aplicador do Direito. Nesse sentido, Francisco Javier Ezquiaga explica: "Tampoco el derecho proporciona al juez ninguna pauta para determinar cuándo dos casos son semejantes o gozan de igual razón, de tal modo que se le permite apreciarlo de forma completamente libre. Ello trae consigo que se aquí donde se concentre el nudo fundamental de los problemas derivados del argumento analógico, ya que el nexo que justifica la extensión de la regulación de un supuesto a otro distinto - precisamente, la similitud entre ellos - queda sin justificarse o, en el mejor de los casos, se justifica exclusivamente a partir de los valores propios del juez." EZQUIAGA, Francisco Javier. Argumentos Interpretativos y Postulado del Legislador Racional. In: VÁZQUEZ, Rodolfo (coord.) Interpretación jurídica $y$ decisión judicial. Cidade do México: Fontamara, 2003. pp. 165-166. (Série Doctrina Jurídica Contemporánea). 
quanto animais podem caminhar, então isso não seria suficiente para garantir o direito à vida mediante a analogia.

Especificamente para fins de interpretação do Direito Tributário ${ }^{117}$, é importante, neste ponto, estabelecer a distinção entre os conceitos de analogia e de interpretação extensiva das normas. Diversamente da analogia, já conceituada acima, a interpretação extensiva visa determinar o alcance de um conceito indeterminado previsto na própria norma tributária, não sendo ultrapassado o limite da previsão normativa. Assim, a diferença entre ambas reside, precisamente, nos efeitos de uma e de outra. Enquanto pela analogia cria-se uma nova norma jurídica mediante a interpretação, já na interpretação extensiva, estende-se a norma para os casos não expressamente previstos nela ${ }^{118}$.

Um exemplo comum de interpretação extensiva está na legislação do imposto sobre circulação de mercadorias, que incide sobre o fornecimento de alimentos e bebidas em bares, restaurantes e "similares". Pois bem, quais seriam tais similares? A interpretação extensiva permitirá a conclusão de que podem ser considerados na categoria dos "similares" uma mercearia, um botequim, ou mesmo uma boite.

É interessante também distinguir os conceitos de analogia legal (analogia legis) e analogia jurídica (analogia juris). Nesse aspecto, pela clareza da exposição, vale citar a lição do administrativista Oswaldo Aranha Bandeira de Mello:

"Distingue-se a analogia em legal e jurídica. A legal diz respeito à aplicação da lei a caso por ela não regulado mas no qual há identidade de razão e semelhança de situação jurídica. Já, a jurídica diz respeito à aplicação dos princípios das instituições do direito positivo, isto é, dos princípios resultantes do sistema jurídico, a caso onde há identidade de razão e semelhança de situação jurídica.

Assim, há analogia legal quando se aplica texto de lei regulando a responsabilidade das estradas de ferro no transporte de mercadorias em caso de transporte por estrada de rodagem.

\footnotetext{
117 LAPATZA, J. J. Ferrero. La interpretación en el derecho financiero: especial referencia al derecho tributario. In: Revista de Direito Tributário. Jan. fev. mar. 1990. ano 14. v. 51, pp. 7-10.

${ }^{118}$ BOBBIO, Norberto. Teoria do Ordenamento Jurídico. Trad. Maria Celeste Cordeiro Leite dos Santos. Rev. Claudio de Cicco. 6. Ed. Brasília: Editora Universidade de Brasília, 1995. p. 155.
} 
Ao contrário, tem-se a analogia jurídica quando inexiste texto legal que se possa aplicar analogicamente, mas princípios jurídicos que decorrem de vários dispositivos. Extrai-se que o princípio jurídico que explica, justifica e domina essas soluções legais particulares.

Destarte, diz um texto de lei que os pais são responsáveis pelos atos dos filhos menores que estiverem sob o seu poder e em sua companhia; outro declara que o tutor e o curador são responsáveis pelos atos dos pupilos e curatelas que se acharem nas mesmas condições; (...)"..119

Por fim, é necessário distinguir a analogia da indução. A indução é uma forma de raciocínio para se chegar a uma norma jurídica, seja ela uma regra ou um princípio, enquanto a analogia consiste numa forma de aplicação de tais dispositivos. Assim, enquanto os princípio e, em menor grau, as regras, têm aplicabilidade geral, a sua aplicação analógica será sempre de caráter particular.

A analogia é prevista como o primeiro mecanismo de supressão de lacunas no artigo $108^{120}$ do Código Tributário Nacional, mas sua utilização é limitada, sendo vedada a aplicação da analogia com a finalidade de exigir tributo não previsto em lei. Um exemplo desta situação é o seguinte:

"Seria exemplo de analogia o intérprete oficial do Executivo tributar com o ICMS pelo valor total, quando há o exercício da opção de compra, o valor do contrato de leasing (arredamento mercantil), ao argumento de que, economicamente, tem os mesmos efeitos de uma compra e venda em prestações. A equiparação seria arbitrária porque no leasing, antes do

\footnotetext{
119 MELlO, Osvaldo Aranha Bandeira de. Princípios Gerais de Direito Administrativo. 3. ed., vol. 1 Introdução. São Paulo: Malheiros, 2007, p. 419. No mesmo sentido, v. BOBBIO, Norberto. Teoria do Ordenamento Jurídico. Trad. Maria Celeste Cordeiro Leite dos Santos. Rev. Claudio de Cicco. 6. ed. Brasília: Editora Universidade de Brasília, 1995. pp. 154-156.

120 “Art. 108. Na ausência de disposição expressa, a autoridade competente para aplicar a legislação tributária utilizará sucessivamente, na ordem indicada:

I - a analogia;

II - os princípios gerais de direito tributário;

III - os princípios gerais de direito público;

IV - a equidade.

$\S 1^{\circ} \mathrm{O}$ emprego da analogia não poderá resultar na exigência de tributo não previsto em lei.

$\S 2^{\circ} \mathrm{O}$ emprego da equidade não poderá resultar na dispensa do pagamento de tributo devido."
} 
exercício da opção, inexiste transmissão da propriedade, e tampouco se trata de mercancia o aluguel de um bem. "121

Embora a analogia tenha a sua aplicação vedada no Direito Tributário material ou substantivo (ou seja, no campo dos elementos formadores da regra matriz de incidência da obrigação tributária), sendo necessária lei nova em sentido estrito para suprir tal ausência, nada impede que a ela se recorra durante a interpretação do chamado Direito Tributário adjetivo e infracional.

Cumpre destacar, por fim, que a ordem de preferência estabelecida pelo artigo 108 não possui aplicabilidade prática, uma vez que os recursos nele enumerados geralmente são utilizados todos ao mesmo tempo, com fins de fornecer a melhor fundamentação jurídica possível para as decisões.

\subsubsection{Equidade}

A outra limitação prevista para a solução de lacunas por força do artigo 108 do CTN consiste na vedação de dispensa do pagamento de tributo devido em razão da aplicação da norma mediante a equidade.

$\mathrm{O}$ conceito de equidade é intimamente ligado ao conceito de justiça ${ }^{122}$, e relaciona-se com a reflexão e o sopesamento dos valores e das normas jurídicas em face dos fatos que lhe são apresentados. Mediante a aplicação do princípio da equidade, o intérprete do direito "observa os fatos sociais e examina-lhes as proporções na sua grandeza real, abrandando os rigores da lei e imprimindo-lhe ares de maior suavidade e dimensão humanitária" "123. Ou, nas palavras de Sacha Calmon, "a equidade é o sumo do bem e da compreensão na aplicação da lei" ${ }^{\text {124 }}$ embora esta não tenha o condão de dispensar o pagamento do tributo, em virtude da expressa vedação legal.

\footnotetext{
${ }^{121}$ COÊLHO, Sacha Calmon Navarro. Curso de Direito Tributário Brasileiro. 8. ed., rev. e atual. de acordo com o Código Civil de 2002. Rio de Janeiro: Forense, 2005. p. 687.

${ }^{122}$ PERELMAN, Chaïm. Ética e Direito. Trad. Maria Ermantina de Almeida Prado Galvão. 2. ed. São Paulo: Martins Fontes, 2005. pp. 157-168.

${ }^{123}$ CARVALHO, Paulo de Barros. Curso de Direito Tributário. 16. ed. São Paulo: Saraiva, 2004. p. 104.

${ }^{124}$ COÊLHO, Sacha Calmon Navarro. Curso de Direito Tributário Brasileiro. 8. ed., rev. e atual. de acordo com o Código Civil de 2002. Rio de Janeiro: Forense, 2005. p. 687.
} 
Neil MacCormick dá um exemplo em sua obra Argumentação Jurídica e Teoria do Direito que ilustra perfeitamente a noção de equidade. Confira-se:

“(...) Por exemplo, uma lei que permita o divórcio com base no abandono do lar por um periodo superior a três anos pode especificar que o abandono só prossegue sem interrupção por três anos se o cônjuge originalmente abandonado, ao longo desse triênio, continuar disposto a aceitar o cônjuge abandonador, caso ele ou ela volte ou se ofereça a voltar à coabitação. No entanto, é conceptível que possa ser justo aplicar essa norma se em determinado caso a conduta do cônjuge abandonador, após o abandono, tiver sido tão desregrada que seria totalmente despropositado esperar que o cônjuge abandonado retomasse a coabitação, mesmo que lhe fosse oferecida? Aparentemente a resposta a essa pergunta bem poderia ser negativa. Se fosse esse o caso, entretanto, seria justo obrigar aos estritos termos da lei alguém que estivesse pedindo o divórcio nessas circunstâncias? É evidente que não. Ressalte-se, porém, o seguinte: dizer que existe um bom motivo, neste caso, no qual as circunstâncias se concretizaram, para afastar-se dos estritos dispositivos legais significa necessariamente dizer que, em qualquer caso em que um cônjuge tenha abandonado o lar e tido um comportamento desregrado, a mesma decisão deveria vigorar.(...),"125

Observa-se, em face do conceito explicado anteriormente e do exemplo acima, que a equidade tem sua aplicação para amenizar as situações em que a aplicação da norma jurídica em seus estritos dizeres conduziria a uma situação de evidente injustiça. Ela atua suprindo a deficiência que consiste na extremada generalidade do texto legal, aparando as arestas da lei para melhor acomodar os fatos jurídicos.

Sabe-se, outrossim, que nenhum dos recursos acima explicados constitui fonte formal do direito, todos eles constituem fontes filosóficas do Direito, ligados, portanto, à Ciência do Direito, e ao Direito positivo propriamente dito. E é aí que ganham destaque a interpretação e a argumentação, porque ao recorrer à analogia, aos princípios gerais, etc., para, por exemplo, preencher uma lacuna, o aplicador do direito deverá fundamentar de forma argumentativa o modo como se torna possível aplicar analogamente uma outra

\footnotetext{
${ }^{125}$ MACCORMICK, Neil. Argumentação Jurídica e Teoria do Direito. Trad. Waldéa Barcellos. São Paulo: Martins Fontes, 2006. pp. 124-125.
} 
norma ao caso, ou mesmo para justificar a criação de uma nova norma adequada aos fatos apresentados.

Assim, a norma jurídica criada por meio da decisão do juiz não terá qualquer força em termos de direito positivo geral (no sentido de ser imposta erga omnes), mas valerá entre as partes em decorrência da própria decisão proferida para o caso. Em outras palavras, a analogia, os princípios gerais do direito, os costumes e a equidade constituem “critérios para a aplicação do direito, para a sua formação, na ordem positiva, através do juiz, no caso concreto. As decisões vazadas nos dados e processos fornecidos por esse Direito Científico valem, então, como normas inovadoras da ordem jurídica, coercivamente impostas na hipótese em controvérsia." ${ }^{126}$.

Portanto, as normas criadas pela decisão judicial, embora não sejam de elaboração positiva, possuem, sim, eficácia jurídica, sendo o fundamento de sua obrigatoriedade derivado da decisão judicial em si (a qual faz lei entre as partes), e não da analogia, dos costumes ou mesmo da equidade. Assim, nas palavras de Bobbio, "o problema da validade e da eficácia, que gera dificuldades insuperáveis desde que se considere a norma do sistema (a qual pode ser válida sem ser eficaz), diminui se nos referirmos ao ordenamento jurídico, no qual a eficácia é o próprio fundamento da validade ${ }^{, 127}$.

E, desta forma, compreende-se o motivo pelo qual a jurisprudência é fonte material de direito, qual seja, ela constitui o conjunto das normas jurídicas individuais e concretas criadas pelos juízes a partir da aplicação do direito positivo aos casos concretos. Assim, a jurisprudência adquire a especial característica de informar quais são os princípios e valores prevalecentes na sociedade.

Este entendimento é válido inclusive para o Direito Tributário. Isto porque a restrição ao uso de analogias, costumes e princípios gerais de direito, nos termos do artigo 108 do CTN, é aplicável apenas às hipótese em que se pretende exigir novo tributo, em rigorosa obediência ao princípio da legalidade estrita, não havendo, contudo, qualquer proibição da sua utilização para a interpretação jurídica com finalidade de solucionar lacunas ou antinomias.

\footnotetext{
${ }^{126}$ MELlo, Osvaldo Aranha Bandeira de. Principios Gerais de Direito Administrativo. 3. ed., V. 1 Introdução. São Paulo: Malheiros, 2007, p. 412.

${ }^{127}$ BOBBIO, Norberto. Teoria do Ordenamento Jurídico. Trad. Maria Celeste Cordeiro Leite dos Santos. Rev. Claudio de Cicco. 6. ed. Brasília: Editora Universidade de Brasília, 1995. p. 29.
} 
Vê-se, desta forma, que não há qualquer restrição ao recurso às analogias, princípios gerais de direito e à equidade para auxiliar na interpretação, integração e consequente aplicação do Direito Tributário (inclusive esta hipótese é prevista justamente no capítulo dedicado à interpretação e integração do Direito Tributário, no CTN), desde que se respeite o princípio da legalidade quanto à criação e quanto à majoração de tributos.

\subsubsection{Expressões vagas, ambíguas e confusas}

O Direito contém uma infinidade de expressões vagas, ambíguas e generalizas e até mesmo confusas que, não obstante estas características são bastante frequentes nas leis, necessitando, portanto, de interpretação. Efetivamente, a utilização de termos genéricos e amplos é uma exigência para que a norma jurídica tenha alcance geral. Isto porque, quanto mais genéricos forem os termos de uma norma, maior é o número de situações fáticas que poderão ser regulados por ela. Em contrapartida, verifica-se o indesejável efeito de redução da segurança jurídica. O papel da interpretação, neste caso, é extrair do termo excessivamente amplo e genérico o significado mais adequado para o caso concreto, em nome da segurança jurídica e à luz dos princípios da equidade e isonomia.

Uma das formas de se reduzir a generalidade e a vagueia de um termo jurídico consiste em estabelecer parâmetros quantitativos para facilitar a sua aplicação aos casos concretos. Talvez o exemplo mais frequente de termo jurídico vago é o conceito de embriaguez. A principal questão, neste caso, é: a partir de que ponto uma pessoa pode ser considerada embriagada? Quanto álcool deve ser ingerido para que a pessoa se embriague? É possível considerar a embriaguez como um estado decorrente da ingestão de outras substâncias além do álcool? É necessária e existência de efetivo risco de dano ao patrimônio ou de lesão corporal para que a embriaguez seja punível? A resposta a todas estas perguntas dependem do caso concreto, bem como da legislação considerada. Assim, para fins da legislação de trânsito, fixaram-se parâmetros quantitativos passíveis de verificação objetiva durante fiscalização para a determinação da embriaguez ao volante. Mas, e quando tal medida não pode ser auferida com exatidão, digamos, por exemplo, na ausência de "bafômetros"? Então outros sinais devem fornecer à autoridade responsável os indícios de embriaguez. Se o indivíduo não apresenta comportamento coerente com a normalidade, suas reações físicas estão visivelmente alteradas, então a autoridade pode interpretar tais sinais como representativos do estado de embriaguez, e, dessa forma, efetuar a operação de subsunção dos fatos à norma, aplicando a pena e a multa cabíveis. 
Perelman sintetiza os prós e os contras da utilização de expressões de “conteúdo variável” nas normas jurídicas, entendendo que:

"levando em conta a infinita variedade das circunstâncias, o fato de que não é capaz de prever tudo e regulamentar tudo com precisão, admitindo que regras rígidas se aplicam penosamente a situações variáveis, o legislador pode introduzir deliberadamente, no texto da lei, noções com conteúdo variável, vago, indeterminado, tais como a equidade, o razoável, a ordem pública, a falta grave, deixando ao juiz o cuidado de precisá-las em cada caso especifico." $" 128$

No contexto das convenções de bitributação, o uso de expressões vagas, ou, nas palavras de Perelman, de "conteúdo variável”, é relativamente frequente. Por exemplo, logo no artigo $2^{\mathrm{o}}$, parágrafo $4^{\text {o129 }}$ do Modelo da OCDE, que trata dos impostos visados pela convenção, já se encontram expressões como "idênticos", "substancialmente semelhantes", "mudanças significativas". O mesmo ocorre com a locução "atividades de caráter preparatório", utilizada no artigo 5 , parágrafo $4^{\circ}$, "e" $" 130$, para descrever as atividades que não configuram estabelecimento permanente. O significado e o alcance destas e de várias outras expressões somente pode ser auferido durante a interpretação e a aplicação da convenção.

A questão das expressões indeterminadas assume especial importância para a as convenções contra a bitributação desde o início dos trabalhos de elaboração do seu texto, já que pode ser complicado conciliar a abdicação de parte da soberania fiscal, necessária para a celebração de tais acordos, com os interesses econômicos envolvidos e também com a necessidade de imprimir caráter generalista às normas da convenção e, ao mesmo tempo, manter a segurança jurídica. De fato, utilizar expressões de conteúdo variável permite maior flexibilidade durante a negociação das cláusulas que integrarão o

${ }^{128}$ PERELMAN, Chaïm. Ética e Direito. Trad. Maria Ermantina de Almeida Prado Galvão. 2. ed. São Paulo: Martins Fontes, 2005. p. 662.

129 “4. The Convention shall apply also to any identical or substantially similar taxes that are imposed after the date of signature of the Convention in addition to, or in place of, the existing taxes. The competent authorities of the Contracting States shall notify each other of any significant changes that have been made in their taxation laws."

130 “4. Notwithstanding the preceding provisions of this Article, the term 'permanent establishment' shall be deemed not to include: (...) e) the maintenance of a fixed place of business solely for the purpose of carrying on, for the enterprise, any other activity of a preparatory or auxiliary character;" 
futuro tratado, porém esta medida traz consigo a necessidade de maior rigor na interpretação após a celebração do acordo e durante a sua aplicação, especialmente durante a qualificação de um rendimento, conforme explicamos no Capítulo 5, adiante ${ }^{131}$.

\subsection{Métodos hermenêuticos}

A Hermenêutica tradicional disponibiliza ao intérprete métodos para sistematizar, organizar e conduzir a interpretação. Tais métodos são baseados nos cânones da interpretação, cuja definição e enumeração é assunto bastante controvertido na doutrina, dependente da linha filosófica adotada pelo estudioso da hermenêutica.

Porém, como ressalta Alexy, mais importante que o problema do número de cânones, e, consequentemente, do número de métodos hermenêuticos, é a ordem hierárquica a eles aplicável, que pode levar a resultados distintos. Cada método confere ênfase a um ou outro aspecto da interpretação. Então, considerando estes fatores, surgiu a tendência de utilizá-los em conjunto, como forma de abranger o maior número de aspectos do texto que estiver sendo interpretado.

Desta forma, referir-nos-emos apenas aos métodos hermenêuticos mais comuns, ou seja, aqueles que são mais frequentemente mencionados pela doutrina.

Assim, quanto aos sujeitos, é possível dividir os métodos de interpretação em método autêntico, método judicial e interpretação privada. Já quanto ao contexto em que a norma se insere, temos o método de interpretação textual e o lógico-sistemático.

\subsubsection{Quanto ao contexto no qual a norma se insere:}

\subsubsection{Interpretação textual (literal, gramatical)}

O método de interpretação textual ocupa-se principalmente com a letra da lei, ou seja, com a redação, com as palavras que compõem o texto legal. Este foi o método preferido pela Escola da Exegese, em virtude de seu caráter essencialmente formal e literal, e assim é bastante restritivo. Porém, na época em que predominou a Escola da Exegese

131 ROTHMANN, Gerd W. Interpretação e Aplicação dos Acordos Internacionais contra a Bitributação. São Paulo: USP, 1978. Tese (doutorado), p. 172. 
esta característica era até mesmo desejável, pois representava uma forma de se ater exatamente ao que o legislador prescreveu, evitando a arbitrariedade que era comum no período absolutista do qual a França estava recém saída.

A interpretação literal cuida, especificamente, da determinação do sentido técnico dos termos, expressões e conceitos utilizados no texto legal. Por exemplo, a expressão "boa fé" assume sentido especial de rigor de honestidade e retidão de comportamento quando se trata de relações jurídicas. Além disso, a interpretação literal parte do princípio de que a lei não contém letra morta, ou seja, todas as palavras e expressões utilizadas pelo legislador, bem como a forma como elas se encontram dispostas no texto legal têm uma razão de ser específica, relacionada com a finalidade e com a vontade da norma em questão, não sendo permitido ao intérprete desconsiderar qualquer termo utilizado na redação da norma.

Como já afirmamos, hoje em dia os métodos hermenêuticos não são utilizados de maneira isolada. Isto porque, caso a interpretação literal fosse a única utilizada, o resultado da interpretação poderia ser excessivamente restritivo e deixar de abarcar casos que não se encaixassem perfeitamente ao que estivesse positivado na letra da lei. Isso acabaria sacrificando valores maiores, como a equidade e a segurança jurídica. Por isso, atualmente, o método literal passou a ser apenas o primeiro a ser utilizado pelo intérprete durante o processo de interpretação.

Um campo muito importante onde a interpretação literal tem espaço é o da tradução. Quando se traduz qualquer texto, não apenas textos legais, é necessário antes interpretá-lo para que seja possível estabelecer a correta correlação entre as palavras utilizadas em um e em outro idioma, uma vez que, na maioria das vezes, as palavras de ambos os idiomas podem ter diversos significados. Por isso, apesar de já estar superado como método isolado para a interpretação de normas jurídicas em um único idioma, a interpretação literal ainda tem espaço garantido quando se trata da necessária interpretação que se faz antes da realização da tradução.

\subsubsection{Interpretação sistemática (lógica)}

O método de interpretação sistemática geralmente é o segundo a ser utilizado pelo intérprete, vindo logo em seguida à interpretação gramatical ou literal. Como o próprio nome diz, trata-se de interpretar a norma jurídica em vista do ordenamento no qual 
ela se insere, considerando as relações entre ela e as demais normas que lhe são superiores e inferiores, bem como a observância dos princípios informadores do ordenamento jurídico, verificando, desta forma, os critérios de validade perante o sistema. É a partir destes critérios que a interpretação lógico-sistemática se aplica.

Em virtude do caráter de permanência das normas jurídicas, ou seja, em decorrência do fato de que elas são elaboradas com o objetivo de permanecerem vigentes com o transcorrer do tempo até que outra norma a revogue, outro aspecto que é considerado na interpretação lógica são as relações que as normas jurídicas mantém no tempo e no espaço. Neste caso, são avaliados os seus critérios de vigência e eficácia.

A interpretação lógica sempre tem, em maior ou menor grau, certa consideração pelas finalidades da norma e pelas circunstâncias em que se deu a sua elaboração. Em outras palavras, significa dizer que dentro da interpretação lógica situa-se a interpretação teleológica e a interpretação histórica, embora o grau de sua influência no resultado final da interpretação varie de acordo com cada situação concreta. Nesse sentido, Tércio Sampaio Ferraz Jr. destaca o fato de que, como o intérprete participa ativamente da criação do direito mediante a interpretação, demonstra-se assim uma interpretação histórico-evolutiva que acaba se desvinculando das intenções originais do legislador à época em que a norma foi elaborada ${ }^{132}$. Ademais, é necessário considerar que a interpretação do fins buscados pela norma jurídica pode variar com o passar do tempo, e é isso que permite que a norma jurídica se mantenha atual. Esta é a premissa da interpretação histórico-evolutiva que se encontra prevista na Lei de Introdução ao Código Civil Brasileiro, que em seus artigos $4^{\circ}$ e $5^{\circ}$ prevê, respectivamente, que quando a lei for omissa, o juiz decidirá o caso de acordo com a analogia, os costumes e os princípios gerais de direito, e que na aplicação da lei, o juiz atenderá aos fins sociais a que ela se dirige e às exigências do bem comum.

Deste modo, observa-se que a interpretação sistemática é mais adequada do que a simplesmente literal porque considera a norma jurídica como uma entidade independente do legislador e do texto no qual está consubstanciada, mas ao mesmo tempo relacionada com o sistema no qual está inserida. É em razão desta independência do texto

\footnotetext{
${ }^{132}$ FERRAZ JR., Tércio Sampaio. A ciência do direito. São Paulo: Atlas, 1977, p. 80. No memo sentido: SCHIMILL, Ulises. COSSÍO, José Ramón. Interpretation del derecho y conceptions del mundo. In: VÁZQUEZ, Rodolfo (coord.) Interpretación jurídica y decisión judicial. Cidade do México: Fontamara, 2003. p. 63. (Série Doctrina Jurídica Contemporánea).
} 
legal que as normas sobrevivem no tempo, e é justamente a interpretação que as mantém vivas e em uso, impedindo que se cristalizem em padrões estáticos e ultrapassados.

\subsubsection{Quanto aos intérpretes da norma:}

\subsubsection{Interpretação autêntica}

A interpretação autêntica é aquela realizada pelas fontes produtoras das normas jurídicas, ou seja, pelos legisladores. Geralmente a interpretação autêntica tem espaço quando o próprio legislador percebe que o texto da lei foi mal elaborado, resultando em proposições ambíguas ou confusas. Então procuram esclarecê-lo, geralmente por meio de atos interpretativos.

Muito se discute acerca da importância da interpretação autêntica e sobre seus efeitos. Os adeptos da Escola da Exegese consideravam-na como a mais importante forma de interpretação, já que provinha diretamente da fonte produtora da norma legal, conferindo-lhe, inclusive, caráter retroativo. Isto porque os exegéticos entendiam que o que deveria prevalecer sempre era a vontade do legislador, então o texto deveria ser interpretado sempre de acordo com o contexto à época de sua elaboração. Este entendimento, como já destacamos anteriormente, encontra-se superado, pois não considera o caráter de continuidade do direito.

Por outro lado, os seguidores da Escola Histórica e os adeptos da Teoria do Direito Livre tendem a atribuir menor importância para a interpretação autêntica, especialmente quando considerada em face da interpretação judicial. É que ambas as correntes seguem a linha de que o direito se cria por meio da interpretação, então o papel do aplicador do direito é mais relevante do que o do legislador ${ }^{133}$. Geralmente nos países que seguem a sistemática da Common Law é esse o entendimento que prevalece, embora atualmente esta seja uma tendência bastante difundida mesmo dentre os países que adotam a Civil Law.

Há autores, como Oswaldo Aranha Bandeira de Mello, que entendem que a interpretação autêntica não se restringe apenas ao legislador, sendo também realizada por

\footnotetext{
${ }^{133}$ MELLO, Osvaldo Aranha Bandeira de. Princípios Princípios Gerais de Direito Administrativo. 3. ed., v. 1 - Introdução. São Paulo: Malheiros, 2007, pp. 408-409. v. 1.
} 
órgãos do Executivo através da expedição de regulamentações administrativas e também por meio da atuação nos órgãos administrativos de solução de controvérsias.

"Os órgãos executivos também interpretam a lei através de determinações superiores, na sua ação regulamentar, e mesmo nas deliberações de cada um dos seus órgãos, decidindo sobre pretensões de particulares, e formando precedentes administrativos, ou baixando instruções e ordens de serviço e sugerindo praxes administrativas. E, assim, aplicam a lei, após sua interpretação, procurando harmonizá-la com os textos constitucionais, ou, mesmo, deixam de aplicá-la, desconhecendo-a, se a entenderem inconstitucional, pois, ocorrendo incompatibilidade entre a lei nova ordinária e o dispositivo constitucional, hierarquicamente superior, devem obedecer à Lei Maior. "134

Este posicionamento, visivelmente mais adequado ao atual estado de evolução do direito, obriga-nos a discordar da noção de que apenas o judiciário aplica o Direito. De fato, ao Poder Executivo também cabe a interpretação e a aplicação do direito, dentro da sua esfera de competência, ou seja, quando exerce seu poder regulamentar e quando desempenha função judicante em tribunais administrativos. Para ilustrar a questão, basta lembrar dos Atos Declamatórios Administrativos que são emitidos pela Receita Federal do Brasil, órgão máximo da administração tributária nacional, a respeito de certas disposições das convenções de bitributação de que o Brasil é parte. Os Atos Declamatórios Administrativos são atos administrativos regulamentares de natureza interpretativa, os quais são aptos a demonstrar claramente o exercício da interpretação e da aplicação do direito pela autoridade administrativa. Em outras palavras, por meio deles, a autoridade fiscal brasileira, após ter previamente interpretado e analisado as cláusulas dos tratados em questão, torna público o seu entendimento com a finalidade de orientar a aplicação de tais acordos na prática. E tais atos administrativos constituem regulações válidas, inclusive, para eventual discussão judicial.

Outro exemplo bastante claro da interpretação feita pelo Poder Executivo consiste na atuação dos Conselhos de Contribuintes, que nada mais são do que tribunais administrativos cuja competência engloba a solução de controvérsias tributárias. Neste

134 MELlo, Osvaldo Aranha Bandeira de. Princípios Gerais de Direito Administrativo. 3. ed., v. 1 Introdução. São Paulo: Malheiros, 2007, p. 409. 
caso, a Administração pública interpreta, aplica e, assim, cria o direito, por meio das decisões que emitem para os casos que lhe são apresentados. De fato, embora a competência de tais tribunais seja restrita, não lhes sendo permitido, por exemplo, avaliar a constitucionalidade de normas jurídicas, e mesmo havendo a possibilidade de futura rediscussão judicial da matéria já julgada administrativamente, se as partes não levarem a controvérsia ao Judiciário, a decisão administrativa se estabelece definitivamente e subordina as partes, não sendo exigido o reconhecimento judicial para que seus efeitos se operem. E o efeito disso é que a decisão administrativa criará o direito entre as partes. Por isso entendemos ser correta a noção de que a interpretação derivada de órgãos da administração pública quando esta exerce sua função regulamentar e em seu papel judicante também pode criar direito, mesmo sendo mais difícil de verificar tal fato na prática, já que a tendência geral é sempre chegar à discussão judicial.

Mais um exemplo é dado pelo Professor Bandeira de Mello:

"Ficam ressalvados, apenas, em matéria penal, os casos de anistia legislativa e de graça executiva, que constituem atos de clemência governamental, e, ainda, os de possibilidade de modificação em juízo, excepcionalmente, mediante ação rescisória do julgado e revisão criminal, segundo hipóteses previstas em lei, em que se comprove a nulidade total da decisão." 135

Assim, embora a noção clássica determine que somente a interpretação judicial é capaz de criar direito, acreditamos que esta é uma ideia bastante restritiva e que, em face do atual estágio das relações jurídicas, acabou se tornando inverídica. O exemplo acima demonstra, de modo simples, que mesmo o Poder Executivo interpreta a lei e cria direito, dento de sua esfera de competência.

\subsubsection{Interpretação judicial (ou interpretação positiva ${ }^{136}$ )}

\footnotetext{
135 MELlo, Osvaldo Aranha Bandeira de. Principios Gerais de Direito Administrativo. 3. ed., v. 1 Introdução. São Paulo: Malheiros, 2007, p. 410.

136 "En resumen, en el caso de la interpretación positiva, la significación dada a los materiales jurídicos (o, simplesmente, al derecho escrito) se manifesta en actos de aplicación (y creación) del orden jurídico positivo." TAMAYO Y SALMORÁN, Rolando. Interpretación Constitucional - La falacia de la interpretación cualitativa. In: VÁZQUEZ, Rodolfo (coord.) Interpretación jurídica y decisión judicial. Cidade do México: Fontamara, 2003. p. 90. (Série Doctrina Jurídica Contemporánea.).
} 
A Interpretação judicial, como o próprio título diz, é aquela realizada pelos aplicadores do Direito, notadamente juízes, desembargadores e ministros, ou seja, pelos órgãos incumbidos da aplicação do Direito, sendo encontrada principalmente na parte decisória de sentenças e acórdãos, mas em toda a fundamentação destes. A interpretação judicial constitui, pois, um pressuposto da aplicação da norma jurídica, já que ela necessariamente será realizada durante o processo de aplicação do direito de qualquer espécie. Entretanto, quando se fala que o Direito é criado a partir da interpretação judicial, a parte da sentença ou do acórdão ao que se refere é a parte decisória, e não a fundamentação, a qual não tem poder de "criar" o direito.

Entretanto, a interpretação judicial não cria norma jurídica. Os acórdãos e súmulas publicados pelos tribunais são apenas indicativos da interpretação adotada por aquela Corte em relação a determinada matéria. E, no que se refere às súmulas vinculantes, é necessário esclarecer que o caráter vinculante destas está relacionado ao resultado final da ação, e não da interpretação das normas. Isto porque elas representam o entendimento que, em última instância, será conferido à matéria em discussão. A interpretação judicial, em homenagem ao princípio da independência e da imparcialidade das decisões judiciais, não é vinculada, cada juiz interpreta a norma de acordo com os fatos que lhes são apresentados e segundo seus princípios e suas convicções culturais e pessoais.

Como mencionamos acima, há atualmente uma tendência à valorização da interpretação judicial, especialmente nos países em que o Judiciário assume papel proeminente como intérprete máximo da legislação (como é o caso do Brasil), podendo, inclusive, declarar a inconstitucionalidade de lei, de modo que nem o Executivo nem o Legislativo podem restabelecer o poder normativo de uma lei declarada inconstitucional pelo Judiciário.

\subsubsection{Interpretação doutrinária (dogmática ou privada) $)^{137}$}

A interpretação privada é aquela realizada pelo cidadão e por seus consultores e advogados. A interpretação doutrinária (dogmática), ou seja, aquela realizada pelos

\footnotetext{
${ }^{137}$ Há alguns autores que consideram a existência de outros métodos interpretativos, citando-se, como exemplo, a interpretação ideológica, econômica, psicossocial, dentre outras. De fato, tais modalidades existem, porém em virtude do marco teórico adotado no presente trabalho, entendemos não ser necessário discorrer a respeito delas. Maiores informações sobre estes métodos podem ser obtidas em: TAMAYO Y SALMORÁN, Rolando. Interpretación Constitucional - La falacia de la interpretación cualitativa. In: VÁZQUEZ, Rodolfo (coord.) Interpretación jurídica y decisión judicial. Cidade do México: Fontamara, 2003. p. 102. (Série Doctrina Jurídica Contemporánea).
} 
estudiosos da ciência do Direito, não deixa de ser uma forma de interpretação privada que possui especial importância por ter, além da finalidade de aprimoramento científico, o propósito de influenciar a interpretação judicial e, consequentemente, as decisões judiciais. Em ambos os casos, porém, a interpretação não é vinculada à aplicação da norma, isto é, trata-se de interpretar a norma jurídica in abstrato, sem influência de argumentos dialéticos, embora esta mesma interpretação possa ser destinada a instruir uma postulação judicial.

Assim, ao contrário do que ocorre na interpretação judicial, em que o significado que constitui o resultado da interpretação é disposto em atos vinculativos de aplicação do direito (sentenças, acórdãos, etc.) que se tornam parte do ordenamento assim como as fontes do direito que foram interpretadas, na interpretação doutrinária o resultado obtido pelo intérprete não se consubstancia em atos de aplicação do direito, a rigor, não produz direito novo, representando apenas o conhecimento da significação das normas jurídicas $^{138}$.

Entretanto, embora o material produzido a partir da interpretação doutrinária não constitua direito novo, ele pode exercer considerável influência ${ }^{139}$ durante a interpretação judicial, como parte do background do intérprete, no caso, do aplicador do direito.

\footnotetext{
${ }^{138}$ Nesse sentido é a lição de Kelsen: “(...) Sobretudo, porém, tem de distinguir-se rigorosamente a interpretação do Direito feita pela ciência jurídica, como não autêntica, da interpretação realizada pelos órgãos jurídicos. A interpretação científica é pura determinação cognoscitiva do sentido das normas jurídicas. Diferentemente da interpretação feita pelos órgãos jurídicos, ela não é criação jurídica. (...) A interpretação jurídico-cientifica não pode fazer outra coisa senão estabelecer as possiveis significações de uma norma jurídica. Como conhecimento do seu objeto, ela não pode tomar qualquer decisão entre as possibilidades por si mesma reveladas, mas tem de deixar tal decisão ao órgão que, segundo a ordem jurídica, é competente para aplicar o Direito." KELSEN, Hans. Teoria Pura do Direito. Trad. João Baptista Machado. São Paulo: Martins Fontes, 1999, p. 250-251.

139 "Um advogado que, no interesse do seu constituinte, propõe ao tribunal apenas uma das várias interpretações possíveis da norma jurídica a aplicar a certo caso, e um escritor que, num comentário, elege uma interpretação determinada, de entre as várias interpretações possíveis, como a única "acertada”, não realizam uma função jurídico-científica mas uma função jurídico-política (de política jurídica). Eles procuram exercer influência sobre a criação do Direito. Isto não lhes pode, evidentemente, ser proibido. Mas não o podem fazer em nome da ciência jurídica, como frequentemente fazem. A interpretação jurídicocientifica tem de evitar, com o máximo cuidado, a ficção de que uma norma jurídica apenas permite, sempre e em todos os casos, uma só interpretação: a interpretação "correta". Isto é uma ficção de que se serve a jurisprudência tradicional para consolidar o ideal da segurança jurídica. Em vista da plurissignificação da maioria das normas jurídicas, este ideal somente é realizável aproximativamente." KELSEN, Hans. Teoria Pura do Direito. Trad. João Baptista Machado. São Paulo: Martins Fontes, 1999, p. 250-251.
} 


\subsection{Agentes interpretativos}

No Latim, o termo "intérprete" serve para designar um agente que serve de intermediário numa negociação, a quem cabe a tarefa de comunicar aos demais, geralmente em linguagem comum, o significado que se atribui a certas coisas, sinais ou acontecimentos $^{140}$. Em outras palavras, o intérprete permite o conhecimento geral, mediante certos cânones, do significado de determinados objetos. Nesse sentido é a lição de Rolando Tamayo y Salmorán:

“'Interpretación’ proviene del lat.: interpretatio, a su vez, del verbo interpretor que significa: 'servir de intermediario', 'venir en ayuda de'. El verbo interpretor deriva de interpres, que significa 'agente', 'intermediario'. Así, por ejemplo, el comerciante es un intermediario, un negociador que se encuentra interpret, negociando, aclarando o 'explicando' el prettium ('precio').

Interpres designa también al tradutor; un intermediario singular: el que aclara, el que explica o que hace accessible (en un lenguaje inteligible) lo que no se entende. Así, interpretatio se aplica a lo que hace aquel que 'lee' o entende otras cosas (los sueños, los augurios u otras lenguas)."141

No que se refere aos agentes interpretativos das normas jurídicas, e, por consequência, também das convenções de bitributação, a doutrina tradicional sugere uma sistematização em três níveis, que partem do contribuinte, até chegar à autoridade máxima judicial (no caso do Brasil, o STF). Segundo Vogel:

“Como qualquer preceito de Direito Administrativo ou Tributário, devem ser diferenciados, do ponto de vista sistemático, três níveis no procedimento interpretativo. Em primeiro lugar, o contribuinte e seu consultor interpretam o acordo, no momento em que eles entregam a declaração de imposto de renda, ou mesmo antes, quando eles planejam seus negócios do ponto de vista tributário. O segundo intérprete é, então, a administração tributária; sua interpretação será a decisiva, caso o contribuinte fique resignado com ela, ou

\footnotetext{
140 TAMAYO Y SALMORÁN, Rolando. Interpretación Constitucional - La falacia de la interpretación cualitativa. In: VÁZQUEZ, Rodolfo (coord.) Interpretación jurídica y decisión judicial. Cidade do México: Fontamara, 2003. p. 91. (Série Doctrina Jurídica Contemporánea.).

141 TAMAYO Y SALMORÁN, Rolando. Interpretación Constitucional - La falacia de la interpretación cualitativa. In: VÁZQUEZ, Rodolfo (coord.) Interpretación jurídica y decisión judicial. Cidade do México: Fontamara, 2003. p. 90. (Série Doctrina Jurídica Contemporánea.).
} 
caso a administração tributária e o contribuinte consigam chegar a um acordo. No caso de ele se valer de um meio jurídico contra a decisão, então cabe às cortes a decisão, como terceiros intérpretes. Também entre elas, há ainda vários níveis: o das cortes administrativas ou financeiras, a corte constitucional e a Corte Européia. Sempre, entretanto, quando todas as instâncias tiverem sido percorridas, esta interpretação de terceiro grau será vinculante para a administração tributária e para o contribuinte; ela será, pois, final. "142

Entretanto, apesar de reconhecidamente correta e importante, acreditamos que esta visão tradicional restringe-se à fase de aplicação da convenção apenas no âmbito interno, desconsiderando a interpretação que é realizada ainda durante a fase de elaboração do acordo, e desconsiderando também a interpretação realizada pelos Estados nacionais, que pode ocorrer tanto na fase de elaboração quanto na fase de aplicação da convenção.

Nesse sentido, o professor Manuel Pires ${ }^{143}$ destaca que a interpretação incumbe ao órgão aplicativo ou ao órgão que celebrou a convenção, designadamente o Governo, já que a celebração de um tratado internacional exige um demorado processo que envolve diversos órgãos da administração pública federal ${ }^{144}$.

Detalhando a noção já introduzida por Manuel Pires, Riccardo Guastini ${ }^{145}$ menciona que a interpretação pode ser realizada por alguns operadores típicos, originando, desta forma, quatro modalidades básicas de interpretação, a saber:

\footnotetext{
${ }^{142}$ VOGEL, Klaus. Problemas na Interpretação de Acordos de Bitributação. Trad. Luís Eduardo Schoueri. In: SCHOUERI, Luís Eduardo (Coord.). Direito Tributário: Homenagem a Alcides Jorge Costa, São Paulo: Quartier Latin, 2003. pp. 966-967. vol. II.

143 PIRES, Manuel. Da Dupla Tributação Jurídica Internacional sobre o Rendimento. Lisboa: Centro de Estudos Fiscais - Ministério das Finanças, 1984. p. 457.

${ }^{144} \mathrm{Na}$ mesma linha, Oswaldo Aranha Bandeira de Mello destaca que: "Como se salientou, os particulares, nas suas relações jurídicas recíprocas, outrossim, aplicam o direito, e o fazem depois de interpretá-lo, por si ou por seus consultores, para obterem o significado das leis a que se subsumem. Porém, essa interpretação da lei realiza-se principalmente pelos órgãos estatais, e compete tanto aos órgãos legislativos, a quem cabe a elaboração da lei, como aos executivos e judiciários, a quem cabe a aplicação da lei.". MELLO, Osvaldo Aranha Bandeira de. Princípios Gerais de Direito Administrativo. 3. ed., v. 1 - Introdução. São Paulo: Malheiros, 2007, pp. 407-408.

${ }^{145}$ GUASTINI, Riccardo. La Interpretación: objetos, conceptos y teorías. In: VÁZQUEZ, Rodolfo (coord.) Interpretación jurídica y decisión judicial. Cidade do México: Fontamara, 2003. pp. 35-36. (Série Doctrina Jurídica Contemporánea).
} 
(a) interpretação autêntica, elaborada pelos autores do documento interpretado, no caso das normas jurídicas, é a interpretação realizada pelos legisladores mediante outras leis sucessivas;

(b) interpretação oficial, que é aquela realizada pelos órgãos do Estado no exercício de suas funções;

(c) interpretação judicial, também denominada de interpretação jurisprudencial, que, como o nome diz, é efetuada pelos órgãos jurisdicionais do Estado, incluindo tanto tribunais judiciais quanto administrativos. A interpretação judicial assume especial importância em virtude da própria função jurisdicional. Em outras palavras, a interpretação feita pelos tribunais é o que conduz às decisões judiciais. Por isso é tão importante que o trabalho do intérprete judicial seja extremamente criterioso e rigoroso durante a interpretação e aplicação das normas jurídicas.

(d) interpretação doutrinária, ou seja, como já mencionamos, aquela realizada pelos acadêmicos do Direito. Via de regra, os juristas se preocupam, principalmente, com questões abstratas, fazendo com que sua interpretação seja orientada ao texto, buscando o significado dos textos normativos em abstrato, e não ao caso concreto, como ocorre na interpretação judicial. Os juízes não se preocupam com o significado de um dado termo "em abstrato", mas sim com o significado daquele termo dentro do contexto dos fatos que compõem a controvérsia que lhes é apresentada pelas partes. Esta diferença de orientação não retira, de forma alguma, a importância da interpretação doutrinária, a qual exerce fundamental influência na interpretação judicial, possuindo caráter de recomendação.

Em face disso, elaboramos um esquema dividido em duas etapas, quais sejam, a "fase de elaboração" e a "fase de aplicação", em relação às quais podemos determinar quem são os agentes interpretativos, tanto no âmbito interno quanto no plano internacional $^{146}$.

${ }^{146}$ ROCHA, Sérgio André. Interpretação dos Tratados contra a Bitributação da Renda. Rio de Janeiro: Lumen Juris, 2008, p. 173. 
$\mathrm{Na}$ fase de elaboração do tratado, em que ocorrem as negociações internacionais e, portanto, expõe-se a opinião do Estado enquanto ente do Direito Internacional Público, entendemos que devem ser considerados intérpretes os membros do corpo diplomático e agentes plenipotenciários envolvidos nas negociações e na celebração do acordo, bem como o próprio Presidente da República, a quem incumbe o ato de assinar o acordo, obrigando o país na esfera internacional. Estes seriam os intérpretes internacionais do tratado então celebrado.

Passando à esfera interna de aplicação da convenção, os primeiros intérpretes que se nota são os membros do Poder Legislativo envolvidos com o referendo o acordo então assinado pelo Presidente, permitindo, desta forma, que a convenção possa ter eficácia dentro do território nacional, permitindo que os contribuintes passem a requerer a sua aplicação.

Por estarem diretamente envolvidos na elaboração do tratado, entendemos que os agentes diplomáticos, os agentes plenipotenciários, o Presidente da República e os membros do Poder Legislativo podem ser considerados como os verdadeiros intérpretes autênticos das normas contidas na convenção de bitributação.

Após concluídos os procedimentos formais, estando a convenção em pleno vigor, durante a fase de aplicação surgem como agentes hermenêuticos ordinários os contribuintes, que realizarão a interpretação primária da norma, seguidos pelas Autoridades Fiscais, ou, na linguagem fiscal internacional, Autoridades Competentes ${ }^{147}$ (no caso do Brasil, o órgão responsável é a Receita Federal do Brasil), às quais recorrerão com fins de reconhecer e efetivar a aplicação do acordo. Havendo concordância entre estas duas partes e sendo a convenção aplicada de modo satisfatório para ambas, teoricamente, a interpretação terminaria aí.

Contudo, na maioria das vezes o que se verifica é justamente o contrário. Então, surgem como agentes interpretativos as autoridades jurisdicionais inferiores, nomeadamente os tribunais administrativos (no Brasil, trata-se do Conselho de

\footnotetext{
${ }^{147}$ A expressão "competent authorities", presente nas convenções contra a bitributação internacional, deve ser interpretada de acordo com o que cada um dos Estados contratantes dispuser. Ao celebrar a convenção, eles devem incluir nas definições gerais qual será a autoridade competente para interpretar e aplicar o acordo. Esta expressão consta dos tratados em virtude da diferença do grau de poder atribuído às autoridades no sistema de Common Law e de Civil Law: no primeiro, o poder é restrito, e no segundo, é bastante amplo. AVERY JONES, John F. et Al. The origins of Concepts and Expressions Used in the OECD Model and their Adoption by States. In: Bulletin - Tax Treaty Monitor. Jun. 2006. IBFD, p. 226.
} 
Contribuintes e das suas Câmaras Superiores) e os tribunais judiciais federais (Tribunais Regionais Federais).

Se nesta esfera as divergências relacionadas com a aplicação do tratado de bitributação ainda não tiverem sido resolvidas, restará o recurso aos Tribunais Judiciais Superiores, que no Brasil são o Superior Tribunal de Justiça, dedicado aos assuntos infraconstitucionais, e o Supremo Tribunal Federal, que julga somente os casos que envolvem violação direta da Constituição. Dele virá a decisão final e irrevogável, fruto de sua interpretação, tendo em vista que o Direito brasileiro não prevê uma Corte supranacional à qual se possa recorrer nestes casos, diferentemente do que ocorre com os países da Europa, que podem recorrer, ainda à Corte Européia.

Quadro-resumo dos agentes interpretativos

\begin{tabular}{|l|l|l|}
\hline $\begin{array}{l}\text { Âmbito } \\
\text { Internacional }\end{array}$ & $\begin{array}{l}\text { Fase de } \\
\text { Elaboração e } \\
\text { Celebração }\end{array}$ & $\begin{array}{l}\text { Diplomatas } \\
\text { Agentes plenipotenciários } \\
\text { Presidente da República }\end{array}$ \\
\hline Âmbito interno & Fase de Aplicação & $\begin{array}{l}\text { Membros do Poder Legislativo } \\
\text { Contribuintes }\end{array}$ \\
& $\begin{array}{l}\text { Autoridades Fiscais: Receita Federal do } \\
\text { Brasil } \\
\text { Tribunais: } \\
\text { - Administrativos: Conselho de } \\
\text { Contribuintes e Câmaras Superiores } \\
\text { - Judiciais: Tribunais Regionais } \\
\text { Federais, Tribunais Judiciais } \\
\text { Superiores, Superior Tribunal de } \\
\text { Justiça - STJ, Supremo Tribunal } \\
\text { Federal - STF }\end{array}$ \\
\hline
\end{tabular}




\section{A TEORIA DA ARGUMENTAÇÃO JURÍDICA}

\subsection{Interpretar é decidir: os motivos que nos levaram a estudar a Teoria da Argumentação Jurídica}

Mas antes de iniciarmos a análise da Teoria da Argumentação Jurídica, é necessário esclarecer um dos principais motivos que nos levaram a estudá-la, e principalmente, o motivo pelo qual entendemos que ela se aplica à interpretação das convenções contra a bitributação.

Ao fundamentar uma decisão jurídica, o juiz necessariamente interpreta normas e fatos. E, para decidir, ele deverá realizar uma escolha, ou seja, deverá eleger uma dentre as interpretações possíveis.

Mesmo quando não se trata de decidir um caso jurídico, a todo tempo interpreta-se a legislação e escolhas são realizadas. É que, quando se interpreta algo, especialmente uma norma jurídica, diversos são os resultados possíveis, mas sempre haverá um que será mais apropriado à situação fática apresentada. Por isso é correto afirmar que interpretar é decidir: decide-se pela interpretação mais adequada, interpretamse os fatos e as normas e elege-se um comportamento em detrimento de vários outros.

Os valores do aplicador do Direito exercem influência neste processo de escolher o que é mais adequado ao caso. Esta constatação apenas reforça a idéia de que a interpretação e a aplicação do Direito vão muito além das operações de subsunção da lógica formal. É preciso efetivamente considerar tais valores, mas tal operação não constitui algo fácil de ser realizado. Segundo ensina Alexy, o ponto central de toda a teoria da argumentação jurídica consiste em resolver três questões: (i) "onde e em que medida são necessárias valorações", (ii) "como atuam essas valorações nos argumentos qualificados como especificamente jurídicos", e (iii) "se tais valorações são passíveis de fundamentação racional". Da resposta a estas três indagações e da sua relação com os métodos hermenêuticos depende a atribuição de caráter científico à interpretação e à argumentação jurídicas, e consequentemente à decisão delas decorrente.148

\footnotetext{
148 ALEXY, Robert. Teoria da Argumentação Jurídica: A Teoria do Discurso Racional como Teria da Justificação Jurídica. Trad. Zilda Hutchinson Schild Silva. Introd. à ed. brasileira Claudia Toledo. São Paulo: Landy, 2005. pp. 38-39.
} 
A atividade valorativa do intérprete durante o processo hermenêutico da norma jurídica não é, contudo, irrestrita ou ilimitada. Em outras palavras, não se trata de estabelecer um campo aberto à subjetividade do intérprete. É importante e necessário, sim, considerar tais valores, porém é igualmente necessário e relevante deixar espaço para os critérios do correto.

Para estabelecer a medida destes limites, Alexy cita como uma primeira alternativa a consideração apenas das convicções e consensos faticamente existentes, incluindo aqueles não jurídicos. Entretanto, este critério, demasiado abrangente, revela-se inadequado, já que o conjunto de valores pode variar muito de um grupo social para outro, de forma que a segurança e a certeza do limite em questão seria posta em dúvida.

Sob outro aspecto, seria possível pensar nessas limitações como inerentes ao próprio sistema jurídico, de forma que os valores a serem considerados seriam somente aqueles positivados no ordenamento. No entanto, uma limitação desta natureza se revela insuficiente, uma vez que o conjunto das valorações do ordenamento pode não ser fácil, ou até mesmo impossível, de ser determinado. Esta dificuldade em determinar com exatidão o conjunto de valores do sistema acaba retornando à análise para a resposta dada à primeira pergunta, ou seja, acaba levando o intérprete a considerar os valores sociais além daqueles estritamente jurídicos. Isto não significa, entretanto, que o conjunto de valores expressos no ordenamento jurídico, geralmente positivado na forma de enunciações e princípios, não deva ser considerado como uma ferramenta útil e relevante para a interpretação149.

Uma terceira alternativa para se determinar o limite da atividade valorativa seria considerar apenas os valores contidos em uma determinada ordem objetiva sob a forma de princípios suprapositivos, que pode tanto ser o conjunto de valores expressos na Constituição como o conjunto de valores que inspiram o Direito Natural. No entanto, como destaca Alexy, isso depende de convicções filosóficas que podem tornar o conjunto de valores eleito inadequado aos fatos que compõem a questão em discussão. Este fato não implica, contudo, a conclusão de que um enunciado que diga que a liberdade e a igualdade são valores supremos e permanentes do Estado não seja correto.150

\footnotetext{
149 ALEXY, Robert. Teoria da Argumentação Jurídica: A Teoria do Discurso Racional como Teria da Justificação Jurídica. Trad. Zilda Hutchinson Schild Silva. Introd. à ed. brasileira Claudia Toledo. São Paulo: Landy, 2005. p. 41.

150 ALEXY, Robert. Teoria da Argumentação Jurídica: A Teoria do Discurso Racional como Teria da Justificação Jurídica. Trad. Zilda Hutchinson Schild Silva. Introd. à ed. brasileira Claudia Toledo. São Paulo: Landy, 2005. p. 43.
} 
Uma quarta hipótese seria a consideração apenas dos conhecimentos empiricamente comprovados para fornecer a fundamentação das decisões judiciais, porém sabe-se que não é possível extrair normas apenas de conhecimentos empíricos.

Disso tudo é possível concluir que apenas as valorações não são suficientes para legitimar a criação do direito por meio da interpretação e da decisão judicial.

\subsection{As origens - Os pensamentos que influenciaram a Teoria da Argumentação Jurídica de Robert Alexy}

A Teoria da Argumentação Jurídica de Alexy situa-se historicamente na fase da crise do positivismo jurídico, caracterizada pela retomada da associação entre o Direito e a moral. É sob esta perspectiva de que o direito deve ser justo que Alexy entende, por exemplo, que um juiz não pode sentenciar um caso aplicando normas jurídicas que, embora aplicáveis sob o ponto de vista formal, levariam a uma decisão manifestamente injusta. Nisso consiste a pretensão de correção do Direito sustentada por Alexy.

Toda a teoria de Alexy perpassa a noção de racionalidade. De fato, o Autor entende que a argumentação jurídica tem como substrato o discurso jurídico, e este, por sua vez, consiste numa espécie do gênero discurso prático. Em todos os casos ele analisa o elemento racionalidade, partindo da racionalidade na interpretação para chegar à racionalidade na argumentação. Assim é que a teoria da argumentação jurídica é também uma teoria do discurso prático racional, e, desta forma, Alexy analisa as diversas teorias do discurso prático como forma de evidenciar os fundamentos que influenciaram o seu pensamento.

Considerando estes aspectos, observa-se que o início da construção da obra de Alexy corresponde à seguinte indagação: "a justificação de convicções morais e possível, e se é, como?" "151. Ademais, outra premissa por ele adotada refere-se à constatação de que qualquer teoria sobre fundamentação pressupõe uma teoria da linguagem normativa. A partir daí, ele analisa as algumas teorias da linguagem que servem de base para a elaboração da teoria do discurso prático.

151 ALEXY, Robert. Teoria da Argumentação Jurídica: A Teoria do Discurso Racional como Teria da Justificação Jurídica. Trad. Zilda Hutchinson Schild Silva. Introd. à ed. brasileira Claudia Toledo. São Paulo: Landy, 2005. p. 58. 


\subsubsection{Teorias Metaéticas: do Naturalismo à teoria de Baier}

Várias linhas filosóficas buscaram encontrar uma resposta para o questionamento sobre a possibilidade de justificação das convicções morais. Algumas partiam de uma noção empirista pela qual os enunciados normativos seriam, na verdade, enunciados descritivos, comprováveis mediante procedimentos descritivos aplicáveis às ciências naturais e às ciências sociais de caráter empírico. Este era o princípio básico dos adeptos do Naturalismo. Porém, o pensamento naturalista desconsiderava o fato de que os conceitos não são interpretados de forma igual por todas as pessoas, o que tornava a hipótese naturalista inválida. Então, em oposição ao Naturalismo, mencionam-se as teorias da corrente intuicionista, pela qual não se trata de definir empiricamente todos os conceitos da vida, mas, sim, de encontrar seu significado a partir de uma espécie de sexto-sentido, uma intuição inerente às pessoas, definida como uma espécie de conhecimento a priori. Seria como se a tarefa do discurso prático fosse demonstrar verdades que já seriam evidentes para as pessoas, através da intuição. Porém, como diferentes pessoas respondem de formas distintas às mesmas evidências, o Intuicionismo falha por não apresentar nenhum critério para distinguir o que seria uma interpretação correta de uma errada. Desta forma, tanto a tese naturalista, fundada no empirismo, quanto a tese intuicionista, fundada na intuição inerente as pessoas, não eram válidas para explicar como poderiam ser justificadas as convicções morais da sociedade.

A partir dos equívocos constatados nas duas correntes anteriores, o Emotivismo sustentava a ideia de que as proposições normativas não se restringem a simplesmente descrever algo, elas teriam também a (principal) função de influenciar sentimentos ou atitudes nas pessoas. Assim, as expressões morais representariam instrumentos de influência psíquica que ultrapassam a sua simples função cognitiva. $O$ principal representante desta corrente foi Stevenson, para quem o significado das palavras possuía dois aspectos distintos: o aspecto descritivo, que se refere à atitude do falante, e o aspecto emotivo, que se refere à influência, à sugestão que se faz sobre o comportamento de outras pessoas, mesmo que isso ocorra de forma inconsciente. $\mathrm{O}$ significado emotivo das palavras pode levar a definições persuasivas, que servem para influenciar as opiniões mediante a determinação ou mudança do significado descritivo, ao mesmo tempo que preservam o significado emotivo. Um exemplo de definição persuasiva é a palavra 
democracia, que possui um significado emotivo positivo ${ }^{152}$. Assim, o erro das duas teorias anteriores (Naturalismo e Intuicionismo) era considerar isoladamente dois aspectos que, na realidade, se complementam, ou seja, o significado descritivo e o significado emotivo de uma palavra são como os dois lados de uma moeda.

Além disso, segundo Stenvenson, numa argumentação moral não existem relações lógicas (nem dedutivas, nem indutivas), mas tão-somente relações psíquicas. Não obstante, Stevenson acredita que a argumentação moral baseia-se em fundamentos racionais, quando os fatos podem ser expostos por razões, e também em fundamentos nãoracionais, também denominados de persuasivos, que recorrem a outros meios para influenciar o comportamento do ouvinte. Estes dois tipos de fundamentos não são excludentes entre si, ou seja, na maioria das argumentações práticas encontram-se fundamentos racionais e persuasivos concomitantemente. Stevenson entende, ainda, que numa argumentação, formada por proposições feitas pelos falantes, o que importa é a persuasão, e não a verdade ou falsidade dos argumentos. Desta forma, o discurso moral seria eminentemente psicológico, essencialmente atrelado à atitude dos intérpretes, e, por este motivo, não lhe seriam aplicáveis critérios de validade.

Embora reconheça que as palavras têm, sim, uma função persuasiva e que possam, igualmente, ser instrumentos de persuasão psicológica, Alexy critica a abordagem do discurso moral de Stenvenson partindo justamente da noção de que não se pode considerar uma proposição como um argumento se não for possível submetê-la a um critério de validade. Só é possível considerar algo como verdadeiro ou falso, certo ou errado, quando há critérios para distinguir tais posicionamentos. Desta forma, Alexy aponta que o principal erro na teoria de Stevenson foi "desconhecer o caráter do discurso moral como uma atividade guiada por regras ${ }^{, 153}$.

Mesmo sendo alvo de duras críticas, a teoria da argumentação moral como forma de persuasão psicológica de Stevenson contribuiu para a elaboração da teoria da argumentação jurídica de Alexy na medida em que tornou claro que o papel desempenhado pela linguagem moral ultrapassa a mera função de descrição, servindo também para

${ }^{152}$ ALEXY, Robert. Teoria da Argumentação Jurídica: A Teoria do Discurso Racional como Teria da Justificação Jurídica. Trad. Zilda Hutchinson Schild Silva. Introd. à ed. brasileira Claudia Toledo. São Paulo: Landy, 2005. pp. 63-65.

153 ALEXY, Robert. Teoria da Argumentação Jurídica: A Teoria do Discurso Racional como Teria da Justificação Jurídica. Trad. Zilda Hutchinson Schild Silva. Introd. à ed. brasileira Claudia Toledo. São Paulo: Landy, 2005. p. 69. 
influenciar e coordenar o comportamento de pessoas. Além disso, a separação entre métodos racionais e métodos persuasivos também possui sua relevância. Assim, o que Alexy considerou como o fundamental equívoco da teoria de Stevenson, isto é, o fato de não apresentar critérios ou regras que permitissem distinguir argumentos válidos de inválidos, deixando de reconhecer a natureza do discurso moral como uma atividade regida por regras ${ }^{154}$, acabou conduzindo ao problema central da teoria do discurso racional. A partir daí, Alexy inicia sua busca pelas regras que regem o discurso moral.

Considerando que qualquer discurso somente pode ser conhecido mediante a linguagem, a teoria dos jogos de linguagem elaborada por Wittgenstein assume posição relevante nos estudos de Alexy. Isto porque os exemplos mencionados por Wittgenstein para ilustrar seus jogos de linguagem permitem várias conclusões importantes, e dentre elas, Alexy cita as quatro que mais se destacam para a elaboração da teoria do discurso racional. A primeira é a de que a linguagem não possui apenas função descritiva, ela pode, dentre várias outras coisas, ter função persuasiva, função de entretenimento, etc. Isto implica que no campo da ética não é possível se orientar apenas pelas ciências empíricas, e, assim, a função descritiva da linguagem não deve ser vista como a única possível. A segunda é que existe um estreito vínculo entre a linguagem e o agir humano, de forma que o discurso racional deve considerar não somente a linguagem falada, mas, também, o comportamento, o não-verbal. A terceira é que os jogos de linguagem que se verificam nos discursos são submetidos a regras, não se tratando, desta forma, de uma atividade aleatória. A quarta, e última, consiste na constatação de que as representações do mundo e as formas de vida, conceitos estes intimamente ligados à noção de jogo de linguagem, não podem ser fundamentados, e, desta forma, não são passíveis de crítica.

Outra teoria que influenciou o estudo do discurso prático foi a Teoria dos Atos de Fala, de John Langshaw Austin. Atos de fala são aqueles atos que se realizam quando se diz algo ${ }^{155}$. Assim, quando alguém fala: "prometo que estarei lá", além de se expressar por meio da linguagem, ela também está expressando uma promessa. Esta ação de fazer algo por meio da linguagem é o que Austin denomina de ato ilocucionário ${ }^{156}$, e nisto consiste a

\footnotetext{
154 ALEXY, Robert. Teoria da Argumentação Jurídica: A Teoria do Discurso Racional como Teria da Justificação Jurídica. Trad. Zilda Hutchinson Schild Silva. Introd. à ed. brasileira Claudia Toledo. São Paulo: Landy, 2005. p. 70.

${ }^{155}$ Sobre os diferentes tipos de atos de fala e suas classificações, v. AUSTIN, John Langshaw. How to do Things with Words. 2. ed. United States: Harvard University Press, 1975. p. 6 e seguintes.
} 
verdadeira contribuição original de sua tese. Outro ponto relevante sobre a teoria de Austin é a assertiva de que as proposições normativas também podem ser julgadas sob critérios de verdade ou falsidade, assim como as proposições descritivas, mas que esta ação depende de inúmeras considerações outras além daquelas referentes aos fatos. Desta forma, podemos resumir a contribuição da teoria de Austin para a análise do discurso prático feita por Alexy em dois pontos principais: (i) a teoria dos atos de fala de Austin demonstra que a atividade de falar um idioma é regida por regras, (ii) o uso da linguagem normativa se distingue do uso da linguagem descritiva porque oferece um sistema de conceitos básicos próprios. Então, partindo destes pontos, Alexy passa a analisar quais são as regras que guiam o discurso prático e quais regras determinam as razões pelas quais um argumento pode ser considerado bom ou ruim para fundamentar uma proposição.

Em seguida, Alexy analisa a teoria da argumentação moral desenvolvida por Richard M. Hare ${ }^{157}$. As regras que regem o discurso e a argumentação prática também estão presentes na teoria de Hare, e podem ser divididas em basicamente dois princípios: o princípio da universalidade, relativo ao significado descritivo do discurso, e o princípio da prescritividade, atinente à sua função prescritiva. Ele demonstra que as expressões possuem um caráter universal ligado à sua função descritiva, e que mesmo as proposições normativas trazem consigo uma certa dose de descritividade. As características prescritivas seriam relacionadas ao juízo moral de cada indivíduo, e os aspectos descritivos corresponderiam à parte não-moral do discurso. Nesse sentido, Alexy, traduzindo Hare, menciona que

"Quando fazemos um juízo moral sobre algo, fazemo-lo porque possui certas propriedades não-morais. Assim, ambas perspectivas conduzem ao fato de que os juízos morais sobre coisas potenciais se fazem por razões; e a noção de razão, como leva sempre consigo a noção de uma regra que afirma que algo é uma razão para outra coisa”.

As regras morais, cujo grau de generalidade pode variar, são denominadas por Hare de princípios morais.

\footnotetext{
156 Sobre os atos ilocucionários, v. AUSTIN, John Langshaw. How to do Things with Words. 2. ed. United States: Harvard University Press, 1975. p. 98 e seguintes.

${ }^{157}$ HARE, Richard M. A Linguagem da Moral. São Paulo: Martins Fontes, 1996.
} 
Embora Alexy estabeleça uma série de críticas ao modelo teórico de Hare, ele também destaca quatro importantes contribuições para uma teoria do discurso prático racional, quais sejam: (i) a distinção entre atos de fala valorativos e atos de fala prescritivos, (ii) a noção da universalidade dos juízos morais, que implica que quem expressa um juízo moral pressupõe uma regra, (iii) os juízos morais devem ser submetidos à comprovação, sendo a sua aceitação relacionada com a sua justificação moral, e, por fim, (vi) a concepção de Hare sobre o discurso moral como atividade racional em posição equivalente ao das ciências empíricas ${ }^{158}$.

Outro filósofo cujos estudos tiveram influência na elaboração da teoria do discurso prático de Alexy foi Stephen E. Toulmin. Sua tese centrava-se na questão acerca de o que exatamente torna um conjunto de fatos uma boa razão para fundamentar uma conclusão moral particular. Para ele, além das regras lógicas e científicas, existem regras de inferência específicas para os argumentos morais. Isto porque tanto a ciência quanto a moral participam de experiências sensoriais primitivas, porém de formas diferentes. Toulmin ainda distingue duas formas e dois níveis da argumentação moral. A primeira forma de argumentação moral refere-se à justificação da ação humana em virtude de uma regra moral vigente na sociedade do falante, sendo, portanto, fundamentada por meio de um apelo a uma regra e assumindo, desta maneira, características deontológicas. Já a segunda forma trata de escolher, numa situação de conflito de regras, dentre as fundamentações possíveis, aquela regra que causará menos sofrimento desnecessário, referindo-se às consequências dos atos, revelando-se, assim, sua faceta teleológica e sua função crítica. Já o primeiro e o segundo níveis da argumentação moral referem-se, respectivamente, à fundamentação das regras morais. Toulmin também introduz a noção de lógica como uma teoria da fundamentação das proposições e da expressão argumentativa, diminuindo a importância da lógica matemática aristotélica e diminuindo, também, a importância dos raciocínios por meio de silogismos. Isto porque, segundo ele, a lógica formal (tradicional) não é suficiente para explicar a força e as vicissitudes dos argumentos não-analíticos ${ }^{159}$. Seu modelo de argumentação, já mencionado no Capítulo 1 , demonstra

158 ALEXY, Robert. Teoria da Argumentação Jurídica: A Teoria do Discurso Racional como Teria da Justificação Jurídica. Trad. Zilda Hutchinson Schild Silva. Introd. à ed. brasileira Claudia Toledo. São Paulo: Landy, 2005. p. 99.

${ }^{159}$ Para Toulmin, os argumentos analíticos são aqueles que podem ser utilizados por meio de um silogismo. Ao contrário destes, os argumentos não-analíticos, ou materiais, são aqueles pelos quais uma conclusão não pode ser extraída a partir de premissas simplesmente por meio de um silogismo. ALEXY, Robert. Teoria da 
que na teoria de Toulmin a argumentação jurídica assume características bem próximas às de um debate, no qual um proponente dirige sua pretensão a um oponente, que pode aceitála, encerrando a discussão, ou rejeitá-la, reiniciando uma cadeia de argumentos em que ambas as partes expõem, sucessivamente, os argumentos que sustentam suas respectivas pretensões.

Embora Alexy tenha discordado de Toulmin em alguns aspectos, especialmente quanto à vagueza de suas regras fundamentais (por exemplo, como definir o que é "sofrimento desnecessário") e também por considerar que a tese de Toulmin tivesse, até certo ponto, inclinações utilitaristas, e, por isso, tenha estabelecido uma série de reservas à sua teoria, ele reconhece que ela também contribuiu para o desenvolvimento da teoria do discurso prático. De fato, Alexy concorda com Toulmin no sentido de que há regras de discurso moral que caracterizam determinados fatos como boas razões para fundamentar valorações, e como o conteúdo normativo destas seria correspondente ao conteúdo dos princípios morais, logo tais regras morais seriam inigualáveis às regras da lógica formal. Outro ponto comum consiste em que o juízo de valor completamente desenvolvido é fruto da consideração de todo o material relevante de acordo com regras morais específicas, de forma que uma argumentação moral não pode ter seu início do nada, ela sempre surge em face de fatores do mundo real, ou seja, sempre a partir do "material normativo surgido historicamente" 160 . Outrossim, ambos concordam que para que se organize e se desenvolva a argumentação, são necessárias algumas premissas e algumas regras. Por fim, Alexy ressalta a utilidade da divisão dos argumentos em duas formas e dois níveis, como já explicado acima.

Evoluindo a noção de estrutura da argumentação moral já existente na teoria de Toulmin, a teoria de Kurt Baier parte da indagação sobre se o significado da pergunta "o

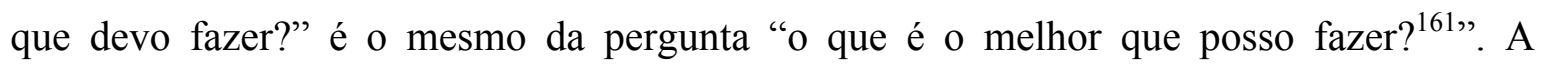
resposta a estas perguntas depende de várias reflexões e deliberações, e perpassa a

Argumentação Jurídica: A Teoria do Discurso Racional como Teria da Justificação Jurídica. Trad. Zilda Hutchinson Schild Silva. Introd. à ed. brasileira Claudia Toledo. São Paulo: Landy, 2005. pp. 104-105.

160 ALEXY, Robert. Teoria da Argumentação Jurídica: A Teoria do Discurso Racional como Teria da Justificação Jurídica. Trad. Zilda Hutchinson Schild Silva. Introd. à ed. brasileira Claudia Toledo. São Paulo: Landy, 2005. p. 109.

161 ALEXY, Robert. Teoria da Argumentação Jurídica: A Teoria do Discurso Racional como Teria da Justificação Jurídica. Trad. Zilda Hutchinson Schild Silva. Introd. à ed. brasileira Claudia Toledo. São Paulo: Landy, 2005. p. 111. BAIER, Kurt. The Moral Point of View. Ithaca/NY: Cornell University Press, 1958, p. 85. 
determinação das razões que sustentam a melhor ação. Tais deliberações ocorrem em dois níveis: primeiro pesquisam-se os fatos e se analisa a sua relevância, e depois se avaliam as razões obtidas a partir de tais fatos. Quando, a partir dos fatos, surgirem razões tanto para fazer como para deixar de fazer algo, entram em ação as regras de prioridade, que auxiliarão na ponderação. O ponto distintivo da teoria Baier consiste justamente nessa possibilidade de ponderação das razões contrárias e a favor que fundamentam uma argumentação, e a decisão fica para o nível das prioridades. De toda forma, a sua contribuição para a teoria da argumentação jurídica de Alexy consiste na distinção entre as regras de razão e aquelas que estabelecem uma hierarquia entre elas, bem como o conceito de generalizabilidade, que mais tarde se revela como um dos conceitos centrais da teoria do discurso prático geral ${ }^{162}$.

\subsubsection{Filosofia Analítica - Habermas e a Escola de Erlangen}

As teorias acima resumidas são classificadas como teorias metaéticas. Porém, a teoria da argumentação jurídica de Alexy também sofreu influência das teorias analíticas sobre a ética. Dentre estas, destacam-se a Teoria Consensual da Verdade de Habermas, e a Teoria da Deliberação Prática da Escola de Erlangen.

Objetivamente, a Teoria Consensual da Verdade, elaborada por Jürgen Habermas, afirma que “as expressões normativas, como ordens (mandamentos) $e$ valorações podem ser fundamentadas basicamente da mesma maneira que as proposições empíricas "163 , com a adaptação do critério de verdade, aplicável a estas, para o critério de correção, aplicável àquelas. Habermas inicia sua análise questionando-se sobre o conceito de verdade, e chega à conclusão de que existe uma diferença entre os fatos e o objeto da experiência. Ao contrário do que normalmente se pensa, os fatos somente podem ser conhecidos depois que se prova a verdade de um enunciado sobre eles. Antes disso, eles são o objeto da experiência. Assim, o que chamamos de "fatos no mundo" corresponde, segundo Habermas, aos objetos da experiência.

\footnotetext{
162 ALEXY, Robert. Teoria da Argumentação Jurídica: A Teoria do Discurso Racional como Teria da Justificação Jurídica. Trad. Zilda Hutchinson Schild Silva. Introd. à ed. brasileira Claudia Toledo. São Paulo: Landy, 2005. p. 116.

163 ALEXY, Robert. Teoria da Argumentação Jurídica: A Teoria do Discurso Racional como Teria da Justificação Jurídica. Trad. Zilda Hutchinson Schild Silva. Introd. à ed. brasileira Claudia Toledo. São Paulo: Landy, 2005. p. 116.
} 
Outra questão relevante sobre a doutrina de Habermas é a constatação de que, se por um lado, os fatos somente podem ser conhecidos por meio da linguagem, por outro, os enunciados dependem dos fatos para se provarem verdadeiros. Desta forma, pela teoria consensual da verdade, somente é possível atribuir um predicado a um objeto se também qualquer outra pessoa que puder entrar num diálogo comigo puder atribuir ao objeto em questão o mesmo predicado. A condição para considerar uma assertiva qualquer como verdadeira é, pois, o potencial consenso entre as pessoas. Então, para Habermas, a verdade é uma pretensão de validade que se anexa aos atos de fala constativos, de maneira que a verdade de uma proposição decorre da fundamentação da própria proposição, e não o contrário. Desta forma, Habermas comprova que as proposições normativas também podem ser sujeitas a critérios de verdade, derrubando a noção aristotélica de que a verdade consistiria numa relação positiva entre a proposição e o mundo real, de modo que apenas às proposições descritivas seria aplicável o critério da verdade. E, com esta quebra de paradigma, ocorre a transferência do conceito de verdade do nível da semântica para o nível da pragmática.

Habermas estabelece, ainda, a distinção entre ação e discurso. Enquanto as ações correspondem a jogos de linguagem nos quais há um reconhecimento tácito sobre as pretensões de validade, não se questionando se as proposições afirmadas nos atos de fala são verdadeiras ou se os fatos mencionados realmente existem, os discursos se ocupam das situações em que há problemas em relação às pretensões de validade, ou em relação à verdade dos fatos, e o seu resultado consistirá, pois, no reconhecimento ou na rejeição destas pretensões de validade. Assim, a única coisa que se produz num discurso são os argumentos. A partir desta distinção, Habermas chega ao conceito de "fato", que corresponde a algo que "expressa uma proposição que pode ser fundamentada discursivamente" ${ }^{164}$, bem como à noção e "ato de fala normativo", que corresponde a todos aqueles atos de fala que tenham como seu significado locucionário (aqui retomando a nomenclatura sugerida por Austin) uma proposição normativa, consistente na expressão de um dever ou num juízo de valor ${ }^{165}$.

164 ALEXY, Robert. Teoria da Argumentação Jurídica: A Teoria do Discurso Racional como Teria da Justificação Jurídica. Trad. Zilda Hutchinson Schild Silva. Introd. à ed. brasileira Claudia Toledo. São Paulo: Landy, 2005. p. 123.

165 ALEXY, Robert. Teoria da Argumentação Jurídica: A Teoria do Discurso Racional como Teria da Justificação Jurídica. Trad. Zilda Hutchinson Schild Silva. Introd. à ed. brasileira Claudia Toledo. São Paulo: Landy, 2005. p. 126. 
Alexy critica o critério de verdade proposto por Habermas esclarecendo que o consenso universal sobre qualquer coisa é uma utopia, o que o inviabiliza para servir de critério para a determinação da verdade. E, mesmo que um consenso geral fosse possível, não haveria garantias de que este acordo não houvesse sido obtido mediante coerção. Em face disso, Habermas explica que não se trata da necessidade de consenso universal em si, mas, sim, de um consenso fundamentado, ou seja, um consenso obtido a partir da força do melhor argumento ${ }^{166}$, a qual somente pode ser medida num contexto de lógica (pragmática) do discurso. E, segundo Alexy, "a força de um argumento para produzir consenso depende de um desenvolvimento cognitivo que garanta que o sistema descritivo é adequado e que precede toda argumentação singular." ${ }^{167}$ Desta forma, chega-se ao conceito de consenso fundado proposto por Habermas para servir como critério de verdade, traduzido do alemão por Alexy:

"Um consenso argumentativamente produzido pode ser considerado um critério de verdade apenas se existe a possibilidade estrutural de interrogar, modificar e substituir a respectiva linguagem de fundamentação em que as experiências são interpretadas" ${ }^{\prime 68}$.

Tal como ocorreu em relação às demais teorias filosóficas analisadas por Alexy, a teoria de Habermas também sofreu críticas como a já mencionada acima, o que não lhe retirou, contudo, a importância para a elaboração da teoria do discurso prático. Talvez a mais importante contribuição de Habermas tenha sido a elaboração das três regras da razão. As "Regras da Razão" representam um objetivo que pode ser atingido por aproximação (embora não possa ser cumprido totalmente), e representam, ainda, uma relevante evidência das críticas às limitações injustificáveis aos direitos dos interlocutores. Além disso, as regras da razão consubstanciam um critério hipotético e negativo sobre a correção ou sobre a verdade de uma proposição. Por todos estes motivos, é possível concluir que as regras da razão desempenham papel fundamental para a garantia da

\footnotetext{
${ }^{166}$ A definição de argumento já foi exposta no item referente à Argumentação, no Capítulo 1.

167 ALEXY, Robert. Teoria da Argumentação Jurídica: A Teoria do Discurso Racional como Teria da Justificação Jurídica. Trad. Zilda Hutchinson Schild Silva. Introd. à ed. brasileira Claudia Toledo. São Paulo: Landy, 2005. p. 129.

168 ALEXY, Robert. Teoria da Argumentação Jurídica: A Teoria do Discurso Racional como Teria da Justificação Jurídica. Trad. Zilda Hutchinson Schild Silva. Introd. à ed. brasileira Claudia Toledo. São Paulo: Landy, 2005. p. 129. Texto original em alemão em: HABERMAS, Jurgen. Wahrheitstheorien, In: FAHRENBACH, H. (org.) Wirklichkeit und Refeixion, Festschrift für W. Schulz. Pfillingen, 1973. p. 250.
} 
racionalidade dos discursos. Então, cumpre resumi-las nas seguintes assertivas: 1 - Regra de Admissibilidade no Discurso: "quem pode falar, pode tomar parte no discurso"; 2 Regra da Liberdade de Discussão, que se desdobra em três sub-regras: 2.1 - "todos podem problematizar qualquer asserção”, 2.2 - "todos podem introduzir qualquer asserção no discurso”, 2.3 - “todos podem expressar suas opiniões, desejos e necessidades”; 3 - Regra de proteção contra a coerção: "não se pode impedir nenhum falante de exercer seus direitos estabelecidos nas regras 1 e 2 mediante coerção existente dentro ou fora do discurso”. Esta regra poderia até mesmo, como já ressaltado por Alexy, ser considerada uma regra especial de garantia do cumprimento das duas primeiras ${ }^{169}$.

Cumpre, então, tecer breves comentários acerca da Escola de Erlangen e de sua teoria construtivista, outra importante influência na teoria da argumentação racional desenvolvida por Alexy. A principal contribuição da Escola de Erlangen consubstancia-se no princípio da razão (também denominado de princípio da deliberação) e no princípio da moral.

O princípio da razão desdobra-se na necessidade de observância a três requisitos, denominados de níveis da comunidade racional: (i) assegurar o mesmo uso das palavras para ambos os participantes do diálogo, podendo ser a linguagem ordinária, mediante alguns ajustes; (ii) requisito da sinceridade, ou seja, quem faz uma afirmação dirigida a um interlocutor deve acreditar nessa afirmação antes do próprio interlocutor, ou seja, deve ser sincero ao propor seu enunciado; (iii) as proposições devem ser construídas de modo que seja possível que outras pessoas, além do falante e de seu interlocutor, possam aceitá-las, ou seja, trata-se de um requisito de generalidade aplicável aos enunciados. Se estas exigências são cumpridas, verificar-se-á a racionalidade necessária para que o discurso possa orientar a tomada de decisões, e assim, tornar-se-á possível a determinação do que é uma deliberação racional ${ }^{170}$, a qual, a seu turno, exige, além dos três níveis da razão, outros três níveis de fundamentação, os quais correspondem, respectivamente, à fundamentação de uma ação mediante a indicação de uma finalidade, a

169 ALEXY, Robert. Teoria da Argumentação Jurídica: A Teoria do Discurso Racional como Teria da Justificação Jurídica. Trad. Zilda Hutchinson Schild Silva. Introd. à ed. brasileira Claudia Toledo. São Paulo: Landy, 2005. pp. 154/157.

170 ALEXY, Robert. Teoria da Argumentação Jurídica: A Teoria do Discurso Racional como Teria da Justificação Jurídica. Trad. Zilda Hutchinson Schild Silva. Introd. à ed. brasileira Claudia Toledo. São Paulo: Landy, 2005. pp. 154/157. 
fundamentação desta finalidade por meio de uma norma, e por fim, a fundamentação da referida norma.

O princípio da moral é aplicável para resolver situações de conflito em que existam várias normas aplicáveis, porém para fins incompatíveis entre si. Alexy cita a exigência que formula o princípio da moral: "Numa situação de conflito, estabeleça quais são as normas superiores compativeis entre si, em relação às normas que se usam como razões para fins incompatíveis entre si, e formule subnormas destas supernormas que sejam compatíveis entre si”, mas destaca que o princípio moral não apresenta nenhum critério para justificar esta exigência de modificação das normas, e também não explica a questão de quais dentre as normas ou fins incompatíveis devem ser modificados, e de que forma isso deve ser realizado. Em face destes problemas, ele conclui que o que se chama de princípio da moral, na verdade, constitui um argumento que pode ser utilizado em algumas situações, porém não se pode afirmar que se trate de um procedimento de fundamentação geral.

A terceira e mais importante contribuição da teoria construtivista da Escola de Erlangen consiste na teoria da gênese crítica, por meio da qual fica estabelecido que a ciência da cultura deve cumprir três objetivos: a interpretação, a crítica e a reforma da cultura. A interpretação consiste em estabelecer precisa e objetivamente qual é o sistema de normas vigentes numa determinada sociedade, mediante a reprodução da história deste sistema normativo e mediante a comprovação empírica, enquanto possível, dos fatos encontrados. Uma vez estabelecido o sistema de normas daquela sociedade, passa-se à análise crítica cultural com o objetivo de verificar se a cultura daquela sociedade permite a aplicação do princípio da razão. A este juízo crítico do sistema normativo convencionou-se chamar de gênese crítica. A importância da teoria da gênese crítica pode ser vista mediante dois exemplos. O primeiro ocorre quando uma norma perfeitamente razoável do ponto de vista lógico perde seu sentido em virtude de mudanças nas circunstancias fáticas reais de sua aplicação. Em outras palavras, ela permite analisar criticamente e explicar por que uma norma pode deixar de ser aplicável em virtude de modificação do contexto histórico e fático no qual ela deve produzir seus efeitos. A segunda hipótese corresponde a uma norma que não foi produzida sob circunstancias racionais e nem teria sido aprovada numa deliberação crítica inicial, mas que, não obstante isso, é aplicada. Isto pode ser explicado também em virtude das modificações históricas do contexto ao qual ela deva ser aplicada. Ou seja: algo que não tinha nenhum sentido antes, num novo contexto histórico, e 
mediante boas razões que lhe fundamentem, pode passar a ter. Estes dois exemplos servem para demonstrar que a convicção acerca da validade de uma norma pode ser atingida não somente sob condições racionais, mas também mediante condições irracionais da socialização individual ${ }^{171}$.

Desta forma, para a teoria do discurso racional de Alexy, importam os seguintes aspectos. A exigência de alcançar um uso comum das palavras vai ao encontro da necessidade de clareza e precisão linguística durante a análise do discurso prático. Em outras palavras, a redução da obscuridade linguística é algo que deve ser perseguido quando se quer examinar a forma como se desenvolve o discurso prático. Além disso, o princípio da razão prática corresponde ao princípio da universalidade e da generalidade que deve estar presente nas normas do discurso. Quanto ao princípio da moral, embora este não possa ser considerado um princípio por lhe faltar a característica da generalidade, ele ainda pode ser considerado um argumento válido para algumas hipóteses. Por fim, como já ressaltamos, a maior contribuição da Escola de Erlangen consiste na teoria da gênese crítica, cujos termos gerais resumimos nos parágrafos anteriores.

\subsection{Outras Teorias da Argumentação Jurídica}

A teoria elaborada por Alexy não é a única teoria que tratou de examinar a forma como se constroem os argumentos jurídicos e o processo de tomada de decisão. Outros autores, anteriores e contemporâneos a Alexy, também desenvolveram teorias paralelas sobre o mesmo tema, e sua análise, embora adotemos a teoria de Alexy como nosso referencial teórico, é também relevante.

\subsubsection{A Teoria da Argumentação de Chaïm Perelman}

Chaïm Perelman foi um dos mais importantes precursores no estudo da argumentação e do uso prático da razão. Sua teoria da argumentação foi publicada

171 ALEXY, Robert. Teoria da Argumentação Jurídica: A Teoria do Discurso Racional como Teria da Justificação Jurídica. Trad. Zilda Hutchinson Schild Silva. Introd. à ed. brasileira Claudia Toledo. São Paulo: Landy, 2005. pp. 159-163. 
originalmente em 1958, com o título La nouvelle rhétorique. Traité de l'argumentation, cujo título em português é Tratado da Argumentação: A Nova Retórica ${ }^{172}$.

Perelman contribui significativamente para a retomada da tópica e da retórica que já havia sido iniciada por Viehweg, na metade do século XX. A principal noção desenvolvida por Perelman foi a de que o raciocínio jurídico não se desenvolve da mesma forma que o raciocínio lógico formal (cartesiano), ou seja, não utiliza a lógica formal, mas utiliza, outrossim, a lógica dialética e a retórica. Além disso, ele acredita que a principal fonte onde é possível perceber a estrutura do raciocínio jurídico são os documentos produzidos pelos órgãos aplicadores do direito, notadamente as sentenças e decisões judiciais.

Outra noção fundamental na teoria de Perelman é a necessidade de um auditório para que a argumentação se desenvolva. O fim da argumentação é, desta forma, a persuasão deste auditório, e para tanto, é essencial conhecer previamente as intenções deste auditório. Nas palavras do próprio Perelman:

"O conhecimento daqueles que se pretende conquistar é, pois, uma condição prévia de qualquer argumentação eficaz. (...) Há apenas uma regra a esse respeito, que é a adaptação do discurso ao auditório, seja ele qual for: o fundo e a forma de certos argumentos, apropriados a certas circunstâncias, podem parecer ridiculos noutras. ${ }^{, 173}$.

E a legitimidade da argumentação estaria ligada ao livre convencimento do auditório, ou seja, a argumentação somente é legítima enquanto não se impõe mediante coerção ${ }^{174}$. O auditório aceita os argumentos e se convence por si só, sem a necessidade de uso da força. Neste ponto, cumpre esclarecer a diferença que Perelman estabelece entre persuadir e convencer ${ }^{175}$. Em breves palavras, uma argumentação persuasiva vale apenas

\footnotetext{
172 PERELMAN, Chaïm. OLBRECHTS-TYTECA, Lucie. Tratado da argumentação: A nova retórica. Trad. Maria Ermantina de Almeida Prado Galvão. 2. ed. São Paulo: Martins Fontes, 2005. V. também: ATIENZA, Manuel. As razões do Direito: teorias da argumentação jurídica. Trad. Maria Cristina Gumarães Cupertino. 3. ed. São Paulo: Landy, 2006. pp. 59-92. ALEXY, Robert. Teoria da Argumentação Jurídica: A Teoria do Discurso Racional como Teria da Justificação Jurídica. Trad. Zilda Hutchinson Schild Silva. Introd. à ed. brasileira Claudia Toledo. São Paulo: Landy, 2005. p. 165.

${ }^{173}$ PERELMAN, Chaïm. OLBRECHTS-TYTECA, Lucie. Tratado da argumentação: A nova retórica. Trad. Maria Ermantina de Almeida Prado Galvão. 2. ed. São Paulo: Martins Fontes, 2005. p. 23, 28.

174 Em razão da necessidade de convencimento do auditório é que Perelman denomina a sua teoria de Retórica, e não de Dialética. ATIENZA, Manuel. As razões do Direito: teorias da argumentação jurídica. Trad. Maria Cristina Gumarães Cupertino. 3. ed. São Paulo: Landy, 2006. p. 61.
} 
para um auditório particular, já uma argumentação convincente vale para todo ser dotado de razão, ou seja, para o auditório universal ${ }^{176}$. A partir da separação destes conceitos é possível inferir outra diferença importante, qual seja, a distinção existente entre argumento eficaz e argumento válido. $\mathrm{O}$ argumento válido está relacionado com a obtenção de acordo com o auditório universal, já aqueles argumentos que permitem a obtenção de acordos particulares são apenas eficazes ${ }^{177}$.

Perelman propõe a classificação das técnicas argumentativas (às quais ele se refere como "argumentos") em três categorias, e dentro destas são enquadrados os diversos tipos de argumentos. É exatamente esta classificação que determina o caráter analítico à teoria perelmaniana. Assim, em linhas bastante resumidas, descrevemos a sistematização que Perelman elaborou com a finalidade de analisar as estruturas dos argumentos e, assim, permitir a determinação de seu valor.

1) Técnicas de associação ou de reunião: como o nome diz, tratam de estabelecer o elo de ligação entre os elementos que compõem um fato ou um acontecimento. As técnicas de associação ou de reunião incluem uma extensa diversidade de argumentos, cujos principais serão brevemente explicados abaixo.

175 Sobre a diferença entre "persuadir" e "convencer", v. PERELMAN, Chaïm. OLBRECHTS-TYTECA, Lucie. Tratado da argumentação: A nova retórica. Trad. Maria Ermantina de Almeida Prado Galvão. 2. ed. São Paulo: Martins Fontes, 2005. pp. 29-34.

176 O conceito de "auditório universal" não fica claramente estabelecido, porém é possível depreender algumas características principais, enumeradas por Atienza, em análise ao Tratado da Argumentação Jurídica de Perelman. Assim, o auditório universal caracteriza-se pelos seguintes aspectos: "1) é um conceito limite, no sentido de que a argumentação diante do auditório universal é a norma da argumentação objetiva; 2) dirigir-se ao auditório universal é o que caracteriza a argumentação filosófica; 3) o conceito de auditório universal não é um conceito empírico: o acordo de um auditório universal 'não é uma questão de fato, e sim de direito' (...); 4) o auditório universal é ideal no sentido de que é formado por todos os seres dotados de razão, mas por outro lado é uma construção do orador, quer dizer, não é uma entidade objetiva; 5) isso significa não apenas que oradores diferentes constroem auditórios universais diferentes, mas também que o auditório universal de um mesmo orador muda." ATIENZA, Manuel. As razões do Direito: teorias da argumentação jurídica. Trad. Maria Cristina Gumarães Cupertino. 3. ed. São Paulo: Landy, 2006. p. 63. Entretanto, como ressalta Alexy, a composição do auditório universal é algo controvertido, porque dependa das ideias de indivíduos particulares de diversas culturas, de forma que as características do auditório universal dependem de fatos contingentes de tipo individual e social. Em face da extremada amplitude deste conceito, Alexy questiona-se sobre até que ponto ele serviria para fundamentar a valoração de argumentos. ALEXY, Robert. Teoria da Argumentação Jurídica: A Teoria do Discurso Racional como Teria da Justificação Jurídica. Trad. Zilda Hutchinson Schild Silva. Introd. à ed. brasileira Claudia Toledo. São Paulo: Landy, 2005. pp. 169-171.

177 ALEXY, Robert. Teoria da Argumentação Jurídica: A Teoria do Discurso Racional como Teria da Justificação Jurídica. Trad. Zilda Hutchinson Schild Silva. Introd. à ed. brasileira Claudia Toledo. São Paulo: Landy, 2005. p. 171. 
- Argumentos quase-lógicos: Existem vários tipos de técnicas de associação ou de reunião, e dentre os principais, citamos o que Perelman chama de "argumentos quase-lógicos", que recebem esta denominação justamente por se aproximarem, mas não se identificarem, com os argumentos puramente lógicos ou matemáticos. Os argumentos quase-lógicos referem-se, por exemplo, às noções de contradição, identidade e transitividade ${ }^{178}$, embora, na verdade não se relacionem diretamente a estas, uma vez que se trata de conceitos abstratos que só seriam possíveis no âmbito da lógica formal. Assim, os argumentos quase-lógicos trabalham com os conceitos concretos que se aproximam daqueles conceitos abstratos. Então, para a contradição, trabalha-se com a noção de incompatibilidade; para a identidade, trabalha-se com a ideia de definição (identidade total), regra de justiça e reciprocidade (não fazer aos outros o que não se deseja para si próprio); e para a transitividade, opera-se com a noção de solidariedade (os amigos dos seus amigos são meus amigos) e antagonismo, quando se ordenam seres ou acontecimentos sobre os quais não cabe confrontação direta (se A é melhor que B e B é melhor que C, então A é melhor que C). ${ }^{179}$

- Argumentos baseados na estrutura do real: por exemplo, argumentos baseados no nexo causal e argumentos pragmáticos, cuja função é estabelecer um vínculo de sucessão ou de coexistência com a finalidade de possibilitar uma solidariedade entre juízos admitidos e os demais que a argumentação pretende promover ${ }^{180}$. Por exemplo, os argumentos com base no nexo causal permitem desenvolver

\footnotetext{
${ }^{178}$ Aqui pretendemos apenas exemplificar os mais comuns. Perelman ainda cita muitos outros exemplos de argumentos quase-lógicos. PERELMAN, Chaïm. OLBRECHTS-TYTECA, Lucie. Tratado da argumentação: A nova retórica. Trad. Maria Ermantina de Almeida Prado Galvão. 2. ed. São Paulo: Martins Fontes, 2005. pp. 219-290.

179 ATIENZA, Manuel. As razões do Direito: teorias da argumentação jurídica. Trad. Maria Cristina Gumarães Cupertino. 3. ed. São Paulo: Landy, 2006. pp. 68-69.

${ }^{180}$ PERELMAN, Chaïm. OLBRECHTS-TYTECA, Lucie. Tratado da argumentação: A nova retórica. Trad. Maria Ermantina de Almeida Prado Galvão. 2. ed. São Paulo: Martins Fontes, 2005. p. 297. ATIENZA, Manuel. As razões do Direito: teorias da argumentação jurídica. Trad. Maria Cristina Gumarães Cupertino. 3. ed. São Paulo: Landy, 2006. p. 69.
} 
argumentações que tendem a relacionar dois acontecimentos sucessivos entre si em virtude de um nexo causal, permitindo também determinar a causa da ocorrência de determinado acontecimento ou da existência de determinada coisa ou, então, o efeito que determinado fato desencadeará ${ }^{181}$. Outro exemplo é o argumento pragmático, no qual existe uma relação de coexistência e por meio do qual se avalia um ato ou acontecimento a partir de suas consequências favoráveis ou desfavoráveis ${ }^{182}$. Assim, consequências boas podem resultar em valoração positiva, e da mesma forma consequências desfavoráveis acarretarão valoração negativa sobre o evento em questão.

- Argumentos que fornecem a base para a estrutura do real: estes constituem ligações que fundamentam o real pelo caso particular, como ocorre no caso dos exemplos, das ilustrações ou dos modelos. Assim, na argumentação mediante exemplos, permite-se uma generalização, supondo-se um acordo prévio sobre a própria generalização realizada a partir de casos particulares ${ }^{183}$. E, enquanto o exemplo visa fundamentar uma regra, a ilustração tem o objetivo de reforçar a adesão a uma regra já conhecida e já aceita ${ }^{184}$. Por fim, o modelo tem o objetivo de estimular a imitação de condutas inspiradas numa regra geral.

2)Técnicas de dissociação: as técnicas de dissociação possuem objetivo oposto àquele visado nas técnicas de associação ou de reunião. Em outras palavras, como o próprio nome diz, trata-se de recusar a existência de ligação entre os elementos que compõem o acontecimento, opondo-se ao estabelecimento de

\footnotetext{
${ }^{181}$ PERELMAN, Chaïm. OLBRECHTS-TYTECA, Lucie. Tratado da argumentação: A nova retórica. Trad. Maria Ermantina de Almeida Prado Galvão. 2. ed. São Paulo: Martins Fontes, 2005. p. 301.

182 PERELMAN, Chaïm. OLBRECHTS-TYTECA, Lucie. Tratado da argumentação: A nova retórica. Trad. Maria Ermantina de Almeida Prado Galvão. 2. ed. São Paulo: Martins Fontes, 2005. pp. 302-303.

${ }^{183}$ PERELMAN, Chaïm. OLBRECHTS-TYTECA, Lucie. Tratado da argumentação: A nova retórica. Trad. Maria Ermantina de Almeida Prado Galvão. 2. ed. São Paulo: Martins Fontes, 2005. pp. 399-400.

${ }^{184}$ PERELMAN, Chaïm. OLBRECHTS-TYTECA, Lucie. Tratado da argumentação: A nova retórica. Trad. Maria Ermantina de Almeida Prado Galvão. 2. ed. São Paulo: Martins Fontes, 2005. p. 407.
} 
solidariedade entre eles ${ }^{185}$. As técnicas de dissociação das noções possuem duas modalidades: a técnica da ruptura de ligações, que consiste em afirmar que são indevidamente associados elementos que deveriam ser tomados de forma independente, e a técnica da dissociação propriamente dita, que parte de uma pressuposta unidade primitiva dos elementos dentro de uma mesma concepção, os quais são referidos por uma mesma noção, impondo, desta forma, um rearranjo profundo das informações conceituais que fundamentam a $\operatorname{argumentação~}^{186}$.

O próprio Perelman ressalta, contudo, que esta classificação dos argumentos e o seu arranjo em técnicas argumentativas não exaure a possibilidade de se encontrarem novos argumentos, nem tampouco implica que os argumentos sejam excludentes entre si mesmos. Isto significa que um mesmo argumento real pode ser explicado a partir de várias técnicas argumentativas. Por exemplo, o argumento dos precedentes jurisprudenciais constitui, ao mesmo tempo, argumento de autoridade, aplicação da regra de justiça, argumento a partir de exemplos e também um argumento a partir da analogia ${ }^{187}$. Disso é possível extrair a conclusão de que os argumentos estão em permanente interação, sendo, desta forma, mais importante considerar o todo do que um ou outro argumento isolado.

Mas então como seria possível descobrir qual foi o(s) argumento(s) responsável(eis) pelo convencimento do auditório, se todos são considerados ao mesmo tempo? A resposta a esta pergunta vem com a determinação da força dos argumentos, que está diretamente vinculada "à intensidade da adesão do ouvinte às premissas, inclusive às ligações utilizadas" ${ }^{188}$, bem como "à relevância dos argumentos no debate em curso",189, revelando-se, por fim, tanto por meio da dificuldade que haveria para refutá-los quanto por

${ }^{185}$ PERELMAN, Chaïm. OLBRECHTS-TYTECA, Lucie. Tratado da argumentação: A nova retórica. Trad. Maria Ermantina de Almeida Prado Galvão. 2. ed. São Paulo: Martins Fontes, 2005. p. 467.

${ }^{186}$ PERELMAN, Chaïm. OLBRECHTS-TYTECA, Lucie. Tratado da argumentação: A nova retórica. Trad. Maria Ermantina de Almeida Prado Galvão. 2. ed. São Paulo: Martins Fontes, 2005. p. 468.

${ }^{187}$ PERELMAN, Chaïm. OLBRECHTS-TYTECA, Lucie. Tratado da argumentação: A nova retórica. Trad. Maria Ermantina de Almeida Prado Galvão. 2. ed. São Paulo: Martins Fontes, 2005. p. 524. No mesmo sentido, v. ATIENZA, Manuel. As razões do Direito: teorias da argumentação jurídica. Trad. Maria Cristina Gumarães Cupertino. 3. ed. São Paulo: Landy, 2006. p. 73.

${ }^{188}$ PERELMAN, Chaïm. OLBRECHTS-TYTECA, Lucie. Tratado da argumentação: A nova retórica. Trad. Maria Ermantina de Almeida Prado Galvão. 2. ed. São Paulo: Martins Fontes, 2005. p. 524.

${ }^{189}$ PERELMAN, Chaïm. OLBRECHTS-TYTECA, Lucie. Tratado da argumentação: A nova retórica. Trad. Maria Ermantina de Almeida Prado Galvão. 2. ed. São Paulo: Martins Fontes, 2005. p. 524. 
suas qualidades inerentes ${ }^{190}$. A força dos argumentos varia, desta forma, em função do tipo de auditório e do objetivo da argumentação, podendo ser medida através de diversos critérios que Perelman propõe. Porém, mesmo estes critérios não são muito bem definidos. Nas palavras do próprio Perelman,

"um argumento forte é um argumento eficaz, que determina a adesão do auditório, ou um argumento válido, que deveria determiná-la? A força de um argumento constitui uma qualidade descritiva ou normativa? E seu estudo depende da psicologia individual e social ou, ao contrário, da lógica”191

E, ao mesmo tempo, a própria força do argumento pode ser usada para fins argumentativos. Um orador pode aumentar a força de seus argumentos superestimando-os por meio da presunção de que os seus interlocutores o tenham aceitado durante a discussão, mesmo que esta aceitação não tenha sido explícita. Figuras como a insinuação, a reticência, ou mesmo a atenuação do argumento consistem em formas de se aumentar a sua força. Isto ocorre em praticamente todo discurso que não é meramente retórico, ou seja, em todo discurso em que o orador pretende persuadir ou convencer o auditório.

Apesar de tecer algumas críticas à teoria da argumentação de Perelman, especialmente no que concerne à obscuridade de seus conceitos mais fundamentais, bem como em relação à renúncia aos instrumentos analíticos modernos no seu esboço de estrutura da argumentação, outros pontos foram de considerável relevância para a elaboração da teoria do discurso prático de Alexy, que mais tarde conduziu à sua teoria da argumentação jurídica. Precisamente, são três os pontos em que Alexy expressa sua concordância com Perelman: primeiro, Alexy constatou a identificação entre a noção de auditório universal de Perelman e a ideia da situação ideal de fala de Habermas, confirmando a possibilidade da atribuição de caráter geral a uma regra ou uma norma, ou seja, uma regra deve ser susceptível de generalização. Em segundo lugar, além de orientar seu raciocínio à universalidade, Perelman soube destacar também que a argumentação racional também deve ser vinculada aos aspectos históricos e sociais dos conceitos. Nas palavras de Alexy, Perelman "busca chegar, a partir do faticamente dado como concepções e atitudes, mediante um processo de elaboração racional, a resultados

\footnotetext{
${ }^{190}$ PERELMAN, Chaïm. OLBRECHTS-TYTECA, Lucie. Tratado da argumentação: A nova retórica. Trad. Maria Ermantina de Almeida Prado Galvão. 2. ed. São Paulo: Martins Fontes, 2005. p. 524.

${ }^{191}$ PERELMAN, Chaïm. OLBRECHTS-TYTECA, Lucie. Tratado da argumentação: A nova retórica. Trad. Maria Ermantina de Almeida Prado Galvão. 2. ed. São Paulo: Martins Fontes, 2005. p. 526.
} 
aceitáveis de maneira geral." 192 E, a partir desta noção, conclui-se que, na argumentação jurídica e na lógica jurídica não é possível indicar apenas um único resultado como correto e definitivo, abrindo espaço para a crítica e para a tolerância.

\subsubsection{A teoria da argumentação de Stephen E. Toulmin}

Toulmin inicia sua teoria propondo uma quebra de paradigma em relação à lógica, a qual, em sua visão, corresponde à teoria que fundamenta a expressão $\operatorname{argumentativa~}^{193}$. Seu conceito de argumentação aproxima-se muito mais de um debate onde se apresentam proposições, razões, contra-razões, réplicas, etc., do que do conceito perelmaniano de argumentação como retórica, como esforço para o convencimento de um auditório.

Desta forma, o conceito de argumentação proposto por Toulmin corresponde à atividade total de propor pretensões, questioná-las, apresentar razões e contra-razões, criticá-las e apresentar réplicas a estas críticas ${ }^{194}$. Nesta definição é fácil perceber os quatro elementos que, segundo Toulmin, caracterizam a argumentação: (i) as pretensões, que são, ao mesmo tempo, o ponto de partida e de chegada numa argumentação, isto é, onde se inicia e para onde se dirige a argumentação, é o que se pretende impor ao interlocutor; (ii) as razões, que são os fatos específicos do caso que são mencionados com o fim específico de fundamentar a pretensão, devendo ser, concomitantemente, relevantes e suficientes para que se possa cumprir o objetivo de persuadir o interlocutor, (iii) as garantias, que correspondem aos enunciados gerais que se aplicam aos argumentos - tais enunciados não descrevem fatos, mas permitem a passagem de uns enunciados a outros ${ }^{195 ;}$ e os (vi) respaldos, que se constituem no campo geral de informação, o pressuposto da garantia

192 ALEXY, Robert. Teoria da Argumentação Jurídica: A Teoria do Discurso Racional como Teria da Justificação Jurídica. Trad. Zilda Hutchinson Schild Silva. Introd. à ed. brasileira Claudia Toledo. São Paulo: Landy, 2005. p. 179.

193 TOULMIN, Stephen Edelston. The uses of Argument. New York: Cambridge University Press, 2003. p. 6 e seguintes.

194 ATIENZA, Manuel. As razões do Direito: teorias da argumentação jurídica. Trad. Maria Cristina Gumarães Cupertino. 3. ed. São Paulo: Landy, 2006. p. 94.

${ }^{195}$ Manuel Atienza ilustra de forma simples e precisa a distinção entre razões e garantias, comparando-as aos ingredientes e ao modo de fazer de uma receita de bolo. Enquanto as razões/fatos são como os ingredientes que compõem a receita do bolo, as garantias/enunciados determinam o modo como a receita deve ser executada para que se produza, afinal, um bolo. ATIENZA, Manuel. As razões do Direito: teorias da argumentação jurídica. Trad. Maria Cristina Gumarães Cupertino. 3. ed. São Paulo: Landy, 2006. p. 97. 
apresentada, e assim, será variável de acordo com o tipo de argumento e de garantia em questão. ${ }^{196 .}$

Estes elementos são dispostos como uma cadeia justificativa da argumentação, sendo que a atividade central de expor as razões para fundamentar uma pretensão constitui o raciocínio. Desta forma, o conceito de argumento proposto por Toulmin possui dois sentidos: primeiro, o argumento consiste no encadeamento do raciocínio, ou seja, é o encadeamento das razões com o objetivo de sustentar uma pretensão em face de outrem, e no seu segundo sentido, o argumento consiste em algo em que as pessoas se vêem envolvidas, ou seja, as relações humanas nas quais se debatem tais sequências de raciocínios $^{197}$.

Exemplificando: o indivíduo A (proponente) apresenta sua pretensão ao indivíduo B (oponente, ou interlocutor), que a rejeita. Então, A expõe as razões de fato e de direito que fundamentam sua pretensão, e B pode, querendo, oferecer uma réplica, também expondo as razões de fato e de direito que a sustentam. Em face disso, A pode treplicar, apresentando as garantias e os respaldos de sua pretensão, e B pode fazer o mesmo. Como se vê, as pretensões (de ambos) são fundamentadas pelas razões (fatos que sustentam a pretensão), as quais, por sua vez, são embasadas nas garantias (provas materiais, princípios jurídicos), que, por seu turno, são fundadas nos respaldos (enunciados categóricos do direito) ${ }^{198}$.

\footnotetext{
${ }^{196}$ Com propriedade, Manuel Atienza faz uma crítica a Toulmin pela falta de clareza na distinção de alguns de seus elementos centrais. Ele explica que “(...) há ocasiões (...) em que não é fácil perceber qual é a diferença existente entre garantia e o respaldo. Toulmin parece sugerir que a primeira é uma regra de inferência (uma 'licence inference', como às vezes ele chama) e o segundo, um enunciado sobre fatos. Mas isso suscita problemas, pelo menos se se está no terreno da argumentação jurídica. Por um lado, se a função do respaldo é oferecer uma justificação da garantia, então não se vê por que ele há de consistir num enunciado empírico (ou num postulado definicional, axioma, etc., como seria o caso dos argumentos formais) e não, por exemplo, num enunciado normativo ou valorativo. Por outro lado, dá a impressão de que, com relação aos argumentos jurídicos (ou a um grupo destes, os argumentos interpretativos), a garantia estaria constituída por uma norma jurídica (que estabelecesse, por exemplo, que os filhos têm o direito a herdar dos pais, quando estes morrem sem deixar testamento) e o respaldo, pela proposição normativa correspondente que afirma a existência de uma norma válida com esse conteúdo." ATIENZA, Manuel. As razões do Direito: teorias da argumentação jurídica. Trad. Maria Cristina Gumarães Cupertino. 3. ed. São Paulo: Landy, 2006. p. 111.
}

197 ATIENZA, Manuel. As razões do Direito: teorias da argumentação jurídica. Trad. Maria Cristina Gumarães Cupertino. 3. ed. São Paulo: Landy, 2006. p. 96.

${ }^{198}$ ALEXY, Robert. Teoria da Argumentação Jurídica: A Teoria do Discurso Racional como Teria da Justificação Jurídica. Trad. Zilda Hutchinson Schild Silva. Introd. à ed. brasileira Claudia Toledo. São Paulo: Landy, 2005. pp. 104-106. 
Seria, desta forma, como uma cadeia de justificativas que embasam o argumento, aqui entendido como um debate, cujo último respaldo seria o bom senso comum, uma vez que os seres humanos, de forma geral, possuem necessidades semelhantes e, embora possam não viver em condições semelhantes, partilham de comportamentos e fundamentos semelhantes.

Dentre os vários tipos de argumentos que Toulmin descreve, talvez a mais importante seja a distinção entre argumentos formais e não-formais. Assim, argumentos formais são aqueles em que a ligação entre as garantias e os respaldos é puramente formal, independente de experiência prática. Este é o caso dos argumentos utilizados para provar, por exemplo, uma pretensão matemática, cuja conclusão pode ser obtida apenas a partir da cadeia de proposições, sem necessidade de interferência de fatores externos. Tais fatores externos são, por exemplo, a verificação se o argumento tem força naquela situação concreta da vida, se o raciocínio que se aplica está correto. De outro lado, os argumentos não-formais são aqueles em relação aos quais apenas a cadeia de proposições não é suficiente para se chegar a uma conclusão, sendo imprescindível a consideração dos fatores externos acima mencionados. Os argumentos não formais são, portanto, os mais comuns na vida prática e, especialmente, na seara do Direito.

Além disso, atento à qualificação da força dos argumentos, Toulmin entende que um bom argumento é aquele que resiste às críticas e atende aos critérios exigidos para a obtenção de uma decisão favorável, e a correção do argumento não é derivada apenas da correção das premissas e da conclusão como num silogismo. Um argumento correto é aquele que, além de ter premissas corretas, também obedece a um procedimento, obedece a critérios substantivos e variáveis historicamente. ${ }^{199}$

Outro ponto de destaque na teoria de Toulmin é a consideração de que a argumentação é diferente em cada campo de aplicação. Esta noção é relacionada com a ideia proposta por Perelman da adequação do discurso ao auditório que se pretende convencer. Assim, a argumentação que se desenvolve no âmbito jurídico é distinta daquela que se aplica às ciências exatas, a qual, por sua vez, diferencia-se daquela válida para os assuntos ligados à arte, aos negócios ou à ética. Embora haja diferenças e semelhanças entre todas as modalidades argumentativas, é possível afirmar, como já destacado por

199 ATIENZA, Manuel. As razões do Direito: teorias da argumentação jurídica. Trad. Maria Cristina Gumarães Cupertino. 3. ed. São Paulo: Landy, 2006. p. 94. 
Toulmin, que a seara do Direito é a que fornece mais espaço para a prática da argumentação e para a análise do raciocínio.

Uma das principais características da Teoria da Argumentação de Toulmin consiste no fato de que ela se voltou mais para a prática da argumentação em si, sendo o foco de sua análise o aspecto dialético do processo argumentativo, ou seja, estudou a argumentação enquanto debate, a sua estrutura externa, com seus elementos e com as etapas de sua evolução. Nisso ela se diferencia da Teoria da Argumentação de Perelman, que deu preferência à análise da argumentação enquanto retórica, e priorizando o exame das estruturas internas dos argumentos voltados para o discurso em forma de monólogo.

\subsubsection{A teoria da argumentação de Neil MacCormick}

No campo da filosofia e da hermenêutica contemporâneas, duas teorias em especial tiveram grande difusão: as teorias da argumentação jurídica desenvolvidas por Neil MacCormick e por Robert Alexy. Embora sejam originários de tradições diferentes, sendo Alexy discípulo da escola alemã e MacCormick da escola inglesa/escocesa, suas teorias possuem algumas semelhanças significativas.

Contrariamente à tendência presente nas obras de Viehweg, Perelman e Toulmin de abandonar a lógica formal (lógica dedutiva) para a composição e análise da argumentação jurídica, MacCormick retoma a possibilidade de aplicação do raciocínio dedutivo à argumentação jurídica em sua obra Argumentação Jurídica e Teoria do Direito. De fato, MacCormick é enfático ao afirmar que, em certa medida, uma forma de raciocínio dedutivo é essencial para a argumentação jurídica ${ }^{200}$, o que confere à sua teoria características tanto descritivas quanto normativas. Ele salienta ainda que é justamente em razão deste caráter descritivo que se torna possível explicar e compreender os elementos não-descritivos de uma decisão.

Para MacCormick, a argumentação prática e a argumentação jurídica devem sempre ser tomadas em conjunto com a finalidade de justificar uma decisão, embora ele reconheça que a argumentação possui também caráter retórico, com objetivo de convencer um auditório, segundo já ressaltado na Nova Retórica de Perelman. Para ele o conceito de “justificar” é subjacente à noção de persuadir, e corresponde à ação de fornecer razões que

${ }^{200}$ MACCORMICK, Neil. Argumentação Jurídica e Teoria do Direito. Trad. Waldéa Barcellos. São Paulo: Martins Fontes, 2006. p. IX. 
permitam concluir que as decisões jurídicas estão em conformidade com a justiça e com o Direito. Além disso, MacCormick propõe uma fórmula extremamente simples para ilustrar o seu conceito de argumentação: "N $+\mathrm{F}=\mathrm{C}$ ", onde "N" = normas, " $\mathrm{F} "=$ fatos e "C" = conclusão. Lendo a fórmula chegamos à verdade essencial na teoria da argumentação de MacCormick, ou seja, "normas mais fatos geram conclusão"201. Para ele, a argumentação jurídica é uma espécie de raciocínio prático que estabelece quais as atitudes corretas em situações nas quais haja multiplicidade de escolhas, e, desta forma, a argumentação jurídica trata da justificação. ${ }^{202}$

Todas as pretensões jurídicas que dão origem aos litígios podem ser enquadradas nesta fórmula. A única diferença é que enquanto o autor de uma ação interpreta os fatos de uma forma à luz das normas e obtém uma conclusão "X", o réu interpreta os mesmos fatos de outra maneira à luz das normas, que podem não ser as mesmas, e obtém uma conclusão "Y". Caberá, assim, ao juiz, reconstituir os fatos a partir da narração de ambos e interpretá-los novamente de acordo com o Direito aplicável para, então, proferir sua decisão, que será a representação da sua conclusão, que poderá ser idêntica à do autor ou do réu, ou mesmo distinta de ambos. Tanto as pretensões do autor, como as pretensões do réu, como a decisão judicial, são locais onde se desenvolve a atividade de justificação. Mas, especificamente a decisão judicial, por seu caráter impeditivo às partes, necessariamente deverá ser justificada, ou seja, deverá ser fundamentada de acordo com o Direito vigente e seguindo uma linha argumentativa lógica.

MacCormick entende que em uma decisão judicial a lógica possui dois significados. Primeiro, em seu sentido dedutivo, uma decisão é lógica na medida em que os seus argumentos e as premissas das quais eles partem são corretamente encadeados para produzir uma conclusão. Em outro sentido, agora no sentido normativo, a decisão judicial é lógica na medida em que é justa, ou seja, enquanto é coerente com os princípios do Direito e com as regras deles decorrentes, e que está de acordo com o senso comum. Em outras palavras, estes dois "significados" da lógica em uma decisão judicial representam nada mais do que a necessidade que toda decisão tem de estar justificada interna e

\footnotetext{
${ }^{201}$ MACCORMICK, Neil. Argumentação Jurídica e Teoria do Direito. Trad. Waldéa Barcellos. São Paulo: Martins Fontes, 2006. p. X.

${ }^{202}$ MACCORMICK, Neil. Argumentação Jurídica e Teoria do Direito. Trad. Waldéa Barcellos. São Paulo: Martins Fontes, 2006. p. XIV.
} 
externamente $^{203}$. A justificação interna refere-se à conformidade em relação às premissas do ordenamento jurídico (aqui teria aplicação a "lógica dedutiva"), enquanto a justificação externa está relacionada com os fatores externos ao ordenamento, ao que chamamos de background histórico-cultural do legislador e a fatores como, por exemplo, o senso comum e o julgamento por equidade (aqui teria aplicação a "lógica jurídica", as provas dialéticas). Desta forma, é possível concluir que, embora sejam independentes, a segunda não surge se não houver a primeira. Ou seja, a justificação interna (ou "de primeira ordem", como denomina MacCormick) é condição para a justificação externa, mas o fato de uma decisão ser justificada internamente não assegura que haverá a justificação externa (ou "de segunda ordem", segundo MacCormick), o que não implica, outrossim, que a justificação externa seja dispensável ${ }^{204}$.

Indo mais além, MacCormick sustenta que, em alguns casos, é possível que a argumentação jurídica seja puramente dedutiva, afirmando que às vezes é possível demonstrar em termos conclusivos que a determinação da decisão é legalmente justificada por meio de um argumento puramente dedutivo. Para ilustrar tais situações, cita o exemplo do caso Daniels \& Daniels v. R. White \& Sons e Tarbard, no qual um senhor compra uma garrafa de limonada em uma loja e, após consumir a limonada, passa mal em virtude da presença de ácido carbólico na bebida. A dona da loja é condenada a indenizá-lo, embora a culpa pela presença da referida substância no produto vendido não é, a rigor, culpa dela, já que se tratava de um produto industrializado que vinha lacrado ${ }^{205}$. O autor demonstra que na decisão proferida pelo juiz para este caso houve argumentação puramente dedutiva:

"Uma argumentação dedutiva é uma argumentação que se propõe a demonstrar que uma proposição, a conclusão da argumentação, esta implícita em alguma outra proposição ou proposições, as 'premissas' da argumentaria. Uma argumentação dedutiva será válida se, não importa qual seja o teor das premissas e da conclusão, sua forma for tal que suas premissas de fato impliquem (ou acarretem) a conclusão. Com isso, o que se quer dizer é que

\footnotetext{
203 Esta terminologia é utilizada na teoria da argumentação de Alexy (na obra Teoria da Argumentação Jurídica), mas entendemos que se aplica também à teoria de MacCormick.

204 ATIENZA, Manuel. As razões do Direito: teorias da argumentação jurídica. Trad. Maria Cristina Gumarães Cupertino. 3. ed. São Paulo: Landy, 2006. p. 122.

${ }^{205}$ MACCORMICK, Neil. Argumentação Jurídica e Teoria do Direito. Trad. Waldéa Barcellos. São Paulo: Martins Fontes, 2006. pp. 23-26.
} 
seria uma contradição que alguém afirmasse as premissas e ao mesmo tempo negasse a conclusão.

Para ilustrar e explicar, tomemos uma frase do supracitado parecer do juiz Lewis: 'a garrafa que na realidade continha ácido carbólico com a limonada não era de qualidade própria para comercialização’. O juiz Lewis com efeito faz duas proposições:

A garrafa de limonada comprada pelo sr. Daniels continha ácido carbólico.

Portanto, a garrafa de limonada comprada pelo Sr. Daniels não era de qualidade própria para comercialização.

Por que razão pode-se dizer com tanta confiança que a primeira dessas proposições implica a segunda? A resposta é, naturalmente, que o juiz Lewis considera como líquido e certo o significado que a expressa 'de qualidade própria para comercialização' tem fins legais no contexto do artigo 14(2) da Lei de Venda de Mercadorias de 1893. (...) algo não é de qualidade própria para comercialização... se contiver defeitos que tornem impróprio para seu único uso devido mas que não sejam aparentes em um exame normal. Reformulando a definição numa proposição equivalente:

A) em qualquer caso, se as mercadorias vendidas a uma pessoa por outra tiverem defeitos não aparentes em um exame normal que as tornem impróprias para seu único uso devido, então elas não são de qualidade própria para comercialização.

(...)

B) No caso em questão, a mercadoria vendida por uma pessoa a outra tinha defeitos que a tornavam imprópria para seu único uso devido, mas que não eram aparentes em um exame normal.

\section{(...)}

C) Portanto, no caso em questão, a mercadoria vendida não é de qualidade própria para comercialização.

(...) 
Reconhecer este ponto é reconhecer que a argumentação é formalmente válida. Qualquer argumentação que tenha a mesma forma de nossa argumentação será igualmente válida, não importando qual seja a substância das premissas. "206

$\mathrm{Na}$ realidade, se observarmos atentamente, a decisão do juiz de condenar a dona do estabelecimento a pagar a indenização ao cliente baseou-se não no fato de que a limonada fez mal ao consumidor, mas no fato de que, ao vender uma mercadoria imprópria para o consumo, a dona do estabelecimento infringiu uma cláusula legalmente estabelecida (obrigação de somente vender mercadorias próprias para o consumo) para o contrato de compra e venda. E, mediante esta conclusão, torna-se possível afirmar que o juiz utilizou apenas a lógica dedutiva para decidir o caso. E MacCormick salienta, ainda, que neste caso, a decisão é perfeitamente válida, porque em cada uma das etapas do raciocínio do juiz, as premissas e as conclusões eram verdadeiras. Vale citar as palavras dele próprio:

"Pode ser observado que na análise da argumentação acima exposta, cada estágio é um argumento hipotético válido, cujas premissas são enunciados de proposições referentes a questões de direito que na época pertinente eram verdadeiras para fins legais, ou conclusões factuais que também são consideradas verdadeiras para fins legais, ou conclusões intermediárias dessas premissas. Como cada passo da argumentação é válido, toda a argumentação é válida. Como cada premissa (à luz dos critérios legais pertinentes) é verdadeira (por ser uma real proposição do direito, uma conclusão fatual ou uma conclusão depreendida dessas premissas), a conclusão final a que se chegou, além de estar estabelecida em termos válidos pelo raciocínio dedutivo, deve também ser verdadeira de acordo com aqueles mesmos critérios. "207

Outra utilidade da lógica dedutiva nos processos judiciais consiste em sua aplicação pelos advogados durante a seleção, dentre todos os fatos que os clientes lhes disponibilizam, aqueles que merecem ser afirmados e provados no que diz respeito à futura ação judicial que se tenha em vista. E é justamente a presença de normas jurídicas

\footnotetext{
${ }^{206}$ MACCORMICK, Neil. Argumentação Jurídica e Teoria do Direito. Trad. Waldéa Barcellos. São Paulo: Martins Fontes, 2006. pp. 29-30.

${ }^{207}$ MACCORMICK, Neil. Argumentação Jurídica e Teoria do Direito. Trad. Waldéa Barcellos. São Paulo: Martins Fontes, 2006. p. 40.
} 
regulando a apresentação e a importância das provas que revela a importância da lógica dedutiva para a elaboração das decisões judiciais ${ }^{208}$.

Entretanto, a justificação dedutiva das decisões não ocorre de forma ampla e irrestrita. Ela parte de pressupostos e está sujeita a limites. O primeiro dos pressupostos consiste no dever do juiz de decidir aplicando as normas do Direito válido ao caso exposto pelas partes ${ }^{209}$. O segundo consiste na capacidade dos juízes de identificar as normas válidas aplicáveis aos casos sob julgamento, implicando a existência de critérios de reconhecimento partilhados pelos juízes ${ }^{210}$.

Para a análise dos limites, remetemo-nos à distinção entre os casos "fáceis" e os casos "difíceis", já explicada no primeiro capítulo desta tese. Lembramos apenas que, pela doutrina de MacCormick, os casos fáceis são aqueles em relação aos quais a argumentação dedutiva é suficiente para apresentar uma solução satisfatória. Já os casos difíceis são aqueles que o raciocínio dedutivo não consegue resolver sozinho, dado o fato de que nestes casos a interpretação dedutiva da norma jurídica conduz a resultados ambíguos, obscuros ou indeterminados ${ }^{211}$. Em face disso afirma-se que é aos casos difíceis que se aplicam os tais "limites", os quais são referidos por MacCormick como “problemas", já que eles identificam o motivo pelo qual a lógica dedutiva não foi capaz de

${ }^{208}$ MACCORMICK, Neil. Argumentação Jurídica e Teoria do Direito. Trad. Waldéa Barcellos. São Paulo: Martins Fontes, 2006. p. 61. ATIENZA, Manuel. As razões do Direito: teorias da argumentação jurídica. Trad. Maria Cristina Gumarães Cupertino. 3. ed. São Paulo: Landy, 2006. p. 122.

${ }^{209}$ MACCORMICK, Neil. Argumentação Jurídica e Teoria do Direito. Trad. Waldéa Barcellos. São Paulo: Martins Fontes, 2006. p. 68.

${ }^{210}$ MACCORMICK, Neil. Argumentação Jurídica e Teoria do Direito. Trad. Waldéa Barcellos. São Paulo: Martins Fontes, 2006. pp. 78-79.

${ }^{211}$ Neste ponto é interessante relembrar a Teoria da Abertura da Linguagem, desenvolvida por Herbert Hart, na qual ele nega a existência de conceitos ou normas completamente determinados ou fechados. Segundo Hart, qualquer norma, em algum momento de sua aplicação, mostrar-se-á indeterminada e aberta, e isso é uma conseqüência da utilização de conceitos gerais nas próprias normas, que necessitam dessa generalidade para serem aplicadas. Outro aspecto importante da indeterminação dos termos legais consiste no efeito de aumentar a discricionariedade do juiz durante a interpretação da norma. É como se a indeterminação fosse o preço pago para que as normas pudessem ter aplicabilidade ampla. Nesse ponto, há uma crítica ao formalismo de conceitos, que prega a conceituação precisa de tudo que existe. Essa mesma indeterminação é também uma característica da própria linguagem humana, e tem sua utilidade ao permitir ao aplicador do direito uma certa margem de discricionariedade e ponderação para que desenvolva a sua interpretação da norma de acordo com as peculiaridades de cada caso concreto. Para Hart, em último grau, a indeterminação da norma poderia levar à lacuna legal, o que não seria possível pela teoria de Kelsen, que acredita que sempre pode ser extraída pelo menos uma (senão várias) norma individual e concreta, fruto da interpretação da norma geral e abstrata. HART, Herbert L. A. O Conceito de Direito. Trad. Antonio de Oliveira SetteCâmara. São Paulo: Martins Fontes, 2009, pp. 161-199. V. também MACCORMICK, Neil. Argumentação Jurídica e Teoria do Direito. Trad. Waldéa Barcellos. São Paulo: Martins Fontes, 2006. p. 83. 
resolver o caso. Assim, quando se esbarra em um destes limites, a solução é dada pela lógica argumentativa, dialética, que recorre aos princípios e à valoração de fatos e provas. Cumpre, então, tecer alguns comentários sobre cada uma das quatro modalidades que podem assumir:

(a) Problemas de interpretação: um problema de interpretação surge, como o próprio nome diz, quando são possíveis duas ou mais interpretações da norma que está sendo aplicada. Entretanto, poderíamos argumentar que, em princípio, toda e qualquer norma apresenta infinitas possibilidades de interpretação. Então, para caracterizar o limite em questão, entendemos que MacCormick referiu-se à ambiguidade que algumas expressões utilizadas na norma jurídica podem suscitar, gerando conclusões contraditórias. De fato, nas palavras dele próprio: “(...) as normas podem ser ambíguas em determinados contextos e podem ser aplicadas de um modo ou de outro somente depois que a ambigüidade for resolvida. No entanto, resolver a ambigüidade de fato envolve escolher entre duas

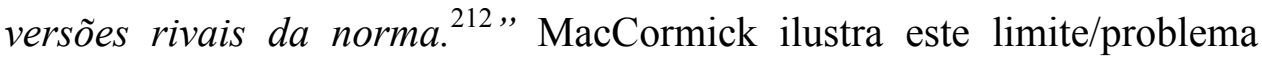
mediante o seguinte exemplo:

“A Lei de Relações Raciais de 1968, do Reino Unido, por exemplo, proíbe a discriminação 'com base na cor, na raça ou na origem étnica ou nacionalizem relação inter alia à disponibilização de moradia. Torna-se bastante claro o modo de aplicação desse dispositivo se alguém se recusar a vender ou alugar uma casa a outra pessoa por essa pessoa ter a pele negra ou por ser descendente de irlandeses. O que dizer, porém, se uma autoridade municipal, ao selecionar entre inscritos para receber moradia da prefeitura, aplicar uma norma de que somente súditos britânicos, de acordo com o significado da Lei de Nacionalidade Britânica de 1948, podem ser admitidos nessa lista? Essa autoridade municipal estará cometendo uma forma de discriminação proibida pela Lei? (...)

São duas as respostas possíveis: que se trata de discriminação ilícita e que não se trata de discriminação lícita. Uma ou outra deve estar correta; ambas não podem estar corretas. O problema é que há duas visões

\footnotetext{
${ }^{212}$ MACCORMICK, Neil. Argumentação Jurídica e Teoria do Direito. Trad. Waldéa Barcellos. São Paulo: Martins Fontes, 2006. p. 86.
} 
possíveis acerca da interpretação da Lei: (a) que a discriminação 'com base nas origens nacionais' inclui a discriminação com base na nacionalidade oficial de um indivíduo; e (b) que ela não inclui a discriminação com base na nacionalidade oficial de um indivíduo. ,213

(b) Problemas de pertinência: os problemas de pertinência são relativos à existência da norma válida no sistema. Dito de outra forma, trata-se de descobrir se a norma que se pretende aplicar realmente pertence ao sistema. Poderia, portanto, ser perfeitamente denominado de problema de validade. É um limite relacionado, em último caso, com a validade das normas aplicáveis ao caso. Este problema tem maior importância nos países em que vigora o regime da Common Law, já que em virtude de lá o Direito não ser altamente codificado, dependendo basicamente da jurisprudência para sua introdução no ordenamento, há mais espaço para sua ocorrência, uma vez que pode não haver um precedente que já tenha introduzido tal norma, o que exigiria um esforço maior do juiz para comprovar a sua pertinência ao sistema legal. Portanto, eles são anteriores aos problemas de interpretação, que pressupõem uma norma válida (e, portanto, existente e pertinente ao sistema) e aplicável ao caso, mas muitas vezes podem ser confundidos com estes, como explica MacCormick:

"uma característica inevitável de um sistema de direito não codificado é que muitas questões de disputa e decisões a respeito surgem e são solucionadas sem referência à lei estabelecida (ou 'escrita') de qualquer forma que seja. Na medida em que o precedente judicial funcione como fonte de 'lei válida' para esses sistemas, haverá naturalmente o recurso frequente aos argumentos dedutivos que apliquem normas derivadas dessa fonte, e 'problemas de interpretação', como definidos acima,

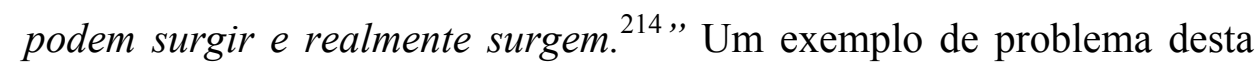
natureza é citado por MacCormick:

\footnotetext{
${ }^{213}$ MACCORMICK, Neil. Argumentação Jurídica e Teoria do Direito. Trad. Waldéa Barcellos. São Paulo: Martins Fontes, 2006. pp. 83-84.

${ }^{214}$ MACCORMICK, Neil. Argumentação Jurídica e Teoria do Direito. Trad. Waldéa Barcellos. São Paulo: Martins Fontes, 2006. p. 87.
} 
"É do conhecimento de todos como em Donoghue v. Stevenson ([1932] A.C. 562: 1932 S.C. (H.L.) 31), a aurora, a sra. Donoghue, iniciou uma ação de reparação contra o réu, um fabricante de águas gaseificadas, com base no fato de (como ela afirmou) ter bebido parte do conteúdo de uma garrafa opaca de gengibirra Stevenson antes de descobrir na parte restante do conteúdo, quando despejado, os restos de uma lesma em decomposição. Que isto lhe causara gastroenterite e trauma nervoso; e que a presença das lesma na gengibirra era devida ao fato de o fabricante não ter tomado cuidados razoáveis na preparação $e$ engarrafamento do refrigerante. Como o réu tinha para com ela o dever de tomar cuidados razoáveis nesses processos e como ela havia sofrido danos decorrentes da sua falta de cuidado, a autora tinha direito a uma indenização como compensação pelos danos físicos e pelo trauma nervoso que tinha sofrido.

Nenhuma lei estabelecida cobria (nem cobre) a responsabilidade civil para um dano semelhante; e na época em que seu recurso foi do Supremo Tribunal da Escócia para a Câmara dos Lordes, não havia nenhum precedente vinculante que decidisse a questão em termos conclusivos para um lado ou para o outro, embora (...) houvesse uma boa quantidade de precedentes suficientemente análogos para exercer influência persuasiva de cada lado do caso.

Num caso como esse, a questão, como dispõe o procedimento processual escocês, é se as alegações da autora são 'pertinentes' nos termos da lei com relação à conclusão em busca da qual ela recorreu a tribunal.(...),215

\footnotetext{
${ }^{215}$ Um exemplo de problema desta natureza é citado por MacCormick: "É do conhecimento de todos como em Donoghue v. Stevenson ([1932] A.C. 562: 1932 S.C. (H.L.) 31), a aurora, a sra. Donoghue, iniciou uma ação de reparação contra o réu, um fabricante de águas gaseificadas, com base no fato de (como ela afirmou) ter bebido parte do conteúdo de uma garrafa opaca de gengibirra Stevenson antes de descobrir na parte restante do conteúdo, quando despejado, os restos de uma lesma em decomposição. Que isto lhe causara gastroenterite e trauma nervoso; e que a presença das lesma na gengibirra era devida ao fato de o fabricante não ter tomado cuidados razoáveis na preparação e engarrafamento do refrigerante. Como o réu tinha para com ela o dever de tomar cuidados razoáveis nesses processos e como ela havia sofrido danos decorrentes da sua falta de cuidado, a autora tinha direito a uma indenização como compensação pelos danos físicos e pelo trauma nervoso que tinha sofrido.

Nenhuma lei estabelecida cobria (nem cobre) a responsabilidade civil para um dano semelhante; e na época em que seu recurso foi do Supremo Tribunal da Escócia para a Câmara dos Lordes, não havia nenhum precedente vinculante que decidisse a questão em termos conclusivos para um lado ou para o outro, embora
} 
É interessante notar, neste ponto, que tanto os limites referentes à validade quanto os limites relativos à interpretação referem-se à premissa normativa da argumentação, ou seja, à premissa maior num raciocínio jurídico dedutivo. Os dois tipos de limites/problemas explicados a seguir, de outro lado, são referentes às premissas fáticas da argumentação, sendo atinentes, desta forma, à premissa menor do silogismo.

(c) Problemas referentes à comprovação: os limites relativos à comprovação dos fatos são especificamente referentes ao estabelecimento da premissa menor acima mencionada. Isto porque "provar significa estabelecer proposições verdadeiras sobre o presente e, a partir delas, inferir proposições sobre o passado"216. Além disso, as provas devem ser admitidas em duas situações - quando forem pertinentes para fazer uma inferência sobre uma questão do caso ou relativa a um fato em questão no caso, ou então quando não for excluída por alguma norma baseada na suposição de que sua confiabilidade não seria idônea, ou que seria injusta. $\mathrm{Na}$ realidade, trata-se de uma questão de coerência. O que torna um caso plausível e convincente é a coerência entre os fatos narrados e as provas apresentadas, como se fossem um quebra-cabeças em que as peças se encaixam perfeitamente. Vale citar o trecho da explicação de MacCormick:

"O melhor tipo de razão que se pode ter para acreditar na veracidade de alguma proposição sobre o passado consiste em ela ser mais coerente do que qualquer outra com nossas crenças gerais sobre causa e efeito e sobre motivação dos atos humanos, bem como uma série de outras proposições particulares referentes a fatos que sejam elas mesmas

(...) houvesse uma boa quantidade de precedentes suficientemente análogos para exercer influência persuasiva de cada lado do caso.

Num caso como esse, a questão, como dispõe o procedimento processual escocês, é se as alegações da autora são 'pertinentes'nos termos da lei com relação à conclusão em busca da qual ela recorreu a tribunal.(...)” MACCORMICK, Neil. Argumentação Jurídica e Teoria do Direito. Trad. Waldéa Barcellos. São Paulo: Martins Fontes, 2006. pp. 87-88.

216 ATIENZA, Manuel. As razões do Direito: teorias da argumentação jurídica. Trad. Maria Cristina Gumarães Cupertino. 3. ed. São Paulo: Landy, 2006. p. 124. 
coerentes entre si e que incluam algumas proposições fundamentadas em percepções sensoriais atuais. , 217

(d) Problemas de classificação $o^{218}$ : os "problemas de classificação" destacados por MacCormick ocorrem quando, embora não haja dúvidas acerca dos fatos primários, ou seja, aqueles que já se consideram provados, surgem questionamentos acerca dos fatos secundários, isto é, aqueles sobre os quais ainda há dúvidas sobre se integram ou não ou caso em julgamento, sobre se devem ou não ser subsumidos à norma jurídica em questão. $\mathrm{Na}$ realidade, percebemos que os "problemas de classificação", assim denominados por MacCormick, aproximam-se bastante do que em Direito Tributário Internacional se denomina de "problemas de qualificação", que se observam em situações nas quais surgem dúvidas durante a subsunção de um fato à norma jurídica. Precisamente, o problema de qualificação surge durante a verificação das características que um fato deve reunir para ser qualificado sob um determinado conceito jurídico ${ }^{219}$. A importância em resolver este tipo de problema reside na pressuposição de que o juiz somente deve se interessar pelos fatos que possam ser qualificados e subsumidos aos termos da lei ${ }^{220}$, e enquanto pairarem dúvidas sobre eles, o julgamento não pode prosseguir e o processo não evolui. Na realidade, seria possível argumentar que o problema de qualificação/classificação nada mais seria do que um problema de interpretação. E, de fato, não deixa de sê-lo. Porém, existem bons motivos que justificam tratar, digamos, essas duas faces da mesma moeda, separadamente. E estes motivos são de ordem processual. O que ocorre é que, em alguns países, por razões de

${ }^{217}$ MACCORMICK, Neil. Argumentação Jurídica e Teoria do Direito. Trad. Waldéa Barcellos. São Paulo: Martins Fontes, 2006. pp. 115-116.

218 Aqui importa destacar que os "problemas de qualificação" examinados por MacCormick aproximam-se, de certa forma, dos "problemas de qualificação" que analisamos no Capítulo 5. mais adiante.

219 Sobre os problemas de qualificação, v. PIRES, Manuel. Da Dupla Tributação Jurídica Internacional sobre o Rendimento. Lisboa: Centro de Estudos Fiscais - Ministério das Finanças, 1984. p. 454. XAVIER, Alberto. Direito Tributário Internacional do Brasil, 6. ed. Rio de Janeiro: Forense, 2006. pp. 190 e seguintes. MACHADO, João Baptista. Lições de Direito Internacional Privado, 4a. Ed., Coimbra: Almedina, 1990. págs. 111/112. ROTHMANN, Gerd W. Interpretação e Aplicação dos Acordos Internacionais contra a Bitributação. Tese (doutorado). Faculdade de Direito da Universidade de São Paulo. São Paulo, 1978. Pág. 57.

${ }^{220}$ PERELMAN, Chaïm. Ética e Direito. São Paulo: Martins Fontes, 2005. págs. 485/486. 
política judiciária voltada a evitar uma enxurrada de processos nas instâncias judiciais superiores, o ordenamento jurídico só permite que uma Corte recursal admita e julgue um recurso quando o objeto deste restringirse apenas às questões de direito. Em outras palavras, não se admite que sejam rediscutidas e reavaliadas questões sobre os fatos que originaram o processo em instância recursal. Nesses países, todas as questões de fato devem ser tratadas em primeiro grau, de forma que o juízo recursal aceitará e tomará como verdadeiras as premissas estabelecidas pelo juiz de primeiro grau sobre os fatos que conduziram à lide judicial, para então decidir exclusivamente sobre as questões de direito que ainda restarem controversas. É exatamente em virtude desta necessidade prática que se justifica o tratamento separado dos "problemas de interpretação", que se referem às normas jurídicas e, portanto, às questões de direito, e dos "problemas de classificação/qualificação", que se referem às questões de fato. Um bom exemplo é dado por MacCormick:

"Por exemplo, em Maclennan v. Maclennan (1958 S.C. 105) o sr. M. moveu uma ação junto ao Supremo Tribunal escocês para obter o divórcio de sua mulher, com base no adultério cometido por ela, afirmando entre outras coisas que ela havia tido um filho mais de um ano depois de seu encontro mais recente. Em sua defesa, a mulher admitiu esses fatos, mas confessou que a criança tinha sido concebida por meio de inseminação artificial com sêmen de um doador, não tendo ocorrido nenhuma relação sexual adulterina. O marido alegou que a defesa era descabida e concluiu com o pedido de uma sentença de divórcio. (...) O que significa 'adultério' para as finalidades da lei escocesa sobre o divórcio? De outro ponto de vista, porém, poderia ser alegado que o problema crucial nesse caso não é tanto uma questão de interpretar a lei como de apreciar os fatos. Supondo-se que essa mulher tenha conseguido engravidar por um processo de inseminação artificial, isso equivale a adultério, conta como ou constitui adultério? Certos fatos 'primários' foram comprovados ou pressupostos como comprovados para as finalidades do debate: esses fatos primários contam como 
ocorrência do requerido 'fato secundário'- o adultério - para fundamentar uma solicitação de divórcio? ${ }^{221}$.22 $^{22}$

Continuando na análise da justificação dos casos difíceis, a questão que surge é precisamente como se deve argumentar juridicamente quando é necessário ir além da justificação dedutiva característica dos casos fáceis. Para MacCormick, a justificação dos casos difíceis baseia-se em três pilares: a universalidade, a consistência e a coerência, e a isso ele denomina de requisito da justiça formal ${ }^{223}$. Isto significa que a decisão de um caso difícil deve ser pautada em princípios e regras que também possam ser aplicados a outros casos de modo universal (premissa maior da argumentação dedutiva), e deve também ser substancialmente fundamentada, ou seja, consistente, e fazer sentido em observância ao ordenamento jurídico e em relação ao mundo, ou seja, deve ser também coerente ${ }^{224}$. Nesse sentido, a tese de MacCormick se aproxima bastante da tese de Toulmin, explicada anteriormente, em que uma decisão judicial deve ser baseada nas razões (referentes aos fatos concretos) e nas garantias (referentes ao direito) $)^{225}$.

Uma distinção importante que MacCormick estabelece em sua teoria relacionase com os conceitos de universalidade e generalidade, no sentido de que uma norma pode ser mais específica do que a outra, mas mesmo assim manter o seu caráter universal, uma vez que a universalidade é um requisito lógico que não tem relação com a maior ou menor especificidade de uma norma.

Quanto ao requisito da consistência, trata-se de basear o raciocínio em premissas normativas que não entrem em confronto com as normas validamente estabelecidas. Além disso, como ressaltado por Manuel Atienza, o requisito da consistência não deve se restringir ao plano normativo, ele também deve ser observado em

${ }^{221}$ MACCORMICK, Neil. Argumentação Jurídica e Teoria do Direito. Trad. Waldéa Barcellos. São Paulo: Martins Fontes, 2006. p. 121.

${ }^{222}$ MACCORMICK, Neil. Argumentação Jurídica e Teoria do Direito. Trad. Waldéa Barcellos. São Paulo: Martins Fontes, 2006. pp. 119-120.

223 "A exigência da justiça formal consiste em tratarmos casos semelhantes de modo semelhante, e casos diferentes de modo diferente; e dar a cada um o que lhe é devido." Ou seja, a justiça formal, para MacCormick, nada mais é do que a exigência de equidade. MACCORMICK, Neil. Argumentação Jurídica e Teoria do Direito. Trad. Waldéa Barcellos. São Paulo: Martins Fontes, 2006. p. 95.

${ }^{224}$ MACCORMICK, Neil. Argumentação Jurídica e Teoria do Direito. Trad. Waldéa Barcellos. São Paulo: Martins Fontes, 2006. p. 131.

225 ATIENZA, Manuel. As razões do Direito: teorias da argumentação jurídica. Trad. Maria Cristina Gumarães Cupertino. 3. ed. São Paulo: Landy, 2006. p. 126. 
relação às provas, já que as proposições sobre o passado, ou seja, o fato cuja existência se infere, não devem entrar em contradição com as afirmações verdadeiras sobre o presente $^{226}$.

Uma argumentação consistente não traz muitos resultados se ela não for também coerente. Na verdade, a consistência não é um requisito para a coerência. A coerência é uma característica da argumentação como um todo, enquanto a consistência diz respeito aos seus elementos isoladamente. Nas palavras de Manuel Atienza: “(...) pode-se entender que o requisito de consistência deriva, por um lado, da obrigação dos juízes de não infringir o Direito vigente e, por outro lado, da obrigação de se ajustar à realidade em termos de prova",227. Então, é possível que uma história seja coerente, mas que apresente uma ou mais inconsistências em seu interior. Desta forma, para que uma argumentação seja eficaz e atinja os objetivos propostos, ela deve ser coerente tanto sob o aspecto normativo, e neste ponto a coerência se refere às relações entre as normas e os princípios que informam o ordenamento, quanto narrativa, na medida em que os fatos e as provas que se apresentam não podem se contradizer reciprocamente.

Ainda com referência a esta noção, MacCormick destaca dois tipos de argumentos que se baseiam na coerência: os argumentos a partir de princípios e os argumentos por analogia. A relação entre estes dois tipos de argumentos e o requisito da coerência pode ser identificada exatamente por essa necessidade de "fazer sentido" perante o sistema.

A necessidade de coesão das decisões é outro fator de destaque na teoria de MacCormick. Segundo ele, não basta que uma decisão seja apenas justificada por bons argumentos a partir de consequências e/ou a partir de princípios ou analogias. Também é essencial que a decisão não seja incompatível com o direito estabelecido.

A ideia de princípio, na teoria de MacCormick, está associada à ideia de generalidade e de valor positivo. Em outras palavras, ele entende que:

“chamar uma norma de 'princípio' significa, portanto, que ela tanto é relativamente geral como tem valor positivo. (...) Os princípios de um sistema

\footnotetext{
${ }^{226}$ ATIENZA, Manuel. As razões do Direito: teorias da argumentação jurídica. Trad. Maria Cristina Gumarães Cupertino. 3. ed. São Paulo: Landy, 2006. p. 128.

227 ATIENZA, Manuel. As razões do Direito: teorias da argumentação jurídica. Trad. Maria Cristina Gumarães Cupertino. 3. ed. São Paulo: Landy, 2006. p. 129.
} 
jurídico são as normas gerais conceitualizadas por meio das quais seus funcionários [do próprio sistema jurídico] racionalizam as normas que pertencem ao sistema em virtude de critérios observados internamente, 228.

Mais adiante, no capítulo conclusivo de sua obra, MacCormick reforça este conceito, afirmando que “(...) os princípios são normas relativamente gerais que são concebidas como normas ou conjuntos de normas 'racionalizastes'. 229 Dito de outra forma, os princípios, enquanto normas gerais, exercem uma função explicativa e informativa (informam e inspiram as regras de conduta), e como expressão de valores positivos, desempenham papel de justificação.

Além disso, ele destaca a diferença essencial entre regras e princípios baseado no fato de que as regras são sujeitas ao critério de exclusão (se se aplica uma regra, então não se pode aplicar outra ao mesmo fato), enquanto os princípios sua sujeitos a uma dimensão de peso, sendo possível que dois princípios, os quais sustentem dois valores distintos, sejam aplicáveis concomitantemente a uma situação fática (por exemplo, direito à liberdade individual e proteção da ordem pública), e ambos continuarão válidos. Ou seja, no caso dos princípios, é uma questão de estabelecer, para aquela situação concreta, qual dos valores é mais adequado, e assim determinar qual dos dois princípios deve ter mais "peso" e, portanto, ser aplicado concretamente, embora isso não invalide o outro princípio. Um exemplo ilustra claramente a distinção acima:

"Permitam-me reafirmar o que acredito que queremos dizer quando falamos de 'princípios do direito', em contraste com normas do direito. A meu ver, pode-se conceber que normas jurídicas (permitam-me para este efeito chamálas de 'normas jurídicas compulsórias'), individualmente ou, com freqüência muito maior, em grupos afins, tendem a garantir ou têm o objetivo de garantir, algum fim que se considera valioso, ou algum modo de conduta geral que se repute desejável. Expressar a linha de ação para atingir esse objetivo ou a conveniência desse modo de conduta geral, num enunciado normativo geral é, portanto, enunciar 'o princípio da lei' subjacente à norma ou normas em questão.

\footnotetext{
${ }^{228}$ MACCORMICK, Neil. Argumentação Jurídica e Teoria do Direito. Trad. Waldéa Barcellos. São Paulo: Martins Fontes, 2006. p. 198, 201.

${ }^{229}$ MACCORMICK, Neil. Argumentação Jurídica e Teoria do Direito. Trad. Waldéa Barcellos. São Paulo: Martins Fontes, 2006. p. 304.
} 
Desse modo, é uma norma do direito no Reino Unido que os veículos sejam conduzidos pelo lado esquerdo da via. Não existe nenhum motivo especial pelo qual devêssemos escolher a esquerda em vez da direita, mas existe uma razão compulsória, a segurança, pela qual deveríamos nos fixar num lado ou no outro. O princípio é o de que a segurança nas estradas deveria ser garantida pela estipulação de códigos de conduta para motoristas, ou que as pessoas deveriam dirigir de um modo que reduzisse a um mínimo o perigo para outros usuários das vias públicas. "230

MacCormick analisa os argumentos com base na analogia também a partir de exemplos. Ele cita o caso Steel v. Glasgow Iron and Steel Co. Ltd. (1944 S.C. 237), no qual um vigia de uma empresa ferroviária localizada na Escócia morreu em uma tentativa desafortunada de evitar a colisão de um trem desgovernado que, por negligência dos funcionários do posto de manutenção, havia se desprendido e vinha descendo em alta velocidade por uma parte íngreme de seu trajeto. Evidentemente, se não tivesse tentado evitar a colisão, o vigia em questão não teria falecido. Porém, como o seu cargo de vigia impunha que tomasse medidas para preservar os bens do empregador, assim procedeu tentando evitar o choque da locomotiva, e em razão disso perdeu a vida. Sua viúva, então, processou a empresa requerendo indenização por danos materiais e por danos morais, fundada no fato de que a morte do marido seria decorrente da negligência punível dos outros funcionários da empresa que deixaram a locomotiva descer desgovernada. A questão era: deveria o falecido vigia ter deixado de lado suas funções e, assim, ter salvado a própria vida? Em que medida o risco do acidente poderia ter sido minimizado pela empresa? Não havia nenhum precedente que permitisse conceder a indenização à viúva, mas havia um precedente já estabelecido no direito escocês no sentido de que o ato de um resgatador destinado a salvar uma pessoa exposta a perigo pelo ato ilícito de um terceiro enseja compensação por parte deste terceiro caso o resgatador venha a sofrer alguma lesão. Neste precedente, o princípio norteador era claramente a proteção à vida. No entanto, o tribunal recorreu a este precedente para reconhecer o direito da viúva à indenização pleiteada, aplicando-o mediante analogia ao caso em questão. A analogia é evidente enquanto todos os elementos de uma situação de "salvamento de vidas" estão também presentes numa situação de "salvamento de bens", ainda mais no caso em questão, no qual

${ }^{230}$ MACCORMICK, Neil. Argumentação Jurídica e Teoria do Direito. Trad. Waldéa Barcellos. São Paulo: Martins Fontes, 2006. p. 202. 
as funções do vigia incluíam zelar e proteger o patrimônio da empresa. E, de fato, a justificativa da decisão baseava-se no fato de que a diferença entre a intervenção para salvar vidas e a intervenção para salvar bens constitui uma distinção de grau, e não de natureza. Nos dois casos, é necessário que haja um perigo real e que se assuma um risco justificado. Em ambos o casos deve haver a justa reparação do dano, porém é imperiosa a diferenciação entre os graus de perigo que se considera razoável assumir em um e em outro caso, para então quantificar a indenização ${ }^{231}$. Desta forma, é razoável concluir que a analogia depende da percepção de um princípio racional segundo o qual as duas situações comparáveis possam ser enquadradas junto com outras situações de tipos afins ${ }^{232}$.

Assim, é possível concluir que os argumentos de princípios e os argumentos de analogia são duas modalidades bastante próximas. Isto porque, enquanto os princípios se caracterizam como normas gerais cuja função é informar o valor inspirador das regras, cumprindo uma função de justificação, a analogia consiste, por assim dizer, numa aplicação indireta do princípio, mediante a observação de semelhança relevante entre duas situações. As analogias pressupõem um juízo de valor na medida em que a semelhança que se exige, na realidade, não é constatada, e sim construída mediante a interpretação dos fatos. Portanto, ambos pressupõem a coerência do Direito e implicam um juízo de valor, seja em relação aos fatos.

Outro aspecto importante na teoria da argumentação de MacCormick é o que ele denomina de argumentos consequencialistas. De fato, MacCormick entende que, para os casos difíceis, a argumentação jurídica é essencialmente uma argumentação consequencialista, porém, sempre dentro dos parâmetros de universalidade, consistência e coerência já mencionados anteriormente. Uma argumentação consequencialista é aquela que pondera os fatos, as regras, as provas e os princípios tendo em vista as consequências que poderão advir se a decisão for em um sentido ou em outro. O caso do divórcio, mencionado alguns parágrafos acima, ilustra de forma clara o que constitui um argumento consequencialista. Se o juiz considerasse que uma inseminação artificial constitui adultério, isso poderia gerar consequências absurdas, como, por exemplo, considerar ser possível cometer adultério com uma pessoa falecida. Desta forma, percebe-se que, além da

\footnotetext{
${ }^{231}$ MACCORMICK, Neil. Argumentação Jurídica e Teoria do Direito. Trad. Waldéa Barcellos. São Paulo: Martins Fontes, 2006. pp. 209-211.

${ }^{232}$ MACCORMICK, Neil. Argumentação Jurídica e Teoria do Direito. Trad. Waldéa Barcellos. São Paulo: Martins Fontes, 2006. p. 212.
} 
aplicação do princípio da razoabilidade e do senso comum, houve a ponderação das consequências práticas da decisão no sentido de gerar precedentes juridicamente absurdos. Neste ponto, é interessante notar a distinção entre resultado de uma decisão e consequências de uma decisão. O resultado de uma decisão corresponde ao fato de ser criada uma nova norma jurídica, do tipo individual e concreta (ainda que imponível apenas entre as partes envolvidas no processo, nos países que seguem a Civil Law). As consequências vão além do resultado, podendo atingir pessoas completamente estranhas à lide, como ficou demonstrado no exemplo acima. $\mathrm{O}$ argumento consequencialista pode ser observado mais frequentemente em decisões de alguns ramos específicos do direito, como é o caso do Direito Tributário, em que há tributos manifestamente extrafiscais, ou seja, cuja função não é apenas arrecadaria, mas principal e propositadamente política, ou seja, cujo objetivo é intervir em determinado setor econômico ou social. Em situações desta natureza, é comum encontrar argumentos consequencialistas nas decisões judiciais.

Enfim, MacCormick encerra sua obra destacando os limites da racionalidade prática e concluindo que não é possível pretender que haja sempre uma única resposta correta para os casos judiciais, e nesse sentido, discorda de Dworkin, cuja teoria é uma de suas fontes inspiradoras. As respostas nas questões judiciais dependem do modo como se relacionam os fatos, as regras, as provas, os princípios e a forma como a argumentação se desenvolve. Já quanto aos limites da racionalidade prática, observa-se que MacCormick destaca três aspectos: a temporalidade, a subjetividade e a objetividade. A temporalidade representa um limite à racionalidade prática na medida em que a relação entre os argumentos racionais (as razões, os fundamentos) e os fatos que formam o caso deve ser vista sob um conjunto de circunstâncias vigentes no tempo em que é feita a análise da questão. Já a subjetividade relaciona-se com as crenças subjacentes à ação e também ao requisito da sinceridade, ou seja, quem propõe uma ação judicial deve, antes de mais nada, acreditar sinceramente no que está requerendo e nos fundamentos que sustentam sua pretensão. Já a racionalidade objetiva depende da observância dos preceitos do direito, neles inclusas as regras, os princípios, os valores e a moral, como forma de justificar objetivamente a pretensão.

Passemos então à análise da teoria que constitui o nosso referencial teórico. 


\subsection{A Teoria de Robert Alexy - Da Teoria do Discurso Racional à Teoria da Argumentação Jurídica}

Robert Alexy constrói sua teoria da argumentação jurídica a partir da Teoria do Discurso Prático. Isto porque ele considera que o discurso jurídico é uma espécie do gênero discurso prático.

Veremos, adiante, que na sua teoria da argumentação jurídica, Alexy sugere o deslocamento do exame da racionalidade jurídica do âmbito da interpretação para a esfera da argumentação.

As regras do discurso racional referem-se, desta forma, tanto às proposições quanto ao comportamento do falante, e refletem uma série de exigências de fundamentação consubstanciadas em regras pragmáticas, cujo cumprimento não garante o resultado, mas evita situações em que o dever de fundamentar pudesse ser levado ao infinito.

E, também como veremos adiante, as regras da teoria da argumentação jurídica surgem justamente em virtude das necessidades decorrentes das limitações que se aplicam à teoria geral do discurso.

Entretanto, é necessário compreender primeiro a Teoria do Discurso Prático para em seguida analisar a Teoria da Argumentação Jurídica.

\subsubsection{Teoria do Discurso Prático}

Segundo Alexy, os discursos correspondem a um conjunto de ações interconectadas que visam a comprovar a verdade ou a correção de enunciados ou proposições $^{233}$. E, quando se trata especificamente de determinar a correção de proposições normativas, os discursos recebem a denominação de discursos práticos, e, dentro desta categoria, situam-se os discursos jurídicos, que se revelam como uma espécie do gênero discurso prático geral que se desenvolve dentro de certos limites, como a lei, a ciência do Direito e os precedentes jurisprudenciais.

Seja na forma mais geral (discurso prático geral) ou na modalidade mais específica que aqui nos interessa (discurso jurídico), é correto pressupor, em ambos os

233 ALEXY, Robert. Teoria da Argumentação Jurídica: A Teoria do Discurso Racional como Teria da Justificação Jurídica. Trad. Zilda Hutchinson Schild Silva. Introd. à ed. brasileira Claudia Toledo. São Paulo: Landy, 2005. p. 183. 
casos, a pluralidade de participantes. Aqui fica clara a tendência de Alexy de aproximar o discurso de um diálogo, embora também seja possível pensar no discurso (prático e jurídico) como um monólogo no qual o indivíduo "conversa" consigo mesmo tentando antecipar os argumentos de um possível interlocutor, elaborando de antemão as suas respostas.

Esta hipótese de discurso enquanto monólogo não é, contudo, o objeto da análise de Alexy, cujo foco de estudo é precisamente a forma como a interpretação ocorre na medida em que ela se manifesta por meio de argumentos jurídicos produzidos entre, no mínimo, dois interlocutores, que podem ser tanto um advogado em relação ao juiz, ou o juiz em relação às partes e a seus advogados, por exemplo. A externalização da interpretação por meio de argumentos e seus respectivos fundamentos é o que confere a racionalidade ao processo de aplicação do direito.

\subsubsection{Perspectivas de análise das regras do discurso racional}

A teoria do discurso racional de Alexy enquadra-se na categoria de teoria normativa do discurso, uma vez que seu objetivo é a busca pela solução para o problema da fundamentação das regras do discurso racional. Estas, a seu turno, podem ser analisadas sob quatro perspectivas:

(i) Regras do discurso racional como regras de fundamentação técnica: são aquelas que prescrevem os meios para atingir determinados fins. Porém, neste caso, surge o problema da fundamentação do fim em si mesmo. Como se deve fundamentar o fim, ou seja, quais regras se aplicam à fundamentação do fim, e o quê, exatamente, deve ser este fim que justifica os meios? Seria possível, por exemplo, definir a justiça e a verdade como fins do discurso? Então seria necessário, antes de mais nada, definir os conceitos de justiça e de verdade, o que, como se sabe, é algo que até hoje não foi satisfatoriamente realizado.

(ii) Regras do discurso racional como regras de fundamentação empírica: vistas sob a perspectiva empírica, as regras do discurso racional seriam aquelas que, de fato, são seguidas na prática e conduzem a resultados singulares correspondentes às convicções normativas realmente existentes. Esta perspectiva só é possível se assumirmos a premissa de que a prática 
existente é racional. O problema é que a prática de uma determinada época não corresponde à prática que se desenvolvia no passado, nem é a mesma que se verificará anos mais tarde. Em outras palavras, a prática é variável. Por isso a fundamentação empírica é sempre provisória, dependente das correções estabelecidas a partir de outros modos de fundamentação.

(iii) Regras do discurso racional como regras de fundamentação definitória: trata-se de apresentar um sistema de regras que definem uma prática e considerá-lo como motivação para a decisão de aceitar referida prática. $\mathrm{Ou}$ seja, a apresentação de um sistema de regras, independentemente da indicação de outras razões, constitui por si só a fundamentação para a aceitação da prática.

(iv) Regras do discurso racional como regras de fundamentação pragmáticouniversal: sob este aspecto, as regras de fundamentação do discurso racional assumem o papel de condição de possibilidade para a comunicação linguística. Esta categoria de regras de fundamentação apresenta, contudo, alguns problemas. O primeiro deles está na determinação de a quais regras pode ser atribuído o caráter de pressupostos gerais de possíveis processos de comunicação. Outro problema consiste na determinação de quais regras são constitutivas para quais atos de fala, e quais atos de fala são necessários para as formas de comportamento especificamente humanas. Apesar destes problemas, é possível manter a opinião de que há determinadas regras que constituem o pressuposto geral e necessário da comunicação linguística, ou que são constitutivas de formas de comportamento humano.

Todas estas quatro perspectivas de análise das regras de fundamentação do discurso apresentam pontos fracos, mas ao mesmo tempo, possuem características que as tornam merecedoras de crédito. Por exemplo, as regras da fundamentação pragmático universal devem ser consideradas, segundo Alexy, como um relevante material de base, eis que já se encontram consolidadas, ou seja, prevaleceram, embora isso, por si só, não constitua garantia de sua racionalidade. Mas como Alexy destaca, até o presente momento não surgiram críticas fortes o suficiente para abandoná-las. Ademais, a aplicação destas regras de fundamentação do discurso depende de cada participante do discurso. Elas não 
procuram esgotar a análise do discurso - ao contrário - servem, outrossim, de ponto de partida $^{234}$ para o desenvolvimento do estudo.

\subsubsection{As regras e formas do discurso prático geral}

O discurso prático geral (ou seja, o discurso voltado para as ações humanas gerais) não se produz de forma irracional e aleatória. Sua construção, embora as pessoas nem sempre se dêem conta disso, obedece a uma série de regras e formas. Neste ponto, convém destacar a distinção entre as regras e as formas do discurso. As formas do discurso relacionam-se com as formas de argumento que devem ser utilizadas em determinadas situações argumentativas. Mas, para que sejam conhecidas quais formas de discurso devem ser usadas em cada situação argumentativa, são necessárias regras que disponham nesse sentido, ou seja, que determinem a utilização de determinadas formas de argumento especificamente dirigidas para os variados tipos de argumentação. Observa-se, pois, que formas e regras do discurso são institutos próximos, mas não se confundem. Entretanto, a distinção acima conduz, ainda, à conclusão de que, em última análise, sempre haverá regras, sejam elas regras propriamente ditas, ou regras que determinem a forma do argumento a ser utilizado.

Feitas estas considerações iniciais, passamos à análise das seis regras do discurso prático geral, segundo a classificação proposta por Alexy.

(i) Regras Fundamentais: As regras abaixo explicadas são denominadas de "regras fundamentais" porque são elementares para qualquer tipo de comunicação linguística. Assim, apresentamos as seguintes regras fundamentais do discurso:

a. Nenhum falante pode contradizer-se: ou seja, trata-se de uma regra lógica não apenas da lógica formal, em que os valores de referência são verdadeiro ou falso (como já ressaltamos anteriormente, o critério de verdade e falsidade não se aplica no caso de proposições normativas) - mas, sobretudo, da lógica deôntica, em que os critérios são de validade ou de correção em face de uma referência pré-estabelecida. Outra maneira de se aplicar esta regra consiste na construção de teorias de modelos nos quais os

234 ALEXY, Robert. Teoria da Argumentação Jurídica: A Teoria do Discurso Racional como Teria da Justificação Jurídica. Trad. Zilda Hutchinson Schild Silva. Introd. à ed. brasileira Claudia Toledo. São Paulo: Landy, 2005. p. 190. 
enunciados normativos possam ser avaliados segundo o critério de verdade ou falsidade.

b. Todo falante só pode afirmar aquilo em que ele mesmo acredita: esta é uma regra constitutiva para qualquer comunicação linguística. Ela tem a função de assegurar a sinceridade da discussão, mas não exclui a possibilidade de expressão de conjecturas, desde que isso fique claro para os falantes.

c. Princípio da universalidade: Todo falante que aplicar uma determinada qualidade $\mathrm{F}$ a um objeto $\mathrm{A}$ deve estar disposto a aplicar esta mesma qualidade $\mathrm{F}$ a qualquer objeto igual a $\mathrm{A}$ em todos os aspectos relevantes: esta é uma regra que visa garantir a coerência do discurso, refletindo nada mais que o princípio da universalidade de Hare (já mencionado anteriormente). Em outras palavras, ela determina que cada falante deve expressar suas opiniões de forma coerente, ou seja, todo falante fica obrigado a somente manifestar juízos de valor ou de dever que ele próprio afirmaria, da mesma forma, em todas as situações cujos aspectos relevantes sejam iguais.

d. Princípio da coerência: Diferentes falantes não podem usar a mesma expressão com diferentes significados: aqui também se trata de uma regra de coerência, com a diferença que ela se dirige à coletividade de falantes, exigindo que todos utilizem as expressões da linguagem com o mesmo significado durante o discurso. Em termos coloquiais, é uma regra exige que todos "falem a mesma língua", para que todos possam se entender mutuamente, e que para a mensagem que se pretende passar tenha clareza e sentido.

(ii) Regras de Razão: As "regras da razão" destinam-se a permitir a justificação da asserção (afirmação) de enunciados normativos, definindo as condições mais importantes para a racionalidade do discurso. Em outras palavras, elas permitem a fundamentação das proposições feitas pelos falantes, como forma de sustentá-las perante seus interlocutores, sejam tais proposições de caráter normativo ou não. Nas palavras de Alexy:

"quem fundamenta algo pretende, ao menos no que se refere a um processo de fundamentação, aceitar o outro como parte na fundamentação, com os 
mesmos direitos, e não exercer coerção nem se apoiar na coerção exercida por outros. Também pretende assegurar sua asserção não só perante seu interlocutor, mas perante qualquer um. Os jogos de linguagem que não pretendam cumprir pelo menos esta exigência, não podem considerar-se fundamentação”.

Entretanto, como se tratam de regras dirigidas ao discurso, e não ao conteúdo da fundamentação em si, as regras da razão não podem garantir que os fundamentos apresentados sejam válidos ou que sejam bons o suficiente para sustentar as afirmações.

Além disso, é relevante destacar que as regras da razão não implicam que toda e qualquer assertiva feita por um falante deva ser fundamentada. Ao contrário, a fundamentação somente deve ser realizada quando requerida pela outra parte. Isto porque, se assim não fosse, ou seja, se todas as assertivas feitas pelos falantes num discurso devessem ser fundamentadas, os discursos ou os diálogos nunca chegariam a um final, e acabariam se perdendo nas próprias fundamentações.

Em resumo, as regras que a seguir serão apresentadas desempenham três funções de extrema importância para o discurso: servem de critério hipotéticonormativo para a correção das proposições normativas, servem como instrumento de crítica às restrições dos direitos e das oportunidades dos participantes de um discurso e, por fim, proporcionam uma explicação da pretensão de verdade ou de correção das asserções, sendo a pretensão de justiça um caso especial da pretensão de correção.

Assim, as regras da razão visam a garantir três objetivos: a igualdade de direitos, a universalidade e a não-coerção das partes. Baseando-se nisso, formulam-se as seguintes regras:

a. Regra geral de fundamentação: todo falante deve, se lhe for solicitado, fundamentar o que afirma, salvo se puder fornecer razoes que justifiquem negar-se a fornecer tal fundamentação. Desta regra geral de fundamentação, decorrem outras três regras secundárias:

a.1. Regra de admissão no discurso: esta é uma regra da razão que regula a capacidade para participar de um discurso, garantindo que quem pode 
falar (ou se expressar, não apenas em linguagem oral), pode tomar parte no discurso.

a.2. Regra da liberdade da discussão: esta regra da razão visa garantir a liberdade de expressão dos falantes na discussão, ou seja, todos os participantes de um discurso podem problematizar qualquer asserção, e podem, ainda, introduzir qualquer asserção no discurso, expressar suas opiniões, desejos e necessidades. Assim, qualquer falante pode formular perguntas, expressar dúvidas sem ter, ele mesmo, que fornecer as razões.

a.3. Regra da proibição de coerção no discurso: todo falante deve ter o direito de integrar o discurso e nele expor suas opiniões livremente sem sofrer qualquer forma de coerção interna ou externa. Esta é uma regra que manifesta também um dos ideais do discurso (e até mesmo do Direito), embora, na prática, seja difícil de ser alcançada.

(iii) Regras sobre a carga da argumentação: Diferentemente das regras anteriores, que são dirigidas às asserções (afirmativas), as regras sobre a carga da argumentação dirigem-se especificamente à fundamentação de dúvidas ou perguntas. Como já vimos, segundo a regra da liberdade da discussão, todos podem problematizar uma asserção. Mas o que significa "problematizar" algo? Ora, como o próprio nome diz, "problematizar" consiste em tornar uma afirmativa uma proposição de um problema que precisa ser resolvido, ou seja, equivale a propor uma questão, suscitar uma dúvida. As regras sobre a carga de fundamentação são derivadas da conjugação do princípio da universalidade, já exposto acima, com a regra geral de fundamentação, também já explicada no item anterior. O princípio da inércia, proposto por Perelman, também se reflete nas regras da carga da argumentação ${ }^{235}$. Considerando tais características, elaboram-se as seguintes regras de carga da fundamentação:

\footnotetext{
${ }^{235}$ Perelman propõe o que se denomina de princípio da inércia, que corresponde à noção de que uma opinião ou uma práxis que tenha sido aceita uma vez não pode ser abandonada sem um motivo fundamentado. É nesse sentido que Perelman afirma que "de fato, a inércia permite contar com o normal, o habitual, o real, o atual e valorizá-lo, quer se trate de uma situação existente, de uma opinião admitida ou de um estado de desenvolvimento contínuo e regular. A mudança, em compensação, deve ser justificada; uma decisão, uma vez tomada, só pode ser alterada por razões suficientes.(...)”. PERELMAN, Chaïm. OLBRECHTSTYTECA, Lucie. Tratado da argumentação: A nova retórica. Trad. Maria Ermantina de Almeida Prado Galvão. 2. ed. São Paulo: Martins Fontes, 2005. p. 120.
} 
a. Quem pretende tratar uma pessoa A de maneira diferente de uma pessoa $B$ está obrigado a fundamentá-lo: trata-se de uma expressão da obrigatoriedade do princípio da isonomia e da igualdade. Em outras palavras, esta regra de fundamentação expressa o princípio da isonomia, ou presunção de igualdade, de forma que quem pretende tratar alguém ou alguma coisa de forma diferente, deve explicar a diferença existente entre as duas pessoas ou duas coisas, e também apresentar os motivos que justifiquem o tratamento diferenciado.

b. Quem questiona uma proposição ou uma norma que não é objeto da discussão deve fornecer as razões para tanto: aqui vemos claramente a influência do princípio da inércia, formulado por Perelman. Por outro lado, esta regra permite que uma proposição que já esteja aceita como válida na comunidade dos falantes seja questionada, desde que se demonstre uma razão pertinente.

c. Regra da obrigação de fornecer mais argumentos, em caso de contraargumentação: esta regra determina, simplesmente, que caso o interlocutor apresente um contra-argumento ao falante, este está obrigado a apresentar novos argumentos que sustentem sua opinião, enquanto e na medida em que o interlocutor apresentar novos contra-argumentos, até que uma das partes se dê por satisfeita. Esta regra deriva das regras de liberdade de discussão e de introdução de novos argumentos no discurso, bem como da vedação à coerção, já analisadas anteriormente.

d. Quem introduz no discurso uma afirmação sobre suas opiniões, desejos ou necessidades que não se apresentem como argumento a uma manifestação anterior, tem, se for solicitado, de fundamentar por que esta manifestação foi introduzida na afirmação: também em decorrência das regras de liberdade de discussão e da vedação à coerção, qualquer pessoa pode fazer um comentário ou expor uma opinião sobre um assunto que não seja relacionado ao objeto do discurso; entretanto, esta pessoa ficará obrigada a fornecer as razões que embasam sua asserção se a outra parte assim requerer, bem como apresentar os motivos que justificam a inserção dessa 
assertiva em questão (assertiva esta que não guarda relações com o objeto da discussão) na discussão.

(iv) Regras sobre as formas de argumento: Segundo Alexy, existem basicamente duas formas de se fundamentar um enunciado normativo singular $(\mathrm{N})$ : uma, mediante referência a uma regra $(\mathrm{R})$, ou então, assinalando-se as consequências do enunciado que se pretende fundamentar (C). Quando se fundamenta um enunciado normativo por referência a uma regra, é necessário pressupor que as condições para a aplicação desta regra foram atendidas. Por sua vez, quando se fundamenta um enunciado normativo com base nas consequências dele decorrentes, é necessário supor, da mesma forma, que tais consequências são obrigatórias ou boas. Aqui nota-se a influência de Toulmin e de sua forma geral de argumento, segundo a qual um enunciado normativo pode ser fundamentado mediante a apresentação de uma regra de qualquer nível e uma razão (grounds) ${ }^{236}$.

Contudo, é possível que a utilização de regras diferentes conduza a disputas sobre os fatos presentes nos enunciados, ou mesmo sobre as próprias regras, gerando resultados incompatíveis. Neste caso, a argumentação parte para o segundo nível, tornando-se necessário o estabelecimentos de regras de prioridade capazes de determinar em quais situações deve-se fundamentar o enunciado sob uma ou outra regra.

E, quanto às regras de prioridade, é importante determinar, ainda, se elas serão absolutas, ou seja, aplicáveis em qualquer caso, ou se sua aplicação será condicionada à verificação de determinadas circunstâncias.

As formas de argumento são utilizáveis, assim, tanto para a fundamentação de enunciados normativos quanto para a comprovação de enunciados normativos gerais. A relação entre fundamentação e comprovação é decorrente das próprias regras do discurso, ou seja, quem faz uma afirmação, deve apresentar razões que lhe fundamentem. Mas isso não se estende ao infinito, ou seja, não é necessário apresentar fundamentos para os próprios fundamentos, no sentido de

${ }^{236}$ TOULMIN, Stephen E. Os Usos do Argumento. Trad. Reinaldo Guarany e Marcelo Brandão Cipolla. 2. ed. São Paulo: Martins Fontes, 2006. p. 139 e seguintes. 
comprovar os fundamentos inicialmente apresentados. Isto só se aplica às situações em que há contra-argumentação.

Como se vê, fundamentação e comprovação ocorrem em etapas subsequentes, e a argumentação tem prioridade sobre a comprovação, uma vez que esta somente se faz necessária na medida em que existam contra-argumentos que requeiram a comprovação dos argumentos inicialmente apresentados.

(v) Regras de fundamentação (que são distintas das regras fundamentais): As regras de fundamentação, como o próprio nome diz, referem-se diretamente ao conteúdo das proposições normativas que se busca justificar. Então, elas sempre devem ser aplicadas em conjunto com as formas de argumento acima explicadas. Alexy divide as regras de fundamentação em três sub-grupos:

a. Variantes do princípio da generalizabilidade (universalidade): As regras deste tipo relacionam-se com a regra fundamental exposta anteriormente de que todo falante que aplique uma qualidade a um objeto deve estar disposto a aplicar esta mesma qualidade a qualquer outro objeto que possua características idênticas ao primeiro objeto qualificado. Alexy se baseia nas versões de generalizabilidade/universalidade apresentadas por Hare, Habermas e Baier.

a.1. Hare - Regra da inclusão na coletividade: mediante a conjugação dos princípios da universalidade e da prescritividade, Hare propõe o seguinte: quem afirma uma proposição normativa que pressupõe uma regra para a satisfação dos interesses de outras pessoas, deve poder aceitar as consequências de dita regra também no caso de ele próprio se encontrar na situação daquelas pessoas. Ou seja, quem faz uma proposição normativa dirigida à generalidade das pessoas, deve considerar que as consequências dela decorrentes dirigir-se-ão também a si próprio, eis que o falante se inclui nessa generalidade. Assim, observa-se que esta regra permite partir das diferentes convicções normativas fáticas dos respectivos falantes.

a.2. Habermas - Cada individuo deve estar de acordo com cada regra: a universalidade de Habermas está relacionada com as 
regras de admissão no discurso, liberdade de discussão, igualdade e vedação à coerção, que fazem parte da categoria de regras da razão, e também com a noção de opiniões comuns obtidas por meio do discurso. Trata-se, pois, do caráter ideal das regras de razão. Desta forma, na visão de Habermas, se todos deliberam sobre questões práticas em pé de igualdade de direitos, somente podem encontrar o acordo geral aquelas proposições normativas e regras que cada um puder aceitar. Ou seja, cada indivíduo deve estar de acordo com cada regra.

a.3) Baier - Toda regra deve ser ensinada de forma aberta e geral: a regra da universalidade de Baier representa uma concreção do princípios da sinceridade (acreditar nas proposições e nos argumentos que se colocam no discurso) e da abertura do discurso (este no sentido de estender o discurso a todos que dele desejarem participar). Desta forma, para Baier, toda regra deve ser ensinada de forma aberta e geral, excluindo-se apenas algumas poucas regras morais ${ }^{237}$.

b. O argumento genético: embora Alexy não mencione expressamente, entendemos que este tipo de regra está relacionado com a necessidade de permanência das regras do discurso no tempo, de modo que haja pelo

237 Tais regras morais que não podem ser ensinadas de forma aberta e geral são denominadas por Baier de morally impossible rules. Um exemplo de regra moral impossível seria: "Sempre afirme que o que você pensa não é verdade", ou, "sempre negue o que você pensa que é verdade". De fato, se esta regra fosse ensinada universalmente, os ouvintes simplesmente acrescentariam uma negação a cada proposição. Seria como afirmar algo, e ao mesmo tempo, negar esta mesma afirmação. Em situações em que as opções são excludentes entre si, não haveria maiores problemas. Por exemplo: o indivíduo A pergunta para B se está chovendo, numa situação em que efetivamente não está chovendo no momento do discurso. Embora tenha certeza de que não está chovendo, B responde que está. Mas como A sabe que a resposta de B corresponde à negação do que ele acredita ser verdade (ou seja, se ele responde que está chovendo é porque, na verdade, não está), A poderá concluir corretamente que não está chovendo. Em outras situações, nas quais as opções de resposta não são excludentes entre si, o raciocínio não se aplica, e justamente em virtude destas situações é que este tipo de regra moral é impossível de ser generalizado. Vejamos o exemplo: uma pessoa A pergunta a B que horas são. B sabe que, naquele momento, o relógio marca 12 horas, mas ao invés disso, B responde que o relógio marca 6 horas (ou então responde simplesmente que não são 12 horas naquele momento). Mesmo que a pessoa A saiba que a resposta de B não condiz com o que B acredita, ou seja, mesmo que A saiba que a resposta de B é exatamente a negativa do que $\mathrm{B}$ pensa, ele não tem como utilizar a resposta que $\mathrm{B}$ forneceu, porque não existem apenas duas marcações horárias (12 ou 6) num dia, de modo que, se fosse possível desconsiderar a resposta de A (6 horas), B obtivesse a informação correta (12 horas). ALEXY, Robert. Teoria da Argumentação Jurídica: A Teoria do Discurso Racional como Teria da Justificação Jurídica. Trad. Zilda Hutchinson Schild Silva. Introd. à ed. brasileira Claudia Toledo. São Paulo: Landy, 2005. p. 114. BAIER, K. The Moral Point of View. Londres: Ithaca, 1958, p. 197 e seguintes. 
menos uma estabilidade relativa para que se torne possível a transformação de concepções incompatíveis em um acordo racional. Isto porque, de nada adiantariam regras que se apliquem a uma situação hoje, mas que não possam se aplicar a uma situação semelhante amanhã. É claro que não se exige a imutabilidade, eis que isso seria uma verdadeira utopia, entretanto, é necessário que haja um ambiente de estabilidade para que os falantes do discurso possam se entender. Desta forma, temos as seguintes regras de permanência:

b.1. Regra de permanência $n$. 1 : as regras morais que servem de base às concepções morais do falante devem resistir à comprovação de sua gênese histórico-crítica. Uma regra moral não resiste a tal comprovação se (i) originariamente se pudesse justificar racionalmente, mas depois perdeu sua justificação, ou então se (ii) originariamente não se pôde justificar racionalmente e não se podem apresentar também novas razões suficientes.

b.2) Regra de permanência $n$. 2: As regras morais que servem de base às concepções morais do falante devem resistir à comprovação de sua formação histórica individual. Uma regra moral não resiste a tal comprovação se se estabeleceu com base apenas em condições de socialização não justificáveis. Alexy não define com precisão o que seriam tais condições de socialização não justificáveis, indicando apenas que são aquelas que levam a que o interessado não esteja disposto ou não possa tomar parte no discurso.

c. Dever de realizabilidade: devem ser respeitados os limites de realizabilidade faticamente dados: o que Alexy chama de "realizabilidade" corresponde à exigência de que o discurso prático se desenvolva com a finalidade de resolver uma questão efetivamente existente no mundo real, ou seja, uma questão que seja, de fato, prática.

(vi) Regras de transição: As regras de transição são aquelas que se aplicam quando é necessária a transição para um outra forma de discurso em virtude de o discurso prático não ter sido capaz de resolver a questão que constitui o seu objeto. Estas regras refletem a aplicação do princípio de razão, da Escola de Erlangen. 
a. Para qualquer falante e em qualquer momento, é possível passar a um discurso teórico (empírico); esta regra tem especial importância porque, embora frequentemente haja concordância dos falantes a respeito das premissas normativas, não se verifica acordo a respeito dos fatos, não há certeza a respeito destes. Então é necessário recorrer às regras de presunção racional para determinar os fatos que constituem o objeto do discurso.

b. Para qualquer falante e em qualquer momento é possível passar a um discurso de análise de linguagem: aqui cita-se o discurso analíticolinguístico, no qual o objetivo perseguido é o esclarecimento de problemas de comunicação linguística. Trata-se, pois, de resolver ambiguidades ou obscuridades, dentre outras carências de sentido observáveis durante a utilização prática da linguagem.

c. Para qualquer falante e em qualquer momento é possível passar a um discurso de teoria do discurso: quando a própria evolução do discurso se torna um problema, então é necessário recorrer à teoria do discurso para permitir que os participantes possam compreender e argumentar com as proposições uns dos outros. No caso, a teoria do discurso a que nos referimos é a teoria do discurso racional.

\subsubsection{Os limites do discurso prático geral}

Quando Alexy fala em limites do discurso prático geral, ele está se referindo precisamente às dificuldades que atrapalham o desenvolvimento do discurso na vida real. Isto pode ser visto pela impossibilidade de cumprimento total, na prática, das regras do discurso prático, explicadas na tabela acima. Estas dificuldades são mais frequentes do que se imagina, e são elas que impõem os limites ao discurso prático geral mencionados por Alexy.

Por exemplo, a regra de que todos podem tomar parte no discurso e argumentar livremente não poderia ser cumprida, na prática, por alguém que tivesse a condição de escravo, que apesar de saber se comunicar, não goza do status de pessoa, sendo equiparados a objetos, e, portanto, não teria sua opinião nem seus argumentos considerados pelos demais falantes. Da mesma forma, um deficiente auditivo que não consiga se comunicar nem por linguagem oral, nem por linguagem escrita, e nem por sinais 
inteligíveis, não conseguiria, na maioria das vezes, tomar parte num discurso racional. Uma pessoa com graves deficiências das faculdades mentais, os loucos, os esquizofrênicos em períodos de crise, nenhum desses consegue tomar parte num discurso de forma satisfatória.

Outra regra cujo cumprimento dificilmente é observado na prática é a liberdade de expressão e a vedação à coerção. Atualmente, nem mesmo os jornalistas, que deveriam ter, por excelência, a liberdade de expressão, conseguem se manifestar com toda a liberdade. É comum verificar, embora de forma disfarçada e velada, a existência de censura, especialmente em países, como a Venezuela, que atualmente vivem sob regimes ditatoriais. Tomando o próprio exemplo da Venezuela, o exemplo mais contundente do cerceamento à liberdade de expressão talvez tenha sido a recente retirada do ar de cinco canais de televisão, por ordem do Governo Federal, em virtude da oposição que manifestavam ao governo. Assim, atualmente, apenas os canais que transmitem as opiniões que o governo entende corretas, e que transmitem o conteúdo exigido pelo governo, podem transmitir "livremente" sua programação.

Outro exemplo desta natureza pode ser verificado na China, em que a empresa virtual de buscas Google ameaçou se retirar do país em virtude da censura exercida pelo governo aos resultados apresentados pelo serviço de buscas que ela oferece a seus clientes.

Mais um exemplo: nos países islâmicos extremistas, que adotam a forma mais radical da sharia, como é o caso do Afeganistão e de algumas regiões do Paquistão, as mulheres não têm nenhum direito de expressão, sua opinião não é considerada em qualquer discussão sobre qualquer assunto. Apenas os homens têm o direito de decidir sobre os fatos da vida quotidiana, inclusive sobre aqueles que dizem respeito direta e exclusivamente às mulheres.

Todos estes exemplos ilustram o que Alexy chama de impossibilidade discursiva, ou de necessidade discursiva. São casos, todos eles, em que o discurso não chega a se desenvolver completamente, e em algumas hipóteses, como no último exemplo, não chega a se desenvolver de modo algum.

A própria criação destas dificuldades, as quais somente existem por obra humana, exige juízos de valor. Ou seja: é porque alguém realizou um juízo de valor e entendeu que as mulheres não possuem direito de expressão (ou possuem de forma bastante limitada) que surge a limitação ao discurso. O que pretendemos afirmar, aqui, é 
que uma limitação não surge do nada, ela só existe porque alguém, exercendo um juízo de valor, a criou.

Em face disso, é razoável supor que a existência de tais limites para a efetivação do discurso prático racional conduza à necessidade de estabelecimento de outras regras que permitam superar estas dificuldades. E, como ensina Manuel Atienza:

"Essa dupla limitação das regras do discurso prático suscita a necessidade de estabelecer um sistema jurídico que sirva, em certo sentido, para preencher essa lacuna de racionalidade. Assim, o direito é justificado em termos discursivos, tanto na sua dimensão propriamente normativa, isto é, como um conjunto de normas (...) que, movendo-se dentro do campo do discursivamente possível, fazem com que aumente a possibilidade de resolução das questões práticas, quanto na sua dimensão coativa, isto é, na medida em que suas normas podem se impor, também, a quem não está disposto a segui-las de bom grado., 238

É a partir daí que se verifica o início de uma transição para o discurso jurídico. Efetivamente, o discurso jurídico nasce da necessidade de superar os obstáculos presentes no discurso prático que podem afetar os direitos dos cidadãos, ou, nas palavras do próprio Alexy, "os limites do discurso prático fundamentam a necessidade de regras jurídicas ",239, sendo que o papel destas não se restringe apenas à ação de possibilitar soluções para as situações em que não se haja obtido um acordo discursivo, incluindo, da mesma forma, a função de assegurar os pressupostos que tornam possível a realização prática dos discursos.

\subsubsection{Teria da Argumentação Jurídica}

\subsubsection{Características gerais do discurso jurídico}

Segundo Alexy, o discurso jurídico é uma espécie do discurso prático, que deste se distingue por se originar justamente a partir das suas dificuldades e limites. É nos

\footnotetext{
${ }^{238}$ ATIENZA, Manuel. As razões do Direito: teorias da argumentação jurídica. Trad. Maria Cristina Gumarães Cupertino. 3. ed. São Paulo: Landy, 2006. p. 171.

239 ALEXY, Robert. Teoria da Argumentação Jurídica: A Teoria do Discurso Racional como Teoria da Justificação Jurídica. Trad. Zilda Hutchinson Schild Silva. Introd. à ed. brasileira Claudia Toledo. São Paulo: Landy, 2005. p. 208.
} 
discursos jurídicos que se encontram os argumentos jurídicos, os quais se diferenciam da argumentação geral por possuírem pretensões de correção, e não de verdade240. Em outras palavras, no discurso jurídico os participantes limitam-se a discutir o que é correto à luz de determinado ordenamento jurídico,, o que não implica que se discuta somente a correção de condutas. Pelo contrário, no discurso jurídico são analisadas também questões de fato e questões dogmáticas.

Existem vários tipos de discursos jurídicos, e nestes é possível identificar inúmeras formas para a sua realização. Por exemplo, o discurso feito por um advogado dirigindo-se a um tribunal durante um julgamento é uma forma de discurso jurídico institucionalizado e regido por regras e procedimentos específicos. $\mathrm{O}$ discurso feito por um advogado ao elaborar uma peça processual destinada a integrar os autos de um processo judicial também é discurso jurídico, só que se realiza pela forma escrita, e seu desenvolvimento está sujeito a limites temporais (os prazos processuais). De outro lado, o discurso jurídico que desenvolve entre um professor e um estudante de Direito não tem uma forma específica, mas nem por isso perde seu caráter de discurso jurídico.

Sempre existe, em maior ou menor grau, uma certa interação entre o discurso jurídico e o discurso prático. Isto é mais fácil de ser visualizado, por exemplo, durante a inquirição de testemunhas, durante um julgamento. Já quando o debate é entre os advogados, geralmente o discurso se mantém apenas na esfera jurídica.

Como se vê, é impossível enumerar todas as situações em que o discurso jurídico têm lugar, bem como é impossível citar todas as formas sob as quais ele pode se desenvolver. Contudo, ao menos uma característica é constante e comum a qualquer destes tipos e formas: toda argumentação jurídica é sempre e necessariamente vinculada às normas do Direito vigente241. Esta característica fornece, por outro lado, a principal distinção entre o discurso jurídico e o discurso prático geral, ou seja, numa discussão jurídica, não são todos os fatos que merecem ponderação e que podem, assim, ser objeto da discussão, mas apenas aqueles que sejam juridicamente relevantes.

\footnotetext{
${ }^{240}$ Por exemplo, no processo penal, ao réu não interessa que se prove a verdade, a ele interessa apenas que a sua versão dos fatos (que pode ser mentirosa, em virtude do princípio de que ninguém é obrigado a produzir prova em seu desfavor) que ele apresenta seja considerada correta pelo tribunal, evitando a aplicação da sanção penal.

241 ALEXY, Robert. Teoria da Argumentação Jurídica: A Teoria do Discurso Racional como Teoria da Justificação Jurídica. Trad. Zilda Hutchinson Schild Silva. Introd. à ed. brasileira Claudia Toledo. São Paulo: Landy, 2005. p. 210.
} 
Outro ponto comum entre o discurso jurídico e o discurso prático geral consiste no dever de fundamentar e justificar as asserções. A diferença é que no discurso jurídico as razões que integram esta fundamentação fica adstrita ao direito vigente.

No que se refere às limitações que são impostas ao discurso jurídico, é possível afirmar que, o campo da dogmática jurídica (ciência do direito) é onde se desenvolvem as discussões jurídicas mais livres, enquanto que a esfera processual produz as discussões jurídicas mais limitadas, e aqui utilizamos a expressão "limitadas" não no sentido de serem restritas ou medíocres, mas no sentido de serem regulamentadas segundo parâmetros objetivamente definidos - as normas processuais.

Após estas considerações introdutórias, convém mencionar três aspectos que são de considerável relevância para a adequada compreensão do conceito e das particularidades dos discursos jurídicos:

(i) A possibilidade de discussão de questões práticas: Quando se pensa em discursos jurídicos ou em argumentação jurídica, somos equivocadamente levados a acreditar que neles são discutidas apenas questões jurídicas. Entretanto, se isto fosse correto, seria o mesmo que ignora o fato de que o direito nasce a partir dos fatos, as normas jurídicas não existiriam se não houvesse fatos que justificassem e requeressem a sua aplicação. Só existe direito porque a vida em sociedade exige que se estabeleça uma ordem para as coisas, de modo que sejam garantidas as mínimas condições de convivência. Desta forma, seria absurdo desconsiderar as questões práticas que são discutidas na esfera jurídica, especialmente aquelas que são discutidas na História do Direito, na Sociologia Jurídica, na Filosofia e na Teoria do Direito ou mesmo na Medicina Legal. Portanto, é um equívoco acreditar que no discurso jurídico são discutidas apenas questões jurídicas, sendo imprescindível considerar também as questões práticas.

(ii) A pretensão de correção: a pretensão de correção no discurso jurídico é distinta daquela que vale para o discurso prático. Isto porque a correção jurídica é avaliada mediante os parâmetros contidos no ordenamento jurídico vigente, e desta forma se torna possível fundamentar as pretensões jurídicas. Tanto a exigência de fundamentação das assertivas que também se aplica ao discurso jurídico quanto a pretensão de correções das pretensões jurídicas encontram sua base no ordenamento jurídico, pelo menos no que se refere às decisões 
judiciais. Questiona-se, entretanto, se todas as decisões judiciais teriam pretensão de correção, no sentido de que fosse a correção o seu critério de validade. Alexy entende que a pretensão de correção não tem relação com a validade das decisões judiciais, ou seja, é possível existir decisões judiciais que sejam incorretas, mas que, apesar disso, sejam válidas. A validade está condicionada à observância dos critérios materiais e processuais estabelecidos pelo direito. No entanto, ele mesmo afirma que a ausência de correção numa decisão judicial constitui um defeito grave, inclusive moralmente.

(iii) Os cânones da interpretação: As limitações que são impostas ao discurso jurídico não impedem que ele seja um discurso racional. É, inclusive, bastante comum que as argumentações que se desenvolvem nas instâncias superiores do Judiciário sejam precedidas de longas discussões dogmáticas sobre os direitos envolvidos. E, como já explicamos anteriormente, é no campo da dogmática jurídica que se têm mais liberdade para desenvolver e elaborar o discurso jurídico enquanto discurso racional. É nesse sentido que Alexy afirma que “ $a$ teoria do discurso racional, como teoria da argumentação jurídica, não pressupõe que todas as discussões jurídicas devam colocar-se como discurso no sentido de uma comunicação sem coerção e sem restrições, mas somente que nas discussões jurídicas os debates ocorrem sob a pretensão de correção, e, por isso, têm como referencia condições ideais." 242

Desta forma, é possível concluir que o discurso jurídico constitui uma forma de discurso especial porque nele a pretensão de correção não guarda relação com a racionalidade das proposições normativas, mas, sim, com a possibilidade de fundamentar racionalmente as assertivas segundo as normas vigentes no ordenamento jurídico.

\subsubsection{Características gerais da argumentação jurídica}

Nos discursos jurídicos, as proposições que devem ser fundamentadas (ou, segundo Alexy, justificadas) são principalmente aquelas constantes das decisões judiciais. Embora Alexy não mencione, assim como Perelman também não se manifeste nesse

242 ALEXY, Robert. Teoria da Argumentação Jurídica: A Teoria do Discurso Racional como Teoria da Justificação Jurídica. Trad. Zilda Hutchinson Schild Silva. Introd. à ed. brasileira Claudia Toledo. São Paulo: Landy, 2005. pp. 216-217. 
sentido, parece-nos óbvio que todo texto que trate de questões jurídicas deve ser fundamentado, e não apenas as decisões judiciais. Então, entendemos que a necessidade de fundamentação se estende também às peças processuais e aos artigos de doutrina. Apesar disso, reconhecemos que numa decisão judicial é mais fácil reconhecer os elementos da justificação, e, por isso, manteremos as decisões judiciais como ponto de referência para o estudo da teoria da argumentação jurídica.

Como já destacamos inicialmente, a teoria da argumentação proposta por Alexy transfere a análise da racionalidade jurídica da interpretação para a argumentação, ou seja, a ele interessa a interpretação exteriorizada na forma de argumentação entre no mínimo dois falantes. Em outras palavras, não interessa a interpretação enquanto ela esteja no foro íntimo do falante, enquanto ela não tenha sido exteriorizada por meio de uma forma de linguagem.

\subsubsection{Regras de justificação interna e de justificação externa}

A estrutura da teoria da argumentação jurídica de Alexy está baseado em dois pilares: as regras de justificação ${ }^{243}$ interna e as regras de justificação externa, que analisaremos nos parágrafos a seguir.

\section{A) Justificação Interna}

As regras de justificação interna são relativas à coesão lógica dos silogismos jurídicos, e se destinam a verificar se a conclusão apresentada constitui uma decorrência lógica das premissas estabelecidas. Desta forma, elas têm o objetivo de assegurar uma certa medida de racionalidade nas premissas que compõem o discurso jurídico.

Trata-se, pois, da concretização do princípio da universalidade de Hare, que integra as regras fundamentais do discurso prático ${ }^{244}$, analisados na tabela anterior. É nesse sentido que Alexy afirma que o princípio da universalidade de Hare $^{245}$ constitui o

\footnotetext{
243 Alexy utiliza o termo "justificação" com o mesmo sentido de "fundamentação". Nesse sentido, v. ALEXY, Robert. Teoria da Argumentação Jurídica: A Teoria do Discurso Racional como Teoria da Justificação Jurídica. Trad. Zilda Hutchinson Schild Silva. Introd. à ed. brasileira Claudia Toledo. São Paulo: Landy, 2005. p. 58 e seguintes, 218 e seguintes.

${ }^{244}$ Todo falante que aplicar uma determinada qualidade $F$ a um objeto A deve estar disposto a aplicar esta mesma qualidade $F$ a qualquer objeto igual a A em todos os aspectos relevantes.
} 
fundamento do princípio da justiça formal, que exige "observar uma regra que obriga tratar da mesma maneira todos os seres da mesma categoria"246.

Neste ponto, é até mesmo possível traçar um paralelo com a teoria da argumentação jurídica de MacCormick, no ponto em que ele afirma que pelo menos uma parte dos casos e das questões jurídicas pode ser resolvido mediante recurso ao silogismo dedutivo. De fato, Alexy não afirma em momento algum que seja possível recorrer apenas ao raciocínio dedutivo, mas é possível concluir que as regras de justificação interna nada mais são do que a aplicação do silogismo dedutivo aos casos simples. Entretanto, é necessário ressalvar que as regras de justificação interna não são aplicáveis apenas nas situações em que exista uma norma evidente no direito positivo. Caso esta norma não exista, caberá ao juiz criá-la, mediante a interpretação jurídica.

Podemos, então, enumerar as regras de justificação interna a partir do seguinte esquema:

(i) Regra de justificação interna n. 1: Há questões jurídicas para as quais é suficiente apenas uma justificação elaborada com base em regras universais. Por exemplo, temos a seguinte situação: Premissa maior: Todo soldado deve dizer a verdade em questões de serviço (regra universal - norma geral e abstrata) --> Premissa menor: O senhor M é um soldado" (situação fática) --> Conclusão: O senhor M deve dizer a verdade em questões de serviço (norma individual e concreta). Um outro exemplo: Premissa maior: Aplica-se a presunção de violência em caso de relações sexuais mantidas com menores de 14 anos, cominando-se a pena de 6 (seis) a 10 (dez) anos de reclusão. Premissa menor: X, maior de idade, manteve relações sexuais com Y, de 13 anos. Conclusão: X deve cumprir pena de 6 (seis) a 10 (dez) anos de reclusão.

Entretanto, segundo destaca o próprio Alexy, esta regra é insuficiente, não devendo, portanto, ser aplicada (isoladamente, em nossa opinião),

\footnotetext{
${ }^{245} \mathrm{O}$ princípio da universalidade de Hare pode ser visto também como princípio da igualdade, dependendo da perspectiva.

${ }^{246}$ ALEXY, Robert. Teoria da Argumentação Jurídica: A Teoria do Discurso Racional como Teoria da Justificação Jurídica. Trad. Zilda Hutchinson Schild Silva. Introd. à ed. brasileira Claudia Toledo. São Paulo: Landy, 2005. p. 219.
} 
nas seguintes situações: (1) quando a norma geral em questão contiver diversas propriedades alternativas referentes ao fato hipotético; (2) quando a sua aplicação exige um complemento através de normas jurídicas explicativas, limitativas ou extensivas, tanto aquelas já previstas em lei quanto aquelas que necessitam ser formuladas mediante interpretação pelo aplicador do direito; (3) quando a partir da norma geral abstrata são previstas diversas consequências jurídicas, ou (4) quando na formulação da norma se usam expressões que admitem diversas interpretações ${ }^{247}$.

Relativamente a esta última hipótese, ousamos fazer uma crítica à teoria de Alexy. Nossa crítica se deve ao fato de que, ao afirmar que não se aplicam as regras de justificação interna, ou pelo menos a primeira delas, às situações em que na formulação da norma se utilizem expressões que admitam diversas interpretações, Alexy acaba sem querer afirmando que a regra de justificação interna não se aplica a nenhuma norma jurídica, uma vez que, como já explicamos no capítulo 1 do presente trabalho, toda norma jurídica pode ser interpretada de diversas formas, não sendo possível falar em um único sentido correto. A determinação do sentido das expressões depende da finalidade da norma e dos fatos aos quais ela se aplica. Desta forma, entendemos que este ponto da teoria de Alexy deve ser aceito com as devidas reservas.

(ii) Regra de Justificação Interna n. 2: Esta segunda regra se aplica especialmente nos casos em que a regra n. 1 não é suficiente, ou seja, sempre que for necessário desenvolver uma cadeia de justificação interna sobre determinado aspecto do fato jurídico. Ela se divide em 5 enunciados, dos quais tratamos a seguir: 2.1) Para a fundamentação de uma decisão jurídica deve-se apresentar pelo menos uma norma universal. Observamos que esta é uma regra bastante simplificada, na medida em que desconsidera a possibilidade de estruturas mais complexas de hipóteses normativas e de consequências. 2.2) A decisão

${ }^{247}$ ALEXY, Robert. Teoria da Argumentação Jurídica: A Teoria do Discurso Racional como Teoria da Justificação Jurídica. Trad. Zilda Hutchinson Schild Silva. Introd. à ed. brasileira Claudia Toledo. São Paulo: Landy, 2005. p. 220. 
jurídica deve seguir-se logicamente ao menos de uma norma universal, junto a outras proposições. 2.3) Sempre que houver dúvidas sobre se A é um T ou um M (se o fato A é igual ao fato $\mathrm{T}$ ou ao fato $\mathrm{M}$ ), deve-se apresentar uma regra que decida a questão. Para estas situações complexas, temos as regras 2.4 e 2.5. Vejamos: 2.4) São necessárias as etapas de desenvolvimento que permitam formular expressões cuja aplicação ao caso em questão não seja discutível. 2.5) Deve-se articular o maior número possível de etapas de desenvolvimento.

\section{B) Justificação Externa}

Se as regras de justificação interna destinavam-se a assegurar uma certa medida de racionalidade nas premissas que compõem o discurso jurídico, as regras de justificação externa atuam sobre o juízo que se faz acerca da racionalidade da decisão de adotar tais premissas. Para melhor compreender estas regras, voltemos ao exemplo da presunção de violência em relações sexuais com menores de 14 anos. O raciocínio silogístico está logicamente correto, porém nada garante que as premissas relativas aos fatos ou mesmo às normas sejam válidas. Por exemplo, o que garante que $\mathrm{X}$ e Y realmente mantiveram relações sexuais? Havia algum documento que provasse que $Y$ tinha apenas 13 anos à época do ocorrido? A lei que determina a presunção de violência para o caso em questão era vigente à época do ocorrido? X, apesar de ser maior de idade, estava no pleno gozo de suas faculdades mentais de forma que fosse imputável?

Estes são exatamente os aspectos aos quais se dirigem as regras de justificação externa, ou seja, as premissas relativas às regras do direito positivo, os enunciados empíricos (dependentes de prova) e as premissas que não se encaixam nem em uma nem na outra categoria. Em outras palavras, a fundamentação externa trata exatamente da justificação das premissas, e para cada premissa existe um método de fundamentação. Desta forma, Alexy estabelece que as premissas referentes às regras do direito positivo são fundamentadas mediante a sua conformação com os critérios de validade do ordenamento jurídico. Já as premissas empíricas são fundamentadas mediante recurso a diversas formas de procedimento, incluindo desde os métodos das ciências empíricas, passando pelas máximas da fundamentação racional e chegando até mesmo às regras de ônus da prova no processo. Em face disso, seria razoável perguntar qual seria o papel da argumentação jurídica nisso tudo, já que nem nas premissas legais nem nas empíricas houve menção à argumentação jurídica. E a resposta é: a argumentação jurídica se aplica justamente às 
premissas que não são nem legais nem empíricas, especialmente na interpretação de uma norma válida ou mesmo para determinar a própria validade desta norma.

Então, cumpre analisarmos as características e o modo como se desenvolve a justificação externa das premissas de uma decisão. Inicialmente, destacamos os seis grupos de regras e formas de justificação externa propostos por Alexy: (1) regras e formas de interpretação, (2) regras e formas da argumentação da Ciência do Direito, (3) regras e formas relativas ao uso dos precedentes, (4) regras e formas referentes à argumentação prática geral, (5) regras e formas da argumentação empírica, e (6) regras e formas especiais de argumentos jurídicos. Estes grupos integram as três categorias abaixo.

B.1. Argumentação empírica: A importância da argumentação empírica na justificação externa reside no fato de que basicamente todas as formas de argumentação jurídica, assim como praticamente em todas as formas da argumentação prática geral, existem enunciados empíricos. Enunciados empíricos são aqueles que se referem, em geral, ao estado das coisas ou das pessoas, às características inatas ou adquiridas dos seres vivos e dos seres inanimados. Por exemplo, quando afirmamos que Maria é mulher, estamos em face de um enunciado empírico correspondente à constatação de uma característica biológica. Da mesma forma, quando dizemos que Maria é arquiteta, trata-se de um enunciado empírico afeto à sociologia e à antropologia. Em alguns casos, dependendo da situação concreta, os enunciados empíricos podem depender de prova ou então se relacionarem com uma presunção legal. Esta é a hipótese da incapacidade absoluta dos menores de 16 anos para os atos da vida civil. Ou seja, presume-se absolutamente incapazes civicamente as pessoas que tem menos de 16 anos. Estes exemplos servem para demonstrar que há enunciados empíricos dos mais diversos tipos: sobre regularidade nas ciências naturais, sobre ações ou fatos concretos, ou ainda aqueles relativos aos motivos que levaram o agente a praticar determinada ação, e ainda há aqueles que se relacionam com o estado das coisas e das pessoas. E, desta forma, torna-se correto observar que eles correspondem às mais diversas áreas das ciências, não apenas das ciências naturais ou exatas, mas também das ciências sociais, como a biologia, a psicologia, a Medicina, a Linguística, etc. É possível concluir, em face destas características, que numa argumentação jurídica, os enunciados empíricos 
correspondem ao que se denomina de "questões de fato". De fato, com relativa frequência não se verificam discordância acerca dos elementos normativos que regrem o caso concreto, e a argumentação jurídica, nestes casos, destina-se a provar a existência ou a ocorrência de determinadas questões fáticas. Nestes casos, trata-se de argumentação empírica, em que o critério de validade não é o de correção (que se aplica à argumentação normativa), mas o critério de verdade. Assim, voltando mais uma vez ao exemplo da presunção de violência na relação sexual, não se trata de avaliar se foi correto ou não o indivíduo $X$ manter relações sexuais com Y, mas sim se isso efetivamente ocorreu, ou seja, se o fato é verdadeiro ou falso.

B.2. Os cânones interpretativos: Os cânones interpretativos correspondem aos métodos de interpretação das normas. Embora já sejam estudados desde os primórdios da análise da interpretação jurídica, até o presente momento não se chegou a um consenso sobre quantos ou quais exatamente são, nem quanto à sua formulação exata, e muito menos sobre a ordem hierárquica eventualmente existente entre eles. Em face disso, qualquer classificação que se exponha será, de certa forma, arbitrária, o que não implica, contudo, que seja irracional. Assim, ressalvando que a exposição a seguir não pretende, nem de longe, esgotar o assunto, passamos a analisar a classificação das formas concretas de argumentos segundo a teoria de Alexy ${ }^{248}$.

B.1.1. Argumento Semântico: o argumento semântico é aquele que tem por objetivo justificar (fundamentar), criticar ou afirmar como possível uma norma jurídica, com base no uso da linguagem. Possui 3 modalidades: (a) $\mathrm{O}$ enunciado R' deve ser aceito como interpretação da proposição R sobre a base linguística W (modalidade de justificação); (b) O enunciado R' não pode deve ser aceito como interpretação da proposição $\mathrm{R}$ sobre a base linguística $\mathrm{W}$ (modalidade de crítica); (c) É possível aceitar o enunciado R' como interpretação de $\mathrm{R}$ e é possível não aceitar R' como interpretação de R, pois não regem nem Wi nem Wk (modalidade de afirmação como possibilidade). Nas duas primeiras modalidades, o argumento semântico é suficiente para fundamentar uma decisão por meio do enunciado R. Porém, a terceira

${ }^{248}$ ALEXY, Robert. Teoria da Argumentação Jurídica: A Teoria do Discurso Racional como Teoria da Justificação Jurídica. Trad. Zilda Hutchinson Schild Silva. Introd. à ed. brasileira Claudia Toledo. São Paulo: Landy, 2005. pp. 230 e seguintes. 
modalidade demonstra a limitação de aplicação deste tipo de argumento nos casos em que, a princípio, determinada interpretação tanto pode ser aceita quanto pode não ser aceita (casos vagos, ambíguos, imprecisos, etc.), sendo necessário o recurso a outros tipos de argumentos para que a decisão seja satisfatoriamente fundamentada. Cumpre observar, neste ponto, que o que Alexy denomina de Argumento Semântico, na realidade, é algo bem próximo, quando não correspondente, ao método de interpretação literal da Hermenêutica tradicional. As características de ambos são as mesmas ${ }^{249}$, e a limitação referente aos casos vagos e imprecisos é aplicável a ambos.

B.1.2. Argumento Genético: aqui também se observa uma significativa semelhança, desta vez com o método de interpretação autêntica da Hermenêutica tradicional. $\mathrm{O}$ argumento genético serve para fundamentar uma norma a partir da "intenção do legislador". Afirma-se que determinada interpretação reflete a vontade do legislador quando ela é a que melhor promove os fins desejados por ele, e, neste caso, estaríamos muito próximos do método teleológico de interpretação segundo a Hermenêutica tradicional. $\mathrm{Na}$ realidade, o argumento genético é de difícil aplicação prática, eis que para se definir a "vontade do legislador" é necessário o recurso a uma ficção ou a uma metáfora. Além disso, a lei não é fruto da vontade de um único legislador embora o projeto de lei possa ser, mas o fato é que o seu texto final é submetido à vontade de vários legisladores, cujas intenções podem ser as mais variadas. Por isso é que o próprio Alexy ${ }^{250}$ ressalva que tanto o argumento semântico quanto o argumento genético são incompletos, requerendo o auxílio de outros tipos de argumento para "saturar", ou seja, para tornar suficiente, a fundamentação das proposições jurídicas. Em ambos os casos, porém, busca-se o estabelecimento das premissas fáticas, e desta forma, é possível afirmar que a argumentação semântica e a argumentação genética são casos especiais da argumentação empírica.

B.1.3. Argumento Histórico: fala-se em argumento histórico quando se expõem fatos relacionados com a história do problema suscitou a questão

\footnotetext{
${ }^{249}$ Sobre o método da interpretação literal, v. Capítulo 1.

${ }^{250}$ ALEXY, Robert. Teoria da Argumentação Jurídica: A Teoria do Discurso Racional como Teoria da Justificação Jurídica. Trad. Zilda Hutchinson Schild Silva. Introd. à ed. brasileira Claudia Toledo. São Paulo: Landy, 2005. p. 234.
} 
jurídica em discussão. Tais fatos históricos apresentam-se como razões a favor e contrárias a uma interpretação. No argumento histórico, avalia-se se determinada interpretação, solução ou decisão já foi ou não adotada no passado e quais foram as consequências disso. No argumento histórico frequentemente há o recurso a conhecimentos de outras ciências, como a História, Sociologia, a Antropologia, etc., e também se trata de uma forma frágil de argumentação, pelos mesmos motivos das duas anteriores, requerendo, da mesma forma, a complementarão por meio de outros argumentos para tornar suficiente a fundamentação de uma proposição.

B.1.4. Argumento Comparativo: como o título já diz, trata-se de estabelecer uma comparação em relação a outros ordenamentos, a outras sociedades, visando à percepção de quais foram as interpretações ou soluções dadas para a questão e suas consequências. Aproxima-se do argumento histórico por incluir pelo menos uma premissa normativa (por exemplo, que a solução adotada é correta) e várias premissas fáticas, que permitem estabelecer o vínculo entre os fatos a partir de vários referenciais. A diferença, aqui, é que a comparação que se estabelece entre os fatos tem como referência o tempo presente. Este é um tipo de argumento que tem considerável relevância na interpretação das convenções contra a bitributação, especialmente no que diz respeito à interpretação de termos e expressões de acordo com a linguagem fiscal internacional ${ }^{251}$, já que neste caso é necessário considerar a forma como diversos países interpretam um mesmo termo jurídico.

B.1.5. Argumento Sistemático: este tipo de argumento considera tanto a posição da norma no ordenamento como a relação lógica ou teleológica desta norma em relação a outras normas (regras), fins e princípios. $\mathrm{O}$ argumento sistemático se aproxima, evidentemente, do método lógico ou sistemático de interpretação da Hermenêutica tradicional. Assim, se a interpretação de uma norma conduz a uma contradição em relação às demais normas do sistema, então esta interpretação precisa ser revista ou abandonada, conforme o caso.

B.1.6. Argumento Teleológico: o último tipo de argumento apresentado por Alexy é o argumento teleológico, o qual se assemelha ao método teleológico de

${ }^{251}$ Sobre a linguagem fiscal internacional, v. Capítulo 5. 
interpretação da Hermenêutica tradicional. Este argumento pressupõe uma análise detalhada das noções de fim e de meio, bem como os conceitos relativos à vontade, intenção, necessidade, prática e fim $^{252}$. É necessário destacar que os fins que se consideram no argumento teleológico são aqueles objetivamente propostos pelo próprio diploma normativo em análise, tanto explícita quanto implicitamente. Não se trata, portanto, dos fins que se verifiquem empiricamente, mas dos fins caracterizados normativamente, os quais correspondem, nos dizeres de Alexy, a um estado de coisas prescrito ou a um fato prescrito ${ }^{253}$, ou seja, previsto pelo Direito. São objetivos corretos, à luz da teoria do discurso, aqueles que os próprios envolvidos nos processos de decisão, através da argumentação, estabelecem como sendo corretos. Um aspecto importante sobre os argumentos teleológicos é a sua estreita relação com os argumentos empíricos, especialmente em situações que envolvam premissas diferentes ou até mesmo contraditórias entre si.

O grande problema destes tipos de argumento é que eles quase nunca se bastam em si próprios, ou seja, quase nunca são suficientes para fundamentar suficientemente uma proposição, isto é, dificilmente um cânone isolado atenderá ao requisito de saturação da fundamentação. De fato, Alexy destaca que "um argumento de uma forma só é completo se contém todas as premissas pertencentes a esta forma. A isto se chama o requisito de saturação. As premissas que precisam ser saturadas são de diferentes tipos, o que gera maneiras completamente diferentes de fundamentação.",254 A partir do conceito do requisito de saturação torna-se possível elaborar a seguinte regra da argumentação: "Deve resultar saturada toda forma de argumento que se deva incluir entre os cânones da interpretação",255. Ela impede, justamente, a

${ }^{252}$ ALEXY, Robert. Teoria da Argumentação Jurídica: A Teoria do Discurso Racional como Teoria da Justificação Jurídica. Trad. Zilda Hutchinson Schild Silva. Introd. à ed. brasileira Claudia Toledo. São Paulo: Landy, 2005. p. 234.

253 ALEXY, Robert. Teoria da Argumentação Jurídica: A Teoria do Discurso Racional como Teoria da Justificação Jurídica. Trad. Zilda Hutchinson Schild Silva. Introd. à ed. brasileira Claudia Toledo. São Paulo: Landy, 2005. p. 236.

254 ALEXY, Robert. Teoria da Argumentação Jurídica: A Teoria do Discurso Racional como Teoria da Justificação Jurídica. Trad. Zilda Hutchinson Schild Silva. Introd. à ed. brasileira Claudia Toledo. São Paulo: Landy, 2005. p. 240. 
possibilidade de haver falas vazias no discurso. Além disso, a noção de saturação nos conduz a outro problema de fundamental importância: dependendo do cânone (tipo de argumento) interpretativo que se adote, um mesmo fato pode ser interpretado de formas tão diferentes que pode haver até mesmo conflito entre elas.

$\mathrm{Na}$ verdade, como bem ressaltado por Alexy, os cânones, os tipos de argumento explicados acima não são regras, eles não indicam o que devem ser feito ou o que deve ser alcançado. Eles representam simplesmente linhas investigativas que fornecem o caminho para se chegar a uma interpretação e à fundamentação de uma ou mais proposições ${ }^{256}$.

E, embora não se possa estabelecer uma clara hierarquia entre eles, Alexy defende ser possível fixar algumas regras de prevalência em favor dos cânones dos argumentos semânticos e genéticos, porque estes possibilitariam a vigência do princípio da universalidade. Desta forma, com o objetivo de atender ao requisito de saturação da fundamentação, Alexy propõe as seguintes regras de prevalência:

“(J.7) Os argumentos que expressam uma vinculação ao teor literal da lei ou à vontade do legislador histórico prevalecem sobre outros argumentos, a não ser que se possam apresentar motivos racionais que dêem prioridade a outros argumentos.

\section{(...)}

(J.8) A determinação do peso dos argumentos de diferentes formas deve ocorrer segundo regras de ponderação.

\section{(...)}

\footnotetext{
${ }^{255}$ ALEXY, Robert. Teoria da Argumentação Jurídica: A Teoria do Discurso Racional como Teoria da Justificação Jurídica. Trad. Zilda Hutchinson Schild Silva. Introd. à ed. brasileira Claudia Toledo. São Paulo: Landy, 2005. p. 241.

${ }^{256}$ Neste ponto, o próprio Alexy se remete às técnicas argumentativas de Perelman. Cf. ALEXY, Robert. Teoria da Argumentação Jurídica: A Teoria do Discurso Racional como Teoria da Justificação Jurídica. Trad. Zilda Hutchinson Schild Silva. Introd. à ed. brasileira Claudia Toledo. São Paulo: Landy, 2005. p. 240. PERELMAN, Chaïm. OLBRECHTS-TYTECA, Lucie. Tratado da argumentação: A nova retórica. Trad. Maria Ermantina de Almeida Prado Galvão. 2. ed. São Paulo: Martins Fontes, 2005. pp. 211-398.
} 
(J.9) Devem-se levar em consideração todos os argumentos possíveis e que possam ser incluídos por sua forma entre os cânones da interpretação. ,257

Enfim, as regras de prevalência têm o objetivo de auxiliar para a melhor utilização dos cânones interpretativos, mas nem mesmo elas podem garantir a saturação da fundamentação, muito menos podem garantir que se encontre um único resultado correto.

B.3) A argumentação dogmática: A argumentação segundo a dogmática jurídica pressupõe que se tenha a exata noção do que é a ciência do Direito. Alexy define a dogmática jurídica como uma série de enunciados que se referem à legislação e à aplicação do Direito, mas que não se podem identificar com sua descrição, que estão entre si numa relação de coerência mútua, formam-se e discutem dentro de uma Ciência do Direito que funciona institucionalmente e têm conteúdo normativo ${ }^{258}$. Dito de outra forma, o conceito de dogmática jurídica abrange a análise lógica dos conceitos previstos na legislação (por exemplo: usucapião, capacidade contributiva, boa fé, interesse público, imputabilidade, função social da propriedade, prescrição, perempção, preclusão, dentre milhares de outros). Incluem-se nestes conceitos tanto aqueles que são exclusivos do Direito, como é o caso da preclusão e da perempção, como outros que sejam afetos a outras áreas da ciência, mas que tenham aplicação específica no âmbito jurídico, isto é, aos quais o Direito empresta um sentido especificamente jurídico, como é o caso da definição de estado de embriaguez ou a noção de faturamento, ou mesmo a definição de estabelecimento permanente.

Assim, os objetivos da Ciência do Direito consistem em analisar logicamente os conceitos jurídicos, reconduzir esta análise a um sistema e aplicar os resultados dela provenientes na fundamentação das decisões jurídicas. A ciência do Direito possui, ainda, as seguintes funções: (a) Função de estabilização do Direito, isto é, manter durante períodos longos de tempo

\footnotetext{
257 ALEXY, Robert. Teoria da Argumentação Jurídica: A Teoria do Discurso Racional como Teoria da Justificação Jurídica. Trad. Zilda Hutchinson Schild Silva. Introd. à ed. brasileira Claudia Toledo. São Paulo: Landy, 2005. pp. 242-243.

258 ALEXY, Robert. Teoria da Argumentação Jurídica: A Teoria do Discurso Racional como Teoria da Justificação Jurídica. Trad. Zilda Hutchinson Schild Silva. Introd. à ed. brasileira Claudia Toledo. São Paulo: Landy, 2005. p. 249.
} 
determinadas formas de decisão; (b) Função de permitir o progresso, na medida em que estende os debates jurídicos em seus aspectos temporal, objetivo e subjetivo; (c) Função técnica, uma vez que a dogmática permite a apresentação sistemática e organizada do Direito, possibilitando a difusão; (d) Função de descarga, torna desnecessário voltar a discutir tudo o que já foi discutido novamente; (e) Função de controle e aumento da eficácia do princípio da universalidade e da justiça, por permitir a referência aos casos anteriores, e (f) Função heurística, por conter modelos de solução e sugerir novas perguntas e respostas. ${ }^{259}$

Para atingir seus objetivos e desempenhar as suas funções, a dogmática jurídica utiliza-se das seguintes regras de argumentação:

“(J.10)Todo enunciado dogmático, se é posto em dúvida, deve ser fundamentado mediante o emprego, pelo menos, de um argumento prático de tipo geral. (J.11) Todo enunciado dogmático deve enfrentar uma comprovação sistemática, tanto em sentido estrito quanto em sentido amplo (...) (J.12) Se são possiveis argumentos dogmáticos, devem ser usados „260.

Estas são as chamadas "regras da argumentação dogmática", e se referem à necessidade de fundamentar as proposições jurídico-científicas, que são as que possuem maior grau de liberdade argumentativa, em último caso, em argumentos práticos gerais.

E o motivo para recorrer aos argumentos práticos gerais se deve ao caráter instrumental da dogmática, que possibilita atingir resultados, como a estabilização das decisões e a realização do princípio da universalidade, que não poderiam ser produzidos mediante apenas o discurso geral. Assim, é correto afirmar que a argumentação dogmática é racional na medida em que se remete à argumentação prática geral.

B.4) Precedentes: Os precedentes são elementos de primordial importância na argumentação jurídica, não apenas nos países adeptos do sistema da Common

259 ATIENZA, Manuel. As razões do Direito: teorias da argumentação jurídica. Trad. Maria Cristina Gumarães Cupertino. 3. ed. São Paulo: Landy, 2006. p. 177.

${ }^{260}$ ALEXY, Robert. Teoria da Argumentação Jurídica: A Teoria do Discurso Racional como Teoria da Justificação Jurídica. Trad. Zilda Hutchinson Schild Silva. Introd. à ed. brasileira Claudia Toledo. São Paulo: Landy, 2005. pp. 258, 264. 
Law, nos quais eles são fundamentais para a construção do Direito, mas também naqueles em que vigora a Civil Law. Não nos cabe aqui discutir se os precedentes constituem fonte do direito, embora entendamos que sim, especialmente no que diz respeito às normas individuais e concretas. A questão que por hora nos interessa consiste em determinar o papel dos precedentes sob o ponto de vista da teoria do discurso, bem como a relação que se estabelece entre os argumentos baseados em precedentes e os outros tipos de argumentos.

A utilização de precedentes para justificar decisões tem muito que ver com o recurso à dogmática jurídica na medida em que ambos representam uma forma de concretizar o princípio da universalidade de Hare (igualdade). Além disso, muitos enunciados dogmáticos são incorporados aos precedentes, de modo que seria possível utilizar duas formas de argumentação ao mesmo tempo. Por outro lado, os precedentes podem, eles próprios, se transformar em objeto da dogmática. Independente deste aspecto, a diferença entre a argumentação segundo a dogmática e a argumentação segundo os precedentes está em que, naquela, os enunciados são elaborados abstratamente, ou seja, antes dos casos concretos ocorrerem, enquanto nos últimos, os enunciados são elaborados a partir do caso concreto.

Ademais, é necessário considerar que quando se recorre a um precedente, em última instância recorre-se à norma que fundamenta este precedente. Assim, ao aplicar um precedente a um caso novo, na realidade aplica-se a norma a ele subjacente para um caso novo. Outro aspecto importante é que não existe um caráter vinculante dos precedentes, não é obrigatório segui-los para que uma decisão seja bem fundamentada. Apesar disso, é possível afirmar que a Súmula Vinculante é uma tentativa de institucionalizar este argumento, tornando-o obrigatório em determinados casos. Em qualquer caso, porém, é inegável que, em virtude da necessidade de coesão e coerência, o julgador tende a decidir, ou pelo menos tenta decidir, nos casos semelhantes, da mesma forma como já foi decidido no passado, guardadas as devidas e necessárias adaptações, já que não existem dois casos absolutamente idênticos. Em outras palavras, os precedentes, tanto quanto a Ciência do Direito, são capazes de fornecer estabilidade, promover o progresso e desafogar o judiciário, contribuindo para a eficiência na justiça e contribuindo, sob outra perspectiva, também para a 
segurança jurídica Isto também é uma forma de aplicação do princípio da inércia, de Perelman. Por isso, há uma espécie de ônus argumentativo daquele que busca afastar o precedente. Então, convém ao julgador ponderar sobre em que medida seria útil para a fundamentação de sua decisão o recurso a um precedente, lembrando sempre que cabe ao julgador a carga da argumentação. Assim, considerando os limites do discurso prático geral em face da necessidade de segurança jurídica, é possível elaborar as seguintes regras sobre a utilização de precedentes para fins de justificação de decisões: “( $J$. 13) Quando se puder citar um precedente a favor ou contra uma decisão, deve-se faz-lo. (J.14) Quem quiser se afastar de um precedente, assume a carga da argumentação. ${ }^{, 261}$.

Quando é necessário rejeitar a aplicação de um precedente, Alexy destaca duas técnicas, denominadas de distinguishing e de overruling. A primeira se caracteriza por uma interpretação estrita da norma que subjaz ao precedente, por exemplo, mediante a introdução de uma característica do antecedente (hipótese de incidência) não existente no caso a ser decidido, de forma que o precedente não seja aplicável. Já técnica do overruling consiste na simples rejeição do precedente. Quanto a estas técnicas, é importante destacar que, independentemente de qual se escolha, deve haver a necessária e suficiente fundamentação que justifique a recusa do precedente.

Desta forma, é possível concluir que os precedentes constituem, de fato, um tipo de argumento que deve ser considerado em virtude de razões práticogerais, seja em virtude do princípio da universalidade ou em decorrência da regra da carga da argumentação.

B.5) Formas e argumentos jurídicos especiais: Nesta categoria se incluem aquelas formas de argumentos previstos na metodologia jurídica, como é o caso da analogia ${ }^{262}$, do argumento a contrario $^{263}$ e do argumento $d a$

\footnotetext{
261 ALEXY, Robert. Teoria da Argumentação Jurídica: A Teoria do Discurso Racional como Teoria da Justificação Jurídica. Trad. Zilda Hutchinson Schild Silva. Introd. à ed. brasileira Claudia Toledo. São Paulo: Landy, 2005. p. 267.

${ }^{262}$ Sobre a analogia, v. Capítulo 1. Cfr. também: PERELMAN, Chaïm. OLBRECHTS-TYTECA, Lucie. Tratado da argumentação: A nova retórica. Trad. Maria Ermantina de Almeida Prado Galvão. 2. ed. São Paulo: Martins Fontes, 2005. pp. 423-466. PERELMAN, Chaïm. Ética e Direito. Trad. Maria Ermantina de Almeida Prado Galvão. 2. ed. São Paulo: Martins Fontes, 2005. pp. 659-670. HART, Hderbert L. A. $O$ conceito de Direito. Trad. Antônio de Oliveira Sette-Câmara. São Paulo: Martins Fontes, 2009, pp. 299-306.
} 
absurdum. ${ }^{264}$ Em sua obra, Alexy não entra no mérito de nenhum deles, pois acredita que cada um seria objeto para um estudo completo em separado. De fato, entendemos que ele tem razão, e, por isso, analisaremos apenas superficialmente cada um deles. Já tratamos da analogia em item específico no Capítulo 1, motivo pelo qual aqui não entraremos em maiores detalhes. $\mathrm{O}$ argumento a contrário consiste em afirmar a inexistência do consequente a partir do antecedente da norma. É, assim, um contra-senso lógico. Seria como afirmar que a consequência que se constata não é imputável ao fato previsto no antecedente. $\mathrm{O}$ argumento a contrario busca a não aplicação de uma opinião comum a duas espécies do mesmo gênero. Além disso, o argumento a contrario pressupõe que o comportamento previsto no antecedente da norma exclui todos os demais. Como isso dificilmente ocorre na prática, já que as normas legais não necessariamente são exaustivas em seus dizeres, na maioria das vezes o argumento a contrario não é suficiente para fundamentar sozinho uma decisão

Por outro lado, o argumento ad absurdum, ou redução ao absurdo, utiliza a mesma lógica do argumento utilizado pelo interlocutor, mas aplicando-a a uma situação tão absurda que implica o reconhecimento da invalidez do argumento inicialmente apresentado pelo interlocutor. É, desta forma, uma maneira de rebater os argumentos de um oponente, remetendo-se ao princípio da universalidade, ou seja, demonstrando que a asserção feita pelo interlocutor não possui caráter geral, por isso não pode ser considerada um argumento racional e, desta forma, não serve para fundamentar a proposição. Um exemplo seria o seguinte: o indivíduo A afirma que todas as religiões são boas. B não concorda, e afirma que, pelo raciocínio de A, seria possível afirmar que uma

263 Sobre o argumento a contrário, v. AMADO, Juan Antonio García. Sobre el argumento a contrario en la aplicación del Derecho. Disponível em: $<$ http://www.cervantesvirtual.com/servlet/SirveObras/01372719768028837422802/doxa24/doxa24_05.pdf. $>$ Acesso em 29 dez.2009.

${ }^{264}$ Existem inúmeras outras formas de argumentos especiais, como é o caso do argumento ad hominem, que se baseia na opinião do interlocutor; o argumento ad res, que se refere ao objeto da discussão em si, o argumento ad humanitatem, pelo qual se pressupõe que a opinião em questão seja partilhada por toda a humanidade, argumento a pari, segundo o qual é possível estender uma característica ou opinião a duas espécies do mesmo gênero, argumento etimológico, por meio do qual defende-se o significado de um termo ou expressão dentro de um contexto a partir de sua raiz etimológica, etc. Sobre os diversos tipos de argumentos jurídicos, v. GANUZAS, Francisco Javier Ezquiaga. Tipos de argumentos jurídicos. Disponível em

http://www.tedf.org.mx/ccje/investigacion/pdf/TIPOS\%20DE\%20ARGUMENTOS\%20JUR\%CDDICOS.Pd f. Acesso em 29 dez.2009. 
religião que prega o sacrifício injustificado de animais também é boa, o que não é verdade.

B.6) Argumentos práticos gerais no discurso jurídico: Os argumentos práticos gerais desempenham a função de complementação dos argumentos jurídicos durante a fundamentação de uma decisão. E o recurso aos argumentos práticos gerais é mais frequente e mais necessário do que se poderia imaginar, uma vez que a maioria dos argumentos jurídicos não consegue cumprir o requisito da saturação da justificação isoladamente. Assim, é possível citar como exemplos de sua aplicação a justificação da escola entre dois ou mais tipos de argumentos diferentes, na fundamentação e na comprovação de enunciados dogmáticos, na fundamentação da aplicação das técnicas distinguishing e overrruling para não aplicar um precedente, etc. Enfim, sua aplicação principal resume-se ao atendimento do requisito de saturação das fundamentações.

\subsubsection{Relações entre o discurso jurídico e o discurso prático geral}

Em toda a teoria desenvolvida por Alexy é possível perceber que o discurso prático geral e o discurso jurídico guardam relações estreitas entre si, em muitos aspectos. Desta forma, numa síntese conclusiva, Alexy resume em quatro tópicos principais a forma e os motivos pelos quais o discurso jurídico depende, em certos pontos, do discurso prático, e este, por sua vez, é auxiliado pelo discurso jurídico, quando se faz necessário. Considerando isso, explicamos a seguir os tópicos que sintetizam as relações entre o discurso jurídico e o discurso prático geral:

(i) A necessidade do discurso jurídico em face da natureza do discurso prático geral, principalmente em virtude da relativa carência de segurança deste, também porque suas regras não prescrevem de que premissas normativas devem partir os participantes do discurso, por não serem fixadas todas as etapas da argumentação e algumas e ainda em face da impossibilidade prática de cumprir totalmente algumas regras da argumentação, o que faz com que a argumentação prática não surta o efeito desejado em alguns casos. Portanto, observa-se uma relação de interdependência entre ambas, de forma que uma supre as deficiências da outra. 
(ii) A coincidência parcial com a pretensão de correção, isto é, tanto num discurso jurídico quanto num discurso prático geral os falantes pretendem que suas assertivas sejam tomadas como corretas pelos interlocutores (ou, se seguimos a terminologia de Perelman, do auditório), e assim obtenham a sua adesão. Além disso, no discurso jurídico a pretensão de correção está relacionada mais com a fundamentabilidade racional no âmbito do ordenamento vigente do que com a necessidade de absoluta racionalidade em todos os enunciados normativos.

(iii) A coincidência estrutural das regras e formas do discurso jurídico com as do discurso prático geral, que pode ser observada pela submissão de ambos ao princípio da universalidade e ao princípio da justiça formal (igualdade), bem como em virtude do relevante papel desempenhado pela argumentação empírica, já que muitas vezes, embora haja acordo quanto às premissas normativas, existem divergências quanto aos fatos. Outro aspecto que demonstra esta semelhança estrutural consiste na coincidência de vários cânones da interpretação jurídica com os cânones da interpretação geral. A própria dogmática jurídica representa a institucionalização do discurso prático sob a condição de existência do ordenamento, permitindo alcançar resultados que não seriam possíveis apenas por meio do discurso prático geral. Quanto ao uso de precedentes para fundamentar o discurso jurídico, a correspondência é feita pelos princípios da universalidade e da inércia do discurso prático geral. E, por fim, as formas de argumento especiais do discurso jurídico também encontram correspondência no discurso geral, de modo que a analogia pode ser considerada uma forma especial de implementação do princípio da universalidade e o argumento de redução ao absurdo consiste numa variante do argumento consequencialista.

(iv) A necessidade de argumentação prática geral para complementar a argumentação jurídica, que, segundo Alexy, é o vínculo mais frequentemente mencionado entre o discurso jurídico e o discurso prático. Isto porque, embora o discurso jurídico tenha justamente a função de suprir as deficiências do discurso prático, sua função não se reduz a apenas isso, e ele próprio, por sua vez, também possui deficiências que requerem 
o retorno ao discurso geral (por exemplo, no caso dos argumentos empíricos).

A racionalidade do discurso jurídico, e da Ciência do Direito, não estão na segurança definitiva de suas proposições, até porque, nem mesmo para as ciências exatas ou naturais se pode afirmar que tal grau de segurança exista. $\mathrm{O}$ que garante a racionalidade ao Direito é, assim, o cumprimento de uma série de condições, critérios e regras que tornam a sua aplicação ordenada e impedem o arbítrio e os excessos de discricionariedade.

Desta forma, o requisito da racionalidade não é a segurança do resultado, mas sim a certeza da obediência aos critérios, princípios e regras que regem o próprio sistema jurídico, é, pois, a segurança do procedimento. Não se pode determinar um único e correto resultado, mesmo porque, cada indivíduo pode interpretar a norma jurídica de uma forma distinta, mas é possível determinar um resultado que seja o mais adequado aos fatos mediante a argumentação jurídica.

\subsection{Princípios e regras - limites do discurso jurídico}

Os limites que se aplicam ao discurso jurídico, dados pelas normas, princípios e regras, constituíram o objeto de um estudo separado, que culminou na obra Teoria dos Direitos Fundamentais ${ }^{265}$. Nela, Alexy conceitua os três institutos, e estabelece como premissa que as normas jurídicas são um gênero do qual princípios e regras são espécies.

Esta distinção foi uma das maiores contribuições de Alexy para a ciência do Direito. Na realidade, a separação entre princípios e regras não é originária de Alexy, esta distinção entre os institutos já existia desde a obra Levando os Direitos a Sério, de Ronaldo Dworkin $^{266}$. O que Alexy fez foi, assim, aprofundar o estudo e aperfeiçoar as noções estabelecidas por Dworkin, de modo que atualmente a teoria sobre a distinção entre princípios e regras elaborada por Alexy é a mais difundida e, ao mesmo tempo, é também o paradigma para as críticas que se desenvolvem sobre o tema.

De modo bastante objetivo, segundo a teoria de Alexy, é possível distinguir regras e princípios na medida em que regras correspondem a normas aplicáveis por

\footnotetext{
${ }^{265}$ ALEXY, Robert. Teoria de Los Derechos Fundamentales. Trad. para Espanhol Ernesto Garzón Valdés. Madrid: Centro de Estudios Constitucionales, 1993. pp. 81-136.

${ }^{266}$ DWORKIN, Ronaldo. Levando os Direitos a Sério. Trad. Nelson Boeira. 2. ed. São Paulo: Martins Fontes, 2007, pp. 35-50.
} 
subsunção, ao passo que os princípios são efetivos mandamentos de otimização, ou seja, refletem as finalidades e os objetivos que o Estado deve perseguir sempre, bem como os valores que aquela nação considera importantes, de forma que esta busca pela concretização dos princípios deve sempre ser realizada na maior medida possível.

Esta noção de "princípio" somente é possível a partir da premissa de que os chamados "valores morais" são intrínsecos ao direito, os quais, na verdade, seriam responsáveis pela inspiração das normas jurídicas. E, justamente por isso, na época em que o positivismo e especialmente o normativismo de Kelsen tiveram maior expressão não se admitiam princípios no Direito, mas apenas regras, eis que, segundo o positivismo, o direito e a moral eram duas instituições distintas e que jamais deveriam se misturar. Este pensamento, como já explicamos no capítulo 1, há muito já se encontra superado, e atualmente os princípios desempenham um dos mais importantes papéis na aplicação racional do Direito.

Voltando à distinção, percebemos que as regras são excludentes entre si: os fatos que são regulados por uma regra não podem ser regulados por outra regra sobre os mesmos aspectos ao mesmo tempo. Em outras palavras, havendo concorrência ou conflito de regras, uma delas necessariamente sairá vitoriosa, e a outra deixará de ser aplicável. Já em relação aos princípios, não se verifica este tipo de embate. É possível que dois princípios se apliquem a uma mesma situação ao mesmo tempo. O que variará é a força ou a intensidade com que cada um deles exercerá influência nas decisões a respeito de tais fatos. Isto porque, o julgador, ao aplicar o direito, realizará um juízo de valor, pesará os prós e os contras de cada um deles, avaliará os valores que informam cada princípio, e determinará, em nome do interesse geral, ou do interesse particular, conforme for o caso, qual dos princípios deverá prevalecer. Entretanto, não é possível determinar este "peso" dos princípios abstratamente, isto é, o "peso" que a eles se atribui depende estritamente das circunstâncias de fato aos quais eles sejam aplicáveis.

Essa operação de sopesamento, ao contrário do que afirmam os críticos da teoria de Alexy, não constitui algo subjetivista nem mesmo voluntariosa ou discricionária. Como o próprio Alexy já explicou na teoria da argumentação jurídica, essa ponderação deve ser realizada de modo racional, segundo os parâmetros estabelecidos pelo próprio direito, e tendo em vista as circunstâncias fáticas. Enfim, tudo é uma questão de argumentação e de objetivos do Estado. 
Entretanto, ao que nos interessa neste trabalho, talvez o mais importante seja o fato de que sejam precisamente os princípios que permitem perceber a insuficiência da lógica dedutiva para o Direito. Dizemos que ela é insuficiente porque ela não comporta a variabilidade dos princípios, ela não permite a ponderação dos valores que é intrínseca dos princípios e inerente ao Direito. Por isso é que a lógica e o raciocínio jurídicos são dialéticos, baseados em argumentos, e não simplesmente em silogismos, embora estes comportem aplicação, em alguns $\operatorname{casos}^{267}$. De fato, em muitos casos, isso se não for na grande maioria dos casos, a decisão só é possível mediante o recurso aos princípios, ou seja, o fundamento do direito, a justificação da decisão, vai alem das normas e se apóia, em último caso, nos princípios.

${ }^{267}$ Sobre a possibilidade de aplicação de silogismos e de lógica dedutiva no direito, v. MACCORMICK, Neil. Argumentação Jurídica e Teoria do Direito. Trad. Waldéa Barcellos. São Paulo: Martins Fontes, 2006. pp. 23-26. 


\section{PRINCÍPIOS GERAIS DA INTERPRETAÇÃO JURÍDICA, EM ESPECIAL DAS NORMAS DO DIREITO TRIBUTÁRIO INTERNACIONAL}

\subsection{Aspectos gerais}

Mesmo diante de sua evidente importância, os princípios jurídicos somente passaram a ser devidamente reconhecidos na fase pós-positivista da Ciência do Direito. Isto porque, até o Positivismo, predominava a noção de que o direito era fundado apenas em regras. O exemplo mais notável era visto na Teoria Pura do Direito, de Kelsen, o qual defendia a separação entre direito e moral, e por consequência, a separação entre o direito e os valores. Desta maneira, Kelsen analisa o direito apenas sob o prisma da validade das regras, e entende, desta forma, que uma norma tem seu fundamento de validade numa outra que lhe seja superior, e assim sucessivamente, até a norma fundamental, que era pressuposta e extrínseca ao ordenamento ${ }^{268}$.

Somente após a crise do positivismo, quando houve a retomada da unidade entre o direito e os valores que o informam, notadamente a noção de segurança jurídica, é que se desenvolveu a noção de princípio defendida por Alexy e por outros teóricos da argumentação.

Assim, seguindo a definição proposta por Alexy, os princípios "são enunciados normativos de um alto grau de generalidade que, normalmente, não podem ser aplicados sem agregar premissas normativas adicionais" ${ }^{\text {269 }}$. São normas determinam que algo seja realizado em sua maior medida possível, dentro das possibilidades jurídicas e reais. Em outras palavras, os princípios jurídicos constituem mandatos de otimização, ou seja, objetivos que devem ser constantemente perseguidos pelo Estado, sendo que tais mandatos podem, contudo, ser cumpridos em maior ou menor grau, também a depender das possibilidades jurídicas e reais.

\footnotetext{
${ }^{268}$ Dedicamos um item à análise da distinção entre princípios e regras no Capítulo 2.

269 ALEXY, Robert. Teoria da Argumentação Jurídica: A Teoria do Discurso Racional como Teria da Justificação Jurídica. Trad. Zilda Hutchinson Schild Silva. Introd. à ed. brasileira Claudia Toledo. São Paulo: Landy, 2005. p. 252. Sobre os princípios constitucionais tributários, v. CARRAZZA, Roque Antônio. Curso de Direito Constitucional Tributário. 8. ed., rev. e ampl. São Paulo: Malheiros, 1996. pp. 27-103.
} 
Os princípios ${ }^{270}$ são, pois, informadores dos valores que o legislador perseguia ao elaborar as regras jurídicas, implicando a conclusão de que toda regra jurídica é baseada num princípio, e que nestes a pretensão de correção e de justiça do direito é mais visível. Eles refletem, desta forma, os valores que são caros à sociedade. Nesse sentido, Sacha Calmon Navarro Coelho é categórico ao afirmar que:

"o que caracteriza os princípios e que não estabelecem um comportamento específico, mas uma meta, um padrão. Tampouco exigem condições para que se apliquem. Antes, enunciam uma razão para a interpretação dos casos. Servem, outrossim, como pauta para a interpretação das leis, a elas se sobrepondo. ,271

Além disso, aos princípios não se aplicam critérios de exclusão, e eles não podem ser aplicados por mera subsunção, como ocorre com as regras ${ }^{272}$. E, no caso de conflito de princípios, trata-se de atribuir maior ou menor "peso" a um princípio em detrimento do outro. O desempate entre princípios é, desta forma, qualitativo, ou seja, um princípio prevalece sobre o outro em virtude dos objetivos perseguidos no caso concreto. Os princípios são utilizados, ainda, com a finalidade de desempatar uma situação em que haja a concorrência de regras.

Quando se fala em interpretar a norma jurídica segundo os princípios jurídicos, a noção que imediatamente se deve ter em mente é que o primeiro limite aplicável à interpretação está na própria constituição. Dito de outra forma, a interpretação jurídica sempre deve ser conforme a constituição do país e visando à garantia da segurança jurídica $^{273}$, e obedecendo aos limites impostos pela razoabilidade.

De fato, a segurança jurídica nas relações tributárias é resultante da associação de diversos princípios, cuja aplicação, a seu turno, é estritamente dependente da correta interpretação dos fatos e das normas jurídicas. No caso das normas tributárias brasileiras,

\footnotetext{
${ }^{270}$ Considerando que o presente estudo se dirige à interpretação das normas constantes das convenções de bitributação, analisaremos somente os princípios aplicáveis ao Direito Internacional, ao Direito Público, ao Direito Tributário e ao Direito Tributário Internacional.

${ }^{271}$ COÊLHO, Sacha Calmon Navarro. Curso de Direito Tributário Brasileiro. 8. ed., rev. e atual. de acordo com o Código Civil de 2002. Rio de Janeiro: Forense, 2005. p. 95.

272 Isto implica a conclusão de que a subsunção da lógica formal não é suficiente para o direito, sendo necessária a aplicação do direito mediante os cânones da lógica argumentativa.

273 ALMEIDA JR. Fernando Osório de. Considerações sobre o princípio da interpretação conforme à Constituição e sobre sua aplicação na jurisprudência do STF em matéria tributária. In: Revista de Direito Tributário. São Paulo: Malheiros, 2000. n. 77, pp. 265-284.
} 
os princípios que inspiram e limitam a sua interpretação são aqueles previstos de forma expressa e implícita tanto no artigo $5^{\circ}$ da $\mathrm{CF} / 88$, que trata dos direitos fundamentais dos cidadãos, quanto nos artigos que compõem o Título VI da Constituição, o qual contém as normas constitucionais relativas à tributação e ao orçamento. Nesse sentido, o Código Tributário Nacional especificamente prevê a aplicação dos princípios gerais do Direito Público e do Direito Tributário para a interpretação da legislação tributária ${ }^{274}$, até mesmo em virtude do fato de que a estrutura das normas tributárias é a mesma das demais normas jurídicas $^{275}$. Cumpre mencionar, neste ponto, que os princípios que se aplicam à interpretação das normas tributárias incluem os princípios do Direito Tributário em geral, cujo fundamento, a seu turno, é a proteção aos direitos fundamentais do contribuinte e a garantia da estabilidade e da segurança jurídica das relações tributárias, mas vão além destes, devendo ser considerados, outrossim, os princípios do Direito Internacional Público e os princípios do Direito Público interno ${ }^{276}$.

A importância da proteção dos direitos fundamentais ${ }^{277}$ do contribuinte, consubstanciada por meio dos princípios que explicaremos a seguir, está relacionada com o fato de que a tributação é, na maioria das vezes, o principal meio de financiamento da máquina estatal, e, assim, seria fácil violar tais direitos em nome das necessidades arrecadatórias do Estado. De fato, dentre todos os poderes governamentais, num índice de

274 “Com razão, observa Aliomar Baleeiro, que o art. 108 do CTN fixa as regras de interpretação, em enumeração obrigatória apenas para a Administração Fazendeira. O Poder Judiciário deve interpretar a lei tributária, utilizando-se dos métodos existentes, socorrendo-se dos melhores princípios juridicos, tudo na busca da interpretação mais razoável e adequada. Cabe ao próprio Poder Judiciário rever as próprias decisões, fiscal único dos limites da própria interpretação”. Misabel Derzi, em nota à obra de Aliomar Baleeiro. BALEEIRO, Aliomar. Direito Tributário Brasileiro. 11. ed. Atual. por Misabel Derzi. Rio de Janeiro: Forense, 2005. p. 684.

${ }^{275}$ Nesse sentido, Alfredo Augusto Becker ensina: "Modernamente, para a tranqüilidade de todos, chegouse à conclusão, tão verdadeira quanto simples, que (sic) as leis tributárias são regras jurídicas com estrutura lógica e atuação dinâmica idênticas às das demais regras jurídicas, e, portanto, interpretam-se como qualquer outra lei, admitem todos os métodos de interpretação jurídica e não existe qualquer peculiar princípio de interpretação das leis tributárias.” BECKER, Alfredo Augusto. Teoria Geral do Direito Tributário. 2. ed. São Paulo: Saraiva, 1972. p. 100.

276 “Tais 'princípios gerais do direito reconhecidos pelas nações civis' são tanto os princípios gerais de Direito Internacional quanto os de 'Direito Internacional particular', princípios gerais dos sistemas jurídicos nacionais que, por serem admitidos como regra geral, foram tomados como fonte de Direito Internacional pela Corte de Haia, em seu art. 38.” TORRES, Heleno Taveira. Direito Tributário Internacional: Planejamento Tributário e Operações Transnacionais. São Paulo: Editora Revista dos Tribunais, 2001. p. 375.

277 “(...) ditos princípios traduzem (...) em suas expansões projeções de direitos fundamentais, ou melhor, no miolo, são garantias de direitos fundamentais, notadamente capacidade, liberdade, dignidade humana, propriedade e igualdade, além de valores republicanos, federalizas e solidaristas." COÊLHO, Sacha Calmon Navarro. Curso de Direito Tributário Brasileiro. 8. ed., rev. e atual. de acordo com o Código Civil de 2002. Rio de Janeiro: Forense, 2005. p. 198. 
perversidade, o poder de tributar se encontraria no mesmo nível do poder de punir criminalmente, no sentido de restringir a liberdade ${ }^{278}$ e outros direitos fundamentais da pessoa. E, considerando especialmente a história brasileira, marcada por regimes totalitaristas num passado recente, com uma democracia relativamente jovem, a proteção dos direitos fundamentais se torna a principal forma de efetivar e consolidar o Estado Democrático de Direito $^{279}$. Justamente por esta razão foi que a Constituição de 1988 elevou os direitos fundamentais à condição de cláusula pétrea. ${ }^{280}$

Considerando estes aspectos, afirma-se que a tendência contemporânea, em face da real necessidade financeira dos Estados, consiste na compatibilidade entre a proteção aos direitos fundamentais e o dever fundamental de pagar tributos ${ }^{281}$.

Então, após estes breves comentários introdutórios, explicaremos nos itens que se seguem os princípios que informam a interpretação das normas do Direito Tributário Internacional, em especial as normas dos tratados contra a dupla tributação internacional.

\subsection{Soberania}

A soberania pode ser definida como a faculdade total e exclusiva de um Estado de impor a sua própria vontade perante os demais Estados, bem como na competência

${ }^{278}$ TORRES, Ricardo Lobo. A idéia de liberdade no Estado Patrimonial e no Estado Fiscal. Rio de Janeiro: Renovar, 1991. pp. 127-128.

279 TÔRRES, Heleno. Direito Tributário e Direito Privado: autonomia privada, simulação, elusão tributária. São Paulo: Editora Revista dos Tribunais, 2003. pp. 55-56.

${ }^{280}$ COÊLHO, Sacha Calmon Navarro. Curso de Direito Tributário. 8. ed. rev. e atual. de acordo com o Código Civil de 2002. Rio de Janeiro: Forense, 2005. p. 199.

281 “E, quanto à explicação lógica ou racional dos deveres fundamentais podemos dizer que duas linhas de orientação têm sido desenvolvidas, a saber: a que os remete para suportes basicamente formais, como são o da estadualidade ou soberania do Estado constitucional e o da socia(bi)lidade do indivíduo, e a que os recodunz a suportes essencialmente materiais, como são o da reciprocidade ou da igual liberdade de todos os cidadãos e o da dignidade da pessoa humana. Relativamente àqueles, como desde logo se retira do seu carácter formal, imputa-se-lhes, o atirarem a base do conjunto dos deveres fundamentais para um apriorístico, pré-estadual e não escrito dever de obediência ou dever de solidariedade, respectivamente. Especificamente à legitimação através do dever de obediência, decorrente da estadualidade ou soberania do estado constitucional, objecta-se que os deveres fundamentais acabam por se situar simultaneamente tanto acima da constituição, na medida em que um tal dever é visto como pressuposto do próprio estado, como abaixo da constituição, na medida em que os específicos deveres materialmente contidos no dever de obediência são determináveis apenas pelo legislador ordinário, e tem o seu suporte exlusivamente na lei (ordinária), ideia esta que, como havemos de ver, não é exacta." NABAIS, José Casalta. O dever fundamental de pagar impostos: contributo para a compreensão constitucional do estado fiscal contemporâneo. Coimbra: Almedina, 1998, pp. 54-55. Em relação ao dever solidário de pagar tributos, v. também: NABAIS, José Casalta. Por um Estado Fiscal Suportável: Estudos de Direito Fiscal. Coimbra: Almedina, 2005. pp. 103-118. 
única que lhe assiste com relação aos poderes de legislar, administrar e julgar dentro do seu âmbito territorial ${ }^{282}$. Além disso, a soberania, decorrendo do direito de autodeterminação, confere ao Estado o direito de contrair vínculos com os demais sujeitos do Direito Internacional Público, compromissos estes que, sob a perspectiva material, acabam limitando este mesmo direito de autodeterminação. Nesse sentido, Buhler destaca que:

“(...) La tendencia fundamental en la evolución del derecho internacional apunta claramente a la limitación del carácter absoluto de esa voluntad de cada Estado mediante la multiplicación de las vinculaciones en tratados colectivos, estatutos, comunidades estatales, pertenencia a las Naciones Unidas, etcétera; a este respecto, lo decisivo en esas comunidades es la tendencia - lenta, pero indudablemente progresiva -, pese al principio de unanimidad, a la sumisión a las decisiones mayoritarias. "283

É justamente a limitação das soberanias estatais que possibilita a organização de uma comunidade internacional em nível mundial, de forma eficaz, o que implica a conclusão de que a soberania é um conceito relativo. Efetivamente, se a soberania fosse absoluta, não haveria relações internacionais, muito menos comunidade internacional. É importante notar, contudo, que a soberania do Estado é limitada pelos compromissos internacionais apenas em seu aspecto de liberdade de ação do Estado. Desta forma, a soberania enquanto autoridade jurídica suprema dentro do território do país permanece intocada $^{284}$.

\footnotetext{
${ }^{282}$ Sobre o princípio da soberania tributária, v. BUHLER, Ottmar. Principios de Derecho Internacional Tributario. Trad. Fernando Cervera Torrejon. Madrid: Editorial de Derecho Financiero, 1968, p. 173. TORRES, Ricardo Lobo. A idéia de liberdade no Estado Patrimonial e no Estado Fiscal. Rio de Janeiro: Renovar, 1991. pp. 118-120. BASSANEZE, João Marcello Tramujas. Pluritributação Internacional: Origem, Conceito e Medidas Unilaterais Destinadas à sua Eliminação. In: TORRES, Heleno Taveira (coord.). Direito Tributário Internacional Aplicado. São Paulo: Quartier Latin, 2003. pp. 438-440. v. 1. COÊLHO, Sacha Calmon Navarro. Noções da Fiscalidade Interancional. Belo Horizonte: Movimento Editorial Faculdade de Direito da UFMG, 1998. DORNELLES, Francisco Neves. A Dupla Tributação Internacional da Renda. Rio de Janeiro: Editora da Fundação Getúlio Vargas, 1979, p. 3. NABAIS, José Casalta. O dever fundamental de pagar impostos: contributo para a compreensão constitucional do estado fiscal contemporâneo. Coimbra: Almedina, 1998, pp. 54-60. TAVOLARO, Agostinho Toffoli. Globalização, Soberania e Tributação. In: Revista Tributária e de Finanças Públicas n. 60. jan. fev. 2005. Ano 13. São Paulo: Revista dos Tribunais, 2005. pp. 285-303.

${ }^{283}$ BUHLER, Ottmar. Principios de Derecho Internacional Tributario. Trad. Fernando Cervera Torrejon. Madrid: Editorial de Derecho Financiero, 1968, p. 174.

${ }^{284}$ KELSEN, Hans. Teoria Pura do Direito. Trad. João Baptista Machado. São Paulo: Martins Fontes, 1999, p. 252.
} 
Ainda analisando o conceito de soberania, porém sob a perspectiva dogmática, Heleno Torres afirma que "a soberania é conceito demarcador da autonomia sistêmica e da expressão do poder de um Estado, ao conceder a este uma posição jurídica de supraordenação e de independência em face dos demais"285. É, pois, com base nas características da separação das ordens jurídicas e da autodeterminação do Estado que a soberania possibilita a destacar o Estado de qualquer outra forma de instituição ou pessoa. A soberania, pois, é o que identifica a supremacia do poder político e da ordem jurídica em um determinado território ${ }^{286}$.

Outra decorrência importante do princípio da soberania é a instituição do poder de tributar. De fato, o poder tributário do Estado é instituído na ordem interna com o objetivo de coletar receitas suficientes para o financiamento da manutenção das atividades inerentes ao próprio Estado. É possível afirmar, desta forma, que o poder de tributar consiste numa verdadeira manifestação, no âmbito interno, da soberania estatal. Já na esfera das relações exteriores o princípio da soberania atua negativamente, impedindo ingerências e interferências das soberanias estatais umas sobre as outras,

O princípio da soberania tem especial importância na seara do Direito Tributário Internacional, uma vez que o seu principal instrumento veiculador de normas é ao mesmo tempo um instrumento de limitação do poder soberano, ou seja, as convenções de dupla tributação internacional pressupõem, para sua aplicação, a limitação da vontade soberana dos Estados em prol da consecução de seus objetivos. Neste ponto, importa conceituar a noção de soberania fiscal como sendo o direito exclusivo de cada Estado ao exercício do poder tributário em seu território e em seu espaço aéreo e marítimo ${ }^{287}$, ou, nas palavras de Heleno Torres,

"o poder institucionalizado que coloca o Estado como sujeito na ordem mundial, proporcionando-lhe autonomia e independência na determinação dos fatos tributáveis e nos procedimentos de arrecadação e fiscalização dos

\footnotetext{
${ }^{285}$ TORRES, Heleno Taveira. Pluritributação Internacional sobre as Rendas de Empresas. 2. ed. Rev., ampl. e atual. São Paulo: Editora Revista dos Tribunais, 2001. p. 62.

${ }^{286}$ TORRES, Heleno Taveira. Pluritributação Internacional sobre as Rendas de Empresas. 2. ed. Rev., ampl. e atual. São Paulo: Editora Revista dos Tribunais, 2001. p. 62. CARRAZZA, Roque Antônio. Curso de Direito Constitucional Tributário. 8. ed., rev. e ampl. São Paulo: Malheiros, 1996. pp. 77-80.

${ }^{287}$ BUHLER, Ottmar. Principios de Derecho Internacional Tributario. Trad. Fernando Cervera Torrejon. Madrid: Editorial de Derecho Financiero, 1968, p. 175.
} 
tributos, nos termos das autolimitações de fontes originariamente internas e constitucionais, bem como de fontes internacionais. "288

A relação entre a soberania e a interpretação e aplicação das normas jurídicas assume duas características distintas quando se trata de direito interno e de direito internacional. De fato, na ordem interna, a soberania, enquanto autodeterminação do Estado, consiste no fundamento da aplicabilidade das normas jurídicas. Por sua vez, na ordem internacional, as normas jurídicas são obrigatórias para os Estados precisamente porque eles próprios assim consentiram. Então, o fundamento das aplicação das normas internacionais é a soberania enquanto autonomia e independência, associada ao princípio do pacta sunt servanda ${ }^{289}$.

\subsection{Boa fé}

O princípio da boa fé constitui um princípio de Direito Internacional que tem vasta aplicação no âmbito do Direito Internacional Tributário, especialmente no que se refere à interpretação dos tratados de bitributação. Tamanha é sua relevância prática que a Convenção de Viena para o Direito dos Tratados, ao prescrever a regra geral de interpretação de tais instrumentos, dispôs os princípios que devem nortear a interpretação, mencionando a boa fé em primeiro lugar.

O princípio da boa fé tem origem no Direito Privado, especificamente no Direito dos Contratos, e seu conceito está ligado à forma como as partes conduzem as negociações que culminam no acordo de vontades, ou seja, às noções de lisura, honestidade, retidão de conduta e de caráter, probidade e presunção de que as partes executam o acordo com em conformidade com a lei. Além disso, segundo ensina o Professor Arnoldo Wald ${ }^{290}$, no Direito angloamericano o conceito de boa fé está relacionado às ideias de equidade, de honestidade de propósitos, bem como à ausência de

\footnotetext{
288 TORRES, Heleno Taveira. Pluritributação Internacional sobre as Rendas de Empresas. 2. ed. Rev., ampl. e atual. São Paulo: Editora Revista dos Tribunais, 2001. p. 67.

${ }^{289}$ Uma das normas jurídicas de Direito internacional geral produzidas por via consuetudinária reconhece aos Estados poder para regular as suas relações mútuas através de tratados. Nesta norma consuetudinariamente criada têm o seu fundamento de vigência as normas jurídicas do Direito internacional criadas por tratados. Esta norma é usualmente formulada no princípio: pacta sunt servanda." KELSEN, Hans. Teoria Pura do Direito. Trad. João Baptista Machado. São Paulo: Martins Fontes, 1999, p. 235.

${ }^{290}$ WALD, Arnoldo. Obrigações e Contratos. 14. ed., rev., atual. e ampl. com a colaboração do prof. Semy Glanz. São Paulo: Editora Revista dos Tribunais, 2000. p. 187.
} 
intenções de ser injusto, de fraudar ou de obter vantagens indevidas de outrem, ou seja, a ausência de dolo de lesão a outras pessoas. O mesmo professor ensina, ainda, que a boa fé é uma noção jurídica enquanto princípio geral de direito que consagra uma exigência geral de lealdade nas relações contratuais, de forma que seja possível presumir que o contrato, cujas partes se presumem livres e responsáveis (autonomia da vontade), está conforme a justiça.

Todos os valores acima são aplicáveis ao Direito dos Tratados. Isto porque, um tratado internacional nada mais é do que um contrato firmado entre entidades do Direito Público, nações soberanas que, em virtude do princípio da autodeterminação dos povos, são capazes de executar acordos e exercer a sua autonomia da vontade. Logo, por este motivo é que tanto as cláusulas de um contrato quanto aquelas presentes num tratado internacional devem ser interpretadas de boa fé.

Neste ponto, é importante mencionar que o conceito de boa fé possui duas facetas: uma psicológica e uma ética, sendo necessário distingui-las. A boa fé em sentido psicológico está associada à noção de ignorância em relação à culpa ou à negligência das partes que praticam o ato ${ }^{291}$, e por isso é chamado de "conceito negativo de boa fé". Já o conceito ético não se contenta com a ignorância, ou seja, se uma pessoa age culposamente ou ignora uma circunstancia que poderia ser prejudicial ao contrato, ela estará agindo mal, e não segundo a boa fé. Desta forma, percebe-se que, sob a perspectiva ética, a boa fé assume contornos objetivos e se aproxima mais da lealdade, enquanto que pelo prisma psicológico suas feições são essencialmente subjetivas e são próximas do conceito de inocência.

Em vista disso, sabendo-se que os tratados internacionais são a fonte suprema de normas jurídicas no Direito Internacional, e também tendo em mente que os tratados internacionais são, no fim, contratos celebrados entre entes soberanos, observa-se que o princípio da boa fé é quem introduz os valores que regem a criação e aplicação de todos os direitos e obrigações na seara internacional. Outra razão pela qual a boa fé deve reger as relações internacionais consiste na inexistência de órgãos formais de produção ou de aplicação legislativa, inclusive de sanções para a hipótese de descumprimento de normas

\footnotetext{
${ }^{291}$ É esse o sentido da expressão "boa-fé” utilizada no artigo 167, § 2o, do Código Civil de 2002.

“Art. 167. É nulo o negócio jurídico simulado, mas subsistirá o que se dissimulou, se válido for na substância e na forma.

(...)

$\S 2_{-}^{o}$ Ressalvam-se os direitos de terceiros de boa-fé em face dos contraentes do negócio jurídico simulado."
} 
internacionais, o que acarreta que geralmente não há a aplicação de sanções jurídicas eficazes $^{292}$.

Além disso, conforme detalharemos em item dedicado à análise das regras de interpretação positivadas na Convenção de Viena, o princípio da boa fé impõe que as partes interpretem os tratados internacionais de forma que se permita o total adimplemento das obrigações jurídicas pactuadas, devendo ser evitadas as interpretações que conduzam ao treaty override ${ }^{293}$.

Cumpre mencionar, outrossim, que a aplicação do princípio da boa fé na interpretação de tratados de bitributação também constitui uma forma de manter a segurança jurídica do pacto firmado entre as partes. Isto porque a boa fé impõe que os Estados passem a ter que agir de modo previsível, adotando condutas relacionadas aos direitos e obrigações, tanto deles enquanto entes do Direito internacional Público, quanto dos contribuintes, fundados nos acordos de bitributação, de acordo com valores de retidão, lealdade e constância, presentes na comunidade internacional. No Direito Internacional, pois, a boa fé está estritamente ligada à lealdade de conduta e aos princípios da razoabilidade e justiça, decência, ética, honestidade e segurança jurídica, além do princípio do pacta sunt servanda. Isto não implica, contudo, que as partes devam abdicar de seus interesses em favor umas das outras. Boa fé não se confunde com altruísmo ${ }^{294}$.

\subsection{Razoabilidade e proporcionalidade}

O princípio da razoabilidade e da proporcionalidade, que já se encontra tão bem difundido no que se refere às normas tributárias internas, também possui ampla aplicação às normas tributárias internacionais. Especialmente no caso das convenções contra a dupla tributação internacional, tais princípios tem aplicação tanto durante a fase de negociação dos termos que passarão a compor o acordo, quanto durante a aplicação de suas cláusulas.

\footnotetext{
${ }^{292}$ MELLO, Celso Albuquerque. Direito Constitucional Internacional, Rio de Janeiro: Renovar, 2000. p. 15.

${ }^{293}$ ROCHA, Sérgio André. Interpretação dos Tratados contra a Bitributação da Renda. Rio de Janeiro: Lumen Juris, 2008, p. 169.

${ }^{294}$ KEILY, Troy. Good Faith \& the Vienna Convention on Contracts for the International Sale of Goods (CISG), VJ 1999/1. at 15 et seq. Disponível em www.Trans-Lex.org/131400. Acesso em 18 out.2009.
} 
Humberto Ávila trabalha os conceitos de razoabilidade e de proporcionalidade, ensinando que ambos constituem diretrizes para a administração pública e para o Judiciário. Nesse sentido, a razoabilidade tem a função de fornecer a "diretriz que exige a relação das normas gerais com as individualidades do caso concreto, quer mostrando sob qual perspectiva a norma deve ser aplicado, quer indicando em quais hipóteses, o caso individual, deixa de se enquadrar na norma geral", ${ }^{295}$ enquanto a proporcionalidade consistiria no critério de adequação entre meios e fins, "vedando a imposição de obrigações, restrições e sanções em medida superior àquelas estritamente necessárias ao atendimento do interesse público. "296 Trata-se, portanto, de se verificar a congruência entre as medidas adotadas e os fins pretendidos, utilizando-se os meios adequados, necessários e proporcionais.

A razoabilidade e a proporcionalidade implicam, desta forma, que um Estado não poderá exigir do outro, por exemplo, uma compensação fiscal exagerada, do mesmo modo como o outro Estado não poderá exigir que o primeiro isente totalmente um rendimento internacional. Isto não quer dizer que não possa existir imputação total ou isenção total referentes a rendimentos internacionais, mas, para que seja legítima tal possibilidade, a iniciativa deve partir do próprio Estado a conceder os benefícios.

“A Constituição brasileira, ao agasalhar um princípio como o da capacidade contributiva, e, ao mesmo tempo, garantir os direitos à igualdade e à propriedade, impõe aos legisladores, com exclusividade, o valor de único critério de graduação e discriminação na incidência tributária, como meio de alcançar qualquer espécie de justiça fiscal. É como se lê no art. 145, §1o: '(...) os impostos terão caráter pessoal e serão graduados segundo a capacidade econômica do contribuinte (...)’. Graduação, esta, que poderá

295 ÁVILA, Humberto. Teoria dos Princípios: da definição à aplicação dos princípios jurídicos. São Paulo: Malheiros, 2003. p. 121. V. também: TORRES, Ricardo Lobo. Tratado de Direito Constitucional Financeiro e Tributário (Os Direitos Humanos e a Tributação: Imunidades e Isonomia). Rio de Janeiro: Renovar, 1999, v. III, pp. 371-374. GUERRA FILHO, Willis Santiago. Sobre Princípios Constitucionais Gerais: Isonomia e Proporcionalidade. In: Revista dos Tribunais v. 719. Ano 84. set. 1995. pp. 57-63. ZANCANER, Weida. Razoabilidade e moralidade na Constituição de 1988. In: Revista Trimestral de Direito Público. n. 2. São Paulo: Malheiros, 1993. p. 205-210. SOUZA, Carlos Affonso Pereira de. SAMPAIO, Patrícia Regina Pinheiro. O princípio da razoabilidade e o princípio da proporcionalidade: uma abordagem constitucional. In: Revista Forense. Jan. fev. mar. 2000. ano 96, pp. 28-41. Rio de Janeiro: Forense, v. 349. ROSAS, Roberto. Devido Processo Legal: Proporcionalidade e Razoabilidade. In: Revista dos Tribunais. Jan. 2001. ano 90. v. 783. TÁCITO, Caio. A razoabilidade das leis. In: Revista Forense. Jul. ago. set. 1996. ano 92. pp. 3-7. BARROSO, Luiz Roberto. Os princípios da razoabilidade e da proporcionalidade no direito constitucional. In: Revista Forense. Out. Nov. dez. 1996. ano 92. pp. 125-136. Rio de Janeiro: Forense, v. 336.

296 ÁVILA, Humberto. Teoria dos Princípios: da definição à aplicação dos princípios jurídicos. São Paulo: Malheiros, 2003. p. 102. 
oscilar entre dois limites inafastáveis: i) do mínimo existencial, para pessoas físicas, ou dos custos necessários à produção da renda e manutenção do patrimônio, no quadro das pessoas jurídicas, àquele no ii) não-confisco. „297

Desta forma, observa-se que a proporcionalidade, ou progressividade, constitui uma das formas de se buscar a consecução do princípio da igualdade, atuando como um mecanismo que possibilita a personalização dos tributos, nos termos do artigo 145, parágrafo $1^{\circ}$, da Constituição de $1988^{298}$.

\subsection{Pacta Sunt Servanda}

O princípio jurídico de Direito Internacional consubstanciado no brocardo latino pacta sunt servanda (traduzido livremente: "o contrato é lei entre as partes") designa a norma cogente que obriga os Estados a cumprirem os acordos que estabelecerem entre si, por meio dos tratados internacionais. Entretanto, esta obrigatoriedade não é irrestrita. Segundo a lição de Arnoldo Wald ${ }^{299}$, o princípio pacta sunt servanda deve sempre ser aplicado juntamente com a chamada clausula rebus sic stantibus, o que, em outras palavras, significa que o contrato (e, logicamente, um tratado), somente pode obrigar as partes enquanto as circunstancias em que se deu a sua celebração permanecerem as mesmas. Se houver alterações substanciais das situações das partes, então a obrigatoriedade do contrato passa a ser questionada, exigindo-se uma revisão contratual para que permaneça intacta.

De fato, os entes do Direito Internacional Público - Estados e Organizações Internacionais - são livres para firmarem entre si tratados nos quais sejam previstas regras de conduta aplicáveis reciprocamente, e uma vez estabelecido o pacto, na forma do tratado, ficam seus órgãos internos e seus cidadãos obrigados a cumprir o que foi internacionalmente pactuado.

297 TORRES, Heleno Taveira. Lucros auferidos por meio de controladas e coligadas no exterior. In: TORRES, Heleno Taveira. (Coord.). Direito Tributário Internacional Aplicado, São Paulo: Quartier Latin, 2005. p. 121. v. 3.

298 BALEEIRO, Aliomar. Direito Tributário Brasileiro. 11. ed. Atual. por Misabel Derzi. Rio de Janeiro: Forense, 2005. p. 254.

${ }^{299}$ WALD, Arnoldo. Obrigações e Contratos. 14. ed., rev., atual. e ampl. com a colaboração do prof. Semy Glanz. São Paulo: Editora Revista dos Tribunais, 2000. p. 186. 
Este é um princípio de suma importância para a aplicação dos tratados de dupla tributação, já que impõe a aplicação de suas cláusulas quando verificados os seus pressupostos de fato, ou seja, quando ocorre uma situação de dupla tributação internacional. Além disso, pelo pacta sunt servanda as autoridades fiscais dos países ficam obrigadas a cooperar umas com as outras em caso de solicitação de assistência para a cobrança dos impostos visados pela convenção, fornecendo as informações solicitadas (respeitando, evidentemente, aquelas protegidas por sigilo fiscal), e auxiliando o outro Estado contratante no que for necessário.

Ao lado do princípio da boa fé nas relações internacionais, o pacta sunt servanda forma um dos principais mecanismos para garantir a eficácia das normas internacionais. É nesse sentido que a Convenção de Viena adota ambos os princípios em seu preâmbulo, e também determina, em seu artigo 26, que todo tratado em vigor obriga as partes e deve ser cumprido por elas de boa fé. Por sua vez, a boa fé, mencionada neste artigo, determina que as partes não poderão invocar seu direito interno para deixar de cumprir o que foi pactuado internacionalmente. Isto se encontra disposto no artigo 27 da Convenção de Viena.

As obrigações internacionais estabelecidas por meio de tratados somente podem ser descumpridas quando suas cláusulas instituam normas conflitantes com as normas imperativas do Direito Internacional Geral (jus cogens) ${ }^{300}$. Em outras palavras, o princípio do pacta sunt servanda somente deixará de ser aplicado quando houver sensível alteração no estado das partes, ou quando outra norma cogente assim o determinar.

\footnotetext{
300 Convenção de Viena - "Artigo 53 - Tratado em Conflito com uma Norma Imperativa de Direito Internacional Geral (jus cogens): É nulo um tratado que, no momento de sua conclusão, conflite com uma norma imperativa de Direito Internacional geral. Para os fins da presente Convenção, uma norma imperativa de Direito Internacional geral é uma norma aceita e reconhecida pela comunidade internacional dos Estados como um todo, como norma da qual nenhuma derrogação é permitida e que só pode ser modificada por norma ulterior de Direito Internacional geral da mesma natureza."
} 


\subsection{Isonomia ${ }^{301}$ (igualdade tributária) e não-discriminação}

As origens do princípio da igualdade remontam à era clássica, com a definição aristotélica segundo a qual a igualdade era sempre ligada à idéia de equidade, no sentido de tratar igualmente os iguais e desigualmente os desiguais, na medida de sua desigualdade, baseando-se no critério do mérito. No entanto, prevaleceu até o início da era moderna o pensamento segundo o qual a igualdade somente se aplicava aos cidadãos, o que automaticamente excluía mulheres, escravos, crianças e bárbaros. Logo, o próprio conceito de igualdade era corrompido desde o seu início, quando discriminações em razão do sexo, idade, cor ou origem eram consideradas legítimas.

Em meados do séc. XVIII, com o surgimento das idéias iluministas com a Revolução Francesa, a idéia de igualdade passou a ser associada à de liberdade. A primeira menção expressa ao conceito de igualdade foi na Declaração dos Direitos do Homem e do Cidadão, em 1789, como uma reação ao sistema de privilégios e discriminações. Neste enfoque de liberalismo, a idéia de igualdade se desdobra em paridade de tratamento perante a lei, sem quaisquer privilégios. Com ele surgem os princípios tributários da vedação à discriminação, tributação proporcional à capacidade contributiva e generalidade.

Com o advento do constitucionalismo moderno, iniciou-se uma busca pela igualdade material, visando alcançar-se a justiça social, a qual, junto da igualdade formal ou isonomia e a liberdade formaram o principal pilar de sustentação do Estado Democrático de Direito. Nesta fase, sempre se cogitou a isonomia associada à igualdade como justiça fiscal, atendendo aos princípios da capacidade contributiva, vedação ao confisco, vedação de privilégios e de discriminações e razoabilidade.

Para compreender o conceito de igualdade, é necessário considerar sempre a idéia de relatividade. Somente é possível constatar a igualdade ou desigualdade a partir da comparação e da diversidade. Portanto, a igualdade será sempre relativa. O problema consiste justamente em determinar quais seriam os critérios de valoração e comparação corretos para se avaliar os dois sujeitos e determinar se entre eles pode existir uma situação de igualdade. Assim, impõe-se a conclusão de que a igualdade nunca é absoluta, porque se

301 “Art. 150. Sem prejuízo de outras garantias asseguradas ao contribuinte, é vedado à União, aos Estados, ao Distrito Federal e aos Municípios:

(...)

II - instituir tratamento desigual entre contribuintes que se encontrem em situação equivalente, proibida qualquer distinção em razão de ocupação profissional ou função por eles exercida, independentemente da denominação jurídica dos rendimentos, títulos ou direitos;" 
pudéssemos considerar dois objetos absolutamente iguais, então não mais teríamos dois objetos, mas sim um único e mesmo objeto.

Nenhum dos conceitos de igualdade conseguiu determinar com clareza e precisão quais seriam os tais critérios para sua aferição. Assim, dizemos que o princípio da igualdade constitui uma norma de tratamento que pressupõe a dessemelhança "relativa" entre todos os seres. A comparação entre os seres, portanto, pressupõe a adoção de critérios, os quais, por sua vez, são eleitos com base em valoração determinada pela Constituição ou pelas normas fundamentais de cada sistema.

No Direito Brasileiro, diversos outros vetores serviram de fundamento para a atual noção de igualdade. Dentre eles, podemos citar a uniformidade geográfica dos tributos federais, estaduais e municipais; a igualdade perante a lei tributária e a igualdade dos brasileiros e estrangeiros residentes no país.

A aplicação tributária do princípio da isonomia, também denominada igualdade formal, segundo o conceito aristotélico, consiste na conclusão de que a tributação deve ser idêntica para as pessoas ou atividades igualmente situadas e desigual para aquelas que entre si se desigualem e, se possível, na medida da desigualdade apurada. Portanto, o princípio da isonomia não impede que o Estado discrimine para fins de tributação. O que se veda são os privilégios odiosos, cuja contrapartida são as discriminações odiosas.

O princípio da igualdade tributária encontra seu fundamento ético na busca pela justiça fiscal. Assim, a igualdade tributária pode assumir uma feição instrumental que tem por finalidade proteger as condições de concorrência efetiva e livre circulação de bens, tanto na esfera interna quanto na ordem internacional. No Direito Comunitário Europeu, a igualdade possui status de direito fundamental, e está relacionada à proteção da livre circulação, bem como à proteção contra o arbítrio do Estado ${ }^{302}$.

A noção de igualdade tributária sempre vem atrelada ao princípio da nãodiscriminação ${ }^{303}$ e à vedação à concessão de privilégios odiosos ${ }^{304}$. De acordo com o IBFD

\footnotetext{
302 CALIENDO, Paulo. Princípio da Igualdade de Tratamento entre Nacionais e Estrangeiros em Direito Tributário, In: TORRES, Heleno Taveira (Coord.). Direito Tributário Internacional Aplicado, São Paulo: Quartier Latin, 2005. pp. 31-35. v. 3. TORRES, Ricardo Lobo. A idéia de liberdade no Estado Patrimonial e no Estado Fiscal. Rio de Janeiro: Renovar, 1991. pp. 110-111. TORRES, Ricardo Lobo. Tratado de Direito Constitucional Financeiro e Tributário (Os Direitos Humanos e a Tributação: Imunidades e Isonomia). Rio de Janeiro: Renovar, 1999, v. III, pp. 281-334.
} 
International Tax Glossary, "discriminação"305 é definida como o tratamento igual para casos distintos, ou o tratamento distinto conferido a casos similares ou comparáveis. Esta é a definição que foi adotada pela jurisprudência européia ${ }^{306}$ e que também inspira a norma do artigo 24 do Modelo da OCDE de convenção contra a dupla tributação internacional, que prevê expressamente a adoção do princípio da não-discriminação para a elaboração e aplicação das convenções de bitributação.

É com base nestes conceitos que alguns autores entendem que a obrigatoriedade de tratamento isonômico é imposta pelo legislador constitucional sob duas perspectivas, uma positiva e outra negativa. Em seu sentido positivo, o princípio da isonomia corresponderia ao conceito de igualdade material e estaria relacionado com o

303 Sobre a aplicação prática e análise de jurisprudência referente ao princípio da não-discriminação
tributária, no Brasil, v. OKUMA, Alessandra. Tributação dos Dividendos Remetidos aos Não-residentes.
Comentários à decisão do Superior Tribunal de Justiça no Recurso Especial n. 602.725/PR. In: TORRES,
Heleno Taveira (Coord.). Direito Tributário Internacional Aplicado, São Paulo: Quartier Latin, 2005. pp.
341-358, v. 3. TORRES, Ricardo Lobo. Tratado de Direito Constitucional Financeiro e Tributário (Os
Direitos Humanos e a Tributação: Imunidades e Isonomia). Rio de Janeiro: Renovar, 1999, v. III, pp. 375-
390. Sobre o princípio da não discriminação como princípio de relacionamento entre as nações, v. TORRES,
Heleno Taveira. O princípio da não-discriminação tributária na Constituição e no GATT a a prevalência dos
tratados internacionais em matéria tributária. In: Construindo o Direito Tributário na Constituição: Uma
análise da Obra do Ministro Carlos Mário Velloso. Belo Horizonte: Del Rey, 2004. MOLINA, Pedro M.
Herrera. CARRETERO, Belén García. Imposición Directa, no Discriminación y Libertades Comunitarias. In:
TORRES, Heleno Taveira (coord.). Direito Tributário Internacional Aplicado. São Paulo: Quartier Latin,
2003. v. 1. pp. 144-155. LEHNER, Moris. The National Power of Taxation and the Fundamental Freedoms
and Non-Discrimination Clause of the EC Treaty. In: Revista de Direito Tributário. São Paulo: Malheiros,
2002. v. 83. pp. 87-101. LEHNER, Moris. The influence of EU Law on Tax Treaties from a German
Perspective. In: Bulletin - IBFD. Aug. Sep. 2000. pp. 465-466. TORRES, Heleno Taveira. Capital
Estrangeiro e Princípio da Não-Discriminação Tributária no Direito Interno e nas Convenções Internacionais.
In: Revista Dialética de Direito Tributário n. 87, dez. 2002. São Paulo: Dialética, 2002. pp. 33-53.

304 TORRES, Ricardo Lobo. A idéia de liberdade no Estado Patrimonial e no Estado Fiscal. Rio de Janeiro: Renovar, 1991. p. 129. CARRAZZA, Roque Antônio. Curso de Direito Constitucional Tributário. 8. ed., rev. e ampl. São Paulo: Malheiros, 1996. pp. 52-54.

305 "Discrimination may broadly be defined as the equal treatment of different cases or the unequal treatment of comparable cases. In an international tax context, discrimination often takes the form of different treatment of taxpayers whose situations are comparable except in respect of a characteristic such as nationality. Discrimination may be direct (or overt), or indirect (or covert) as opposed to direct (or overt), i.e., where the rule in question does not expressly differentiate by reference to the characteristic in question but in practice has this effect. Tax treaties generally contain non-discrimination rules which prohibit direct discrimination in a number of circumstances, including discrimination between nationals and between enterprises of the two contracting states. A distinction may also be made between horizontal discrimination and vertical discrimination, where (in case of the discrimination on the basis of residence) the former refers to different tax treatment by one jurisdiction as between residents of two different jurisdictions (other than the taxing jurisdiction), and the latter refers to different tax treatment by one jurisdiction as between residents of that jurisdiction and another jurisdiction." IBFD International Tax Glossary. $5^{\text {th }}$ Edition. Completely revised. IBFD: Amsterdam, 2005. pp. 124-125.

${ }^{306}$ CALIENDO, Paulo. Princípio da Igualdade de Tratamento entre Nacionais e Estrangeiros em Direito Tributário, In: TORRES, Heleno Taveira (Coord.). Direito Tributário Internacional Aplicado, São Paulo: Quartier Latin, 2005. p. 34. v. 3. 
respeito à capacidade contributiva individual, mediante a adoção de atitudes positivas por parte do legislador com o objetivo de exigir o tributo proporcionalmente à capacidade econômica particular a cada contribuinte. De outro lado, o sentido negativo do princípio da isonomia poderia ser expresso pelo princípio da não-discriminação. ${ }^{307}$

Trata-se, pois, de conceitos distintos. Enquanto o princípio da igualdade de tratamento insere um mandamento positivo, no sentido de tratar desigualmente os desiguais, na medida de sua desigualdade, exigindo, desta forma, uma ação positiva de buscar todos os meios necessários para se atingir a igualdade material, o princípio da nãodiscriminação introduz uma ordem negativa, que atua precisamente limitando as condutas que pudessem conduzir à concessão de privilégios odiosos, ou seja, que conduzissem à situações discriminatórias sem justificativa objetiva. ${ }^{308}$

Ora, se o dever de pagar o tributo constitui, de fato, um sacrifício imposto ao cidadão, é no mínimo justo que este sacrifício seja repartido de maneira que todos contribuam igualmente, para que ninguém seja submetido uma carga menor do que deveria em prejuízo de outros que ficariam, necessariamente, sobrecarregados. É o equilíbrio da balança da justiça. Então, a igualdade enquanto capacidade contributiva e a vedação à discriminação surgem como duas faces de uma mesma moeda, dois aspectos de um mesmo princípio (da isonomia) que possuem o mesmo objetivo, ou seja, manter o equilíbrio das relações tributárias em face da obrigatoriedade do pagamento do tributo.

${ }^{307}$ COÊLHO, Sacha Calmon Navarro. Curso de Direito Tributário Brasileiro. 8. ed., rev. e atual. de acordo com o Código Civil de 2002. Rio de Janeiro: Forense, 2005. pp. 271-272. DERZI, Misabel Abreu Machado. COÊLHO, Sacha Calmon Navarro. Do Imposto sobre a Propriedade Predial e Territorial Urbana. São Paulo: Saraiva, 1982. pp. 56 e 61.

${ }^{308}$ Kelsen, em sua visão estritamente normativista, entende que "A igualdade dos individuos sujeitos à ordem jurídica, garantida pela Constituição, não significa que aqueles devam ser tratados por forma igual nas normas legisladas com fundamento na Constituição, especialmente nas leis. Não pode ser uma tal igualdade aquela que se tem em vista, pois seria absurdo impor os mesmos deveres e conferir os mesmos direitos a todos os indivíduos sem fazer quaisquer distinções, por exemplo, entre crianças e adultos, sãos de espírito e doentes mentais, homens e mulheres. Quando na lei se vise a igualdade, a sua garantia apenas pode realizar-se estatuindo a Constituição, com referência a diferenças completamente determinadas, como talvez as diferenças de raça, de religião, de classe ou de patrimônio, que as leis não podem fazer acepção das mesmas, quer dizer: que as leis em que forem feitas tais distinções poderão ser anuladas como inconstitucionais. (...) Com a garantia da igualdade perante a lei, no entanto, apenas se estabelece que os órgãos aplicadores do Direito somente podem tomar em conta aquelas diferenciações que sejam feitas nas próprias leis a aplicar. Com isso, porém, apenas se estabelece o princípio, imanente a todo o Direito, da juridicidade da aplicação do Direito em geral e o princípio imanente a todas as leis da legalidade da aplicação das leis, ou seja, apenas se estatui que as normas devem ser aplicadas de conformidade com as normas”. (KELSEN, Hans. Teoria Pura do Direito. São Paulo: Martins Fontes, 1999, pp. 99-100) Esta visão, como se sabe, já se encontra superada, uma vez que o princípio da igualdade visa diretamente à consecução da justiça, de modo que a ausência de previsão legal expressa de todos os critérios que devam ser analisados para a determinação da situação de um indivíduo não impede que o juiz, por equidade, busque os critérios não expressamente mencionados e julgue o fato aplicando o princípio da igualdade. 
No contexto da tributação internacional, a discriminação ocorre mediante o tratamento distinto conferido a contribuintes que estejam em situações jurídicas comparáveis, não fosse pela sua nacionalidade ${ }^{309}$ distinta. Em outras palavras, a discriminação, para o Direito Tributário Internacional, está relacionada, em geral, com a nacionalidade dos contribuintes, mas também pode ser relativa a diversas outras características. Por este motivo é que a igualdade de tratamento no Direito Tributário Internacional requer que situações similares não devam ser tratadas de forma diferenciada, especialmente quanto ao critério da nacionalidade, exceto quando tal diferenciação for objetivamente justificada $^{310}$. Na realidade, esta justificação objetiva é possível por meio do atendimento aos critérios de proporcionalidade e de razoabilidade, já destacados por Sampaio Dória. Desta forma, a razoabilidade da discriminação deve ser baseada em diferenças reais entre as pessoas ou os objetos tributados, bem como na existência de um objetivo que justifique a discriminação, e deve haver, necessariamente, um nexo lógico entre o objetivo perseguido e a discriminação que permitirá alcançá-lo. Assim, é possível concluir que o que torna uma discriminação inconstitucional não é a natureza de tratamento diferenciado, mas a injustiça dos motivos que levam a este tratamento e, por consequência, à discriminação grosseira e arbitrária ${ }^{311}$.

Especificamente quanto a este aspecto, Ottmar Buhler ressalta que a tributação em princípio dos estrangeiros enquanto participantes, de qualquer modo, da economia do país não significa que estes sejam (ou que devam ser) equiparados, em todos os aspectos da vida, aos nacionais ${ }^{312}$ daquele país. E cita como exemplo o fato de ser altamente

309 Sobre a nacionalidade das pessoas jurídicas, v. TORRES, Heleno Taveira. Direito Tributário Internacional: Planejamento Tributário e Operações Transnacionais. São Paulo: Editora Revista dos Tribunais, 2001. pp. 393-407.

${ }^{310}$ CALIENDO, Paulo. Princípio da Igualdade de Tratamento entre Nacionais e Estrangeiros em Direito Tributário, In: TORRES, Heleno Taveira (Coord.). Direito Tributário Internacional Aplicado, São Paulo: Quartier Latin, 2005. p. 35. v. 3.

${ }^{311}$ DÓRIA, Antônio Roberto Sampaio. Direito Constitucional Tributário e Due Process of Law. 2. ed. Rio de Janeiro: Forense, 1986. pp. 138-139.

312 O significado da expressão "nationals", ou "nacionais", comumente encontrada em tratados de bitributação, inclui tanto as pessoas naturais (indivíduos) quanto as pessoas jurídicas, sociedades e associações de qualquer natureza. Entretanto, o seu significado dependerá do que determinar o direito de cada Estado e, principalmente, do que ambos pactuarem nas definições gerais do acordo. Especificamente quanto às pessoas jurídicas, há duas teorias principais para a determinação da nacionalidade: (i) a teoria da incorporação, pela qual se considera que a pessoa jurídica é nacional do Estado onde se deram os atos de incorporação (ou de constituição, segundo o Direito brasileiro), e (ii) a teoria do local da administração central, pela qual considera-se que a empresa será nacional do país onde estiver localizada a sede de sua administração central, ou então do país onde forem exercidos os atos de administração vitais para a 
questionável a imposição do pagamento de um imposto excepcional em virtude de guerra a um estrangeiro que só é considerado residente no país em virtude de uma mera fícção jurídica, ou seja, que embora seja considerado residente para fins fiscais, não participa da vida social e econômica daquele Estado $^{313}$. Neste aspecto, é interessante notar a observação de Sampaio Dória, segundo o qual a vedação à discriminação entre nacionais e estrangeiros só vale entre os residentes. Entre os não-residentes é possível que haja discriminação, mas esta deve ser objetivamente justificada para que sejam legítima ${ }^{314}$. Desta forma, é possível concluir que o que a não-discriminação procura evitar, desta forma, é o estabelecimento de privilégios odiosos em favor de uma ou outra parte ${ }^{315}$.

Reforçando este entendimento, o mestre Sacha Calmon ressalta que nas situações revestidas de extrafiscalidade, nas quais o tributo é utilizado com fins outros que não a arrecadação de receitas, ou seja, em que ele constitui um instrumento de política social e econômica, ou, ainda, nas hipóteses em que se faça necessário o uso do poder de polícia do Estado com vistas ao bem comum, o legislador pode ser autorizado a tratar desigualmente os iguais, sem, contudo, violar o princípio da isonomia. Seriam exemplos de situações como as descritas acima os casos em que se impõe tributação exacerbada de certos consumos nocivos, como o tabaco, as bebida alcóolicas e o jogo de azar; a imposição de imposto territorial progressivo como forma de desestimular a propriedade improdutiva, promovendo a sua função social; a exigência de IPTU progressivo sobre lotes vazios como forma de deter a especulação imobiliária; bem como instituir isenções fiscais como forma de incentivo ao desenvolvimento de regiões socialmente subdesenvolvidas.

Apesar da sua inquestionável relevância, o princípio da igualdade tributária não se encontra expressamente previsto, em seu sentido positivo, em nenhum diploma normativo brasileiro. Entretanto, isso não afeta de qualquer maneira a sua obrigatoriedade,

continuidade da empresa. AVERY JONES, John F. et Al. The origins of Concepts and Expressions Used in the OECD Model and their Adoption by States. In: Bulletin - Tax Treaty Monitor. Jun. 2006. IBFD, p. 227.

${ }^{313}$ Sobre a permissão de privilégios, v. TORRES, Ricardo Lobo. A idéia de liberdade no Estado Patrimonial e no Estado Fiscal. Rio de Janeiro: Renovar, 1991. pp. 130-131.

${ }^{314} \mathrm{E}$, nesse sentido, ele acrescenta que “as discriminações tributárias com relação às pessoas jurídicas devem atender aos pressupostos da razoabilidade da classificação, fundada em diferenças substanciais, da existência de finalidade na discriminação e da conexão lógica entre o fim colimado e a distinção proposta. A exemplo das pessoas físicas, também as empresas não podem ser discriminadas em razão exclusiva do local de sua sede ou de seu estabelecimento." DÓRIA, Antônio Roberto Sampaio. Direito Constitucional Tributário e Due Process of Law. 2. ed. Rio de Janeiro: Forense, 1986. pp. 158, 164.

315 BUHLER, Ottmar. Principios de Derecho Internacional Tributario. Trad. Fernando Cervera Torrejon. Madrid: Editorial de Derecho Financiero, 1968, p. 195. 
dado o seu status de jus cogens. No direito brasileiro, há apenas menções genéricas, como as previsões contidas no artigo $5^{\circ}$, caput ${ }^{316}$, e no artigo 150 , inciso $\mathrm{II}^{317}$, da Constituição de 1988, que seriam mais adequadas ao princípio da não discriminação do que ao princípio da igualdade em si. Outro artigo da Constituição de 1988 que parece mais dirigido à não discriminação é o artigo 152, que veda aos Estados, ao Distrito Federal e aos Municípios estabelecer diferença tributária entre bens e serviços, de qualquer natureza, em razão de sua procedência ou destino. Este dispositivo, o bem jurídico que se visa proteger é a livre circulação de bens e serviços, mas também sob o prisma do conceito da não discriminação tributária $^{318}$, e não da igualdade de tratamento. Mesmo assim, entendemos, como já mencionamos acima, que, por se tratar de um princípio metajurídico, com caráter de jus cogens, o fato de não haver previsão expressa não lhe retira, de modo algum, a obrigatoriedade de cumprimento, embora na prática a sua concretização genérica seja impossível, e a sua realização individualizada seja difícil.

\subsubsection{Relações entre o princípio da igualdade e outros princípios}

tributários

A) Igualdade e Justiça (fiscal): o relacionamento entre os princípios de igualdade e de justiça é íntimo. A igualdade, como princípio vazio, é medida de justiça; esta se torna impensável sem a igual repartição das cargas fiscais. A igualdade, porém, transcende a justiça, eis que penetra também em outros valores e pode estar presente na própria injustiça. Não se explica circularmente a igualdade pela justiça, nem vice-versa. $O$ conceito de igualdade fiscal, vazio que é, recebe seu conteúdo dos princípios constitucionais vinculados à idéia de justiça. Por outro lado, a

\footnotetext{
316 “Art. $5^{\circ}$ Todos são iguais perante a lei, sem distinção de qualquer natureza, garantindo-se aos brasileiros e aos estrangeiros residentes no País a inviolabilidade do direito à vida, à liberdade, à igualdade, à segurança e à propriedade, nos termos seguintes: (...)"

317 “Art. 150. Sem prejuízo de outras garantias asseguradas ao contribuinte, é vedado à União, aos Estados, ao Distrito Federal e aos Municípios:

(...)

II - instituir tratamento desigual entre contribuintes que se encontrem em situação equivalente, proibida qualquer distinção em razão de ocupação profissional ou função por eles exercida, independentemente da denominação jurídica dos rendimentos, títulos ou direitos;"

318 FERNANDES, Edison Carlos. Acordos Multilaterais do Comercio, não-discriminação tributária e controle fiscal dos preços de transferência. In: PANZARINI FILHO, Clóvis (coord.). Revista de Direito Tributário Internacional. São Paulo: Quartier Latin, 2006. pp. 68-75. v. 4.
} 
justiça fiscal se obtém pelo tratamento desigualmente os desiguais, o que faz com que algum grau de desigualdade e injustiça sempre existam na tributação.

B) Igualdade, Capacidade Econômica e Capacidade Contributiva: a igualdade impõe ao legislador o dever de não-discriminação e, ao mesmo tempo, o dever de distinguir quando as situações de fato assim o exigirem. Porém, como o cumprimento destes deveres depende de critérios valorativos, a Constituição arrolou, em seus artigos $3^{\circ}$, IV e $5^{\circ}$, os critérios que não servirão para embasar qualquer discriminação. São eles: sexo, raça, cor, idade, origem, convicções políticas, crenças religiosas, e, no Direito Tributário, destaca-se a proibição de distinguir entre os que sejam fiscalmente iguais $\left(\mathrm{CF}\right.$, art. 145 , parágrafo $\left.1^{\circ}\right)$. os princípios informadores da capacidade contributiva que fornecem conteúdo ao conceito de igualdade são a progressividade $(\mathrm{CF}$, art. 152, § $\left.2^{\circ}, \mathrm{I}\right)$; proporcionalidade; personalização $(\mathrm{CF}$, art. 145); seletividade $(\mathrm{CF}$, art. 153, parágrafo $3^{\circ}$, I e 155 , parágrafo $2^{\circ}$, III) e neutralidade. Para atender à justiça fiscal, o dever de pagar impostos deve implicar o mesmo grau de sacrifício de todos os contribuintes. Capacidade econômica e Capacidade Contributiva são duas coisas distintas. A capacidade contributiva somente pode ser definida após a dedução dos gastos necessários à aquisição, produção e manutenção da renda e do patrimônio, assim como o mínimo existencial do contribuinte e de sua família. É importante ressaltar que a Constituição eleva a proteção à família como garantia fundamental, portanto, os gastos com a manutenção digna da família sempre deverão ser considerados quando da avaliação da capacidade contributiva.

C) Igualdade e Generalidade: o princípio da generalidade do art. 150, II, da CF/88 proíbe distinções entre contribuintes em situação econômica equivalente, coibindo a consideração da ocupação profissional ou da função exercida para a concessão de favores ou privilégios.

D) Igualdade e Devido Processo Legal: a igualdade no devido processo legal relaciona-se com a equivalência de posições entre as partes perante 
o juiz, o que garante o equilíbrio entre as partes e, ao mesmo tempo, assegura o contraditório.

E) Igualdade e Segurança Jurídica: a igualdade perante a lei reforça a segurança jurídica, na medida em que representa uma garantia contra o arbítrio na aplicação das normas. "Igualdade perante a lei” significa que, dado um fato subsumível à hipótese descrita em uma norma, obrigatoriamente deverá o aplicador da lei realizar a consequência normativa, podendo esta se consubstanciar numa faculdade, numa proibição ou numa sanção. A relação entre a igualdade e a segurança jurídica reside na vedação ao aplicador de realizar quaisquer distinções ilegítimas onde o legislador não haja distinguido. Em outras palavras, a igualdade de todos perante a lei significa tão-somente a correta aplicação da norma, o que decorre de sua própria estrutura lógica. A igualdade serve ainda de medida e legitimação para a segurança jurídica.

F) Igualdade, isonomia e não-confisco: tanto o princípio da igualdade quanto o da vedação ao confísco são oriundos da capacidade contributiva. Comparando a isonomia (ou igualdade formal, art. 145, parágrafo $1^{\circ}$ ), com o Não-confisco, temos que, apesar de ambos serem assentados na capacidade contributiva, a primeira (isonomia) exige que a lei faça justiça tributária de acordo com a proporcionalidade, possuindo caráter relativo e baseado na comparação de situações (ou seja, somente podemos auferir a isonomia a partir da comparação de duas ou mais situações de fato), enquanto que o segundo (não-confisco) é um princípio absoluto e amplo, não aceitando comparações. Assim, o não-confisco, apesar de assegurar a justiça fiscal, não assegura a igualdade, enquanto que a isonomia sempre assegura a igualdade, ainda que formal.

G) Igualdade e Valoração dos Atos Administrativos: os atos de aplicação de normas válidas sempre contêm aspectos axiológicos e, por isso, existe a obrigatoriedade de motivação dos julgamentos e dos atos administrativos. Os princípios da legalidade, impessoalidade, imparcialidade, moralidade, publicidade, motivação e probidade são garantidores da igualdade, assim como a uniformidade e a regularidade dos atos de aplicação das normas. 


\subsubsection{Instrumentos e meios para atingir a isonomia tributária}

Embora seja um princípio de difícil mensuração prática, existem alguns instrumentos, que geralmente são positivados na forma de princípios, que são destinados a garantir a isonomia e a igualdade. Dentre eles, destaca-se logo de início a razoabilidade, cuja tarefa consiste em afastar a arbitrariedade e os excessos. Em seguida, cita-se a proporcionalidade, que sinaliza para a imposição fiscal proporcional à riqueza, através de alíquotas uniformes para cada base de cálculo, aplicando-se preferencialmente aos impostos sobre o patrimônio.

Outro meio para garantir a igualdade é a proibição de privilégios odiosos, os quais são definidos como a permissão para fazer ou deixar de fazer alguma coisa contrária ao direito comum, sem justificativa razoável. Do ponto de vista fiscal, o caráter odioso de um privilégio relaciona-se com a possibilidade de pagar tributo menor que o previsto para os outros contribuintes, não pagá-lo (isenção) ou obter subvenções ou incentivos, tudo em razão de diferenças subjetivas, afastadas dos princípios da segurança jurídica. A concessão do privilégios odiosos ofende a liberdade relativa de terceiros que ficam obrigados ao desembolso do tributo de que o detentor do privilégio foi dispensado: alguém sempre paga pelos benefícios concedidos a outrem. A proibição dos privilégios odiosos tem origem a partir do Estado Fiscal, após as grandes revoluções do séc. XVIII. A CF/88 trouxe em seu art. 150, II, a vedação explícita aos privilégios odiosos, vedação esta que já existia no Direito brasileiro desde a Constituição de 1924. Outras vedações de privilégios odiosos estão contidas nos artigos 151, 152 e 173, parágrafo2o da $\mathrm{CF} / 88$. O fundamento da proibição dos privilégios odiosos está na garantia da liberdade relativa, na proteção ao direito fundamental da igualdade de tratamento e no respeito ao direito de propriedade. Os privilégios odiosos ofendem a liberdade porque, primeiro, cada subvenção, direta ou indireta, aumenta a tributação dos não privilegiados, e, segundo, porque cada subvenção prejudica a liberdade de decisão do beneficiados, aumentando-lhe a dependência do Estado. O que diferencia os privilégios odiosos dos legítimos é justamente o seu fundamento. Assim, privilégios legítimos como isenções e créditos fiscais podem se tornar odiosos se não forem baseados na idéia de justiça, correspondendo aos princípios da capacidade contributiva, da redistribuição de renda ou do desenvolvimento econômico. Podem ser considerados privilégios odiosos ainda a anistia, a remissão, as subvenções, as deduções, os subsídio e as restituições de tributos a título de incentivos. Por fim, 
lembramos que os privilégios fiscais odiosos são nulos de pleno direito, e a declaração de sua nulidade gera efeitos ex tunc, gerando efeitos retroativos até a data de sua concessão.

Bem próxima à vedação aos privilégios odiosos está a proibição de discriminações infundadas, ou seja, o próprio princípio da não-discriminação. As discriminações desta natureza consistem em desigualdades infundadas que prejudicam diretamente o contribuinte. Qualquer discrime que, estabelecendo regra contrária ao direito comum, agrave a tributação de alguém, em razão de considerações subjetivas, afastadas dos princípios da justiça ou da segurança jurídica, está proibido constitucionalmente. Vale ressaltar que, as desigualdades que possuam fundamento razoável na justiça, na segurança ou na liberdade não constituem privilégio ou discriminação odiosos, exibindo o status de privilégio legítimo e permitido pela Constituição. As discriminações odiosas são o aspecto negativo da desigualdade não razoável que o privilégio odioso institui. A vedação às discriminações odiosas relativamente às profissões encontra-se explícita no art. 150, II, da $\mathrm{CF} / 88$.

Há ainda a vedação à discriminação em razão da localização geográfica, que equivale à proibição dos privilégios geográficos federais. Em outras palavras, trata-se de fazer valer o princípio da uniformidade tributária. São vedadas ainda as discriminações entre brasileiros e estrangeiros residentes no país, bem como as discriminações entre as pessoas políticas (entes federativos).

\subsection{Territorialidade}

O princípio da territorialidade ${ }^{319}$ é corolário da noção de soberania fiscal, e embora não se encontre positivado na Constituição Brasileira de 1988, é de extrema importância para o Direito Tributário e para o Direito Tributário Internacional.

\footnotetext{
${ }^{319}$ Heleno Torres ensina que "a universalidade e a territorialidade são princípios no sentido de limite objetivo, que se perfaz como regra que permite a concretização de valores, como é o caso do princípio da autodeterminação, do federalismo e do princípio da capacidade contributiva. Princípio, como valor, é o que eles pretendem realizar. Satisfaz apenas ao interesse de demarcação espacial de alcance das normas de qualificação de rendimentos, limitando-se ao território ou localizando-os ultraterritorialmente (universalidade), em face de um dado critério de conexão”. TORRES, Heleno Taveira. Pluritributação Internacional sobre as Rendas de Empresas. 2. ed. Rev., amp. e atual. São Paulo: Editora Revista dos Tribunais, 2001. p. 94. Sobre a relação entre o princípio da territorialidade e universalidade, v. CARVALHO, Paulo de Barros. O princípio da territorialidade no regime de tributação da renda mundial (universalidade). In: Revista de Direito Tributário. São Paulo: Malheiros, 2002. v. 76. pp. 5-14. COÊLHO, Sacha Calmon Navarro. Noções da Fiscalidade Interancional. Belo Horizonte: Movimento Editorial Faculdade de Direito da UFMG, 1998. ALVES, Taciana Stanislau Afonso Bradley. O Princípio da Renda Mundial no Direito
} 
Ottmar Buhler, em sua obra Princípios de Direito Internacional Tributário, conceitua o princípio da territorialidade como a limitação do poder exclusivo do Estado em função de seu território, de modo que deixam de ser considerados lícitos os atos de um poder tributário estrangeiro que sujeitem pessoas ou coisa dentro do território de tal Estado. Não se permite, desta forma, que a administração tributária de um Estado A, enquanto não obtenha o consentimento do Estado B, exija prestações materiais ou formais de sujeitos no Estado B, tanto diretamente quanto através de um representante do outro Estado, por exemplo, a matriz de uma empresa ${ }^{320}$. Similarmente, Hamaekers define o princípio da territorialidade como o exercício da competência tributária exclusivamente dentro dos limites territoriais de um Estado soberano ${ }^{321}$.

Além disso, a territorialidade é o fator que legitima a tributação de rendimentos internacionais no Estado da fonte. Além do mais, segundo ensina Heleno Tôrres, "é o princípio da territorialidade que fundamenta o alcance espacial das normas tributárias sobre os fatos juridicizados pelo ordenamento, estabelecendo uma reserva de exclusividade para a aplicação das leis do Estado, mesmo que tais fatos sejam identificados fora do respectivo território (...), ${ }^{, 322}$.

A relação entre o princípio da territorialidade e a soberania fiscal se deve ao fato de que todo Estado soberano exerce seus poderes, dentre os quais se inclui o poder de tributar, sobre uma base territorial definida. A territorialidade está, portanto, presente no aspecto espacial da regra matriz de incidência tributária. E, desta forma, para fins tributários, considera-se como território qualquer superfície espacial juridicamente

Brasileiro. In: TORRES, Heleno Taveira (coord.). Direito Tributário Internacional Aplicado. São Paulo: Quartier Latin, 2003.v. 1. p. 605-637.

${ }^{320}$ BUHLER, Ottmar. Principios de Derecho Internacional Tributario. Trad. Fernando Cervera Torrejon. Madrid: Editorial de Derecho Financiero, 1968, p. 217.

${ }^{321}$ HAMAEKERS, Hubert. The source principle versus the residence principle. In: Revista dos Tribunais. Abr. mai. jun/1993. São Paulo: Malheiros, 1993. p. 164.

${ }^{322}$ TORRES, Heleno Taveira. Pluritributação Internacional sobre as Rendas de Empresas. 2. ed. Rev., ampl. e atual. São Paulo: Editora Revista dos Tribunais, 2001. pp. 70-71. No mesmo sentido: SACCHETTO, Claudio. Territorialità - diritto tributario. Enciclopédia del Diritto. Milano: Giuffrè, 1999, pp. 303-333. ANTÓN, Fernando Serrano. Hacia la Unificación del Decrecho Tributario para Residentes y no Residentes? In: TORRES, Heleno Taveira (Coord.). Direito Tributário Internacional Aplicado. São Paulo: Quartier Latin, 2005. pp. 70-77, v. 3. 
limitada, dentro da qual os cidadãos possam exercer direitos e cumprir deveres jurídicos, sob a jurisdição do Estado $^{323}$.

O campo onde o princípio da territorialidade revela sua real importância é o da interpretação e aplicação das normas tributárias internacionais, especialmente aquelas provenientes das convenções de bitributação. Tanto é assim que as convenções costumam conter a definição do conceito de território, definição esta que faz parte da chamada "linguagem fiscal internacional".

Assim, a territorialidade pode ser definida como o princípio segundo o qual a lei impositiva de determinado Estado alcança, segundo suas hipóteses de incidência, apenas as rendas decorrentes de serviços prestados em seu território, mediante aplicação do critério da fonte produtora, ou seja, o critério de onde a renda foi gerada, ou as rendas pagas a partir de seu território, hipótese em que a fonte indica o local de onde provém os fundos remuneratórios pagos em virtude do fornecimento de bens ou da prestação de serviços ${ }^{324}$. Por isso a tributação pelo princípio da territorialidade é geralmente associada à tributação no Estado da fonte ${ }^{325}$. Além disso, o princípio da territorialidade implica que as leis tributárias se aplicam aos fatos ocorridos no território da ordem jurídica a que pertencem, independentemente de outros fatores, como a nacionalidade ${ }^{326}$, o domicílio ou a residência do contribuinte ${ }^{327}$.

${ }^{323}$ TORRES, Heleno Taveira. Pluritributação Internacional sobre as Rendas de Empresas. 2. ed. Rev., ampl. e atual. São Paulo: Editora Revista dos Tribunais, 2001. p. 72.

${ }^{324}$ SARAIVA FILHO, Oswaldo Othon de Pontes. IRPJ e os tráfegos entrante e sainte de telecomunicações internacionais. In: PIRES, Adilson Rodrigues, et Al. Tributação, Justiça e Liberdade: homenagem da Associação Paulista de Estudos Tributários a Ives Gandra da Silva Martins. Curitiba: Juruá, 2005. p. 517.

${ }^{325}$ HAMAEKERS, Hubert. The source principle versus the residence principle. In: Revista dos Tribunais. Abr. mai. jun/1993. São Paulo: Malheiros, 1993. p. 167-168.

${ }^{326}$ Embora a nacionalidade também seja um princípio do Direito Tributário Internacional utilizado como critério de conexão em tratados internacionais, não faremos aqui uma análise específica de suas características, uma vez que se trata de critério que caiu em desuso, sendo atualmente utilizado por um reduzido grupo de países (apenas Estados Unidos e Filipinas), tendo sido largamente substituído pelo princípio da residência fiscal ou do domicílio. Sobre o princípio da nacionalidade, v. BUHLER, Ottmar. Principios de Derecho Internacional Tributario. Trad. Fernando Cervera Torrejon. Madrid: Editorial de Derecho Financiero, 1968, p. 215 e seguintes. ANTÓN, Fernando Serrano. Hacia la Unificación del Decrecho Tributario para Residentes y no Residentes? In: TORRES, Heleno Taveira (Coord.). Direito Tributário Internacional Aplicado. São Paulo: Quartier Latin, 2005. pp. 84-86. v. 3. AVERY JONES, John F. et al. The origins of Concepts and Expressions Used in the OECD Model and their Adoption by States. In: Bulletin - Tax Treaty Monitor. Jun. 2006. IBFD, pp. 232-233. DORNELLES, Francisco Neves. A Dupla Tributação Internacional da Renda. Rio de Janeiro: Editora da Fundação Getúlio Vargas, 1979, p. 5.

${ }^{327}$ XAVIER, Alberto. Direito Tributário Internacional do Brasil. 6. ed. reform. e atual. Rio de Janeiro: Forense, 2007. p. 22. 
Segundo destaca o professor Alberto Xavier, o princípio da territorialidade somente pode ser devidamente compreendido se forem considerados os seus três aspectos ou critérios, quais sejam: (i) a territorialidade em sentido positivo e negativo; (ii) em sentido real e em sentido pessoal, e (iii) em sentido material e em sentido formal. Em qualquer dos casos, entretanto, trata-se de um elemento informador do aspecto espacial da regra matriz de incidência tributária ${ }^{328}$, tanto sob a perspectiva da vigência e aplicação da norma quanto sob a perspectiva de produção de seus efeitos próprios.

O sentido positivo do princípio da territorialidade implica que as leis do país, inclusive as tributárias, se aplicam em seu território nacional de forma generalizada a todos os indivíduos que nele estejam presentes, independentemente de sua nacionalidade ou de seu local de residência, constituindo, desta forma, o elemento mínimo da conexão que se estabelece entre o sujeito e a jurisdição. Já o sentido negativo do termo implica que as leis estrangeiras tributárias não se aplicam no território do país em questão com seus efeitos típicos de constituir obrigação tributária. No entanto, o sentido negativo da territorialidade deve ser interpretado de forma relativa, já que existe a possibilidade de aplicação da lei estrangeira no território nacional com a finalidade de integrar os pressupostos de aplicação da própria lei interna, isto é, as questões prévias que devem ser analisadas antes de sua aplicação, como a residência, a nacionalidade, a condição de membro do corpo diplomático, etc. ${ }^{329}$

$\mathrm{O}$ aspecto real da territorialidade relaciona-se com a conexão entre os elementos materiais da vida, ou, em outras palavras, os aspectos objetivos dos fatos tributários, como o local da situação de bens, o local da fonte pagadora de um rendimento ou o local da prestação de um serviço. Contudo, com o passar do tempo e em face da evolução das normas tributárias, que adquiriram feições mais personalizadas, o aspecto pessoal do princípio da territorialidade passou a ter mais importância, de modo que os elementos ligados diretamente aos aspectos subjetivos das normas tributárias, por exemplo, a residência do contribuinte, passaram a ter mais destaque, excetuando-se a nacionalidade, que por si só constitui um critério de conexão, embora utilizado por poucos países ${ }^{330}$. O

${ }^{328}$ XAVIER, Alberto. Direito Tributário Internacional do Brasil. 6. ed. reform. e atual. Rio de Janeiro: Forense, 2007. p. 25.

${ }^{329}$ XAVIER, Alberto. Direito Tributário Internacional do Brasil. 6. ed. reform. e atual. Rio de Janeiro: Forense, 2007. pp. 23-24.

${ }^{330}$ Como os Estados Unidos. XAVIER, Alberto. Direito Tributário Internacional do Brasil. 6. ed. reform. e atual. Rio de Janeiro: Forense, 2007. p. 24. 
que importa, no atual estágio das relações tributárias internacionais, é a noção de que o aspecto material da territorialidade tem sido identificada simplesmente como "critério territorial" de conexão com o ordenamento, correspondendo, desta forma, ao princípio da tributação no Estado da fonte, enquanto que o aspecto pessoal corresponde ao "critério pessoal”, que se identifica com o princípio da tributação no Estado de residência do contribuinte ${ }^{331}$.

Em seguida, cumpre analisar a territorialidade sob sua faceta material e formal. Segundo ensina Heleno Torres ${ }^{332}$, inspirado em Kelsen ${ }^{333}$, a territorialidade material está relacionada com a questão da vigência das normas tributárias no espaço, entendida como a aptidão para produzir seus efeitos, ou seja, incidir sobre os fatos jurídicos tributários e constituir o crédito fiscal. Nesse sentido, o mestre pernambucano explica que:

“(...) Assim, a vigência da norma pressupõe a existência de validade, para definir o alcance espacial dentro do qual a norma poderá surtir seus efeitos, resguardando-se pela coercitividade, sendo o território do Estado o limite máximo desse alcance.

Contudo, os limites espaciais dentro do qual (sic) a norma pode produzir efeitos, pela eficácia da norma tributária no espaço, não devem ser confundidos com a localização de fatos sujeitos à tributação, que podem ser extraterritoriais. " 334

A territorialidade material se presta, desta forma, a identificar precisamente a localização espacial da ocorrência do fato gerador da obrigação tributária, imputando-se os

${ }^{331}$ Sobre os critérios ou elementos de conexão, v. Capítulo 4.

332 TORRES, Heleno Taveira. Pluritributação Internacional sobre as Rendas de Empresas. 2. ed. Rev., ampl. e atual. São Paulo: Editora Revista dos Tribunais, 2001. p. 81.

333 “ A ordem jurídica internacional estatui, além disso, que o domínio territorial deste Estado, ou a esfera de validade espacial da ordem jurídica estadual, tem a extensão que tiver a eficácia desta ordem jurídica, que todos os indivíduos que vivam neste território - com certas exceções, determinadas pelo Direito internacional - estão submetidos a esta e a nenhuma outra ordem jurídica. Isto significa que, segundo o Direito internacional, cada Estado fundamentalmente apenas pode aparecer revestido da sua qualidade de aparelho de coerção dentro do seu próprio domínio territorial, isto é, dentro do território que lhe é atribuído pelo Direito internacional; ou, para falar sem recorrer a imagens, que a ordem jurídica do Estado singular apenas deve estatuir os seus atos de coerção específicos para o espaço de validade que jurídicointernacionalmente lhe é reservado e que estes atos de coerção apenas podem ser estabelecidos sem ofensa do Direito internacional dentro deste espaço." KELSEN, Hans. Teoria Pura do Direito. Trad. João Baptista Machado. São Paulo: Martins Fontes, 1999, p. 235.

334 TORRES, Heleno Taveira. Pluritributação Internacional sobre as Rendas de Empresas. 2. ed., rev., ampl. e atual. São Paulo: Editora Revista dos Tribunais, 2001. p. 81. 
efeitos pertinentes, dentro do território nacional. Em outras palavras, nos dizeres de Alberto Xavier, corresponde à jurisdiction to prescribe ${ }^{335}$, relacionando-se com o aspecto abstrato da norma tributária e com a delimitação do âmbito espacial de seus efeitos, não afetando, desta forma, a soberania dos Estados estrangeiros. Assim, como ilustra o exemplo dado por Xavier, "pode a lei brasileira, pela escolha do domicílio ou da sede do sujeito passivo como conexão relevante, tributar os lucros auferidos no estrangeiro ou os imóveis ali situados; só que o crédito tributário decorrente dessa lei não poderá ser coercivamente executado no exterior" 336 .

Analisando o princípio da territorialidade sob o prisma formal, temos que se trata da chamada jurisdiction to enforce, o que significa que as leis tributárias somente podem ser coercivamente impostas aos contribuintes dentro do território a cuja ordem jurídica se integram ${ }^{337}$. A territorialidade em sentido formal é, desta forma, relacionada com a autodeterminação do Estado e a possibilidade de fazer valer as suas normas jurídicas dentro de seus limites territoriais, bem como a possibilidade de recusar a aplicação de leis ou atos estrangeiros no âmbito interno. Desta forma, a imposição coerciva da norma do Estado A no território do Estado B constitui, pois, uma violação da soberania do Estado B. Por isso se tornou universalmente reconhecida a impossibilidade da extraterritorialidade formal, ou seja, a impossibilidade de execução forçada de créditos tributários fora do território nacional de um Estado. O máximo que se pode conseguir, em termos de execução forçada de créditos no estrangeiro, é a colaboração das autoridades fiscais do outro Estado mediante troca de informações, procedimentos amigáveis ou colaborações judiciais, todas estas alternativas dependendo, logicamente, da concordância deste outro Estado.

Considerando o atual estágio da evolução do Direito Tributário interno e internacional, bem como em face da dinâmica das relações comerciais estabelecidas no nível internacional, é correto afirmar que o princípio da territorialidade se tornou insuficiente para, isoladamente, fornecer o critério de conexão necessário para permitir a

\footnotetext{
335 XAVIER, Alberto. Direito Tributário Internacional do Brasil. 6. ed. reform. e atual. Rio de Janeiro: Forense, 2007. p. 25.

336 XAVIER, Alberto. Direito Tributário Internacional do Brasil. 6. ed. reform. e atual. Rio de Janeiro: Forense, 2007. p. 26.

337 XAVIER, Alberto. Direito Tributário Internacional do Brasil. 6. ed. reform. e atual. Rio de Janeiro: Forense, 2007. p. 25.
} 
tributação. De fato, reconhece-se que sua adequação é maior com relação aos tributos cujo fato gerador consiste em ato ou fato materialmente verificável, como é o caso dos tributos aduaneiros, cuja hipótese de incidência consiste na transposição da linha de fronteira territorial de um país; ou ainda no caso dos impostos sobre o consumo, cuja ocorrência do fato gerador é mais fácil de ser constatada e provada. Entretanto, para as formas tributárias mais sofisticadas, como os impostos incidentes sobre a renda mundial o princípio da territorialidade pode não ser suficiente, já que a renda não necessariamente precisa ser contritamente verificável.

\subsection{Universalidade}

A tributação em bases universais, ou worldwide taxation, como o nome diz, considerada a renda mundial do indivíduo ou da pessoa jurídica para fins de imposição da norma tributária ${ }^{338}$. Suas origens ${ }^{339}$ remontam ao século XIX, sendo inicialmente previsto na lei do imposto de renda da Prússia, e no Brasil o princípio foi acolhido pela primeira vez no artigo 21, VIII do Regulamento do Imposto de Renda de $1980^{340}$. A tributação em bases universais está atualmente prevista no Direito brasileiro, tanto na Constituição Federal, em seu artigo 153, parágrafo $2^{\circ}$, inciso $I^{341}$, quanto no Código Tributário Nacional,

\footnotetext{
${ }^{338}$ Sobre o princípio da universalidade no Direito brasileiro, v. ALVES, Taciana Stanislau Afonso Bradley. O Princípio da Renda Mundial no Direito Brasileiro. In: TORRES, Heleno Taveira (coord.). Direito Tributário Internacional Aplicado. São Paulo: Quartier Latin, 2003. v. 1. p. 605-637.

339 “Com efeito, até a vigência da Lei $n^{\circ}$ 9.249, editada em 26 de dezembro de 1995, vigorava no Brasil o princípio da territorialidade, segundo o qual, apenas os rendimentos que mantivessem elemento de conexão com o território detentor da pretensão tributária poderiam ser submetidos à tributação. Isto implicava, no campo pragmático, na impossibilidade de incidência de qualquer espécie tributária sobre rendimentos não produzidos no Brasil. A partir de dezembro de 1995, contudo, o cenário legislativo foi substancialmente alterado pela introdução da referida lei. Desse momento em diante, passou-se a tolerar a tributação sobre rendimentos não produzidos no Brasil, adotando-se, pois, o princípio da universalidade. Veja-se, a propósito, a redação conferida ao artigo 25 da Lei $n^{\circ}$ 9.249/1995. “Os lucros, rendimentos e ganhos de capital auferidos no exterior serão computados na determinação do lucro real das pessoas jurídicas correspondente ao balanço levantado em 31 de dezembro de cada ano." Trecho do voto da Conselheira Karem Jureidini, no Processo n. 13603.002794/2003-50. Recurso n. 140.320. Recorrente: Refratec Produtos Eletrofundidos Ltda., Recorrida: 3a Turma/DRJ Belo Horizonte/MG, julgado em 23 de março de 2006. Acórdão n. 108-08.765. Inteiro teor disponível para consulta no site do Conselho de Contribuintes: www.conselhos.fazenda.gov.br.
}

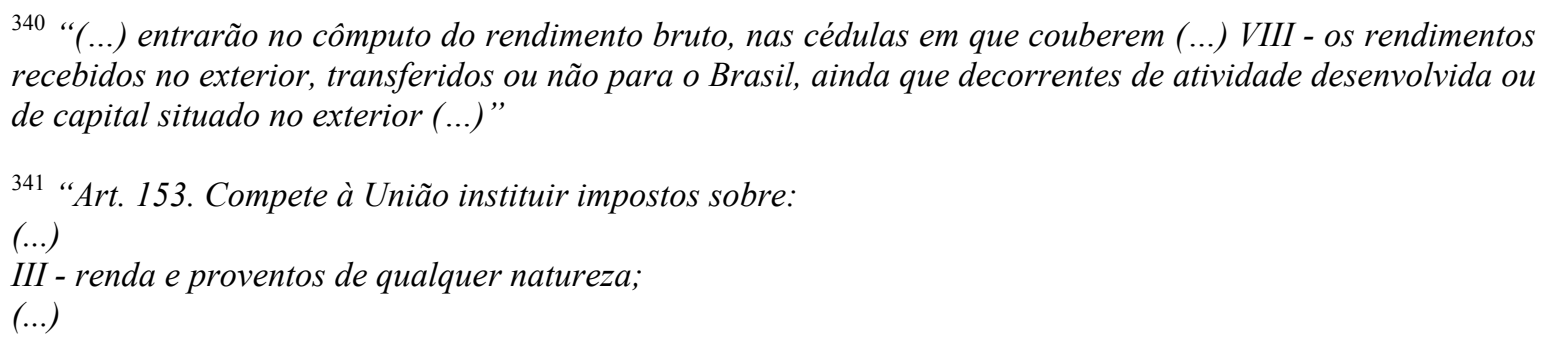
recebidos no exterior, transferidos ou não para o Brasil, ainda que decorrentes de atividade desenvolvida ou de capital situado no exterior (...)”

341 “Art. 153. Compete à União instituir impostos sobre:

(...)

III - renda e proventos de qualquer natureza;

(...) 
no artigo 43, parágrafo $1^{\mathrm{o} 342}$, bem como no artigo $38^{343}$ do Regulamento do Imposto de Renda de 1999 (Decreto n. 3.000/1999) e, ainda, na lei n. 9.249/95, em seu artigo $25^{344}$.

Como na worldwide taxation não importa a origem, a natureza da fonte ou a localização do patrimônio ou dos rendimentos tributáveis, é necessária a verificação da presença do elemento de conexão residência no território nacional para que possa haver a tributação. Por isso a universalidade também é denominada de territorialidade pessoal.

Não é difícil concluir que um dos motivos que levam os países a adotarem a tributação com bases universais consiste na possibilidade de tributar rendimentos localizados em paraísos fiscais ou em países com tributação favorecida ${ }^{345} 346$, como forma

$\S 2^{\circ}$ - O imposto previsto no inciso III:

I - será informado pelos critérios da generalidade, da universalidade e da progressividade, na forma da lei;

(...)"

342 “Art. 43. O imposto, de competência da União, sobre a renda e proventos de qualquer natureza tem como fato gerador a aquisição da disponibilidade econômica ou jurídica:

I - de renda, assim entendido o produto do capital, do trabalho ou da combinação de ambos;

II - de proventos de qualquer natureza, assim entendidos os acréscimos patrimoniais não compreendidos no inciso anterior.

$\S 1^{\circ}$ A incidência do imposto independe da denominação da receita ou do rendimento, da localização, condição jurídica ou nacionalidade da fonte, da origem e da forma de percepção. (Parágrafo incluído pela Lei Complementar . $^{\circ}$ 104. de 10.1.2001)"

343 “Art. 38. A tributação independe da denominação dos rendimentos, títulos ou direitos, da localização, condição jurídica ou nacionalidade da fonte, da origem dos bens produtores da renda e da forma de percepção das rendas ou proventos, bastando, para a incidência do imposto, o benefício do contribuinte por qualquer forma e a qualquer título (Lei n- 7.713, de 1988, art. 3-, § 4-)."

344 “Art. 25. Os lucros, rendimentos e ganhos de capital auferidos no exterior serão computados na determinação do lucro real das pessoas jurídicas correspondente ao balanço levantado em 31 de dezembro de cada ano. (Vide Medida Provisória no 2158-35, de 2001)”

${ }^{345}$ De acordo com o relatório de 1998 da OCDE, os países com tributação favorecida são aqueles que reunem as seguintes características: possuem baixa tributação ou efetivamente não exercem tributação, impossibilitam ou dificultam a troca de informações tributárias, não aplicam as regras da transparência na aplicação da legislação fiscal, ou seja, não possuem a chamada "CFC legislation" e concedem benefícios fiscais que não afetam a economia local. No Brasil, a Instrução Normativa SRF n. 188/02 estabeleceu o critério para incluir países na lista de países com tributação favorecida o fato de não tributar a renda ou de tributá-la em alíquotas inferiores a $20 \%$, bem como opor sigilo relativo à composição societária de pessoas jurídicas ou à sua titularidade, e também traz a lista dos países já classificados sob esta denominação. Assim, são países com tributação favorecida, segundo a Receita Federal do Brasil: Andorra; Anguilla; Antígua e Barbuda; Antilhas Holandesas; Aruba; Comunidade das Bahamas; Bahrein; Barbados; Belize; Ilhas Bermudas; Campione D'Italia; Ilhas do Canal (Alderney, Guernsey, Jersey e Sark); Ilhas Cayman; Chipre; Cingapura; Ilhas Cook; República da Costa Rica; Djibouti; Dominica; Emirados Árabes Unidos; Gibraltar; Granada; Hong Kong; Lebuan; Líbano; Libéria; Liechtenstein; Luxemburgo (no que respeita às sociedades holding regidas, na legislação luxemburguesa, pela Lei de 31 de julho de 1929); Macau; Ilha da Madeira; Maldivas; Malta; Ilha de Man; Ilhas Marshall; Ilhas Maurício; Mônaco; Ilhas Montserrat; Nauru; Ilha Niue; Sultanato de Omã; Panamá; Federação de São Cristóvão e Nevis; Samoa Americana; Samoa Ocidental; San Marino; São Vicente e Granadinas; Santa Lúcia; Seychelles; Tonga; Ilhas Turks e Caicos; Vanuatu; Ilhas Virgens Americanas; Ilhas Virgens Britânicas. 
de evitar e combater a evasão fiscal. Nesse sentido, o Regulamento do Imposto de Renda brasileiro de 1999 estabelece em seu artigo $2^{\text {o347 }}$ que o contribuinte pessoa-física é caracterizado em função da residência, enquanto que por meio de seus artigos 146 e $147^{348}$ fica definido o domicílio como critério de conexão para as pessoas jurídicas.

Dentre os motivos que levam um Estado a adotar a tributação com bases universais, o mais óbvio é certamente a possibilidade de aumentar a arrecadação. Além deste, visa-se à manutenção do princípios da isonomia e da capacidade contributiva, especialmente nos países que dispõem de muitos operadores econômicos no exterior, como forma de tributar de maneira igualitária tanto estes agentes, os quais podem receber algum tipo de incentivo no Estado de destino de seus investimentos, quanto os residentes no território do país, que recebem rendimentos somente a partir de fontes internas.

No que tange às pessoas jurídicas ${ }^{349}$, o princípio da tributação universal determina que toda a renda da pessoa jurídica deve ser tributada no país de domicílio, incluindo-se os rendimentos provenientes do exterior, mesmo que obtidos a partir de filiais ou subsidiárias. Quanto a estas últimas, cumpre esclarecer que, pelo fato de possuírem personalidade jurídica própria, a tributação universal a elas aplicável incide sobre os

346 Sobre os países com tributação favorecida, v. TORRES, Heleno Taveira. Direito Tributário Internacional: Planejamento Tributário e Operações Transnacionais. São Paulo: Editora Revista dos Tribunais, 2001. pp. 67-158.

347 “Art. $2^{\circ}$ As pessoas físicas domiciliadas ou residentes no Brasil, titulares de disponibilidade econômica ou jurídica de renda ou proventos de qualquer natureza, inclusive rendimentos e ganhos de capital, são contribuintes do imposto de renda, sem distinção da nacionalidade, sexo, idade, estado civil ou profissão (Lei $n .^{\circ}$ 4.506. de 30 de novembro de 1964, art. $1^{\circ}$, Lei $n .^{\circ}$ 5.172, de 25 de outubro de 1966. art. 43, e Lei $n .^{\circ}$ 8.383, de 30 de dezembro de 1991. art. $4^{\circ}$ )."

348 “Art. 146. São contribuintes do imposto e terão seus lucros apurados de acordo com este Decreto (Decreto-Lei $n .^{\circ}$ 5.844, de 1943, art. 27):

I - as pessoas jurídicas (Capítulo I);

II - as empresas individuais (Capítulo II).

$\S 1^{\circ}$ As disposições deste artigo aplicam-se a todas as firmas e sociedades, registradas ou não (Decreto-Lei n. ${ }^{o}$ 5.844, de 1943, art. $27, \S 2^{\circ}$ ).

(...)

Art. 147. Consideram-se pessoas jurídicas, para efeito do disposto no inciso I do artigo anterior:

I - as pessoas jurídicas de direito privado domiciliadas no Pais, sejam quais forem seus fins, nacionalidade ou participantes no capital (Decreto-Lei $n .^{\circ}$ 5.844, de 1943, art. 27, Lei ${ }^{\circ}{ }^{\circ} 4.131$, de 3 de setembro de 1962 , art. 42, e Lei $n .^{\circ} 6.264$, de 1975, art. $^{\circ}$ );

II - as filiais, sucursais, agências ou representações no País das pessoas jurídicas com sede no exterior (Lei $n .^{\circ}$ 3.470. de 1958, art. 76, Lei . $^{\circ} 4.131$, de 1962, art. 42, e Lei $n .^{\circ}$ 6.264, de 1975, art. $1^{\circ}$ );

III - os comitentes domiciliados no exterior, quanto aos resultados das operações realizadas por seus mandatários ou comissários no País (Lei n. ${ }^{\circ} 3.470$. de 1958, art. 76)."

${ }^{349}$ Sobre a aplicação do princípio da universalidade à tributação da renda das pessoas jurídicas, v. TORRES, Heleno Taveira. Lucros auferidos por meio de controladas e coligadas no exterior. In: TORRES, Heleno Taveira. (Coord.). Direito Tributário Internacional Aplicado, São Paulo: Quartier Latin, 2005. pp. 109-111. v. 3 . 
dividendos distribuídos, que constituem a efetiva renda da sociedade controladora, mas não incide sobre os lucros acumulados ou retidos na subsidiária, que constituem renda da própria subsidiária, que não foi disponibilizada para a controladora. Este, segundo Alberto Xavier, é o sistema utilizado pela maioria dos países desenvolvidos ${ }^{350}$.

Pela tributação universal, não se exige, outrossim, que o rendimento deva ser transferido para o Brasil. Mesmo os rendimentos mantidos no exterior, desde que atribuíveis a residentes no Brasil, podem ser aqui tributados. Em outras palavras, isso significa que o Brasil tributa a renda e o patrimônio de seus residentes em bases universais.

Em face das características acima, é possível concluir que o a tributação com base no princípio da universalidade não exclui, de forma alguma, a aplicação do princípio da territorialidade ${ }^{351}$. Muito pelo contrário, conforme explicamos linhas acima, a tributação em bases universais necessita da aplicação do critério da residência (territorialidade pessoal) para que possa ser efetivada ${ }^{352}$. Assim, conclui-se que, mesmo quando o Estado segue a worldwide income taxation, sempre haverá também a tributação pela territorialidade, só que em seu aspecto pessoal, e não real.

\subsection{Legalidade}

Um dos pilares de sustentação de todo o regime democrático e do Estado de Direito é o princípio da legalidade ${ }^{353}$, que se encontra positivado na Constituição brasileira

\footnotetext{
${ }^{350}$ XAVIER, Alberto. Direito Tributário Internacional do Brasil. 6. ed. reform. e atual. Rio de Janeiro: Forense, 2007. p. 431.

${ }^{351}$ Sobre o debate entre os princípios da universalidade e da territorialidade, v. ANTÓN, Fernando Serrano. Hacia la Unificación del Decrecho Tributario para Residentes y no Residentes? In: TORRES, Heleno Taveira (Coord.). Direito Tributário Internacional Aplicado. São Paulo: Quartier Latin, 2005. pp. 77-84. v. 3.

${ }^{352}$ Em sentido oposto, Ottmar Buhler entende que o princípio da universalidade constitui, desta forma, o contraponto lógico aos princípios da territorialidade e da nacionalidade, e, especificamente quanto a este, pode também significar a delimitação do alcance material da obrigação tributária já estabelecida em relação ao sujeito. BUHLER, Ottmar. Principios de Derecho Internacional Tributario. Trad. Fernando Cervera Torrejon. Madrid: Editorial de Derecho Financiero, 1968, p. 220.
}

353 “Existen pues unos principios de orden superior que le Dan un sentido a las normas jurídicas, y que las hacen idóneas para realizar el orden social, la estabilidad de los derechos, el progreso de la sociedad y el completo desarrollo de las personas individuales.

Tales principios apuntan a unos valores fundamentales, que son la equidad y la estabilidad de las situaciones particulares nacidas al amparo de las instituciones legales.

Las relaciones entre la seguridad y la justicia, como valores fundamentales as cuales apunta el Derecho, son puestas de presente por Recasens Siches en la forma siguiente:

'Todos los valores superiores del derecho deben cumplirse precisamente en el Derecho. Pero no hay Derecho donde no hay orden cierto y seguridad. Es verdad que no basta con crear un orden cierto, pues este debe ser, 
de 1988 em seu artigo $5^{\circ}$, II ${ }^{354}$, e também em seu artigo $150, \mathrm{I}^{355}$. Porém, muito antes de o Brasil sequer ser descoberto, no remotíssimo século XI já havia a noção de que a carga tributária deve ser consentida por aqueles que a suportam ${ }^{356}$, constituindo uma espécie de "sacrifício coletivamente consentido",357. No decorrer do tempo, o conceito evoluiu e perdeu esta característica, passando a estar mais relacionado com a legitimidade e o controle da atuação estatal em face dos direitos fundamentais do indivíduo ${ }^{358}$. Efetivamente, após a Revolução Francesa, o princípio passou a ser amplamente difundido com a Escola da Exegese e sua doutrina formalista, associado à noção de legitimidade do

además, justo. Pero no puede haber justicia cuando no hay seguridad. Por tanto, podemos decir que cabe un Derecho que no sea justo. Pero no cabe que en la sociedad haya justicia sin seguridad. (Filosofía Del Derecho. Editorial Porrua, México, p. 618).'

Existen pues dos valores fundamentales, para el Derecho, uno de orden inferior y otro de categoría superior: la estabilidad y la justicia." ARTEAGA, Juan Rafael Bravo. Nociones Fundamentales de Derecho Tributario. $2^{a}$ edición. Ediciones Rosaristas: Santa Fé de Bogotá-DC. 1997, pp. 85-86. V. também: TORRES, Ricardo Lobo. A idéia de liberdade no Estado Patrimonial e no Estado Fiscal. Rio de Janeiro: Renovar, 1991. pp. 112-114. DORNELLES, Francisco Neves. A Dupla Tributação Internacional da Renda. Rio de Janeiro: Editora da Fundação Getúlio Vargas, 1979, p. 3.

354 “Art. $5^{\circ}$ Todos são iguais perante a lei, sem distinção de qualquer natureza, garantindo-se aos brasileiros e aos estrangeiros residentes no País a inviolabilidade do direito à vida, à liberdade, à igualdade, à segurança e à propriedade, nos termos seguintes:

(...)

II - ninguém será obrigado a fazer ou deixar de fazer alguma coisa senão em virtude de lei;

(...)"

355 “Art. 150. Sem prejuizo de outras garantias asseguradas ao contribuinte, é vedado à União, aos Estados, ao Distrito Federal e aos Municípios:

I - exigir ou aumentar tributo sem lei que o estabeleça;

(...)"

${ }^{356}$ BALEEIRO, Aliomar, Limitações Constitucionais ao Poder de Tributar, 7. ed. Rev. e compl. por Misabel Abreu Machado Derzi, Rio de Janeiro: Forense, 2006, p. 50.

357 XAVIER, Alberto, Os Princípios da Legalidade e da Tipicidade da Tributação. São Paulo: Editora Revista dos Tribunais, 1978, p. 7.

358 “Com o evolver dos séculos, o princípio da legalidade da tributação vai incorporar outra conotação. Isto ocorre precisamente com o surgimento da teoria e da prática da tripartição de Poderes, na esteira de uma concepção na qual o Estado, antes uno, aparece, necessariamente, dividido, com três Poderes, exercentes de três funções: a de criar a lei, deferida ao Legislativo, a de aplicar a lei de ofício, entregue ao Executivo, e a de dirimir os conflitos em razão da aplicação da lei, cometida ao Judiciário. O princípio da legalidade da tributação assume a conotação de norma feita pelo Poder Legislativo (forma), com o caráter de prescrição impessoal, abstrata e obrigatória. Noutras palavras, a tributação passa a exigir lei estrita (Lex escripta) em sentido formal (ato do Congresso) e material (norma impessoal, abstrata e obrigatória). A fascinação exercida pela tripartição dos Poderes em tema de tributação foi tamanha que, mesmo nos países de Direito Consuetudinário, o precedente é descartado como veículo de norma tributária. Prevalece em toda parta a lex escripta e stricta decidida pelos representantes do povo especialmente eleitos para fazer leis, afastandose o príncipe, isto é, o chefe do Executivo, e o juiz, do poder de fazer a lei tributária. O jus tributandi, antes apanágio dos reis, é, agora, indeclinável função dos parlamentos." COÊLHO, Sacha Calmon Navarro. Curso de Direito Tributário Brasileiro. 8. ed. Rev. e atual. de acordo com o Código Civil de 2002. Rio de Janeiro: Forense, 2005. pp. 217-218. 
poder público pelo povo. Sob este aspecto o professor espanhol Ferreiro Lapatza analisa o princípio:

“El principio de legalidad, según el cual la ley y sólo la ley há de regular ciertas matérias, precisamente aquellas que garantizan uma organización social baseada em la libertad individual, incorpora, esencialmente, la idea de que em uma sociedad libre sólo la comunidad puede darse a si misma, a través de sus representantes, normas sobre tales matérias. „359

Mais tarde, durante a consolidação dos Estados de Direito, a legalidade assumiu ainda mais a feição de meio para a efetivação da justiça ${ }^{360}$, ganhando ainda maior destaque a sua feição de garantia da legitimidade da imposição tributária. Como se vê, desde que se tem notícia, a legalidade sempre esteve associada à tributação ${ }^{361}$.

Inegavelmente, o poder de tributar os cidadãos é, ao lado do poder de punir a prática de delitos, o mais forte e perverso de todos os poderes estatais, e justamente por sua magnitude, é facilmente capaz de violar os direitos humanos em busca da maior arrecadação possível. O poder de tributar limita legitimamente os direitos dos indivíduos por lhes absorver o patrimônio econômico ${ }^{362}$. Desta forma, o princípio da legalidade, especialmente a legalidade tributária, que é mais rigorosa do que a legalidade geral, atua evitando e reprimindo eventuais abusos que podem ser (e muitas vezes são) praticados por parte do Estado.

O principio da legalidade geral, tal como previsto no artigo 5o, II, corresponde ao princípio da preeminência da lei; já a legalidade estrita, ou legalidade tributária, relaciona-se com o princípio da reserva de lei, que eleva a lei à categoria de pressuposto necessário de toda e qualquer atividade administrativa e, desta forma, representa uma garantia dos cidadãos contra intervenções arbitrárias do poder público ${ }^{363}$.

\footnotetext{
359 LAPATZA, José Juan Ferreiro. Curso de Derecho Financiero Español, 19. ed., Madrid: Marcial Pons, 1997, pp. 44-45.

360 XAVIER, Alberto, Os Princípios da Legalidade e da Tipicidade da Tributação. São Paulo: Editora Revista dos Tribunais, 1978, pp. 8-9.

${ }^{361}$ Sobre a evolução histórica do princípio da legalidade v. UCKMAR, Victor. Princípios comuns de Direito Constitucional tributário, trad. Marco Aurélio Greco, São Paulo: Editora Revista dos Tribunais, 1976, pp. 922.

${ }^{362}$ DÓRIA, Antônio Roberto Sampaio. Direito Constitucional Tributário e Due Process of Law. 2. ed. Rio de Janeiro: Forense, 1986, p. 39.
} 
Além disso, a legalidade tributária requer a obediência a dois requisitos, quais sejam: (i) a "legalidade formal", segundo a qual todo e qualquer tributo que seja criado ou majorado no Brasil deve ser fruto de lei em sentido estrito e deve ser, desta forma, absolutamente compatível com a Constituição; e, (ii) a "legalidade material", sinônima de tipicidade tributária, princípio que obriga que toda exação tributária deve ter sua regra matriz de incidência prevista em lei em todos os seus estritos detalhes, não sendo possível a aplicação de qualquer tipo de analogia com fins de criação ou majoração de tributos, ou mesmo para exigir tributos indevidamente. Estes dois requisitos podem ser resumidos por meio do brocardo nullum tributum sine lege, que significa "é nulo o tributo, é nula a cobrança, se não houver previsão em lei”.

A importância do princípio da legalidade como garantia de manutenção do Estado Democrático de Direito e dos direitos fundamentais é amplamente reconhecida na comunidade internacional. Tanto é que a maioria dos países em que vigora um Estado de

363 XAVIER, Alberto, Os Princípios da Legalidade e da Tipicidade da Tributação. São Paulo: Editora Revista dos Tribunais, 1978, pp. 12-18. 
Direito existe a previsão constitucional da legalidade, tanto explicitamente ${ }^{364}$ quanto implicitamente ${ }^{365}$.

${ }^{364}$ Bélgica: "Art. 170. (1) Taxes to the benefit of the State may be imposed only by virtue of a law. (...) (3.2) A law determines, with respect to the taxes described in Paragraph (1), those exceptions of proven necessity. (...)"; Israel: "Taxes, compulsory loans and fees - 1. (a) Taxes, compulsory loans and other compulsory payments shall not be imposed, and their amounts shall no be varied, save by or under Law; the same shall apply with regard to fees."; Bulgária: "Article 60. (1) Citizens shall pay taxes and duties established by a law proportionately to their income and property. (2) Any tax concession or surtax shall be established by a law."; Peru: "Artículo $74^{\circ}$. Los tributos se crean, modifican o derogan, o se establece una exoneración, exclusivamente por ley o decreto legislativo en caso de delegación de facultades, salvo los aranceles y tasas, los cuales se regulan mediante decreto supremo. Los Gobiernos Regionales y los Gobiernos Locales pueden crear, modificar y suprimir contribuciones y tasas, o exonerar de éstas, dentro de su jurisdicción, y con los límites que señala la ley. El Estado, al ejercer la potestad tributaria, debe respetar los principios de reserva de la ley, y los de igualdad y respeto de los derechos fundamentales de la persona. Ningún tributo puede tener carácter confiscatorio. Las leyes de presupuesto y los decretos de urgencia no pueden contener normas sobre materia tributaria. Las leyes relativas a tributos de periodicidad anual rigen a partir del primero de enero del año siguiente a su promulgación. No surten efecto las normas tributarias dictadas en violación de lo que establece el presente artículo." Japão: "Art. 84. No new taxes shall be imposed or existing ones modified except by law or under such conditions as law may prescribe."; Singapura: "Article 59. Introduction of Bills (...) (2) A Bill or amendment making provision (whether directly or indirectly) for (a) imposing or increasing any tax or abolishing, reducing or remitting any existing tax; (...), Article 143. No tax or rate shall be levied by, or for the purposes of, Singapore except by or under the authority of law. "; Índia: "Article 265 [Taxes not to be imposed save by authority of law] No tax shall be levied or collected except by authority of law."; China: "Article 56. It is the duty of citizens of the People's Republic of China to pay taxes in accordance with the law." Angola: "Artigo 14\%. 1. O sistema fiscal visa a satisfação das necessidades económicas, sociais e administrativas do Estado e uma repartição justa dos rendimentos e da riqueza. 2. Os impostos só pedem ser criados e extintos por lei, que determina a sua incidência, taxas, beneficios fiscais e garantias dos contribuintes." Canadá: "53. Appropriation and Tax Bills: Bills for appropriating any part of the Public Revenue, or for imposing any Tax or Impost, shall originate in the House of Commons.".

${ }^{365}$ Áustria: "Article 13 [Taxation] - The competencies of the Federation and the States in the field of taxation will be prescribed in a special federal constitutional law." Espanha: "Articulo 31. 1. Todos contribuirán al sostenimiento de los gastos públicos de acuerdo con su capacidad económica mediante un sistema tributario justo inspirado en los principios de igualdad y progresividad que, en ningún caso, tendrá alcance confiscatorio. 2. El gasto público realizará una asignación equitativa de los recursos públicos y su programación y ejecución responderán a los criterios de eficiencia y economía. 3. Sólo podrán establecerse prestaciones personales o patrimoniales de carácter público con arreglo a la ley..” (...) Artículo 133. 1. La potestad originaria para establecer los tributos corresponde exclusivamente al Estado, mediante ley. 2. Las Comunidades Autónomas y las Corporaciones locales podrán establecer y exigir tributos, de acuerdo con la Constitución y las leyes. 3. Todo beneficio fiscal que afecte a los tributos del Estado deberá establecerse en virtud de ley. 4. Las administraciones públicas sólo podrán contraer obligaciones financieras y realizar gastos de acuerdo con las leyes." Dinamarca: "Section 43 [Taxes] No taxes shall be imposed, altered, or repealed except by Statute; nor shall any man be conscripted or any public loan be raised except by Statute."; Holanda: "Article 104. Taxes imposed by the State shall be levied pursuant to Act of Parliament. Other levies imposed by the State shall be regulated by Act of Parliament." Noruega: "Article 18 [Collection of Taxes and Duties]: As a general rule the King shall provide for the collection of the taxes and duties imposed by the Parliament [Storting]."; Chile: "20 $0^{\circ}$ - La igual repartición de los tributos en D.O. proporción a las rentas o en la progresión o forma que fije la ley, y la igual repartición de las demás cargas públicas. En ningún caso la ley podrá establecer tributos manifiestamente desproporcionados o injustos. Los tributos que se recauden, cualquiera que sea su naturaleza, ingresarán al patrimonio de la Nación y no podrán estar afectos a un destino determinado. Sin embargo, la ley podrá autorizar que determinados tributos puedan estar afectados a fines propios de la defensa nacional. Asimismo, podrá autorizar que los que gravan actividades o bienes que tengan una clara identificación regional o local puedan ser aplicados, dentro de los marcos que la misma ley señale, por las autoridades regionales o comunales para el financiamiento de obras de desarrollo;" [Sobre os princípios tributários na Constituição Chilena: LA 
E, por mais que possa ser surpreendente, até hoje ainda existem países que não prevêem o princípio da legalidade nem de modo expresso nem implícito ${ }^{366}$. Entretanto, como se trata de um princípio metajurídico, também denominado de "princípio de sobredireito", admite-se a sua aplicação mesmo nos países em que não se faz menção expressa ou implícita.

\subsection{Capacidade Contributiva}

A sociedade tem o dever solidário de custear a máquina estatal ${ }^{367}$. Entretanto, a distribuição do ônus de tal dever deve ser feita de modo que seja respeitado, principalmente, o princípio da dignidade da pessoa humana ${ }^{368}$ e da isonomia. Em outras palavras, o princípio da capacidade contributiva ${ }^{369}$ é relacionado à noção de que todos devem contribuir em razão de sua igualdade/desigualdade perante o sistema ${ }^{370}$, e assim, o

CUADRA, Enrique Evans de. ESPIÑEIRA, Eugenio Evans. Los Tributos Ante la Constitución. Editorial Jurídica de Chile: Santiago, 1997.]; Colômbia: “ARTICULO 338. En tiempo de paz, solamente el Congreso, las asambleas departamentales y los concejos distritales y municipales podrán imponer contribuciones fiscales o parafiscales. La ley, las ordenanzas y los acuerdos deben fijar, directamente, los sujetos activos y pasivos, los hechos y las bases gravables, y las tarifas de los impuestos. La ley, las ordenanzas y los acuerdos pueden permitir que las autoridades fijen la tarifa de las tasas y contribuciones que cobren a los contribuyentes, como recuperación de los costos de los servicios que les presten o participación en los beneficios que les proporcionen; pero el sistema y el método para definir tales costos y beneficios, y la forma de hacer su reparto, deben ser fijados por la ley, las ordenanzas o los acuerdos. Las leyes, ordenanzas o acuerdos que regulen contribuciones en las que la base sea el resultado de hechos ocurridos durante un periodo determinado, no pueden aplicarse sino a partir del período que comience después de iniciar la vigencia de la respectiva ley, ordenanza o acuerdo.”

${ }^{366}$ Este é o caso da Argentina, da Bolívia, da Costa Rica e do Uruguai.

367 NABAIS, José Casalta. O dever fundamental de pagar impostos: contributo para a compreensão constitucional do estado fiscal contemporâneo. Coimbra: Almedina, 1998, pp. 54-55. NABAIS, José Casalta. Por um Estado Fiscal Suportável: Estudos de Direito Fiscal. Coimbra: Almedina, 2005. pp. 103-118.

368 Sobre a proteção à dignidade da pessoa humana em face da tributação, v. BORGES, José Souto Maior. Direitos Humanos e Tributação. In: Revista Tributária e de Finanças Públicas. Set. out. 2001. São Paulo: Editora Revista dos Tribunais, 2001. v. 40. pp. 188-192.

369 Sobre o princípio da capacidade contributiva e da igualdade no Direito Tributário Internacional, v. CARRERO, José M. Calderón. La doble imposición internacional y los métodos para su eliminación. Madrid: McGraw-Hill, 1997, pp. 64-83.

370 "Existe el deber moral de contribuir al mantenimiento del Estado porque si los hombres para su subsistencia se han agrupado en organizaciones jurídico- políticas como el Estado, parece natural que concurran al mantenimiento de la organización que han creado. Está implícito en este razonamiento que la creación del Estado obedece a razones de orden, seguridad y bien público de los miembros de la sociedad. Si se logran estos bienes, los mismos hombres que han privilegiado esos valores son los que deben sustentar la organización que han creado. (...)

La relación entre el Estado y el individuo, en el caso de los impuestos, importa unir la necesidad del estado y el derecho de propiedad del individuo, pero sin contraprestación como en el caso de los vínculos contractuales sinalagmáticos, sin que se trate de una liberalidad a favor del Estado como en el supuesto de 
legislador constitucional brasileiro cuidou de incluí-lo expressamente no artigo 145, parágrafo $1^{0371}$, da Constituição Federal de 1988.

Outro valor que deve ser considerado durante a distribuição do ônus físcal geral é a proteção da propriedade privada, até mesmo como forma de evitar a falência do próprio sistema. Isto porque, se a propriedade privada não for devidamente protegida e respeitada, os cidadãos não terão meios para prover o sustento financeiro do próprio Estado, o que inexoravelmente levaria à sua falência. Assim, somente quando são atendidos estes requisitos é que o dever coletivo de pagar tributos adquire legitimidade.

Considerando estes aspectos, observa-se que a observância da capacidade contributiva é um dos pilares do Direito Tributário, e, embora possa parecer que se trate de um princípio que não afeta a interpretação de suas normas, verifica-se que esta deve, sim, levar em conta o seu mandamento.

Isto se deve ao fato de que um dos principais valores que norteiam qualquer atividade interpretativa em matéria tributária é a isonomia, a qual, por sua vez, informa o dever de não-discriminação, bem como a proteção dos cidadãos contra os excessos do Estado.

Desta forma, se a legalidade pode ser considerada, como pretendem alguns autores $^{372}$, a causa jurídica da tributação, a capacidade contributiva será a sua legítima medida $^{373}$. E esta medida deve ser analisada a partir de dois aspectos: primeiro, verifica-se

las donaciones, sin contraprestación o beneficio a favor del contribuyente como en los casos de las tasas y de las contribuciones." DAMARCO, Jorge Hector. El Principio de Capacidad Contributiva como Fundamento $y$ Medida de Los Impuestos. Disponível em: www.econ.uba.err/www/institutos/epistemology/marco archivos/potencies/Actas\%20XIII/Trabajos\%20Epis te/Damarco trabajo.pfd. Acesso em 29 out.2009. No mesmo sentido: DE MITA, Enrico. O princípio da Capacidade Contributiva. In: FERRAZ, Roberto. (Coord.). Princípios e Limites da Tributação. São Paulo: Quartier Latin, 2005. p. 231.

371 “Art. 145, $\S 1^{\circ}$ - Sempre que possível, os impostos terão caráter pessoal e serão graduados segundo a capacidade econômica do contribuinte, facultado à administração tributária, especialmente para conferir efetividade a esses objetivos, identificar, respeitados os direitos individuais e nos termos da lei, o patrimônio, os rendimentos e as atividades economicas do contribuinte."

372 JARACH, Dino. O Fato Imponível, Teoria geral do Direito Tributário Substantivo. 2. ed. Rev. da trad. de Dejalma de Campos, São Paulo: Editora Revista dos Tribunais, 2004. p. 115. BUJANDA, Sainz de. Hacienda y Derecho, Estudios de Derecho Financeiro, Madrid: Editorial de Estudios Políticos, 1996, p. 551. Tomo 4.

373 Dino Jarach destaca que a capacidade contributiva é "a única razão que explica a existência como pressuposto de obrigação tributária de fatos aparentemente diferentes, mas todos com a mesma natureza econômica; e é a única razão que explica a graduação do imposto segundo a magnitude econômica do pressuposto de fato; é o único conceito que representa uma ponte entre a lei e o fato imponível. Por isto, 
a capacidade contributiva objetiva, que se verifica em relação à fixação dos fatos passíveis de tributação, e, em segundo lugar, examina-se a capacidade contributiva subjetiva, esta referente ao critério quantitativo dos tributos. São estes os aspectos que a interpretação deve considerar quando se fala em obediência a este princípio. Desta forma, quando se interpreta uma norma tributária, é necessário ter em mente a capacidade contributiva durante a qualificação dos rendimentos do contribuinte, para que se possa classificá-los corretamente, evitando, assim, a inclusão de rendimentos indevidos na base de cálculo, de forma que o cálculo final do tributo devido seja correto.

Desta forma, ao se interpretar a norma tributária à luz da capacidade contributiva garante-se a isonomia ${ }^{374}$ em seu aspecto quantitativo, o que tem como consequência imediata a proteção do direito fundamental à dignidade dos indivíduos e do mínimo existencial, e como efeito mediato a promoção de justiça fiscal ${ }^{375}$.

parece-nos que se pode identificar o conceito de capacidade contributiva com o de causa jurídica do imposto.” Rev. da trad. de Dejalma de Campos, São Paulo: Editora Revista dos Tribunais, 2004. p. 124.

${ }^{374}$ A relação entre a capacidade contributiva e o princípio da isonomia também é explorada nas constituições de diversos países, como se observa dos exemplos a seguir: Turquia: "Article 73 [Obligation to Pay Taxes]. Everyone is under obligation to pay taxes according to his financial resources, in order to meet public expenditure. An equitable and balanced distribution of the tax burden is the social objective of fiscal policy."; Suíça: “Article 127 [Principles of Taxation]. (1) The definition of taxes, by name the circle of taxpayers, the object of tax and its assessment, is to be regulated in fundamentals by law. (2) Insofar the nature of tax allows it, the principles of generality and equability of taxation as well as the principle of taxation according to economic capacity are particularly to be considered. (3) Intercantonal double taxation is prohibited. The Federation takes the necessary measures.", Venezuela: "Artículo 316. El sistema tributario procurará la justa distribución de las cargas publicas según la capacidad económica del o la contribuyente, atendiendo al principio de progresividad, así como la protección de la economía nacional y la elevación del nivel de vida de la población, y se sustentará para ello en un sistema eficiente para la recaudación de los tributos. La igualdad es la base del tributo. Ningún impuesto tendrá carácter confiscatorio. Su creación y su vigencia atenderán a la capacidad contributiva de los habitantes y a las condiciones generales de la economía del país."; Bulgária: “Art. 60. (1) Citizens shall pay taxes and duties established by law proportionately to their income and property.(...)”; Paraguai: "Artículo 181 - [De La Igualdad Del Tributo] La igualdad es la base del tributo. Ningún impuesto tendrá carácter confiscatorio. Su creación y su vigencia atenderán a la capacidad contributiva de los habitantes y a las condiciones generales de la economía del país."; Itália: "Art. 53: Tutti sono tenuti a concorrere alle spese pubbliche in ragione della loro capacità contributiva. Il sistema tributario è informato a criteri di progressività.”; Espanha: "Artículo 31. (1) Todos contribuirán al sostenimiento de los gastos públicos de acuerdo con su capacidad económica mediante un sistema tributario justo inspirado en los principios de igualdad y progresividad que, en ningún caso, tendrá alcance confiscatorio. (2) El gasto público realizará una asignación equitativa de los recursos públicos, y su programación y ejecución responderán a los criterios de eficiencia y economía. (3) Sólo podrán establecerse prestaciones personales o patrimoniales de carácter público con arreglo a la ley."; México: “Artículo 31. Son obligaciones de los mexicanos: (...) IV. Contribuir para los gastos públicos, así de la Federación, como del Distrito Federal o del Estado y Municipio en que residan, de la manera proporcional y equitativa que dispongan las leyes."

${ }^{375}$ MARTINS, Ives Gandra da Silva. Teoria da imposição tributária. 2. ed., rev. e atual., São Paulo: LTr, 1998. 
Em face de todos estes aspectos, conclui-se que a correta interpretação dos fatos e das normas jurídicas é de suma importância para a efetiva aplicação prática do princípio da capacidade contributiva. Isto porque se trata de um princípio essencialmente subjetivo, dependente, portanto, do bom senso do aplicador do direito durante a análise e interpretação dos fatos, especialmente se comparado a princípios cuja verificação empírica é mais fácil, como a legalidade.

\subsection{Princípio da não-surpresa do contribuinte: irretroatividade e anterioridade}

A garantia da estabilidade e da segurança jurídica na aplicação do direito é um dos principais objetivos perseguidos mediante a interpretação e a argumentação jurídicas. Assim, desde muito cedo os países buscaram incluir em suas constituições dispositivos que visavam deixar clara a intenção de se conferir tal proteção ${ }^{376}$. No Brasil, desde a Constituição de 1924 já existia a previsão da irretroatividade das leis, sendo que na atual Constituição a irretroatividade legislativa possui status de princípio geral de Direito, prevista no artigo $5^{\circ}$, inciso XXXVI, o qual determina que a lei não prejudicará o ato jurídico perfeito e a coisa julgada. A rigor, nem seria necessária uma previsão específica acerca da aplicação do princípio da irretroatividade às leis tributárias. Porém, o legislador constitucional de 1988 foi mais detalhista e estabeleceu a irretroatividade específica das leis tributárias no artigo 150, inciso III, alínea “a”, da $\mathrm{CF} / 88^{377}$. Este detalhamento da irretroatividade tributária consiste, como já mencionado, em mais uma garantia do contribuinte contra a cobrança de tributos em relação ao fatos pretéritos, reforçando a proteção dos direitos patrimoniais do indivíduo já concedida pelo princípio da legalidade.

A garantia da irretroatividade também se encontra prevista em relação aos tratados internacionais. De fato, a Convenção de Viena sobre o Direito dos Tratados, em

\footnotetext{
${ }^{376}$ Nesse sentido, a primeira vez que se teve notícia do princípio da irretroatividade foi com a constituição Norte-Americana de 1787, que continha uma previsão de caráter geral que proibia expressamente a votação de leis com efeitos retroativos.

377 “Art. 150. Sem prejuizo de outras garantias asseguradas ao contribuinte, é vedado à União, aos Estados, ao Distrito Federal e aos Municípios:

(...)

III - cobrar tributos:

a) em relação a fatos geradores ocorridos antes do início da vigência da lei que os houver instituído ou aumentado;

b) no mesmo exercício financeiro em que haja sido publicada a lei que os instituiu ou aumentou;

c) antes de decorridos noventa dias da data em que haja sido publicada a lei que os instituiu ou aumentou, observado o disposto na alínea $b$; (Incluido pela Emenda Constitucional $n^{\circ} 42$, de $\underline{19.12 .2003) ”}$

d)
} 
seu artigo 28, dispõe expressamente que "a não ser que uma intenção diferente se evidencie do tratado, ou seja estabelecida de outra forma, suas disposições não obrigam uma parte em relação a um ato ou fato anterior ou a uma situação que deixou de existir antes da entrada em vigor do tratado, em relação a essa parte.”

A segurança jurídica, como já mencionado anteriormente, é suportada por diversos princípios, embora alguns assumam posição de maior destaque do que outros. Este é o caso da legalidade, da irretroatividade e da anterioridade. A primeira porque protege, de forma ampla, o patrimônio do indivíduo contra investidas arbitrárias do Estado. E as últimas duas, que informam também o chamado princípio da não-surpresa tributária, são relacionados com a garantia da certeza do direito e também com a proteção à propriedade privada.

Assim, o princípio da não-surpresa em Direito Tributário tem o objetivo de permitir que os contribuintes fiquem cientes, com razoável antecedência, do ônus fiscal a que estarão obrigados, a fim de que possam, desta forma, organizar-se para devidamente cumprir tal encargo. Desta forma, as leis fiscais não podem ter eficácia imediata, devendo produzir efeitos somente após decorrido um lapso temporal após a sua publicação, e também não podem retroagir no tempo, sob pena de ferir-se o ato jurídico perfeito e a coisa julgada.

Considerando estes aspectos, é correto afirmar que o princípio da não-surpresa está relacionado com o aspecto temporal da interpretação e da aplicação das normas jurídicas, especialmente na consideração do tempo em que se operam seus efeitos.

Assim, a relação entre a irretroatividade da lei tributária e a sua interpretação (especialmente a interpretação autêntica) consiste em que os fatos jurídicos tributários devem ser interpretados e considerados somente após o início da vigência da lei, ou seja, do presente e para o futuro. Em outras palavras, com o objetivo de proteger o direito adquirido, o ato jurídico perfeito, a segurança jurídica e a estabilidade do direito, a lei tributária não retroage para atingir fatos pretéritos, ou seja, não pode haver cobrança de tributos em relação a fatos geradores ocorridos antes do início da vigência da lei que os houver instituído ou aumentado ${ }^{378}$. Isto porque, aquele que praticou fato sobre o qual não

\footnotetext{
${ }^{378}$ Não obstante a relevância amplamente reconhecida da irretroatividade das leis tributárias, alguns países centrais na comunidade internacional permitem, em algumas hipóteses, a tributação retroativa. Este é o caso dos Estados Unidos, cuja constituição permite que os tribunais decidam pela possibilidade de tributação retroativa, ao argumento de que a tributação retroativa pode ser legítima desde que obedeça a um propósito legislativo legítimo promovido por meios racionais. Com este fundamento uma lei federal norte-americana
} 
há previsão legal de exação tributária, adquiriu o direito de não ser tributado sobre aquela prática.

No Brasil não há nenhuma previsão de formas de atenuação do princípio da irretroatividade tributária. Contudo, há autores que entendem, equivocadamente, em nossa opinião, que o Código Tributário Nacional, em seu artigo 106, institui o efeito retroativo para algumas hipóteses. A redação deste dispositivo é a seguinte:

“Art. 106. A lei aplica-se a ato ou fato pretérito:

I - em qualquer caso, quando seja expressamente interpretativa, excluída a aplicação de penalidade à infração dos dispositivos interpretados;

II - tratando-se de ato não definitivamente julgado:

a) quando deixe de defini-lo como infração;

b) quando deixe de tratá-lo como contrário a qualquer exigência de ação ou omissão, desde que não tenha sido fraudulento e não tenha implicado em falta de pagamento de tributo;

c) quando lhe comine penalidade menos severa que a prevista na lei vigente ao tempo da sua prática.

Conforme já antecipamos, acreditamos que o artigo em comento não introduz, de forma alguma, uma hipótese de exceção ao princípio da irretroatividade ${ }^{379}$. Isto porque, em nenhum dos casos, a lei tributária posterior operará de forma a modificar ou desconstituir uma situação jurídica já aperfeiçoada (isto é, que já esgotou seus efeitos próprios), no passado. A norma prevista no artigo 106, como todas as normas tributárias, agem para o futuro. A diferença é que o referencial cronológico de sua aplicação é dado por fatos que ocorreram no passado. Analisemos, então, as hipóteses previstas nos três incisos.

exigiu tributos retroativamente dos proprietários de minas com o objetivo de arrecadar recursos em benefício de vítimas de doenças pulmonares causadas pelo trabalho em suas respectivas minas. PAULSEN, Leandro. Direito Tributário - Constituição e Código Tributário à Luz da Doutrina e da Jurisprudência. 9. ed. Porto Alegre: Livraria do Advogado/ESMAFE, 2007, p. 201-202. Sobre a possibilidade de tributação retroativa nos Estados Unidos: SILVA, Ênio Moraes da. Limites Constitucionais Tributários no Direito NorteAmericano. Curitiba: Juruá, 2001.

${ }^{379}$ Em sentido contrário: PAULSEN, Leandro. Direito Tributário - Constituição e Código Tributário à Luz da Doutrina e da Jurisprudência. 9. ed. Porto Alegre: Livraria do Advogado/ESMAFE, 2007, p. 824. 
O primeiro caso trata justamente das chamadas leis interpretativas. Cumpre deixar claro que, aqui, o CTN se refere às leis que são exclusivamente interpretativas, ou seja, aquelas que claramente visam esclarecer e suprir o que foi anteriormente legislado, resolvendo obscuridades e ambiguidades sem introduzir qualquer forma de direito novo para os cidadãos, mesmo que não haja o título de "exclusivamente interpretativa" no corpo da $1 \mathrm{ei}^{380}$. Ora, as leis interpretativas, por sua própria natureza, referem-se a situações passadas, uma vez que não há como interpretar algo que ainda não aconteceu. Assim, não se trata de conferir efeito retroativo a uma lei, mas sim de interpretar o conteúdo de uma outra lei, a qual necessariamente deve ser pré-existente. Reiteramos: não há como interpretar uma norma jurídica que ainda não existe no ordenamento. Logo, pela própria natureza da atividade interpretativa, entendemos que seria dispensável, a fim de evitar confusões conceituais, a menção ao suposto caráter "retroativo" de leis interpretativas. Isto porque elas não "retroagem" no sentido específico do termo, mas necessariamente se aplicam aos objetos que lhe são preexistentes, sejam eles fatos jurídicos ou mesmo outras leis.

Não obstante a crítica acima, entendemos ser correta a expressa exclusão das hipóteses de aplicação de penalidade à infração dos dispositivos interpretados, prevista no mesmo inciso I do artigo 106. Na realidade, entendemos que o enunciado em questão refere-se a uma parte da lei que sequer poderia ser considerada de interpretativa, eis que a interpretação visa somente ao esclarecimento, e não à modificação de situações jurídicas já constituídas, etapa esta que é posterior à interpretação. De fato, as leis são compostas de diversos artigos, sendo perfeitamente possível que uma parte da lei seja interpretativa e outra parte da mesma lei tenha caráter modificativo, inovando ou alterando situações preexistentes. No caso, a aplicação da lei acarretaria uma modificação de uma situação jurídica já aperfeiçoada no passado. Neste caso, sim, teríamos efeitos propriamente retroativos, e não simplesmente interpretativos, e ocorreria também uma violação ao ato jurídico perfeito e, consequentemente, uma violação à segurança jurídica.

Já a hipótese prevista no segundo inciso do artigo 106 trata da suposta "retroatividade" da lei mais benigna ao contribuinte. Aqui, ousamos discordar do grande

\footnotetext{
${ }^{380}$ BALEEIRO, Aliomar. Direito Tributário Brasileiro. 11. ed. Atual. por Misabel Derzi. Rio de Janeiro: Forense, 2005. p. 670.
} 
mestre Aliomar Baleeiro ${ }^{381}$ para afirmarmos que, novamente, não se trata de retroatividade normativa em sentido estrito. Isto porque se trata de "ato não definitivamente julgado", ou seja, que ainda não esgotou todas as instâncias e que se ainda não se aperfeiçoou, de forma que, desde já, não caberia falar em violação do ato jurídico perfeito, muito menos da coisa julgada. Trata-se, pois, de uma situação pendente de resolução. Por isso é que uma lei posterior que deixe de definir um fato anterior como infração, desde que o ato em questão ainda não tenha sido julgado, não está retroagindo, e, sim, sendo aplicado normalmente de forma mais benéfica ao infrator. O mesmo raciocínio se aplica, em nossa opinião, no que se refere à aplicação de leis mais benéficas, às outras duas hipóteses do inciso ${ }^{382}$.

Ainda sobre a questão envolvendo a suposta e excepcional "retroatividade" de algumas leis tributárias, é necessário esclarecer, outrossim, a dúvida relativa às leis que instituem anistias e remissões fiscais. Leis deste tipo contêm normas que, por sua própria natureza, que devem ser interpretadas e aplicadas tendo em conta fatos pretéritos, caso contrário, perderiam todo o seu sentido. Isso não significa que leis que conferem anistias ou remissões fiscais tenham o efeito de desconstituir ou modificar as situações aperfeiçoadas no passado, o que, de fato, não têm. Estas leis que concedem benefícios fiscais aos contribuintes, como todas as normas tributárias, agem apenas para o futuro, embora tenham como referencial fatos que ocorreram no passado, ou seja, dispensam o pagamento do tributo ou de multas decorrentes de fatos jurídicos tributários pretéritos, como uma forma de perdão de dívida, e não por meio da anulação da situação que deu origem às obrigações tributárias perdoadas. Portanto, não ocorre retroação da lei. Nestes casos, os fatos geradores que criaram as obrigações tributárias ocorreram perfeitamente, as obrigações foram exigidas da maneira correta segundo a lei, mas o contribuinte não teve condições de adimpli-las. São duas situações independentes: uma em que surge para o contribuinte o dever de pagar o tributo, e outra, em momento posterior, em que o contribuinte efetivamente paga o tributo devido. As leis de anistia e remissão fiscal não

\footnotetext{
${ }^{381}$ Baleeiro afirma, em sua obra Direito Tributário Brasileiro, que "O inciso II do art. 106 do CTN estabelece três casos de retroatividade da lei mais benigna aos contribuintes e responsáveis, desde que se trate de ato ainda não definitivamente julgado" (BALEEIRO, Aliomar. Direito Tributário Brasileiro. 11. ed. Atual. por Misabel Derzi. Rio de Janeiro: Forense, 2005. p. 670). Entendemos que esta afirmação contém um verdadeiro contra-senso, já que não há forma de haver retroatividade normativa se a lei anterior ainda não teve a sua aplicação definitivamente reconhecida pelas autoridades competentes.

382 "Não conseguimos ver qualquer diferença entre as hipóteses da letra a e da letra b. Na verdade, tanto faz deixar de definir um ato como infração, como tratá-lo como contrário a qualquer exigência de ação ou omissão.” MACHADO, Hugo de Brito. Curso de Direito Tributário. 12. Ed. São Paulo: Malheiros, 1997, p. 71.
} 
incidem sobre a obrigação tributária que já estava perfeitamente constituída, elas atuam sobre o momento posterior, perdoando o não-pagamento da dívida, e, não, desconstituindo a obrigação tributária. Portanto, não há qualquer possibilidade de ocorrer retroatividade muito pelo contrário - tais normas criam uma situação jurídica nova, cujos efeitos operam para o futuro, logo são plenamente dotadas de legitimidade.

Em razão disso, discordamos da afirmação de que, tal como ocorre no Direito Penal, em que a lei mais benéfica ao réu pode retroagir. No Direito Tributário não há retroatividade. O que pode ocorrer é a aplicação da norma jurídica posterior a fatos que ainda não estejam aperfeiçoados aos olhos da justiça, ou seja, que ainda não constituam atos jurídicos perfeitos.

Outro ponto que costuma gerar dúvidas é a interpretação do artigo 150, III, "a"383, da Constituição Federal, que consubstancia o princípio da irretroatividade tributária. O problema surge, precisamente, na determinação exata do momento da ocorrência do fato gerador. Isto porque, numa leitura rápida e desatenta do referido dispositivo, é possível confundir o momento da ocorrência do fato gerador com o aspecto temporal da regra matriz de incidência.

Contudo, a correta interpretação do dispositivo nos remete à análise do conceito de fato gerador, constante do artigo 114 do Código Tributário Nacional ${ }^{384}$, ou seja: fato gerador consiste na situação definida em lei como necessária e suficiente ao surgimento da obrigação tributária. Este é, na verdade, o critério material da regra matriz de incidência, e não o critério temporal.

De fato, existe um motivo para esta infeliz, porém comum, confusão de conceitos. É que, frequentemente o legislador se socorre às ficções jurídicas a fím de estabelecer com clareza o momento de ocorrência do fato gerador, de forma a facilitar a mensuração da obrigação tributária ${ }^{385}$. Desta forma, o momento temporal utilizado pela lei

\footnotetext{
383 “Art. 150. Sem prejuízo de outras garantias asseguradas ao contribuinte, é vedado à União, aos Estados, ao Distrito Federal e aos Municípios:

(...)

III - cobrar tributos:

1) em relação a fatos geradores ocorridos antes do início da vigência da lei que os houver instituído ou aumentado; (...)"

384 “Art. 114. Fato gerador da obrigação principal é a situação definida em lei como necessária e suficiente à sua ocorrência."
} 
para calcular o tributo não necessariamente corresponde ao momento de ocorrência do fato gerador, este entendido como o instante da efetiva ocorrência da situação definida em lei como necessária e suficiente ao aperfeiçoamento da obrigação tributária. Por isso é indispensável que o intérprete tenha cautela na hora de interpretar a legislação tributária.

Nesse sentido, o efeito mais pernicioso e mais indesejável desta confusão entre o aspecto temporal e o material da norma tributária consiste na chamada "retroatividade imprópria", ou "retrospectividade", que ocorre quando o fato gerador do tributo é do tipo complexivo ou sucessivo, isto é, que necessita se estender durante um período de tempo para se aperfeiçoar, e nesse interregno é alcançado por nova lei, que institui novo tributo ou aumenta o já existente. Segundo a "retrospectividade", a nova lei poderia retroagir e atingir o fato gerador anterior à sua vigência, em franca violação ao princípio da legalidade, à segurança jurídica, e à irretroatividade tributária propriamente dita. Para estes casos, uma maneira de se assegurar o respeito à irretroatividade quanto aos tributos cujos fatos geradores são complexivos, seria incluir a exigência de lei prévia ao início do seu período de aperfeiçoamento, como fizeram as constituições de Portugal $^{386}$ e da Itália $^{387}$. Por fim, cumpre mencionar que, mesmo nos países que não adotam a irretroatividade tributária como garantia constitucional, nos quais a tese da retrospectividade tributária seria, em tese, possível, haveria ainda o obstáculo da própria legalidade.

O princípio da não-supresa do contribuinte, no Brasil, conta ainda com a garantia da anterioridade de exercício e com a anterioridade nonagesimal, estabelecidas, respectivamente, no artigo 150, III, "b"388 (anterioridade geral) no artigo 150, III, "c" e

${ }^{385}$ Exemplo disso é o Imposto de Importação, cujo fato gerador considera-se ocorrido na data do registro da declaração de importação para fins de desembaraço aduaneiro, conforme o artigo 23 do Decreto Lei n. 37-66 (Regulamento Aduaneiro), o que não necessariamente coincide com o momento da importação em si.

386 Portugal: "Lei Geral Tributária, Art. 12. Aplicação da Lei Tributária no Tempo. I - As normas tributárias aplicam-se aos factos posteriores à sua entrada em vigor, não podendo ser criados quaisquer impostos retroactivos. 2 - Se o facto tributário for de formação sucessiva, a lei nova só se aplica ao período decorrido a partir da sua entrada em vigor. (...)”. PAULSEN, Leandro. Direito Tributário - Constituição e Código Tributário à Luz da Doutrina e da Jurisprudência. 9. ed. Porto Alegre: Livraria do Advogado/ESMAFE, 2007, p. 203.

${ }^{387}$ Itália: "Legge 27, de 31 de julho de 2000 - Statuto del contribuente - Art. 3. Salvo quando previsto dall'articolo 1, comma 2, le disposizioni tributarie no hanno effetto retroattivo. Relativamente ai tributi periodici le modifiche introdotte si applicano solo a partire dal periodo d'imposta sucessivo a quello in corso alla data di entrata in vigore delle disposizioni Che le prevedono." PAULSEN, Leandro. Direito Tributário - Constituição e Código Tributário à Luz da Doutrina e da Jurisprudência. 9. ed. Porto Alegre: Livraria do Advogado/ESMAFE, 2007, p. 203.

388 “Art. 150. Sem prejuizo de outras garantias asseguradas ao contribuinte, é vedado à União, aos Estados, ao Distrito Federal e aos Municípios: 
também no artigo 195, parágrafo $6^{0^{389}}$ (anterioridade nonagesimal), da Constituição de 1988.

O princípio da anterioridade geral ${ }^{390}$ (ou anterioridade de exercício ou anualidade) distingue-se da irretroatividade por determinar que a lei que cria ou majora o tributo deve ser anterior em relação à data inicial do exercício para a cobrança do tributo. Além da anterioridade geral, aos tributos brasileiros aplica-se também a anterioridade nonagesimal (art. 150, III, “c” e art. 195, parágrafo $6^{\circ}$, da CF/88), que estabelece um prazo mínimo de 90 dias para o início da cobrança das obrigações tributárias instituídas ou majoradas no exercício anterior. Além dos tributos novos ou majorados, a revogação ou redução de um benefício fiscal, que impliquem aumento da carga tributária para os contribuintes, também estão sujeitos à anterioridade. ${ }^{391}$

A anterioridade de exercício originou-se com o surgimento dos Estados de Direito, concomitantemente ao desenvolvimento das noções de legalidade e previsão orçamentária. Isto porque, naquela época, a legislação tributária e a orçamentria eram unificadas e eram votadas anualmente, de forma que os tributos cobrados em um determinado ano poderiam não ser os mesmos a serem cobrados no ano seguinte. Com a evolução do Direito, embora a necessidade de votação anual tenha permanecido

(...)

III - cobrar tributos:

(...)

1) no mesmo exercício financeiro em que haja sido publicada a lei que os instituiu ou aumentou;

2) antes de decorridos noventa dias da data em que haja sido publicada a lei que os instituiu ou aumentou, observado o disposto na alinea b; (Incluido pela Emenda Constitucional $n^{\circ} 42$, de 19.12.2003)"

389 “Art. 195. A seguridade social será financiada por toda a sociedade, de forma direta e indireta, nos termos da lei, mediante recursos provenientes dos orçamentos da União, dos Estados, do Distrito Federal e dos Municípios, e das seguintes contribuições sociais:

(...)

$\S 6^{\circ}$ - As contribuições sociais de que trata este artigo só poderão ser exigidas após decorridos noventa dias da data da publicação da lei que as houver instituído ou modificado, não se lhes aplicando o disposto no art. 150, III, " $b "$. ",

390 Alguns autores definem o princípio da anterioridade como um qualificador do princípio da irretroatividade. Nesse sentido, Luciano Amaro explica que "O princípio da anterioridade qualifica a irretroatividade da lei tributária: se a lei tributária cria ou majora tributo não sujeito àquele princípio, a irretroatividade é simples; se cria ou majora tributo por ele acobertado, a irretroatividade é qualificada, pois não basta a antecedência da lei em relação ao fato jurígeno, exigindo-se essa antecedência da lei em relação ao ano (ou exercício) da realização do fato." AMARO, Luciano da Silva. O imposto de renda e os princípios da irretroatividade e da anterioridade. São Paulo: RDT nº 25/6, pp. 151-152.

${ }^{391}$ Assim decidiu o STF, conforme demonstra o acórdão da ADIn MC 2.325-DF. 
relativamente à lei orçamentária ${ }^{392}$, com a independência da legislação tributária percebeuse que era preciso conferir-lhe caráter de permanência, de modo que se perdeu a necessidade de renovação anual das leis tributárias. Assim, os tributos passaram a ser os mesmos ao longo dos anos, então foi preciso criar um mecanismo que garantisse que o contribuinte não fosse surpreendido com uma nova exação inesperadamente. Este mecanismo foi, justamente, o princípio da anterioridade de exercício financeiro, passando a proteger o futuro do contribuinte, enquanto a irretroatividade já se encarregava de seu passado.

A seu turno, a anterioridade "nonagesimal", ou simplesmente "noventena" (art. 150, III, “c”, e 195, parágrafo $6^{\circ}$ da Constituição de 1988), é aplicável a todos os tributos e representa um reforço à anterioridade geral de 1 ano. Este "reforço", inovação da Constituição brasileira, é necessário porque apenas a anterioridade de exercício não era suficiente para evitar a surpresa tributária, já que, a rigor, uma lei que criasse ou elevasse tributos que fosse publicada em 31 de dezembro poderia entrar em vigor e ter plena eficácia já em $1^{\circ}$ de janeiro, surpreendendo os contribuintes sem qualquer desrespeito formal ao princípio da anterioridade. Mesmo assim, restaria violada a segurança jurídica e o contribuinte seria materialmente surpreendido. Em virtude disso, o legislador constitucional instituiu a "noventena", prazo de 90 dias que se soma à anterioridade de exercício, para quaisquer tributos, não apenas para as contribuições sociais do artigo 195.

Desta forma, enquanto a irretroatividade visa à proteção do passado do contribuinte, a anterioridade, em suas duas modalidades, visa à proteção de seu futuro imediato $^{393}$, tendo como objetivo evitar que o contribuinte seja surpreendido com uma

\footnotetext{
${ }^{392}$ Alguns países, contudo, ainda seguem uma linha tradicionalista e prevêem que a legislação tributária será renovada anualmente. Este é o caso da Bélgica e de Luxemburgo. Bélgica: "Article 171 [Annual Vote on Taxes] - (1) Taxes to the benefit of the State, the Community, or the Region are voted on an annual basis. (2) Rules which determine them remain valid for one year if they are not renewed." Luxemburgo: "Article 100 [Renewing Taxation] - Taxes for the benefit of the State are voted annually. Legislation introducing them remains in force for only one year, unless renewed. (...) Article 104 [Accounts, Budget] - Each year, the Chamber passes the Accounts Bill and votes the budget. All revenue and expenditure of the State is shown in the budget and in the accounts."

393 Embora a importância do princípio da anterioridade seja largamente reconhecida pela comunidade internacional, a Constituição da Índia expressamente prevê a possibilidade de aumento de tributos a qualquer tempo em seu artigo 271, referente às cobranças adicionais sobre tributos e obrigações devidos à União: Índia: "Art. 271. Surcharge on certain duties and taxes for purposes of the Union. Notwithstanding anything in articles 269 and 270, Parliament may at any time increase any of the duties or taxes referred to in those articles by a surcharge for purposes of the Union and the whole proceeds of any such surcharge shall form part of the Consolidated Fund of India."
} 
cobrança inesperada, permitindo, assim, que organize as suas finanças para que possa manter a sua dignidade pessoal e pagar suas obrigações tributárias.

\subsection{Vedação ao confisco}

Outro princípio que está diretamente relacionado com a interpretação jurídica é a chamada vedação ao efeito confiscatório ${ }^{394}$, que se encontra positivada na Constituição Federal de 1988 no artigo 150, IV $^{395} .{ }^{396}$ A vedação ao efeito confiscatório fundamenta-se no princípio da capacidade contributiva como forma de proporcionar a justa medida da tributação, visando proteger, especialmente, o direito de propriedade e a dignidade da pessoa humana.

$\mathrm{O}$ conceito de confisco corresponde à tomada compulsória de propriedade privada pelo Estado, sem a justa e devida indenização. Vê-se, portanto, que o confisco tem natureza punitiva. A partir deste conceito é possível concluir pela existência de duas modalidades de confisco: direto e indireto. A modalidade direta ocorre quando o Estado expropria o cidadão de seus bens, e a modalidade indireta, que entendemos seria mais corretamente denominada pela expressão "efeito confiscatório", ocorre por meio da tributação excessiva, desproporcionada e irrazoada, por parte do Estado.

O confisco, enquanto sanção tributária, não é condenável. Uma pena de perdimento de bens, quando devidamente aplicada, não é ilegítima nem ilegal. O que se condena é o efeito confiscatório obtido a partir da apropriação desmesurada pelo Estado do patrimônio dos contribuintes com o pretexto da tributação ${ }^{397}$. Nesta hipótese, ocorre uma

394 TORRES, Ricardo Lobo. A idéia de liberdade no Estado Patrimonial e no Estado Fiscal. Rio de Janeiro: Renovar, 1991. pp. 136-138.

395 “Art. 150. Sem prejuizo de outras garantias asseguradas ao contribuinte, é vedado à União, aos Estados, ao Distrito Federal e aos Municípios:

(...)

IV-utilizar tributo com efeito de confisco;"

${ }^{396}$ Há quem considere, entretanto, que a vedação ao confisco já existia na Carta de 1934: “Antes da $C F / 88, a$ nossa história constitucional apenas tratou o princípio do não confisco de forma expressa na Constituição de 1934. onde inclusive chegou a estabelecer parâmetros objetivos para a caracterização do efeito de confisco pela tributação. Em seu artigo 185 estabeleceu que nenhum imposto poderia ser elevado além de $20 \%$ do seu valor ao tempo do aumento." IATAROLA, Ana Cristina Silva. Capacidade Contributiva Princípio norteador de justiça tributária e sua limitação pelos direitos fundamentais: mínimo existencial versus não confisco tributário. Dissertacao de mestrado. Rio de Janeiro: Universidade Gama Filho. 2005. Disponível em http://www.dominiopublico.gov.br/download/texto/cp000807.pdf. Acesso em 05 jun. 2009.

397 No Direito Comparado esta distinção entre confisco e efeitos confiscatórios da tributação também é utilizada. Por exemplo, a Constituição da Espanha veda expressamente a tributação com alcance 
grave violação da capacidade contributiva do cidadão, violando também a proteção ao mínimo existencial e ao direito de propriedade, e, desta forma, restará seriamente comprometida a justiça fiscal. Em poucas palavras, tributo confiscatório é aquele que não observa os limites da capacidade contributiva, esgotando ou reduzindo sensivelmente a riqueza tributável das pessoas, alcançando o mínimo vital ${ }^{398}$.

Assim como ocorre em relação à capacidade contributiva, a medida do que se deve considerar tributação com caráter confiscatório é difícil de ser precisada, e até hoje a legislação tributária brasileira não fixou um parâmetro quantitativo com este fim. Desta forma, o aplicador do direito se vê refém de uma expressão (confisco) demasiadamente ampla, que necessariamente requer uma interpretação argumentativa com base nos fatos para que se possa ter a exata medida do que deverá ser considerado confiscatório. Nesse sentido, segundo já ressaltado por Perelman:

"quando as condições de aplicação de uma lei estão definidas mais vagamente, aumenta-se o poder de apreciação do juiz; em contrapartida, se se quer diminuir esse poder de apreciação, devem-se precisar os termos da lei, substituindo, por exemplo, um critério qualificativo por um critério quantitativo (...). ${ }^{399, "}$

A lição de Perelman, acima transcrita, tem utilização prática nos Tribunais brasileiros. De fato, em acórdão relatado pelo Min. Celso de Mello, na ADI 2010, o Pleno do STF, aplicando o princípio da vedação ao confisco em matéria tributária, decidiu que o aumento da contribuição previdenciária do servidor público ao nível de $25 \%$, associado à alíquota de $27,5 \%$ do Imposto de Renda, tornava a tributação excessivamente onerosa para o contribuinte, violando o princípio da dignidade da pessoa humana ${ }^{400}$.

confiscatório, expressão esta que, segundo alguns autores, confere características quantitativas à vedação constitucional.

398 CARRAZZA, Roque Antônio. Imposto de renda-pessoa física. In: Revista de Direito Tributário $\mathrm{n}^{\circ} 74$. São Paulo: Malheiros, 1999, p. 41.

${ }^{399}$ PERELMAN, Chaïm. Ética e Direito. São Paulo: Martins Fontes, 2005. p. 486.

400 “A identificação do efeito confiscatório deve ser feita em função da totalidade da carga tributária de que dispõe o contribuinte - considerando o montante de sua riqueza (renda e capital) - para suportar e sofrer a incidência de todos os tributos que ele deverá pagar, dentro de determinado período, à mesma pessoa política que os houver instituído (a União Federal, no caso), condicionando-se, ainda, a aferição do grau de insuportabilidade econômico-financeira, à observância, pelo legislador, de padrões de razoabilidade destinados a neutralizar excessos de ordem fiscal eventualmente praticados pelo Poder Público.

Resulta configurado o caráter confiscatório de determinado tributo, sempre que o efeito cumulativo resultante das múltiplas incidências tributárias estabelecidas pela mesma entidade estatal - afetar 
Desta forma, a quantificação do que se pode considerar como efeito confiscatório depende de cada caso concreto, e embora a definição deste parâmetro seja um dos objetivos mais importantes do Direito Tributário, entendemos que, dada a variedade de tributos e de alíquotas vigentes no Direito brasileiro, seria inviável estabelecer a priori uma medida ${ }^{401}$. E, de fato, uma pesquisa nas constituições estrangeiras demonstra que a maioria dos países opta por uma previsão apenas genérica do principio da vedação ao confisco, assim como ocorre no Brasil. Este é o caso da Espanha ${ }^{402}$, do Paraguai $^{403}$, do Peru ${ }^{404}$ e da Venezuela ${ }^{405}$.

Na realidade, na prática, a determinação do ponto a partir do qual a tributação adquire caráter confiscatório depende das circunstâncias de cada contribuinte em face da legislação vigente, o que demonstra a real importância do juiz em seu papel de criar o direito mediante a jurisprudência. É importante deixar claro, entretanto, que é perfeitamente possível que se tenha uma tributação com carga total elevada, mas que seja,

substancialmente, de maneira irrazoável, o patrimônio elou os rendimentos do contribuinte.” ADI 2010, Tribunal Pleno - STF, Rel. Min. Celso de Mello, DJ de 28/03/2003, disponível em www.stf.jus.br.

${ }^{401}$ A determinação de um critério objetivo para melhor identificar o ponto a partir do qual a tributação teria efeito confiscatório já se faz presente em algumas constituições estrangeiras. Na Alemanha, a Constituição fixou como limite a alíquota total de $50 \%$ para a determinação de efeito confiscatório, isto é, lá, se a carga tributária sobre um contribuinte superar $50 \%$ dos seus rendimentos ("princípio da repartição pela metade"), a tributação é considerada confiscatória. Na Argentina este limite é ainda menor, tendo a Corte Suprema determinado que são considerados confiscatórios os impostos sobre o patrimônio que absorvam mais de $33 \%$ da renda do imóvel ${ }^{136}$. Diferentemente, na Espanha o Tribunal Superior de Justiça da Catalunha firmou o entendimento de que os impostos sobre os jogos de azar, aumentados em $300 \%$ sobre o montante das cotas únicas cobradas sobre as máquinas, possuíam caráter confiscatório. PAULSEN, Leandro. Direito Tributário: Constituição e Código Tributário à Luz da Doutrina e da Jurisprudência. 9. ed. Porto Alegre: Livraria do Advogado/ESMAFE, 2007, p. 222.

${ }^{402}$ Espanha: "Artículo 31. Todos contribuirán al sostenimiento de los gastos públicos de acuerdo con su capacidad económica mediante un sistema tributario justo inspirado en los principios de igualdad y progresividad que, en ningún caso, tendrá alcance confiscatorio."

${ }^{403}$ Paraguai: "Artículo 181 [De La Igualdad Del Tributo]. La igualdad es la base del tributo. Ningún impuesto tendrá carácter confiscatorio. Su creación y su vigencia atenderán a la capacidad contributiva de los habitantes y a las condiciones generales de la economía del pais."

${ }^{404}$ Peru: “Artículo 74․ “[...] Los Gobiernos Regionales y los Gobiernos Locales pueden crear, modificar y suprimir contribuciones y tasas, o exonerar de éstas, dentro de su jurisdicción, y con los límites que señala la ley. El Estado, al ejercer la potestad tributaria, debe respetar los principios de reserva de la ley, y los de igualdad y respeto de los derechos fundamentales de la persona. Ningún tributo puede tener carácter confiscatorio."

${ }^{405}$ Venezuela: “Artículo 317. No podrá cobrarse impuesto, tasa, ni contribución alguna que no estén establecidos en la ley, ni concederse exenciones y rebajas, ni otras formas de incentivos fiscales, sino en los casos previstos por la ley que cree el tributo correspondiente. Ningún tributo puede tener efecto confiscatorio." 
ao mesmo tempo, legítima, sem feições confiscarias. Basta que o contribuinte efetivamente seja beneficiado com a contrapartida estatal vinculada à tributação.

Porém, se o contribuinte é submetido a uma carga tributária altíssima e não recebe os serviços que, supostamente, paga para que o Estado lhe forneça, é razoável admitir que, embora não se declare abertamente seu caráter punitivo, a tributação assume, sim, características confiscatória, já que o contribuinte tem severamente restrito o seu direito de propriedade, sendo violada, igualmente, a dignidade da pessoa humana. Como bem salientado pela Professora Misabel Derzi, o que a norma do artigo 150, IV, da Constituição Federal, veda é que o tributo gere os mesmos efeitos econômicos que o confisco, que é uma penalidade, geraria ${ }^{406}$.

De fato, a definição do efeito de confisco, para os fins do art. 150, IV, da $\mathrm{CF} / 88$, é de caráter cumulativo, conforme já se firmou na jurisprudência do STF. Em outras palavras: não se exige que um tributo tenha, isoladamente, efeitos confiscatórios: se o conjunto dos tributos impostos aos cidadãos resultar em oneração excessiva, violando a capacidade contributiva, isto já constitui fato suficiente para a caracterização da tributação com efeitos confiscatórios. Nesse sentido, mesmo antes de a vedação ao confisco ser elevada à categoria de princípio constitucional, a doutrina já entendia pela proibição implícita de tributos com efeitos confiscatórios, como informa Aliomar Baleeiro, em relação à Constituição de 1969:

"Dentre os efeitos dos arts. 153, $\S \S 1^{\circ}, 11$ e 22, se inclui (sic) o da proibição de tributos confiscatórios, como tais entendidos os que absorvem parte considerável do valor da propriedade, aniquilam a empresa ou impedem exercício de atividade lícita e moral ${ }^{, 407}$.

E foi justamente por isso que na Constituição de 1988 o legislador utilizou a expressão efeito de confisco, ao invés de proibir simplesmente o confisco. Isto porque, como já mencionamos, o confisco, enquanto sanção penal tributária, não é vedado pelo ordenamento. Além disso, é possível concluir que a menção à expressão efeito de confísco indica que não se veda apenas a expropriação total dos bens do contribuinte, mas também a apropriação desarrazoada, excessiva, de seu patrimônio e de sua renda. Em face dessa

\footnotetext{
${ }^{406}$ BALEEIRO, Aliomar, Limitações Constitucionais ao Poder de Tributar, $7^{\mathrm{a}}$ ed. revista e complementada por Misabel Abreu Machado Derzi, Rio de Janeiro: Forense, 2006. p. 573.

407 GOLDSCHMIDT, Fabio Brun. O Princípio do não-confisco no Direito Tributário. São Paulo: Editora Revista dos Tribunais, 2004. p. 564.
} 
característica, percebe-se que o efeito confiscatório pode já estar configurado em momento bem anterior à completa expropriação, encontrando nesta o seu limite máximo ${ }^{408}$.

Outra questão interessante envolvendo a vedação ao caráter confiscatório consiste na aplicação ou não do princípio às multas tributárias. A doutrina é bastante dividida. Enquanto uns entendem que o princípio não deve ser aplicável às multas, dado o seu caráter punitivo, que é essencialmente diferente do caráter de dever solidário da tributação; outros defendem que o princípio da capacidade contributiva e da proteção à propriedade privada e ao mínimo existencial são valores que se situam acima do caráter punitivo das multas, e desta forma, as sanções pecuniárias tributárias também não poderiam ter caráter confiscatório. O STF adota o segundo posicionamento, como demonstra a decisão proferida na ADI 1.075-DF ${ }^{409}$. Particularmente, também somos partidários desta segunda corrente, uma vez que, independente da natureza ou da origem da obrigação, ou seja, tratando-se de tributo ou de multa, ambos podem violar seriamente não apenas a capacidade contributiva, mas também a igualdade, a razoabilidade e o direito de propriedade, em, em última (e mais importante) instância, a própria dignidade da pessoa humana.

${ }^{408}$ GOLDSCHMIDT, Fabio Brun. O Princípio do não-confisco no Direito Tributário. São Paulo: Editora Revista dos Tribunais, 2004. pp. 50-51.

409 “A TRIBUTAÇÃO CONFISCATÓRIA É VEDADA PELA CONSTITUIÇÃO DA REPÚBLICA. É cabivel, em sede de controle normativo abstrato, a possibilidade de o Supremo Tribunal Federal examinar se determinado tributo ofende, ou não, o princípio constitucional da não-confiscatoriedade consagrado no art. 150, IV, da Constituição da República. Hipótese que versa o exame de diploma legislativo (Lei 8.846/94, art. $3^{\circ}$ e seu parágrafo único) que instituiu multa fiscal de $300 \%$ (trezentos por cento).

A proibição constitucional do confisco em matéria tributária - ainda que se trate de multa fiscal resultante do inadimplemento, pelo contribuinte, de suas obrigações tributárias - nada mais representa senão a interdição, pela Carta Política, de qualquer pretensão governamental que possa conduzir, no campo da fiscalidade, à injusta apropriação estatal, no todo ou em parte, do patrimônio ou dos rendimentos dos contribuintes, comprometendo-lhes, pela insuportabilidade da carga tributária, o exercício do direito a uma existência digna, ou a prática de atividade profissional licita, ou, ainda, a regular satisfação de suas necessidades vitais básicas." ADI-MC 1.075-DF, Tribunal Pleno, STF, DJ 24/11/2006. 


\section{AS CONVENÇÕES CONTRA A DUPLA TRIBUTAÇÃO INTERNACIONAL}

\subsection{O Direito Tributário Internacional e o Direito Tributário Interno}

O Direito Tributário Internacional corresponde ao ramo do Direito responsável pela sistematização das normas que visam limitar o exercício da soberania físcal e do Estado. Assim, o Direito Tributário Internacional pode atuar delimitando a aplicação tanto das suas próprias normas, ou seja, daquelas oriundas de tratados, acordos e convenções, quanto limitando a aplicação das normas do Direito Tributário Interno.

Como não há regras ou princípios tributários que proíbam a bitributação, revela-se a importância do Direito Tributário Internacional, ao qual cabe evitar ou minimizar o referido fenômeno, justamente por meio da limitação do exercício da soberania fiscal dos Estados.

Por suas características, o Direito Tributário Internacional relaciona-se tanto com Direito Internacional Público quanto com o Direito Internacional Privado.

Relaciona-se com o primeiro na medida em que as fontes de suas normas são os tratados internacionais. De fato, o Direito Tributário Internacional é qualificado de "internacional" em virtude da fonte de produção de suas normas, qual seja, os tratados internacionais tributários. Estes surgem a partir da comunhão de vontades das pessoas de Direito Internacional Público - os Estados. Assim, observa-se que as normas do Direito Internacional Tributário possuem sua validade fundada nos princípios e regras do ordenamento internacional $^{410}$. Entretanto, é necessário notar que, por serem oriundas de tratados internacionais, estas normas dependem do ordenamento interno para que possuam validade dentro de cada Estado e também eficácia ${ }^{411}$.

\footnotetext{
410 "A validade responde pela relação de pertinencialidade de normas a um dado ordenamento jurídico e a pergunta legítima deve ser a seguinte: existe um ordenamento jurídico internacional, apto à produção de normas de conduta dirigidas a Estados soberanos? A resposta é sim, existe esse ordenamento, porque toda e qualquer ordem soberana coloca-se na ambiência interestatal com responsabilidade e respeito às demais ordens jurídicas e soberanas existentes." TORRES, Heleno Taveira. Pluritributação Internacional sobre as Rendas de Empresas. 2. ed. rev., ampl. e atual. São Paulo: Revista dos Tribunais, 2001. p. 57.
}

411 “Essa divisão teórica relativa ao Direito Tributário, quanto aos seus aspectos internacionalísticos, apresenta-se plenamente de acordo com a teoria dualista (pluralismo de ordens jurídicas), segundo a qual o direito interno e o direito internacional são ordens diversas e como tais devem ser tratadas diversamente pelos critérios metodológicos e técnicos específicos a cada uma. (...) É que, quanto à validade, a dualidade entre direito interno e internacional só é aceitável se se faz referência à existência de procedimentos e 
O Direito Tributário Internacional também se relaciona com o Direito Internacional Privado. Efetivamente, estes dois ramos se aproximam na medida em que ambos regulamentam fatos ou situações que produzem efeitos fora das fronteiras territoriais de um Estado. Outra similitude entre o Direito Tributário Internacional e o Direito Internacional Privado se deve ao fato de ambos têm origem em acordos internacionais, sendo semelhantes também os seus respectivos domínios de aplicação.

Entretanto, as diferenças entre estes dois ramos do Direito são igualmente relevantes. Assim, o Direito Tributário Internacional distancia-se do Direito Internacional Privado pelo fato de possuir normas que objetivam à solução de situações de concorrência (e não de conflito) na aplicação de normas de Direito material (no caso, do Direito Tributário interno de cada Estado). Em outras palavras, ao atuar solucionando concorrência de normas (também mencionadas pela doutrina como "cúmulo de pretensões impeditivas"), o Direito Tributário Internacional delimita o exercício da soberania tributária dos Estados, e, assim, diferencia-se do Direito Internacional Privado, uma vez que este trata não da concorrência de normas, mas, sim, do conflito entre ordenamentos jurídicos dos países em relação a uma mesma situação internacional.

Explicando as distinções entre o Direito Tributário Internacional e o Direito Internacional Privado, o Professor Manuel Pires ensina que:

"Entre diversas diferenças, indica-se que o Direito Internacional Privado opta entre duas leis contraditórias susceptiveis de se aplicar, enquanto que o direito

autoridades competentes diversos para o ato de produção de normas. (...) O ordenamento interno, que é presidido pela Constituição, se perfaz pela composição de dois grupos normativos: o grupo de normas legisladas, produzidas de acordo com as prescrições do processo legislativo estabelecido pela Constituição (válidas internamente), e o grupo de normas (também internas) integradas por normas internacionais, cuja validade advém de procedimentos específicos da comunidade internacional e cuja aplicabilidade depende dos mecanismos adotados na Constituição de cada Estado para sua admissão sistêmica (incorporação ou recepção), qualidade esta (a aplicabilidade) que as normas internas receberam da Constituição. Esta digressão é necessária haja vista ser o Direito Internacional um ordenamento incompleto porque, apesar de capacitado para a produção de normas válidas, é dependente dos ordenamentos internos para fins de aplicabilidade, por ser esta uma forca que só a ordem nacional está em condições de administrar: a da eficácia das normas. Por este motivo, há quem defina o Direito Internacional como sendo um sistema autônomo, não disponível totalmente pelo sistema jurídico nacional, de produção de normas eventualmente integrantes dos ordenamentos internos. (...) Como mencionado, temos um grupo de normas exclusivamente de Direito interestatal ou supra-estatal, dirigidas precipuamente a regular a atuação dos vários Estados (em matéria tributária) no âmbito da comunidade internacional. Estas são as normas do Direito Internacional Tributário, entendendo-se aqui o termo 'Internacional' como conotativo da fonte de produção normativa, externa ao sistema, por serem produzidas por fontes normativas distintas, dependentes de comunhão de vontades das pessoas de direito público internacional cuja validade interna se perfaz exclusivamente pelos efeitos de recepção ou incorporação do diploma internacional ao direito interno." TORRES, Heleno Taveira. Pluritributação Internacional sobre as Rendas de Empresas. 2. ed. rev., ampl., atual. São Paulo: Revista dos Tribunais, 2001. p. 54 -57. 
internacional fiscal não visa regular a contradição entre duas normas. Assim, o direito internacional privado deve determinar para cada relação jurídica uma lei aplicável, que pode ser estrangeira, ao contrário do Direito internacional fiscal, que pode conduzir à aplicabilidade de várias regras.

Escreve-se ainda que o direito internacional privado é um direito de aplicação (...), porque estabelece normas que determinam o sistema legal competente, diferentemente do direito internacional fiscal, que procura determinar se é aplicável o próprio direito (caráter universal). Este não escolhe a lei, mas limita-a (...), contendo os tratados de dupla tributação normas unilaterais aceites em conjunto por dois Estados. "412

Por isso entendemos ser incorreto afirmar que as normas dos tratados internacionais tributários, dentre eles os tratados de bitributação, possuam natureza de normas de conflito.

Os princípios tributários se aplicam normalmente ao Direito Tributário Internacional, e dentre eles, destacam-se os princípios da territorialidade, universalidade, isonomia, boa fé, pacta sunt servanda e legalidade estrita. Este último, inclusive, é o que justifica o fato de os tratados tributários serem tão extensos e detalhados na redação de suas normas.

Os tratados, acordos e convenções tributárias que formam a base normativa do Direito Tributário Internacional apresentam sempre dois tipos de normas. As primeiras são as chamadas normas de qualificação, encarregadas de definir os tipos de rendimento aos quais se aplicam as normas convencionais, às quais cabe ainda estabelecer as condições em que referidos rendimentos podem ser tributáveis, enquanto que o segundo conjunto de normas engloba as normas materiais, que modificam aspectos da regra matriz de incidência dos tributos abrangidos pela convenção durante a sua aplicação. Estas normas do Direito Tributário Internacional têm sua aplicabilidade condicionada à verificação de um elemento de conexão, como, por exemplo, a residência, o domicílio ou a fonte. Os elementos de conexão são, desta forma, responsáveis por fixar a ligação entre o fato tributável dotado de elemento de estraneidade e o ordenamento jurídico interno do país de forma a possibilitar e legitimar a tributação internacional.

412 PIRES, Manuel. Da Dupla Tributação Jurídica Internacional sobre o Rendimento. Lisboa: Centro de Estudos Fiscais , Ministério das Finanças, 1984. p. 469-471. 
Contudo, é importante lembrar que as normas internacionais, do mesmo modo como as nacionais, sofrem limitações de ordem formal e material ao incidir sobre os fatos jurídicos de que tratam. As limitações formais dizem respeito às competências e conceitos de validade $^{413}$, vigência ${ }^{414}$ e eficácia ${ }^{415}$, enquanto que os limites materiais relacionam-se com as regras de qualificação dos conceitos que as compõem.

Revela-se, desta forma, a importância da definição do âmbito de validade das normas internacionais em face das nacionais. Em outras palavras, trata-se de estabelecer se podem ser considerados válidos, em face do Direito interno, conceitos, formas e institutos

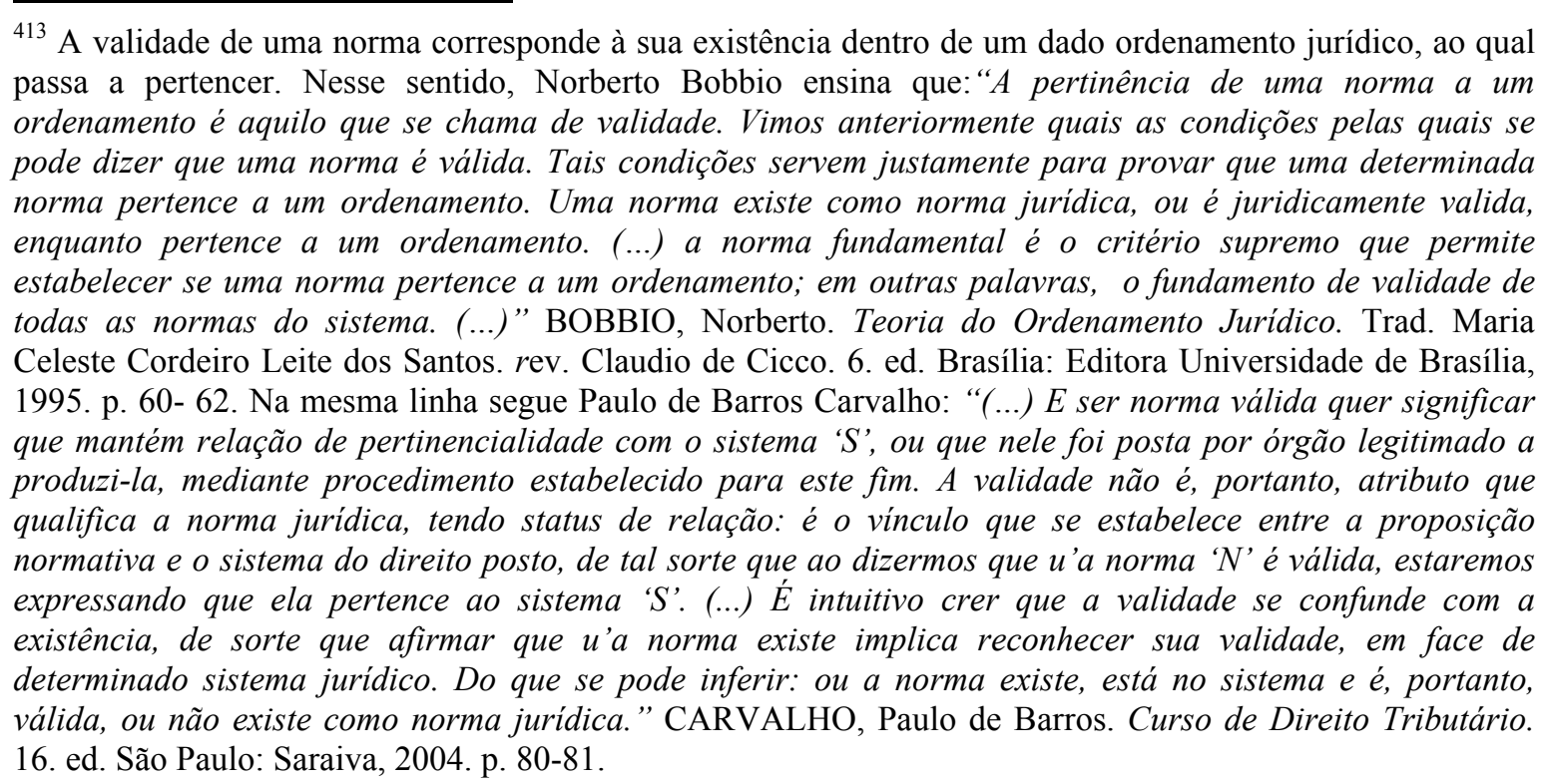

414 "Viger é ter força para disciplinar, para reger, cumprindo a norma seus objetivos finais. A vigência é propriedade das regras jurídicas que estão prontas para propagar efeitos, tão logo aconteçam, no mundo fático, os eventos que elas descrevem. (...) A vigência não se confunde com a eficácia. U'a norma pode estar em vigor e não apresentar eficácia técnica (sintática ou semântica) e, igualmente, não ostentar eficácia social. Pode por outro lado, não estar em vigor, apresentando, porém, eficácia técnica e social. Todavia, é bom repetir que não cabe falar de norma válida e vigente como dotada, ou não, de eficácia jurídica, já que tal caráter é qualidade de fatos jurídicos, não de normas. (...)"CARVALHO, Paulo de Barros. Curso de Direito Tributário. 16. ed. São Paulo: Saraiva, 2004. p. 84.

${ }^{415}$ A eficácia de uma norma corresponde à sua capacidade de produzir efeitos, e pode ser analisada sob três aspectos, quais sejam: a eficácia jurídica, a eficácia técnica e a eficácia social, como esclarece Paulo de Barros Carvalho: "Eficácia jurídica é a propriedade de que está investido o fato jurídico de provocar a irradiação dos efeitos que lhe são próprios, ou seja, a relação de causalidade jurídica.(...) Sob a rubrica de eficácia técnica vemos a condição que a regra de direito ostenta, no sentido de descrever acontecimentos que, uma vez ocorridos no plano do real-social, tenham o condão de irradiar efeitos jurídicos, já removidos os obstáculos de ordem material que impediam tal propagação.(...) A eficácia social ou efetividade, por sua vez, diz respeito aos padrões de acatamento com que a comunidade responde aos mandamentos de uma ordem jurídica historicamente dada. Indicaremos como eficaz aquela norma cuja disciplina foi concretamente seguida pelos destinatários, satisfazendo os anseios e as expectativas do legislador (...). ”CARVALHO, Paulo de Barros. Curso de Direito Tributário. 16. ed. São Paulo: Saraiva; 2004. p. 8283. 
firmados convencionalmente em acordos internacionais, determinando-se, deste modo, a posição hierárquica ocupada pelos tratados internacionais em relação ao Direito interno ${ }^{416}$.

\subsubsection{Monismo $x$ Dualismo: ainda seria importante esta dicotomia?}

Para fixar a posição hierárquica ocupada pelas normas do Direito Tributário Internacional, ou seja, aquelas oriundas de tratados internacionais tributários, em relação ao Direito interno, é necessário, antes de mais nada, verificar a relação existente entre o Direito internacional e o Direito interno e, assim, determinar a situação das normas internacionais em relação ao ordenamento jurídico nacional.

O Direito internacional e o Direito nacional compreendem conjuntos de normas que possuem relações entre si. É comum ilustrar tal situação com a figura de duas esferas que podem ser tangentes ou interconexas, sobrepondo-se em parte uma da outra.

A simbologia das esferas tangentes ilustra o raciocínio desenvolvido de acordo com a Teoria Dualista, corrente de pensamento derivada da concepção voluntarista do Direito que teve origem na Alemanha e na Itália, com os estudos de $\operatorname{Triepel}^{417}$ e Anzilotti $^{418}$, segundo a qual a ordem jurídica internacional e a interna são absolutamente distintas e paralelas, sendo completamente independentes entre si. Em decorrência desta independência e da posição paralela dos sistemas em questão, não haveria possibilidade lógica de ocorrerem conflitos entre as normas do direito interno e do direito internacional, sendo igualmente impossível a existência de relações hierárquicas entre as normas de um e de outro sistema.

De acordo com a doutrina dualista, os tratados internacionais não são imediatamente aplicáveis na ordem interna, devendo eles ser necessariamente introduzidos

\footnotetext{
416 As expressões "Direito interno" e "Direito Internacional" são aqui grafadas desta maneira porque designam, respectivamente, o ordenamento jurídico interno de cada país e o ramo autônomo da Ciência do Direito dedicado ao estudo das normas jurídicas internacionais.

${ }^{417}$ Em sua concepção original, a Teoria Dualista de Triepel representava uma forma de reafirmar a existência do Direito Internacional como ramo do Direito, oponível a quem violasse as normas internacionais, revelando uma visão bastante positivista de Triepel. TRIEPEL, Heinrich. Völkerrecht und Landersrecht. Leipzig: Verlag C.L. Hirschfed, 1899, apud STIRK, Peter M. R. Twentieth-century German political thought. Edinburgh: Edinburgh University Press, 2006. p. 39.

418 ANZILOTTI, Dionísio. Il diritto Internazionale nel giudizi interni. Bologna: Ditta Nicola Zanichelli, 1905.
} 
no sistema interno por meio de um ato normativo nacional, aplicando-se a chamada Teoria da Incorporação.

Efetivamente, os seguidores da corrente dualista entendem que os fundamentos de validade das normas internacionais e das normas internas são distintos. Analisando este aspecto, o professor Heleno Torres destaca que a fonte de produção das normas internacionais deriva do princípio do pacta sunt servanda, e a sua formação atende a critérios específicos, definidos em estatutos supra-estatais, como por exemplo, a Carta da Organização das Nações Unidas (ONU), enquanto que a fonte das normas internas é baseada no ordenamento jurídico nacional de cada Estado. Em virtude desta diferença de fundamentos de validade, as relações entre o Direito Internacional e o Direito interno somente podem ser classificadas como sendo de aplicabilidade, e não de validade $^{419}$.

Conforme já mencionado acima, seguindo o raciocínio dualista, as normas oriundas de tratados internacionais somente poderiam ter eficácia internamente se e quando fossem recepcionadas por normas internas especificamente responsáveis por sua introdução no ordenamento nacional. Deste modo, no caso dos tratados internacionais tributários celebrados pelo Brasil, suas normas adquiririam aplicabilidade interna a partir do momento que fossem nacionalizadas por meio de um Decreto Legislativo editado pelo Congresso Nacional.

Apesar de ser uma corrente de pensamento amplamente difundida no Brasil, o raciocínio dualista, quando aplicado ao Direito Tributário brasileiro, gera polêmica em relação à norma contida no artigo $98^{420}$ do Código Tributário Nacional (CTN). Isto porque, segundo o referido artigo, os tratados internacionais tributários revogam ou modificam a legislação tributária interna, devendo ser observados pela lei que lhes sobrevenham.

Em outras palavras, o Direito Tributário brasileiro coloca os tratados internacionais tributários em posição hierarquicamente superior à legislação interna, com

\footnotetext{
${ }^{419}$ Heleno Torres explica que "do principio da separação entre os dois ordenamentos deriva, pois, que as normas internas não podem dispor sobre preceitos de Direito Internacional e, reciprocamente, que as normas internacionais não podem substituir as fontes do direito interno, salvo estipulação consentânea em contrário. Por este motivo, entre ambas existem relações de aplicabilidade, mas não de validade. Uma norma interna pode ser usada para admitir a entrada sistêmica de uma norma internacional ou dizer da sua inaplicabilidade, mas, não pode se referir à sua validade ou colocar esta em questão." TORRES, Heleno Taveira. Pluritributação Internacional sobre as Rendas de Empresas. 2. ed. rev. ampl. e atual. São Paulo: Revista dos Tribunais, 2001. p. 556.

420 “Artigo 98 - Os tratados e as convenções internacionais revogam ou modificam a legislação tributária interna, e serão observados pela que lhes sobrevenha."
} 
poder para revogá-la total ou parcialmente, devendo ser observados, inclusive, pela legislação superveniente. Com isso, acaba se estabelecendo uma relação de validade entre as normas tributárias internas e aquelas oriundas de tratados internacionais, e não apenas de aplicabilidade, como seria o normal. É neste ponto que surge a polêmica: se, de acordo com o dualismo, os tratados $\mathrm{e}$ as normas internas pertencem a esferas distintas $\mathrm{e}$ independentes, não seria possível existir hierarquia entre ambos. Em face disso, autores declaradamente dualistas ${ }^{421}$ defendem que a norma contida no artigo 98 do CTN seria inconstitucional. E é exatamente a partir daí que surge a controvérsia do posicionamento hierárquico dos tratados internacionais tributários no ordenamento jurídico brasileiro. ${ }^{422}$

Como se vê, a doutrina dualista não é perfeita. $\mathrm{Na}$ realidade, esta corrente, apesar de ser largamente difundida, é alvo de críticas por não ser capaz de explicar temas importantes do Direito Internacional, como é o caso da validade do costume como fonte de normas internacionais, e também a questão da personalidade jurídica das organizações

421 “Percebemos, pois, que é inconstitucional o artigo 98 do Código Tributário Nacional quando prescreve $q u e$ 'os tratados e as convenções internacionais revogam ou modificam a legislação tributária interna, e serão observados pela que lhes sobrevenha'. Particularmente inaceitável, ao lume de nossa Constituição, a idéia de que os tratados 'revogam ou modificam a legislação tributária interna e serão observados pela que lhes sobrevenha'." CARRAZZA, Roque Antônio. Curso de Direito Constitucional Tributário. 20. ed. São Paulo: Malheiros, 2004. p. 218.

${ }^{422}$ A dicotomia entre as teorias monista e dualista já foi analisada pelo STF, que, em 1977, seguiu a linha dualista: "Entre nós, Amílcar de Castro, um dos maiores estudiosos do Direito Internacional no Brasil, filiando-se à segunda corrente, teve oportunidade de escrever: 'o direito internacional privado, para quem o considere setor da ordem jurídica nacional, não pode, como direito positivo, emanar diretamente de tratado. Este só opera na ordem internacional, que é independente da nacional, e entre ordens independentes não podem as normas de um provir de outra. É aceitável, por isso, a opinião de Ansilotti (sic) no sentido de que 'as normas internacionais não podem influir sobre o valor obrigatório das normas internas e vice-versa'. É certo que, em torno dos efeitos dos tratados, duas teorias se formaram: uma a afirmar que o tratado, por si mesmo, desde o instante em que entra regularmente em vigor, e tenha sido publicado, é fonte formal de direito nacional, obrigando diretamente particulares e tribunais a obedecê-lo, sem a necessidade do permeio de ato legislativo (lei ou decreto); outra a dizer que, ratificado e publicado, obriga o governo na ordem internacional, mas ainda não converte o que foi convencionado em direito positivo nacional, que imponha a povo e aos tribunais, havendo necessidade de procedimento especial de adaptação do direito nacional ao internacional, denominado ordem de execução. E esta última doutrina é a verdadeira: tratado não é lei, é ato internacional que obriga o povo considerado em bloco, que obriga o governo na ordem externa, e não o povo na ordem interna. Não é admissível, que um só ato, ao mesmo tempo, possa ser tratado e ato legislativo ordinário; nem se concebe que um tratado normativo se converta em ato legislativo (lei ou decreto), formas jurídicas inconfundiveis e inconversíveis, cada qual com sua esfera própria de ação. O tratado explana relações entre governantes (horizontais, sendo as pessoas coordenadas), enquanto que a lei e o decreto explicam relações do governo com seus súditos (verticais, entre subordinante e subordinados). Por conseguinte, as regras de direito internacional privado contidas em tratado normativo, para se converterem em direito nacional e serem, então, obedecidas pelo povo e pelos tribunais, devem ser postas em vigor por uma ordem de execução. E assim, sendo fonte formal de direito internacional privado, é sempre essa ordem de execução, ato praticado com base no direito nacional, nunca tratado normativo baseado no direito das gentes. O tratado normativo é fonte de direito internacional, só obriga o governo no meio internacional (para fora), mas não é fonte de direito nacional, nem obriga os particulares individualmente considerados (para dentro).' CASTRO, Amilcar de. Direito Internacional Privado, v.1.n.55. p.126. BRASIL. Tribunal Pleno, STF. RE 80.004/SE, Relator para o acordão Ministro Cunha Peixoto, Diário da Justiça de 29 dez/1977. p.25-27 do acordão. 
internacionais, ou ainda a frequente aplicação direta de normas internacionais por tribunais internos sem os necessários atos de recepção e transformação destas para o direito interno.

Por outro lado, a Teoria Monista, cujos mais conhecidos defensores são Hans Kelsen e seu discípulo Alfred Verdross ${ }^{423}$, estabelece uma concepção unitária do Direito, determinando a existência de apenas uma única e indivisa ordem jurídica ${ }^{424}$. Assim, em virtude da unicidade do sistema jurídico, é possível falar na existência de relações de hierarquia e subordinação entre normas nacionais e internacionais, podendo ocorrer a primazia do Direito interno ou do Direito internacional, conforme a opção legislativa de cada Estado. Em face desta característica, a Teoria Monista pode ser subdividida em três linhas derivadas: (i) Monismo com primado do Direito interno, (ii) Monismo com primado do Direito Internacional e (iii) monismo moderado. ${ }^{425}$

O Monismo com primado do Direito interno considera que o fundamento do Direito Internacional está no Direito interno dos Estados, negando ao Direito Internacional, desta forma, o status de ramo autônomo da Ciência do Direito. Isto porque, segundo esta corrente, o Direito Internacional teria surgido em decorrência da autolimitação das

\footnotetext{
${ }^{423}$ Segundo Verdross, o Direito internacional possui uma forma de "constituição" que não é escrita, como se verifica na maioria dos Estados Modernos e na Liga das Nações, mas, sim, é uma constituição baseada no direito costumeiro internacional, o qual, por sua vez, tem seu fundamento nos princípios do direito internacional, formando, desta forma, um sistema unificado de normas que é seguido pela comunidade internacional. FASSBENDER, Bardo. UN security council reform and the right of veto: a constitutional perspective. The Hague/Netherlands: Kluwer Law International, 1998. p. 37-39.
}

${ }^{424}$ Dentre os monistas contemporâneos, mencionamos Alberto Xavier (XAVIER, Alberto. Direito Tributário Internacional do Brasil. 6.ed. reform. e atual. Rio de Janeiro: Forense, 2007.) (SANTIAGO, Igor Mauler. Direito Tributário Internacional:- Métodos de Solução dos Conflitos. São Paulo: Quartier Latin, 2006.p. 32).

${ }^{425}$ Analisando a teoria monista e suas variantes, Toru Yamamoto explica que: "O monismo pressupõe a unidade do conjunto de normas jurídicas, de onde decorre o princípio da subordinação, segundo o qual todas as normas jurídicas são subordinadas entre si, umas às outras, dentro de uma ordem rigorosamente hierárquica; logo, dependendo da escolha do ponto de partida, comporta divisão em monismo com primado do direito internacional e monismo com primado do direito interno; mas, seja no um como no outro, sustenta-se, na sintese de Vicente Marotta Rangel que: 'as dessemelhanças entre o Direito internacional e o Direito interno não são de essência, senão de grau, meramente acidentais, ou comportam conseqüências técnicas a que o Direito internacional recorre por motivos políticos ou constitucionais, como sucede com a teoria da transformação, a que tanta importância atribuíram os dualistas. A primeira é que 'os domínios de validade do Direito internacional são em princípio ilimitados, enquanto que o Direito nacional, concebido como o Direito de um Estado, vale somente para um território e para um período determinado'. A segunda consiste na relativa descentralização do Direito internacional e na relativa centralização do Direito interno. Imediatidade das normas internacionais em relação ao direito interno. Equiparação de sujeitos, fontes, objetos e estrutura das duas ordens jurídicas que se comunicam e se interpenetram. Necessidade de optar entre ordens jurídicas conflitantes. Eis os demais pontos defendidos pela Escola.'." YAMAMOTO, Toru. Direito Internacional e Direito Interno. Porto Alegre: Sérgio Antônio Fabris, 2000. p. 237-238. 
respectivas soberanias ${ }^{426}$, encontrando seu fundamento de validade na fixação da primeira Constituição histórica. A negação da existência do Direito Internacional como ramo autônomo da ciência jurídica, reduzindo sua análise apenas aos Direitos nacionais, tem acarretado diversas críticas à teoria monista com primado do Direito interno. Outro motivo de críticas a esta teoria consiste no fato de ela não explicar, por exemplo, o princípio da continuidade do Estado, segundo o qual os tratados celebrados pelos Estados não são afetados por modificações constitucionais supervenientes.

Por sua vez, o Monismo com primado do Direito Internacional fundamenta-se na existência de diferenças essenciais entre o Direito interno e o Direito Internacional. A própria noção de soberania dos Estados deve ser entendida de modo relativo, mais no sentido de competência do que como poder absoluto. Segundo Kelsen ${ }^{427}$, o fundamento de validade das normas internacionais, no caso do monismo com primado do Direito internacional, seria o próprio princípio pacta sunt servanda, que fornece o fundamento para a força obrigacional dos tratados em relação aos Estados que os celebram. Dito de outra forma, o fundamento de validade desta linha doutrinária seria a existência de uma norma fundamental em virtude da qual o costume dos Estados é um fato gerador de direitos, conforme as inclinações ético-políticas seguidas por cada um deles. Desta forma, a primazia pela ordem nacional ou internacional dependeria dos valores adotados pelos sujeitos de Direito: aqueles que consideram a soberania do Estado como o bem jurídico mais valioso, adotam o primado no Direito interno; já aqueles que acreditam na noção de uma organização internacional prevalecente sobre os interesses nacionais, adotariam o primado do Direito Internacional. Esta linha também é alvo de críticas, especialmente por sustentar a anterioridade do Direito internacional em relação ao Direito interno, o que contraria a própria linha da história.

\footnotetext{
426 CALIENDO, Paulo. Estabelecimentos Permanentes em Direito Tributário Internacional. São Paulo: Revista dos Tribunais, 2005. p. 164.

427 “(...) Uma das normas jurídicas de Direito internacional geral produzidas por via consuetudinária reconhece aos Estados poder para regular as suas relações mútuas através de tratados. Nesta norma consuetudinariamente criada têm o seu fundamento de vigência as normas jurídicas do Direito internacional criadas por tratados. Esta norma é usualmente formulada no princípio: pacta sunt servanda. Na norma fundamental pressuposta do Direito internacional que institui o costume dos Estados como fato gerador de Direito exprime-se um princípio que é o pressuposto fundamental de todo Direito consuetudinário - o indivíduo deve conduzir-se como os outros, na convicção de que assim devem proceder, costumam conduzirse - aplicado à conduta dos Estados uns em relação aos outros, isto é, à conduta dos indivíduos que, segundo a ordem jurídica estadual, são qualificados por determinada forma como órgãos, a saber, como órgãos do governo. (...)" KELSEN, Hans. Teoria Pura do Direito. Trad. João Baptista Machado. São Paulo: Martins Fontes, 1999 p. 162.
} 
Por fim, a terceira vertente da doutrina monista é denominada de Monismo moderado, as normas internas e internacionais são hierarquicamente equivalentes, e os eventuais conflitos decorrentes de sua aplicação devem ser resolvidos pela aplicação do princípio lex posteriori derrogat lex priori.

$\mathrm{Na}$ realidade, o grande problema advindo da aplicação do raciocínio monista puro é que, levado às últimas consequências, acarretaria a perda da vigência e eficácia de todos os tratados internacionais firmados por um país caso houvesse uma mudança radical em seu Direito interno. Em outras palavras, não há como garantir a segurança jurídica em relação à vigência e eficácia dos tratados internacionais. Em face desta crítica, os defensores da corrente sustentam que tal fato não ocorreria em virtude do princípio da continuidade, segundo o qual o Estado permanece obrigado a cumprir os tratados concluídos no regime jurídico anterior.

Há quem defenda ${ }^{428}$, ainda, a perda do sentido da dicotomia entre as teorias monista e dualista, tendo em vista que a questão envolvendo as normas de Direito Internacional e de Direito interno seria matéria tratada na Constituição de cada Estado. Deste modo, as normas introduzidas por tratados internacionais teriam que ser analisadas em face da constitucionalidade do tratado em si, e, assim, estar-se-ia analisando também a sua regularidade em face de todo o ordenamento interno.

Especificamente no caso do Brasil, a Constituição Federal de 1988 não trata do assunto expressamente, não havendo nela qualquer norma que permita claramente concluir pela adoção de uma ou outra teoria ${ }^{429}$. As construções doutrinárias a esse respeito são fruto da interpretação das normas constitucionais e internacionais. Dentre tais interpretações, entendemos ser correta aquela segundo a qual a Constituição brasileira teria seguido a corrente dualista ao prever normas que consubstanciam um procedimento específico para a recepção e consequente validade dos tratados internacionais ${ }^{430}$ no direito interno ${ }^{431}$. O

${ }^{428}$ MAGALHÃES, José Carlos de. O Supremo Tribunal Federal e o Direito Internacional: uma análise critica. Porto Alegre: Livraria do Advogado, 2000. p. 18.

${ }^{429}$ Apesar disso, o Professor Alberto Xavier entende que a Constituição Nacional teria adotado a corrente monista com primazia do Direito Internacional. Nesse sentido, v. XAVIER, Alberto. Direito Tributário Internacional do Brasil. 6. ed. reform. e atual. Rio de Janeiro: Forense, 2007. p. 111-113.

${ }^{430}$ Exceto no que diz respeito aos tratados internacionais sobre direito humanos e garantias individuais, cujas normas são automaticamente incorporadas ao ordenamento interno e são hierarquicamente equivalentes às disposições constitucionais, por força do disposto no artigo $5^{\circ}$, parágrafo $2^{\circ}$, da Constituição Federal de 1988. Sobre o tema: PIOVESAN, Flávia. Direitos Humanos e o Direito Constitucional Internacional. São Paulo: Max Limonad, 1996. 
processo de introdução das normas dos tratados no Direito interno (referendo, ratificação, publicação e promulgação) evidenciaria a existência de duas ordens jurídicas paralelas, uma interna e uma internacional, uma vez que, caso assim não fosse, não haveria necessidade de existirem mecanismos para a introdução de norma internacionais no ordenamento interno. Outro aspecto que nos leva a esta conclusão consiste no fato de que os tratados internacionais não são introduzidos como tais no Direito interno, mas, sim, as suas normas passam a integrar um diploma normativo do direito interno, o decreto legislativo, e, desta forma, tornam-se normas internas como quaisquer outras. As normas do tratado internacional, enquanto consideradas como integrantes do próprio tratado, não são sujeitas aos mesmos critérios de validade das normas internas, uma vez que as suas fontes de produção são distintas. As relações que se desenvolvem entre o tratado e a legislação interna são, assim, classificáveis como de aplicabilidade, e não de validade. Só podemos falar em aplicação de critérios de validade quando as normas internacionais já tiverem sido internalizadas.

\subsection{Os critérios (elementos) de conexão}

O exercício da competência tributária dos Estados soberanos para além dos seus limites territoriais pressupõe a existência de elementos que estabeleçam a conexão entre os rendimentos ou o capital eventualmente tributáveis e a jurisdição tributária daquele Estado. Entretanto, apesar de o poder de tributar ultrapassar as fronteiras

\footnotetext{
${ }^{431} \mathrm{O}$ reconhecimento da dualidade de ordens jurídicas pela Constituição Federal é explicado claramente pelo Professor Heleno Torres, segundo o qual: "Toda essa descrição sobre a possibilidade de resolução de conflitos em matéria de tratados visa a demonstrar que a Constituição Federal deixou muito bem definida a posição dos tratados em face das leis, do que se conclui que: I - o tratado mantém-se como 'Direito Internacional' na ordem interna, comprovando o dualismo, afinal, dispor sobre 'declarar a inconstitucionalidade de tratado ou lei federal' seria despiciendo, se o 'tratado' fosse 'lei' para o direito interno, cabendo falar apenas em declaração de inconstitucionalidade de 'leis'; II - as distribuições de competências aos juízes federais e tribunais, com exclusividade para as matérias veiculadas por tratados internacionais, na mesma linha, também seriam inúteis, bastando a expressa referencia à 'lei federal'; III os tratados firmados pela República são mantidos no direito interno subordinados à Constituição e com prevalência de aplicabilidade sobre qualquer lei, complementar ou ordinária: federal, estadual, distrital ou municipal, anterior ou posterior ao seu ingresso na ordem jurídica. Estivéssemos falando de direito forâneo, de direito estrangeiro propriamente dito, que devesse ser aplicado na ordem interna, por determinação de uma regra de conflito, como acontece no Direito Internacional privado, então, aí sim, caberia dizermos de uma coordenação hierárquica entre a lei estrangeira e a lei nacional, equiparando-as às leis internas, mas não ao Direito Internacional. Por isso é que, nada obstante varias construções doutrinarias opinarem sobre a adoção do princípio monista pelo ordenamento nacional, infere-se, tanto da Constituição quanto dos textos convencionais firmados pelo Brasil, um particular reconhecimento à existência de uma dualidade de ordens, a interna e a internacional." TORRES, Heleno Taveira. Pluritributação Internacional sobre as Rendas de Empresas. 2. ed. rev. ampl. e atual. São Paulo: Revista dos Tribunais, 2001.
} p. 577. 
territoriais, o mesmo não ocorre com a capacidade do Estado de compelir os contribuintes a pagarem tributos. Em outras palavras, o poder da Administração Tributária, responsável pela atividade de cobrança e gestão do sistema tributário, é restrito ao território nacional.

Assim, os elementos de conexão podem ser definidos como um instrumento que efetua a ligação do fato jurídico à norma tributária aplicável. Pela definição apresentada pelo Professor Gerd W. Rothmann, a expressão elementos de conexão "referese a determinado evento, a partir do qual a norma vincula a atribuição da competência tributária a determinado Estado." ${ }^{432}$

A partir deste conceito, observa-se que os principais elementos de conexão atualmente utilizados no Direito Tributário Internacional são o domicílio, a residência fiscal $^{433}$, o local da sede da administração da pessoa jurídica, o estabelecimento permanente, o local da situação do bem, a fonte dos rendimentos, o país de origem ou o país de destino.

Os elementos de conexão sempre estão presentes na estrutura da norma às quais se referem, e, deste modo, a ligação que estabelecem possui caráter estritamente jurídico, embora possa acarretar, também, conexões de ordem econômica e política. No entanto, para que a norma possa produzir seus efeitos sobre determinado fato, é essencial que a ligação seja jurídica, não bastando apenas uma relação econômica ou política. ${ }^{434}$

Em face disso, a necessidade e também a importância dos elementos de conexão ultrapassam o ato de possibilitar a incidência das normas tributárias em limites extraterritoriais, uma vez que eles permitem, outrossim, que o Estado possa efetivamente cobrar os tributos eventualmente incidentes em uma situação internacional.

Deste modo, conclui-se que a principal função, assim como a maior importância dos elementos de conexão corresponde justamente ao fato de eles revelarem a

\footnotetext{
${ }^{432}$ ROTHMANN, Gerd W. Tributação Internacional sem Sujeito Passivo: uma nova modalidade do imposto de renda sobre ganhos de capital? In: Grandes Questões Atuais de Direito Tributário. São Paulo: Dialética, 2006. v. 10. p. 109-110.

${ }^{433}$ HAMAEKERS, Hubert. The source principle versus the residence principle. In: Revista dos Tribunais. abr. mai. jun. ,1993. São Paulo: Malheiros, 1993. p. 165-169.

${ }^{434}$ Nesse sentido, XAVIER, Alberto. Direito Tributário Internacional do Brasil. 6. ed. reform. e atual. Rio de Janeiro: Forense, 2007. p. 252.
} 
relação de pertença econômica ${ }^{435}$ entre o fato jurídico ocorrido em território estrangeiro e o poder de tributar do Estado.

\subsubsection{Definições dos elementos de conexão}

Os elementos de conexão podem ser ligados ora aos sujeitos das relações jurídicas ${ }^{436}$, como ocorre com a nacionalidade, a residência ou o domicílio, ora aos fatos jurídicos tributáveis, como o local da situação do bem, ou, mesmo, a ambos, como no caso do critério do país de origem ou de destino.

A nacionalidade é um elemento de conexão que caiu em desuso na prática das convenções contra a dupla tributação internacional, tendo sido substituída pelos elementos residência e domicílio.

A residência fiscal consiste na situação jurídica de um sujeito relativamente a um país para fins do exercício da tributação, geralmente em bases universais. A expressão domicílio é empregada por alguns países como sinônima de residência, porém, tecnicamente, a definição de domicílio é mais genérica, enquanto que a de residência.

$\mathrm{Na}$ realidade, a distinção entre domicílio e residência está no fato de que o domicílio é um conceito definido pela subjetividade, para o qual se exige a manifestação de vontade do sujeito, enquanto que a residência é definida pela intenção de permanência por tempo indeterminado. Deste modo, a residência é um dado objetivamente verificável, e, por isso, para fins tributários, adota-se o critério da residência preferencialmente ao domicílio.

435 “(...) Conforme relata um dos pioneiros do Direito Tributário Internacional, Armin Spitaler, foram feitas várias tentativas de descobrir princípios exógenos para justificar esta atribuição ou repartição dos fatos imponíveis entre os Estados. Na sua opinião, porém, a tributação não pode ser justificada com base em critérios exógenos, tais como princípios filosóficos, da soberania e da territorialidade. Para Spitaler, o fundamento da tributação deve ser encontrado na assim chamada 'pertença econômica' (...) pela qual a competência para tributar determinado bem deve ser atribuída a um Estado ou repartida entre Estados, de acordo com a vinculação mais estreita do bem à economia de determinado Estado (...) ou com base na soberania do Estado, que lhe permite tributar qualquer bem econômico ao seu alcance (...). Conforme este último critério, é necessário e suficiente que, sob o aspecto técnico e de praticabilidade, exista algum elemento de conexão, que possibilite ao Estado alcançar o bem tributável. Esta relação com o País é necessária para justificar a tributação. Sem ela, a tributação constituiria um abuso do direito ou uma violação da proibição ao arbitrio.” ROTHMANN, Gerd W. Tributação Internacional sem Sujeito Passivo: uma nova modalidade do imposto de renda sobre ganhos de capital? In: Grandes Questões Atuais de Direito Tributário. São Paulo: Dialética, 2006. v. 10. p. 109-110.

436 Sobre os critérios de conexão pessoais e materiais, v. ALVES, Taciana Stanislau Afonso Bradley. O Princípio da Renda Mundial no Direito Brasileiro. In: TORRES, Heleno Taveira (coord.). Direito Tributário Internacional Aplicado. São Paulo: Quartier Latin, 2003. v. 1. p. 605-637. 
Para as pessoas físicas, a residência geralmente é determinada com base no grau da ligação existente entre o sujeito e o país. Neste caso, examinam-se as suas relações econômicas e, em segundo plano, as profissionais e pessoais, com o intuito de determinar o quão intensos são seus laços com o país. $\mathrm{Na}$ determinação da residência fiscal o que importa são os laços econômicos e, somente em segundo plano, é que são considerados os laços sociais.

Já no caso de pessoas jurídicas, a residência normalmente é determinada com base no critério do local de registro dos atos constitutivos (critério formal), ou então por meio da investigação do local da efetiva administração, onde são tomadas as decisões substanciais da vida da pessoa jurídica (critério material).

Ainda com relação à residência de pessoas jurídicas, outro elemento de conexão extremamente importante é o do local do estabelecimento permanente. O conceito de estabelecimento permanente normalmente designa a presença de um estabelecimento secundário (filial) de uma empresa não residente em um país, de modo que a permanência deste estabelecimento e o grau de suas relações econômicas com tal país permitam que ele seja tributado como se residente fosse.

Em resumo, a residência fiscal permite, assim, que um Estado tribute universalmente a renda daquelas pessoas físicas ou jurídicas que nele residam ou que nele tenham seu domicílio, possibilitando, ainda, a utilização dos meios coativos de cobrança fiscal (lembrando que a Administração tributária somente pode atuar dentro dos limites territoriais do Estado). Vale destacar que o princípio da tributação em bases universais (worldwide income taxation) é previsto no Direito brasileiro, tanto na Constituição Federal, em seu artigo 153 , parágrafo $2^{\circ}$, inciso $I^{437}$, quanto no Código Tributário Nacional, no artigo 43, parágrafo $1^{\text {o438}}$. Além disso, os elementos residência e domicílio são

\footnotetext{
437 “Art. 153. Compete à União instituir impostos sobre:

(...)

III - renda e proventos de qualquer natureza;

(...)

$\S 2^{\circ}$ - O imposto previsto no inciso III:

I - será informado pelos critérios da generalidade, da universalidade e da progressividade, na forma da lei; $(\ldots)$ ".

438 “Art. 43. O imposto, de competência da União, sobre a renda e proventos de qualquer natureza tem como fato gerador a aquisição da disponibilidade econômica ou jurídica:

I - de renda, assim entendido o produto do capital, do trabalho ou da combinação de ambos;

II - de proventos de qualquer natureza, assim entendidos os acréscimos patrimoniais não compreendidos no inciso anterior.
} 
explicitamente utilizados pelo regulamento do Imposto de Renda (RIR/99 - Decreto n. 3.000/99) para caracterizar, respectivamente, o contribuinte pessoa física, por meio do critério da residência (artigo $2^{\circ}$ do RIR/99 ${ }^{439}$ ), e o contribuinte pessoa jurídica, através do domicílio no Brasil (artigos 146 e 147 do RIR/9940).

Quando se trata de bens imóveis, tanto os imóveis por natureza quanto os imóveis por ficção jurídica, o elemento de conexão aplicável é o do local da situação do bem, de modo equivalente ao elemento residência. Em outras palavras, o Estado competente para tributá-lo será aquele no qual o bem imóvel estiver situado.

Por outro lado, o elemento de conexão fonte pode ser servir tanto para apontar o local onde é exercida a atividade que produz os rendimentos tributáveis (fonte econômica, fonte de produção, indicando a origem e a natureza da renda e identificando o sujeito ativo e o aspecto objetivo da eventual obrigação tributária ${ }^{441}$ ), quanto para indicar a fonte de pagamento, ou seja, o local onde reside o devedor que paga rendimentos a um beneficiário residente no exterior. Assim, o critério da fonte é essencialmente ligado ao objeto tributável. No Direito brasileiro, para que seja aplicável o critério da fonte, exige-se

$\S 1^{\circ}$ A incidência do imposto independe da denominação da receita ou do rendimento, da localização, condição jurídica ou nacionalidade da fonte, da origem e da forma de percepção. (Parágrafo incluído pela Lei Complementar n. ${ }^{\circ} 104$, de 10.1.2001)"

439 “Art. $2^{\circ}$ As pessoas físicas domiciliadas ou residentes no Brasil, titulares de disponibilidade econômica ou jurídica de renda ou proventos de qualquer natureza, inclusive rendimentos e ganhos de capital, são contribuintes do imposto de renda, sem distinção da nacionalidade, sexo, idade, estado civil ou profissão (Lei $n .^{\circ} 4.506$, de 30 de novembro de 1964, art. $1^{\circ}$, Lei ${ }^{\circ}{ }^{\circ}$ 5.172, de 25 de outubro de 1966, art. 43, e Lei $n .^{\circ}$ 8.383, de 30 de dezembro de 1991. art. $4^{\circ}$ )."

440 “Art. 146. São contribuintes do imposto e terão seus lucros apurados de acordo com este Decreto (Decreto-Lei . $^{\circ}$ 5.844, de 1943, art. 27):

I - as pessoas jurídicas (Capítulo I);

II - as empresas individuais (Capítulo II).

$\S 1^{\circ}$ As disposições deste artigo aplicam-se a todas as firmas e sociedades, registradas ou não (Decreto-Lei n. ${ }^{o}$ 5.844, de 1943, art. 27, $\$ 2^{\circ}$ ).

(...)

Art. 147. Consideram-se pessoas jurídicas, para efeito do disposto no inciso I do artigo anterior:

I - as pessoas jurídicas de direito privado domiciliadas no País, sejam quais forem seus fins, nacionalidade ou participantes no capital (Decreto-Lei $n .^{\circ}$ 5.844, de 1943, art. 27, Lei ${ }^{\circ}{ }^{\circ} 4.131$, de 3 de setembro de 1962 , art. 42, e Lei $n .^{\circ} 6.264$, de 1975 , art. $1^{\circ}$ );

II - as filiais, sucursais, agências ou representações no País das pessoas jurídicas com sede no exterior (Lei $n .^{\circ} 3.470$, de 1958, art. 76, Lei ${ }^{\circ}{ }^{\circ}$ 4.131, de 1962, art. 42, e Lei $n .^{\circ} 6.264$, de 1975, art. $1^{\circ}$ );

III - os comitentes domiciliados no exterior, quanto aos resultados das operações realizadas por seus mandatários ou comissários no País (Lei n. ${ }^{\circ} 3.470$, de 1958, art. 76)."

${ }^{441}$ ROTHMANN, Gerd W. Tributação Internacional sem Sujeito Passivo: uma nova modalidade do imposto de renda sobre ganhos de capital? In: Grandes questões atuais de Direito Tributário. São Paulo: Dialética, 2006. v. 10. p. 112. 
cumulativamente que a fonte de pagamento e a fonte de produção estejam situadas no território nacional, nos termos dos artigos 682 e 685 do Regulamento do Imposto de Renda de 1999 (Decreto n. 3.000/1999) ${ }^{442}$.

Considerando as características de ambos os elementos, observa-se, na prática, que a fonte é geralmente adotada pelos países em desenvolvimento, importadores de capital, como é o caso do Brasil, enquanto que a residência e do domicílio são utilizados por países economicamente desenvolvidos, exportadores de capital, como ocorre com a maioria dos países europeus.

Isto pode ser facilmente verificado a partir das convenções de dupla tributação celebrada por países em desenvolvimento, que possuem diversas cláusulas prevendo a tributação na fonte dos rendimentos, ao passo em que nas convenções celebradas entre países desenvolvidos, a maioria das cláusulas prevê a tributação a partir da residência ou do domicílio para evitar a dupla tributação. Exemplo disso é o artigo $10^{443}$ da Convenção

442 “Art. 682. Estão sujeitos ao imposto na fonte, de acordo com o disposto neste Capítulo, a renda e os proventos de qualquer natureza provenientes de fontes situadas no País, quando percebidos:

I - pelas pessoas físicas ou jurídicas residentes ou domiciliadas no exterior (Decreto-Lei n. ${ }^{\circ}$ 5.844, de 1943, art. 97, alinea " $a ")$;

II-pelos residentes no País que estiverem ausentes no exterior por mais de doze meses, salvo os mencionados no art. 17 (Decreto-Lei . $^{\circ}$ 5.844, de 1943, art. 97, alínea " $b "$ );

III - pela pessoa física proveniente do exterior, com visto temporário, nos termos do $\S 1$ o do art. 19 (DecretoLei . $^{\circ}$ 5.844, de 1943, art. 97, alinea "c", e Lei n. ${ }^{\circ} 9.718$, de 1998, art. 12);

IV - pelos contribuintes que continuarem a perceber rendimentos produzidos no País, a partir da data em que for requerida a certidão, no caso previsto no art. 879 (Lei n. ${ }^{\circ} 3.470$, de 1958, art. 17, $\S 3-$ ).

(...)

Art. 685. Os rendimentos, ganhos de capital e demais proventos pagos, creditados, entregues, empregados ou remetidos, por fonte situada no País, a pessoa física ou jurídica residente no exterior, estão sujeitos à incidência na fonte (Decreto-Lei $n .{ }^{\circ}$ 5.844, de 1943, art. 100, Lei ${ }^{\circ}{ }^{\circ} 3.470$, de 1958, art. 77, Lei $n .^{\circ} 9.249$, de 1995, art. 23, e Lei.$^{\circ} 9.779$, de 1999, arts. 7- e 8o):

I - à alíquota de quinze por cento, quando não tiverem tributação específica neste Capítulo, inclusive:

a) os ganhos de capital relativos a investimentos em moeda estrangeira;

b) os ganhos de capital auferidos na alienação de bens ou direitos;

c) as pensões alimentícias e os pecúlios;

d) os prêmios conquistados em concursos ou competições;

II - à alíquota de vinte e cinco por cento:

a) os rendimentos do trabalho, com ou sem vínculo empregatício, e os da prestação de serviços;

b) ressalvadas as hipóteses a que se referem os incisos V, VIII, IX, X e XI do art. 691, os rendimentos decorrentes de qualquer operação, em que o beneficiário seja residente ou domiciliado em país que não tribute a renda ou que a tribute à alíquota máxima inferior a vinte por cento, a que se refere o art. 245.

$\S 1^{\circ}$ Prevalecerá a alíquota incidente sobre rendimentos e ganhos de capital auferidos pelos residentes ou domiciliados no País, quando superior a quinze por cento (Decreto-Lei $n .^{\circ} 2.308$, de 1986, art. $2^{\circ}$, e Lei $n .^{\circ}$ 9.249, de 1995, art. 18).

$\S 2^{\circ}$ No caso do inciso II, a retenção na fonte sobre o ganho de capital deve ser efetuada no momento da alienação do bem ou direito, sendo responsável o adquirente ou o procurador, se este não der conhecimento, ao adquirente, de que o alienante é residente ou domiciliado no exterior.

$\S 3$ - O ganho de capital auferido por residente ou domiciliado no exterior será apurado e tributado de acordo com as regras aplicáveis aos residentes no País (Lei n. ${ }^{\circ} 9.249$, de 1995, art. 18)."” 
Brasil-África do Sul, que prevê a tributação dos juros no local onde esteja situada a fonte pagadora.

\subsubsection{Classificação dos elementos de conexão}

Considerando os conceitos acima explicados e as relações estabelecidas entre os elementos de conexão e os sujeitos/objetos da relação jurídica tributária, é possível classificar os elementos de conexão de acordo com as seguintes categorias:

a) Elementos de conexão subjetivos: caracterizam-se quando se referem à nacionalidade ou à residência dos sujeitos. Exemplo disso é o artigo $1^{\circ}$ da Convenção Modelo da OCDE, que determina que a Convenção será aplicável a todos os residentes de um dos Estados contratantes, de acordo

1. Os dividendos pagos por uma sociedade residente de um Estado Contratante a um residente do outro Estado Contratante poderão ser tributados nesse outro Estado.

2. Todavia, esses dividendos poderão também ser tributados no Estado Contratante em que reside a sociedade que os paga e de acordo com a legislação desse Estado, mas, se o beneficiário efetivo dos dividendos for um residente do outro Estado Contratante, o imposto assim estabelecido não poderá exceder: a) 10 por cento do montante bruto dos dividendos, se o beneficiário efetivo for uma sociedade que detiver pelo menos 25 por cento do capital da sociedade que pagar os dividendos; ou

b) 15 por cento do montante bruto dos dividendos em todos os demais casos.

O presente parágrafo não afetará a tributação da sociedade com referência aos lucros que derem origem ao pagamento dos dividendos.

3. O termo "dividendos", conforme usado no presente Artigo, significa os rendimentos provenientes de ações, ações ou direitos de fruição, ações de empresas mineradoras, partes de fundador ou outros direitos de participação em lucros, com exceção de créditos, assim como rendimentos de outras participações de capital sujeitos ao mesmo tratamento tributário que os rendimentos de ações pela legislação do Estado Contratante em que a sociedade que os distribui é residente.

4. As disposições dos parágrafos 1 e 2 não se aplicarão se o beneficiário efetivo dos dividendos, residente de um Estado Contratante, exercer, no outro Estado Contratante de que é residente a sociedade que paga os dividendos, atividade empresarial por intermédio de um estabelecimento permanente aí situado, ou prestar serviços de caráter independente nesse outro Estado por intermédio de uma instalação fixa aí situada, e a participação geradora dos dividendos estiver efetivamente ligada a esse estabelecimento permanente ou instalação fixa. Nesse caso, aplicar-se-ão as disposições do Artigo 7 ou do Artigo 14, conforme couber.

5. Quando um residente de um Estado Contratante mantiver um estabelecimento permanente no outro Estado Contratante, esse estabelecimento permanente poderá aí estar sujeito a um imposto retido na fonte de acordo com a legislação desse outro Estado Contratante. Todavia, esse imposto não poderá exceder 10 por cento do montante bruto dos lucros desse estabelecimento permanente, determinado após o pagamento do imposto de renda de sociedades referente a esses lucros.

6. Quando uma sociedade residente de um Estado Contratante receber lucros ou rendimentos do outro Estado Contratante, esse outro Estado não poderá cobrar nenhum imposto sobre os dividendos pagos pela sociedade, exceto na medida em que esses dividendos forem pagos a um residente desse outro Estado ou na medida em que a participação geradora dos dividendos estiver efetivamente ligada a um estabelecimento permanente ou a uma instalação fixa situados nesse outro Estado, nem exigir nenhum imposto a título de tributação dos lucros não distribuídos da sociedade, mesmo se os dividendos pagos ou os lucros não distribuidos consistirem, total ou parcialmente, de lucros ou rendimentos provenientes desse outro Estado. 7. As disposições do presente Artigo não se aplicarão se o principal propósito, ou um dos principais propósitos, de qualquer pessoa envolvida com a criação ou transferência das ações ou outros direitos em relação aos quais o dividendo for pago tiver sido o de tirar proveito do presente Artigo mediante tal criação ou transferência." 
com o conceito de residência que também é estabelecido no artigo $4^{\circ}$ do mesmo Modelo.

b) Elementos de conexão objetivos: quando são relativos às circunstâncias nas quais ocorrem os fatos, os elementos de conexão recebem a classificação de objetivos. Assim, são exemplos de elementos de conexão objetivos o local onde é produzido um rendimento, como determina o primeiro parágrafo do artigo $7^{0444}$ do Modelo da OCDE, tratando especificamente dos lucros das empresas, ou mesmo o local onde está situado o bem imóvel que gera rendimentos para seu titular, conforme estabelecido no primeiro parágrafo do artigo $6^{\text {o445 }}$ e também no artigo $22^{446}$ do mesmo modelo, ou, ainda, o local do estabelecimento permanente, nos termos do artigo $5^{\circ}$.

c) Elementos de conexão simples (únicos) ou complexos (múltiplos): são assim classificados quando o critério é o número de conexões estabelecidas, os elementos de conexão podem ser classificados como simples (ou únicos) caso estabeleçam apenas uma ligação entre o fato e a norma, ou complexos (ou múltiplos), quando estabelecem várias conexões. Neste último caso, as múltiplas conexões estabelecidas também são classificáveis em três subespécies, quais sejam, as conexões subsidiárias, as conexões alternativas e as conexões cumulativas.

d) Elementos de conexão subsidiários: as conexões serão subsidiárias quando a norma previr duas conexões, sendo a segunda delas aplicável somente na hipótese de a primeira não o ser. A Convenção Modelo da OCDE possui diversos exemplos de conexões subsidiárias, como as chamadas tie breaker rules, ou, traduzindo literalmente, regras de

\footnotetext{
444 "1. The profits of an enterprise of a Contracting State shall be taxable only in that State unless the enterprise carries on business in the other Contracting State through a permanent establishment situated therein. If the enterprise carries on business as aforesaid, the profits of the enterprise may be taxed in the other State but only so much of them as is attributable to that permanent establishment. (...)”

445 " 1 . Income derived by a resident of a Contracting State from immovable property (including income from agriculture or forestry) situated in the other Contracting State may be taxed in that other State. (...)”

446 "1. Capital represented by immovable property referred to in Article 6, owned by a resident of a Contracting State and situated in the other Contracting State, may be taxed in that other State. (...)"
} 
desempate, contidas no art. $4^{0447}$, que trata da determinação da residência. De acordo com este artigo, um indivíduo será considerado residente de um Estado contratante quando possuir sua residência neste Estado, mas, se não for possível determinar a sua residência, então, o critério aplicável passa a ser o do centro de interesses vitais, e assim por diante, de acordo com o referido artigo $4^{\circ}$. Este exemplo ilustra, inclusive, que um elemento de conexão, no caso, a residência, pode ser, ele próprio, objeto de outras normas de conexão.

e) Elementos de conexão alternativos: de outra forma, as conexões poderão ser alternativas quando a norma estabelecer que um ou o outro Estado será competente para tributar aquele fato.

f) Elementos de conexão cumulativos: uma conexão será classificada como cumulativa quando a norma dispuser que dois ou mais elementos de conexão devam ser observados para que um dos Estados contratantes possa tributar um dado rendimento. $\mathrm{O}$ exemplo clássico seria a norma do segundo parágrafo do artigo 11 do Modelo da OCDE, que determina que os juros deverão ser pagos ao beneficiário efetivo, e este beneficiário efetivo deve ser residente do outro Estado contratante, para que este Estado seja competente para tributar tais importâncias.

\footnotetext{
447 "1. For the purposes of this Convention, the term "resident of a Contracting State" means any person who, under the laws of that State, is liable to tax therein by reason of his domicile, residence, place of management or any other criterion of a similar nature, and also includes that State and any political subdivision or local authority thereof. This term, however, does not include any person who is liable to tax in that State in respect only of income from sources in that State or capital situated therein.

2. Where by reason of the provisions of paragraph 1 an individual is a resident of both Contracting States, then his status shall be determined as follows:

a) he shall be deemed to be a resident only of the State in which he has a permanent home available to him; if he has a permanent home available to him in both States, he shall be deemed to be a resident only of the State with which his personal and economic relations are closer (centre of vital interests);

b) if the State in which he has his centre of vital interests cannot be determined, or if he has not a permanent home available to him in either State, he shall be deemed to be a resident only of the State in which he has an habitual abode;

c) if he has an habitual abode in both States or in neither of them, he shall be deemed to be a resident only of the State of which he is a national;

d) if he is a national of both States or of neither of them, the competent authorities of the Contracting States shall settle the question by mutual agreement.

3. Where by reason of the provisions of paragraph 1 a person other than an individual is a resident of both Contracting States, then it shall be deemed to be a resident only of the State in which its place of effective management is situated."
} 
g) Elementos de conexão fixos (invariáveis) e móveis (variáveis): são assim classificados segundo o critério da suscetibilidade a mudanças no tempo e no espaço. Assim, temos os elementos de conexão fixos (invariáveis), conforme sejam imutáveis no tempo e no espaço, ou, então, móveis (variáveis), conforme estejam suscetíveis a mudanças desta natureza. São fixos, por exemplo, o local da situação dos bens imóveis, e, ainda, o local de celebração de um contrato, enquanto que são variáveis elementos como a nacionalidade, a residência, a sede, etc. $)^{448}$.

As categorias acima explicadas não são excludentes entre si, podendo uma mesma convenção contra a bitributação apresentar elementos de conexão de várias espécies ao mesmo tempo, ou até mesmo apresentar todas as espécies juntas. Pode ocorrer, também, que as convenções ou mesmo os ordenamentos jurídicos internos dos países recorram às presunções ou ficções jurídicas para determinar o elemento de conexão. Este é o caso da presunção de aquisição de residência fiscal para o sujeito que permaneça por mais de 183 dias, seguidos ou não, em território brasileiro.

O quadro abaixo resume a classificação dos elementos de conexão segundo os critérios acima explicados:

\section{ClassificaÇÃo dos Elementos de CONEX̃̃o}

$$
\begin{aligned}
& \text { CRITÉRIO } \underline{\text { CLASSIFICAĊ̃̃O }} \\
& \text { Quanto ao destinatário: }\left\{\begin{array}{l}
\text { Subjetivos } \\
\text { Objetivos }
\end{array}\right. \\
& \text { Quanto ao número de conexões: }\left\{\begin{array}{l}
\text { Simples (únicos) } \\
\text { Múltiplos (complexos) }
\end{array}\right\}\left\{\begin{array}{l}
\text { Subsidiária } \\
\text { Alternativa } \\
\text { Quanto à suscetibilidade a }
\end{array}\right. \\
& \text { mudanças no tempo e no espaço: }
\end{aligned}
$$

${ }^{448}$ XAVIER, Alberto. Direito Tributário Internacional do Brasil. 6. ed.. reform. e atual. Rio de Janeiro: Forense, 2007. p. 253. 


\subsection{O fenômeno da dupla tributação internacional}

O fenômeno denominado dupla tributação ${ }^{449}$ internacional ou pluritributação internacional ocorre quando dois ou mais Estados soberanos submetem uma mesma pessoa (física ou jurídica), em concomitante período de tempo, ao pagamento de impostos comparáveis em razão de um mesmo fato gerador. De forma bastante objetiva, Vogel define a dupla tributação internacional como sendo a imposição de tributos comparáveis ou equiparáveis por dois ou mais Estados soberanos relativamente ao mesmo sujeito e ao mesmo objeto tributável e durante períodos de tempo idênticos ${ }^{450}$. Apesar de ser aparentemente simples, o conceito de dupla tributação possui nuances que tornam seu estudo controvertido entre os doutrinadores. Alguns o dividem em categorias distintas, referindo-se à dupla tributação jurídica e dupla tributação econômica, enquanto outros acreditam que tal distinção não passa de equívoco teórico.

Partidário da primeira corrente doutrinária, o Professor Alberto Xavier analisa o conceito de dupla tributação internacional sob os prismas jurídico e econômico, por meio da regra das quatro identidades. Segundo ele, a dupla tributação jurídica ocorre quando se verifica a absoluta identidade dos sujeitos, do objeto, do período tributável e do tributo em si. A isto se chama de regra das quatro identidades ${ }^{451}$, cuja função consiste exatamente em identificar a ocorrência da dupla tributação jurídica, a qual, por sua vez, é o objeto de que

${ }^{449}$ No presente trabalho, utilizaremos as expressões dupla tributação internacional e bitributação como sinônimas.

${ }^{450}$ Klaus Vogel define o fenômeno da bitributação internacional e ressalta a importância de combatê-lo em nome do bom desenvolvimento das relações comerciais entre os países: "1. [Definition of international juridical double taxation] International juridical double taxation can be generally defined as the imposition of comparable taxes in two (or more) States on the same taxpayer in respect of the same subject matter and for identical periods. Its harmful effect on the exchange of goods and services and movements of capital, technology and persons are so well known that it is scarcely necessary to stress the importance of removing the obstacles that double taxation presents to the development of economic relations between countries." VOGEL, Klaus. On double taxation conventions: a commentary to the OECD, UN and US model conventions for the avoidance of double taxation of income and capital with particular reference to German treaty practice. 3. ed. Germany: Kluwer Law International, 1997, p. 2. Sobre o conceito de dupla tributação internacional, v. também: DORNELLES, Francisco Neves. A Dupla Tributação Internacional da Renda. Rio de Janeiro:FGV, 1979. p. 3. XAVIER, Alberto. Direito Tributário Internacional do Brasil. 6. ed. reform. e atual.,Rio de Janeiro:Forense,2007.p.31 e seguintes. TORRES, Heleno Taveira. Pluritributação Internacional sobre as Rendas de Empresas. 2. ed. rev., ampl. e atual. São Paulo: Revista dos Tribunais, 2001. p.378. ROTHMANN, Gerd W. Interpretação e Aplicação dos Acordos Internacionais contra a Bitributação. São Paulo: USP, 1978. p.67. Tese (doutorado)

451 XAVIER, Alberto. Direito Tributário Internacional do Brasil. 6. ed. reform. e atual., Rio de Janeiro: Forense, 2007. p. 33 [e seguintes]. 
se encarregam as convenções contra a dupla tributação. Em contrapartida, a dupla tributação econômica diferencia-se da dupla tributação jurídica por não exigir a identidade dos sujeitos, bastando apenas a coincidência de objetos, de tributo e do aspecto temporal. Numa situação de dupla tributação econômica, um mesmo rendimento seria tributado por normas tributárias distintas, quando, por exemplo, passasse da titularidade da sociedade para a titularidade do sócio. Verifica-se, pois, que, na dupla tributação econômica, apesar da identidade de objetos, não ocorre a identidade de sujeitos ${ }^{452}$.

Ainda segundo Alberto Xavier, além da regra das quatro identidades, que revela a identidade do fato jurídico tributável sujeito à dupla tributação jurídica, é necessário observar o requisito da pluralidade de normas. Deste modo, quando um mesmo fato for tributado de acordo com normas jurídicas provenientes de Estados soberanos distintos, teremos o fenômeno da dupla tributação jurídica internacional, e, quando as normas que incidirem sobre um mesmo fato forem provenientes de Estados Federativos, regiões ou territórios distintos, dentro de um mesmo Estado soberano, ocorrerá a dupla tributação interna ou interterritorial. Portanto, segundo o autor, as convenções contra a dupla tributação internacional ocupam-se da dupla tributação jurídica internacional.

Efetivamente, o Modelo da OCDE, em seus artigos 23-A e 23-B, distingue a dupla tributação internacional jurídica da econômica, determinando ser jurídica a dupla tributação internacional que ocorre quando se verificam todas as quatro identidades (sujeito, objeto, período tributável e tributo), ao passo que, para a verificação da dupla tributação econômica internacional não se faz necessária a identidade de sujeitos, desde que seja tributável um mesmo rendimento por dois ou mais Estados soberanos em períodos de tempo concomitantes. Contudo, apesar de estabelecer tal diferença, os próprios comentários ao Modelo da $\mathrm{OCDE}^{453}$ esclarecem que as convenções de bitributação visam tão somente a combater a dupla tributação jurídica, ficando a cargo de negociações bilaterais entre os Estados a questão relativa à dupla tributação econômica.

\footnotetext{
452 Nesse sentido, XAVIER, Alberto. Direito Tributário Internacional do Brasil. 6. ed. reform. e atual., Rio de Janeiro: Forense, 2007. p. 33-36.

453 "1.[1] These Articles deal with the so-called juridical double taxation where the same income or capital is taxable in the hands of the same person by more than one State.

2.[2] This case has to be distinguished especially from the so-called economic double taxation, i.e. where two different persons are taxable in respect of the same income or capital. If two States wish to solve problems of economic double taxation, they must do so in bilateral negotiations." Commentaries to the OECD Model Tax Convention, In Materials on International e EC Tax Law, selected and edited by Kees van Raad. Leiden: IBFD, 2007/2008, v. p. 303.
} 
Heleno Torres, por sua vez, entende não ser correto classificar a dupla tributação internacional em jurídica e econômica, defendendo a inexistência da chamada dupla tributação econômica internacional ${ }^{454}$. Para ele, a dupla tributação internacional somente pode ser jurídica, já que o caráter econômico é pressuposto do próprio conceito de tributação. Assim, ao qualificar a dupla tributação internacional de econômica, como se esta fosse uma categoria distinta e específica, seria possível a conclusão pela existência de um tipo de tributação que não tivesse caráter econômico, o que seria contraditório ao próprio conceito de tributação. Conclui-se, então, que o caráter econômico é implícito, não sendo tecnicamente correta a divisão da dupla tributação internacional nas duas categorias supramencionadas. Além disso, este autor entende que a expressão dupla tributação econômica é imprecisa e contraditória, tendo em vista que o conceito de dupla tributação pressupõe a dupla incidência de normas, e não apenas a mera repercussão fiscal pelo efeito de uma dupla cobrança de impostos. Portanto, pela doutrina de Heleno Torres, somente seria correto falar-se em dupla tributação jurídica internacional, haja vista que qualquer dupla tributação pressupõe a existência de uma pluralidade de normas incidindo sobre o mesmo fato econômico tributável, ao mesmo tempo.

Ainda neste ponto, entendemos que a dupla tributação internacional não deve ser classificada em jurídica ou econômica. Concordamos com o Professor Heleno Torres no sentido de que o caráter econômico é implícito ao conceito de tributação, seja ela nacional ou internacional, não sendo necessário, portanto, especificá-lo na denominação do fenômeno. Da mesma forma, entendemos que o caráter jurídico é igualmente pressuposto da tributação, isto é, não pode sequer existir tributação se esta não for decorrente de normas jurídicas. Deste modo, ao destacar como se fosse uma espécie distinta a dupla tributação jurídica internacional, poderia surgir a conclusão pela possibilidade de

454 "Para que a dupla tributação econômica internacional pudesse ser admitida como dupla tributação e, assim, conduzida à definição geral de pluritributação internacional, necessitaria, de início, ser, pelo menos indiretamente, reconduzivel aos elementos basilares da respectiva definição: concurso impositivo entre duas ou mais legislações fiscais soberanas contemporaneamente incidentes sobre um mesmo suporte fático dotado de elementos de estraneidade, o que não se verifica, como demonstraremos.

Além desses motivos, a expressão dupla tributação econômica, terminologicamente, é pouco precisa e contraditória. O termo "dupla tributação" é conotativo de um esquema mais complexo e faz supor a existência de uma dupla incidência de normas, e não apenas de uma mera repercussão fiscal, pelos efeitos de uma dupla cobrança de impostos. Já o termo "econômica", que aparece como uma qualificação à dupla tributação, como se fosse uma forma particular de manifestação daquilo que se define como pluritributação internacional, que acondiciona os elementos pluralidade de normas em concurso e identidade do fato-evento tributável, cai em profunda ambigüidade e expõe a definição a especulações alheias ao discurso jurídico." TORRES, Heleno Taveira. Pluritributação Internacional sobre as Rendas de Empresas. 2. ed. rev. ampl. e atual. São Paulo: Revista dos Tribunais, 2001. p. 406-407. 
existência de tributação que não fosse decorrente de normas jurídicas, o que também não é aceitável. Em decorrência disso, entendemos ser não apenas desnecessário, como também tecnicamente incorreto, falar em dupla tributação jurídica internacional, haja vista que o caráter jurídico também é pressuposto necessário da tributação. Tal classificação, em nossa opinião, poderia ser apenas ilustrativa, não devendo possuir qualquer caráter distintivo em relação a outras espécies de bitributação supostamente existentes.

Portanto, entendemos que classificar a dupla tributação internacional em duas categorias distintas com base nos critérios do caráter econômico ou jurídico não só é desnecessário, como também é teoricamente incorreto, podendo levar a conclusões equivocadas, como demonstramos acima. Portanto, no presente trabalho, para fins de interpretação das convenções contra a dupla tributação, adotamos apenas a denominação dupla tributação internacional.

Superada a questão acima analisada, entendemos que o conceito de dupla ou pluritributação internacional pode ser resumido como a realização de operações com elementos de conexão com mais de mais de um Estado soberano, associada à utilização de critérios díspares por cada um deles para delimitar a sua própria competência tributária, ou, até mesmo, pela utilização de um mesmo critério definido de modo distinto. ${ }^{455}$

Desta forma, independentemente de classificações, observa-se que a dupla tributação constitui algo pernicioso e indesejável, podendo ser denominada até mesmo de patologia tributária. A despeito disso, não existe nos tratados de dupla tributação internacional uma cláusula geral ou mesmo específica que declare materialmente ilícita a dupla tributação internacional ${ }^{456}$. Na realidade, não há nem mesmo um princípio que a proíba, mas mesmo assim, a dupla tributação é algo altamente indesejável em virtude de seus efeitos danosos à economia e especialmente aos contribuintes.

De fato, muitas são as causas ${ }^{457}$ deste fenômeno, assim como existem diversos fundamentos para a sua eliminação. Dentre as principais causas, cita-se o fato de os

${ }^{455}$ RUBINSTEIN, Flávio. Interpretazione e Aplicazione delgli Accordo contro la Doppia Imposizione: il ruolo della buona fede oggetiva. In: Diritto i Pratica Tributaria Internazionale n. 01/2006., Disponível em http://www.dpti.it:80/documenti/528624.asp?linkparam=Preleva\%20la\%20rivista. Acesso em 26 jul. 2006.

${ }^{456}$ BUHLER, Ottmar. Principios de Derecho Internacional Tributario. Trad. Fernando Cervera Torrejon. Madrid: Editorial de Derecho Financiero, 1968. p. 79.

457 Analisando as causas da bitributação, Heleno Torres destaca os seguintes fatores: “a diversidade dos princípios de conexão adotados pelos Estados com relação aos fatos geradores dotados de elementos de estraneidade, seja com relação às pessoas envolvidas (conforme o princípio world-wide income taxation), 
Estados soberanos poderem tributar não somente rendimentos localizados em seu território, mas também serem detentores de competência para tributar bens, direitos e rendimentos localizados no exterior, mediante a aplicação dos critérios de conexão previstos em seus ordenamentos ${ }^{458}$. De fato, teoricamente, os Estados deveriam respeitar limites jurídicos. Porém, na prática, o que se observa é a tributação de fatos jurídicos externos de acordo com a conveniência financeira de cada Estado, independente de limites jurídicos. Na realidade, a opção por tributar fatos jurídicos situados fora do território de um Estado depende muito mais da conveniência financeira do que da localização do rendimento que se pretende tributar, o que faz com que os Estados deixem de observar limites territoriais e até mesmo jurídicos no intuito de obter maior arrecadação. Assim, é possível concluir que a soberania físcal não possui laços muito estreitos com a soberania territorial.

Por sua vez, os fundamentos para a sua eliminação podem ser resumidos em dois itens: primeiro, a eliminação da dupla tributação internacional constitui uma premissa exigida pelo princípio de justiça que deve reger o sistema tributário e a repartição da riqueza internacional; além disso, sob o ponto de vista econômico, a eliminação dos efeitos da dupla tributação internacional se impõe como medida indispensável para obter um grau adequado de neutralidade nas relações econômicas internacionais ${ }^{459}$.

Efetivamente, os limites à tributação internacional estão relacionados à necessidade de um elemento de conexão que ligue o fato tributável à soberania fiscal, e também possuem relação com as limitações aplicáveis à execução das pretensões fiscais, já que o Estado não pode agir coativamente fora de seu território. Desta forma, o fundamento

seja face ao lugar da fonte de produção da renda ou do benefício [domicílio] do contribuinte (pelo princípio da territorialidade), ou mesmo a distinção entre os critérios de qualificação das rendas tributáveis, da tipologia do imposto ou dos sujeitos envolvidos entre os modos de localização das fontes de rendas, dos sujeitos passivos ou do período de ocorrência." TORRES, Heleno Taveira. Dupla (Múltipla) Tributação Internacional. Rendas de Empresas: 'Dupla tributação Jurídica Internacional' e 'Dupla Tributação Econômica Internacional'. In: Revista de Direito Tributário .São Paulo: Malheiros, 1995. n.65, p. 68. Ainda sobre as causas da bitributação internacional, v. também: SILVEIRA, Rodrigo Maitto da. Aplicação de Tratados Internacionais contra a Bitributação : Qualificação de Partnership Joint Ventures. São Paulo: Quartier Latin, 2006. p. 23. CARRERO, José M. Calderón. La doble imposición internacional y los métodos para su eliminación. Madrid: McGraw-Hill, 1997. p. 54-64. ROTHMANN, Gerd W. Interpretação e Aplicação dos Acordos Internacionais contra a Bitributação. São Paulo: USP, 1978. Tese (doutorado), p. 67-74.

${ }^{458}$ Por exemplo: a renda e/ou a riqueza obtidas no exterior, atribuíveis a um residente pessoa física ou pessoa jurídica são muitas vezes sujeitas à tributação com base no critério da residência, o que implica a tributação em bases universais (worldwide income taxation).

${ }^{459}$ CARRERO, José M. Calderón. La doble Imposición Internacional y los Métodos para su eliminación. Madrid: McGraw-Hill, 1997. p. 88-89. 
da tributação internacional consiste na lógica de que o estrangeiro somente pode ser tributado enquanto participe da vida do Estado, seja porque possui residência neste Estado ou porque a fonte de seus pagamentos esteja localizada neste Estado ${ }^{460}$. Na verdade, basta que exista uma relação de pertença econômica dada por meio de elementos de conexão entre o Estrangeiro e o Estado para que seja legítima a pretensão tributária.

A dupla tributação internacional pode ser evitada ou minimizada a partir de métodos unilaterais, ou seja, medidas internas unilaterais ou condicionadas à reciprocidade, ou então por meio de soluções bilaterais, que compreendem as convenções contra a bitributação, os acordos de comércio e outros acordos internacionais. Basicamente, os métodos unilaterais compreendem o método da isenção tributária (tax exemption) e o método do crédito de imposto (tax credit), também chamado de método da imputação. Contudo, por questões metodológicas, não adentraremos a análise dos métodos unilaterais, passando, diretamente, ao exame das convenções contra a dupla tributação para, então, analisarmos as questões relativas à interpretação e aplicação destes acordos à luz da Teoria da Argumentação Jurídica.

\subsection{Celebração de tratados internacionais no Direito Brasileiro}

Para que um tratado ou convenção internacional faça parte do ordenamento jurídico de um país e se torne uma de suas fontes de direitos e obrigações, é essencial que se atenda, antes de tudo, aos mandamentos do Direito Internacional e, em seguida, aos requisitos de validade presentes no direito constitucional de cada um dos países signatários. $^{461}$

No Direito Brasileiro, a celebração de tratados internacionais está disciplinada nos artigos 49, inciso I ${ }^{462}$, e 84, inciso VIII ${ }^{463}$ da Constituição Federal de 1988. O conteúdo

\footnotetext{
460 "Tanto em relação aos estrangeiros como aos cidadãos, o tributo deve vincular-se à participação pessoal na vida do Estado tributante, através da presença no território ou de uma relação econômica mediante a percepção de rendimentos produzidos dentro do território. Esta possibilidade de usufruir as vantagens decorrentes da atividade do Estado constitui o fundamento do dever de suportar a tributação." ROTHMANN, Gerd W. Interpretação e Aplicação dos Acordos Internacionais contra a Bitributação. São Paulo: USP, 1978. p.3 Tese (doutorado)

${ }^{461}$ TORRES, Heleno Taveira. O princípio da não-discriminação tributária na Constituição e no GATT e a prevalência dos tratados internacionais em matéria tributária. In: Construindo o Direito Tributário na Constituição: Uma análise da Obra do Ministro Carlos Mário Velloso. Belo Horizonte: Del Rey, 2004. p. 436.
}

462 “Art. 49. É da competência exclusiva do Congresso Nacional: 
destas normas demonstra que, no Brasil, a celebração de atos e tratados internacionais constitui ato complexo, do qual participam conjuntamente o Presidente da República, responsável pela celebração do tratado, agindo na qualidade de representante máximo da nação, e o Congresso Nacional, a quem incumbe o dever de verificar a legalidade do ato presidencial e, assim, ratificar o tratado celebrado. O referendo legislativo constitui, deste modo, a chancela necessária para que o ato internacional adentre a esfera jurídica interna e nela possa produzir efeitos. Caso o Congresso constate que não foram obedecidas as formalidades pertinentes durante a celebração do acordo internacional, cabe a ele rejeitá-lo, impedindo o ingresso de normas eivadas de vícios no ordenamento pátrio ${ }^{464}$.

$\mathrm{O}$ ato de celebração de tratados, como já mencionado acima, é um ato complexo, do qual participam várias pessoas. Assim, num esforço de sistematização bastante objetivo, é possível descrever as fases da celebração de um tratado internacional conforme o esquema abaixo:

1) Negociações: a fase de negociações constitui o primeiro passo para a celebração de um acordo internacional, sendo realizada por meio de um ou mais plenipotenciários designados pelo Estado, geralmente membros do corpo diplomático, com o auxílio de especialistas do setor público e privado. É nesta etapa que são analisadas a oportunidade e conveniência do acordo, bem como se elabora a redação preliminar das normas que formarão o texto do futuro tratado internacional ${ }^{465}$.

I - resolver definitivamente sobre tratados, acordos ou atos internacionais que acarretem encargos ou compromissos gravosos ao patrimônio nacional;"

463 “Art. 84. Compete privativamente ao Presidente da República:

(...)

VIII - celebrar tratados, convenções e atos internacionais, sujeitos a referendo do Congresso Nacional;"”

464 Embora haja uma polêmica discussão doutrinária sobre a necessidade de referendo para os tratados internacionais que não acarretem encargos ou compromissos gravosos ao patrimônio nacional, entendemos que tal discussão não se aplica ao caso das convenções de bitributação, eis que estas, claramente, acarretam compromissos gravosos ao erário público mediante a abdicação de parte das receitas tributárias. Assim, no que concerne às convenções de bitributação, é pacífico o entendimento de que a competência para celebrá-las é do Presidente da República, devendo necessariamente haver o referendo posterior do Congresso nacional para conferir-lhes validade perante o ordenamento jurídico interno. Sobre esta questão: MEDEIROS, Antônio Paulo Cachapuz. O poder de celebrar tratados. Porto Alegre: Sérgio Antônio Fabris. 1995. p. 382396.

${ }^{465}$ No presente trabalho, por uma questão de praticidade, utilizaremos as expressões "acordo", "tratado" e "convenção" como sinônimas, apesar de o professor Gerd W. Rothmann esclarecer a distinção entre as três denominações: "De fato, a terminologia dos tratados é bastante imprecisa, na prática internacional. Para os efeitos do presente trabalho, podemos limitar-nos a três denominações comumente utilizadas para os acordos internacionais em matéria tributária: 1. Tratado: é a expressão utilizada para os acordos solenes, como por exemplo, o tratado de paz; 2. Convenção: é o tratado que cria normas gerais, por exemplo, 
2) Celebração: nesta fase ocorre a expressão do acordo de vontades dos Estados envolvidos por meio da assinatura do documento que contém as cláusulas pactuadas. No Brasil, a assinatura de tratados internacionais é ato de competência privativa do Presidente da República, nos termos do artigo 84, VIII, da Constituição Federal de 1988. A celebração de um acordo internacional também pode ser feita por meio de troca dos instrumentos de constituição do tratado, aceitação, adesão, aprovação, ou por qualquer outra forma equivalente, apesar de serem mais comuns a assinatura e a troca dos instrumentos.

3) Referendo: o referendo é o ato pelo qual o Congresso Nacional, segundo o artigo 49, I, da Constituição Federal de 1988, aprova o texto do tratado assinado anteriormente pelo Presidente da República, autorizando, em seguida, a sua ratificação, que também é ato privativo do Presidente da República, nos termos do artigo 84, VIII da Constituição de 1988. Caso o Congresso Nacional rejeite o acordo previamente assinado pelo Presidente da República, não poderá ocorrer a ratificação. Entretanto, caso isto ocorra, o Presidente poderá reapresentar o tratado na próxima sessão legislativa para nova apreciação e eventual aprovação, tornando, possível, então, a ratificação.

4) Ratificação: como já mencionado acima, no Direito brasileiro a ratificação do tratado é ato privativo do Presidente da República, possuindo caráter de irretratabilidade. $\mathrm{O}$ ato de ratificação é o que confere vigência ao tratado. Após a ratificação do tratado, o Estado está obrigado, perante o(s) outro(s) Estado(s) envolvido(s) e perante a Comunidade Internacional, a cumprir os termos do acordo firmado. Como o ato de ratificação é irretratável, caso o Estado desista do acordo ou não deseje manter o pactuado, caberá somente a denúncia do tratado. Neste ponto, vale lembrar a lição de Heleno Torres, o qual ensina que o início do prazo de vigência de uma convenção internacional, a partir do qual os interessados poderão reclamar os compromissos assumidos pelos

Convenção sobre Mar Territorial; 3. Acordo: é geralmente usado para os tratados de cunho econômico, financeiro, comercial e cultural, que regem situações particulares.” ROTHMANN, Gerd W. Interpretação e Aplicação dos Acordos Internacionais contra a Bitributação. São Paulo: USP, 1978. p.3 . Tese (Doutorado). 
Estados partes, não decorre do ato administrativo que, consuetudinariamente, a título de conferir-lhe publicidade e execução, pretende servir como pressuposto de validade, pelo procedimento. A vigência do acordo internacional terá seu início somente a partir do ato de ratificação, o qual marca o comprometimento do Estado em relação aos compromissos assumidos por meio do tratado internacional, pela aprovação mediante o Decreto Legislativo expedido pelo Congresso Nacional. Além disso, ele ressalva que as disposições convencionais não mantém relação de validade com a ordem interna, ou seja, não exatamente pertencem à ordem interna. Isto porque as fontes de produção normativa (agentes e procedimentos) interna e internacional são distintas, assim como são diferentes os seus respectivos fundamentos de validade. Deste modo, conclui-se que as disposições presentes nos tratados internacionais são normas autorizadas a serem aplicadas na ordem interna, mas que não fazem parte dela como uma lei ordinária comum ${ }^{466}$.

5) Eficácia: sob a perspectiva internacional, a vigência e eficácia de um tratado têm seu início a partir da ratificação (ou da troca dos instrumentos de ratificação, como geralmente ocorre), ou ainda, após a data estipulada pelos Estados pactuantes para o início da sua vigência. Já no âmbito interno, no caso brasileiro, o Presidente da República promulga um Decreto Presidencial por meio do qual o tratado adquire executoriedade. Este Decreto Presidencial é, em seguida, aprovado por um decreto legislativo, que traz consigo três consequências: primeiro, confere publicidade ao texto do tratado, segundo, confere eficácia interna às normas pactuadas no tratado e, por fim, constitui o ato de promulgação oficial do tratado. Em outras palavras, a partir da promulgação e publicação do decreto legislativo é que tem início a vigência e eficácia no âmbito interno das normas internacionais criadas por meio do tratado. Também a partir deste ponto, consideram-se oficialmente introduzidas no

466 TORRES, Heleno Taveira. O princípio da não-discriminação tributária na Constituição e no GATT e a prevalência dos tratados internacionais em matéria tributária. In: Construindo o Direito Tributário na Constituição: Uma análise da obra do Ministro Carlos Mário Velloso. Belo Horizonte: Del Rey, 2004. p. 438. 


\author{
Direito interno ${ }^{467}$ as normas jurídicas internacionais pactuadas no \\ tratado $^{468}$. Vale lembrar, porém, que a eficácia do tratado após a \\ publicação do decreto legislativo possui efeitos ex tunc, ou seja, que \\ podem retroagir, até a data da ratificação. ${ }^{469}$
}

\begin{abstract}
${ }^{467}$ Para Betina Treiger Grupenmacher, não é o Decreto Legislativo que introduz as normas internacionais no Direito interno, mas sim o próprio tratado internacional. Segundo ela: "A necessidade de prévia aprovação pelo Congresso Nacional não retira dos tratados internacionais a sua aptidão para ser fonte formal de direito, pois ao Congresso cabe apenas a aprovação ou rejeição do compromisso anteriormente firmado pelo Poder Executivo. O decreto legislativo não 'cria' o direito, não inova a ordem jurídica, na apontada hipótese, apenas aprova ou não os direitos e deveres anteriormente criados pelos tratados internacionais, ou seja, quem introduz o elenco de direitos e deveres na ordem jurídica interna é o próprio tratado internacional, e não o Decreto Legislativo que o aprova." GRUPENMACHER, Betina Treiger. Tratados internacionais em matéria Tributária e a Ordem Interna. São Paulo: Dialética, 1999. p. 61. Em sentido contrário, Paulo de Barros Carvalho entende que o decreto legislativo constitui o estatuto expressivo das competências exclusivas do Congresso Nacional, e está no mesmo nível hierárquico das demais leis, adquirindo "grande importância no direito brasileiro como forma de introdução do conteúdo dos tratados e das convenções internacionais no sistema normativo, da mesma forma que se presta às assembléias legislativas estaduais para absorver o teor dos convênios celebrados entre as unidades federadas, transformando-os em regras jurídicas válidas". CARVALHO, Paulo de Barros. Tratados internacionais em matéria tributária : estudo de um caso concreto. In: AMARAL, Antônio Carlos Rodrigues do (coord.). Tratados Internacionais na Ordem Jurídica Brasileira. São Paulo: Aduaneiras, 2005. p. 256.
\end{abstract}

${ }^{468}$ Sobre o momento da eficácia dos tratados internacionais tributários, Rodrigo Maitto da Silveira destaca o seguinte: "Parece-nos válido dizer que, no Brasil, a publicação, no Diário Oficial, de decreto do Presidente da República, apenas faz confirmar os efeitos produzidos pelo tratado correspondente, que passaram a existir desde a troca dos instrumentos de ratificação, ou seja, no mesmo momento em que o acordo passou a vigorar no plano internacional. Tal entendimento é confirmado pelo disposto no Parecer Normativo do Coordenador do Sistema de Tributação - CST n. 3, de 09/01/1979, que embora condicione a executoriedade do acordo à publicação do decreto presidencial, reconhece que as normas do tratado têm efeitos ex tunc em relação às datas de vigência nele previstas. [Brasil, Parecer Normativo - Coordenador do Sistema de Tributação - CST n. 3, de 09/01/1979. Diário Oficial da União: 02/02/1979. A conclusão desse parecer é a seguinte: ' 4.2 - A executoriedade do tratado, todavia, só será possivel, em face do direito interno de cada Estado, através de publicação que leve ao conhecimento geral a existência daquela norma internacional que, repita-se, já era obrigatória antes da publicação. Tais atos, que em direito internacional público denominam-se promulgações, receberam de Hildebrando Accioly a seguinte conceituação: 'o ato jurídico, de natureza interna, pelo qual o governo de um Estado afirma ou atesta a existência de um tratado por ele celebrado e o preenchimento das formalidades exigidas para sua conclusão, e, além disto, ordena sua execução dentro dos limites aos quais se estende a competência estatal'." SILVEIRA, Rodrigo Maitto da. Aplicação de Tratados Internacionais contra a Bitributação - Qualificação de Partnership Joint Ventures. São Paulo: Quartier Latin, 2006. p.83. Ainda sobre a eficácia dos tratados internacionais no Direito brasileiro: CAMINHA, Maria do Carmo Puccini. Os Tratados Internacionais Tributários e a eficácia de suas Normas no Ordenamento Jurídico Brasileiro. In: Revista Tributária e de Finanças Públicas. Nov. dez. 2001. Ano 9. São Paulo: Malheiros, 2001. v. 41. p. 29-52.

${ }^{469}$ Segundo ensina o professor Heleno Torres, o tratado em si não adquire validade na ordem interna, apenas na esfera internacional. $\mathrm{Na}$ ordem interna, possuem validade apenas os atos que internalizam as normas internacionais. Nas palavras do professor: "Merece destaque lembrar que o tratado não adquire validade na ordem interna. Válidos devem ser os atos de recepção. Válida deve ser a edição do Decreto Legislativo. Encontrando-se este eventualmente inquinado de algum defeito que lhe afete a existência jurídica, isso seguramente não se transfere ao tratado, que continua plenamente válido no direito das gentes." TORRES, Heleno Taveira. Pluritributação Internacional sobre as Rendas de Empresas. 2. ed. rev. ampl. e atual. São Paulo: Revista dos Tribunais, 2001. p. 568. 
Assim como todos os tratados, a celebração de acordos internacionais tributários necessariamente passa pelas fases acima explicadas ${ }^{470}$. Todos os acordos de bitributação celebrados pelo Brasil foram introduzidos no ordenamento interno por meio de decretos legislativos, cujo inteiro teor pode ser obtido por meio do site da Receita Federal do Brasil (www.receita.fazenda.gov.br), e também no site do Ministério das Relações Exteriores (www.mre.gov.br), onde também podem ser encontrados os acordos já celebrados, mas que ainda não entraram em vigor.

\subsection{Os tratados internacionais em matéria tributária e sua hierarquia no ordenamento jurídico brasileiro}

Assim como não existem na Constituição de 1988 disposições expressas sobre a adoção da teoria monista ou dualista, também inexistem quaisquer normas específicas relativamente à hierarquia dos tratados tributários com relação às normas de Direito interno, o que acarreta grande controvérsia em torno da existência ou não de relações de superioridade entre normas de tratados internacionais e normas infraconstitucionais internas.

O Estado brasileiro é profundamente comprometido com a ordem internacional, como está exposto no preâmbulo ${ }^{471}$ da Constituição Federal de 1988 (CF/88) e também em diversos de seus dispositivos. A CF/88 também reconhece a legitimidade das fontes de produção das normas internacionais em seu artigo $5^{\circ}$, parágrafo $2^{\mathrm{o}^{472}}$, bem como

\footnotetext{
470 Sobre procedimento de celebração de tratados no Direito Brasileiro, v. XAVIER, Alberto. Direito Tributário Internacional do Brasil. 6. ed. reform. e atual., Rio de Janeiro: Forense, 2007. p. 105-108. MEDEIROS, Antônio Paulo Cachapuz. O poder de celebrar tratados. Porto Alegre: Sérgio Antônio Fabris. 1995. NIARADI, George Augusto. O 'iter' de elaboração dos tratados internacionais no Brasil. In: AMARAL, Antônio Carlos Rodrigues do (coord.). Tratados Internacionais na Ordem Jurídica Brasileira. São Paulo: Aduaneiras, 2005. p. 131-139. ALBUQUERQUE, Simone Gasperin. Isenção por meio de tratados internacionais \& autonomia tributária. Curitiba: Juruá, 2005, p. 68-74. TRINDADE, Otávio Augusto Drummond Cançado. O Mercosul no Direito Brasileiro: Incorporação de Normas e Seguranca Juridica. Belo Horizonte: Del Rey, 2006. p. 68-76.

471 Preâmbulo da CF/88: "Nós, representantes do povo brasileiro, reunidos em Assembléia Nacional Constituinte para instituir um Estado Democrático, destinado a assegurar o exercício dos direitos sociais e individuais, a liberdade, a segurança, o bem-estar, o desenvolvimento, a igualdade e a justiça como valores supremos de uma sociedade fraterna, pluralista e sem pré conceitos, fundada na harmonia social e comprometida, na ordem interna e internacional, com a solução pacífica das controvérsias, promulgamos, sob a proteção de Deus, a seguinte CONSTITUIÇÃO DA REPÚBLICA FEDERATIVA DO BRASIL."

472 “ $\$ 2^{\circ}$ - Os direitos e garantias expressos nesta Constituição não excluem outros decorrentes do regime e dos princípios por ela adotados, ou dos tratados internacionais em que a República Federativa do Brasil seja parte."
} 
protege constitucionalmente os direitos criados por meio de tratados internacionais dos quais o Brasil seja parte. No caso dos direitos humanos previstos em tratados internacionais, a proteção constitucional é ainda maior, ostentando tais garantias o status de norma constitucional protegida pela cláusula pétrea (art. 60, IV, da CF/88), não podendo ser modificadas nem mesmo por emendas constitucionais. Além disso, em diversas outras matérias, a Constituição Federal especificou expressamente a prevalência do Direito Internacional sobre o Direito interno ${ }^{473}$.

Exceto pelos direitos humanos, que possuem status de norma constitucional, as demais normas introduzidas por meio de tratados internacionais devem necessariamente estar em conformidade com a Constituição. Em outras palavras, isso significa que no Direito brasileiro, os tratados internacionais são hierarquicamente inferiores à Constituição, devendo todo o seu conteúdo ser compatível com o disposto na Magna Carta, podendo, inclusive, haver declaração de inconstitucionalidade sobre seus dispositivos, nos termos do art. 102, III, "b" pressuposto, observa-se que as normas tributárias internacionais, provenientes de tratados, são subordinadas à Constituição Federal, sendo desnecessários maiores questionamentos a esse respeito.

Assim, no estudo das normas introduzidas pelos tratados internacionais tributários, a análise que se faz necessária é a da posição hierárquica ocupada por estas em relação à legislação infraconstitucional tributária. E é exatamente em torno desta questão que se situa uma das maiores polêmicas do Direito Tributário interno e internacional.

A CF/88, em seu artigo 146, III $^{475}$, expressamente delega à lei complementar a competência para dispor sobre normas gerais em matéria tributária. Em face deste mandamento constitucional, o Código Tributário Nacional (CTN), lei complementar

\footnotetext{
${ }^{473}$ Por exemplo, os seguintes dispositivos: artigo $4^{\circ}$; artigo 178, parágrafo $1^{\circ}$; artigo 192.

474 “Art. 102. Compete ao Supremo Tribunal Federal, precipuamente, a guarda da Constituição, cabendolhe:

(...)

III - julgar, mediante recurso extraordinário, as causas decididas em única ou última instância, quando a decisão recorrida:

(...)

b) declarar a inconstitucionalidade de tratado ou lei federal;"

475 “Art. 146. Cabe à Lei Complementar:

(...)

III - estabelecer normas gerais em matéria de legislação tributária, especialmente sobre:

$(\ldots)$ "
} 
competente para tal fim, dispôs sobre a hierarquia das disposições normativas tributárias constantes de tratados internacionais em seu artigo 98, o qual determina que "Os tratados e as convenções internacionais revogam ou modificam a legislação tributária interna, e serão observados pela que lhes sobrevenha".

Heleno Torres analisa o referido dispositivo e explica que ele possui duas funções claramente definidas: a primeira seria de declarar a recepção das normas convencionais no sistema jurídico nacional, e a segunda seria a de informar o princípio da prevalência das normas internacionais, proibindo, assim, o legislador ordinário de criar leis incompatíveis com o disposto nos textos dos tratados internacionais tributários ${ }^{476}$. Nesse sentido, a prevalência das normas internacionais constantes em tratados de dupla tributação foi reconhecida pelo mestre alemão Ottmar Buhler, segundo o qual:

“En el ámbito de los tratados jurídico-tributarios existen motivos especiales para limitar el rango superior de los TDI frente a las disposiciones de Derecho interno mediante el principio de la 'lex posterior'; la movilidad de las leyes fiscales internas es una necesidad absoluta; ésta no sería posible si un Estado que ha concertado unos veinte o más TDI con otros países estuviera imposibilitado de introducir en sus leyes futuras modificaciones que en virtud de uno cualquiera de dichos tratados pudieran ser impugnadas". 477

Além disso, as discussões em torno do dispositivo supracitado giram em torno de duas questões: (i) qual a força vinculante do tratado em face das normas infraconstitucionais internas, e (ii) como se opera a "revogação" mencionada na segunda parte da norma do artigo 98.

Analisando as questões acima, Paulo de Barros Carvalho ${ }^{478}$ afirma que não são os tratados e convenções internacionais que possuem idoneidade jurídica para revogar ou modificar a legislação interna, mas sim os decretos legislativos que os ratificam, ou seja, que aprovam o seu conteúdo, incorporando-os à ordem jurídica brasileira. Nesse sentido, o Professor ressalta a importância do decreto legislativo, já que os tratados, segundo ele, não

\footnotetext{
476 TORRES, Heleno Taveira. O princípio da não-discriminação tributária na Constituição e no GATT e a prevalência dos tratados internacionais em matéria tributária. In: Construindo o Direito Tributário na Constituição: Uma análise da Obra do Ministro Carlos Mário Velloso. Belo Horizonte: Del Rey, 2004. p. 441 .

477 BUHLER, Ottmar. Principios de Derecho Internacional Tributario. Trad. Fernando Cervera Torrejon. Madri: Editorial de Derecho Financiero, 1968. p. 59.

${ }^{478}$ CARVALHO, Paulo de Barros. Curso de Direito Tributário. 12. ed. São Paulo: Saraiva, 1999. p. 78.
} 
possuem qualquer força vinculante enquanto não ingressam no ordenamento pátrio. Seguindo esta linha, a atual orientação do Supremo Tribunal Federal (STF) é no sentido de que o tratado internacional somente adquire capacidade de produzir efeitos no âmbito interno após ser homologado por meio de decreto legislativo ${ }^{479}$.

No entanto, nem mesmo o fato de o Supremo Tribunal Federal já ter se manifestado sobre a questão em alguns julgamentos foi capaz de dirimir a controvérsia existente em torno da interpretação do artigo 98 do CTN. Na realidade, a determinação da posição hierárquica ocupada pelos tratados internacionais dentro do ordenamento jurídico interno é questão mal resolvida até mesmo dentro do próprio Supremo Tribunal Federal, até os dias de hoje.

No julgamento do Recurso Extraordinário - RE n. $71.154^{480}$, consolidou-se o entendimento de que os tratados internacionais aprovados e promulgados passavam a integrar a legislação interna com o mesmo status de leis federais ${ }^{481}$. Seguindo este posicionamento, o Ministro Celso de $\mathrm{Mello}^{482}$, no voto proferido no acórdão da Ação Direta de Inconstitucionalidade - ADI 1.480-MC, entendeu que a relação entre as normas dos tratados internacionais em matéria tributária e o Direito interno é de paridade, não havendo superioridade hierárquica entre aqueles e estas ${ }^{483}$. Por sua vez, o Ministro Antônio

${ }^{479}$ Nesse sentido são as seguintes decisões: STF, Pleno, CR (AgRg) n. 8.279-ARGENTINA, Relator Min. Celso Mello, j. 17/06/1998) e RHC 79.785-RJ, Relator Min. Sepúlveda Pertence, j. 29/03/2000.

480 "Lei uniforme sobre o cheque, adotada pela Convenção de Genebra. Aprovada essa Convenção pelo Congresso Nacional, e regularmente promulgada, suas normas têm aplicação imediata, inclusive naquilo em que modificarem a legislação interna. Recurso Extraordinário conhecido e provido." (STF, Tribunal Pleno, RE 71.154, Relator Min. Oswaldo Trigueiro. Julgado em 04 ago. 1971. Publicado no Diário da Justiça de 27 ago. 1971.

${ }^{481}$ HENRIQUES JR., Fernando do Couto. Conflito entre norma interna e norma de tratado internacional. In: AMARAL, Antônio Carlos Rodrigues do (coord.). Tratados Internacionais na Ordem Jurídica Brasileira. São Paulo: Aduaneiras, 2005. p. 127.

${ }^{482}$ Nesse sentido, confira-se o despacho proferido nos autos da CR n. 8.279-Argentina, em maio de 1998 : "Cumpre assinalar, finalmente, que os atos internacionais, uma vez regularmente incorporados ao direito interno, situam-se no mesmo plano de validade e eficácia das normas infraconstitucionais. Esta visão do tema foi prestigiada em decisão proferida pelo Supremo Tribunal Federal no julgamento do RE n. 80.004SE (RTJ 83/809, Rel. para o Acórdão Min. Cunha Peixoto), quando se consagrou entre nós a tese - até hoje prevalecente na jurisprudência desta Corte (e recentemente reiterada no julgamento da ADI n. $1.480-D F$, Min. Celso de Mello) - de que existe, entre tratados internacionais e leis internas brasileiras, de caráter ordinário, mera relação de paridade normativa. A normatividade dos tratados internacionais, dentro do sistema jurídico brasileiro, por isso mesmo, permite situar esses atos no mesmo plano e no mesmo grau de eficácia em que se posicionam as leis internas." Grifos nossos.

483 “(..) PARIDADE NORMATIVA ENTRE ATOS INTERNACIONAIS $\quad$ E NORMAS INFRACONSTITUCIONAIS DE DIREITO INTERNO. - Os tratados ou convenções internacionais, uma vez regularmente incorporados ao direito interno, situam-se, no sistema jurídico brasileiro, nos mesmos planos de validade, de eficácia e de autoridade em que se posicionam as leis ordinárias, havendo, em conseqüência, 
Carlos Lafayette de Andrade, julgando a Apelação Cível n. 9.587 484 , entendeu que o tratado revoga as leis que lhes são anteriores, e não pode ser revogado pelas leis que lhe são posteriores, exceto quando tais leis posteriores referem-se especificamente à revogação do tratado ou à sua denúncia. Neste caso, o Ministro entendeu que "uma simples lei que dispõe sobre imposto de consumo não tem força para alterar os termos de um tratado internacional. "485. Já nos acórdãos proferidos no Pedido de Extradição n. 3, de 1913 (cujo acórdão é de 1914) e na Apelação Cível n. 7.872, de 1943, o STF determinou que o tratado continuaria em vigor mesmo em face de lei posterior que lhe contrariasse. Em sentido contrário foi o acórdão proferido no Recurso Extraordinário - RE n. 80.004, no qual foi consolidado o entendimento de que o tratado pode ser derrogado pela lei posterior. Mais tarde, reviu-se este entendimento conforme restou demonstrado pelo voto do Ministro Moreira Alves ${ }^{486}$, exposto no julgamento do Recurso Extraordinário - RE 90.824, segundo o qual os tratados internacionais prevalecem sobre o Direito interno, independentemente de sua natureza, em matéria tributária.

Nesse sentido, é importante citar a opinião do próprio Ministro Carlos Mário das Silva Velloso, que analisou a jurisprudência antiga do STF sobre a questão da posição hierárquica dos tratados internacionais em face da legislação infraconstitucional interna, e concluiu o seguinte:

entre estas e os atos de direito internacional público, mera relação de paridade normativa. Precedentes. No sistema jurídico brasileiro, os atos internacionais não dispõem de primazia hierárquica sobre as normas de direito interno. (STF, Pleno, ADI 1.480-MC, Relator Min. Celso de Mello, Publicado no Diário da Justiça de 18 mai. 2001). No mesmo sentido, Apelação Cível n. 2002.03.99.013893-3, TRF-3, Turma Suplementar da $2^{a}$ Seção, Relatora Juíza Federal Convocada Eliana Marcelo, julgado em 28 jun. 2007; Apelação Cível n. 1998.51.01.023848-8, TRF-2, Quarta Turma Especializada, Relator Desembargador Federal Luiz Antonio Soares, Publicado no Diário da Justiça de 29 ago. 2006.

484 “Tratado internacional. Sua força quanto às leis que regulam os casos nele estabelecidos. Só por leis que a ele se refiram expressamente, pode ser revogado. Imposto. Como deve ser cobrado." (STF, Tribunal Pleno, ACi 9.587, Relator Min. Lafayette de Andrada, Segunda Turma, julgado em 21 ago. 1951. Publicado no Diário da Justiça de 18 out. de 1951).

485 Trecho do voto do Ministro Antônio Carlos Lafayette de Andrada, p. 10 do acórdão. Disponível em http://www.stf.jus.br/portal/inteiroTeor/obterInteiroTeor.asp?numero=9587\&classe=ACi. Acesso em 10 jan. 2010 .

486 “(...) na hermenêutica jurídica, vigora o princípio de que se deve dar à lei hierarquicamente inferior, desde que possível, interpretação que a compatibilize com preceito legal, hierarquicamente superior. De feito, em matéria tributária, independentemente da natureza do tratado internacional, se observa o princípio contido no artigo 98 do Código Tributário Nacional: 'Art. 98. Os tratados e convenções internacionais revogam ou modificam a legislação tributária interna e serão observados pela lei que lhes sobrevenha. '(...)” (STF, Tribunal Pleno, RE 90.824. Obtido em: RTJ 95/350). 
"No Brasil, antiga jurisprudência do Supremo Tribunal Federal sustentava o primado do direito internacional sobre o direito interno. Hoje, entretanto, a jurisprudência do Supremo Tribunal Federal orienta-se no sentido da paridade entre o tratado e a lei federal. Assim decidiu o Supremo Tribunal, em 04/08/71, portando o acórdão a seguinte ementa:

'Lei uniforme sobre o cheque, adotada pela Convenção de Genebra. Aprovada essa Convenção pelo Congresso Nacional, e regularmente promulgada, suas normas têm aplicação imediata, inclusive naquilo em que modificarem a legislação interna.'

A mais importante decisão proferida pelo Supremo Tribunal Federal, entretanto, foi tomada no julgamento do RE 80.004/SE, relator originário o ministro Xavier de Albuquerque e, relator para o acórdão, o ministro Cunha Peixoto, julgamento realizado em 1o/06/77.

O relator originário, ministro Xavier de Albuquerque, sustentou, vencido, o primado do Direito Internacional. A maioria, entretanto, reconhecendo o conflito entre o tratado e a lei nacional, esta posterior àquele, garantiu a autoridade da lei nacional, mais recente, tendo em vista a paridade entre o tratado e a lei nacional. Os ministros Cordeiro Guerra, Rodrigues Alckmin, Thompson Flores e Cunha Peixoto votaram no sentido de que, da mesma forma que o tratado posterior derroga a lei, também a lei posterior derroga o tratado anterior, segundo a regra lex posteriori derrogat legi priori. $O$ ministro Antônio Neder, com base em argumentos diferentes, acompanhou a conclusão dos votos dos ministros Peixoto, Guerra, Leitão, Alckmin e Flores. $O$ voto mais importante foi o do ministro Leitão de Abreu, voto que, segundo Rezek, melhor equacionou a controvérsia. Segundo Leitão de Abreu, a lei posterior não revoga o tratado anterior, 'mas simplesmente afasta, enquanto em vigor, as normas do tratado com ela incompativeis', pelo que 'voltará ele a aplicar-se, se revogada a lei que impediu a aplicação das prescrições nele consubstanciadas'. Prevaleceu, na verdade, o entendimento de Leitão de Abreu, por isso que, revogado, posteriormente o D.L. 427 pelo D.L. 1.700/79, o Supremo Tribunal Federal continuou a aplicar as Convenções de Genebra. Realmente, no julgamento do RE 95.002/PR, relator o ministro Soares Muñoz, julgamento ocorrido em 15/09/81, o Supremo Tribunal aplicou o art. 20 da Lei 
Uniforme sobre Letras de Câmbio e Notas promissórias, que regula o endosso dado após o vencimento. ",487

No entanto, o próprio Ministro Velloso ressalva seu entendimento em relação aos tratados internacionais em matéria tributária, que, segundo ele, são superiores à legislação infraconstitucional interna em razão do mandamento contido no artigo 98 do $\mathrm{CTN}^{488}$.

A doutrina, por sua vez, apresenta uma tendência a defender a superioridade das normas tributárias internacionais com fundamento no critério da especialidade ${ }^{489}$. Em outras palavras, normas tributárias internacionais específicas seriam superiores às internas gerais.

Este também é o argumento utilizado em algumas decisões administrativas do Conselho de Contribuintes ${ }^{490}$, nas quais os tratados internacionais foram considerados superiores à legislação tributária.

${ }^{487}$ VELLOSO, Carlos Mário da Silva. Tratados internacionais na jurisprudência do Supremo Tribunal Federal. In: AMARAL, Antônio Carlos Rodrigues do (coord.). Tratados Internacionais na Ordem Jurídica Brasileira. São Paulo: Aduaneiras, 2005. p. 15-16.

${ }^{488}$ VELLOSO, Carlos Mário da Silva. Tratados internacionais na jurisprudência do Supremo Tribunal Federal. In: AMARAL, Antônio Carlos Rodrigues do (coord.). Tratados Internacionais na Ordem Jurídica Brasileira. São Paulo: Aduaneiras, 2005. p. 16.

489 TORRES, Heleno Taveira. Pluritributação Internacional sobre as Rendas de Empresas. 2. ed. rev., ampl. e atual. São Paulo: Revista dos Tribunais, 2001. pp. 578-582. HENRIQUES JR., Fernando do Couto. Conflito entre norma interna e norma de tratado internacional. In: AMARAL, Antônio Carlos Rodrigues do (coord.). Tratados Internacionais na Ordem Jurídica Brasileira. São Paulo: Aduaneiras, 2005. p. 127.

490 “TRATADOS E CONVENÇÕES INTERNACIONAIS. Não obstante o STF tenha se posicionado no sentido de inexistência de primazia hierárquica do tratado internacional, em se tratando de Direito Tributário a prevalência da norma internacional decorre de sua condição de lei especial em relação à norma interna. CONVENÇÃO Brasil-ARGENTINA PARA EVITAR DUPLA TRIBUTAÇÃO. LUCRO DE SUCURSAL BRASILEIRA NA ARGENTINA. No caso específico, a norma interna prevalecerá sobre a norma internacional, posto que a própria convenção internacional admite a possibilidade de modificação do tratamento aplicável às filiais a empresas brasileiras situadas no exterior por meio de alteração a legislação interna brasileira. IMPOSTO PAGO NO EXTERIOR. COMPENSAÇÃO. Para fins de compensação do imposto de renda incidente no exterior, a comprovação pode ser feita na forma do art. 16 da Lei 9.430/96. COMPENSAÇÃO. PREJUÍZOS ACUMULADOS DE PERÍODOS-BASE ANTERIORES A 1996. Comprovado nos autos o trânsito em julgado de decisão judicial admitindo a compensação integral dos prejuizos anteriores a 1995, deve ser atendido o pleito do contribuinte de utilizar os saldos dos prejuizos compensáveis com os lucros tributáveis apurados no procedimento em litígio. Recurso provido em parte." (Processo n. 16327.000619/2001-61. Recurso Voluntário n. 138.932. Acórdão n. 101-94910, Primeiro Conselho de Contribuintes, Primeira Câmara, Relatora Conselheira Sandra Maria Faroni, sessão de 13/04/2005). No mesmo sentido: Processo n. 16327.003372/2003-04, Recurso Voluntário n. 144.538. Acórdão n. 101-95476, Primeiro Conselho de Contribuintes, Primeira Câmara, Relatora Conselheira Sandra Maria Faroni, sessão de 26/04/2006; Processo n. 10830.005220/00-93, Recurso Voluntário n. 124.526. Acórdão n. 104-18587, Primeiro Conselho de Contribuintes, Quarta Câmara, Relator Conselheiro Roberto William Gonçalves, sessão de 24/01/2002. 
Verifica-se, portanto, que até o presente momento não se chegou a uma conclusão sobre a posição hierárquica ocupada pelos tratados recepcionados pelo ordenamento jurídico brasileiro. Em decorrência da polêmica em torno da hierarquia dos tratados, surge a controvérsia sobre o significado e alcance da expressão "revogam", contida na segunda parte do art. 98 do CTN.

Heleno Torres explica que esta expressão deve ser analisada no contexto da prática do Direito Internacional e das convenções internacionais tributárias. Isto significa que a expressão "revogam", tal qual colocada no artigo 98 do CTN, deve ser interpretada sob os estritos limites das relações jurídico-tributárias entre as partes pactuantes do tratado internacional em questão. Em outras palavras, não se trata de uma norma geral no sentido de que deva ser aplicada indistintamente em todas as situações. Trata-se, sim, de uma norma destinada a disciplinar as relações tributárias estabelecidas durante a aplicação de um tratado internacional, e, ainda assim, apenas nas relações envolvendo as partes contratantes. $^{491}$

Deste modo, não se trata de revogação stricto sensu das normas tributárias, mas sim de uma revogação "funcional", que atinge apenas as situações envolvendo os sujeitos e os elementos de estraneidade descritos na norma do tratado internacional. O que ocorre é uma limitação da eficácia normativa, a norma interna perde a sua aplicabilidade naquele caso específico, mas não perde a sua existência ou validade em relação ao sistema normativo interno. Em outras palavras, a "revogação funcional" ou "limitação da eficácia normativa" torna as normas internas relativamente inaplicáveis àquelas situações previstas no tratado internacional, envolvendo determinadas pessoas, situações e relações jurídicas específicas, mas não acarreta a revogação stricto sensu da norma para as demais situações jurídicas.

Alberto Xavier ${ }^{492}$, também entende que a revogação contida no artigo 98 do CTN acarreta tão somente uma limitação da eficácia das normas internas quando em conflito com as normas internacionais, tornando a lei nacional apenas relativamente inaplicável naquelas situações especificamente reguladas no acordo internacional. Tal

\footnotetext{
${ }^{491}$ Analisando o artigo 98, Heleno Torres explica a questão da revogação das normas internas por tratados internacionais tributários. TORRES, Heleno Taveira. Pluritributação Internacional sobre as Rendas de Empresas. 2. ed. rev., ampl. e atual. São Paulo: Revista dos Tribunais, 2001. p. 578 - 582.

${ }^{492}$ XAVIER, Alberto. Direito Tributário Internacional do Brasil. 6. ed. reform. e atual. Rio de Janeiro: Forense, 2004. p. 113-115.
} 
opinião é partilhada por Ricardo Lobo Torres ${ }^{493}$, que também defende a suspensão da eficácia da norma nacional.

Sob outro prisma, a Professora Misabel Derzi entende que a revogação prevista no artigo 98 do CTN acarreta, sim, a perda da eficácia e da validade da norma interna revogada pela norma do tratado internacional, não se tratando de uma mera limitação de aplicabilidade. E, segundo a Professora, isto decorre da primazia dos tratados internacionais em matéria tributária sobre as leis internas ${ }^{494}$, o que, por sua vez, advém do caráter de lei especial dos tratados em relação à generalidade das normas internas ${ }^{495}$.

Evidencia-se, desta forma, que a discussão acerca do artigo 98 do CTN, tanto no que tange à hierarquia normativa dos tratados quanto no que se refere ao alcance dos dispositivos contidos em seus textos está longe de ser pacificada na doutrina e na jurisprudência nacionais. Entretanto, a maior parte da doutrina parece concordar em um

493 “(...) não se trata, a rigor, de revogação da legislação interna, mas de suspensão da eficácia da norma tributária nacional, que readquirirá a sua aptidão para produzir efeitos se e quando a o tratado for denunciado”. TORRES, Ricardo Lobo. Curso de Direito Financeiro e Tributário. 7. ed. Renovar, 2000 p. 45.

494 “Como se sabe, o art. 98 do Código Tributário Nacional estabelece que 'os tratados e convenções internacionais revogam ou modificam a legislação tributária interna e serão observados pela legislação que lhes sobrevenha'. A União representa o Estado brasileiro na ordem internacional. Uma vez celebrado o acordo ou ato internacional pelo Presidente da República e ratificado pelo Congresso Nacional em decreto legislativo, incorpora-se à ordem jurídica interna, revogando as normas incompativeis que lhe sejam contrárias.

Para certa corrente doutrinária (cf. Sacha Calmon, 'Validade e Extensão dos Tratados Internacionais em Matéria Tributária, perante a Constituição Federal do Brasil de 1988', in Imposto de Renda. Estudos, $n .^{o}$ 13, São Paulo. Ed. Resenha Tributária, nov. 92, pp. 52-53) os tratados, atos e convenções internacionais, uma vez referendados pelo Poder Legislativo da União, mão apenas revogam e modificam a legislação interna federal, mas também a estadual, obrigando Estados federados e Municípios (...).” BALEEIRO, Aliomar. Direito Tributário Brasileiro. 11. ed. atual. Misabel Abreu Machado Derzi. Rio de Janeiro: Forense, 2005. p. 640.

${ }^{495}$ No mesmo sentido, confira-se: CALIENDO, Paulo. Estabelecimentos Permanentes em Direito Tributário Internacional. São Paulo: Revista dos Tribunais, 2005.. p. 171. Outros renomados juristas também partilham desta mesma opinião, como Geraldo Ataliba e Aires Barreto, citados pela Professora Misabel Derzi nota de atualização à obra de Aliomar Baleeiro, a saber: "Analisam o art. 98 do Código Tributário Nacional, por outro prisma, Geraldo Ataliba e Aires Barreto. Explicam eles que o princípio de que a lei posterior derroga a anterior cede lugar a outro, ou seja, leis especiais não são revogadas por leis gerais. Daí o sentido próprio do art. 98. Assim:

'Os acordos internacionais tributários são leis internas que descrevem as hipóteses de incidência dos tributos diversos. São especiais porque prescrevem a) regulações diferentes, peculiares e específicas, para b) situações especiais discriminadas para alguns, enquanto as leis tributárias contêm a.1) regras gerais ou especificas para b.1) todas as situações gerais ou específicas que descrevem.

(...) Em resumo, por tratar-se de leis especiais - no confronto com a lei que cria o tributo, o acordo ou o tratado internacional prevalece sobre essa não podendo ser revogados ("leis especiais não são revogadas pela geral').

Assim, a prevalência das normas dos tratados não provém de sua índole internacional nem de uma superioridade extrassistemática do direito internacional: essa prevalência decorre direta e simplesmente das regras de nosso ordenamento jurídico'.” BALEEIRO, Aliomar. Direito Tributário Brasileiro. 11. ed. atual Misabel Abreu Machado Derzi. Rio de Janeiro: Forense, 2005. p. 642-643. 
ponto: os tratados internacionais, por seu caráter de lei especial, são superiores à legislação infraconstitucional interna, no que se refere às situações especificamente nele previstas.

Como forma de contornar a polêmica, os Tribunais têm restringido a aplicação deste artigo somente aos tratados de natureza contratual ${ }^{496}$. Na realidade, a jurisprudência tem entendido que o mandamento contido no art. 98 do CTN não atribui ascendência às normas de Direito Internacional em detrimento do Direito positivo interno, donde se deduz que o referido artigo 98 do CTN estaria dirigido especificamente aos tratados de natureza contratual.

$\mathrm{Na}$ realidade, a distinção entre tratados-contrato e tratados-leis é uma questão já amplamente debatida na doutrina. Para compreender esta distinção, é necessário considerar, antes de tudo, que a finalidade das normas jurídicas internacionais é sempre decorrente da manifestação da vontade convergente dos Estados soberanos. Cientes disso, torna-se possível subdividir as normas internacionais em duas categorias: (i) aquelas que possuem como objetivo beneficiar os Estados enquanto entes de Direito Internacional Público, e (ii) aquelas que visam regulamentar os direitos dos particulares, no âmbito do Direito interno. Com base nesta divisão, é possível afirmar que as normas do primeiro conjunto visam à realização de operações jurídicas entre Estados soberanos, podendo ser encontradas nos tratados de natureza contratual (ou simplesmente "tratados-contrato"), enquanto que as do segundo grupo destinam-se a firmar regras e procedimentos cuja aplicação se dará no âmbito interno, integrando os chamados tratados de natureza normativa. Como exemplo de tratados-contrato cita-se os tratados de comércio, enquanto que as convenções de paz e as convenções da OMC seriam exemplos de tratados normativos.

O objetivo da criação desta classificação foi para facilitar a compreensão dos efeitos das normas internacionais. Porém, é comum que se encontrem, num mesmo tratado, disposições de cunho contratual e provisões normativas. Deste modo, apesar de alguns autores $^{497}$ ainda considerarem importante classificar os tratados segundo a sua natureza

\footnotetext{
${ }^{496}$ STJ, Resp 196.650, Rel. Min. Demócrito Reinaldo, j. 18/03/1999.

497 Jacob Dolinger ressalta a importância desta classificação como forma de garantir a supremacia dos tratados contratuais, mediante aplicação do princípio do pacta sunt servanda. Segundo ele, os danos advindos do inadimplemento de um tratado-contrato seriam bem maiores do que aqueles decorrentes do descumprimento de um tratado-lei. DOLINGER, Jacob. As soluções da Suprema Corte brasileira para os conflitos entre o direito interno e o direito internacional: um exercício de ecletismo. In: Revista Forense. Rio de Janeiro, v. 334, abr. jun. 1996. p. 102-103.
} 
contratual ou normativa, observa-se uma tendência ao abandono da divisão, já que sua importância é maior apenas do ponto de vista metodológico e descritivo, não possuindo tanta relevância prática.

Trazendo a análise para o campo das convenções contra a bitributação internacional, observa-se que os tratados de bitributação são, concomitantemente, tratadoscontrato e tratados-normativos. Isto porque tratados deste tipo são celebrados entre dois ou mais países que acordam entre si a limitação de suas próprias soberanias fiscais e competências tributárias, representando, portanto, um acordo de vontades, e, ao mesmo tempo, as normas de Direito Tributário Internacional neles consubstanciadas são aplicáveis do mesmo modo como as leis internas, regendo relações jurídicas entre os sujeitos e acarretando implicações jurídicas. Assim, a classificação entre um ou outro tipo não possui muita importância para a análise deste tipo de convenção. ${ }^{498}$

Não obstante as discussões acerca das classificações acima explicadas, concordamos com Heleno Torres no sentido de que a superioridade hierárquica dos tratados internacionais tributários advém não do fato de serem normas internacionais, mas, sim, em virtude de serem normas especiais em relação às normas internas, atendendo, portanto, ao critério lex specialis derrogat generalis. ${ }^{499} \mathrm{E}$ são normas especiais porque

${ }^{498}$ Destacando a irrelevância da distinção entre tratados-contrato e tratados-normativos, especialmente com relação aos tratados de bitributação, Vogel e Prokisch explicam que: "In principle, the VCLT [Vienna Convention on the Law of Treaties] does not differentiate between the interpretation of law-making treaties (...) and contract-treaties (...). This is justified, since the interpretation in the field of international treaties is identical (...). Though it is true that international reciprocal treaties have more in common with contracts between private parties than with law-making and multilateral treaties, while rules of interpretation in private law are primarily intended for interpretation by the courts, in international law every state interprets its own obligations. (...) it should not be neglected that double taxation conventions not only create rights and obligations of Contracting States, but also have a direct implication for the taxpayer, whose tax planning depends on the definiteness and reliability of treaty provisions. National tax authorities and courts apply these conventions in the same way as laws, hence terms used in the conventions become legal terms. Moreover, conventions today have to follow, to a great extent, the OECD and UN Model Conventions, and therefore lose part of their character as reciprocal agreements and move closer to law-making treaties. This must be taken into consideration when interpreting double taxation conventions." VOGEL, Klaus. PROKISCH, Rainer G. General Report. Interpretation of Double Taxation Conventions. Cahiers de Droit Fiscal International. 1993. Florence Congress, International Fiscal Association., vol. LXXVIIIa. p. 67/68.

${ }^{499}$ Heleno Torres explica como caráter de especialidade das normas contidas em convenções internacionais tributárias as tornam superiores às normas infraconstitucionais internas: "Como diz Tixier e Gest, uma convenção sobre a renda e o capital é um simples acordo entre dois sistemas fiscais, que não possui como objetivo a pretensão de substituir o Direito Tributário interno dos Estados contratantes, mas permitir um relacionamento harmonioso dos sistemas entre si, oferecendo um complemento comum para atingir as finalidades às quais se destina. Desse caráter de subsidiariedade, as convenções de Direito Internacional Tributário, pelo tipo de relação com o direito interno, passam a ter a natureza de uma lex specialis, limitando-se a colocar em vigor um mecanismo para evitar o concurso de pretensões impositivas entre os Estados contratantes. O termo 'especial' pode ser usado sob duas perspectivas distintas. Pode designar, em primeiro lugar, a preeminência da norma convencional, de modo que o direito interno não possa derrogar ulteriormente as suas disposições (prevalência de aplicabilidade), como o princípio lex posterior generalis 
regulam situações específicas, pormenorizadamente detalhadas em suas cláusulas, contando com o auxílio, inclusive, de protocolos e portarias para descrever as situações em que devem ser aplicadas, ao contrário das normas internas, que possuem caráter notadamente genérico. É nesse sentido que o artigo 98 determina a superioridade hierárquica dos tratados internacionais tributários, não havendo qualquer inconstitucionalidade nisso, independente de serem tais tratados classificados de tratadoscontratos ou tratados-normativos.

$\mathrm{E}$, mesmo que se argumente que os tratados internacionais somente possuem eficácia interna após sua introdução no ordenamento nacional, vale lembrar que decretos legislativos que os internalizam possuem força de lei ordinária, autorizando a aplicação do critério lex specialis derrogat generalis em relação às normas gerais tributárias internas.

Além disso, outro argumento que corrobora a tese da superioridade dos tratados internacionais em matéria tributária em relação ao Direito interno consiste no raciocínio de que os Estados, ao pactuarem obrigações e benefícios recíprocos, criam normas que produzem efeitos diretamente sobre os seus respectivos interesses, vinculandoos vigorosamente um ao outro. Desta forma, caso fosse admissível a revogação destas normas convencionais por normas internas supervenientes, através de ato unilateral e sem e devida observância do procedimento de revogação estabelecido no próprio tratado, estaria sendo afetado sensivelmente o compromisso internacionalmente estabelecido.

\subsection{O Direito Tributário Internacional e as convenções contra a dupla tributação internacional}

É inquestionável que a fonte primária das normas do Direito Tributário Internacional constitui-se dos tratados internacionais tributários. Estes acordos podem ser de diversas espécies, apesar de os mais comuns serem os tratados para evitar a dupla tributação. Estes podem ser gerais, baseados em modelos como o da Organização para Cooperação e Desenvolvimento Econômico (conhecido como OECD Model Tax Convention), Organização das Nações Unidas (UN Model Tax Convention), US Model ou Modelo do Pacto Andino, mas podem também ser específicos, como é o caso dos acordos

non derogat lex priori speciali pode valer como presunção de interpretação, de modo que a interpretação das leis ulteriores não possa derrogar o conteúdo das respectivas normas constantes do diploma convencional (por exemplo, Alemanha e Suiça)." TORRES, Heleno Taveira. Pluritributação Internacional sobre as Rendas de Empresas. 2. ed. rev. ampl. e atual. São Paulo: Revista dos Tribunais, 2001. p. 593-594. 
para evitar a bitributação no transporte marítimo e aéreo, ou, ainda, serem específicos para alguns tipos de impostos, como é o caso dos acordos para evitar a bitributação relativamente a impostos sobre sucessões e doações. Estes últimos não são tão comuns, sendo muito mais difundidos os tratados de bitributação gerais.

Há ainda os acordos de harmonização tributária, os acordos de livre comércio, as uniões aduaneiras, também denominadas de mercados comuns (ex.: MERCOSUL, ALADI, NAFTA, etc.), os quais normalmente tratam da concessão de benefícios mútuos com a finalidade de fomentar o desenvolvimento econômico de uma determinada região ou visando beneficiar um determinado setor da economia de uma região, por exemplo, através da eliminação de impostos sobre a importação de determinado produto.

Além destas espécies, há também os acordos de livre trânsito internacional e aqueles referentes à concessão de imunidades e privilégios diplomáticos, e também os que tratam de cooperação técnica e científica, sendo também importantes os acordos sobre a troca de informações, como é o caso do Acordo de Cooperação Administrativa firmado entre o Brasil e a França em 1995..$^{500}$

Todas as espécies de acordos tributários possuem diversas nuances que fazem com que cada uma delas possa ser objeto de uma pesquisa completa em separado. Por esse motivo, e também em razão do objetivo do presente estudo, analisaremos apenas os acordos para evitar a dupla tributação internacional.

\subsubsection{Surgimento e evolução $o^{501}$ das convenções contra a dupla}

\section{tributação internacional}

As convenções contra a dupla tributação internacional são uma criação germânica. A primeira convenção contra a bitributação internacional é datada de 1899, celebrada entre o Império Austro-Húngaro e a Prússia. Porém, há registros de acordos bilaterais celebrados dentro da Federação Germânica desde antes desta data.

\footnotetext{
${ }^{500}$ O Professor Heleno Torres explica detalhadamente as espécies de acordos internacionais tributários em TORRES, Heleno Taveira. Pluritributação Internacional sobre as Rendas de Empresas. 2. ed. rev. ampl. e atual. São Paulo: Revista dos Tribunais, 2001. p. 582- 584.

${ }^{501}$ YAMASHITA, Douglas. Evolução da Convenção-Modelo da OCDE e a influência de suas alterações na interpretação de tratados para evitar a bitributação. In: AMARAL, Antônio Carlos Rodrigues do (coord.). Tratados Internacionais na Ordem Jurídica Brasileira. São Paulo: Aduaneiras, 2005. p. 103-123.
} 
Somente anos mais tarde, no período compreendido entre 1921 e 1928, a Liga das Nações, predecessora da futura Organização das Nações Unidas (ONU), empreendeu estudos e pesquisas para a elaboração de um modelo de convenção para evitar a dupla tributação. Assim surgiu o primeiro modelo, chamado de Modelo de Genebra, publicado em 1928.

Após a Primeira Guerra Mundial, com o incremento das relações comerciais entre os Estados e o consequente aumento da importância das medidas para evitar a dupla tributação internacional, as organizações internacionais, atuando em conjunto com países isolados, iniciaram os trabalhos de estruturação dos modelos de convenções. Deste modo, em 1922, a Inglaterra firmou um tratado para evitar a dupla tributação com a Irlanda e, em 1925, a Alemanha firmou com a Itália seu primeiro tratado contra a bitributação internacional.

Durante o período entre a Primeira e a Segunda Guerra Mundial, precisamente em 1928, numa reunião da Liga das Nações, em conclusão aos trabalhos iniciados em 1921, foi publicado o Relatório em Matéria de Dupla Tributação e Evasão Fiscal ${ }^{502}$, o qual continha três projetos de modelos de convenções. Então, a partir destes projetos, surgiram outros modelos de convenção, como foi o caso do Modelo de Genebra, de 1928, da Convenção Modelo do México, de 1943, e da Convenção Modelo de Londres, de 1946.

Com o fim da Segunda Guerra Mundial e o surgimento da Organização das Nações Unidas - ONU, em 1945 (que sucedeu a extinta Liga das Nações), bem como da Organização para Cooperação e Desenvolvimento Econômico - OCDE, em 1961, intensificaram-se ainda mais os trabalhos de elaboração de projetos para eliminar a dupla tributação.

Assim, em 1963 foi publicado o primeiro Projeto de Convenção de dupla tributação concernente à renda e ao patrimônio elaborado pela OCDE, bem como o seu primeiro comentário, o qual interpretava a Convenção Modelo e servia de recomendação aos membros daquela organização. No entanto, como muitos dos países-membros da OCDE não aceitaram as disposições deste primeiro comentário, apresentou-se as respectivas reservas aos comentários, e assim tem sido até os dias atuais, com sucessivas interpretações e comentários novos publicados periodicamente pela OCDE.

${ }^{502}$ Sobre os trabalhos da Liga das Nações para a elaboração de um modelo de convenção de bitributação, e sobre o Modelo da Genebra de 1928, v. DORNELLES, Francisco Neves. A Dupla Tributação Internacional da Renda. Rio de Janeiro: Editora FGV, 1979. p. 27-35. 
Após a publicação deste projeto, foram celebrados vários acordos bilaterais entre os países-membros, seguindo o modelo proposto. Datam desta época os primeiros acordos de bitributação celebrados pelo Brasil ${ }^{503}$.

Em 1977 foram concluídos os primeiros trabalhos de revisão ao Modelo da OCDE, tendo sido publicado o primeiro Modelo da OCDE revisado. Dez anos mais tarde, em 1980, sob a influência do Modelo da OCDE, foi publicado o Modelo da ONU (The UN Model), privilegiando o princípio da territorialidade, “constituindo, de certa forma, um compromisso de relacionamento congruente entre aquele princípio e o da tributação da renda mundial - o da universalidade $504, .505$

Existem, ainda, o modelo norte-americano (U.S. Model, concluído em 1976), e o Modelo do Pacto Andino, este último concluído em 1971, a partir de uma aliança entre Bolívia, Chile, Equador, Colômbia, Peru e Venezuela, como uma alternativa ao Modelo da OCDE, sendo mais direcionado para os interesses especiais dos países em desenvolvimento. Há também o Modelo Asiático ${ }^{506}$, elaborado em 1987, pelos países membros da Associação das Nações do Sudeste Asiático (Association of South East Asean Nations - ASEAN), e, ainda, o Modelo Holandês (The Netherlands Model), elaborado em 1986. Com exceção dos Estados Unidos e da Holanda, normalmente os países não costumam elaborar seus próprios modelos de convenção, já que é mais conveniente seguir um dos modelos propostos pelas organizações, notadamente o modelo da OCDE, mesmo que com adaptações.

Em 1991 o Comitê de Assuntos Fiscais da OCDE, reconhecendo a necessidade de constante revisão e atualização de seu Modelo de Convenção, decidiu publicar, em 1992, uma versão da Convenção Modelo atualizada e revisada, incorporando as mudanças

\footnotetext{
${ }^{503}$ Por exemplo, a Convenção Brasil-Japão, de 1967, a Convenção Brasil-Bélgica, de 1973, a Convenção Brasil-França, de 1972. dentre outras.

504 TORRES, Heleno Taveira. Pluritributação Internacional sobre as Rendas de Empresas. 2. ed. rev. ampl. e atual. São Paulo: Revista dos Tribunais, 2001. p. 342. DORNELLES, Francisco Neves. A Dupla Tributação Internacional da Renda. Rio de Janeiro, FGV, 1979. p. 37-47.

${ }^{505}$ O presente estudo é baseado na versão de 2008 da Convenção Modelo da OCDE.

${ }^{506}$ Embora sejam menos comuns, há também convenções multilaterais contra a bitributação. Por exemplo: a Convenção de Assistência Administrativa de 1964, celebrada entre os três países membros do Benelux (Bélgica, Países Baixos/Holanda e Luxemburgo); o Acordo sobre Impostos Sobre Sucessões, firmado em 1994 entre Batsuoland, Bechuanaland, África do Sul e Suazilândia, dentre outros citados por Kevin Holmes, em: HOLMES, Kevin. International Tax Policy and Double Tax Treaties: An Introduction to Principles and Application. Amsterdam: IBFD, 2007. p. 64-65.
} 
sugeridas desde a sua publicação. Contudo, ao contrário dos Modelos de 1963 e de 1977, o Modelo de 1992 não representou o resultado de uma revisão exaustiva de suas cláusulas, mas sim uma nova proposta de um modelo inicial que serviria de base para inúmeras alterações que se seguiriam.

Com isso, em 2003 foi publicada nova versão revisada do Modelo da OCDE e dos respectivos comentários, assim como ocorreu em 2005. O mesmo aconteceu com o Modelo da ONU, cuja atualização mais recente data do ano de 2001.

Como já destacamos acima, o processo de revisão e atualização dos modelos de convenção, especialmente o da OCDE, é constante, sendo as mais recentes alterações datadas de 2008.

A influência da Convenção Modelo da OCDE revela-se por meio de três efeitos principais: primeiro, a existência de uma convenção modelo facilitou as negociações bilaterais entre os Estados membros da OCDE, tendo facilitado, ainda, a harmonização das convenções celebradas entre os países; segundo, a convenção-modelo da OCDE serviu também de base para a elaboração de outros modelos de convenção, como o Modelo da ONU e o Modelo Norte-americano, e, terceiro, o reconhecimento da validade e utilidade do Modelo da OCDE fez com que os comentários passassem a ser aceitos como uma importante fonte de referencial para a interpretação e aplicação dos tratados de bitributação $^{507}$.

$\begin{array}{lll}1 & \text { África do Sul } & \text { Decreto n. } 5.922 / 06 \\ 2 & \text { Argentina } & \text { Decreto n. } 87.976 / 82 \\ 3 & \text { Áustria } & \text { Decreto n. } 78.107 / 76 \\ 4 & \text { Bélgica } & \text { Decreto } n .72 .542 / 73 \\ 5 & \text { Canadá } & \text { Decreto } n .92 .318 / 86 \\ 6 & \text { Chile } & \text { Decreto } \text { n. } 4.852 / 03 \\ 7 & \text { China } & \text { Decreto n. } 762 / 93 \\ 8 & \text { Coréia } & \text { Decreto n. } 354 / 91\end{array}$

${ }^{507}$ Sobre os comentários ao modelo da OCDE como fonte do Direito Internacional, v. PIJL, Hans. Os comentários da OCDE como fonte do Direito Internacional e o papel do Poder Judiciário. In: PANZARINI FILHO, Clóvis (Coord.). Revista de Direito Tributário Internacional. São Paulo: Quartier Latin, 2006. v.1. p. 203-228. 
10 Equador

11 Espanha

12 Filipinas

13 Finlândia

14 França

15 Hungria

16 Índia

17 Israel

18 Itália

29 Japão

20 Luxemburgo

21 México

22 Noruega

23 Países Baixos

$24 \quad$ Peru

25 Portugal

26 República Eslovaca e República Tcheca

27 Suécia

28 Ucrânia
Decreto n. $75.717 / 88$

Decreto n. $76.975 / 76$

Decreto n. 241/91

Decreto n. $2.465 / 98$

Decreto n. $70.506 / 71$

Decreto n. 53/91

Decreto n. 510/92

Decreto n. 5.576/05

Decreto n. $85.985 / 81$

Decretos n. $61.899 / 67$ e $81.194 / 78$

Decreto n. $85.051 / 80$

Decreto n. 6.000/06

Decreto n. $86.710 / 81$

Decreto n. 355/91

Decreto n. 7.020/09

Decreto n. 4.012/01

Decreto n. 43/91

Decreto n. $77.053 / 76$

Decreto n. $5.579 / 06^{508}$

O Brasil possui, ainda, tratados de bitributação com a Rússia, Trinidad e Tobago e Venezuela ${ }^{509}$, os quais, embora já estejam assinados, ainda não entraram em vigor internamente por não terem sido ainda submetidos a todos os procedimentos legislativos necessários para tanto.

\footnotetext{
${ }^{508}$ www.receita.fazenda.gov.br. Consulta realizada em 02 fev. 2010.

${ }^{509}$ Apesar de ainda não estarem em vigor, o texto destas convenções pode ser encontrado em: Disponivel em: http://www2.mre.gov.br/dai/007.htm.
} 
A legislação tributária brasileira permite, ainda, a aplicação de tratamento de reciprocidade com a finalidade de se evitar a dupla tributação, como ocorre em relação aos Estados Unidos, país com o qual ainda não foi celebrado um acordo de bitributação. Em termos genéricos, o regime de reciprocidade permite a compensação de tributos pagos nos casos de operações entre os dois países.

\subsubsection{Características e objetivos das convenções contra a dupla}

\section{tributação}

As convenções contra a dupla tributação internacional definem a repartição da competência tributária entre os Estados contratantes, ora atribuindo-a de forma exclusiva a um deles, ora deferindo-a concomitantemente a ambos, com previsão, nesse último caso, de mecanismos (isenção ou crédito) para mitigar o concurso de imposições daí decorrente.

No entanto, é importante mencionar que as convenções de bitributação jamais criam obrigações tributárias, no sentido positivo da expressão ${ }^{510}$. Em outras palavras, as normas contidas numa convenção contra a dupla tributação internacional jamais estabelecerão a regra matriz de incidência de qualquer tributo, mas, tão-somente, funcionarão como uma limitação negativa, impondo limites à competência tributária de um ou de ambos os Estados contratantes ${ }^{511}$. Do mesmo modo e pelos mesmos motivos, as convenções contra a dupla tributação internacional não detém o poder de modificar a regra matriz de incidência de tributos no sentido de aumentá-los, ou seja, acordos de bitributação jamais aumentam tributos.

Por serem classificadas como tratados na acepção do Direito Internacional Público, as convenções para evitar a dupla tributação têm sua validade e sua aplicação

\footnotetext{
510 "El interés de la eliminación de la doble imposición, que pudiera derivar, en primer lugar, de las legislaciones nacionales, constituye una finalidad de los TDI limitar las pretensiones fiscales de los Estados titulares de las mismas o suprimirlas totalmente, no ampliarlas o no crear nuevas. Esto hay que entenderlo en el sentido de que un TDI no pueden establecerse nuevas pretensiones." BUHLER, Ottmar. Principios de Derecho Internacional Tributario. Trad. Fernando Cervera Torrejon. Madri: Editorial de Derecho Financiero, 1968. p. 82.

${ }^{511}$ Heleno Torres ensina que: “(...) as convenções não podem nem criar novas obrigações tributárias nem tampouco ampliar as já existentes, como não podem derrogar in totum qualquer disposição de direito interno, quer do sistema formar, quer a fortiori das garantias aos contribuintes. Elas buscam, tão-só oferecer uma pauta de critérios para resolver possiveis concursos de pretensões impositivas entre os signatários, uma vez que predispõem um tratamento mais favorável nas relações que envolvam 'residentes' dos respectivos Estados contratantes apenas quanto aos rendimentos e tributos nela discriminados." TORRES, Heleno Taveira. Pluritributação Internacional sobre as Rendas de Empresas. 2. ed. rev., ampl. e atual. São Paulo: Revista dos Tribunais, 2001. p. 594).
} 
(inclusive quando em contraste em normas de produção interna em sentido contrário, anteriores e posteriores) dependentes das normas constitucionais de cada um dos Estados signatários.

Considerando que a aplicação das convenções contra a bitributação envolve a livre manifestação da vontade dos Estados soberanos, é possível classificar as convenções de bitributação também como verdadeiros contratos, o que permite, inclusive, a previsão de procedimentos amigáveis e eventualmente a arbitragem para a solução de disputas oriundas dos tratados.

A interpretação das convenções contra dupla tributação segue os princípios do Direito Internacional Público, codificados na Convenção de Viena sobre o Direito dos Tratados (CVDT), de $1969^{512}$, embora comporte especificidades bastante significativas.

São múltiplas as finalidades pretendidas pelos acordos de bitributação. Dentre elas, citam-se a distribuição proporcional das receitas tributárias entre os Estados contratantes, a promoção e o incremento de investimento estrangeiro, a remoção de obstáculos fiscais ao comércio, a prevenção e combate à discriminação ${ }^{513}$ e à evasão fiscal, e ainda o incentivo à cooperação internacional para fiscalização tributária e troca de informações entre os signatários.

Em resumo, é seguro afirmar que o principal objetivo das convenções contra a dupla tributação internacional consiste justamente em fornecer uma solução uniforme para as disputas envolvendo situações em que haja dupla tributação internacional.

No entanto, tais objetivos nem sempre são atingidos. A realização das finalidades das convenções contra dupla tributação perpassa a superação de uma série de dificuldades, dentre elas, a ausência de harmonia tributária entre os sistemas, a multiplicidade de idiomas, expressões e institutos, e as distintas qualificações recebidas pelos rendimentos nos variados ordenamentos.

Ademais, na busca pela realização destes objetivos, a interpretação de um acordo de bitributação deve sempre considerar o seu duplo aspecto jurídico. De um lado,

\footnotetext{
${ }^{512}$ A Convenção de Viena sobre o Direito dos Tratados foi assinada em 23/04/1969, mas só entrou em vigor a partir de $27 / 01 / 1980$, com a ratificação pelo $35^{\circ}$. Estado. O Brasil assinou esta convenção, mas até a presente data, ainda não a ratificou.

${ }^{513}$ A vedação à discriminação, também conhecida como "princípio da não discriminação", é expressamente prevista no artigo 24 da Convenção Modelo da OCDE.
} 
os acordos de bitributação possuem caráter normativo, já que são aplicados pelas autoridades fiscais dos países signatários e introduzem institutos, conceitos e definições no ordenamento jurídico interno.

Paralelamente, como se trata de um negócio jurídico realizado mediante acordo de vontades de dois entes soberanos, o que revela a sua natureza contratual, da qual decorrem relações de reciprocidade. Por isso é que durante o processo interpretativo é necessário sempre considerar estes dois aspectos (normativo e contratual), e somente a partir da adequada interpretação é que será garantida a eficácia ${ }^{514}$ das disposições destas convenções.

Deste modo, devido aos fatores enumerados acima, afirma-se que raramente é possível elaborar-se um texto perfeitamente coeso e unívoco. Conclui-se, assim, que tais convenções são muito mais predispostas à interpretação do que as leis internas dos Estados signatários, que são, na grande maioria das vezes, redigidas em termos mais precisos.

Outrossim, a aplicação das convenções perpassa necessariamente, duas fases distintas: a primeira, que compreende o exame da situação fática, ainda no âmbito do direito interno, para se determinar se a situação em questão é realmente de dupla tributação jurídica, aplicando-se a regra das quatro identidades, e, caso efetivamente se trate de uma ocorrência de dupla tributação jurídica, passa-se então à segunda fase, que compreende o exame dos sujeitos e dos tributos que componham a ocorrência de bitributação, uma vez que somente poderão ser objeto da proteção oferecida pelas convenções de dupla tributação aqueles sujeitos que sejam residentes de um dos Estados contratantes, e, além disso, a convenção somente será aplicável aos tributos definidos em seus artigos.

Assim, somente após a certeza de que se trata de uma situação de dupla tributação jurídica, bem como de que os sujeitos e os tributos estão previstos na convenção que se pretende aplicar, é que se torna possível a efetiva interpretação e também a aplicação da convenção. Entretanto, destacamos que, mesmo antes destas fases, sempre haverá um esforço interpretativo pelas partes, haja vista que não seria possível saber sequer

\footnotetext{
514 Sobre a eficácia das convenções de bitributação, confira-se Vogel e Prokisch: "A double taxation convention can only be effective if it is interpreted and applied in a uniform way in both Contracting States. Therefore, it is obviously necessary to define internationally accepted principles for the interpretation of double taxation conventions.". VOGEL, Klaus. PROKISCH, Rainer G. General Report. Interpretation of Double Taxation Conventions. Cahiers de Droit Fiscal International. 1993. Florence Congress, International Fiscal Association., vol. LXXVIIIa. p. 67-68.
} 
se a convenção é aplicável ao caso se não houvesse a interpretação dos eventos e fatos que compõem a ocorrência de dupla tributação.

\subsection{A natureza jurídica das normas constantes das convenções contra dupla tributação}

As normas do Direito Tributário Internacional podem ser classificadas segundo o quadro abaixo ${ }^{515}$ :

\section{Normas Substanciais}

1) Normas materiais: instituem os tributos incidentes sobre situações nacionais e têm sua origem no Direito interno dos Estados;

2) Normas de atribuição, também denominadas de normas de repartição, que se destinam a solucionar as situações de concorrência de pretensões impeditivas pelos Estados, ora atribuindo a competência tributária exclusivamente a um Estado (normas de atribuição exclusiva), ora reconhecendo a legitimidade de ambos os Estados e, assim, repartindo a competência entre eles (normas de cumulação)

3) Normas de atenuação, que se dedicam a atenuar os efeitos da dupla tributação internacional, como é o caso das normas que determinam que um Estado deva conceder isenção parcial em relação a um crédito tributário internacional.

\section{Normas Instrumentais}

1) Normas de competência internacional, que disciplinam o exercício das funções das autoridades de um Estado, com a finalidade de aplicarem o seu Direito Tributário interno, no território de outro Estado.

2) Normas sobre a relevância de atos públicos estrangeiros, que determinam a relevância, na ordem interna de um país, dos atos praticados por autoridades estrangeiras relativamente à obtenção de provas de fatos tributáveis (solicitações de

515 SANTIAGO, Igor Mauler. Direito Tributário Internacional : Métodos de Solução dos Conflitos. São Paulo: Quartier Latin, 2006. p. 60. 
documentos) para o lançamento do tributo e a consequente exigência dos créditos respectivos.

Apesar de serem a principal fonte normativa do Direito Tributário Internacional, as convenções contra a bitributação possuem, dentre as normas substanciais, somente aquelas referentes à atribuição de competência e aquelas relativas à atenuação da bitributação. Já na categoria das normas instrumentais, ambos os tipos são encontrados nas convenções de bitributação.

Como se vê, o único tipo de norma tributária internacional que jamais será encontrado numa convenção de bitributação é aquele que cria ou majora obrigações tributárias, ou seja, as convenções de bitributação não possuem normas tributárias materiais em sentido estrito, não tendo o poder de criar ou majorar obrigações tributárias.

A normas das convenções de bitributação possuem o chamado efeito negativo, que limita o exercício da competência tributária pré-estabelecida pelo Direito interno. É nesse sentido a lição de Manuel Pires, que ensina que pelas convenções de bitributação:

“(...) não se ampliam os poderes dos Estados quer criando sujeições a impostos, não existente no direito interno, quer eliminando beneficios que, estando previstos pela lei interna, poderiam ser considerados como tendo cessado por força da convenção. (...) as convenções são capazes de criar um direito material novo? A resposta é geralmente negativa, porquanto, como já se referiu, das convenções não resultará, em princípio, uma nova imposição ou uma tributação ampliada. (...) No domínio das convenções, as respectivas normas limitam-se, pois, a reconhecer ou não o poder dos Estados contratantes. " 516

516 PIRES, Manuel. Da Dupla Tributação Jurídica Internacional sobre o Rendimento. Lisboa: Centro de Estudos Fiscais - Ministério das Finanças, 1984. p. 459-470. 
Como visto, somente o Direito interno dos Estados é apto para criar ou ampliar obrigações tributárias, cabendo aos tratados de bitributação apenas a função de atribuir a competência tributária e dispor sobre as questões instrumentais. Na mesma linha destacada acima, citamos o entendimento de Kees van Raad, segundo o qual:

"a tributação de determinada renda tem previsão na legislação interna, enquanto o tratado tem por finalidade apenas limitar tal tributação. Dessa forma, o cerne da questão não é se um tratado contém alguma regra que permita a tributação, mas se há nele alguma disposição que proíba a aplicação irrestrita da legislação tributária interna." 517.

Englobando a maioria dentre as normas de um acordo de bitributação, as normas de atribuição possuem, como já mencionado no quadro acima, a tarefa de delimitar o escopo de aplicação do Direito Tributário interno dos Estados contratantes em situações internacionais. Ou seja: tais normas se aplicam para determinar qual dos Estados contratantes será competente para tributar a renda ou bem proveniente de uma operação transnacional.

Alguns autores, como Xavier" ${ }^{518}$, adotam a denominação de "normas de conflito" ao se referirem às normas de atribuição. Entretanto, como explica Vogel ${ }^{519}$, esta denominação, apesar de comum, é imprópria. Isto porque os tratados de bitributação (assim como o Direito Tributário Internacional como um todo) não contêm "normas de conflito" em sentido estrito, ou seja, aquelas normas que não se destinam a regular um fato da vida em si, mas, sim, têm a função de indicar qual deverá ser o Direito aplicável a determinado fato. As genuínas normas de conflito, que também costumam ser chamadas de normas de colisão ${ }^{520}$ (eis que tratam de situações em que há colisão de ordenamentos

${ }^{517}$ RAAD, Kees van. Cinco regras fundamentais para a aplicação de tratados para evitar a dupla tributação. Trad. Helena de Rezende Grabenweger. In: PANZARINI FILHO, Clóvis (coord.). Revista de Direito Tributário Internacional, São Paulo: Quartier Latin, 2005. v. 1. p. 197.

${ }^{518}$ XAVIER, Alberto. Direito Tributário Internacional do Brasil. 6. ed. reform. e atual. Rio de Janeiro: Forense, 2007. p. 53-55.

519 VOGEL, Klaus. On Double Taxation Cconventions: a commentary to the OECD, UN and US model conventions for the avoidance of double taxation of income and capital with particular reference to German treaty practice. 3. ed. Germany: Kluwer Law International, 1997. p. 52-53.

${ }^{520}$ Embora alguns autores como Heleno Torres, Igor Mauler Santiago e Luís Eduardo Schoueri discordem desta denominação. TORRES, Heleno Taveira. Pluritributação Internacional sobre as Rendas de Empresas. 2. ed. rev., ampl. e atual. São Paulo: Revista dos Tribunais, 2001. p. 112-115. SANTIAGO, Igor Mauler. Direito Tributário Internacional: Métodos de Solução de Conflitos. São Paulo: Quartier Latin, 2006. p. 64. SCHOUERI, Luís Eduardo. Direito Tributário Internacional - Qualificação e Substituição - Tributação, no 
jurídicos), são provenientes e podem ser encontradas somente no Direito Internacional Privado.

Considerando isto, é correto afirmar que as normas dos tratados de bitributação não são normas de conflito exatamente porque não dispõem sobre qual Direito, o doméstico ou o internacional, deverá ser aplicado ao caso concreto. Na verdade, como já mencionamos, os tratados de bitributação atuam como verdadeiros "agentes de desempate" naquelas situações em que dois países sentem-se no direito de tributar um mesmo fato jurídico transacional (ou seja, quando há um concurso de pretensões impositivas, e não um conflito), atuando por meio da atribuição da competência tributária ora a um Estado, ora a outro, dependendo do rendimento e dos fatos concretos ${ }^{521}$.

Desta forma, evidencia-se que não há como atribuir a natureza de normas de conflito às normas dos tratados de bitributação, as quais, repita-se, são normas de atribuição de competência, normas estas que são fundamentalmente distintas das normas de conflito oriundas do Direito Internacional Privado.

Superada a questão da denominação, passamos à análise da estrutura da norma convencional. Manuel Pires ensina que as normas constantes das convenções de bitributação possuem três partes: o objeto de conexão, o elemento de conexão e a consequência jurídica. Aplicando-se na prática, nas palavras de Pires, temos que, em face de determinada situação (objeto de conexão) e mediante um aspecto do circunstancialismo

Brasil, de Rendimentos Provenientes de Sociedade de Pessoas Residente na Alemanha. In: Revista Dialética de Direito Tributário .São Paulo: Dialética, n.54. 2000.

521 Explicando esta distinção, Igor Mauler Santiago ensina que: "No que tange às demais (normas de delimitação, cuja existência, aliás, não reconhecemos, e normas de atribuição de competência), começamos por destacar que, ao contrário do que ocorre no Direito Internacional Privado, em que uma situação - o regime de bens de um casamento entre pessoas de nacionalidades diversas celebrado num terceiro Estado e a ser dissolvido num quarto País, v.g. - não pode ficar sem disciplina legal (impossibilidade jurídica da lacuna) e nem pode sujeitar-se simultaneamente a dois ou mais sistemas jurídicos diversos (impossibilidade jurídica do cúmulo), nenhum problema lógico ou jurídico sirito senso há em que a situação internacional escape ao poder tributário de todos os Estados potencialmente interessados ou, noutro giro, recaia no âmbito das normas impeditivas de todos eles. Em suma, em nenhum dos casos há um conflito a exigir solução sob pena de impasse e perplexidade para o aplicador. O que se tem apenas é um cúmulo (positivo ou negativo) de pretensões a reclamar tratamento por razões puramente econômicas - o que não significa, evidentemente, que sejam de menor importância ou que, em casos mais graves, não requeiram mesmo a pronta intervenção do(s) Estado(s), sob pena de grave lesão ao contribuinte." SANTIAGO, Igor Mauler. Direito Tributário Internacional: Métodos de Solução de Conflitos. São Paulo: Quartier Latin, 2006. p. 64. 
concreto (elemento de conexão) é reconhecido o poder de tributação de um Estado (consequência jurídica) ${ }^{522}$.

A estrutura normativa apresentada por Manuel Pires corresponde, de modo simplificado, à estrutura proposição $\rightarrow$ consequência, apresentada por Xavier ${ }^{523}$. Com efeito, o professor Português ensina que, como toda norma jurídica, as normas de atribuição também obedecem à estrutura proposição $\rightarrow$ consequência, só que, para o caso específico das convenções de bitributação, adota-se a denominação conceito-quadro $\rightarrow$ elemento de conexão. Desta maneira, o conceito-quadro apresenta o fato jurídico internacional tributável, enquanto o elemento de conexão determina qual Estado será competente para tributá-lo. Em outras palavras, o conceito-quadro descreve o objeto tributável, ao passo que o elemento de conexão estabelece justamente a ligação entre o fato internacional e o Direito interno do Estado contratante, permitindo a tributação fora dos limites territoriais.

As normas de atribuição são facilmente identificáveis nas convenções de bitributação. Por exemplo, o parágrafo $1^{\circ}$ do artigo $7^{\circ}$ da Convenção Brasil-Chile ${ }^{524}$ (Decreto n. 4.852/2003), que trata da atribuição da competência para tributar os lucros de empresas. Conforme já mencionado no quadro explicativo no início deste item, as normas de atribuição de competência podem ser subdivididas em dois tipos: normas de atribuição exclusiva e normas de atribuição concorrente. As primeiras determinam a exclusividade da tributação apenas em um dos Estados contratantes, enquanto as do segundo tipo permitem que a tributação ocorra nos dois Estados, devendo haver a compensação ou o abatimento do imposto em um dos Estados relativamente ao outro Estado. O parágrafo $1^{\mathrm{o}}$ do artigo $7^{\mathrm{o}}$, supracitado, contém exemplos das duas categorias. A primeira parte (primeira frase) refere-se à norma de atribuição exclusiva, e a segunda parte (segunda frase) prevê a tributação concorrente como exceção à tributação exclusiva.

${ }^{522}$ PIRES, Manuel. Da Dupla Tributação Jurídica Internacional sobre o Rendimento. Lisboa: Centro de Estudos Fiscais - Ministério das Finanças, 1984. p. 472-473.

${ }^{523}$ XAVIER, Alberto. Direito Tributário Internacional do Brasil. 6. ed. reform. e atual. Rio de Janeiro: Forense, 2007. p. 53-55.

524 “ARTIGO $7^{\circ}$ - Lucros das Empresas

1. Os lucros de uma empresa de um Estado Contratante somente podem ser tributados nesse Estado, a não ser que a empresa exerça ou tenha exercido sua atividade no outro Estado Contratante por meio de um estabelecimento permanente ai situado. Se a empresa exerce ou tiver exercido sua atividade na forma indicada, seus lucros podem ser tributados no outro Estado, mas somente na medida em que forem atribuíveis a esse estabelecimento permanente." 
Sabe-se que a tributação efetiva somente pode ser realizada mediante a aplicação de normas do Direito Tributário interno dos Estados contratantes. Em outras palavras, a tributação se opera por meio das normas materiais do Direito Tributário interno, as quais tratam, exatamente, da regra matriz de incidência dos tributos. Tais normas, como já mencionado, nunca estão presentes nas convenções de bitributação, em virtude do princípio da soberania e da legalidade, e também tendo em vista que a função de tais tratados consiste em limitar o exercício da tributação pelos Estados contratantes, não lhes sendo permitido criar obrigações tributárias principais (criar tributos novos).

Porém, é possível encontrar nas convenções de bitributação as chamadas normas atenuantes, as quais possuem natureza substancial (alguns autores denominam de natureza material, entendemos que não faz diferença) e desempenham o papel de auxiliar na redução da bitributação nas ocasiões em que as pretensões tributárias de ambos os Estados forem legítimas. Estas normas de atenuação incidem modificando elementos da regra matriz de incidência ${ }^{525}$ dos tributos abrangidos pela convenção, especialmente a base de cálculo e a alíquota. Um bom exemplo é a cláusula constante no artigo 10, parágrafo $2^{\circ}$, da Convenção Brasil-Chile (Decreto n. 4.852/2003 ${ }^{526}$ ), que impõe limitações às alíquotas praticadas no caso de imposto incidente sobre dividendos.

Além do tipo supracitado, existem ainda pelo menos outras 4 categorias de normas de atenuação que podem ser encontradas nas convenções contra a bitributação. São elas: (a) normas que determinam a isenção de um bem tributável em um dos Estados contratantes, (b) normas que introduzem a obrigação de conceder crédito fiscal contra o imposto devido no outro Estado contratante, (c) normas que alteram a legislação interna de um ou de ambos os Estados contratantes (denominadas de "Cláusula de Reserva de Progressão") e (d) normas que determinam a obrigatoriedade da troca de informações entre os dois Estados contratantes ${ }^{527}$.

\footnotetext{
${ }^{525}$ Sobre a Regra Matriz de Incidência dos tributos, v. CARVALHO, Paulo de Barros. Direito Tributário : Fundamentos Jurídicos da Incidência. 3. ed. São Paulo: Saraiva, 2004. e também CARVALHO, Paulo de Barros. Curso de Direito Tributário. 16. ed. São Paulo: Saraiva, 2004.

526 “ARTIGO 10 - Dividendos

(...) 2. Todavia, esses dividendos podem também ser tributados no Estado Contratante em que resida a sociedade que os pague e de acordo com a legislação desse Estado, mas, se o beneficiário efetivo dos dividendos for um residente do outro Estado Contratante, o imposto assim exigido não poderá exceder de: a) 10 por cento do montante bruto dos dividendos, se o beneficiário efetivo for uma sociedade que controle, direta ou indiretamente, pelo menos 25 por cento das ações com direito a voto da sociedade que pague tais dividendos; b) 15 por cento do montante bruto dos dividendos em todos os demais casos. Este parágrafo não afeta a tributação da sociedade em relação aos lucros que dão origem ao pagamento dos dividendos. "
} 
Vale lembrar que as normas de atenuação das convenções contra a bitributação somente têm aplicação após a incidência das normas de atribuição. Em outras palavras, depois de analisada a questão relativamente a qual dos Estados é competente para tributar o fato, passa a ser aplicável, por exemplo, uma norma de atenuação que delimita a alíquota do tributo incidente.

Definida a natureza jurídica das normas das convenções contra a bitributação, observa-se que tais normas visam à resolução de duas questões principais: as normas de atribuição tratam da limitação espacial da incidência das leis e sua aplicação sempre antecede a aplicação das normas atenuação, cuja função é relativa à solução de concurso de incidências e modificação de aspectos das normas materiais internas.

\subsection{A vantagem das convenções contra a bitributação internacional em face dos métodos unilaterais para evitar a dupla tributação internacional}

Existem basicamente duas formas para se evitar a dupla tributação internacional: os métodos unilaterais e os bilaterais (ou multilaterais). Qualquer que seja o método adotado, sempre haverá a necessidade de renúncia de arrecadação por um dos Estados em favor do outro, mesmo que parcial.

Os métodos unilaterais englobam (i) concessão de isenções internas, (ii) redução de alíquotas internas, (iii) dedução, do valor do tributo pago no exterior, na base de cálculo do tributo devido internamente e, ainda, (iv) compensação de créditos tributários por meio do chamado método da imputação (ou "método do crédito", tax credit).

As medidas internas de isenção podem ser totais ou parciais. Quando é concedida uma isenção total, o rendimento que foi tributado no exterior não é sujeito a nenhuma tributação no país. Já quando a isenção é parcial, podendo ser também progressiva, o valor do tributo pago no exterior é considerado na determinação da alíquota aplicável no âmbito interno. Neste caso, não ocorre a eliminação da bitributação, mas tãosomente uma redução. Outra medida unilateral que apenas reduz a bitributação é a redução da alíquota interna aplicável aos rendimentos internacionais, considerando-se a tributação ocorrida no exterior.

${ }^{527}$ ROTHMANN, Gerd W. Interpretação e Aplicação dos Acordos Internacionais contra a Bitributação. São Paulo: USP, 1978. p.48-49 Tese (Doutorado) 
De acordo com o método da imputação, o Estado de residência do contribuinte (normalmente pessoa jurídica) tributa a totalidade dos rendimentos (worldwide income taxation), mas concede a este contribuinte um crédito referente aos tributos pagos por ele no exterior. Quando se considera na dedução interna o valor total do tributo pago no exterior, trata-se da imputação integral, e quando a dedução do tributo pago no exterior é limitada ao valor do tributo devido internamente, fala-se em imputação parcial, também denominada de imputação ordinária. Em nenhuma hipótese, contudo, poderá o contribuinte receber valores de seu Estado de residência, a título de "excesso de crédito", ou seja, quando a tributação no exterior for maior do que a devida internamente.

Todas estas medidas unilaterais, como o nome já diz, são aplicadas por cada Estado isoladamente, por meio de sua legislação interna, geralmente atuando de forma preventiva à ocorrência da bitributação. Entretanto, justamente por serem aplicados interna e isoladamente, sua atuação é mais restrita e seus resultados menos efetivos.

Os melhores resultados em termos de redução ou eliminação da dupla tributação internacional geralmente são obtidos por meio da utilização dos métodos bilaterais, ou seja, através das convenções contra a bitributação internacional. Isto porque, durante o processo de negociação de tais acordos, no qual são expostos os interesses comerciais e econômicos de cada Estado, surgem mais oportunidades para que a renúncia à arrecadação seja mais efetiva mediante a adoção de medidas mais rígidas por meio do acordo internacional.

A maior eficácia no combate à dupla tributação internacional por meio da aplicação das convenções contra a dupla tributação está relacionada com o fato de que as normas introduzidas por estes acordos possuem caráter específico em relação à legislação interna, e, por isso, numa eventual situação de antinomia em relação a esta, o texto do acordo deve prevalecer, de acordo com o critério lex specialis derrogat generalis. Isto não ocorre quando se trata, por exemplo, de uma norma interna que concede uma isenção, a qual ocupa a mesma posição hierárquica de uma norma que determina a tributação.

Também é importante mencionar que a renúncia de receitas que constitui um dos efeitos dos tratados de bitributação sempre opera em benefício do contribuinte, que é a parte legítima para requerer a aplicação de tais acordos, e jamais em benefício do outro Estado contratante. 
Em virtude de sua maior efetividade e eficácia na consecução de seu objetivo maior, qual seja, evitar ou diminuir a bitributação internacional, é possível afirmar que uma das vantagens das convenções contra a dupla tributação internacional consiste no maior grau de segurança jurídica na relação tributária estabelecida entre o contribuinte e os dois (ou mais) Estados envolvidos na operação transnacional.

Outra vantagem das convenções de bitributação consiste na previsão normativa de auxílio internacional e troca de informações para fins de combate à evasão fiscal, estimulando a cooperação entre os Estados contratantes.

Além disso, as convenções contra a bitributação internacional, quando efetivamente aplicadas pelos países, assumem um caráter de incentivo ao investimento estrangeiro, tendo em vista que a garantia da não ocorrência (ou pelo menos, da diminuição) da bitributação internacional aplicáveis a uma operação representa um fator atrativo para investidores e para o incremento da importação de capital.

Outro benefício da utilização das convenções contra a bitributação internacional consiste na previsibilidade e estabilidade de suas normas, haja vista que o procedimento de alteração das normas de um acordo internacional é bem mais complexo e rigoroso do que aquele referente à legislação ordinária interna. O máximo que pode ocorrer são regulamentações internas relativas à interpretação e aplicação do acordo, não se verificando mudanças substanciais no texto de suas normas.

Em resumo, a grande vantagem do método bilateral, ou seja, das convenções contra a bitributação internacional, consiste na garantia da segurança jurídica e na previsibilidade das normas tributárias que serão aplicadas aos rendimentos transnacionais, facilitando o fluxo de capitais estrangeiros entre os países e, assim, contribuindo para o desenvolvimento econômico.

\subsection{Os principais modelos de convenção contra a bitributação internacional}

\subsubsection{O Modelo da OCDE}

Conforme mencionado anteriormente, as cláusulas de atribuição de competência tributária previstas na Convenção Modelo da OCDE seguem, via de regra, o princípio da tributação no Estado de residência. Isto acaba implicando o direcionamento do 
direito de tributar os rendimentos envolvidos para os países industrializados e desenvolvidos, exportadores de capital, onde normalmente estão localizadas as sedes das grandes empresas que atuam no mercado internacional.

Contudo, este fato não representou empecilho para que o Brasil adotasse este modelo em suas convenções de bitributação internacional. Isto porque a OCDE tem como um de seus objetivos a harmonização das normas contra a bitributação internacional e, para isso, adota uma política de abertura e divulgação de seus estudos e trabalhos para a comunidade internacional como um todo, e não apenas para os países membros.

Assim, apesar de não ser membro da OCDE, e apesar de possuir relativamente pouca tradição no campo dos acordos de bitributação, o Brasil participa ativamente das discussões e dos trabalhos referentes aos comentários ao Modelo da OCDE, na posição de non-member country (país não-membro), apresentando, até mesmo, reservas à aplicação de determinados artigos.

Entretanto, apesar de sua significativa participação nos trabalhos de revisão do referido Modelo, não se pode dizer que o Brasil siga à risca a redação de todas as normas sugeridas no Modelo da $\mathrm{OCDE}^{528}$. Como mencionamos acima, o Brasil faz ressalvas e reservas quanto à aplicação de certas cláusulas, especialmente aquelas não se adaptam à realidade econômica brasileira, como é o caso das normas que prevêem a tributação exclusiva no Estado da residência.

De fato, as primeiras convenções contra a bitributação internacional celebradas pelo Brasil, até mesmo por questões temporais (as primeiras convenções de bitributação brasileiras datam de meados da década de 1960, e a primeira versão do Modelo da OCDE é de 1963) foram redigidas de forma muito mais aproximada ao Modelo da OCDE, com poucas modificações em relação ao modelo. Atualmente, apesar de todas as convenções brasileiras ainda seguirem, relativamente à maioria de suas cláusulas, o Modelo da OCDE,

528 Por exemplo, a convenção entre o Brasil e México, que em o primeiro parágrafo do artigo 21 (rendimentos de estudantes) segue fielmente o modelo da OCDE, mas o artigo da convenção inclui, ainda, outro parágrafo que não está previsto no referido modelo

"ARTIGO 21 - Estudantes - 1. As importâncias recebidas para cobrir gastos com manutenção, estudos ou formação de um estudante, estagiário ou aprendiz que é, ou foi, em período imediatamente anterior à sua visita a um Estado Contratante, residente do outro Estado Contratante e que permaneça no primeiro Estado mencionado apenas com o único fim de ai prosseguir seus estudos ou sua formação, não serão tributadas nesse Estado, desde que esses pagamentos provenham de fontes situadas fora desse Estado. 2. Em relação a subvenções, bolsas de estudo e remunerações de emprego não abrangidas pelo parágrafo 1, os estudantes e aprendizes de que trata o parágrafo 1, durante o período desses estudos ou dessa formação, terão direito, ademais, às mesmas isenções, abatimentos ou reduções de impostos, concedidos aos residentes do Estado que estiverem visitando." 
observa-se uma iniciante tendência à maior liberdade na redação das cláusulas que compõem tais acordos internacionais, mediante a utilização de outros modelos para a composição de uma única convenção.

\subsection{2. $\quad \mathrm{O}$ Modelo da $\mathrm{ONU}$}

As origens do Modelo da ONU remontam à década de 1960, quando os países que formavam a organização passaram a se interessar pelo problema da dupla tributação internacional, em virtude do crescente fluxo de investimento entre eles. O início das discussões sobre o tema da bitributação na ONU coincide com os trabalhos de elaboração da primeira versão do Modelo da OCDE, que foi publicada em $1963^{529}$.

É verdade que, inicialmente, a ONU não se mostrou muito ativa na discussão do problema da bitributação internacional. Esta aparente falta de interesse deve-se, em parte, ao fato de que, até meados da década de 1960, poucos foram os tratados de bitributação celebrados entre Estados desenvolvidos e em desenvolvimento. Uma das razões desta relativa escassez de tratados de bitributação seria o fato de que os modelos de convenção existentes até então seriam adequados somente às necessidades dos países desenvolvidos. Isto porque, segundo as recomendações já propostas no Modelo da OCDE, na maioria das vezes, o Estado da fonte era quem deveria abdicar da tributação, o que prejudicava sensivelmente os países em desenvolvimento, que notadamente são importadores de capital dos países industrializados.

Em face desta constatação, em 4 de agosto de 1967 o Conselho Econômico e Social da ONU editou a Resolução n. 1273, na qual recomendava a criação de um grupo de trabalho composto de especialistas em tributação indicados pelos governos dos países industrializados e em desenvolvimento ${ }^{530}$, com a finalidade de elaborar diretrizes gerais que facilitassem a celebração de acordos para evitar a bitributação entre países em

${ }^{529}$ DORNELLES, Francisco Neves. A Dupla Tributação Internacional da Renda. Rio de Janeiro: FGV, 1979. p. 49-67.

${ }^{530}$ Participaram deste grupo de trabalho representantes dos seguintes países: Argentina, Brasil, Chile, França, Alemanha, Gana, Índia, Israel, Japão, Holanda, Noruega, Paquistão, Filipinas, Sri Lanka, Sudão, Suíça, Tunísia, Turquia, Reino Unido e Estados Unidos. Participaram, ainda, na condição de observadores, representantes dos seguintes países: Áustria, Bélgica, Finlândia, Coréia, México, Nigéria, Espanha, Suazilândia e Venezuela, e também representantes do Fundo Monetário Internacional, da International Fiscal Association - IFA, da Organização dos Estados Americanos - OEA, da Organizacao para Cooperação e Desenvolvimento Economico - OCDE e da Câmara Internacional de Comércio. Disponível em: $<$ http://www.irdcec.it/system/files/imce/aree-tematiche/pac/FINT_ONU\%20Modello\%20all_1.pdf. $>$ Acesso em 13 out. 2009. 
desenvolvimento e industrializados ${ }^{531}$, devendo tais diretrizes serem compatíveis com os interesses e necessidades de ambas as partes. Este grupo de trabalho se reuniu entre os anos de 1968 até 1977, e em 1980 foi publicada a primeira versão do Modelo da ONU, denominada de United Nations Model Double Taxation Convention between Developed and Developing Countries. Esta primeira versão vem sendo revisada e atualizada periodicamente, e em 2001 foi publicada uma nova versão do modelo, a qual é vigente até os dias atuais ${ }^{532}$.

Considerando que a principal motivação para a criação do Modelo da ONU foi a criação de um modelo de convenção que fosse melhor adaptado às necessidades dos países em desenvolvimento, especialmente quando comparado ao Modelo da OCDE, que até então era a única opção, observa-se que a principal característica que distingue os dois consiste na prevalência, no Modelo da ONU, do princípio da fonte, ao contrário do Modelo da OCDE, no qual o princípio da tributação no Estado de residência é mais valorizado.

Porém, esta preferência pela tributação no Estado da fonte não seria ampla e irrestrita. Ao contrário, no Modelo da ONU, a tributação na fonte fundamenta-se na premissa de que os rendimentos derivados de investimentos e de capital estrangeiro seriam tributados em seus valores líquidos, ou seja, após a dedução das despesas a eles correlatas. Além disso, o Modelo da ONU recomenda que a tributação na fonte não seja elevada a ponto de desestimular o investimento estrangeiro, devendo ser igualmente respeitada a repartição da receita gerada com o país estrangeiro que houver realizado o investimento sujeito à tributação.

Realizando uma breve análise comparativa entre o Modelo da ONU e o Modelo da OCDE, percebe-se que há mais semelhanças do que diferenças entre ambos. Entretanto, as distinções encontradas, apesar de poucas, são bastante relevantes. Além da

\footnotetext{
${ }^{531}$ Sobre a experiência prática da aplicação de tratados basedos no Modelo da ONU, v. COURT, J. F. Some reflections on the experience of the UN Model in tax treaties between developed and developing countries. In: Double taxation treaties between industrialized and developing countries: OECD and UN Models, a comparison. Proceedings of a seminar held in Stockholm in 1990 during the $44^{\text {th }}$ Congress of the International Fiscal Association. Deventer/Boston: Kluxer Law and Taxation Publishers, v. 15. pp. 15-19. BRACEWELL-MILNES, Barry. Summary of proceedings of the seminar 'Double Taxation Treaties between Industrialized and Developing Countries: OECD and UN Models, a comparison. In: In: Double taxation treaties between industrialized and developing countries: OECD and UN Models, a comparison. Proceedings of a seminar held in Stockholm in 1990 during the $44^{\text {th }}$ Congress of the International Fiscal Association. Deventer/Boston: Kluxer Law and Taxation Publishers, v. 15. pp. 49-58.

532 RIBES, Aurora Ribes. Convenios para evitar la doble imposición internacional: interpretación, procedimiento amistoso y arbitraje. Madrid: Editoriales de Derecho Reunidas , 2003. p. 208-214.
} 
preferência pela tributação na fonte em detrimento da residência, outra notável distinção consiste na maior valorização dos estabelecimentos permanentes no Modelo da ONU. De fato, este modelo prevê um número bem maior de situações nas quais pode ser caracterizado um estabelecimento permanente se comparado às disposições previstas no Modelo da OCDE. Dentre estas situações destaca-se o período de tempo de apenas 6 meses necessário para a caracterização de um estabelecimento permanente, também merecendo destaque a possibilidade de o fornecimento de serviços, inclusive de consultoria, ser hábil à constituição de um estabelecimento permanente, desde que atendidas certas condições. Outra distinção relevante refere-se à tributação dos lucros de empresas, prevista no artigo $7^{\circ}$ do Modelo, em cujo primeiro parágrafo ${ }^{533}$ está prevista a limitação ao princípio da força de atração, regra esta que é considerada como uma verdadeira norma anti-abuso e é seguida por um grande número de países, não apenas por aqueles classificados como "em desenvolvimento". Há ainda diferenças significativas nos artigos que dispõem sobre a tributação de royalties, ganhos de capital, rendimentos pessoais e rendimentos diversos, as quais poderiam ser objeto de um estudo inteiro em separado. Outra distinção consiste na manutenção do artigo 14, dedicado aos rendimentos provenientes do exercício de profissões independentes ${ }^{534}$, que foi excluído do Modelo OCDE na revisão realizada em 2000 .

Enfim, considerando as características acima descritas, observa-se que, apesar de o Modelo da ONU cumprir a sua função de ser, em diversos aspectos, mais bem adaptado às necessidades dos países em desenvolvimento, ainda há pontos que devem ser

\footnotetext{
533 "Article 7 - BUSINESS PROFITS

1. The profits of an enterprise of a Contracting State shall be taxable only in that State unless the enterprise carries on business in the other Contracting State through a permanent establishment situated therein. If the enterprise carries on business as aforesaid, the profits of the enterprise may be taxed in the other State but only so much of them as is attributable to (a) that permanent establishment; (b) sales in that other State of goods or merchandise of the same or similar kind as those sold through that permanent establishment; or (c) other business activities carried on in that other State of the same or similar kind as those effected through that permanent establishment."
}

\footnotetext{
${ }^{534}$ Este artigo é um dos exemplos de que o Brasil também segue o Modelo da ONU, já que na maioria de suas convenções existe um artigo que trata especificamente dos rendimentos de profissões independentes. É o caso do tratado entre o Brasil e a França, cujo artigo 14 possui a seguinte redação:

"ARTIGO XIV - Profissões independentes - 1. Os rendimentos que um residente de um Estado Contratante obtém pelo exercício de uma profissão liberal ou de outras atividades independentes de caráter similar serão tributáveis somente nesse Estado, a menos que o pagamento dessas remunerações caiba a um estabelecimento permanente ou a uma sociedade residente no outro Estado. Ocorrendo tal situação, esses rendimentos podem ser tributados nesse outro Estado. 2. A expressão "profissão liberal" abrange em especial as atividades independentes do caráter científico, literário, artístico, educativo ou pedagógico, bem como as atividades independentes de médicos, advogados, engenheiros, dentistas e contadores."
} 
aprimorados. Nesse sentido, constata-se que mesmo a sua versão mais recente, publicada em 2001, ainda não contém alguns dispositivos importantes, como a previsão da possibilidade de colaboração e assistência na cobrança de tributos e a questão da troca de informações entre os Estados contratantes. Estes são dispositivos notadamente voltados às finalidades de combate à evasão físcal e promoção da segurança jurídica, que também fazem parte dos objetivos das convenções de bitributação. Em face disso, é possível prever que, nas futuras revisões ao Modelo da ONU possivelmente haverá a inclusão de cláusulas como as mencionadas acima, bem como a inclusão de normas tratando de questões como a negociação dos chamados tax sparing credits $^{535}$, ponto que muitas vezes é objeto de discussão durante a celebração de convenções de bitributação entre países desenvolvidos e em desenvolvimento.

\subsubsection{O U.S. Model}

O modelo de convenção contra a bitributação adotado pelos Estados Unidos foi elaborado em 1976, dirigido especificamente para as necessidades norte-americanas. Em seguida, a partir de 1977, sofreu sucessivas revisões em 1981, $1996^{536}$ e em $2006^{537}$, que é a versão mais recente. Longe de ser concebido um modelo obrigatório, o US Model representa apenas um conjunto de recomendações que servem como ponto de partida para as negociações dos tratados de bitributação celebrados pelos Estados Unidos com outros países, facilitando a identificação dos pontos divergentes entre a política tributária norteamericana (retratada no modelo) e as orientações fiscais do outro país. Esta função facilitadora das negociações tem especial utilidade quando o outro país envolvido é

\footnotetext{
${ }^{535}$ A expressão "tax sparing credit" refere-se à situação na qual o Estado de residência confere um crédito tributário fictício maior do que o tributo efetivamente pago na fonte para certas categorias de rendimentos (geralmente juros, royalties e dividendos). Geralmente o tax sparing credit é limitado pela maior alíquota aplicável, segundo o tratado de bitributação, para a tributação pelo Estado da fonte (International Tax Glossary. IBFD, 5. ed. 2005. p. 409). A questão referente à inclusão de cláusulas desta natureza é analisada por Bart Kosters em artigo apresentado durante conferência promovida pelo Asian Development Bank. KOSTERS, Bart. The UN Model Tax Convention and Its Recent Developments. Disponível em $<$ http://www.adb.org/Documents/Events/2003/Tax_Conference/text_kosters.pdf.> Acesso em 13 out. 2009.

${ }^{536}$ YAMASHITA, Douglas. Evolução da Convenção-Modelo da OCDE e a influência de suas alterações na interpretação de tratados para evitar a bitributação. In: AMARAL, Antônio Carlos Rodrigues do (coord.). Tratados Internacionais na Ordem Jurídica Brasileira. São Paulo: Aduaneiras, 2005. p. 104.

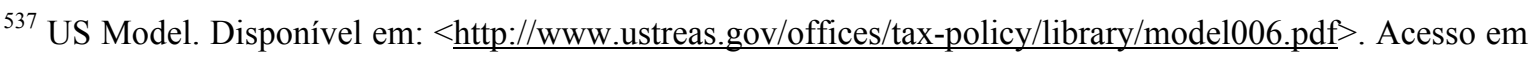
10 out.2009.
} 
membro da OCDE, uma vez que basta comparar os dois modelos para identificar as diferenças. ${ }^{538}$

Como os Estados Unidos são um país membro da OCDE, é possível perceber uma grande influência do modelo daquela organização no Modelo norte-americano, como é possível notar pelo privilégio da tributação no Estado de residência. Entretanto, o US Model diferencia-se do Modelo da OCDE por apresentar cláusulas específicas dirigidas ao combate ao treaty shopping e também por utilizar apenas o método da imputação para evitar a dupla tributação internacional.

Outros pontos importantes distinguem o US Model. Primeiro, seu critério de aplicabilidade pessoal é baseado na residência e nacionalidade cumulativamente. Ou seja, para que o acordo se aplique, é necessário que uma das partes tenha nacionalidade norteamericana e seja residente nos Estados Unidos para fins fiscais. Quanto aos tributos cobertos, a diferença está no fato de que o modelo prevê a aplicação de suas cláusulas apenas para o imposto sobre a renda, excluindo todas as previsões relativas a impostos sobre o capital.

Outra distinção refere-se à existência de categorias de rendimentos específicos que não são previstos em outros modelos, como é o caso das cláusulas referentes à tributação de pensões, prestações de caráter alimentício, anuidades, fundos de pensão, etc. O US Model prevê, ainda, uma cláusula específica dispondo sobre limitação de benefícios, com o objetivo de evitar a utilização indevida da convenção de bitributação cumulativamente com outros benefícios fiscais, representando, desta forma, uma verdadeira cláusula anti-abuso.

Apesar das longas negociações que vem sendo realizadas, até a conclusão deste estudo o Brasil ainda não havia firmado uma convenção de bitributação com os Estados Unidos. Há, sim, regime de reciprocidade entre ambos os países, porém trata-se de um acordo de cavalheiros, não havendo qualquer força impositiva.

Considerando os fortes laços comerciais entre o Brasil e os Estados Unidos, é possível perceber que seriam muitas as vantagens da celebração de uma convenção com este país, sendo possível citar como a mais importante a garantia da segurança jurídica no sentido de não haver a dupla tributação internacional pelo imposto de renda, bem como a

538 RIBES, Aurora Ribes. Convenios para evitar la doble imposición internacional: interpretación, procedimiento amistoso y arbitraje. Madrid: Editoriales de Derecho Reunidas .2003. p. 216. 
garantia da troca de informações e auxílio no combate à evasão fiscal. Ademais, um acordo com os EUA seria interessante para o Brasil pois melhoraria a sua imagem no cenário internacional, já que os Estados Unidos possuem acordos de bitributação com todos os demais países do BRIC, bloco de países em desenvolvimento formado pelo Brasil, Rússia, Índia e China.

Entretanto, a negociação do acordo esbarra em empecilhos que são de difícil solução. A título de exemplo, vale mencionar a questão das trocas de informações entre as autoridades fiscais de um e de outro país. O Brasil argumenta que não pode permitir o intercâmbio de informações no nível desejado pelas autoridades norte-americanas em virtude de limitações constitucionais, como o sigilo fiscal. Além disso, os representantes de um e de outro país não chegam a um acordo quanto às alíquotas que deverão ser aplicáveis, especialmente com relação aos juros, royalties e dividendos.

Somando-se aos pontos controversos e negativos, a recente denúncia do tratado Brasil-Alemanha, ocorrida em 2006, acabou deixando uma imagem negativa das autoridades fiscais brasileiras, tendo em vista que um dos principais motivos levantados pelos representantes do governo alemão foram os reincidentes episódios de desrespeito à convenção então em vigor, associado à relutância das autoridades brasileiras em negociar os termos do acordo.

Além destas questões, resta ainda a controvérsia relativa ao regime dos preços de transferência, que no Brasil segue uma regulamentação própria, distinta das recomendações publicadas pela OCDE.

\subsubsection{O Modelo do Pacto Andino}

O Modelo do Pacto Andino foi criado pelos países da Comunidade Andina, em 1971, como uma alternativa ao modelo da OCDE. Suas normas refletem os interesses dos países do grupo, quais sejam, Bolívia, Chile, Equador, Colômbia, Peru e Venezuela. Por ser dirigido a países em desenvolvimento, nele também se verifica a preferência pelo princípio da fonte em detrimento da residência. Este modelo, que na verdade constitui-se de dois acordos multilaterais entre os países da Comunidade Andina, foi o primeiro modelo elaborado com vistas aos interesses dos países em desenvolvimento, sendo anterior 
até mesmo ao Modelo da ONU de 1980, representando, assim, a primeira alternativa ao já existente modelo da OCDE ${ }^{539}$.

Em 8 de novembro de 1971 foi aprovada a Decisão n. 40 do Acordo de Cartagena $^{540}$, pela qual era aprovada a Convenção de Bitributação entre os Países Membros da Comunidade Andina (artigo $1^{\circ}$ do Anexo 1) e a adoção de um Modelo de Convenção para celebração de tratados desta natureza entre os países membros do bloco e outros países (artigo $2^{\circ}$ do Anexo 2). Tanto a convenção multilateral quanto o modelo de convenção aprovados priorizavam a tributação no Estado da fonte e apresentavam soluções bastante radicais no que se refere ao atendimento dos interesses dos países em vias de desenvolvimento, demonstrando franca oposição ao Modelo da OCDE de 1963, que priorizava a tributação no Estado de residência e, deste modo, favorecia apenas os países desenvolvidos, não sendo adequado para convenções entre estes e aqueles.

Apesar de ter representado, à época de sua conclusão, uma alternativa viável para as convenções celebradas entre países em desenvolvimento e países desenvolvidos, o Modelo do Pacto Andino acabou perdendo relevância prática nos dias atuais. Isto porque os próprios países membros da Comunidade Andina não concluíram todos os procedimentos previstos para que os acordos adquirissem força vinculante. Efetivamente, apesar de o artigo $3^{\circ}$ da Decisão n. 40 dispor que os Estados deveriam adotar as providências necessárias para a entrada em vigor da convenção multilateral até 30 de junho de 1972, apenas o Equador, a Bolívia e a Venezuela cumpriram tal exigência, enquanto que o Peru, apesar de ter ratificado a convenção, não efetuou o depósito dos instrumentos e a Colômbia sequer chegou a ratificar o acordo. Além das questões acima, houve ainda uma série de falhas no cumprimento das disposições necessárias para a entrada em vigor do Modelo de acordo para convenções celebradas com países de fora do pacto andino, de modo que tanto a convenção multilateral quanto o modelo de convenção bilateral para países alheios ao bloco perderam sua importância prática, especialmente depois da

${ }^{539}$ DORNELLES, Francisco Neves. A Dupla Tributação Internacional da Renda. Rio de Janeiro: Editora da FGV, 1979, p. 69-79.

${ }^{540}$ Disponível em: $\quad<$ www.comunidadandina.org/normativa/dec/d040.htm $>\quad$ e

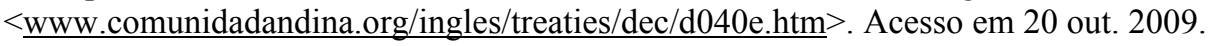


publicação do Modelo da ONU, em 1981, que seguia linha semelhante e atendia aos objetivos visados pelo mal-sucedido Modelo do Pacto Andino. ${ }^{541}$

Atualmente, observa-se a tendência da superação dos extremos representados, de um lado, pelo Modelo da OCDE, e de outro, pelo Modelo do Pacto Andino. Os países tem buscado a solução do meio-termo, conciliando as recomendações de um e de outro modelos, especialmente nas convenções celebradas entre países desenvolvidos e em desenvolvimento, com o objetivo de criar uma situação na qual ambos tenham vantagens, promovendo, assim, o fomento das relações comerciais entre ambos.

541 RIBES, Aurora Ribes. Convenios para evitar la doble imposición internacional: interpretación, procedimiento amistoso y arbitraje. Madrid: Editoriales de Derecho Reunidas S.A., 2003. p. 207-208. 


\section{O MÉTODO CLÁSSICO DE INTERPRETAÇÃO DAS CONVENÇÕES CONTRA A DUPLA TRIBUTAÇÃO}

\subsection{A Convenção de Viena sobre o Direito dos Tratados - Aspectos gerais e aplicação aos tratados internacionais em geral}

A Convenção de Viena sobre o Direito dos Tratados (CVDT), adotada pela Assembléia Geral da ONU, em 22 de maio de 1969, e em vigor desde 27 de janeiro de 1980, é uma convenção multilateral internacional que tem por objetivo disciplinar a elaboração e uniformizar os procedimentos de celebração, de interpretação e de aplicação dos tratados internacionais. Em poucas palavras, ela consiste numa verdadeira codificação das normas internacionais consuetudinárias relativas aos tratados entre os países.

Seu caráter de jus cogens faz com que seja adotada pela maioria dos países, até mesmo por aqueles que não a ratificaram, como é o caso do Brasil, aceita a convenção como norma de Direito Internacional Público. Outros países, como a Grécia ${ }^{542}$, não apenas adotam a Convenção de Viena, como também a reconhecem como parte de seu Direito interno independentemente de quaisquer procedimentos, atribuindo-lhe status de norma superior na hierarquia jurídica.

Como a maioria dos casos levados à Corte Internacional de Justiça envolvem a interpretação de tratados, e considerando que a interpretação de tratados faz parte do dia-adia dos governos das nações, resta inquestionável a relevância da Convenção de Viena em seu papel de uniformizar a produção e, principalmente, a aplicação das normas internacionais.

A Convenção de Viena possui especial importância quando se trata da interpretação de tratados internacionais. A Seção 3 da CVDT, composta pelos artigos 31, 32 e 33, é dedicada exclusivamente ao tema da interpretação de tratados internacionais. Estas normas também refletem o costume internacional relativamente à interpretação de

\footnotetext{
542 "According to Art. 28(1) of the Greek Constitution, recognised rules of international customary law form parto $f$ domestic law as such, without any other action, and stand above domestic laws in the norm hierarchy. This means that even before the ratification of the VCLT by Greece, the interpretative rules provided in it were binding for Greece. Not it is binding as a ratified international treaty, which means that courts are bound to apply the interpretative rules provided in it." PERROU, Katerina. Tax Treaty Interpretation in Greece. In: LANG, Michael. Tax Treaty Interpretation. Viena: Linde Verlag, 2001, p. 159.
} 
tratados, aproximando-se mais de normas procedimentais do que de normas estritamente técnicas. ${ }^{543}$

É importante mencionar, contudo, que os procedimentos de interpretação sugeridos pela Convenção de Viena são flexíveis, não devendo ser utilizados como justificativa para excluir quaisquer evidências relevantes das intenções das partes contratantes durante a aplicação de um tratado internacional. Também é necessário destacar que a estrutura utilizada na Convenção de Viena, subdividindo as regras de interpretação em (i) regra geral de interpretação e (ii) procedimentos suplementares, é adotada apenas para fins didáticos. Na realidade, o processo de interpretação é único e indivisível, todas as fases ocorrem simultaneamente e, na prática, não há esta divisão temporal. Porém, a sistematização é necessária para que sejam compreendidos os princípios e conceitos informadores da interpretação dos tratados internacionais. ${ }^{544}$

\subsection{Aplicação da Convenção de Viena na interpretação das convenções contra a dupla tributação internacional}

As convenções contra a dupla tributação internacional são tratados internacionais com o propósito específico de evitar ou minimizar os efeitos perniciosos da bitributação $^{545}$. Portanto, a elas também se aplicam as normas de interpretação de tratados internacionais contidas na Convenção de Viena ${ }^{546}$.

${ }^{543}$ ENGELEN, Frank. Interpretation of Tax Treaties under International Law. Amsterdam: IBFD, 2004. v. 7 , p. 539 (IBFD Doctoral Series).

${ }^{544}$ ENGELEN, Frank. Interpretation of Tax Treaties under International Law. Amsterdam: IBFD, 2004. v. 7 , p. 540 (IBFD Doctoral Series).

${ }^{545}$ VOGEL, Klaus. Problemas na Interpretação de Acordos de Bitributação. In: SCHOUERI, Luís Eduardo (coord.). Direito Tributário: Homenagem a Alcides Jorge Costa. São Paulo: Quartier Latin, 2003. v. II, pp. 962-964.

546 ARESPACOCHAGA, Joaquín de. Planificación Fiscal Internacional: Convenios doble imposición, Estructuras fiscales, Tributación no residentes. Madrid: Marcial Pons, 1996, pp. 114-115. RIBES, Aurora Ribes. Convenios para evitar la doble imposición internacional: interpretación, procedimiento amistoso y arbitraje. Madrid: Editoriales de Derecho Reunidas S.A., 2003. pp. 81-82. SILVEIRA, Rodrigo Maitto da. Aplicação de Tratados Internacionais contra a Bitributação - Qualificação de Partnership Joint Ventures. São Paulo: Quartier Latin, 2006, p. 114. NOVOA, César Garcia. Interpretación de los convenios de doble imposición internacional. In: FAJARDO, Juan Pablo Godoy. (coord.). Estudios de Derecho Internacional Tributário - Los convenios de doble imposición. Bogotá: Legis, 2006, p. 17. CALIENDO, Paulo. Estabelecimentos Permanentes em Direito Tributário Internacional. São Paulo: Revista dos Tribunais, 2005. p. 264. TORRES, Heleno Taveira. TORRES, Heleno Taveira. Pluritributação Internacional sobre as Rendas de Empresas. 2. ed. rev., ampl. e atual. São Paulo: Revista dos Tribunais, 2001, p. 650. BELLAN, Daniel 
Como já mencionado, todas as disposições da Convenção de Viena possuem importância para a interpretação das convenções de bitributação. Entretanto, são de relevância específica os artigos 31, 32 e 33, que tratam, respectivamente, da regra geral de interpretação, dos meios suplementares de interpretação e das normas de interpretação de tratados autenticados em dois ou mais idiomas.

A premissa básica na qual se assentam os procedimentos de interpretação contidos nos artigos 31 a 33 da Convenção de Viena consiste na presunção de que o texto do tratado internacional representa a expressão máxima da vontade dos Estados contratantes. Assim, o texto do acordo é, necessariamente, o ponto de partida para a interpretação, sendo de extrema importância a compreensão de sua estrutura gramatical, seus termos e expressões, para que o sentido das normas nele contidas possa ser compreendido. Porém, importa lembrar que o texto de qualquer tratado jamais é considerado isoladamente. Ao contrário, ele deve sempre ser interpretado de acordo com o contexto no qual foi firmado, para que os termos e expressões nele contidos sejam compreendidos pelas partes de forma correta, ou seja, revelando a verdadeira intenção das partes contratantes e das normas positivadas.

\subsection{Aplicabilidade às convenções brasileiras independente de ratificação}

Embora o Brasil tenha assinado a Convenção de Viena, e apesar de o seu texto ter sido enviado ao Congresso Nacional em 1992, até a presente data não houve a respectiva ratificação. Deste modo, o Brasil não poderia, em tese, ser considerado "parte" da Convenção.

Entretanto, a ausência de ratificação não impede a aplicação da Convenção de Viena aos tratados internacionais firmados pelo Brasil, uma vez que as normas nela contidas são normas internacionais costumeiras, ou seja, revestem-se da condição de Direito Internacional Público, devendo, assim, serem aplicadas aos tratados internacionais em geral. Considerando isto, conclui-se, pela lógica, que a Convenção de Viena deve ser aplicada durante a interpretação das convenções de bitributação celebradas pelo Brasil ${ }^{547}$.

Vítor. Interpretação dos Tratados Internacionais em Matéria Tributária. In: TORRES, Heleno Taveira (coord.). Direito Tributário Internacional Aplicado. São Paulo: Quartier Latin, 2005. v. 3. p. 613.

${ }^{547}$ TORRES, Heleno Taveira. Pluritributação Internacional sobre as Rendas de Empresas. 2. ed. rev., ampl. e atual. São Paulo: Revista dos Tribunais, 2001, p. 650. ROTHMANN, Gerd W. Interpretação e Aplicação dos Acordos Internacionais contra a Bitributação. São Paulo: USP, 1978. Tese (doutorado). ENGELEN, 


\subsection{1. $\quad O$ artigo 31 da CVDT-Regra geral de interpretação}

O artigo 31 da CVDT encontra-se subdividido em 3 (três) parágrafos, sendo que no primeiro fica estabelecida a regra geral de interpretação de tratados baseando-se na aplicação do princípio da boa fé e do sentido comum dos termos e expressões, e nos dois seguintes são definidos os meios suplementares de interpretação e o procedimento para tratados firmados em dois ou mais idiomas. Como já mencionado acima, esta divisão é puramente didática, os procedimentos determinados na convenção ocorrem simultaneamente. Assim, ao examinar o texto do tratado, o intérprete o fará tomando em consideração o contexto no qual ocorreu a sua celebração, sempre visando atingir os objetivos e finalidades nela propostas.

\section{“Artigo 31}

Regra Geral de Interpretação

1. Um tratado deve ser interpretado de boa fé segundo o sentido comum atribuível aos termos do tratado em seu contexto e à luz de seu objetivo e finalidade.

2. Para os fins de interpretação de um tratado, o contexto compreenderá, além do texto, seu preâmbulo e anexos:

a) qualquer acordo relativo ao tratado e feito entre todas as partes em conexão com a conclusão do tratado;

b) qualquer instrumento estabelecido por uma ou várias partes em conexão com a conclusão do tratado e aceito pelas outras partes como instrumento relativo ao tratado.

Frank. Interpretation of Tax Treaties under International Law. Amsterdam: IBFD, 2004. v. 7, pp. 425 e seguintes (IBFD Doctoral Series). VOGEL, Klaus. On double taxation conventions: a commentary to the OECD, UN and US model conventions for the avoidance of double taxation of income and capital with particular reference to German treaty practice. 3. ed. Germany: Kluwer Law International, 1997, p. 35. GIULIANI, Federico Maria. La Interpretación de Los Convenios Internacionales para Evitar La Doble Imposición sobre las Rentas In: UCKMAR, Victor (coord.). Curso de Derecho Tributario Internacional. Tomo I, 2003. pp. 124-139. GARBARINO, Carlo. La tassazione dei reditti transnazionale. Padova: CEDAM, 1990. pp. 529-532. BELLAN, Daniel Vítor. Interpretação dos Tratados Internacionais em Matéria Tributária. In: TORRES, Heleno Taveira (coord.). Direito Tributário Internacional Aplicado. São Paulo: Quartier Latin, 2005. v. 3. p. 614. SILVEIRA, Rodrigo Maitto da. Aplicação de Tratados Internacionais contra a Bitributação: qualificação de Partnership Joint Ventures. São Paulo: Quartier Latin, 2006, p. 113114. AVERY JONES, John F. The one true meaning of a Tax Treaty. In: Bulletin - Tax Treaty Monitor. Amsterdam: IBFD, 2001 (June), p. 222. XAVIER, Alberto. Direito Tributário Internacional do Brasil. 6. ed. reform. e atual., Rio de Janeiro: Forense, 2007, p. 184. 


\section{Serão levados em consideração, juntamente com o contexto:}

a) qualquer acordo posterior entre as partes relativo à interpretação do tratado ou à aplicação de suas disposições;

b) qualquer prática seguida posteriormente na aplicação do tratado, pela qual se estabeleça o acordo das partes relativo à sua interpretação;

c) quaisquer regras relevantes de Direito Internacional aplicáveis às relações entre as partes.

4. Um termo será entendido em sentido especial se estiver estabelecido que essa era a intenção das partes."

Ao estabelecer a regra geral de interpretação, observa-se que o primeiro parágrafo do artigo 31 busca conferir sentido e significado aos termos e expressões utilizados no texto do tratado, sempre à luz de seus objetivos e finalidades, revelando a aplicação do método intratextual (ou literal) de interpretação, como ponto de partida ${ }^{548}$. Dizemos que a interpretação literal é apenas o ponto de partida uma vez que, sendo restritiva por sua própria natureza, na maioria das vezes requer complementação por meio de outros métodos para que se possa compreender a integralidade do termo. Por isso, a Convenção de Viena associa o método literal aos métodos histórico e teleológico ${ }^{549}$, quando a interpretação do tratado passa a considerar, além do texto do tratado como um todo, também o contexto geral de sua celebração, os documentos produzidos durante a fase de negociações e todas as circunstâncias que cercaram a celebração do acordo.

Alguns autores entendem que a utilização da expressão "à luz de seu objetivo e finalidade" indica a autorização para a utilização do método histórico, enquanto que a expressão "contexto" remeteria ao método teleológico, por meio do qual busca-se desvendar a vontade real dos Estados mediante a análise da celebração do acordo como um todo, envolvendo toda a fase de negociações, os procedimentos de celebração e aproveitando, ainda, os desdobramentos posteriores ao aperfeiçoamento do tratado ${ }^{550}$.

\footnotetext{
548 SANTIAGO, Igor Mauler. Direito Tributário Internacional - Métodos de Solução dos Conflitos. São Paulo: Quartier Latin, 2006, p. 81. TORRES, Heleno Taveira. Pluritributação Internacional sobre as Rendas de Empresas. 2. ed. rev., ampl. e atual. São Paulo: Revista dos Tribunais, 2001, p. 645.

549 REIMER, Ekkehart. Tax Treaty Interpretation in Germany. In: LANG, Michael (org.). Tax Treaty Interpretation. Viena: Linde Verlag, 2001. p. 127.

${ }^{550}$ Nesse sentido, confira-se ROTHMANN, Gerd W. Interpretação e Aplicação dos Acordos Internacionais contra a Bitributação. São Paulo: USP, 1978. Tese (doutorado), p. 135 e 141-142; VOGEL, Klaus. On
} 
Entretanto, há autores que discordam da utilização do método teleológico. Nesse sentido, vale destacar a ressalva feita pelo professor Ekkehart Reimer ${ }^{551}$, que, analisando a jurisprudência federal alemã, destacou que naquele país a aplicação do método teleológico, supostamente implícito no artigo 31(1) da Convenção de Viena, seria bastante restrita, uma vez que, (i) de acordo com a maioria dos estudiosos, a necessidade de prover o orçamento público não seria apta a fornecer o fundamento para a interpretação teleológica, e (ii) porque os objetivos primordiais dos tratados internacionais tributários, quais sejam, evitar a bitributação ou a dupla não-tributação, também não se encaixam no conceito de "objeto e finalidade" como expresso no artigo 31(1). Completando seu raciocínio, ele destaca que a Corte Tributária Federal Alemã (Bundesfinanzhof), em suas decisões, não aplica a interpretação teleológica, mas sim a interpretação sistemática, adotando como parâmetro as próprias normas previstas na Constituição.

\subsubsection{A "boa fé"}

Analisando os princípios que devem informar a interpretação dos tratados internacionais, observa-se que a Convenção de Viena coloca em primeiro lugar o princípio da boa fé. Isto porque o princípio da boa fé rege a criação e aplicação de todos os direitos e obrigações do Direito Internacional, e por isso, o princípio é de extrema importância para os tratados internacionais em qualquer matéria. Outro fator que demonstra a importância do princípio da boa fé no Direito internacional consiste na inexistência de órgãos de aplicação ou mesmo de órgãos formais de produção legislativa, acarretando, na maioria dos casos, a não aplicação de sanções jurídicas eficazes para os casos de descumprimento da norma internacional ${ }^{552}$.

Além disso, sob a visão hermenêutica ${ }^{533}$, o princípio da boa fé impõe que as partes interpretem os tratados internacionais de modo a permitir o total adimplemento das obrigações jurídicas pactuadas, devendo ser evitadas as interpretações que conduzam ao

double taxation conventions: a commentary to the OECD, UN and US model conventions for the avoidance of double taxation of income and capital with particular reference to German treaty practice. 3. ed. Germany: Kluwer Law International, 1997, p. 35.

551 REIMER, Ekkehart. Tax Treaty Interpretation in Germany. In: LANG, Michael (org.). Tax Treaty Interpretation. Viena: Linde Verlag, 2001.

${ }^{552}$ MELLO, Celso Albuquerque. Direito Constitucional Internacional, Rio de Janeiro: Renovar, 2000. p. 15.

553 ROCHA, Sérgio André. Interpretação dos Tratados contra a Bitributação da Renda. Rio de Janeiro: Lumen Juris, 2008, p. 169. 
treaty override. Em vista destes dois conceitos, percebe-se, desde já, a fundamental importância da boa fé para a interpretação das convenções contra a bitributação.

A aplicação do princípio da boa fé na interpretação de tratados de bitribtuacao está também essencialmente relacionada com a manutenção da segurança jurídica. Isto porque, segundo ensina Rubinstein ${ }^{554}$, segundo a boa fé, os Estados passam a ter que agir de modo previsível, adotando condutas relacionadas aos direitos e obrigações, tanto deles enquanto entes do Direito internacional Público, quanto do contribuintes, fundados nos acordos de bitributação, de acordo com valores de retidão, lealdade e constância, presentes na comunidade internacional.

Porém, o conceito de boa fé não é fechado nem precisamente definido. Alguns autores definem boa fé como uma reunião dos princípios fundamentais do direito dos contratos, outros acreditam que se trata de uma expressão sem um conceito estabelecido, mas que objetiva excluir a possibilidade de obtenção de vantagens indevidas por meio da má fé. A boa fé está relacionada com a lealdade de conduta e aos princípios da razoabilidade e justiça, decência, ética e honestidade. Como se vê, o conceito de boa fé é bastante amplo.

É razoável observar, desta forma, que o princípio da boa fé, para fins de interpretação de tratados internacionais segundo a Convenção de Viena, deve sempre ser aplicado juntamente com os princípios do Direito Internacional Público que também são relativos ao princípio do pacta sunt servanda, notadamente a proteção das expectativas de direito, princípio da honestidade, justiça e razoabilidade.

É necessário considerar, contudo, que o princípio da boa fé não implica a obrigação de agir altruisticamente, bem como não requer que as partes (no caso, os Estados) abdiquem de seus interesses em favor umas das outras. De outro lado, a boa fé obriga que entre elas as relações sejam claras e honestas desde o início da negociação contratual. E como os tratados internacionais são, em sua essência, um contrato celebrado entre duas nações soberanas, este conceito é plenamente aplicável. Além disso, para o Direito dos tratados, além dos demais princípios mencionados no parágrafo anterior, a boa fé normalmente vem relacionada ao princípio pacta sunt servanda, ao princípio da

\footnotetext{
${ }^{554}$ RUBINSTEIN, Flávio. Interpretazione ed Applicazione degli Accordi Contro la Doppia Imposizione: Il Ruolo della Buona Fede Oggetiva. In: Diritto e Pratica Tributaria Internazionale. Padova: CEDAM, 2005. v. 1.
} 
razoabilidade (no sentido de as partes terem a obrigação de adotarem sempre posturas e medidas razoáveis) e ao princípio da continuidade contratual ${ }^{555}$.

\subsubsection{O "sentido comum" $e$ o "sentido especial" dos termos de um} tratado internacional

Quando o artigo 31 da Convenção de Viena menciona o "sentido comum" dos termos e expressões de um tratado, evidentemente trata-se do sentido técnico de referidos termos ou expressões, e não apenas do sentido corriqueiro encontrado em dicionários. $\mathrm{Na}$ realidade, é no "sentido comum" (técnico) dos termos e expressões que se baseia o método literal de interpretação para os fins do artigo 31 da Convenção de Viena.

Em outras palavras, o fundamento da adoção do método intratextual ou literal de interpretação consiste na presunção de que as intenções das partes ao celebrarem um acordo internacional foi baseada no sentido comum/técnico dos termos e expressões por elas utilizados. De fato, a linguagem utilizada nas convenções de bitributação é composta por termos técnicos do Direito Tributário Internacional, os quais foram se uniformizando com o passar dos tempos, especialmente em decorrência da bastante frequente utilização dos Modelos de convenção ${ }^{556}$.

Disso ressai que um tratado de bitributação internacional deverá ter seus termos e expressões interpretados de acordo com o Direito Tributário Internacional, e não segundo os Direitos internos dos Estados contratantes. Isto não significa, porém, que o significado encontrado em dicionários deva ser excluído. Ao contrário, ele pode servir de ponto de partida para a interpretação, desde que seja considerado, ao final do processo, o sentido técnico do termo ou expressão, de acordo com o Direito internacional. Além disso, é de se ressaltar que a aplicação prática desta regra está sujeita a algumas ressalvas, conforme lembrado pela Professora Marjaana Helminem, que destaca o fato de os tratados de bitributação atuarem limitando a legislação interna dos países, implicando a

\footnotetext{
${ }^{555}$ KEILY, Troy. Good Faith \& the Vienna Convention on Contracts for the International Sale of Goods (CISG), VJ 1999/1, at 15 et seq. Disponível em <www.Trans-Lex.org/131400"> . Acesso em 18 out. 2009.

${ }^{556}$ ROCHA, Sérgio André. Interpretação dos Tratados contra a Bitributação da Renda. Rio de Janeiro: Lumen Juris, 2008, p. 145. PROKISCH, Rainer. Does it make sense if we speak of an "international tax language"? In: VOGEL, Klaus. Interpretation of Tax Law and Treaties and Transfer Pricing in Japan and Germany. The Hague: Kluwer Law International, 1998, p. 106 (Series on International Taxation n. 20).
} 
impossibilidade de desconsiderar completamente os significados atribuídos pelo Direito doméstico dos Estados contratantes ${ }^{557}$.

A regra da adoção do sentido comum não é absoluta. Se as partes assim convencionarem expressamente, no texto do acordo, um sentido especial pode ser atribuído aos termos e expressões do tratado ${ }^{558}$. Entendemos ser igualmente possível a existência de um acordo tácito pela adoção de um sentido especial referente a determinado termo ou expressão, desde que seja possível identificar tal acordo tácito por meio do contexto da celebração do tratado. Contudo, destaca-se que, em qualquer hipótese, a existência de um acordo passível de comprovação entre as partes contratantes é imprescindível para a atribuição do sentido especial aos termos e expressões.

A principal função da distinção estabelecida entre o sentido comum e o sentido especial consiste em enfatizar que, numa situação de disputa envolvendo a aplicação do acordo, o ônus da prova incumbe à parte que alegar que um termo ou expressão não foi utilizado em seu sentido comum (leia-se: sentido técnico). Além disso, a intenção das partes em adotar um sentido especial para alguma expressão do tratado, nos termos do quarto parágrafo do artigo 31 da CVDT, deve ser claramente dirigida aos elementos da norma envolvendo a expressão em questão, não podendo haver referências a quaisquer outras evidências das intenções das partes, como aquelas encontradas nos documentos preparatórios ou nas circunstâncias antecedentes ao tratado. ${ }^{559}$

Um exemplo da aplicação do "sentido comum" dos termos e expressões pode ser visto no caso referente à Disputa de Terras, Ilhas e Espaço Marítimo. Neste caso, discutiu-se o significado do termo "determinar", e, em sua decisão, a Corte Internacional de Justiça considerou que:

\footnotetext{
${ }^{557}$ HELMINEM, Marjaana. Tax Treaty Interpretation in Finland. In: LANG, Michael (org.). Tax Treaty Interpretation. Viena: Linde Werlag, 2001. p. 82.

558 "Quanto ao 'sentido especial', HUMMER se inclina a atribuir-lhe não um sentido comum escolhido para finalidades especiais, mas um sentido não usual do termo, conscientemente acordado pela intenção comum das partes, deve ser explicitamente expresso ('estabelecido'), a fim de informar o intérprete a não empregar o sentido comum da expressão, mas o sentido especial daquele termo particular, no seu conteúdo semântico, tal como elaborado pelas partes contratantes, para o uso exclusivo no tratado". ROTHMANN, Gerd W. Interpretação e Aplicação dos Acordos Internacionais contra a Bitributação. São Paulo: USP, 1978. Tese (doutorado), p. 166-167.

${ }^{559}$ ENGELEN, Frank. Interpretation of Tax Treaties under International Law. Amsterdam: IBFD, 2004. v. 7 , p. 542 (IBFD Doctoral Series).
} 
"indubitavelmente, a palavra "determine" em inglês (e, conforme informado à Câmara, também o verbo "determinar" em espanhol) pode ser utilizado para demonstrar a ideia de estabelecimento de limites, de modo que, se associado diretamente à expressão "espaços marítimos", seu "sentido comum” pode ser tomado de modo a incluir a delimitação de tais espaços. Porém, o termo deve ser lido em seu contexto; o objeto do verbo "determinar" não corresponde aos espaços marítimos em si mesmos, mas sim à situação jurídica de tais espaços. Nenhuma indicação de intenção comum de obter delimitação pela Câmara pode ser depreendida deste texto no modo como se encontra. ${ }^{, 560}$.

A questão envolvendo "sentido comum" dos termos e expressões de tratados internacionais já foi objeto de diversas discussões, havendo, inclusive, quem critique a manutenção desta locução no corpo do texto da Convenção de Viena. Para tais críticos, nenhuma palavra pode ter um sentido natural e ordinário se considerada isoladamente, fora de contexto. Como se vê, até mesmo as críticas reforçam a necessidade de interpretação de termos e expressões sempre à luz do contexto do tratado.

Apesar de a regra geral ser a aplicação do sentido comum de termos e expressões, há situações em que serão atribuídos aos termos e expressões um sentido especial. Para estes casos, o artigo 31, parágrafo $4^{\circ}$, exige o comum acordo das partes contratantes. Este "sentido especial", contudo, deve ser estabelecido considerando-se o contexto do acordo, conforme o conceito de contexto previsto no segundo parágrafo do próprio artigo 31, devendo ser levados em consideração, outrossim, os acordos subsequentes e as práticas internacionais, nos termos do terceiro parágrafo do artigo 31 .

No entanto, a busca pelo "sentido especial" não pode se socorrer ao recurso dos meios suplementares de interpretação ou aos trabalhos preparatórios. Em outras palavras, caso a leitura do texto permita a compreensão da norma utilizando-se os sentidos comuns dos termos e expressões nela utilizados, é o sentido comum que deve prevalecer, não devendo ocorrer qualquer busca por outro sentido diverso do sentido ordinário através dos meios suplementares de interpretação. Em suma: somente em situações excepcionais e claramente determinadas no contexto do tratado é que poderá prevalecer o sentido especial de termos e expressões, sendo a regra geral sempre a aplicação do sentido comum durante

${ }^{560}$ ICJ Reports 1992. p. 583. In: ENGELEN, Frank. Interpretation of Tax Treaties under International Law. Amsterdam: IBFD, 2004. v. 7, p. 140 (IBFD Doctoral Series). 
a interpretação de normas internacionais. Do contrário, restaria esvaziado de sua eficácia o método intratextual, previsto na regra geral de interpretação do artigo 31 da Convenção de Viena.

\subsubsection{3. “Objetivos e finalidade”}

O primeiro parágrafo do artigo 31 da Convenção de Viena determina, ainda, que os tratados internacionais deverão ser interpretados à luz de seus objetivos e finalidades. $\mathrm{O}$ fato de haver menção expressa aos objetivos e finalidades do tratado conduz à impressão de que a própria convenção estaria recomendando a utilização do método teleológico de interpretação. Entretanto, esta primeira impressão pode levar a equívocos durante a interpretação, podendo resultar em conclusões subjetivas e parciais obtidas indevidamente pela aplicação isolada do método acima referido.

É claro que, em algum momento, haverá, sim, a utilização do método teleológico. Porém, a melhor doutrina destaca a necessidade de muita cautela durante a sua aplicação, para que o intérprete não corra o risco de ultrapassar o que está expressamente dito no texto do tratado ao argumento de estar realizando uma interpretação segundo os objetivos e finalidades do acordo.

$\mathrm{Na}$ realidade, os objetivos e finalidades de qualquer tratado internacional necessariamente deverão ser apreendidos a partir da leitura do seu texto, e não a partir da análise dos trabalhos preparatórios ou das circunstâncias em que ocorreu a celebração do acordo. Neste ponto, é importante lembrar que a Convenção de Viena deixa bem claro, no primeiro parágrafo do artigo 31, que o ponto de partida para a interpretação de qualquer tratado deve sempre ser o seu texto. A redação final de um tratado é considerada como a expressão máxima da vontade das partes contratantes ${ }^{561}$, por isso a interpretação sempre deve começar a partir do texto positivado, e, tanto quanto possível, restringir-se a ele.

Porém, como já mencionado anteriormente, o processo hermenêutico não pode ser dividido em etapas, assim como não poderá haver a interpretação literal isoladamente. Como todo e qualquer texto, a redação de um tratado deve ser interpretada sempre tendo

\footnotetext{
${ }^{561}$ Nesse sentido, Engelen esclarece que: “(...) it is clear that an interpretation going beyond what is expressed or necessarily implied in the actual terms of the treaty so as to give effect to its object and purpose is not in accordance with the textual approach to treaty interpretation underlying Article 31 VCLT." ENGELEN, Frank. Interpretation of Tax Treaties under International Law. Amsterdam: IBFD, 2004. v. 7, p. 172 (IBFD Doctoral Series).
} 
em consideração os elementos formadores do contexto no qual ele está inserido. Assim, o intérprete poderá compreender quais são os objetivos e finalidades de um acordo internacional a partir da leitura cuidadosa do texto do próprio acordo, dentro do contexto de sua celebração. Geralmente, o melhor lugar para se buscar os objetivos e finalidades de um tratado internacional (e também de muitas normas internas dos países ${ }^{562}$ ) é o preâmbulo $^{563}$. Entretanto, como não se trata de uma forma rígida, os objetivos e finalidades de um acordo podem vir expressos de forma diluída nas redações de suas diversas normas $^{564}$.

\footnotetext{
${ }^{562}$ Exemplo disso é o preâmbulo da Constituição Brasileira de 1988, que claramente explicita os objetivos e finalidades da Magna Carta: "Nós, representantes do povo brasileiro, reunidos em Assembléia Nacional Constituinte para instituir um Estado Democrático, destinado a assegurar o exercício dos direitos sociais e individuais, a liberdade, a segurança, o bem-estar, o desenvolvimento, a igualdade e a justiça como valores supremos de uma sociedade fraterna, pluralista e sem preconceitos, fundada na harmonia social e comprometida, na ordem interna e internacional, com a solução pacífica das controvérsias, promulgamos, sob a proteção de Deus, a seguinte Constituição da República Federativa do Brasil."
}

563 Outro exemplo bastante ilustrativo é o preâmbulo da Carta da ONU, que enumera explicitamente os objetivos e finalidades do tratado internacional: "PREAMBLE: WE, THE PEOPLES OF THE UNITED NATIONS, DETERMINED to save succeeding generations from the scourge of war, which twice in our lifetime has brought untold sorrow to mankind, and to reaffirm faith in fundamental human rights, in the dignity and worth of the human person, in the equal rights of men and women and of nations large and small, and to establish conditions under which justice and respect for the obligations arising from treaties and other sources of international law can be maintained, and to promote social progress and better standards of life in larger freedom, AND FOR THESE ENDS: to practice tolerance and live together in peace with one another as good neighbours, and to unite our strength to maintain international peace and security, and to ensure, by the acceptance of principles and the institution of methods, that armed force shall not be used, save in the common interest, and to employ international machinery for the promotion of the economic and social advancement of all peoples, HAVE RESOLVED TO COMBINE OUR EFFORTS TO ACCOMPLISH THESE AIMS accordingly, our respective Governments, through representatives assembled in the city of San Francisco, who have exhibited their full powers found to be in good and due form, have agreed to the present Charter of the United Nations and do hereby establish an international organization to be known as the United Nations." Disponível em http://www.un.org/en/documents/charter/preamble.shtml, acesso em 20 out. 2009.

${ }^{564}$ As convenções de bitributação assinadas pelo Brasil também expressam seus objetivos e finalidades em seus preâmbulos. Por exemplo, a Convenção Brasil-África do Sul (Decreto n. 5.922/2006), dispõe em seu preâmbulo o seguinte: "PREÂMBULO - O Governo da República Federativa do Brasil e o Governo da República da África do Sul, desejosos de concluir uma Convenção para evitar a dupla tributação e prevenir a evasão fiscal em matéria de impostos sobre a renda, acordaram o seguinte: (...)”. (Disponível em http://www.receita.fazenda.gov.br/Legislacao/AcordosInternacionais/AfricadoSul/Dec59222006.htm. Acesso em 20 out. 2009. Da mesma forma ocorre com convenções de bitributação assinadas por outros países. Vide exemplo da Convenção entre França e Espanha para evitar a dupla tributação: "The President of the French Republic and the Head of the Spanish State, desiring to conclude a convention for the avoidance of double taxation on income and fortune, have for that purpose appointed as plenipotentiaries: The President of the French Republic: His Excellency Mr. Robert Gillet, Ambassador Extraordinary and Plenipotentiary of France at Madrid; The Head of the Spanish State: His Excellency Mr. Laureano Lopez Rod, Minister for Foreign Affairs; who, having exchanged their full powers, found in good and due form, have agreed on the following provisions:" Disponível em: http://.untreaty.un.org/unts/1 60000/27/9/00052437.pdf, acesso em 20 out. 2009. 
Analisando a história da elaboração da Convenção de Viena, Engelen ${ }^{565}$ destaca que, segundo a International Law Commission, os objetivos e finalidades de um tratado internacional não poderiam ser separados do contexto do próprio tratado para fins de interpretação. Ao contrário, Engelen menciona que a International Law Commission explicitamente considerava os objetivos e finalidades como os mais importantes elementos integrante do contexto e, por isso, entenderam por bem deixar a menção explícita a tais elementos na redação final do artigo 31.

Em outras palavras, a Convenção de Viena deliberadamente fez referência expressa aos objetivos e finalidades do acordo com a intenção de deixar clara a sua importância para o contexto, e não com a finalidade de indicar que tais elementos devessem ser considerados autonomamente. Isto porque a consideração isolada dos objetivos e finalidades, ou seja, a consideração destes elementos fora do contexto, durante o processo hermenêutico, poderia levar à uma interpretação distorcida do tratado, abrindo caminho para a aplicação isolada do método teleológico, o que certamente resultaria numa interpretação subjetiva e parcial das normas previstas no acordo.

Em vista disso, é razoável concluir que os objetivos e finalidades de um tratado somente devem ser considerados para fins interpretativos na medida em que não sejam contrários ao sentido comum expresso nos seus termos e expressões. Isto é: num eventual impasse entre a escolha do método literal e a escolha do método teleológico, a Convenção de Viena recomenda a prevalência do método literal, sempre dentro do contexto. As conclusões provenientes da aplicação do método literal deverão, a partir daí, ser analisadas à luz dos objetivos e finalidades do tratado, podendo ser confirmadas, concluindo a interpretação da norma em questão, ou, então, podendo ser modificadas, abrindo caminho para o recurso aos meios suplementares de interpretação previstos no artigo 32 da Convenção de Viena ${ }^{566}$.

\footnotetext{
${ }^{565}$ ENGELEN, Frank. Interpretation of Tax Treaties under International Law. Amsterdam: IBFD, 2004. v. 7, pp. 172-173 (IBFD Doctoral Series).

566 “(...) The initial search is for the 'ordinary meaning' to be given to the terms of the treaty in their 'context'; it is in the light of the object and purpose of the treaty that the initial and preliminary conclusion must be tested and either confirmed or modified. It may of course be that the intellectual process can be short-circuited where the object or purpose of the treaty is so overwhelmingly apparent that it must necessarily and from the very outset exercise a determining influence upon the search for the contextual 'ordinary meaning'; but this is likely to be a rare case, given that the most treaties have no single, undiluted object and purpose but a variety of differing and possibly conflicting objects and purposes." SINCLAIR, I. The Vienna Convention on the Law of Treaties, 2. ed., Manchester: Manchester University Press, 1984. n. 404. p. 130.
} 


\subsubsection{A noção de "Contexto" $e$ o conceito de "tratado" segundo o artigo}

\section{1 da Convenção de Viena}

Outro conceito extremamente relevante para a interpretação de tratados internacionais, segundo a Convenção de Viena, é o "contexto". De fato, o artigo 31, em seu segundo parágrafo, destaca o contexto como ponto central para a interpretação das normas contidas nos tratados internacionais.

Para tanto, apresenta o conceito de contexto, no qual são inclusos não apenas o texto do tratado, mas também o preâmbulo e eventuais anexos, bem como outros tratados ou acordos celebrados pelas partes ${ }^{567}$, desde que estes últimos sejam conexos ao tratado que esteja sendo interpretado. É ver a redação da citada norma:

“Art. 31(...)

2. Para os fins de interpretação de um tratado, o contexto compreenderá, além do texto, seu preâmbulo e anexos:

a) qualquer acordo relativo ao tratado e feito entre todas as partes em conexão com a conclusão do tratado;

b) qualquer instrumento estabelecido por uma ou várias partes em conexão com a conclusão do tratado e aceito pelas outras partes como instrumento relativo ao tratado."

Apesar de aparentemente simples, a compreensão do conceito de "contexto do tratado" requer uma análise mais detida dos seus elementos, especialmente no que concerne ao conceito de "tratado" propriamente dito, previsto no artigo $2^{\circ}$, parágrafo $1^{\circ}$, (a), da mesma Convenção. A necessidade de analisar estes dois conceitos conjuntamente decorre da própria regra geral de interpretação, segundo a qual o texto de um tratado deverá ser interpretado à luz de seu contexto, de modo que os conceitos de um e de outro são intimamente relacionados. Além disso, a análise da regra geral de interpretação demonstra que a Convenção de Viena elegeu o método intratextual ou literal como ponto de partida e também como o principal método a ser aplicado para a busca do "sentido comum" dos termos e expressões de um tratado, durante o processo hermenêutico.

${ }^{567}$ De acordo com o artigo $2^{\circ}$, parágrafo $1^{\circ}$, alínea g, “"parte’ significa um Estado que consentiu em se obrigar pelo tratado e com relação ao qual este esteja em vigor;" 
Segundo o artigo $2^{\circ}$, parágrafo $1^{\circ}$, (a), da Convenção de Viena, o conceito de "tratado" é definido como sendo "um acordo internacional concluído por escrito entre Estados e regido pelo Direito Internacional, quer conste de um instrumento único, quer de dois ou mais instrumentos conexos, qualquer que seja sua denominação específica". A primeira conclusão a partir da análise conjunta deste artigo com o artigo 31 , parágrafo $2^{\circ}$, da Convenção, é que os termos "acordo" e "tratado" não são sinônimos. Enquanto o "tratado", segundo a CVDT, necessariamente deve ser celebrado na forma escrita, os “acordos" não estão sujeitos a esta exigência. Os tratados são, portanto, mais abrangentes e mais formais que os acordos, sendo perfeitamente possível que um único tratado seja fruto de diversos acordos, escritos ou não. Deduz-se, assim, que podem existir acordos escritos, orais, expressos ou tácitos, todos eles igualmente válidos perante o Direito Internacional.

Outra conclusão obtida a partir da análise acima é no sentido de ser estabelecido que um tratado internacional não necessariamente será firmado em um único instrumento, e, em caso de pluralidade de instrumentos, as normas contidas em todos eles deverão ser igualmente consideradas como integrantes do tratado. Isto implica afirmar que o texto de um tratado poderá ser composto por dois ou mais documentos, desde que sejam obedecidos os requisitos da forma escrita e do acordo de vontades entre as partes, devendo este último ser expresso para todos os instrumentos.

A análise acima, por si só, já explica a noção de "texto do tratado", que é o primeiro elemento constitutivo do "contexto". Em seguida, a Convenção de Viena determina que, além do texto propriamente dito, o contexto inclui o preâmbulo e seus anexos. Quanto ao preâmbulo, já mencionamos anteriormente que nele geralmente se encontram expostos claramente os objetivos e finalidades do tratado. Isto reforça a idéia também já explicada de que a interpretação literal nunca é isolada, uma vez que, segundo a regra geral, a interpretação deve considerar, além do texto, os objetivos e finalidades do tratado, e, como se observa da análise supra, estes dois elementos são encontrados geralmente no preâmbulo, o qual faz parte do contexto. Por isso é correta a afirmação de que a interpretação literal sempre deve ser realizada dentro do contexto.

Por sua vez, os "anexos" citados no item "a" do parágrafo $2^{\circ}$ do artigo 31 , incluem tanto acordos quanto instrumentos relativos ao tratado. Entretanto, é necessária a obediência a dois requisitos: (i) os acordos e instrumentos devem ser conexos ao tratado, (ii) os acordos e instrumentos devem ser contemporâneos à celebração do tratado e (iii) 
deve haver a concordância das partes relativamente a tais acordos ou instrumentos serem parte integrante do tratado.

Estes três requisitos têm sido objeto de discussões e polêmica na doutrina desde a época da elaboração da própria Convenção de Viena, e as críticas a eles aplicáveis são, de fato, pertinentes.

De fato, o artigo 31 não exige a forma escrita para os acordos que fazem parte do contexto. E nem poderia ser diferente, eis que a exigência de forma escrita para os acordos conexos ao tratado esbarraria no fato de que, durante toda a fase de celebração, muitos acordos importantes acerca do futuro conteúdo do tratado acabam sendo estabelecidos entre as partes apenas oralmente, durante a fase de negociações. Portanto, parece-nos claro que o artigo inclui tanto os acordos escritos quanto os verbais. Relativamente aos instrumentos, não há grandes discussões, tendo em vista que a própria utilização do vocábulo "instrumento" já presume a forma escrita.

Outro ponto polêmico refere-se à necessidade ou não da forma expressa. Isto porque, especialmente com relação aos assuntos e questões que não são objeto de divergência entre as partes, verifica-se a ocorrência de acordos tácitos, os quais, na maioria das vezes, também não são documentados por escrito. Então, qual seria o motivo de toda a polêmica envolvendo os acordos orais e tácitos? Trata-se de um motivo de ordem prática. Efetivamente, da mesma forma como se reconhece a importância destes acordos para a celebração do tratado, também se evidencia a maior dificuldade prática de produzir provas a respeito destes instrumentos. Não obstante, especialmente em face da evolução tecnológica dos tempos atuais, esta maior dificuldade em se produzir a referida prova não constitui motivo suficiente para simplesmente desconsiderar tais documentos e rebaixá-los à categoria de meios suplementares de interpretação, aos quais somente se deve recorrer em caso de interpretação obscura ou ambígua. Em face disso, a moderna doutrina tende a considerar a validade de acordos orais ou tácitos como integrantes do tratado e de seu contexto, desde que tenham sido observados os requisitos da conexão com o objeto do tratado e sejam contemporâneos a este.

Outro requisito posto pela Convenção de Viena para que um documento possa integrar o contexto de um tratado internacional consiste na necessidade de conexão direta com o tratado em questão. Esta conexão inclui tanto os acordos com finalidade especificamente interpretativa quanto aqueles que, embora não tenham sido elaborados 
com esta finalidade expressa, são relacionados com a substância do tratado em si, como é o caso dos acordos firmados para limitar a aplicação de determinadas cláusulas do tratado.

Além dos critérios acima, é necessário que os acordos tenham sido firmados pelas mesmas partes que celebraram o tratado, e até a data da conclusão deste. Desta forma, os acordos firmados pelas mesmas partes após a conclusão do tratado em questão, mesmo que relacionados a este, passam a ser considerados como meios suplementares de interpretação, e não mais como contexto do tratado. Entretanto, é de se considerar que os acordos exclusivamente interpretativos relativos ao tratado em questão devem sempre ser considerados durante a interpretação, sejam eles anteriores ou posteriores à conclusão do tratado.

A Convenção de Viena estabelece critérios distintos relativamente ao acordo de vontades entre as partes para os acordos e para os instrumentos. No item "a", a Convenção determina que os acordos devem ter sido firmados entre as partes, enquanto que no item "b", dispõe que os instrumentos devem ser aceitos por todas as partes. Esta distinção parece indicar que, com relação aos instrumentos, supostamente não haveria a necessidade de assinatura conjunta, como se exige para os acordos. Esta é a opinião de Engelen, segundo o qual a Convenção de Viena não requer a aceitação expressa da outra parte relativamente a um instrumento relacionado com o tratado, muito menos requer que tal aceitação seja por escrito. Segundo o autor, caso a Convenção houvesse pretendido exigir a aceitação expressa da outra parte relativamente a um instrumento referente ao acordo, tal intenção estaria expressamente prevista na redação do item "b" do artigo 31 , parágrafo segundo, a exemplo do que ocorre no artigo 23 da própria Convenção de Viena. Desta forma, caso a outra parte não se manifeste em contrário, presume-se a sua aceitação do instrumento em questão. ${ }^{568}$

Considerando o conceito de contexto explicado nos parágrafos anteriores, citamos aqui como exemplo ilustrativo as próprias convenções contra a bitributação celebradas pelo Brasil. Na maioria das vezes, elas são constituídas, pelos artigos da convenção propriamente ditos que são introduzidos no Direito brasileiro por meio de um Decreto Presidencial e aprovados por um Decreto Legislativo, e também por um protocolo normalmente anexo ao final dos artigos da convenção, no qual são incluídas modificações

${ }^{568}$ ENGELEN, Frank. Interpretation of Tax Treaties under International Law. Amsterdam: IBFD, 2004. v. 7, p. 213 (IBFD Doctoral Series). 
aos artigos originalmente aprovados, o qual é assinado sempre por ambas as partes. Este protocolo adicional, cuja natureza é de acordo anexo, tem o objetivo de esclarecer a forma de aplicação de termos constantes dos artigos da própria convenção, visando facilitar a sua aplicação. Além destes, as autoridades fiscais brasileiras costumam editar atos administrativos internos (portarias e atos declaratórios interpretativos) com a finalidade de estabelecer os procedimentos internos necessários para a aplicação do acordo. Estes poderiam ser classificados na categoria de instrumentos conexos, já que, embora sejam atos unilaterais, refletem e consolidam a interpretação das autoridades fiscais brasileiras acerca de alguns termos do tratado, e assim, por possuírem esta finalidade essencialmente interpretativa, devem ser considerados como contexto do tratado.

\subsubsection{5. “Acordos formais" $e$ "práticas posteriores" - demais elementos de}

\section{interpretação autêntica}

O terceiro parágrafo do artigo 31 introduz elementos que, embora não integrem o contexto, possuem a mesma importância deste durante o processo interpretativo, já que todos eles integram a regra geral de interpretação do artigo 31, e por este motivo, devem ser igualmente considerados para fins de interpretação autêntica do tratado ${ }^{569}$.

Assim, de acordo com o referido dispositivo, os chamados demais elementos de interpretação autêntica englobam os acordos formais relativos à interpretação firmados entre as partes, bem como as práticas posteriores seguidas pelas partes na aplicação do tratado, com relação à interpretação do mesmo, e ainda quaisquer normas relevantes de Direito Internacional aplicáveis às relações estabelecidas entre as partes.

Relativamente aos acordos formais relativos à interpretação e às práticas posteriores adotadas pelas partes, recomenda-se de imediato, cautela em sua aplicação, uma vez que as circunstâncias que envolvem a celebração dos acordos posteriores podem

\footnotetext{
569 "These elements (...) are designated in the Commentary on Article 27 of the 1966 Draft Convention as further authentic elements of interpretation. They are an integral part of the general rule of interpretation and, as such, rank equal with the elements that are to be regarded as forming part of the context. Indeed, the Commentary on Article 27 of the 1966 Draft Convention elucidates that 'the opening phrase of paragraph 3 'There shall be taken into account together with the context' is designed to incorporate in paragraph 1 the elements of interpretation set out in paragraph 3.' It is furthermore explained in the Commentary that these elements, although 'extrinsic' to the text', 'are all of an obligatory character and by their very nature could not be considered norms of interpretation in any way inferior to those which precede them." ENGELEN, Frank. Interpretation of Tax Treaties under International Law. Amsterdam: IBFD, 2004. v. 7, pp. 218-219 (IBFD Doctoral Series).
} 
não necessariamente ser as mesmas que estiveram presentes durante a celebração do tratado principal, de modo que o recurso indiscriminado a tais acordos ou práticas posteriores pode levar a interpretações equivocadas ou mesmo absurdas. Ademais, para a correta utilização destes elementos é imprescindível condicionamento de sua validade aos procedimentos de recepção e vigência dos acordos internacionais previstos no Direito interno dos Estados contratantes.

A expressa menção aos acordos posteriores teve o objetivo de diferenciá-los dos acordos celebrados até a data de celebração do tratado, já que estes integram o contexto, nos termos do segundo parágrafo do artigo 31. Tal como ocorre para os acordos integrantes do contexto, não se exige a forma escrita nem se exige a forma expressa para os acordos posteriores referidos no terceiro parágrafo do artigo 31.

Por sua vez, as práticas posteriormente adotadas pelas partes, bem como os acordos tácitos relativamente à interpretação de tratados internacionais, podem ser verificados por meio de documentos como declarações oficiais de governo, portarias ministeriais, opiniões legais oficiais, relatórios de imprensa, jurisprudência federal ou mesmo legislação doméstica sobre o objeto do tratado. Quanto a esta última, vale esclarecer que não se trata de aplicação da legislação doméstica em detrimento das normas dos tratados internacionais, mas, sim, de verificação da forma de sua interpretação para fins da interpretação do tratado internacional. É cabível ainda uma ressalva no sentido de que as práticas posteriores mencionadas na norma em comento jamais devem ser consideradas isoladamente, sendo imprescindível que sejam uniformes, consistentes e que reflitam de forma evidente a existência de um acordo tácito entre as partes envolvidas no tratado, para que possam ser considerados como elementos de interpretação autêntica. No entanto, em virtude destas exigências, e também em decorrência da dificuldade de diferenciar a natureza interpretativa ou modificativa das referidas práticas, estas acabam perdendo sua relevância como recurso interpretativo da regra geral de interpretação e terminam assumindo mais um caráter de meio suplementar de interpretação.

Sob outro prisma, a aplicação do disposto no item "c" do terceiro parágrafo do artigo 31 suscita duas questões importantes: primeiro, o que deve ser considerado como "norma relevante" de Direito Internacional para fins de interpretação do tratado, e, em segundo lugar, durante a interpretação, qual deverá ser aplicada, a norma internacional vigente à época da celebração do tratado ou a norma internacional em vigor durante a aplicação do tratado. 
Efetivamente, a necessidade de consideração das normas relevantes do Direito Internacional para a interpretação dos tratados representa simplesmente a positivação do princípio básico de que um tratado jamais deverá ser interpretado isoladamente, tendo em vista que toda a "vida" de um tratado é relacionada com as demais normas do Direito internacional. Um tratado internacional não existe senão dentro do contexto da comunidade internacional e de suas respectivas normas.

Deste modo, as "normas relevantes" citadas pela Convenção de Viena incluem os princípios gerais de Direito Internacional, as normas gerais presentes nos tratados internacionais multilaterais e também quaisquer normas internacionais regionais ou bilaterais que sejam pertinentes ao tema da interpretação. Além disso, os tratados celebrados anteriormente pelas mesmas partes, desde que sejam vinculantes para todas as partes envolvidas, também podem ser utilizados durante a interpretação, especialmente com a finalidade de esclarecer o sentido comum de termos já utilizados anteriormente pelas mesmas partes. Em busca deste objetivo, subsidiariamente, é possível até mesmo o recurso a um tratado celebrado entre uma das partes e um terceiro Estado, desde que a interpretação daí decorrente tenha a função de confirmar as conclusões obtidas a partir da aplicação da regra geral de interpretação.

Já a questão referente à evolução temporal das normas internacionais também pode ser resolvida mediante recurso à interpretação segundo a boa fé e a vontade das partes. É de se presumir, entretanto, que durante a celebração de um tratado internacional as partes envolvidas estejam cientes de que os termos e expressões nele utilizados estão sujeitos a atualizações decorrentes da evolução natural dos conceitos jurídicos.

De fato, a Corte Internacional de Justiça tem adotado o entendimento de que os termos e expressões não expressamente definidos no próprio tratado devem, sim, estar sujeitos à evolução conceitual, então seus significados podem ser influenciados pela alteração da legislação internacional superveniente. Este posicionamento pode ser percebido pela leitura de trechos do relatório do caso South West Africa, no qual foram discutidas as consequências legais para os Estados decorrentes da presença contínua da África do Sul na Namíbia, a despeito da Resolução 276 do Conselho de Segurança da 
$\mathrm{ONU}^{570}$, bem como no caso do Projeto Gabcíkovo-Nagymaros ${ }^{571}$, que envolvia a aplicação de novos conceitos jurídicos pertencentes ao Direito Ambiental a um tratado internacional.

Assim, a atualização dos termos e expressões utilizados em tratados internacionais, com as modificações dela decorrentes, pode ser notada principalmente com relação aos conceitos que, por sua própria natureza, são conceitos amplos, abstratos, imbuídos de relatividade e sujeitos a modificações resultantes da evolução temporal. Exemplo disso são expressões como "políticas públicas", "moral”, "jurisdição doméstica”, e até mesmo conceitos como "mar territorial", "território", "residente", "cidadão", "águas internacionais" ou "zona de exploração".

Em vista disso, parece-nos razoável a conclusão de Engelen, segundo o qual a decisão sobre qual norma relevante do Direito Internacional deve ser aplicável (se a da época da celebração do tratado ou aquela vigente durante sua aplicação) depende da intenção das partes, a qual pode ser determinada por meio da análise dos objetivos e finalidades do tratado à luz do princípio da boa fé.

\subsubsection{O artigo $32 \mathrm{da}$ CVDT - Meios suplementares de interpretação}

\footnotetext{
570 "The case concerning the Legal Consequences for States of the Continued Presence of South Africa in Namibia (South West áfrica) notwithstanding Security Council Resolution 276 is yet another example of the interpretation of expressions in a treaty denoting 'relative or evolving issues', which by necessary implication must be taken to be apt to evolve over time with the development of international law. The ICJ first emphasised that it is of the primary necessity of interpreting an instrument in accordance with the intention of the parties at the time of its conclusion' and then continued by saying that: '(...) the Court is bound to take into account the fact that the concepts embodied in Article 22 of the Convenant - 'the strenuous conditions of the modern world' and 'the well-being and development' of the peoples concernedwere not static, but were by definition evolutionary, as also, therefore, was the concept of the 'sacred trust'. The parties to the Convenant must consequently be deemed to have accepted them as such. That is why (...) the Court must take into consideration the changes which have occurred in the supervening half century, and its interpretation cannot remain unaffected by the subsequent developments of law, through the Charter of the United Nations and by way of customary law. Moreover, an international instrument has to be interpreted and applied within the framework of the entire legal system prevailing at the time of the interpretation." 'ENGELEN, Frank. Interpretation of Tax Treaties under International Law. Amsterdam: IBFD, 2004. v. 7, p. 287 (IBFD Doctoral Series). ICJ Reports 1971, p. 31.

571 “(...) the Court wishes to point out that newly developed norms of environmental law are relevant for the implementation of the Treaty and that the parties could, by agreement, incorporate them through the application of Articles 15, 19 and 20 of the Treaty. These articles do not contain specific obligations of perfornance but require the parties, in carrying out their obligations to ensure that the quality of water in the Danube is not impaired and that nature is protected, to take new environmental norms into consideration when agreeing upon the means to be specified in the Joint Contractual plan. By inserting these evolving provision in the Treaty, the parties recognized the potential necessity to adapt the Project. Consequently, the Treaty is not static, and is open to adapt to emerging norms of international law." ENGELEN, Frank. Interpretation of Tax Treaties under International Law. Amsterdam: IBFD, 2004. v. 7, pp. 287-288 (IBFD Doctoral Series). ICJ Reports 1997, p. 67-68.
} 
Os meios suplementares (ou complementares) de interpretação, definidos no artigo 32 da CVDT, como o próprio nome diz, são subsidiários àqueles previstos no artigo 31. Assim, os trabalhos preparatórios e as circunstâncias em que o tratado foi concluído somente devem ser utilizados para a interpretação dos tratado quando as conclusões obtidas nos termos do artigo 31 não permitirem resultados satisfatórios ou levarem a resultados obscuros ou absurdos. É ver a redação da norma:

\section{Artigo 32}

\section{Meios Suplementares de Interpretação}

Pode-se recorrer a meios suplementares de interpretação, inclusive aos trabalhos preparatórios do tratado e às circunstâncias de sua conclusão, a fim de confirmar o sentido resultante da aplicação do artigo 31 ou de determinar o sentido quando a interpretação, de conformidade com o artigo 31 :

a) deixa o sentido ambíguo ou obscuro; ou

b) conduz a um resultado que é manifestamente absurdo ou desarrazoado.

Neste ponto, cumpre ressalvar, novamente, que o fato de a Convenção de Viena ter previsto, em artigos distintos, a regra geral de interpretação e os meios suplementares de interpretação não significa, de modo algum, que o processo interpretativo de um tratado seja composto de fases sequenciais. Muito pelo contrário, como também já mencionado anteriormente, o processo hermenêutico é uno e indivisível, sendo possível o recurso a diversos métodos interpretativos concomitantemente, dependendo do material que o intérprete tem à sua disposição.

Apesar disso, é necessário considerar que a sistematização das referidas normas em artigos distintos não é apenas ilustrativa ou para fins didáticos. Na verdade, a sua função consiste em demonstrar que, na regra geral de interpretação prevista no artigo 31 situam-se os elementos vinculantes e autênticos do texto, que permitem uma interpretação autêntica e literal a partir da própria redação de suas cláusulas à luz do contexto, enquanto que no artigo 32 situam-se os elementos interpretativos que não se encontram expressamente previstos ou mesmo referidos no texto do tratado nem podem ser apreendidos através da análise do contexto. Estes elementos são expressamente enumerados pela Convenção de Viena como trabalhos preparatórios e as circunstâncias da conclusão do tratado, os quais desempenham o papel de fornecer indícios da vontade das 
partes no intuito de complementar ou esclarecer o resultado obtido a partir da interpretação textual e contextual.

De fato, os trabalhos preparatórios, assim como as circunstâncias em que se deu a conclusão do tratado, podem revelar bastante acerca da intenção das partes ao empregar os termos e expressões que compõem a redação final do acordo internacional. Porém, como se trata de um meio subsidiário, os trabalhos preparatórios não devem ser considerados quando o texto do tratado for suficientemente claro per si.

Outro problema frequente se deve ao fato de que, na prática, os referidos trabalhos preparatórios e as circunstâncias em que se deu a celebração do acordo raramente são positivados em documentos oficiais que pudessem ser exibidos às autoridades administrativas e judiciais durante um procedimento interpretativo. Na maioria dos casos, trata-se de negociações verbais, que somente são positivadas quando o texto final do próprio acordo é concluído. Por isso, é razoável afirmar que, em vista destas dificuldades, que a utilidade prática dos trabalhos preparatórios e das circunstâncias que informaram a elaboração do acordo de bitributação é reduzida. ${ }^{572}$

Além disso, são raros os casos em que se verificam verdadeiramente as obscuridades ou absurdos que ensejariam a aplicação do artigo 32. Nestas poucas situações, trata-se quase sempre de vícios ou erros materiais que, por algum descuido ou equívoco das autoridades responsáveis, permaneceram no texto final do tratado. Porém, em geral tais equívocos solucionados por aplicação da regra geral de interpretação contida no artigo 31 .

Qual seria, então, o motivo a justificar a previsão de meios suplementares de interpretação, já que seu caráter é essencialmente subsidiário e os recursos nele previstos são de difícil aplicação prática? Efetivamente, além de possuir a função de permitir a reinterpretação da norma quando os resultados são obscuros ou absurdos, o recurso aos meios suplementares de interpretação pode servir justamente para confirmar as conclusões extraídas a partir da aplicação da regra geral de interpretação. Dito de outra forma, seria o método de interpretação finalística sendo aplicado para corroborar o que já se concluiu pela aplicação do método intratextual ou literal.

${ }^{572}$ HELMINEM, Marjaana. Tax Treaty Interpretation in Finland. In: LANG, Michael (org.). Tax Treaty Interpretation. Viena: Linde Werlag, 2001. p. 82. 
O grande problema surge quando, neste esforço de confirmar as conclusões obtidas a partir da utilização da regra geral, ou seja, resultantes da interpretação literal, a aplicação dos meios suplementares de interpretação evidencia claramente que a intenção das partes contratantes era distinta do que se concluiu a partir da redação do tratado, revelando a existência de uma contradição entre o sentido literal e contextual do tratado e a efetiva intenção das partes, conhecida a partir da aplicação dos meios suplementares de interpretação. Efetivamente, analisando-se a estrutura de toda a Seção III da Convenção de Viena, onde se localizam referidos artigos, verifica-se que a Convenção prioriza o método literal de interpretação, apoiada no fato de que o texto do tratado deve representar a expressão máxima e legítima da vontade das partes contratantes, em detrimento do método finalístico ou teleológico. Por esta razão o método literal (ou intratextual) foi previsto na regra geral de interpretação. Em face disso, impõe-se a conclusão de que o recurso às fontes alheias ao texto e ao contexto do tratado somente é permitido nos casos expressamente previstos no artigo 32, ou seja, se e somente se, a interpretação pela regra geral conduzir a resultados absurdos ou obscuros. Assim, parece logicamente correto deduzir que no caso de a interpretação segundo o artigo 32 contradizer as conclusões obtidas a partir do artigo 31, estas últimas devem prevalecer, salvo se estas forem evidentemente absurdas ou absolutamente obscuras.

Outro aspecto importante consiste na determinação de que tipo de material pode ser enquadrado na categoria de trabalhos preparatórios e de circunstâncias envolvendo a conclusão do tratado. Obviamente, qualquer que seja a sua natureza, os documentos em questão devem fornecer provas objetivas da vontade comum das partes. Isto implica a desconsideração dos documentos unilaterais ou que não hajam sido submetidos à apreciação da outra parte durante as negociações. Desta forma, são exemplos de evidências que podem ser consideradas nos trabalhos preparatórios os arquivos referentes às negociações, as minutas e atas das reuniões, as sucessivas minutas do tratado em si, o relatório da reunião ou conferência onde ocorreu a celebração, etc. Embora não haja formalmente a exigência da publicação dos documentos que integram os trabalhos preparatórios, exige-se a sua plena acessibilidade pelas partes envolvidas.

Finalmente, por circunstâncias que envolveram a conclusão do tratado entendese o ambiente sócio-político e o contexto histórico dentro dos quais se desenvolveram os trabalhos preparatórios e as negociações que culminaram na celebração do tratado. 
Também podem ser considerados outros tratados e acordos internacionais firmados com terceiros países em assuntos correlatos ao do tratado em questão.

\subsubsection{O artigo 33 da CVDT - Interpretação de tratados autenticados em} dois ou mais idiomas

Geralmente, os tratados internacionais são celebrados em dois ou mais idiomas. Para os tratados bilaterais, normalmente são utilizados os idiomas dos respectivos países e também um terceiro idioma diplomático, que tem aplicação na solução de dúvidas interpretativas, se as partes assim convencionarem. Já no caso dos tratados multilaterais, é de costume elaborar versões em cinco ou seis idiomas comumente utilizados pelos países envolvidos. Por isso, a Convenção de Viena dedicou o artigo 33 especialmente para regulamentar estes casos.

\section{$\underline{\text { Artigo } 33}$}

Interpretação de Tratados Autenticados em Duas ou Mais Línguas

1. Quando um tratado foi autenticado em duas ou mais línguas, seu texto faz igualmente fé em cada uma delas, a não ser que o tratado disponha ou as partes concordem que, em caso de divergência, prevaleça um texto determinado.

2. Uma versão do tratado em língua diversa daquelas em que o texto foi autenticado só será considerada texto autêntico se o tratado o previr ou as partes nisso concordarem.

3. Presume-se que os termos do tratado têm o mesmo sentido nos diversos textos autênticos.

4. Salvo o caso em que um determinado texto prevalece nos termos do parágrafo 1, quando a comparação dos textos autênticos revela uma diferença de sentido que a aplicação dos artigos 31 e 32 não elimine, adotar-se-á o sentido que, tendo em conta o objeto e a finalidade do tratado, melhor conciliar os textos.

Analisando a norma acima, o primeiro questionamento que surge refere-se ao motivo pelo qual a Convenção de Viena utiliza a expressão "tratados autenticados em dois ou mais idiomas", em vez de mencionar a expressão "tratados assinados" ou mesmo 
"tratados celebrados". Isto se deve ao fato de que os atos denominados de assinatura, celebração e autenticação constituem procedimentos distintos que integram o processo de celebração de tratados. Na verdade, a distinção destes conceitos é relacionada à força vinculante que é conferida ao texto do tratado após cada uma das fases da celebração. Nesse sentido, somente o texto do tratado que é submetido à autenticação possui força vinculante e pode ser considerado como o texto definitivo do tratado ${ }^{573}$, nos termos do artigo $10^{574}$ da própria Convenção de Viena. Assim, considerando a norma do referido artigo 10 em conjunto com o artigo 33, é possível concluir que os textos autênticos são aqueles que são vinculantes e devem prevalecer; já os textos oficiais, embora hajam sido assinados pelas partes, não são considerados obrigatórios; e, por fim, as traduções oficiais não possuem o condão de obrigar as partes, servindo apenas como referência para fins de interpretação e aplicação do tratado, em virtude de terem sido elaboradas por órgãos oficiais dos governos dos Estados contratantes ou por organizações internacionais reconhecidas pelos Estados contratantes ${ }^{575}$.

O primeiro parágrafo do artigo 33 estabelece a regra da equivalência de valores dos textos autênticos na ausência de disposições específicas em sentido contrário firmadas pelas partes $^{576}$. Contudo, considerando a dificuldade prática de conciliar os textos

\footnotetext{
573 Sobre o procedimento de autenticação de tratados, confira-se: ENGELEN, Frank. Interpretation of Tax Treaties under International Law. Amsterdam: IBFD, 2004. v. 7, p. 287 (IBFD Doctoral Series). ICJ Reports 1971 , p. 31.

\section{4 “Artigo 10}

Autenticação do Texto

O texto de um tratado é considerado autêntico e definitivo:

a) mediante o processo previsto no texto ou acordado pelos Estados que participam da sua elaboração; ou na ausência de tal processo, pela assinatura, assinatura ad referendum ou rubrica, pelos representantes desses Estados, do texto do tratado ou da Ata Final da Conferência que incorporar o referido texto."
}

575 WATTS, Arthur. The International Law Commission, 1949-1998, New York: Oxford University Press. 2000. v. 2. p. 693.

${ }^{576}$ As convenções de bitributação celebradas pelo Brasil são sempre autenticadas em Português e no idioma oficial do outro país signatário. Quando o idioma do outro país é o Inglês, o Espanhol ou o Francês, autenticam-se apenas duas versões (em português e no outro idioma). Nos demais casos, autentica-se também uma versão em Inglês, a qual prevalece em caso de divergências interpretativas. Exemplos: Convenção Brasil-China: "Feito em Pequim aos 5 dias do mês de agosto de 1991, em duas vias, em português, chinês e inglês, sendo os três textos igualmente autênticos. Em caso de divergência de interpretação prevalecerá o texto em inglês."; Convenção Brasil-Coréia: "Feita em duplicata em Seul, aos 7 dias do mês de Março de 1989, nas línguas portuguesa, coreana e inglesa, sendo os três textos igualmente autênticos. Em caso de divergência entre os textos em português e coreano, prevalecerá o texto em inglês. ”; Convenção BrasilHungria: "Feita em Budapeste, aos 20 dias do mês de junho de 1986, em dois originais, cada qual nas línguas portuguesa, húngara e inglesa, sendo autênticos todos os três textos. Em caso de interpretações divergentes dos textos em português e húngaro, prevalecerá o texto em inglês."; Cláusulas idênticas às citadas acima estão presentes também nas convenções firmadas com a Dinamarca, Finlândia, Índia, Israel, Itália, Japão, Noruega, República Checa e Eslováquia, Suécia e Ucrânia. 
autenticados em dois ou mais idiomas, é comum que as partes elaborem uma versão autêntica redigida em um idioma diplomático, geralmente o inglêe ${ }^{577}$, com o objetivo de resolver mais facilmente as dúvidas interpretativas decorrentes da tradução.

Por sua vez, o segundo parágrafo do artigo 33, reforçando a necessidade de procedimento de autenticação do tratado, dispõe que uma versão do tratado em idioma diferente daqueles nos quais o texto tenha sido autenticado somente deverá ser considerada autêntica se as partes assim determinarem. Contudo, o fato de possibilitar que uma versão em outro idioma seja autenticada pelas partes não significa que ela deva ter a mesma força vinculante das versões originalmente autenticadas.

Já o terceiro parágrafo refere-se aos tratados autenticados em diversos idiomas, introduzindo a presunção de que os termos do tratado possuem o mesmo sentido nos diversos textos autênticos. De fato, nem sempre o fato de um tratado ter sido autenticado em diversos idiomas é sinônimo de dificuldades interpretativas. Quando se interpreta um tratado deste tipo, é necessário considerar que, apesar da pluralidade de línguas em que foi vertido o texto, o seu conteúdo jurídico é uno, e como conseqüência lógica, as suas diversas versões representam a expressão máxima da vontade comum das partes contratantes. Ciente disso, quando o intérprete se depara com alguma dificuldade em relação a determinado termo ou expressão no texto elaborado num idioma "X", basta que ele, socorrendo-se da presunção prevista no terceiro parágrafo do artigo 33, recorra à versão do mesmo tratado no idioma "Y", ou "Z", e, assim, solucione o impasse interpretativo. A partir deste exemplo é possível concluir, portanto, que o fato de um

\footnotetext{
${ }^{577}$ Até os Tratados de Westfalia, o latim era o idioma diplomático, oral e escrito. Desde então, o Francês foi paulatinamente substituindo o Latim, até alcançar seu auge no Congresso de Viena de 1815, que foi negociado em Francês. O Francês chegou a ser utilizado para negociações e acordos nos quais sequer participavam delegações francesas. Esta situação se manteve até o fim da Primeira Guerra Mundial, que assinala o início da decadência do Francês como único idioma diplomático. O Tratado de Versalhes simboliza o fim desta era, tendo sido celebrado em dois idiomas: Francês e Inglês. Desde então, o Inglês assumiu posição importante dentre os idiomas mais utilizados pela diplomacia, mas ao mesmo tempo, vem perdendo espaço para outras línguas que também são largamente utilizadas pelo mundo, especialmente o Espanhol e o Mandarim. Atualmente não existe um idioma diplomático único. Ainda assim, a comunidade internacional consagrou a existência de certos idiomas considerados como idiomas de trabalho das Nações Unidas, concedendo-lhes certo grau de reconhecimento internacional. Neste nível, encontram-se os idiomas Inglês, Francês, Espanhol, Russo, Árabe e Chinês (Mandarim). Sobre idiomas diplomáticos: RONCATI, Eduardo Jara. La Función Diplomática. Santiago: RIL Editores, 2000. p. 207 e seguintes. NOVAK, Fabián. PARDO, Fernando. Derecho Diplomático - Comentários a la Convención sobre Relaciones Diplomáticas. Lima: El Fondo Editorial de La Pontifícia Universidad Católica del Peru, 2003. pp. 69-70. MONTÚFAR, Lorenzo. Nociones de Derecho de Gentes Y Leyes de La Guerra. Bibliolife, 2009, pp. 72-73. TABORY, Mala. Multilingualism in international law and institutions. Amsterdam: Sijthoff \& Noordhoff International Publishers, 1980. pp. 4 e seguintes.
} 
tratado ter sido autenticado em diversos idiomas pode constituir até mesmo um verdadeiro mecanismo facilitador para o intérprete.

O quarto e último parágrafo do artigo 33 também é direcionado aos tratados autenticados em diversos idiomas, mas trata das situações em que a pluralidade de línguas acarreta dificuldades interpretativas em virtude da existência de divergências de sentido que a aplicação dos artigos 31 e 32 não foi capaz de solucionar. Para tais situações, a Convenção de Viena determina que se deve recorrer aos objetivos e finalidades do tratado na busca pelo sentido que melhor concilie os textos.

\subsection{A Interpretação de Convenções de Bitributação segundo as recomendações da OCDE}

\subsubsection{Os comentários ao Modelo da OCDE: status e importância para a}

\section{interpretação}

A utilização de modelos de convenção, por si só, constitui indício suficiente das intenções das partes que celebram uma convenção de bitributação quanto à utilização dos comentários a eles referentes durante o processo interpretativo. Este é o entendimento destacado por Klaus Vogel e Rainer Prokisch ${ }^{578}$ no General Report apresentado durante o LXXVIII Congresso da Internacional Fiscal Association (IFA Congress) de 1993, que tratou especificamente do tema da interpretação de tratados de bitributação. Para os referidos autores, tanto os modelos em si quanto os seus comentários constituem essencialmente uma manifestação do princípio da interpretação comum ${ }^{579}$, sendo que estes,

\footnotetext{
578 "The importance of the $O E C D$ and UN model conventions and their commentaries is at bottom an emanation of the principle of common interpretation, since taking them into consideration can result in a high degree of uniformity of interpretations. Should both Contracting States have used such a model convention as a basis of the negotiations, these materials must then be referred to when considering the context of the convention. Following a recommendation by the OECD Council, OECD Member States are bound to use the Model as a basis unless a Contracting State has special reservations or specific reasons for the model not being used. In these cases Model Conventions and commentaries are primarily part of the context and are not simply "preliminary materials" in the sense of Article 32 VCLT." VOGEL, Klaus. PROKISCH, Rainer G. General Report. Interpretation of Double Taxation Conventions. Cahiers de Droit Fiscal International. 1993 Florence Congress, International Fiscal Association., vol. LXXVIIIa. pp. 64-65.
}

579 Princípio da interpretação comum: as convenções de bitributação internacional atuam limitando o exercício da competência tributária dos Estados contratantes, ou, em outras palavras, alocando o poder de tributar a um dos Estados contratantes em detrimento do outro, de modo que a dupla tributação seja evitada. Para que isto aconteça, é essencial que as instituições fiscais responsáveis pela aplicação das convenções de bitributação de um Estado contratante levem em consideração o posicionamento e os fundamentos das 
por refletirem as opiniões de diversos países após extensa discussão dos dispositivos interpretados, seriam capazes de permitir um elevado grau de uniformidade nas interpretações e, desta forma, tanto o modelo quanto os seus respectivos comentários deveriam sempre ser considerados como integrantes do contexto da convenção.

Apesar de relevante e bastante disseminado pela doutrina, o entendimento acima não é unânime, especialmente no que concerne ao grau de obrigatoriedade e à força vinculante atribuída aos comentários ao Modelo da OCDE. Alguns autores entendem que os comentários ao modelo da OCDE somente podem integrar o contexto da convenção nos moldes da regra geral de interpretação do artigo 31 da Convenção de Viena se ambos os países forem membros da referida organização, de modo que o modelo em questão fosse vinculante para eles. Caso os países em questão não sejam membros da OCDE, então o recurso aos comentários somente poderia ser feito como meio suplementar de interpretação.

Por outro lado, há autores, como Frank Engelen ${ }^{580}$ e Sérgio André Rocha ${ }^{581}$, que entendem que o "contexto" definido na regra geral de interpretação do artigo 31 da Convenção de Viena somente pode abarcar instrumentos legais, aqui incluídos os acordos e demais instrumentos do Direito Internacional, dotados de plena força vinculante para ambas as partes. Sob este aspecto, os comentários não poderiam integrar o contexto segundo a Convenção de Viena, já que não possuem força vinculante.

decisões relevantes proferidas por órgãos de natureza similar no outro Estado contratante, de modo que a interpretação da convenção possa atender aos interesses de ambos os países e, desta forma, permitir que o objetivo de evitar a dupla tributação seja efetivamente atingido. Isto não significa, contudo, que as decisões proferidas pelas Cortes dos outros países devam ser seguidas sem a devida revisão e sem as reservas aplicáveis, conforme o caso. Além disso, é recomendável, até mesmo, que se busque a interpretação fornecida por órgãos jurisdicionais de terceiros Estados para casos similares.

${ }^{580}$ ENGELEN, Frank. Interpretation of Tax Treaties under International Law. Amsterdam: IBFD, 2004. v. 7 , p. 459 (IBFD Doctoral Series).

${ }^{581}$ Sérgio André Rocha destaca que "Há que se concordar com essas posições. De fato, sob a perspectiva de um país como o Brasil, que não faça parte da OCDE, os Comentários desta à Convenção-Modelo, embora sejam um elemento a ser considerado no processo hermenêutico, carecem de qualquer força vinculante. (...) Mais do que isso, uma pesquisa nas decisões proferidas pelos tribunais superiores pátrios evidencia que tais Comentários não são normalmente levados em consideração ao serem proferidas decisões sobre questões internacionais." Em nota de rodapé sobre as decisões dos tribunais brasileiros, Rocha destaca que "não há no Brasil um histórico muito grande de discussões judiciais envolvendo a aplicação de tratados internacionais, sendo que em pesquisa não localizamos nenhum julgamento em que os Comentários à Convenção-Modelo tenham sido levados em consideração pelo julgador. Nem mesmo naquele que pode ser considerado o principal julgamento de uma corte superior envolvendo um tratado tributário, o Recurso Especial n. 426.945 (publicação no Diário de Justiça em 25.08.2004), qualquer menção aos Comentários foi feita." ROCHA, Sérgio André. Interpretação dos Tratados contra a Bitributação da Renda. Rio de Janeiro: Lumen Juris, 2008, p. 161. 
De fato, segundo ensina Manuel Pires, "a função dos comentários do MOCDE é digna de nota, embora, contrariamente ao já sustentado, não devam ser considerados como interpretação autêntica das convenções que adoptaram aquele modelo, porque, embora anexos a um texto que lhes serve de base, não foram objeto do formalismo necessário para a celebração de uma convenção "582. Desta forma, os comentários, por não constituírem "acordo" entre as partes, nem tampouco "instrumentos", e muito menos "normas do Direito Internacional”, não poderiam ser considerados como contexto da convenção para fins de interpretação ${ }^{583}$.

Outro ponto polêmico quanto à utilização dos comentários como se fossem contexto da convenção está relacionado com o seu caráter mutável, constantemente sujeito a revisões e reservas pelos países. Os defensores da linha inicialmente proposta por Vogel e Prokisch solucionam esta questão mediante a utilização somente da versão já publicada dos comentários à época da celebração da convenção, passando apenas as versões posteriores à categoria de meio suplementar de interpretação ${ }^{584}$.

Revendo seu posicionamento anteriormente exposto durante o Congresso da IFA de 1993, em 1997 Vogel passou considerar inadequado tanto classificar os comentários como contexto quanto rebaixá-los à categoria de meros meios suplementares

582 PIRES, Manuel. Da Dupla Tributação Jurídica Internacional sobre o Rendimento. Lisboa: Centro de Estudos Fiscais - Ministério das Finanças, 1984. p. 456.

583 Sobre o caráter não vinculante dos comentários e sua utilização pelo Poder Judiciário europeu: "Concluding, at this point, I can say, even without looking at our decisions that we, the courts, are not bound by the OECD Model and/or Commentaries as if they were a treaty. Moreover, even mutual agreements arguably do not bind the courts because they lack democratic approval. (...) To summarize, the OECD Model and Commentaries are not a treaty in the sense that they are binding on taxpayers and on courts. The maximum value of the Commentaries is that of an expert opinion of great weight. They can have an uncontested significance for the interpretation of treaties to the extent they existed at the time a particular treaty was concluded; the significance of the later versions of the Commentaries is less clear. The later versions may be used inasmuch as they clarify what was unclear before. (...)” v. BRUNSCHOT, Frank van. The Judiciary and the OECD Model Tax Convention and its Commentaries. In: Bulletin - Tax Traty Monitor. IBFD, jan. 2005. p. 7. No mesmo sentido: VOGEL, Klaus. The influence of the OECD Commentaries on Treaty Interpretation. In: Bulletin - Tax Treaty Monitor, dec. 2000. IBFD, pp. 612-616. ELLIS, Maarten J. The influence of the OECD Commentaries on Treaty Interpretation - Response to Prof. Dr. Klaus Vogel. In: Bulletin - Tax Treaty Monitor, dec. 2000. IBFD, pp. 617-618. ENGELEN, Frank. Some observations no the Legal Status of the Commentaries on the OECD Model. In: Bulletin - Tax Treaty Monitor. Mar. 2006, IBFD, pp. 105-109. WARD, David A. The role of the Commentaries no the OECD Model In the Tax Treaty Interpretation Process. In: Bulletin - Tax Treaty Monitor, mar. 2006, IBFD, pp. 97-102. ELLIS, Maarten J. The Role of the Commentaries no the OECD Model in the Tax Treaty Interpretation Process - Response to David Ward. In: Bulletin - Tax Treaty Monitor, mar. 2006, IBFD, pp. 103-104. VOGEL, Klaus. Problemas na Interpretação de Acordos de Bitributação. In: SCHOUERI, Luís Eduardo (coord.). Direito Tributário: Homenagem a Alcides Jorge Costa. São Paulo: Quartier Latin, 2003. v. II, pp. 962-964.

${ }^{584}$ Sobre o caráter mutável dos comentários, v. AVERY JONES, John F. The effect of changes in the OECD Commentaries after a treaty is concluded. In: Bulletin - Tax Treaty Monitor. Mar. 2002. IBFD, 2002. pp. 102-109. 
de interpretação. De fato, Vogel passou a entender que, no caso de convenções celebradas entre países membros da OCDE cuja redação segue fielmente ou é substancialmente semelhante ao Modelo da referida organização, então seria razoável concluir que os comentários ao Modelo devem fornecer o sentido comum a ser atribuído aos seus termos e expressões, de acordo com a regra geral de interpretação constante do artigo $31^{585}$. Este raciocínio demonstra a presunção da preponderância do papel dos comentários durante a interpretação das convenções de bitributação. O mesmo seria aplicável às convenções que fossem apenas semelhantes ao modelo, mas que houvessem sido celebradas entre países membros da organização. Já com relação àquelas que, mesmo tendo sido celebradas entre países membros, tiverem sua redação distanciada das cláusulas recomendadas no modelo, os comentários perdem sua aplicabilidade para fins interpretativos. Quanto às convenções firmadas entre países não-membros da OCDE, a presunção de aplicabilidade dos comentários para fins interpretativos somente pode existir se o texto da convenção for idêntico ao modelo, de modo que o contexto indique que as partes assim desejaram proceder quanto à sua interpretação. Além disso, em qualquer dos casos, somente pode ser considerada a versão vigente na data da celebração da convenção, devendo ser desconsideradas as revisões, emendas ou reservas que houverem sido publicadas posteriormente à data da celebração.

Esta profusão de emendas, atualizações e revisões vieram, com o tempo, desgastando a precisão e a contabilidade dos comentários ao Modelo da OCDE. Por isso, em 2000 Vogel reviu novamente sua opinião e passou a entender que somente com extrema cautela e mediante reservas seria possível continuar utilizando os comentários ao Modelo da OCDE durante a interpretação de convenções de bitributação. Em face deste novo posicionamento, Vogel desenvolveu um método dividido em quatro etapas que devem ser observadas durante a utilização dos comentários com fins interpretativos. ${ }^{586}$ Os termos e expressões constantes da versão original de 1963 do Modelo da OCDE devem ser considerados como parte da chamada "linguagem fiscal internacional", e o significado a eles atribuído nos comentários originais deve fornecer o sentido comum dos termos e expressões do tratado para os fins da regra geral de interpretação estabelecida no artigo 31

\footnotetext{
585 VOGEL, Klaus. On double taxation conventions: a commentary to the OECD, UN and US model conventions for the avoidance of double taxation of income and capital with particular reference to German treaty practice. 3. ed. Germany: Kluwer Law International, 1997, pp. 43-47.

${ }^{586}$ ENGELEN, Frank. Interpretation of Tax Treaties under International Law. Amsterdam: IBFD, 2004. v. 7 , pp. 444-445 (IBFD Doctoral Series).
} 
da Convenção de Viena. Já os significados de termos e expressões previstos nas versões subseqüentes do Modelo e dos comentários não integram a "linguagem físcal internacional", porém, podem ser utilizados para fins de definição do "sentido especial", nos termos do parágrafo quarto do artigo 31 da Convenção de Viena, se as partes assim concordarem $^{587}$. Vogel recomenda, neste caso, que a diferença entre a data da celebração do tratado e a data da versão dos comentários que esteja sendo utilizada para sua interpretação não ultrapasse o período de 10 anos. Diversamente, se as partes celebram uma convenção de bitributação e pouco tempo depois os comentários sofrem uma alteração que implique modificação da interpretação dos termos constantes do tratado, então esta modificação somente teria utilidade como meio suplementar de interpretação ${ }^{588}$, e mesmo assim, se os países acordassem nesse sentido.

Apesar da série de alterações, o posicionamento e a doutrina de Vogel são seguidos por diversos autores, embora com reservas relativamente a alguns, pontos. Por exemplo, Ault ${ }^{589}$ e Avery Jones ${ }^{590}$ concordam com Vogel no sentido de que se a convenção celebrada segue fielmente ou é substancialmente semelhante ao Modelo da OCDE, os comentários podem integrar o seu contexto com o objetivo de informar o sentido comum ou o sentido especial, conforme seja o caso.

Independente das opiniões doutrinárias, independente de serem considerados como integrantes do contexto ou como simples meio suplementar ${ }^{591}$ de interpretação, e independente de serem considerados por alguns como vinculantes, uma coisa é certa: os comentários, assim como o modelo em si, a despeito de sua inquestionável importância prática constituem apenas recomendações feitas pela OCDE para facilitar a elaboração e a interpretação das convenções de bitributação, sendo destituídos de qualquer caráter

${ }^{587}$ AULT, H. J. The Role of the OECD Commentaries in the Interpretation of Tax Treaties. Intertax 4. 1994. p. 144-148.

${ }^{588}$ Em sentido contrário: AVERY JONES, John F. The effect of changes in the OECD Commentaries after a treaty is concluded. In: Bulletin - Tax Treaty Monitor. Mar. 2002. IBFD, 2002. pp. 102-104.

${ }^{589}$ Ault, H. J. The Role of the OECD Commentaries in the Interpretation of Tax Treaties. Intertax 4. 1994. p. 144-148.

${ }^{590}$ AVERY JONES, John F. The effect of changes in the OECD Commentaries after a treaty is concluded. In: Bulletin - Tax Treaty Monitor. Mar. 2002. IBFD, 2002. pp. 102-104.

${ }^{591}$ YAMASHITA, Douglas. Evolução da Convenção-Modelo da OCDE e a influência de suas alterações na interpretação de tratados para evitar a bitributação. In: AMARAL, Antônio Carlos Rodrigues do (coord.). Tratados Internacionais na Ordem Jurídica Brasileira. São Paulo: Aduaneiras, 2005. pp. 118-119. 
vinculante ou poder obrigatório ${ }^{592}$. Isto é explícito na própria introdução aos comentários, cujo parágrafo 29 dispõe claramente que embora os comentários não hajam sido elaborados com o propósito de serem anexados às convenções celebradas pelos paísesmembros, as quais, ao contrário do Modelo, constituem instrumentos legais internacionais vinculantes, eles podem, a despeito disso, ser de grande auxílio na interpretação e aplicação das convenções e, em particular, para a solução de controvérsias ${ }^{593}$. Desta forma, conclui-se que cada país é livre para adotar a forma e a interpretação que lhe for mais conveniente, dentro dos princípios e normas do Direito Tributário Internacional, mesmo que diversamente do que se encontra disposto nos comentários.

Parte da doutrina considera que os comentários, a despeito de não possuírem qualquer força legal em termos estritos e formais, poderiam ser dotados de força vinculante em alguns casos específicos, com fundamento nos princípios jurídicos que regem as relações internacionais, especialmente o princípio pacta sunt servanda, e em virtude da proteção às expectativas legítimas contratuais ${ }^{594}$ dele decorrente, correspondendo ao que a doutrina denomina de soft law. Um exemplo da aplicabilidade deste entendimento seria uma convenção celebrada entre dois países membros da OCDE, cujo texto fosse idêntico ao modelo. Mesmo assim, somente os comentários já publicados à época da celebração do tratado poderiam ser considerados vinculantes, segundo esta linha de pensamento.

${ }^{592}$ PIJL, Hans. Os comentários da OCDE como fonte do Direito Internacional e o Papel do Poder Judiciário. Trad. livre por Luiz Carlos de Andrade Jr., e revisão de Clóvis Panzarini Filho. In: PANZARINI FILHO, Clóvis (coord.). Revista de Direito Tributário Internacional. São Paulo: Quartier Latin, 2006, v. 4. pp. 203228 .

593 Tradução livre. “29. (...) Although the Commentaries are not designed to be annexed in any manner to the conventions signed by Member countries, which, unlike the Model are legally binding international instruments, the can, nevertheless be of great assistance in the application and interpretation of the conventions and, in particular, the settlement of any disputes.". RAAD, Kees van (org.). Introduction to the Commentaries. Integrated texts of the OECD Commentaries of 1977 and 1992 (incorporating the changes of 1994. 1995. 1997, 2000. 2003 and 2005) in: Materials on International \& EC Tax Law. Selected and edited by Kees van Raad. 7. ed. Leiden: IBFD, 2007. v. 1, p. 56.

${ }^{594} \mathrm{O}$ princípio da proteção às legítimas expectativas contratuais é intimamente relacionado com a segurança jurídica, com a irretroatividade e com a proteção ao direito adquirido e com a boa fé, e se baseia na noção de que a confiança no ordenamento jurídico e nas relações jurídicas deve ser respeitada. Entretanto, não se trata de um princípio absoluto, isto é, a obrigação de cumprir as legítimas expectativas permanece enquanto permanecerem as circunstâncias em que se deu a formação da relação contratual e das obrigações entre as partes dela decorrentes, em nítida aplicação da cláusula rebus sic stantibus. Se ocorre uma súbita e relevante alteração nos fatos que são subjacentes a estas obrigações, então a proteção às legítimas expectativas torna-se relativa, devendo sujeitar-se à revisão do pactuado em face do novo contexto fático. DOUMA, Sjoerd. The principle of legal certainty enforcing international norms under community law. In: ENGELEN, Frank. DOUMA, Sjoerd (coord.). The Legal Status of the OECD Commentaries. Amsterdam: IBFD, 2008, v. 1, pp. 224-225 (Conflict of Norms in Internetional Tax Law Series). 
Como se vê, trata-se de argumento válido apenas para situações bastante específicas que, por isso mesmo, não possui aplicabilidade geral. Em face disso, filiamonos ao entendimento de que os comentários não possuem status de lei, muito menos caráter vinculante e, desta forma, não possuem o condão de criar obrigações legais para as partes, em qualquer situação, nem mesmo como soft law, em virtude da legalidade estrita aplicável ao Direito tributário.

Entendemos, contudo, que se as partes expressamente acordarem595 no sentido de que a interpretação de termos e expressões fornecida pelos comentários ao modelo da OCDE deva ser seguida durante a interpretação da convenção, então os comentários poderão, sim, ser considerados obrigatórios e vinculantes entre as mesmas. Salientamos, porém, que neste caso, os comentários não são vinculantes por si próprios, mas, sim, em decorrência do expresso acordo de vontades das partes nesse sentido ${ }^{596}$. O acordo de vontades é a fonte da obrigação legal, e não os comentários por si mesmos. Aqui, sim, o princípio pacta sunt servanda pode ser utilizado para justificar a obrigatoriedade de obediência aos comentários durante a interpretação.

Conclui-se, pois, que a relevância dos comentários está justamente em seu papel de antecipar e tornar públicas as opiniões dos países membros da organização. Porém, como não existe uma base jurídica que obrigue a sua utilização ou a torne vinculativa, trata-se apenas de recomendações, como já mencionado acima. Em virtude disso, conclui-se que os comentários representam um recurso interpretativo não obrigatório e sem qualquer caráter vinculante, especialmente no caso do Brasil, que sequer é membro da OCDE. Entretanto, evidentemente recomenda-se a leitura dos comentários durante a

\footnotetext{
${ }^{595}$ Diversamente, alguns autores entendem que bastaria o acordo tácito (ou o silêncio) das partes para que os comentários ao modelo da OCDE pudessem ser vinculantes para as partes, com base nos princípios internacionais "acquiescence and estoppel, as well as the principle of protection of legitimate expectations". Nesse sentido, vale conferir a obra de Engelen, que destaca: "In these circumstances, the presumption must be that the parties have acquiesced in the interpretation set out in the Commentaries. The acquiescence of both parties amounts to a tacit agreement to interpret and apply the provisions of the treaty that are identical to those of the OECD Model Tax Convention, in accordance with the Commentaries thereon, and the context for purpose of the interpretation of the treaty comprises such an agreement on the grounds of Article 31(2)(a) VCLT. In addition, the acquiescence of both parties can also operate as estoppel in cases where one of the parties would later assert that a different interpretation was in fact intended." ENGELEN, Frank. Interpretation of Tax Treaties under International Law. Amsterdam: IBFD, 2004. v. 7, pp. 466-473 (IBFD Doctoral Series).

${ }^{596}$ No mesmo sentido: WEISS, Friedl. Interpretation of tax treaties in accordance with the commentaries on the OECD Model Tax Convention under the Vienna Convention on the Law of Treaties. In: ENGELEN, Frank. DOUMA, Sjoerd (coord.). The Legal Status of the OECD Commentaries. Amsterdam: IBFD, 2008, v. 1, p. 140-141 (Conflict of Norms in Internetional Tax Law Series).
} 
interpretação de um tratado de bitributação, por todos os motivos já explicados acima, inclusive para os países que utilizarem o modelo da referida organização, mesmo não integralmente, e mesmo que não sejam membros da OCDE.

\subsection{2. $A$ "regra geral" de interpretação segundo o Modelo da OCDE -} artigo 3(2)

Embora o título "regra geral de interpretação"597 não esteja expressamente previsto, o artigo $3^{\circ}$, parágrafo $2^{\circ}$ do Modelo da OCDE, a doutrina e os Comentários ao Modelo da OCDE mencionam que o referido artigo introduz a regra geral de interpretação aplicável às suas cláusulas, estabelecendo que:

"As regards the application ${ }^{598}$ of the Convention at any time by a Contracting State, any term not defined therein shall, unless the context otherwise requires ${ }^{599}$, have the meaning that it has at that time under the law of that State for the purposes of the taxes to which the Convention applies, any meaning under the applicable tax laws of that State prevailing over a meaning given to the term under other laws of that State."

Traduzindo livremente, o dispositivo acima determina que, relativamente à aplicação da Convenção a qualquer tempo por um Estado contratante, qualquer termo não definido na convenção deverá, salvo se o contexto indicar de modo diverso, ter o significado que o termo teria naquele tempo de acordo com o Direito interno daquele Estado para os fins dos tributos aos quais a convenção se aplique, devendo qualquer significado deste termo que tenha sido obtido segundo o Direito tributário interno daquele

\footnotetext{
597 Sobre a regra geral de interpretação do artigo 3(2) do Modelo da OCDE: VOGEL, Klaus. On double taxation conventions: a commentary to the OECD, UN and US model conventions for the avoidance of double taxation of income and capital with particular reference to German treaty practice. 3. ed. Germany: Kluwer Law International, 1997, pp. 206-208.

598 Não analisaremos aqui o termo "application" utilizado neste contexto pois entendemos que a aplicação de qualquer norma de um tratado pressupõe a sua interpretação. Entretanto, Vogel examina o termo em VOGEL, Klaus. On double taxation conventions: a commentary to the OECD, UN and US model conventions for the avoidance of double taxation of income and capital with particular reference to German treaty practice. 3. ed. Germany: Kluwer Law International, 1997, pp. 211.

${ }^{599}$ A expressão "unless the context otherwise requires" utilizada pela primeira vez no tratado entre os EUA e o Reino Unido em 1945. é dirigida aos países que adotam a Common Law, já que nos países onde vigora a Civil Law o seu significado já estaria implícito. AVERY JONES, John F. et Al. The origins of Concepts and Expressions Used in the OECD Model and their Adoption by States. In: Bulletin - Tax Treaty Monitor. Jun. 2006. IBFD, p. 221.
} 
Estado prevalecer sobre o significado do mesmo termo previsto em outras leis daquele Estado.

Numa primeira e apressada leitura, somos conduzidos à precipitada conclusão de que a norma acima simplesmente significa que, quando uma expressão não estiver definida no texto do tratado, ou quando a sua interpretação a partir das disposições expressamente contidas na convenção for inviável, os Estados contratantes poderão de comum acordo interpretar a expressão a partir do contexto na qual ela se insere e, se mesmo essa interpretação não conduzir a resultados satisfatórios, então as partes deverão recorrer ao Direito interno dos Estados contratantes para tentar resolver a questão. Afirmamos que esta conclusão é precipitada porque, infelizmente, a compreensão e aplicação da regra do artigo $3^{\circ}$, parágrafo $2^{\circ}$ do Modelo da OCDE não é tão simples quanto parece.

Inicialmente, é necessário considerar que a regra acima, apesar de ser comumente denominada de "regra geral de interpretação", somente pode receber este rótulo se o referencial for o próprio Modelo da OCDE, tendo em vista que a verdadeira regra geral de interpretação de tratados (aqui tomados em seu sentido mais amplo, não apenas as convenções de bitributação) está descrita no artigo 31 da Convenção de Viena.

Ademais, é necessário considerar que o artigo $3^{\circ}$, parágrafo $2^{\circ}$ do Modelo da OCDE constitui norma especial de interpretação em relação às regras gerais do Direito Internacional Público ${ }^{600}$. Nesse sentido, Sérgio André Rocha destaca que "tudo o que o artigo $3^{\circ}$, parágrafo $2^{\circ}$ do Modelo da OCDE faz é estabelecer quais os limites da integração do texto convencional pelo Direito interno de cada um dos Estados contratantes." ${ }^{, 601}$.

Desta forma, o artigo $3^{\circ}$, parágrafo $2^{\circ}$ do Modelo da OCDE deve sempre ser interpretado à luz da Convenção de Viena, e, em vista disso, é possível concluir que o artigo $3^{\circ}$, parágrafo $2^{\circ}$ é, na verdade, uma norma específica sobre a interpretação de tratados, cujo destinatário são as convenções de bitributação ${ }^{602}$.

${ }^{600}$ VOGEL, Klaus. PROKISCH, Rainer G. General Report. Interpretation of Double Taxation Conventions. Cahiers de Droit Fiscal International. 1993 Florence Congress, International Fiscal Association., vol. LXXVIIIa. p. 77.

${ }^{601}$ ROCHA, Sérgio André. Interpretação dos Tratados contra a Bitributação da Renda. Rio de Janeiro: Lumen Juris, 2008, p. 146.

${ }^{602}$ SCHOUERI, Luís Eduardo. The residence of the employer In the '183-day clause' (articule 15 of the OECDs Model Double Taxation Convention. In: Internacional Tax Review - Intertax. Amsterdam: 1993. pag. 23. BELLAN, Daniel Vítor. Interpretação dos Tratados Internacionais em Matéria Tributária. In: 


\subsubsection{Escopo de aplicação - regra geral ou regra específica?}

As dificuldades referentes a esta norma surgem já na definição de seu escopo de aplicação. Paradoxalmente, a "suposta" regra geral de interpretação introduzida pelo artigo $3^{\circ}$, parágrafo $2^{\circ}$ possui escopo bastante limitado. Isto porque se dirige apenas aos termos e expressões "não definidos no tratado", ou, nas palavras de Vogel, dirige-se apenas às "palavras" utilizadas no acordo, sem dispor expressamente sobre a possibilidade de aplicação dos princípios gerais de tributação internacional ou mesmo sobre a aplicabilidade dos princípios hermenêuticos adotados pelos Estados contratantes como forma de suprir eventuais lacunas ou dúvidas surgidas a partir de termos que podem, sim, terem sido definidos no próprio tratado e, ainda assim, terem significado obscuro ou confuso para as partes. ${ }^{603}$ Dessa limitação é possível concluir que não poderá haver reenvio ao Direito interno com relação aos termos que já estiverem definidos no acordo ${ }^{604}$, as chamadas "expressões autônomas", as quais deverão, segundo o próprio artigo $3^{\circ}$, parágrafo $2^{\circ}$, prevalecer sobre aqueles que não estiverem expressamente definidos ${ }^{605}$.

Em face do problema acima, seria natural o questionamento acerca dos motivos pelos quais seria conveniente ou mesmo viável utilizar tantas expressões não expressamente definidas no acordo. O principal motivo, destacado por Rothmann ${ }^{606}$, é associado à soberania dos $\operatorname{Estados}^{607}$, já que, como os acordos de bitributação implicam uma limitação considerável a este princípio, utilizar expressões sem atrelar a elas uma

TORRES, Heleno Taveira (coord.). Direito Tributário Internacional Aplicado. São Paulo: Quartier Latin, 2005. v. 3. p. 627.

${ }^{603}$ XAVIER, Alberto. Direito Tributário Internacional do Brasil. 6. ed. reform. e atual., Rio de Janeiro: Forense, 2007, p. 183-187. VOGEL, Klaus. On double taxation conventions: a commentary to the OECD, UN and US model conventions for the avoidance of double taxation of income and capital with particular reference to German treaty practice. 3. ed. Germany: Kluwer Law International, 1997, p. 212-213.

${ }^{604}$ Diferente de Vogel, Avery Jones entende que é possível aplicar o artigo 3(2) para os termos já definidos no acordo, mas cuja definição seja parcial ou deficiente. AVERY JONES, John F. et al. The Interpretation of Tax Treaties with Particular Reference to Article 3(2) of the OECD Model - I. In: British Tax Review n. 1, 1984. p. 21.

605 VOGEL, Klaus. On double taxation conventions: a commentary to the OECD, UN and US model conventions for the avoidance of double taxation of income and capital with particular reference to German treaty practice. 3. ed. Germany: Kluwer Law International, 1997, pp. 212-213. TORRES, Heleno Taveira. Pluritributação Internacional sobre as Rendas de Empresas. 2. ed. rev., ampl. e atual. São Paulo: Revista dos Tribunais, 2001, p. 644. BELLAN, Daniel Vítor. Interpretação dos Tratados Internacionais em Matéria Tributária. In: TORRES, Heleno Taveira (coord.). Direito Tributário Internacional Aplicado. São Paulo: Quartier Latin, 2005. v. 3. p. 628.

${ }^{606}$ ROTHMANN, Gerd W. Interpretação e Aplicação dos Acordos Internacionais contra a Bitributação. São Paulo: USP, 1978. Tese (doutorado), p. 172.

${ }^{607}$ Relativamente ao princípio da soberania, v. Capítulo 3. 
definição rígida no texto do próprio tratado poderia representar uma vantagem durante a fase de negociações, permitindo, posteriormente, maior flexibilidade durante a interpretação e aplicação das cláusulas. Não obstante, esta mesma flexibilidade que, supõese, poderia ser resolvida pelo recurso ao contexto do tratado ou ao Direito interno dos Estados contratantes, também seria responsável por uma sensível diminuição no grau de segurança jurídica durante a aplicação do tratado.

Diante disso, entendemos que seria mais correto, embora menos prático e mais sacrificante sob o ponto de vista político, trabalhar exaustivamente durante a fase de negociações para definição dos termos e expressões que deverão integrar o acordo, priorizando a utilização de expressões autônomas em detrimento de termos não definidos.

\subsubsection{O alcance da expressão "Law"}

Outro problema é relacionado com a menção à expressão "law", que, nos países que seguem o sistema da Common Law pode assumir um significado muito mais abrangente do que o termo possui nos países que seguem a Civil Law. De fato, a versão em francês do Modelo da OCDE auxilia um pouco ao substituir o termo "Law" pelo termo "Droit". O impasse, neste caso, não está na expressão utilizada, mas sim na sua abrangência, já que o termo "Droit" também pode ser mais ou menos abrangente de acordo com o ordenamento jurídico de cada Estado ${ }^{608}$. Neste ponto, é interessante destacar que as convenções celebradas entre países membros da União Européia incluem, além do Direito interno de cada Estado isoladamente, também a legislação comum da União Européia, como referência ao Direito interno ao qual é possível recorrer durante a interpretação ${ }^{609}$.

\footnotetext{
${ }^{608}$ Dependendo do sistema jurídico que se adote, tanto o termo "law" quanto o termo "Droit" podem tanto ser restritos apenas à legislação formalmente elaborada pelo Poder Legislativo, como podem ser bem mais abrangentes, incluindo a jurisprudência e os costumes como fonte de obrigações jurídicas. VOGEL, Klaus. On double taxation conventions: a commentary to the OECD, UN and US model conventions for the avoidance of double taxation of income and capital with particular reference to German treaty practice. 3. ed. Germany: Kluwer Law International, 1997, pp. 212-213.

609 VOGEL, Klaus. On double taxation conventions: a commentary to the OECD, UN and US model conventions for the avoidance of double taxation of income and capital with particular reference to German treaty practice. 3. ed. Germany: Kluwer Law International, 1997, pp. 211. BELLAN, Daniel Vítor. Interpretação dos Tratados Internacionais em Matéria Tributária. In: TORRES, Heleno Taveira (coord.). Direito Tributário Internacional Aplicado. São Paulo: Quartier Latin, 2005. v. 3. p. 626.
} 


\subsubsection{Interpretação estática ou interpretação dinâmica?}

Além do que já foi destacado acima, há ainda uma questão extremamente relevante no que diz respeito ao reenvio ao Direito interno é relativa ao aspecto temporal, refletido na dicotomia “interpretação estática” x "interpretação dinâmica”. A primeira modalidade é aquela que persegue a verdade do legislador que elaborou e votou o texto da lei, já a segunda é aquela que interpreta a norma legal com base nos princípios da equidade e do bem comum, tal como o julgador os conceber no momento da interpretação e aplicação da norma jurídica ${ }^{610}$.

No caso das convenções contra a bitributação, a opção entre interpretação estática e interpretação dinâmica surge durante a aplicação do artigo $3^{\circ}$, parágrafo $2^{\circ}$, sob a forma de dúvida acerca de qual deverá ser o Direito interno aplicável: aquele vigente à época da celebração da convenção ou o Direito em vigor na data de sua aplicação. Até o ano de 1982 prevalecia o entendimento de que o Direito interno ao qual deve-se fazer referência quando da remissão prevista nos moldes do artigo $3^{\circ}$, parágrafo $2^{\circ}$ seria aquele vigente à época da aplicação do tratado, ou seja, aplicava-se o método da interpretação dinâmica.

Entretanto, após o julgamento do caso The Queen v. Melford Developments Inc. ${ }^{611}$, que envolvia a aplicação do acordo de bitributação entre o Canadá e a Alemanha, a

610 "Essas duas concepções da interpretação parecem, ambas, pouco satisfatórias. Com efeito, na concepção estática, não é o parecer do juiz, mas o do melhor historiador que deveria prevalecer. Se é ao juiz que e concede o direito e a competência de decidir, é porque não se trata, nessa matéria, de história, de verdade, de ciência, mas de decisão que se quereria tão justa quanto possível. Aliás, o recurso à vontade do legislador normalmente sem poder no momento em que a lei é aplicada, muito amiúde é apenas uma fiç̧ão cômoda, pois o legislador que é invocado já não mais pode manifestar-se. Em contrapartida, a concepção dinâmica da interpretação se arrisca a substituir a vontade do legislador pela do juiz e a suprimir a diferença entre a regra que foi promulgada e aquela que se queria ver instaurar. A interpretação de lege lata seria substituída pela de lege ferenda, que não teria nenhuma consideração pela vontade do legislador." PERELMAN, Chaïm. Ética e Direito. Trad. Maria Ermantina de Almeida Prado Galvão. 2. ed. São Paulo: Martins Fontes, 2005. p. 624.

611 "Taxation-Income tax-Guarantee fees-Non-resident-Withholding tax-International Tax Convention-Domestic Tax Law-Conflict-Whether guarantee fees paid to non-resident bank subject to taxation-Whether the Income Tax can override the provisions of the tax treaty-Income Tax Act, 1970-7172 (Can.), c. 63 as amended, ss. 212(1)(b), 214(15)(a)_Canada-Germany Income Tax Agreement Act, 1956 (Can.), c. 33. s. 3-Canada-Germany Tax Convention, Articles II(2), III(1), (5). (...) The guarantee fees were not "interest", within the terms of the Canada-Germany Tax Convention. The Canada-Germany Income Tax Agreement Act, 1956, being the legislative adoption of the international tax Agreement, had not been amended by the income tax amendment of 1974. There is no doubt that the effect of s. 3 of the 1956 Act was to make the operation of any other law of Parliament, including the Income Tax Act, subject to the terms of the 1956 Act and the incorporation Agreement. The guarantee fees were consequently not taxable as Article III(1) of the Agreement did not authorize the taxation of commercial profits of a nonresident where those profits were not earned through a permanent establishment in Canada. " Supreme Court of Canada. R. v. Melford Developments Inc., [1982] 2 S.C.R. 504 Date: 1982-09-28. Disponível em 
hipótese da viabilidade da adoção da interpretação estática passou a ser considerada pela doutrina. Em resumo, o caso em questão envolvia a qualificação de despesas bancárias como juros, em conformidade com a legislação vigente quando da aplicação do tratado, mas que não existia à época de sua celebração. De fato, no caso mencionado acima, a Corte Suprema do Canadá entendeu que a interpretação dinâmica poderia ser semelhante a realizar uma modificação no texto do tratado, e por isso ele deveria ser interpretado à luz da legislação vigente à época de sua celebração ${ }^{612}$.

O argumento da Corte Canadense, apesar de válido, encontraria sérias dificuldades se fosse aplicado para um tratado muito antigo, relativamente ao qual fosse difícil determinar qual a legislação vigente ao tempo de sua celebração, e ainda muito mais difícil estabelecer o significado de termos e expressões de certos termos à época. Por isso a interpretação estática perdeu espaço, e atualmente predomina a corrente que prega a interpretação dinâmica (ou evolutiva), em virtude do princípio da permanência e da continuidade dos tratados internacionais, segundo o qual os acordos entre países são celebrados com o objetivo de perdurarem no tempo, independentemente das mudanças ocorridas na legislação interna.

Além disso, o próprio Modelo da OCDE, ao dispor que "a convenção poderá ser aplicada a tributos novos criados após a sua celebração”, acaba determinando a adoção da interpretação dinâmica. E, mesmo que restassem dúvidas, após a revisão de 1995 do Modelo da OCDE, a nova redação do artigo $3^{\circ}$, parágrafo $2^{\circ}$ não deixa mais dúvidas: a legislação interna à que se deve fazer referência é aquela vigente durante a aplicação do acordo. É importante lembrar, por fim, que cada caso deve ser interpretado de acordo com as normas da convenção, e não segundo o Modelo, o qual, como já dissemos anteriormente, não possui qualquer força vinculativa. Por isso, mesmo existindo a

http://csc.lexum.umontreal.ca/en/1982/1982scr2-504/1982scr2-504.html. Acesso em 24 nov. 2009. V. também: VOGEL, Klaus. On double taxation conventions: a commentary to the OECD, UN and US model conventions for the avoidance of double taxation of income and capital with particular reference to German treaty practice. 3. ed. Germany: Kluwer Law International, 1997, pp. 64-65. XAVIER, Alberto. Direito Tributário Internacional do Brasil. 6. ed. reform. e atual., Rio de Janeiro: Forense, 2007, p. 189. BELLAN, Daniel Vítor. Interpretação dos Tratados Internacionais em Matéria Tributária. In: TORRES, Heleno Taveira (coord.). Direito Tributário Internacional Aplicado. São Paulo: Quartier Latin, 2005. v. 3. p. 626.

${ }^{612}$ BAKER, Philip N. Double Taxation Conventions and International Tax Law. $2^{\text {nd }}$ ed. London: Sweet \& Maxwell, 1994. p. E-26. BELLAN, Daniel Vítor. Interpretação dos Tratados Internacionais em Matéria Tributária. In: TORRES, Heleno Taveira (coord.). Direito Tributário Internacional Aplicado. São Paulo: Quartier Latin, 2005. v. 3. p. 640. TORRES, Heleno Taveira. Pluritributação Internacional sobre as Rendas de Empresas. 2. ed. rev., ampl. e atual. São Paulo: Revista dos Tribunais, 2001, p. 658. NOVOA, César Garcia. Interpretación de los convenios de doble imposición internacional. In: FAJARDO, Juan Pablo Godoy. (coord.). Estudios de Derecho Internacional Tributário - Los convenios de doble imposición. Bogotá: Legis, 2006, pp. 60-61. 
tendência à adoção da interpretação dinâmica, é possível, dependendo do caso, que a interpretação estática seja mais adequada. ${ }^{613}$

\subsubsection{A qual Direito interno deve-se recorrer?}

São dois os aspectos referentes à pergunta acima. Primeiro, é necessário determinar a origem do Direito interno aplicável: do Estado da fonte ou do Estado da residência? Ou de ambos, dependendo do caso? Também quanto a esta questão as opiniões da doutrina são variadas. Uma vez estabelecida a origem do Direito interno ao qual haverá o recurso, torna-se necessário determinar em qual ramo do Direito, se apenas naquele ramo dedicado ao tributo previsto na convenção ou se em todo o Direito interno, a busca pelo significado em questão deverá ser realizada.

No que tange à origem da legislação interna, Giuliani ${ }^{614}$ entende que o Direito interno do Estado da Fonte é que deveria fornecer o subsídio para a definição de termos não expressamente definidos na convenção, nos moldes do artigo $3^{\circ}$, parágrafo $2^{\mathrm{o} 615}$.

Por outro lado, defendendo que o reenvio pode ser feito ao Direito de ambos os Estados, a depender do caso, Heleno Torres, com inspiração em Vogel ${ }^{616}$, Engelen e Pötgens ${ }^{617}$, ensina que “deve prevalecer o reenvio unilateral do Estado contratante ao qual a cláusula convencional distribui previdentemente a competência de tributar o

\footnotetext{
${ }^{613}$ Exemplo disso é o caso do acordo entre a Áustria e a Alemanha, explicado pelo Professor Michael Lang, segundo o qual, naquela hipótese, havia identidade de termos e não havia, na citada convenção, uma cláusula de redação similar ao artigo 3(2) do Modelo da OCDE. Nesta hipótese, o mais adequado era mesmo o método estático. LANG, M. Die Interpretation des Doppelbesteuerungsabkommens zwischen Deutschland nu Österreich, 38 RIW 573. 1992. apud VOGEL, Klaus. On double taxation conventions: a commentary to the OECD, UN and US model conventions for the avoidance of double taxation of income and capital with particular reference to German treaty practice. 3. ed. Germany: Kluwer Law International, 1997, p. 65.
}

614 GIULIANI, Federico Maria. La interpretazione delle convenzioni internazionali contro le doppie imposizioni sui redditi. In: UCKMAR, Victor (coord.). Corso di Diritto Tributário Internacional. 2. ed. Padova: CEDAM, 2000. pp. 132-133.

${ }^{615}$ ELLIS, Maarten J. The Legal Influence of the OECD Commentaries on Treaty Interpretation - Response to Prof. Dr. Klaus Vogel. In: Bulletin - Tax Treaty Monitor, dec. 2000. IBFD, p. 617.

616 VOGEL, Klaus. On double taxation conventions: a commentary to the OECD, UN and US model conventions for the avoidance of double taxation of income and capital with particular reference to German treaty practice. 3. ed. Germany: Kluwer Law International, 1997, p. 213.

${ }^{617}$ ENGELEN, Frank. PÖTGENS, F. P. Report on "The Application of the OECD Model Tax Convention to Partnerships" and the Interpretation of Tax Treaties. In: Bulletin - IBFD, v. 54. 2000. p. 257-259. 
rendimento",618, de modo que, por exemplo, no "caso de rendimentos imobiliários, prevaleceria o reenvio do Estado da Fonte" 619 , enquanto que no caso de "dividendos ou juros, primordialmente atinentes ao Estado de residência do beneficiário, prevaleceria, então, a interpretação deste, com o respectivo reenvio. ${ }^{, 620}$ Esta é a linha que entendemos ser mais correta.

Uma vez determinado o país cujo Direito interno será aplicável, passa-se então à segunda questão, relativa a qual será o Direito material específico que deverá fornecer o subsídio para a pesquisa do significado do termo não definido no tratado.

Numa interpretação literal e restritiva, o artigo $3^{\circ}$, parágrafo $2^{\circ}$ determina que o significado do termo não definido no tratado deverá ser buscado no Direito tributário que especificamente regular o tributo que é objeto da convenção em questão. Todavia, o mesmo artigo $3^{\circ}$, parágrafo $2^{\circ}$ não contém qualquer indicação de como deverão ser solucionados os casos em que, após o reenvio ${ }^{621}$ ao Direito interno, seja constatado que um termo ou expressão não possui definição segundo o Direito Tributário interno que rege o tributo objeto da discussão, mas que, apesar disso, está definido em outro ramo do Direito doméstico do Estado contratante.

Vogel $^{622}$ e Xavier ${ }^{623}$ defendem essa interpretação restritiva do dispositivo, no sentido de que apenas a lei interna que regula especificamente o tributo objeto da convenção poderá ser utilizada para fornecer o significado dos termos não definidos no tratado.

${ }^{618}$ TORRES, Heleno Taveira. Pluritributação Internacional sobre as Rendas de Empresas. 2. ed. rev., ampl. e atual. São Paulo: Revista dos Tribunais, 2001, p. 657.

${ }^{619}$ TORRES, Heleno Taveira. Pluritributação Internacional sobre as Rendas de Empresas. 2. ed. rev., ampl. e atual. São Paulo: Revista dos Tribunais, 2001, p. 657.

${ }^{620}$ TORRES, Heleno Taveira. Pluritributação Internacional sobre as Rendas de Empresas. 2. ed. rev., ampl. e atual. São Paulo: Revista dos Tribunais, 2001, p. 657.

${ }^{621}$ Sobre o reenvio ao direito interno e a natureza das normas jurídicas das convenções contra a dupla tributação, v. MELIS, Giuseppe. Vincoli internazionali e norma tributaria interna. In: TORRES, Heleno Taveira (Coord.). Direito Tributário Internacional Aplicado, São Paulo: Quartier Latin, 2005, v. 3. pp. 575579.

${ }^{622}$ VOGEL, Klaus. PROKISCH, Rainer G. General Report. Interpretation of Double Taxation Conventions. Cahiers de Droit Fiscal International. 1993 Florence Congress, International Fiscal Association., vol. LXXVIIIa. p. 79. VOGEL, Klaus. On double taxation conventions: a commentary to the OECD, UN and US model conventions for the avoidance of double taxation of income and capital with particular reference to German treaty practice. 3. ed. Germany: Kluwer Law International, 1997, p. 210.

${ }^{623}$ XAVIER, Alberto. Direito Tributário Internacional do Brasil. 6. ed. reform. e atual., Rio de Janeiro: Forense, 2007, p. 187. 
Em sentido oposto (e bem mais razoável, segundo entendemos) é a opinião de Baker $^{624}$, que é acompanhado por Garcia $\operatorname{Novoa}^{625}$, para os quais o artigo $3^{\circ}$, parágrafo $2^{\circ}$, em sua versão de 1995, permite o recurso às normas tributárias referentes a outros tributos, e até mesmo às normas não tributárias do Direito interno do país, quando não existir definição do termo cujo significado não está disposto no tratado. Baker ressalta, porém, que se houver a definição legal do termo em questão na legislação específica do tributo objeto do acordo, então esta definição deverá prevalecer sobre outras eventualmente existentes em outras normas legais ${ }^{626}$.

Outro argumento que reforça a possibilidade de recurso a outros ramos do Direito além daquele especificamente dirigido ao tributo objeto do tratado consiste no fato de que o Direito Tributário como um todo encontra suas premissas nos conceitos e institutos provenientes de outros ramos do Direito, especialmente no Direito Privado ${ }^{627}$. Apesar disso, Sérgio André Rocha acredita que não seria possível o recurso a outros ramos do Direito que não fossem o Direito Tributário, entendendo que "o que se encontra afastado pela redação atual do item 2 do artigo $3^{\circ}$ da Convenção-Modelo é a possibilidade da utilização da definição de um termo que não se encontra previsto na legislação tributária, mas exclusivamente em outro campo do ordenamento doméstico de um dos Estados contratantes, ou ainda a preferência por este em detrimento de um

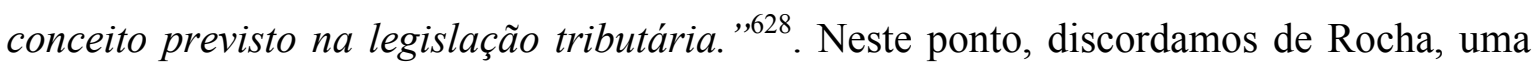
vez que, se um razoável número de institutos do Direito Tributário foi construído a partir dos conceitos e institutos de outros ramos, especialmente do Direito privado, acreditamos que seria razoável e apropriado estender a busca pelo significado dos termos não definidos também a este ramo do Direito.

${ }^{624}$ BAKER, Philip N. Double Taxation Conventions and International Tax Law. 2. ed. London: Sweet \& Maxwell, 1994. p. E-23.

${ }^{625}$ NOVOA, César Garcia. Interpretación de los convenios de doble imposición internacional. In: FAJARDO, Juan Pablo Godoy. (coord.). Estudios de Derecho Internacional Tributário - Los convenios de doble imposición. Bogotá: Legis, 2006, p. 52.

${ }^{626}$ BAKER, Philip N. Double Taxation Conventions and International Tax Law. 2. ed. London: Sweet \& Maxwell, 1994. P. E-23.

${ }^{627}$ A estreita relação entre o Direito Tributário e o Direito Privado é examinada e analisada por Heleno Torres, em: TORRES, Heleno Taveira. Direito Tributário e Direito Privado. São Paulo: Revista dos Tribunais, 2003.

${ }^{628}$ ROCHA, Sérgio André. Interpretação dos Tratados contra a Bitributação da Renda. Rio de Janeiro: Ed. Lumen Juris, 2008, pp. 151. 
Adotando linha ainda mais abrangente e, digamos, mais ousada, Avery Jones ${ }^{629}$ entende que, além das normas constantes do Direito interno do outro país (inclusive as não tributárias), também poderiam ser utilizadas como fonte de pesquisa as demais convenções de bitributação celebradas por aquele país, ao argumento de que tais tratados também são parte integrante do Direito interno do país. Porém, o próprio Avery Jones ${ }^{630}$ destaca que isto somente seria legítimo caso houvesse uma imposição expressa do contexto do tratado.

De toda forma, entendemos que não haveria qualquer problema em recorrer às outras convenções celebradas pelos próprios Estados contratantes (os Parallel Treaties), porque, de fato, entendemos que tais convenções integram o Direito interno do Estado ${ }^{631}$, notadamente no caso das convenções brasileiras, que são internalizadas por meio de um Decreto Legislativo. E, mesmo que não integrassem o Direito interno do Estado contratante, e mesmo que não pudessem ser consideradas contexto da convenção, como defende Rocha ${ }^{632}$, entendemos que seria perfeitamente possível considerar as demais convenções celebradas pelo país como meios suplementares de interpretação, nos termos do artigo 32 da Convenção de Viena, por refletirem a prática adotada pelo país em relação ao objetivo de evitar a dupla tributação (e em relação aos demais objetivos de convenções desta natureza), o que também legitimaria o recurso a elas ${ }^{633}$. Este posicionamento, ao qual particularmente aderimos, encontra fundamento tanto nos Comentários ao Modelo da OCDE quanto na própria Convenção de Viena.

No caso das convenções brasileiras, este problema ainda se subdivide em duas outras questões: a primeira consiste no fato de que grande parte das nossas convenções são baseada na versão de 1977 do Modelo da OCDE, que não permite o recurso à legislação

\footnotetext{
${ }^{629}$ AVERY JONES, John F. et al. The Interpretation of Tax Treaties with Particular Reference to Article 3(2) of the OECD Model - I. In: British Tax Review n. 1, 1984. pp. 24-25.

${ }^{630}$ AVERY JONES, John F. et al. The Interpretation of Tax Treaties with Particular Reference to Article 3(2) of the OECD Model - I. In: British Tax Review n. 1, 1984. pp. 53-54.

631 NOVOA, César Garcia. Interpretación de los convenios de doble imposición internacional. In: FAJARDO, Juan Pablo Godoy. (coord.). Estudios de Derecho Internacional Tributário - Los convenios de doble imposición. Bogotá: Legis, 2006, p. 55.

${ }^{632}$ ROCHA, Sérgio André. Interpretação dos Tratados contra a Bitributação da Renda. Rio de Janeiro: Lumen Juris, 2008, pp. 152.

${ }^{633}$ AVERY JONES, John F. Brittish Report. In: Interpretation of Double Taxation Conventions. Cahiers de Droit Fiscal International. 1993 Florence Congress, International Fiscal Association., vol. LXXVIIIa. p. 611.
} 
tributária outra que não aquela específica dos tributos objeto da convenção ${ }^{634}$, e a segunda questão consiste no fato de que, pelo princípio da legalidade estrita, apenas as leis em sentido formal é que podem ser consideradas para os fins desta cláusula, ficando excluídos os decretos, portarias e outros dispositivos infralegais ou administrativos. Apenas muito recentemente os acordos de bitributação assinados pelo Brasil passaram a seguir a versão de 1995 do Modelo da OCDE, merecendo destaque as convenções celebradas com os seguintes países: África do Sul (Decreto n. 5.922/06) ${ }^{635}$, Chile (Decreto n. 4.852/03), Israel (Decreto n. 5.576/05), México (Decreto n. 6.000/06), Portugal (Decreto n. 4.012/01), e Ucrânia (Decreto n. 5.579/06) ${ }^{636}$. O Brasil possui, ainda, tratados de bitributação com o Peru, Rússia, Trinidad e Tobago e Venezuela ${ }^{637}$, os quais, apesar de já assinados, ainda não estão em vigor, mas que também seguem a linha mais moderna e permitem a flexibilizarão do recurso à legislação tributária interna geral. As exceções ficam por conta das convenções firmadas com a Argentina (Decreto n. 87.976/82) e com o Equador - Decreto n. 75.717/88, as quais, embora sigam a versão de 1977 do Modelo da OCDE, prevêem que as partes podem, de comum acordo, estabelecer um significado para os termos e expressões não definidos no tratado. Esta, segundo o entendimento de Sérgio André Rocha, seria a opção mais adequada ${ }^{638}$.

${ }^{634}$ Exemplos disso são as convenções celebradas com os seguintes países: Áustria (Decreto n. ${ }^{\circ}$ 78.107-76); Bélgica (Decreto n..$^{0}$ 72.542/73); Canadá (Decreto n. ${ }^{0}$ 92.318/86); China (Decreto n. ${ }^{\circ}$ 762/93); Coréia (Decreto n. ${ }^{\circ}$ 354/91); Dinamarca (Decreto n. ${ }^{\circ}$ 75.106/74); Espanha (Decreto n. ${ }^{\circ}$ 76.975/76); Filipinas (Decreto n. ${ }^{\circ}$ 241/91); Finlândia (Decreto n. ${ }^{\circ}$ 2.465/98); França (Decreto n. ${ }^{\circ}$ 70.506/72); Holanda (Países Baixos) (Decreto n. ${ }^{\circ} 355 / 91$ ); Hungria (Decreto n. ${ }^{\circ} 53 / 91$ ); Índia (Decreto n. ${ }^{\circ} 510 / 92$ ); Itália (Decreto n. ${ }^{\circ}$ 85.985/81); Japão (Decretos n. ${ }^{\circ} 61.899 / 67$ e 81.194/78); Luxemburgo (Decreto n. ${ }^{\circ}$ 85.051/80); Noruega (Decreto n. ${ }^{\circ} 86.710 / 81$ ); República Tcheca e República Eslovaca (Decreto n. ${ }^{\circ}$ 43/91) e Suécia (Decreto n. ${ }^{\circ}$ 77.053/76). Embora também possuísse redação similar às convenções acima, a convenção contra a bitributação firmada com a Alemanha (Decreto n. 76.988/76) encontra-se revogada desde 01 de janeiro de 2006, e por isso não foi incluída nesta lista.

635 Convenção Brasil-Africa do Sul (Decreto n. 5.922/2006): “Artigo 3 (...) 2. Para a aplicação das disposições da Convenção a qualquer tempo por um Estado Contratante, qualquer termo ou expressão que nela não se encontrem definidos terá, a não ser que o contexto exija interpretação diferente, o significado que a esse tempo lhe for atribuído pela legislação desse Estado relativa aos impostos que são objeto da Convenção, prevalecendo os efeitos atribuídos a esse termo ou expressão pela legislação tributária desse Estado sobre o significado que lhe atribuam outras leis desse Estado." Disponível em http://www.receita.fazenda.gov.br/Legislacao/AcordosInternacionais/AfricadoSul/Dec59222006.htm. Acesso em 24 nov. 2009.

${ }^{636}$ Convenções disponíveis em www.receita.fazenda.gov.br. Acesso em 3 fev. 2010.

${ }^{637}$ Disponíveis em: http://www2.mre.gov.br/dai/007.htm. Acesso em 24 nov. 2009.

${ }^{638}$ ROCHA, Sérgio André. Interpretação dos Tratados contra a Bitributação da Renda. Rio de Janeiro: Lumen Juris, 2008, pp. 149/150. Somos obrigados a discordar deste autor no que se refere à suposta ausência da norma do artigo 3(2) na Convenção entre o Brasil e a Áustria. De fato, de acordo com o Decreto n. 78.107/76, que se encontra disponível para consulta no site da Receita Federal do Brasil 
À vista de todas as questões e pontos polêmicos apresentados, observa-se que, apesar de sua aparente simplicidade, a norma em questão é uma das mais difíceis de interpretar e aplicar dentre todas do Modelo. Ainda assim, os maiores questionamento que surgem a partir de sua análise são referentes ao reenvio ao Direito interno dos Estados contratantes e ao problema das qualificações, os quais serão analisados a seguir.

\subsubsection{O contexto no Modelo da OCDE e o reenvio ao Direito interno dos}

\section{Estados contratantes}

Em linhas gerais, o artigo $3^{\circ}$, parágrafo $2^{\circ}$ do Modelo da OCDE estabelece que, salvo quando o contexto indicar de modo diverso, a interpretação de um termo ou expressão deverá ter o significado que lhe for atribuído pelo Direito interno de um Estado contratante. Observa-se, que aqui tanto o contexto quanto o reenvio ao Direito interno assumem papel preponderante para o procedimento de interpretação.

Entretanto, apesar da evidente importância do termo, o Modelo da OCDE não apresenta o seu conceito de contexto, sendo necessária a interpretação do termo e o recurso ao artigo $31, \S 2^{\circ}$ da Convenção de Viena para este fim. Não se trata, porém, de utilizar a definição de contexto exatamente como prevista na Convenção de Viena. De fato, o conceito de contexto apresentado na Convenção de Viena é essencialmente objetivo, fundado principalmente no texto do tratado. Já a noção de contexto que se aplica ao artigo $3^{\mathrm{o}}, \S 2^{\mathrm{o}}$ do Modelo da OCDE é bem mais abrangente ${ }^{639}$ e muito mais subjetiva, talvez em virtude do fato de os comentários ao Modelo da OCDE informarem que o contexto mencionado em seu artigo $3^{\circ}, \S 2^{\circ}$ deve ser interpretado a partir da intenção dos Estados contratantes e à luz do Direito interno do outro Estado contratante ${ }^{640}$.

(www.receita.fazenda.gov.br), a norma em questão se faz presente na convenção, e segue o modelo de 1977 , conforme explicamos em nota anterior.

639 Alberto Xavier entende que o contexto mencionado no Modelo da OCDE é mais abrangente do que o conceito de contexto fornecido pelo artigo 31 da Convenção de Viena. XAVIER, Alberto. Direito Tributário Internacional do Brasil. 6. ed. Rio de Janeiro: Forense, 2007. p. 187. Em sentido contrário, Giuliani entende que o "contexto" previsto no artigo 3(2) do Modelo da OCDE é de alcance restrito, e, por isso, nem precisaria, a rigor, estar mencionado. Para o Autor, a própria interpretação do dispositivo conduziria ao conceito de contexto presente no artigo $31, \S 2^{\circ}$, da Convenção de Viena. GIULIANI, Federico Maria. La interpretazione delle convenzioni internazionali contro le doppie imposizioni sui redditi. In: UCKMAR, Victor (coord.). Corso di Diritto Tributário Internacional. 2. ed. Padova: CDEAM, 2000. p. 136.

640 "12. However, paragraph 2 specifies that this applies only if the context does not require an alternative interpretation. The context is determined in particular by the intention of the Contracting States when signing the Convention as well as the meaning given to the term in question in the legislation of the other 
Neste ponto, Santiago destaca, com absoluta propriedade, que a amplitude conferida à noção de contexto para a aplicação do artigo $3^{\circ}, \S 2^{\circ}$ tem como objetivo “ampliar a ressalva contida na fórmula 'unless the context otherwise requires', de modo a reduzir as hipóteses de reenvio para o direito interno e, em conseqüência, os riscos de dupla tributação ou de dupla não-tributação dele decorrentes" ${ }^{641}$. Ainda analisando o dispositivo do artigo $3^{\circ}, \S 2^{\circ}$, Santiago ${ }^{642}$ destaca o ilogismo dos Comentários ao Modelo da OCDE ao dispor que, ao se deparar com termo não definido na convenção, um Estado contratante deva considerar, como inclusas no contexto, as definições de termos jurídicos provenientes do Direito do outro Estado contratante, somente podendo recorrer à sua própria legislação interna em último caso, quando a legislação do outro Estado também não fornecesse a definição necessária.

Apesar destas questões, de modo geral, é possível afirmar que o "contexto do tratado" que deve ser considerado para fins de aplicação de convenções firmadas com base no Modelo da OCDE é aquele que engloba, além do texto do tratado propriamente dito, o preâmbulo e os protocolos, bem como os demais acordos relativos às convenções que já estejam concluídos pelas partes quando da celebração do tratado, ou ainda qualquer instrumento elaborado pelas partes que tenha conexão com o objeto do tratado.

Superada a questão da noção de contexto para os fins do Modelo, passa-se à análise da sua relação com o reenvio ao Direito interno. Para isso, pondera-se, inicialmente, que os dois institutos sempre devem ser analisados conjuntamente, já que a noção de contexto no Modelo da OCDE está ligada ao Direito interno, como mencionado nos próprios comentários. Isto porque, de fato, é no Direito interno que se encontram os motivos que justificaram a celebração do tratado, permitindo a avaliação da intenção das partes. Além disso, nele estão definidos os significados originariamente atribuídos aos termos e expressões utilizados na convenção e, em última instância, é no Direito interno que podem ser encontrados os indivíduos que estarão sujeitos às normas da convenção, ou seja, os reais destinatários das normas contra a bitributação.

Contracting State (an implicit reference to the principle of reciprocity on which the Convention is based). The wording of the Article therefore allows the competent authorities some leeway." RAAD, Kees van. Materials on International \& EC Tax Law. Selected and edited by Kees van Raad. 7. ed. Leiden: IBFD, 2007. v. 1, p. 92.

641 SANTIAGO, Igor Mauler. Direito Tributário Internacional - Métodos de Solução dos Conflitos. São Paulo: Quartier Latin, 2006, p. 100.

${ }^{642}$ SANTIAGO, Igor Mauler. Direito Tributário Internacional - Métodos de Solução dos Conflitos. São Paulo: Quartier Latin, 2006, p. 100. 
Com base na doutrina de Garbarino ${ }^{643}$, diversos autores ${ }^{644}$ mencionam três hipóteses nas quais, de acordo com o artigo $3^{\circ}, \S 2^{\circ}$ do Modelo da OCDE, seria possível o recurso ao Direito interno dos Estados contratantes. Assim, o recurso ao Direito interno teria lugar quando: (i) houvesse disposição expressa nesse sentido no texto da convenção; (ii) a necessidade de recurso ao Direito interno fosse claramente indicada pelo contexto da convenção ou pelos meios suplementares de interpretação; e (iii) na hipótese em que, mesmo após a análise do contexto e dos meios suplementares de interpretação, não fosse possível compreender o significado de termos ou expressões do acordo de modo satisfatório para ambos os Estados contratantes.

Apesar da relativa uniformidade doutrinária quanto a estas três hipóteses, quando o assunto é a ordem de preferência entre o reenvio ao Direito interno e o recurso ao contexto como forma de buscar o significado de termos e expressões não definidos no tratado, as opiniões são divididas. Nesse sentido, enquanto alguns autores advogam pela supremacia da interpretação dos termos não definidos na convenção segundo o contexto em detrimento do reenvio ao Direito interno ${ }^{645}$, outros defendem que a definição presente no Direito interno é a que deverá prevalecer em caso de dúvida ${ }^{646}$. Por sua vez, há quem sustente que a norma do artigo $3^{\circ}, \S 2^{\circ}$ do Modelo da OCDE constitui uma verdadeira cláusula geral de reenvio ao Direito interno ${ }^{647}$, e, numa quarta vertente (ou primeira, se

${ }^{643}$ GARBARINO, Carlo. La tassazione dei redditi transnazionale. Padova: CEDAM, 1990. pp. 529-532.

${ }^{644}$ TORRES, Heleno Taveira. TORRES, Heleno Taveira. Pluritributação Internacional sobre as Rendas de Empresas. 2. ed. rev., ampl. e atual. São Paulo: Revista dos Tribunais, 2001, p. 655. BELLAN, Daniel Vítor. Interpretação dos Tratados Internacionais em Matéria Tributária. In: TORRES, Heleno Taveira (coord.). Direito Tributário Internacional Aplicado. São Paulo: Quartier Latin, 2005. v. 3. p. 623. SILVEIRA, Rodrigo Maitto da. Aplicação de Tratados Internacionais contra a Bitributação: qualificação de Partnership Joint Ventures. São Paulo: Quartier Latin, 2006, p. 124.

${ }^{645}$ PIRES, Manuel. Da Dupla Tributação Jurídica Internacional sobre o Rendimento. Lisboa: Centro de Estudos Fiscais - Ministério das Finanças, 1984. p. 456. XAVIER, Alberto. Direito Tributário Internacional do Brasil. 6. ed. Rio de Janeiro: Forense, 2007. p. 188. TORRES, Heleno Taveira. Pluritributação Internacional sobre as Rendas de Empresas. 2. ed. rev., ampl. e atual. São Paulo: Revista dos Tribunais, 2001, p. 656. TORRES, Heleno Taveira. A interpretação dos Tratados Internacionais em Matéria Tributária sobre a Renda e o Capital. In: Estudios en Memoria de Ramón Valdés Costa. Montevideo: Fundación de Cultura Universitária. 1999. v. 1. p. 353-358. BELLAN, Daniel Vítor. Interpretação dos Tratados Internacionais em Matéria Tributária. In: TORRES, Heleno Taveira (coord.). Direito Tributário Internacional Aplicado. São Paulo: Quartier Latin, 2005. v. 3. p. 639.

${ }^{646}$ ROTHMANN, Gerd W. Interpretação e Aplicação dos Acordos Internacionais contra a Bitributação. São Paulo: USP, 1978. Tese (doutorado), pp. 163-164.

647 BAKER, Phillip. Double Taxation Conventions. London: Sweet and Maxwell, 2002. P. E-20. CARVALHO, André de Souza. Acordo Brasil-EUA: O que ainda falta para a sua conclusão? In: PANZARINI FILHO, Clóvis (Coord.) et. al. Revista de Direito Tributário Internacional. São Paulo: Quartier Latin, 2006, v. 4. pp. 18-19. 
considerarmos o aspecto cronológico), existe a opinião de $\operatorname{Vogel}^{648}$ no sentido de que a interpretação contextual e o reenvio ao Direito interno devem ser opções coordenadas, não sendo possível inferir uma ordem de preferência a partir da regra do artigo $3^{\circ}$, $\S 2^{\mathrm{o}^{649}}$.

De fato, independente da existência de uma “ordem de preferência” aplicável à interpretação segundo o contexto em relação à remissão ao Direito interno, não se questiona o fato de que o reenvio ao Direito interno constitui um recurso tão relevante quanto controverso. Aqui, a controvérsia e a polêmica estão ligadas à necessidade de garantia da segurança jurídica. Isto porque, ao mesmo tempo em que o recurso ao Direito interno teria o condão de aumentar a segurança jurídica por meio da redução da gama de significados que podem ser atribuídos aos termos de expressões de uma convenção de bitributação, esta mesma segurança jurídica restaria diminuída pelo fato de que um mesmo termo ou expressão pode ter significados distintos nos Direitos internos de cada um dos Estados contratantes, sendo difícil, quando não impossível, conciliá-los. A isto se soma o

648 Contrariamente à opinião do Professor Alberto Xavier (XAVIER, Alberto. Direito Tributário Internacional do Brasil. 6. ed. Rio de Janeiro: Forense, 2007, pp. 183-187), acreditamos que Vogel não considera a norma do artigo 3(2) do Modelo da OCDE como uma cláusula geral de reenvio. Vogel atribui o mesmo peso à interpretação contextual e à interpretação segundo o Direito interno dos Estados contratantes, de modo que ambos os métodos devam ser coordenados entre si, em relação de paridade, durante o processo hermenêutico. É o que se infere da seguinte passagem: "The undesirable consequences which may result from treaty interpretation according to domestic law (...) have induced commentators to attempt to limit reference to domestic law by emphasizing that the treaty should to the greatest possible extent to be interpreted according to its context (...). Unfortunately these efforts can be supported only to a limited extent. First, it is impossible to infer from Art. 3(2) a systematic preference for interpretation from the context over interpretation by reference to national law (...). In Germany, the BFH has indeed in the past in individual rulings express the view that recourse to domestic law was not permissible unless and until an interpretation from the treaty's context has proved impossible (...). In its recent case law, however, it occasionally even invokes Art. 3(2) to apply domestic law without even discussing the possibility of an interpretation from the treaty context (...). This approach was correct: whether the context 'otherwise requires', viz. an approach other than the recourse to domestic law, can, in accordance with the rules of logic, be determined only of the meaning of a term has previously been established under that law. From this, it would seem that an interpretation according to domestic law should take preference (...). Since, however, such an interpretation may also require further correction, both interpretation procedures must be viewed in mutual reciprocity." VOGEL, Klaus. On double taxation conventions: a commentary to the $O E C D, U N$ and US model conventions for the avoidance of double taxation of income and capital with particular reference to German treaty practice. 3. ed. Germany: Kluwer Law International, 1997, pp. 213214. No mesmo sentido, VOGEL, Klaus. PROKISCH, Rainer G. PROKISCH, Rainer G. General Report. Interpretation of Double Taxation Conventions. Cahiers de Droit Fiscal International. 1993 Florence Congress, International Fiscal Association., vol. LXXVIIIa, p. 81.

649 Nesse sentido, o professor Igor Mauler Santiago resume os argumentos de Vogel que sustentam a equivalência de "peso" atribuída ao contexto e ao reenvio ao Direito interno, explicando que: "De um modo geral, sustenta VOGEL que, à falta de definição de um termo no tratado, a remissão à lei interna só pode ser afastada quando o contexto o exija, e não quando tão-só o permita. Desse modo, a definição obtida com arrimo na lei doméstica não cederia ante uma interpretação apenas razoável decorrente do contexto, só o fazendo quando esta última se fundasse em razoes especialmente fortes. Em suma, nega o Autor que o dispositivo imponha um dever de exaustão das possibilidades exegética da convenção antes do recurso à lei local." SANTIAGO, Igor Mauler. Direito Tributário Internacional - Métodos de Solução dos Conflitos. São Paulo: Quartier Latin, 2006, p. 101. 
fato de que, em virtude do princípio da soberania, um Estado jamais poderia ser compelido a aceitar a definição jurídica de um termo ou expressão formada a partir do Direito interno de outro Estado soberano.

Considerando estas dificuldades, observa-se que os fatores responsáveis pela diminuição da segurança jurídica na relação entre os Estados acabam superando a vantagem da redução da gama de significados dos termos de um tratado. Efetivamente, o irrestrito e imediato reenvio ao Direito interno durante a interpretação do tratado pode provocar conflitos de qualificações ${ }^{650}$, os quais, por sua vez, podem acarretar a ineficácia do próprio tratado e permitir, assim, a ocorrência da dupla tributação internacional ou mesmo a ocorrência de dupla não-tributação. Em razão de todas estas desvantagens, alguns países ${ }^{651}$ têm preferido não adotar a norma do artigo $3^{\circ}$, parágrafo $2^{\circ}$, priorizando a interpretação autônoma e determinando que o recurso ao Direito interno deve ser feito somente quando o contexto expressamente indicar ou quando não for possível, de modo algum, a interpretação contextual.

Assim, considerando as desvantagens do reenvio ao Direito interno, associadas ao alargado conceito de contexto para os fins do Modelo, parece-nos claro que a norma do artigo $3^{\circ}, \S 2^{\circ}$, mediante a oração "unless the context otherwise requires", pretendeu firmar a preferência pela interpretação contextual em detrimento do reenvio ao Direito interno como forma de fornecer as definições ausentes na convenção ${ }^{652}$. Em outras palavras,

\footnotetext{
${ }^{650}$ Os conflitos de qualificações serão mais detidamente examinados em item separado, a seguir.

${ }^{651}$ Assim está disposto na convenção de bitributação celebrada entre a Alemanha e a Suécia (1992). VOGEL, Klaus. On double taxation conventions: a commentary to the OECD, UN and US model conventions for the avoidance of double taxation of income and capital with particular reference to German treaty practice. 3 . ed. Germany: Kluwer Law International, 1997, p. 209.
}

\footnotetext{
${ }^{652}$ Nesse sentido: AVERY JONES, John F. SINCLAIR, Ian, Sir. RAAD, Kees van. VOGEL, Klaus. WARD, David. Interpretation of Tax Treaties. In: Bulletin - IBFD. Amsterdam: IBFD, fev. 1986, p. 80. AVERY JONES, John F. The "One True Meaning” of a Tax Treaty. In: Bulletin - Tax Treaty Monitor. Amsterdam: IBFD, jun. 2001, p. 221. XAVIER, Alberto. Direito Tributário Internacional do Brasil. 6. ed. Rio de Janeiro: Forense, 2007, p. 188. TORRES, Heleno Taveira. Pluritributação Internacional sobre as Rendas de Empresas. 2. ed. rev., ampl. e atual. São Paulo: Revista dos Tribunais, 2001, p. 656. TORRES, Heleno Taveira. A interpretação dos Tratados Internacionais em Matéria Tributária sobre a Renda e o Capital. In: Estudios en Memoria de Ramón Valdés Costa. Montevideo: Fundación de Cultura Universitária. 1999. v. 1, p. 353-358. BELLAN, Daniel Vítor. Interpretação dos Tratados Internacionais em Matéria Tributária. In: TORRES, Heleno Taveira (coord.). Direito Tributário Internacional Aplicado. São Paulo: Quartier Latin, 2005. v. 3. p. 639. SCHOUERI, Luís Eduardo. Planejamento Fiscal através de Acordos de Bitributação: Treaty Shopping. São Paulo: Revista dos Tribunais, 1995. p. 38.
} 
entendemos que o reenvio ao Direito interno deveria ser a última opção do intérprete para suprir uma lacuna na convenção ${ }^{653}$.

E, pelos mesmos motivos, entendemos que a norma deste artigo não pode ser classificada como uma cláusula geral de reenvio ao Direito interno. Na verdade, acreditamos que a norma do artigo $3^{\circ}, \S 2^{\circ}$ estabelece uma ordem de preferência pela qual, somente em último caso poderá haver o reenvio ao Direito interno, ou seja, somente quando a definição de termos ou expressões fornecidas a partir do contexto não for satisfatória é que poderá ocorrer o recurso ao Direito interno.

\subsubsection{As expressĩes autônomas}

Frequentemente se encontram nos textos dos tratados termos e expressões que não são definidas pelo Direito interno, mas são, por outro lado, fruto da construção do Direito Internacional Tributário ou mesmo do Direito Internacional Público ou Privado. Estas são denominadas de expressões autônomas, as quais assumem grande importância para a correta interpretação e compreensão das convenções, bem como para o efetivo alcance dos objetivos pretendidos.

A principal vantagem das expressões autônomas está no fato de estas serem aplicadas, em princípio, sem a necessidade de recurso ao contexto ou ao Direito interno. Ressaltamos o caráter apriorístico desta relativa desnecessidade do recurso ao Direito interno porque, sabendo que as convenções de bitributação são subsidiárias em relação ao Direito tributário interno, sempre haverá, mesmo que mínima, alguma relação com as normas internas dos Estados contratantes ${ }^{654}$.

653 “Não podemos concordar com a tese (da inexistência de ordem de preferência ou equivalência de 'peso'
entre contexto e reenvio ao Direito interno, defendida por Vogel), por entendermos que o contexto de um
tratado exige, sempre que seja possível, leitura que o prestigie, não nos parecendo coerente admitir que dê
preferência a interpretação que contrarie os fins por ele expressos e que lhe negue força vinculante, pondo-o
em desvantagem ante estipulações em contrário de leis locais." SANTIAGO, Igor Mauler. Direito
Tributário Internacional - Métodos de Solução dos Conflitos. São Paulo: Quartier Latin, 2006, p. 101 .
Comentário nosso.
654 Heleno Torres ressalva, neste aspecto, que: “Mesmo nestes casos, naturalmente, não é factível uma
interpretação insulada, que isole, por completo, as expressões do texto convencional dos significados das
normas internas, com uma atribuição de significado absolutamente autônoma, haja vista o caráter de
subsidiariedade das convenções em relação ao Direito Tributário interno. O que conta para a
caracterização das normas de interpretação autônoma ;e a intensidade da dependência destas em relação às
normas internas, pois existem algumas normas cuja aplicação carece de uma necessária integração e nem
por isso deixam de ter aquela tipologia [de normas autônomas]. Trata-se de uma autonomia demarcada a
priori, como um topos, um ponto de partida.” TORRES, Heleno Taveira. Pluritributação Internacional 
Afirma-se que as expressões autônomas contidas nos textos dos tratados de bitributação devem sempre ser inicialmente compreendidas dentro do âmbito do próprio tratado, ou seja, intratextualmente, para depois ter início a busca pelos possíveis outros significados fora do expressamente disposto na redação das normas convencionais. De fato, como destacado por $\operatorname{Vogel}^{655}$, mesmo as definições que caracterizam as expressões autônomas sempre acabam utilizando, em maior ou menor grau, conceitos indeterminados ou mesmo não definidos no próprio texto da convenção, abrindo a possibilidade para o reenvio ao Direito interno e demonstrando, assim, que em qualquer interpretação sempre haverá espaço, ainda que mínimo, para problemas de qualificação.

Este reenvio mínimo ao Direito interno é analisado por Heleno Torres ${ }^{656}$, que o denomina de "reenvio integrativo". Nesse sentido, Torres explica que há algumas expressões autônomas que, mesmo estando definidas no tratado, ainda comportam um certo grau de reenvio ao Direito interno, o chamado "reenvio integrativo". Exemplificando, Torres cita o termo "sociedade", que se encontra definido na maioria das convenções como "qualquer pessoa jurídica ou qualquer entidade que, para fins tributários, seja considerada como pessoa jurídica", explicando, em seguida, que embora a convenção traga a definição genérica de sociedade, ainda assim seria necessário o reenvio ao Direito interno (o reenvio integrativo) como forma de determinar quais tipos de pessoa jurídica poderiam ser consideradas como sociedades, nos termos da convenção.

No entanto, apesar da efetiva possibilidade de ocorrer o reenvio integrativo, as expressões autônomas ainda representam a forma mais segura de se evitar o problema das

sobre as Rendas de Empresas. 2. ed. rev., ampl. e atual. São Paulo: Revista dos Tribunais, 2001, p. 647. Comentário nosso.

${ }^{655}$ Como exemplo, Vogel cita o caso Pierre Boulez, envolvendo os EUA e a Alemanha, em que houve a discussão da definição do termo royalty, o qual, apesar de ser uma expressão autônoma, acabou sendo interpretado de modo distinto pelos Estados contratantes. O caso envolvia a qualificação da remuneração paga a um maestro de uma orquestra por reger a orquestra numa gravação. Era necessário definir se tal remuneração constituía um royalty ou um pagamento pela execução de serviços pessoais independentes (nos termos do extinto art. 14 do Modelo OCDE / atual artigo 14 do Modelo ONU). VOGEL, Klaus. On double taxation conventions: a commentary to the OECD, UN and US model conventions for the avoidance of double taxation of income and capital with particular reference to German treaty practice. 3. ed. Germany: Kluwer Law International, 1997, pp. 53 e 58.

${ }^{656}$ TORRES, Heleno Taveira. Pluritributação Internacional sobre as Rendas de Empresas. 2. ed. rev., ampl. e atual. São Paulo: Revista dos Tribunais, 2001, p. 648. 
qualificações, facilitando na maioria das vezes a tão desejada realização do que Vogel denominou de "interpretação comum" 657 do tratado pelas partes.

E, de fato, há casos em que nem mesmo é necessário o reenvio integrativo, bastando, por si só, a definição apresentada no tratado. Isto ocorre, na maioria das vezes, em relação aos termos e expressões originários do próprio Direito Tributário Internacional, que fazem parte da chamada "linguagem fiscal internacional" ${ }^{\prime 658}$. Este é o caso da expressão "estabelecimento permanente", que designa, segundo o Modelo da OCDE, "uma instalação fixa de negócios na qual a empresa exerça, no todo ou em parte, sua atividade". Como visto, a expressão "estabelecimento permanente" não requer qualquer recurso ao Direito interno para ser compreendida, bastando, para sua plena aplicabilidade, a definição que a própria convenção (no caso, o Modelo) apresenta.

Também se incluem na categoria de expressões autônomas as definições de alguns princípios do Direito Tributário Internacional, como é o caso do princípio da não discriminação e da imunidade dos agentes diplomáticos (inseridos, respectivamente, nos artigos 24 e 28 da Convenção Modelo da OCDE, versão de 2005), bem como as cláusulas que dispõem sobre o início e término da vigência de um acordo (artigos 29 e 30 do mesmo Modelo).

Os exemplos mais comuns de expressões autônomas são as definições de termos como juros, estabelecimento permanente, dividendos, royalties ${ }^{659}$, dentre muitos

657 VOGEL, Klaus. On double taxation conventions: a commentary to the OECD, UN and US model conventions for the avoidance of double taxation of income and capital with particular reference to German treaty practice. 3. ed. Germany: Kluwer Law International, 1997, pp. 39-42.

${ }^{658}$ Engelen, destacando a doutrina de Vogel, explica que os termos e expressões definidos nos Comentários ao Modelo da OCDE de 1963 integram a chamada "linguagem fiscal internacional", sendo que os significados a eles atribuídos devem servir de base para a determinação do sentido comum de termos e expressões, de acordo com o artigo 31(1) da Convenção de Viena. ENGELEN, Frank. Interpretation of Tax Treaties under International Law. Amsterdam: IBFD, 2004. v. 7, p. 444 (IBFD Doctoral Series).VOGEL, Klaus. The influence of the OECD Commentaries on Treaty Interpretation. In: Bulletin - Tax Treaty Monitor. Amsterdam: IBFD, dez. 2000. pp. 612-616.

${ }^{659}$ De acordo com o IBFD International Tax Glossary: "Tax treaties generally contain their own definitions of royalties which broadly cover payments oft he use of intellectual property and payments for know-how, i.e., information concerning industrial, commercial or scientific experience.". International Tax Glossary. IBFD, 5. ed. 2005. p. 350. Ainda sobre o conceito de royalties, v. BOBBETT, Catherine. JONES, John Avery. Tax Treaty Definition of Royalties. In: Bulletin - Tax Treaty Monitor. IBFD, jan. 2006, pp. 23-28. Sobre a definição de royalties adotada pela Receita Federal do Brasil, v. BELLAN, Daniel Vitor. Algumas Considerações sobre a Tributação dos Royalties pagos a Beneficiários Residentes ou Domiciliados no Exterior. In: TORRES, Heleno Taveira (coord.). Direito Tributário Internacional Aplicado. São Paulo: Quartier Latin, 2003. pp. 361-362.v. 1. 
outros. É possível identificar tais expressões porque normalmente existe no texto dos tratados referência direta ou mesmo indireta ao seu significado ${ }^{660}$.

É inquestionável que quanto mais diferentes forem os sistemas jurídicos dos Estados contratantes, mais importantes se tornam as expressões autônomas em sua função de facilitar a interpretação e aplicação do tratado. Entretanto, infelizmente, muitas vezes os países deixam de utilizá-las (ou as utilizam de forma limitada) no acordo seja porque definir previamente as expressões de um acordo internacional produz o efeito de reduzir sensivelmente a discricionariedade dos países durante a futura aplicação deste acordo, seja porque atingir um consenso prévio em relação às próprias definições e conceitos que formarão as expressões autônomas do futuro acordo envolve a prévia conciliação de interesses dos dois Estados, o que também constitui um fator negativo no sentido de dificultar as e atrasar negociações durante a elaboração do próprio acordo.

Outro aspecto interessante consiste no fato de que a utilização de expressões autônomas reforça a importância de se verificar primeiramente o contexto interno da convenção para compreender como as expressões e termos estão definidos, para então partir para outros modos interpretativos e apreender o seu real significado. Desta forma, as expressões autônomas facilitam a interpretação comum do tratado.

Enfim, apesar das dificuldades, não se pode olvidar o fato de que a mais importante função desempenhada pelas expressões autônomas consiste em atuar reduzindo as chances de concursos entre os critérios de conexão e os problemas de qualificação entre os Estados contratantes durante a interpretação e aplicação das convenções de bitributação.

\subsubsection{O problema das qualificações}

Antes de analisar o "problema" das qualificações, é importante definir o conceito de "qualificação" e a sua relação com a interpretação das normas.

Segundo ensinam Manuel Pires ${ }^{661}$ e Alberto Xavier ${ }^{662}$, ambos citando Baptista Machado $^{663}$, qualificar um certo quid é determiná-lo como subsumível a um conceito, por

\footnotetext{
${ }^{660}$ Como ocorre, por exemplo, no art. $3^{\circ}$, parágrafo 1o, do Modelo da OCDE, dedicado às definições gerais.

${ }^{661}$ PIRES, Manuel. Da Dupla Tributação Jurídica Internacional sobre o Rendimento. Lisboa: Centro de Estudos Fiscais - Ministério das Finanças, 1984. p. 454.

${ }^{662}$ XAVIER, Alberto. Direito Tributário Internacional do Brasil, 6. ed., Rio de Janeiro: Forense, 2007. p. 143.
} 
aplicação desse mesmo conceito, ou seja, verificar ou constatar em certo dado as notas ou características que formam a composição de certo conceito. Esta mesma noção de subsunção dos fatos à norma é encontrada na doutrina de Perelman, segundo o qual o magistrado somente se interessa pelos fatos enquanto estes possam trem consequências legais no processo que lhe é submetido, o que pressupõe que tais fatos devam ser qualificados, ou seja, subsumidos sob os termos da lei ${ }^{664}$. Além disso, segundo o Autor, quando esta operação de subsunção estiver para ser realizada, o juiz sempre terá um poder de apreciação, uma vez que a qualificação muito raramente é determinada apenas pelas propriedades objetivas daquilo que se pretende qualificar, e na prática, observa-se que, no intuito de justificar a qualificação dada a determinado fato, o juiz frequentemente se inspira na intenção do legislador e no exame das consequências legais que decorreriam de sua decisão.

A qualificação ${ }^{665}$ consiste, assim, em verificar ou constatar em certo fato as características que formam a compreensão de certo conceito. Porém, a qualificação não depende apenas de uma descrição clara e incontroversa dos fatos, sendo, por outro lado, essencialmente dependente do modo como o juiz interpretará a lei, precisamente quando ele antecipar, em seu raciocínio lógico, as possíveis consequências atreladas à qualificação de um termo.

Já segundo Ricardo Lobo Torres ${ }^{666}$ a qualificação vai além da simples subsunção do fato à norma, englobando, além da relação lógica e formal estabelecida durante a interpretação, um juízo de valor por parte do aplicador do Direito. O conceito de

${ }^{663}$ MACHADO, João Baptista. Lições de Direito Internacional Privado, 4. ed., Coimbra: Almedina, 1990. pp. 111-112.

${ }^{664}$ Perelman destaca, ainda, que "uma definição jurisprudencial, elaborada por uma instância superior, pode, na falta de definição legal, vir limitar a liberdade de apreciação do juiz, cujo poder permanece, não obstante, considerável no que concerne à qualificação dos fatos e à sua subsunção sob uma norma legal." PERELMAN, Chaïm. Ética e Direito. Trad. Maria Ermantina de Almeida Prado Galvão. 2. ed. São Paulo: Martins Fontes, 2005. pp. 485-486.

${ }^{665}$ Alberto Xavier destaca que o problema das qualificações não é exclusivo das convenções contra a bitributação, podendo ser verificado também em relação ao Direito tributário interno. Porém, como nosso objeto de estudo são as convenções contra a bitributação, não adentraremos a análise deste aspecto. XAVIER, Alberto. Direito Tributário Internacional do Brasil, 6. ed. Rio de Janeiro: Forense, 2007, pp. 190 e seguintes.

${ }^{666}$ TORRES, Ricardo Lobo. Normas de Interpretação e Integração do Direito Tributário. Rio de Janeiro: Renovar, 2006, pp. 309-310. 
qualificação também é analisado por Cesar García Novoa, para quem a qualificação pode ser definida como

"o conjunto de operações que se realizam por parte dos aplicadores do direito com o fim de analisar aquelas circunstancias do mundo real que podem ser incluídas nas hipóteses de incidência da norma"667. Ainda segundo Novoa, "se o objeto da interpretação são normas e, portanto, hipóteses abstratas previstas nas mesmas, a fixação e qualificação de fatos constitui ma fase prévia e imprescindivel do processo de aplicação do direito objetivo. ${ }^{668,}$

Analisando as causas que originam o problema, Rothmann ${ }^{669}$ destaca que a questão das qualificações está intimamente relacionada com a interpretação e aplicação de um acordo, devido à diferença de conceitos jurídicos, acarretando a bitributação. Nesse sentido, ele aponta a interpretação do elemento de conexão, mais precisamente a divergência de conceituação dos elementos de conexão como uma das causas para o problema das qualificações, o qual, por sua vez, pode ser considerado como um dos motivos da bitributação internacional, já que os conceitos jurídicos utilizados nas convenções são relevantes para a determinação da competência tributária dos Estados contratantes $^{670}$. Também explorando o problema das qualificações, Perelman entende que quando se trata de qualificar fatos estabelecidos, ou seja,

Examinando o aspecto cronológico, Xavier afirma que o problema das qualificações surge no momento da aplicação da norma jurídica ${ }^{671}$. Assim, a qualificação

667 NOVOA, César Garcia. Interpretación de los convenios de doble imposición internacional. In: FAJARDO, Juan Pablo Godoy. (coord.). Estudios de Derecho Internacional Tributário - Los convenios de doble imposición. Bogotá: Legis, 2006, p. 65.

668 NOVOA, César Garcia. Interpretación de los convenios de doble imposición internacional. In: FAJARDO, Juan Pablo Godoy. (coord.). Estudios de Derecho Internacional Tributário - Los convenios de doble imposición. Bogotá: Legis, 2006, p.65.

${ }^{669}$ ROTHMANN, Gerd W. Interpretação e Aplicação dos Acordos Internacionais contra a Bitributação. São Paulo: USP, 1978. Tese (doutorado), p. 57.

${ }^{670}$ O Professor Rothmann apresenta a divisão do problema das qualificações em espécies relacionadas ora à definição dos termos, ora à atribuição da competência tributária. Entendemos que esta classificação e resumida por Xavier em sua teoria alternativa de solução para o problema das qualificações ao determinar que o problema se dirige ora ao conceito-quadro (definição dos rendimentos), ora aos pressupostos de aplicação da convenção (elementos de conexão). ROTHMANN, Gerd W. Interpretação e Aplicação dos Acordos Internacionais contra a Bitributação. São Paulo: USP, 1978. Tese (doutorado), p. 58.

671 RIBES, Aurora Ribes. Convenios para evitar la doble imposición internacional: interpretación, procedimiento amistoso y arbitraje. Madrid: Editoriales de Derecho Reunidas S.A., 2003. p. 37. PERELMAN, Chaïm. Lógica Jurídica. São Paulo: Martins Fontes, 2000. pp. 45-46. 
do fato, por subsunção ao conceito, ou por aplicação deste conceito àquele fato, pressupõe a prévia interpretação deste mesmo conceito ${ }^{672}$, de modo que interpretação e aplicação constituiriam fases sucessivas do processo hermenêutico ${ }^{673}$.

Neste ponto, faz-se necessário tecer algumas considerações sobre o processo hermenêutico, a interpretação e a aplicação da norma jurídica e sua relação com o problema das qualificações.

Entendemos que o processo hermenêutico deve ser visto sob dois prismas: o dogmático (e didático) e o prático. Sob a perspectiva acadêmica, dogmática, é cabível e até mesmo relevante a divisão do processo hermenêutico em etapas cronologicamente sucessivas, com a finalidade de permitir a compreensão de suas características e de seu modo de atuação. Entendemos, desta forma, que a separação dos conceitos de interpretação e aplicação constitui, na verdade, um mecanismo facilitador para a compreensão de todo o processo hermenêutico. Deve-se reconhecer, contudo, que na prática, o intérprete e o aplicador da norma jurídica se confundem numa mesma pessoa, de modo que não é possível separar a interpretação da aplicação da norma. Em outras palavras, o ato de interpretar e aplicar uma norma, na prática, são simultâneos, embora seja possível que a norma, embora aplicada, não produza os efeitos esperados.

Em vista disso, acreditamos que seja sob esta perspectiva prática que Sérgio André Rocha ${ }^{674}$, seguindo a lição de Dino Jarach ${ }^{675}$ e de Eros Grau ${ }^{676}$, distancie-se de

${ }^{672}$ MACHADO, João Baptista. Lições de Direito Internacional Privado, 4. ed., Coimbra: Almedina, 1990. pp. 111-112. Ainda sobre a questão da denominação de "conflitos de qualificação", adotando posicionamento distinto, SANTIAGO, Igor Mauler. Direito Tributário Internacional - Métodos de Solução dos Conflitos. São Paulo: Quartier Latin, 2006, pp. 92-96.

${ }^{673}$ BIANCO, João Francisco. Transparência Fiscal Internacional. São Paulo: Dialética, 2007, pp. 92-93.

${ }^{674}$ É interessante notar que o próprio Sérgio André Rocha, em artigo publicado em 2005. portanto, anterior à sua obra "Interpretação dos Tratados contra a Bitributação da Renda", que é de 2008, entendia que, sob a perspectiva do objetivismo metodológico gadameriano, havia, sim, uma separação entre os momentos da interpretação e da aplicação das normas jurídicas. É ver o seu comentário: "Uma das consequências do objetivismo metodológico antes descrito é a separação dos momentos de interpretação e aplicação das normas jurídicas. Com efeito, sob os influxos dessa linha de pensamento tem-se uma separação bem definida entre o intérprete, o objeto da interpretação e a questão que se pretende solucionar. Nesse cenário, o processo hermenêtico se daria em duas etapas distintas: em primeiro lugar, o intérprete desvelaria o sentido do texto legal para, então, aplicar a norma jurídica descoberta a uma determinada situação fática. É nesse sentido que se distinguem os momentos de interpretação e aplicação das normas jurídicas." ROCHA, Sérgio André. A Hermenêutica Jurídica sob o Influxo da Hermenêutica Filosófica de Hans-Georg Gadamer. In: Revista Tributária e de Finanças Públicas n. 64. Set. out. 2005. Ano 13. São Paulo: Revista dos Tribunais, 2005. pp. 291-292. Conclui-se, desta forma, que o autor em comento mudou de opinião entre as duas obras. 
Xavier ao afirmar que a interpretação e a qualificação não podem ser divididas como se fossem etapas sucessivas, estabelecendo uma crítica no sentido de que esta divisão pretendida entre a interpretação do texto e a valoração factual estaria fundamentada em ultrapassado formalismo jurídico, sendo que na moderna teoria hermenêutica não haveria espaço para esta rígida separação entre o fato e o intérprete ${ }^{677}$.

De fato, assiste razão a Rocha ao defender que o processo hermenêutico jurídico envolve o texto normativo, o intérprete e os fatos em questão, rejeitando a idéia de que o texto normativo seria interpretado de forma autônoma para somente após ser aplicado aos fatos. Analisando a tendência moderna já destacada por Rocha, João Francisco Bianco expõe de modo bastante objetivo os seus fundamentos dogmáticos:

"Há autores, no entanto, que sustentam não haver um claro marco temporal separando a interpretação da aplicação da norma jurídica, estando na verdade a primeira diluída na segunda.

Assim, segundo esses autores, inicialmente haveria de se distinguir o dispositivo da norma.

O dispositivo seria o texto normativo escrito; a norma seria o comando ou determinação legal que se extrai da análise do dispositivo. Um dispositivo pode conter duas ou mais normas. $O$ dispositivo que prevê a edição de lei para ser cobrado tributo, por exemplo, contém em si mesmo diferentes normas, quais sejam, o princípio da legalidade, o princípio da determinação dos conceitos, o princípio da vedação dos regulamentos independentes e o princípio da proibição da delegação normativa. E uma norma não necessariamente precisaria ser veiculada através de um dispositivo, pois poderia ser depreendida do exame do sistema. O princípio da segurança jurídica, por exemplo, decorre de uma série de princípios constitucionais -

675 “(...) 'não há interpretação da lei tributária que esteja fora da aplicação concreta da própria lei tributária'. Interpretação e aplicação não são termos antitéticos - dos quais o segundo seja a conseqüência do primeiro - porque a interpretação da lei é sempre a interpretação da realidade dos fatos. (...) ” JARACH, Dino. Hermenêutica no Direito Tributário. In: MORAES, Bernardo Ribeiro de. et al. Interpretação no Direito Tributário. São Paulo: Saraiva, 1975. p. 84.

${ }^{676}$ GRAU, Eros. Ensaio e Discurso sobre a Interpretação e Aplicação do Direito. São Paulo: Malheiros, 2002. p. 71 .

${ }^{677}$ ROCHA, Sérgio André. Interpretação dos Tratados contra a Bitributação da Renda. Rio de Janeiro: Lumen Juris, 2008, pp. 177. 
como o do Estado Democrático de Direito e o da legalidade - embora não conste de nenhum dispositivo específico.

Em função disso - sempre segundo essa corrente doutrinária - a atividade do intérprete não se resumiria a descrever o significado do dispositivo, mas sim a construir o seu sentido, identificando as possíveis normas que podem ser extraídas do texto escrito. Interpretar, portanto, seria produzir o significado da norma, não simplesmente através do exame do texto normativo, mas sim e principalmente a partir dos elementos fáticos do caso ao qual a norma deve ser aplicada.

O intérprete, portanto, interpretaria não só o dispositivo mas também os fatos para poder aplicar o Direito.

É por isso que os processos de interpretação e de aplicação não se realizariam autonomamente. (...),

Entendemos que esta é justamente a perspectiva prática do processo hermenêutico. Segundo já destacado por Sérgio André Rocha, ambas as atividades cognoscitivas desenvolvem-se no horizonte cultural do intérprete/aplicador, no campo de sua pré-compreensão, com implicações mútuas. E, nesse sentido, acompanha Eros Grau, para quem a norma (individual e concreta) é produzida pelo intérprete, não apenas a partir de elementos colhidos no texto normativo, mas também considerando os elementos do caso ao qual serão aplicadas, ou seja, a partir de dados da realidade ${ }^{679}$.

Acreditamos, desta forma, que tanto a doutrina da separação entre interpretação e aplicação como fases sucessivas quanto o entendimento de que ambas ocorrem simultaneamente estão corretas, na medida em que a doutrina do primeiro desenvolve-se sob a perspectiva dogmática, enquanto que o último analisa o problema das qualificações em face da prática do processo hermenêutico como um todo.

\footnotetext{
${ }^{678}$ BIANCO, João Francisco. Transparência Fiscal Internacional. São Paulo: Dialética, 2007, p. 94.

${ }^{679}$ ROCHA, Sérgio André. Interpretação dos Tratados contra a Bitributação da Renda. Rio de Janeiro: Lumen Juris, 2008, pp. 129-131. No mesmo sentido, CAMARGO, Maria Margarida Lacombe. Hermenêutica Jurídica e Argumentação: uma Contribuição ao Estudo do Direito. Rio de Janeiro: Renovar, 2001, pp. 2122. NEVES, Antônio Castanheira. O Actual Problema Metodológico da Interpretação Jurídica - I. Coimbra: Coimbra Editora, 2003. pp. 344-345. GRAU, Eros Roberto. Ensaio e Discurso sobre a Interpretação/Aplicação do Direito. São Paulo: Malheiros, 2002. p. 79. GUASTINI, Riccardo. Das Fontes às Normas. São Paulo: Quartier Latin, 2005. p. 73.
} 
De fato, como destacado por Rocha, na prática, o processo hermenêutico não comporta esta divisão em etapas sucessivas, apresentando-se único e indivisível. Porém, com finalidades didáticas, ou seja, para facilitar a compreensão dos institutos e do processo de qualificação, bem como os problemas a ele relacionados, acreditamos que a separação da interpretação e da aplicação do Direito em fases sucessivas tem sua utilidade e relevância. Entendemos, inclusive, que este é um dos motivos que levaram o Código Tributário Brasileiro a seguir, como demonstram seus artigos 105 a 112, a tradicional doutrina da separação entre interpretação e aplicação da norma tributária como fases sucessivas. Apesar disso, impõe-se reconhecer que durante o julgamento de um caso concreto envolvendo a aplicação de uma convenção de bitributação, o tribunal não dividirá o raciocínio em fase de interpretação e fase de aplicação da norma. Ambas as etapas ocorrerão, sim, simultaneamente.

Portanto, como já dissemos, a separação da interpretação e da aplicação possui, sim, uma finalidade didática, e deste modo, visando à melhor compreensão do problema das qualificações, nosso raciocínio considerará esta separação.

Superada esta questão, passa-se ao exame da relação do problema das qualificações com o Direito Internacional Privado. De fato, apesar de parte da doutrina ${ }^{680}$ tratar a questão envolvendo as qualificações mediante a denominação de "conflitos de qualificação", Vogel discorda dessa denominação por entender que não existe um “conflito" propriamente dito. Por isso, ele utiliza a denominação "problema de qualificações", ao invés de "conflito de qualificações", explicando que o termo "qualificação", originário do Direito Internacional Privado, é sinônimo de "caracterização", e este deve ser o sentido estrito do termo. Considerando que qualificar seria equivalente a caracterizar, não seria correto falar em "conflitos de qualificação", já que não haveria conflito, estritamente falando.

\footnotetext{
${ }^{680}$ Sérgio André Rocha utiliza a denominação "conflitos de qualificação", pois acredita que neste caso existe uma verdadeira antinomia, opinião da qual ousamos discordar. É conferir as palavras do autor: "Dessa forma, ao referirmo-nos a conflitos de qualificação, estaremos nos referindo a antinomias decorrentes da interpretação do direito interno de cada Estado contratante e não de uma etapa da aplicação das regras contidas nas CDTRs." ROCHA, Sérgio André. Interpretação dos Tratados contra a Bitributação da Renda. Rio de Janeiro: Lumen Juris, 2008, p. 179. Também utilizam a denominação "problemas de qualificação" os seguintes autores: SILVEIRA, Rodrigo Maitto da. Aplicação de Tratados Internacionais contra a Bitributação: qualificação de Partnership Joint Ventures, São Paulo: Quartier Latin, 2006, p. 175. ENGELEN, Frank. Interpretation of Tax Treaties under International Law. Amsterdam: IBFD, 2004. v. 7, pp. 502 e seguintes (IBFD Doctoral Series). VOGEL, Klaus. Conflicts of Qualification - The Discussion is not finished. In: Bulletin - Tax Treaty Monitor. fev. 2003. IBFD, pp. 41-44. AVERY JONES, John F. Conflicts of qualification: comment on Prof. Vogel's and Alexander Rust's Articles. In: Bulletin - Tax Treaty Monitor. mai. 2003. IBFD, pp. 184-186.
} 
Desta forma, segundo a doutrina de Vogel, seria mais correto que a denominação "conflitos de qualificação" somente fosse utilizada quando o "conflito" em questão efetivamente se aproximasse do conceito de conflito de qualificação segundo o Direito Internacional Privado, ou seja, divergência na determinação de qual norma seria aplicável para regular uma situação jurídica internacional.

Ademais, segundo já explicado no capítulo em que definimos a natureza jurídica das normas dos tratados de bitributação, não há como atribuir a tais normas a natureza de normas de conflito, uma vez que a sua verdadeira natureza é de normas de atribuição de competência, as quais são fundamentalmente distintas das normas de conflito propriamente ditas.

Por isso, o que impropriamente se denomina de "conflitos de qualificação" no âmbito das convenções de bitributação, na realidade, deveriam ser denominados de "problemas de qualificação", ou mesmo "questões de qualificação", haja vista a fundamental diferença conceitual entre ambos.

Superada a questão terminológica, ilustramos o problema das qualificações com alguns exemplos já mencionados por $\operatorname{Vogel}^{681}$ : (i) a remuneração paga a um maestro de uma orquestra durante por reger a orquestra numa gravação constitui um royalty ou constitui pagamento pela execução de serviços pessoais independentes (caso conhecido como Pierre Boulez ${ }^{682}$, que envolveu a aplicação do acordo entre Estados Unidos e Alemanha, nos termos do extinto art. 14 do Modelo OCDE / atual artigo 14 do Modelo ONU)? (ii) se os juros pagos por uma sociedade aos seus sócios constitui distribuição de lucros do negócio (nos termos do artigo $7^{\circ}$ ) ou constitui juros propriamente ditos (art. 11 do Modelo)? (iii) uma indenização por rescisão de contrato de trabalho paga a um empregado (mencionada por Vogel como um "golden handshake"683) constitui rendimentos de serviços pessoais dependentes (nas convenções brasileiras, rendimentos de

681 VOGEL, Klaus. On double taxation conventions: a commentary to the OECD, UN and US model conventions for the avoidance of double taxation of income and capital with particular reference to German treaty practice. 3. ed. Germany: Kluwer Law International, 1997, pp. 52-54.

682 VOGEL, Klaus. On double taxation conventions: a commentary to the OECD, UN and US model conventions for the avoidance of double taxation of income and capital with particular reference to German treaty practice. 3. ed. Germany: Kluwer Law International, 1997, pp. 52-54. SANTIAGO, Igor Mauler. Direito Tributário Internacional - Métodos de Solução dos Conflitos. São Paulo: Quartier Latin, 2006, p. 92.

683 VOGEL, Klaus. On double taxation conventions: a commentary to the OECD, UN and US model conventions for the avoidance of double taxation of income and capital with particular reference to German treaty practice. 3. ed. Germany: Kluwer Law International, 1997, pp. 52-54. 
empregado, artigo 15 do Modelo) ou deve ser enquadrado na categoria de outros rendimentos (artigo 21 do Modelo)? (vi) se um agente comissionado ou um agente comercial (representante comercial) deve ter seus rendimentos classificados como lucro de negócios (nos termos do artigo $7^{\circ}$ do Modelo) ou como rendimento do exercício de profissões independentes (artigo 14 do Modelo)? (vii) se os rendimentos recebidos pelo acionista majoritário em virtude do exercício do cargo de Diretor da Companhia constituem pagamento pela execução de serviços dependentes (como classificado pela Alemanha) ou se tais rendimentos constituem pagamento pela execução de serviços independentes, ou, ainda, se tais rendimentos enquadram-se na categoria de outros rendimentos?

Como demonstram os exemplos acima, o problema das qualificações ocorre quando dois Estados tratam um mesmo fato jurídico tributário internacional de forma diferente, porém com a mesma finalidade. Isto, segundo Xavier, ocorre em dois estágios: primeiro, no que ele denomina de "qualificação primária", caracteriza-se um fato concreto da vida em face da legislação interna com o objetivo de determinar sua natureza jurídica, e, num momento seguinte, durante a chamada "qualificação secundária", aquele fato que já foi caracterizado pelo conceito do Direito interno, ou seja, quando já ocorreu a subsunção do fato da vida à norma doméstica, ocorre o exame daquele mesmo fato que agora já se encontra previamente qualificado ao conceito presente no tratado ${ }^{684}$.

Nesse sentido, Xavier destaca que não se trata de uma simples subsunção de fatos a conceitos jurídicos, já que esta concepção explica apenas a primeira fase do processo. Desta forma, os fatos concretos da vida constituem o objeto da qualificação primária, enquanto que os fatos jurídicos (fatos da vida sobre os quais já houve a incidência das normas jurídicas domésticas) formam o objeto da qualificação secundária. Desta forma, seria correto afirmar que a qualificação, no âmbito dos tratados (e também do Direito Tributário Internacional), reporta-se a fatos jurídicos, e não a meros fatos quotidianos da vida, sendo que o aspecto relevante para a qualificação nas convenções de bitributação consiste exatamente em quem terá a competência para qualificar o fato jurídico, e não como ele será qualificado.

684 VOGEL, Klaus. On double taxation conventions: a commentary to the OECD, UN and US model conventions for the avoidance of double taxation of income and capital with particular reference to German treaty practice. 3. ed. Germany: Kluwer Law International, 1997, pp. 52-54. XAVIER, Alberto. Direito Tributário Internacional do Brasil, 6. ed. Rio de Janeiro: Forense, 2007, p. 172. ROTHMANN, Gerd W. Interpretação e Aplicação dos Acordos Internacionais contra a Bitributação. Tese (doutorado). Faculdade de Direito da Universidade de São Paulo. São Paulo, 1978, pp. 58 e seguintes. 
Se o tratado não dispuser expressamente sobre como resolver o problema das qualificações, a doutrina tradicionalmente ${ }^{685}$ menciona três métodos básicos para a solução do problema das qualificações, a seguir explicados.

\subsubsection{Qualificação pela Lex Fori}

A qualificação segundo o método da Lex Fori (lei do Estado estrangeiro) consiste em cada país qualificar o termo ou expressão objeto da discussão segundo o seu Direito interno. O argumento favorável a este método está no fato de que as autoridades fiscais de ambos os países contratantes naturalmente entendem melhor o seu Direito interno. Todavia, ambos os Estados envolvidos fatalmente aplicariam o tratado de forma distinta, eis que os Direitos internos nunca são iguais, o que não resolveria o problema das qualificações, mantendo a bitributação ou mesmo gerando uma situação de dupla nãotributação. No caso da indenização paga ao trabalhador descrita no exemplo do "golden handshake" acima mencionado, a indenização paga por uma empresa alemã a um exgerente que era residente na Suíça constituía rendimentos de serviços na visão da Alemanha e, desta forma, seria tributável na Alemanha, que era o Estado-fonte do pagamento. Porém, sob o ponto de vista da Suíça, a indenização em questão enquadrava-se na categoria de "outros rendimentos", os quais, pelo artigo 21 do acordo entre a Alemanha e a Suíça, ensejava a tributação na Suíça, que era o Estado de residência. Sob outra perspectiva, ainda com relação ao exemplo do "golden handshake", caso a empresa em questão fosse suíça e o gerente fosse residente na Alemanha, nenhum dos países poderia tributar o rendimento, nos termos do acordo entre a Alemanha e a Suíça ${ }^{686}$. Neste caso, o problema da dupla não-tributação seria ainda mais grave, já que, no caso da dupla tributação, a questão ainda poderia ser resolvida por meio do procedimento amigável previsto na convenção, o que não seria aplicável para a dupla não-tributação. Este exemplo demonstra, portanto, a ineficácia do método da Lex Fori para resolver o problema das qualificações.

\footnotetext{
685 VOGEL, Klaus. On double taxation conventions: a commentary to the OECD, UN and US model conventions for the avoidance of double taxation of income and capital with particular reference to German treaty practice. 3. ed. Germany: Kluwer Law International, 1997, pp. 52-54.

${ }^{686}$ VOGEL, Klaus. On double taxation conventions: a commentary to the OECD, UN and US model conventions for the avoidance of double taxation of income and capital with particular reference to German treaty practice. 3. ed. Germany: Kluwer Law International, 1997, pp. 56-57.
} 


\subsubsection{Qualificação pelo Estado da Fonte}

Qualificação segundo o país da fonte, pela qual ambos os Estados ficam obrigados a concordar com a qualificação conferida ao termo pela legislação do país da fonte dos rendimentos. Este método foi defendido Avery Jones ${ }^{687}$ e pelos demais membros do chamado "International Tax Group", tendo sido acolhido a partir de 1999, com fundamento na aplicação do artigo 3(2) do Modelo da OCDE, por meio do reenvio ao Direito interno. Nesse ponto, concordamos com Alberto Xavier ${ }^{688}$ e com Rodrigo Maitto da Silveira ${ }^{69}$ no sentido de que o artigo 3(2) é inaplicável para a solução do problema das qualificações porque ele se refere ao momento da interpretação, que é anterior ao da aplicação do tratado ${ }^{690}$. Quando um país interpreta a convenção de bitributação e se depara com um termo não definido na convenção, ele deve inicialmente buscar o significado daquele termo no contexto do tratado. Caso esta solução não traga resultados satisfatórios, então, em último caso ${ }^{691}$, existe a alternativa, pelo artigo 3(2), de recorrer ao ordenamento jurídico interno para defini-lo. Isto necessariamente ocorre antes da aplicação da convenção, ainda no momento da interpretação, eis que não há como aplicar uma norma que contenha uma lacuna em seu corpo. Neste ponto, é importante notar que apesar de o artigo 3(2) não se aplicar com o objetivo de solucionar o problema das qualificações, os fundamentos de aplicação do artigo 3(2) que são válidos para a determinação de qual seria o Direito interno apto a fornecer o significado do termo não definido no tratado (ainda durante a fase de interpretação), são similares aos que servem para embasar, já na fase de

${ }^{687}$ AVERY JONES, John F. et al. The Interpretation of Tax Treaties with Particular Reference to Article 3(2) of the OECD Model - II. In: British Tax Review, n. 2. 1984. AVERY JONES, John F. The one true meaning of a Tax Treaty. In: Bulletin - Tax Treaty Monitor. Amsterdam: IBFD, 2001 (June), p. 220-224.

${ }^{688}$ XAVIER, Alberto. Direito Tributário Internacional do Brasil, 6. ed. Rio de Janeiro: Forense, 2007, pp. 190 e seguintes.

${ }^{689}$ SILVEIRA, Rodrigo Maitto da. Aplicação de Tratados Internacionais contra a Bitributação: qualificação de Partnership Joint Ventures. São Paulo: Quartier Latin, 2006, pp. 135-137.

${ }^{690}$ Embora Vogel defenda que, para os fins do artigo 3(2) as expressões "aplicação" e "interpretação" sejam sinônimas, uma vez que a norma do artigo deve ser aplicada durante a interpretação, acreditamos que, relativamente ao problema das qualificações, tais expressões possuem significados distintos, sendo a interpretação um estágio que antecede a aplicação do acordo. VOGEL, Klaus. On double taxation conventions: a commentary to the OECD, UN and US model conventions for the avoidance of double taxation of income and capital with particular reference to German treaty practice. 3. ed. Germany: Kluwer Law International, 1997, p. 112.

${ }^{691}$ Defendendo que o recurso ao Direito interno deve ocorrer apenas em último caso: PIRES, Manuel. Da Dupla Tributação Jurídica Internacional sobre o Rendimento. Lisboa: Centro de Estudos Fiscais - Ministério das Finanças, 1984. pp. 456. 
aplicação do acordo, a determinação da competência qualificatória. Em outras palavras, durante a interpretação do tratado, pelo artigo 3(2), trata-se de definir qual Estado é competente para fornecer o significado de um termo não definido, ao passo que na solução do problema da qualificação, não se trata de preencher uma lacuna, mas sim de verificar a subsunção de um rendimento descrito faticamente a um conceito jurídico, e o que deve ser definido, neste caso, é exatamente qual o conceito jurídico aplicável para descrever aquela situação fática. Somente depois de definido o tipo de rendimento em questão, ou seja, somente depois qualificado o rendimento, é que será possível aplicar a convenção no sentido de definir qual será o Estado competente para tributá-lo. Superada esta questão, é certo que a qualificação pelo Estado da fonte só funciona desde que o Estado de residência efetivamente aceite a qualificação dada pelo Estado da fonte ao rendimento em questão, o que não pode ser esperado nem muito menos previsto, já que, pelo princípio da soberania, um Estado não pode ser compelido a aceitar a qualificação fornecida pelo outro ${ }^{692}$. Além disso, é necessário considerar que o método da qualificação segundo o país da fonte acaba beneficiando os Estados cujo Direito possua definições mais amplas de seus conceitos, o que vai de encontro a um dos objetivos das convenções de bitributação, qual seja, o de promover a distribuição igualitária da competência tributária entre ambos os Estados contratantes. Assim, observa-se que, embora seja aplicável em casos isolados, o método da qualificação pelo Estado da Fonte não constitui uma solução universal para o problema das qualificações.

\subsubsection{O “New Approach" da OCDE}

O "New Approach", elaborado pelo Comitê de Assuntos Fiscais da OCDE com base na teoria da qualificação pelo Estado da Fonte anteriormente elaborada pelo International Tax Group, constitui uma teoria de qualificação que possui aplicação específica para as partnerships. Segundo Rodrigo Maitto da Silveira, o New Approach pode ser dividido em dois tópicos: (i) exame das situações internacionais envolvendo partnerships sob a perspectiva da tributação pelo Estado da fonte, pelo Estado de residência dos sócios e pelo Estado de residência da própria partnership, (ii) problemas de

${ }^{692}$ MICHELSEN, Aage. Tax Treaty Interpretation in Denmark. In: LANG, Michael (Coord.). Tax Treaty Interpretation. Vienna: Linde Verlag, 2001, pp. 74-75. 
qualificação decorrentes da aplicação de diferentes cláusulas de um tratado pelos países envolvidos, com fundamento na lei interna.

Em linhas gerais, no que se refere à qualificação dos rendimentos, o New Approach determina que a qualificação deverá ser feita pelo Estado da fonte, cabendo ao Estado de residência acatar à qualificação apresentada pelo país-fonte, mediante fundamento no artigo 3(2) do Modelo da OCDE. Isto ocorre com facilidade para os casos em que a norma de atribuição é uma norma fechada, ou de atribuição exclusiva, como preferem alguns autores, contendo a expressão "shall be taxed only", que atribui a competência tributária exclusiva para um dos Estados, devendo o outro Estado, obrigatoriamente, isentar o rendimento.

Contudo, nos casos em que a norma de atribuição é uma norma aberta, ou de atribuição concorrente, caracterizada pela expressão "may be taxed", abre-se a possibilidade de tributação em ambos os Estados. Como esta "possibilidade", na prática, é na verdade uma certeza, então a consequência lógica é a bitributação residual. Assim, segundo o New Approach, torna-se necessária a aplicação, pelo Estado de residência, dos métodos previstos nos artigos 23-A e 23-B do Modelo, que solucionariam a dupla incidência.

Assim, pelo New Approach, a obrigação de evitar a bitributação acaba sempre recaindo sobre o Estado de residência, que de qualquer forma seria compelido a aceitar a qualificação do rendimento fornecida pelo Estado da fonte.

Na realidade, a diferença do New Approach para a teoria da qualificação pelo Estado da fonte, elaborada pelo International Tax Group, consiste na interpretação diferente do artigo 3(2) do Modelo da OCDE, norma que serve de fundamento para ambas. A teoria da qualificação pelo Estado da Fonte é baseada na interpretação do termo "apply", contido no referido artigo 3(2), indicando que somente o Estado de residência aplicaria o tratado, acatando à qualificação fornecida pelo Estado da fonte, o qual, por sua vez, sequer chegaria a aplicar o acordo, já que a tributação na fonte decorreria de seu próprio Direito interno. Porém, como já explicado anteriormente, a aplicação isolada do método da fonte pode culminar em situações em que a dupla tributação não é evitada, ou pior, em situações em que, dependendo da qualificação, ocorre a dupla não-tributação. Para resolver este problema, o New Approach, representando uma verdadeira evolução da teoria da qualificação pelo Estado da Fonte, fundamenta-se no próprio artigo 3(2) para a qualificação pelo Estado da fonte relativamente aos termos e expressões não definidos no 
acordo, porém invoca expressamente a aplicação dos métodos da isenção ou do crédito previstos nos artigos 23-A e 23-B da convenção-Modelo, os quais necessariamente seriam aplicados pelo Estado de residência, que é o Estado que aplica a convenção.

A qualificação pelo Estado da Fonte, segundo o New Approach, seria uma decorrência da aplicação das regras de isenção e imputação presentes nos próprios acordos, não podendo ser considerada, a priori, uma regra de competência qualificatória exclusiva como é o caso do método da qualificação pela fonte.

Apesar de eficaz para os casos envolvendo a qualificação de rendimentos, o New Approach também não é infalível, já que não se aplica para problemas de qualificação relativos aos pressupostos de aplicação do acordo, como aqueles envolvendo a determinação da qualidade da pessoa jurídica ou mesmo a residência de pessoas físicas ou jurídicas. Em outras palavras, o New Approach não se aplica aos problemas de qualificação referentes às disposições convencionais que não sejam relacionadas especificamente com os tipos de rendimentos, e por isso, é um método falho e incompleto ${ }^{693}$.

\subsubsection{Qualificação autônoma}

A qualificação autônoma é baseada na chamada "Linguagem Fiscal Internacional” ${ }^{\prime 694}$, que seria formada precipuamente pelas expressões autônomas contidas nos próprios tratados, bem como pelas explicações constantes dos comentários ao Modelo da OCDE em sua versão original, de 1963, e também na de 1977. Os termos e expressões

\footnotetext{
${ }^{693}$ VOGEL, Klaus. On double taxation conventions: a commentary to the OECD, UN and US model conventions for the avoidance of double taxation of income and capital with particular reference to German treaty practice. 3. ed. Germany: Kluwer Law International, 1997, p. 57. VOGEL, Klaus. Conflicts of Qualification: The Discussion is Not Finished. In: Bulletin - Tax Treaty Monitor. Amsterdam: IBFD, Fev. 2003. pp. 41-44. AVERY JONES, John F. The "One True Meaning” of a Tax Treaty. In: Bulletin - Tax Treaty Monitor. Amsterdam: IBFD, jun. 2001, pp. 220-224. RUST, Alexander. The New Approach to Qualification Conflicts Has its Limits. In: Bulletin - Tax Treaty Monitor. Amsterdam: IBFD, fev. 2003. pp. 45-50. ROCHA, Sérgio André. Interpretação dos Tratados contra a Bitributação da Renda. Rio de Janeiro: Lumen Juris, 2008, p. 184. AVERY JONES, John F. Conflicts of Qualification: Comment on Prof. Vogel's and Alexander Rust's Articles. In: Bulletin - Tax Treaty Monitor. May. 2003. Amsterdam: IBFD, p. 184-186.

694 VOGEL, Klaus. On double taxation conventions: a commentary to the OECD, UN and US model conventions for the avoidance of double taxation of income and capital with particular reference to German treaty practice. 3. ed. Germany: Kluwer Law International, 1997, p. 58 . HACCIUS, Charles. Ireland in International Tax Planning. 2. ed. Amsterdam: IBFD, 2004. pp. 191-234. ENGELEN, Frank. Interpretation of Tax Treaties under International Law. Amsterdam: IBFD, 2004. v. 7, p. 444. (IBFD Doctoral Series). VOGEL, Klaus. The influence of the OECD Commentaries on Treaty Interpretation. In: Bulletin - Tax Treaty Monitor. Amsterdam: IBFD, dez. 2000. pp. 612-616.
} 
definidos segundo a Linguagem Fiscal Internacional prevaleceriam sobre as definições do Direito interno dos Estados. A vantagem deste método está justamente em seu caráter de independência e isenção entre as partes. Contudo, nem sempre os termos já definidos nos tratados serão suficientes para qualificar toda a gama de situações que podem ocorrer envolvendo rendimentos transnacionais, e nem sempre o conceito apresentado no texto terá o desejado grau de definição e certeza, havendo sempre um espaço, mesmo que mínimo, para o reenvio integrativo ao Direito interno. Somam-se a isso as dificuldades relativas às negociações para se chegar à definição que será incluída no tratado. Enfim, como todos os métodos, a interpretação autônoma também encontra uma série de empecilhos, embora seja a única, no nosso entendimento, que reforce a importância de se verificar primeiramente o contexto interno da convenção e aumente as possibilidades de se conseguir a interpretação comum do tratado.

\subsubsection{Qualificação pelo Estado de Residência}

Outro método que, embora não muito difundido na doutrina, também pode ser aplicado para a solução do problema das qualificações consiste na qualificação do termo a partir da definição fornecida pelo Estado de residência, com fundamento no fato de que, de acordo com os modelos de convenção mais utilizados (OCDE e US Model), a regra é a atribuição da competência tributária para o Estado da residência, restringindo-se a tributação pelo Estado da fonte apenas a alguns casos específicos. O problema, neste método, é que nem sempre é possível estabelecer com precisão qual é o Estado de residência do contribuinte. Pode ser, como de fato acontece, que haja um empate nos critérios fornecidos pelo artigo 4o do Modelo da OCDE, de modo que um mesmo contribuinte seja considerado residente de dois, ou mesmo de mais, Estados contratantes, ao mesmo tempo. Além disso, tal como ocorre com o método da qualificação pelo Estado da fonte, a qualificação pelo Estado da residência tenderia a beneficiar o Estado cujo conceito jurídico para o rendimento em questão fosse o mais amplo. Então, no final do processo, a solução para o problema das qualificações acabaria sendo resolvida pelo procedimento amigável, e não pelo critério da residência.

Evidencia-se, pois, que nenhum dos métodos é infalível se considerado isoladamente. Nesse sentido, Vogel defende a combinação de métodos, dependendo do tipo de norma do tratado em relação à qual surge o problema da qualificação. Assim, se o problema de qualificação envolver a aplicabilidade do tratado em si, como por exemplo a 
determinação da residência ou a determinação da possibilidade de sujeição ao tratado, o método mais adequado seria aquele da qualificação pelo Estado que estivesse aplicando o acordo, ou seja, o método da Lex Fori.

A aplicação divergente das normas que instituem os pressupostos de aplicação do tratado teria como efeito a inaplicabilidade deste em um dos Estados, o que, por sua vez, acarretaria dupla tributação residual (que ocorre quando ambos os Estados são considerados competentes para tributar o mesmo fato, mesmo depois da aplicação da norma de atribuição presente no tratado), podendo causar também, dependendo da interpretação, a dupla não-tributação. O método da Lex fori, neste caso, somente poderia resolver o caso da dupla tributação residual, e mesmo assim, na maioria das vezes, com auxílio do procedimento amigável. A dupla não-tributação não poderia ser solucionada.

Sob outro ponto de vista, quando o problema de qualificação é referente à norma de atribuição propriamente dita, precisamente quanto aos seus requisitos, Vogel observa que, de fato, o método da Lex Fori não resolve o problema, devendo ser aplicado sempre que possível o método da interpretação autônoma, incluindo no contexto do tratado os comentários ao Modelo da OCDE e ao Modelo da ONU. Em último caso, poderia ser feito, ainda, o reenvio integrativo já mencionado por Heleno Torres ${ }^{695}{ }^{696}$

\subsubsection{A teoria das competências qualificatórias exclusivas}

Adotando posicionamento distinto do tradicional entendimento de Vogel, Alberto Xavier ensina que existem apenas competências qualificatórias exclusivas, as quais variam de acordo com o objeto e com a natureza das questões ${ }^{697}$.

Segundo ele, quando o problema de qualificação for referente ao tipo de rendimento (que Xavier denomina de "conceito-quadro da norma"), então a competência qualificatória será sempre do Estado da fonte do rendimento. Para esclarecer seu

${ }^{695}$ TORRES, Heleno Taveira. Pluritributação Internacional sobre as Rendas de Empresas. 2. ed. rev., ampl. e atual. São Paulo: Revista dos Tribunais, 2001, p. 648.

696 VOGEL, Klaus. On double taxation conventions: a commentary to the OECD, UN and US model conventions for the avoidance of double taxation of income and capital with particular reference to German treaty practice. 3. ed. Germany: Kluwer Law International, 1997, p. 60. VOGEL, Klaus. The influence of the OECD Commentaries on Treaty Interpretation. In: Bulletin - Tax Treaty Monitor. Amsterdam: IBFD, dez. 2000. pp. 612-616.

${ }^{697}$ XAVIER, Alberto. Direito Tributário Internacional do Brasil, 6. ed. Rio de Janeiro: Forense, 2007, pp. 199. 
entendimento, cita o exemplo do termo "dividendos" (que é o conceito-quadro ao qual Xavier se refere), que, a teor do artigo 10(3) do Modelo, "abrange os rendimentos de ações ou assemelhados aos rendimentos de ações pela legislação tributária do Estado contratante em que seja residente a sociedade que os distribuir”. O mesmo ocorre com relação aos rendimentos imobiliários, os quais, pelo artigo 6(2) do Modelo da OCDE, são definidos de acordo com "a legislação do Estado contratante em que os bens em questão estiverem situados". Com estes exemplos Xavier pretende demonstrar que, em relação aos conceitos-quadro, a competência sempre recai no Estado da Fonte ${ }^{698}$.

Por outro lado, se o problema de qualificação for relativo aos demais pressupostos de aplicação da convenção, por exemplo, a nacionalidade, a residência, ou a condição de pessoa jurídica em relação a um dos Estados contratantes, então a competência qualificatória será do Estado que tenha vocação natural para regular aquele pressuposto, o que Xavier denominou de lex situationis. Desta forma, hipoteticamente, numa situação em que o Brasil esteja aplicando a convenção Brasil-Holanda, digamos que exista um problema de qualificação referente à determinação da aplicação da convenção aos rendimentos pagos por uma pessoa física que alega ser residente no Brasil a uma pessoa física que alega ser residente na Holanda. Qual será o país competente para resolver este problema? Obviamente, o Brasil será competente para determinar se o indivíduo que paga os rendimentos em questão efetivamente é residente no Brasil, enquanto a Holanda será competente para verificar a residência do sujeito que alega ser residente na Holanda. Num outro exemplo, envolvendo o pressuposto de possuir a qualidade de pessoa jurídica, nos termos da Convenção Brasil-Canadá, aplicada no Brasil. Neste caso, o mesmo raciocínio do exemplo anterior é válido para o problema de qualificação relativo a verificar se um trust canadense possui personalidade jurídica, ou seja, se pode ser considerado sujeito para fins de aplicação da convenção. É claro que o Estado competente para determinar a personalidade jurídica do trust canadense será o Canadá, pois seria um absurdo jurídico pretender que a legislação brasileira fosse utilizada para qualificar uma pessoa jurídica criada no Canadá. E, neste caso específico, o absurdo seria ainda maior, já que o Direito brasileiro não regulamenta os trusts. ${ }^{699}$

\footnotetext{
${ }^{698}$ XAVIER, Alberto. Direito Tributário Internacional do Brasil, 6. ed. Rio de Janeiro: Forense, 2007, pp. 201-202.

699 XAVIER, Alberto. Direito Tributário Internacional do Brasil, 6. ed. Rio de Janeiro: Forense, 2007, pp. 203-206.
} 
Desta maneira, Xavier sintetiza: "Lei aplicável é, quanto ao conceito-quadro, a lei do Estado da fonte do rendimento e, quanto aos demais pressupostos, a lex situationis, de tal modo que dizer que ela é a lex fori ou lex causae é de todo irrelevante (...), ${ }^{\natural 00} \mathrm{E}$, especificamente quanto aos meios de solução da bitributação residual, ou seja, os métodos da isenção ou da imputação (previstos nos artigos 23A e B do Modelo da OCDE), Xavier defende a competência qualificatória exclusiva do Estado de residência, uma vez que, segundo os referidos artigos, tais métodos sempre serão aplicados pelo Estado de residência. Em outras palavras, naqueles casos em que ambos os Estados podem tributar o rendimento (hipóteses de tributação cumulativa), caberá ao Estado da Fonte tributar primariamente o rendimento, e caberá ao Estado da residência a tributação secundária, que necessariamente virá acompanhada de um dos métodos (isenção ou imputação) para evitar a dupla tributação.

A teoria alternativa apresentada por Xavier, à qual nos filiamos, apresenta duas importantes conclusões: primeiro, o artigo 3(2) do Modelo da OCDE não se aplica para fins de solução de problemas de qualificação, já que sua aplicabilidade está relacionada precisamente com a interpretação do tratado, fase imediatamente anterior à de aplicação, na qual ocorrem os problemas de qualificação, e, em segundo lugar, demonstra que a solução fornecida pela teoria tradicional, que permite a atribuição cumulativa da competência qualificatória, jamais resolverá o problema, justamente porque ao permitir que os dois Estados exerçam a qualificação concomitantemente, fatalmente acabaremos em uma situação em que a dupla tributação não é evitada, ou então numa situação em que se verifica a dupla não-tributação, a qual também não constitui o objetivo das convenções.

De fato, a teoria de Xavier é fundamentada exatamente na impossibilidade de existir competência qualificatória cumulativa, partindo do pressuposto que, para resolver o problema das qualificações, somente pode haver atribuição de competência exclusiva a um dos Estados, dependendo da natureza do objeto do problema de qualificação. Se a atribuição é sempre exclusiva, então não há como haver dupla tributação, muito menos dupla não-tributação. Em resumo, pela teoria de Xavier, a competência qualificatória será do Estado da fonte quando o problema de qualificação for relativo a um conceito-quadro. Já se o problema de qualificação for relativo aos pressupostos de aplicação da convenção, então a competência será segundo a lex situationis. Por fim, caberá a competência

${ }^{700}$ XAVIER, Alberto. Direito Tributário Internacional do Brasil, 6. ed. Rio de Janeiro: Forense, 2007, p. 206. 
qualificatória ao Estado de residência quando o problema de qualificação for relativo às normas especificamente destinadas à aplicação pelo Estado de residência, ou seja, as normas que visam à solução da bitributação residual mediante a utilização dos métodos de isenção ou imputação, conforme for o caso.

De toda forma, independente da teoria que se escolha, é imprescindível que o problema das qualificações seja sempre considerado à luz do "object and purpose" do tratado, tal como definido no artigo $31(1)$ da Convenção de Viena ${ }^{701}$.

Por fim, é necessário notar que o problema das qualificações jamais será solucionado de forma permanente, já que este é um problema intrínseco às próprias convenções. A própria evolução dos conceitos e institutos jurídicos é, por si só, uma das causas do problema das qualificações. Já explicamos também que nem mesmo utilizando apenas expressões autônomas estaríamos livres do problema, eis que, mesmo as expressões autônomas possuem em sua definição conceitos indeterminados ou conceitos extraídos do Direito interno dos Estados que acabam exigindo, de uma forma ou de outra, o reenvio integrativo. Desta forma, é inquestionável que sempre que se aplicar uma convenção de bitributação, existirá a possibilidade de ocorrência de uma divergência qualificatória em relação a alguma de suas normas. Não que isso necessariamente vá existir, porém, a possibilidade de sua ocorrência jamais será eliminada.

\subsubsection{Métodos de solução de conflitos interpretativos}

\subsubsection{O Procedimento Amigável}

Um dos meios previstos pela Convenção Modelo da OCDE para a solução de questões envolvendo a interpretação de convenções de bitributação consiste no chamado “Procedimento Amigável”, que está previsto no artigo 25 do Modelo, abaixo transcrito.

“Artigo 25 - Procedimento Amigável.

1) Quando uma pessoa considerar que as medidas tomadas por um ou por ambos os Estados Contratantes conduzam ou conduzirão, em relação a si, a tributação em desacordo com as disposições da presente Convenção, esta

\footnotetext{
${ }^{701}$ ENGELEN, Frank. Interpretation of Tax Treaties under International Law. Amsterdam: IBFD, 2004. v. 7 , p. 505 (IBFD Doctoral Series). AVERY JONES. Interpretation of Double Taxation Conventions. In : Interpretation of Double Taxation Conventions. Cahiers de Droit Fiscal International. 1993 Florence Congress, International Fiscal Association., vol. LXXVIIIa. pp. 602 e seguintes.
} 
pessoa poderá, independentemente dos recursos previstos pelas legislações nacionais destes Estados, submeter o seu caso à apreciação da autoridade competente do Estado Contratante de que é residente, ou, se o caso corresponder à disposição do primeiro parágrafo do artigo 24, à autoridade competente do seu Estado de nacionalidade. O caso deverá ser apresentado em até três anos contados a partir da primeira notificação da ação resultante na tributação em desacordo com as disposições da Convenção.

2) A autoridade competente, se a reclamação se lhe afigurar justificada e se a autoridade em questão não estiver ela própria em condições de lhe dar uma solução satisfatória, esforçar-se-á por resolver a questão através de procedimento amigável com a autoridade competente do outro Estado Contratante, a fim de evitar tributação em desacordo com a Convenção. Quaisquer acordos alcançados deverão ser implementados independentemente dos limites temporais provistos na legislação interna dos Estados contratantes.

3) As autoridades competentes dos Estados Contratantes esforçar-se-ão por resolver, através de procedimento amigável, quaisquer dificuldades ou dúvidas relativas à interpretação ou aplicação da Convenção. Poderão, também, consultar-se mutuamente com vistas a eliminar a dupla tributação nos casos não previstos na Convenção.

4) As autoridades competentes dos Estados contratantes poderão comunicar-se entre si diretamente, inclusive por meio de uma comissão conjunta formadas pelos seus próprios membros ou por representantes, com o objetivo de alcançar um acordo no sentido do estabelecido nos parágrafos anteriores. "702

${ }^{702}$ Tradução livre. No original: “ARTICLE - 25 MUTUAL AGREEMENT PROCEDURE.

1. Where a person considers that the actions of one or both of the Contracting States result or will result for him in taxation not in accordance with the provisions of this Convention, he may, irrespective of the remedies provided by the domestic law of those States, present his case to the competent authority of the Contracting State of which he is a resident or, if his case comes under paragraph 1 of Article 24, to that of the Contracting State of which he is a national. The case must be presented within three years from the first notification of the action resulting in taxation not in accordance with the provisions of the Convention.

2. The competent authority shall endeavour, if the objection appears to it to be justified and if it is not itself able to arrive at a satisfactory solution, to resolve the case by mutual agreement with the competent authority of the other Contracting State, with a view to the avoidance of taxation which is not in accordance with the Convention. Any agreement reached shall be implemented notwithstanding any time limits in the domestic law of the Contracting States. 
Em linhas gerais, trata-se da possibilidade de as autoridades fiscais (ou de uma comissão por elas constituída) dos Estados contratantes entrarem em contato direto, sem a necessidade da via diplomática, com o fim de resolver problemas relativos à tributação em descompasso com a convenção, bem como para esclarecer dificuldades ou dúvidas referentes à interpretação dos termos e expressões, e ainda para esclarecer e corrigir erros na avaliação de fatos relevantes para a aplicação do tratado. Sua natureza é, pois, essencialmente instrumental, tendo a função de regular bilateralmente a execução do que foi acordado $^{703}$, embora não se exija que dele surja uma solução definitiva para o problema.

O procedimento amigável também pode ser utilizado para solucionar problemas deste tipo também relacionados com os chamados "triangular tax cases". Neste caso, não se trata de realizar um procedimento multilateral englobando todos os Estados envolvidos ao mesmo tempo. Trata-se, sim, de realizar vários procedimentos amigáveis bilaterais concomitantes ${ }^{704}$.

Um dos objetivos do procedimento consiste em verificar se os fatos que acarretaram tributação em desacordo com a convenção foram devidamente avaliados e subsumidos às normas convencionais, e se a aplicação da convenção atingiu ou não as metas propostas. Em outras palavras, trata-se de constatar se houve a alegada violação da norma convencional e providenciar a devida reparação, caso aplicável ${ }^{705}$, inclusive sendo possível que a solução de um problema individual de um contribuinte assuma caráter geral, especialmente quando o problema em questão é relativo à interpretação do tratado. Desta

3. The competent authorities of the Contracting States shall endeavour to resolve by mutual agreement any difficulties or doubts arising as to the interpretation or application of the Convention. They may also consult together for the elimination of double taxation in cases not provided for in the Convention.

4. The competent authorities of the Contracting States may communicate with each other directly, including through a joint commission consisting of themselves or their representatives, for the purpose of reaching an agreement in the sense of the preceding paragraphs."

703 TORRES, Heleno Taveira. Pluritributação Internacional sobre as Rendas de Empresas. 2. ed. rev., ampl. e atual. São Paulo: Revista dos Tribunais, 2001, p. 685-686.

704 VOGEL, Klaus. On double taxation conventions: a commentary to the OECD, UN and US model conventions for the avoidance of double taxation of income and capital with particular reference to German treaty practice. 3. ed. Germany: Kluwer Law International, 1997, p. 1353.

705 VOGEL, Klaus. On double taxation conventions: a commentary to the OECD, UN and US model conventions for the avoidance of double taxation of income and capital with particular reference to German treaty practice. 3. ed. Germany: Kluwer Law International, 1997, p. 1365. SANTIAGO, Igor Mauler. Direito Tributário Internacional - Métodos de Solução dos Conflitos. São Paulo: Quartier Latin, 2006, p. 184. 
forma, visa-se a um objetivo maior, que é o aperfeiçoamento da própria convenção e o aumento da segurança jurídica na interpretação e aplicação das normas convencionais.

O procedimento amigável pode ser requerido tanto pelo contribuinte, mediante simples alegação da ocorrência de tributação desconforme com a convenção, quanto ex officio, pelas autoridades fiscais dos próprios Estados. Entretanto, é importante considerara que quem dará início ao procedimento amigável será sempre a Autoridade competente do Estado contratante, assim definida nos termos do artigo 3o do Modelo, nunca o contribuinte em si, porque este, a rigor, não constitui "parte" na Convenção. A legitimidade do contribuinte é, pois, para requerer a realização, e não para o ato de iniciar o procedimento amigável $^{706}$.

Conforme expressamente consta do primeiro parágrafo do artigo 25, a requisição pelo contribuinte às autoridades competentes exige apenas que ele seja residente de um dos Estados, ou no caso de alegações envolvendo violação do princípio da nãodiscriminação, que ele seja nacional de um dos Estados contratantes, não sendo-lhes exigido o esgotamento dos remédios disponíveis no Direito interno do seu Estado de residência, mas permitindo-se, outrossim, que as autoridades dos Estados contratantes verifiquem a procedência e legitimidade do pedido do contribuinte antecipadamente ao início dos trabalhos. Como a legitimidade para requerer a execução de um procedimento amigável não depende, a priori, da existência de regulamentação interna no Estado de residência nesse sentido (legislação integrativa), trata-se, conforme ensina Heleno Torres, de uma norma auto-executável ${ }^{707}$.

Também não constitui requisito a efetiva ocorrência de bitributação, sendo suficiente para o início do procedimento amigável que a tributação tenha ocorrido em desacordo com a convenção, como por exemplo, mediante aplicação de uma alíquota indevida. Neste aspecto, $\operatorname{Vogel}^{708}$ destaca que embora seja possível requerer a realização de procedimento amigável para obter a dupla não tributação - desde que esta seja resultante da correta aplicação das cláusulas da convenção - , não é legítima a pretensão de se iniciar

\footnotetext{
706 TORRES, Heleno Taveira. Pluritributação Internacional sobre as Rendas de Empresas. 2. ed. rev., ampl. e atual. São Paulo: Revista dos Tribunais, 2001, pp. 691-692.

${ }^{707}$ TORRES, Heleno Taveira. Pluritributação Internacional sobre as Rendas de Empresas. 2. ed. rev., ampl. e atual. São Paulo: Revista dos Tribunais, 2001, p. 687.

${ }^{708}$ VOGEL, Klaus. On Double Taxation Conventions (A Commentary to the OECD - UN and US Model Conventions for the Avoidance of Double Taxation of Income and Capital), $3^{\text {rd }}$ ed. Londres: Kluwer, 1998, p. $1353-1354$.
} 
procedimento amigável com fins de provar a ocorrência de dupla não tributação, já que esta não é proibida pelas convenções, ela constitui, apenas, um efeito indesejado.

O artigo 25 do Modelo da OCDE também não impõe um formato para a requisição, embora seja razoável admitir que a forma escrita seria a mais $\operatorname{adequada~}^{709}$. Além disso, não é necessário que o requerente apresente prova pré-constituída do suposto prejuízo, bastando uma alegação consistente e fundamentada nesse sentido para que o procedimento amigável possa ser iniciado.

Numa visão geral do artigo 25 do Modelo da OCDE, observa-se que nos seus três primeiros parágrafos estão previstos três modalidades independentes de procedimento amigável. Vale destacar que esta classificação é adotada apenas para fins didáticos, já que, na prática, o procedimento amigável é único, não existindo qualquer autonomia entre as suas normas.

Assim, no primeiro e no segundo parágrafos encontra-se disciplinado o procedimento amigável stricto sensu, relacionado com os casos de tributação em desconformidade com a convenção. Pressupõe-se, assim, a existência de medidas adotadas pelo Estado no sentido de exigir a tributação em descordo com a Convenção, embora não se exija a existência prévia de um ato formal de lançamento tributário, sendo suficiente a possibilidade de realização do lançamento futuro ${ }^{710}$. Aqui a iniciativa é geralmente do contribuinte, e a solução eventualmente fornecida após a realização do procedimento possui caráter reparador, embora não possa constituir coisa julgada entre as partes.

Por outro lado, a segunda modalidade de procedimento amigável é essencialmente preventiva, consistindo no chamado procedimento amigável interpretativo, encontrando-se prevista na primeira frase do terceiro parágrafo (As autoridades competentes dos Estados Contratantes esforçar-se-ão por resolver, através de procedimento amigável, quaisquer dificuldades ou dúvidas relativas à interpretação ou aplicação da Convenção.). Trata-se, aqui, de buscar um esclarecimento interpretativo, resolvendo as dúvidas decorrentes da interpretação dos termos da própria convenção e

\footnotetext{
${ }^{709}$ A única convenção brasileira que contém disposição acerca da forma aplicável ao pedido de procedimento amigável é a convenção celebrada entre o Brasil e a Bélgica, que requer em seu artigo 25(1) que o pedido seja feito mediante petição escrita a fundamentada, dirigida à autoridade do Estado contratante de que o requerente seja residente, dentro do prazo de 2 anos a partir da notificação ou percepção na fonte da tributação em desacordo com a Convenção.

${ }^{710}$ TORRES, Heleno Taveira. Pluritributação Internacional sobre as Rendas de Empresas. 2. ed. rev., ampl. e atual. São Paulo: Revista dos Tribunais, 2001, p. 688.
} 
também atuando com a finalidade de preencher lacunas interpretativas para que seja possível aplicar a convenção.

A terceira modalidade é o procedimento amigável integrativo, previsto na segunda frase do terceiro parágrafo (Poderão, também, consultar-se mutuamente com vistas a eliminar a dupla tributação nos casos não previstos na Convenção.) que também possui caráter preventivo, podendo igualmente ser iniciado de ofício. Entretanto, nesta modalidade integrativa, o procedimento amigável tem como objetivo a solução de casos de dupla tributação não previstos na convenção.

As disposições referentes à implementação destes procedimentos estão previstas no quarto parágrafo do artigo $25^{711}$. Igualmente vago, o dispositivo determina tão somente que a negociação não será mantida pelos membros do corpo diplomático dos Estados contratantes, mas sim pelas respectivas autoridades fiscais.

No que concerne às limitações temporais, fixou-se no artigo 25(1) do Modelo da OCDE o prazo de 3 (três) anos contados a partir da primeira notificação da ação resultante em tributação em desacordo com a convenção, ou no caso de tributação na fonte, contados a partir da primeira vez que se teve notícia da tributação. Este prazo pode variar bastante de acordo com as intenções dos Estados contratantes. Por exemplo, a grande maioria das convenções firmadas pelo Brasil não contém qualquer menção ao prazo aplicável. Apenas quatro convenções (entre o Brasil e a Argentina, Bélgica, Equador e Portugal) estabelecem o prazo de 2 anos; outras duas (com a China e Finlândia) determinam o prazo de 3 anos e mais outras duas (com a Índia e com a Holanda), por sua vez, fixam o limite temporal em de 5 anos (Índia e Holanda), sempre contando a partir da primeira notificação da tributação em descompasso com a convenção. Outras convenções brasileiras mais recentes adotam caminho distinto e remetem a fixação do limite temporal para a legislação interna de cada Estado. Este é o caso das convenções firmadas com a África do Sul, Ucrânia a Peru, esta última ainda não em vigor.

Entretanto, é necessário destacar que o procedimento amigável não constitui uma forma de contencioso entre o contribuinte e os Estados contratantes, nem é admissível

711 VOGEL, Klaus. On double taxation conventions: a commentary to the OECD, UN and US model conventions for the avoidance of double taxation of income and capital with particular reference to German treaty practice. 3. ed. Germany: Kluwer Law International, 1997, p. 1347. 
para contestação de tributação supostamente contrária ao Direito interno de qualquer um, exceto se a violação em questão acarretar uma violação também ao tratado ${ }^{712}$.

O procedimento amigável interpretativo é a modalidade que mais nos interessa, em virtude das características deste estudo. Nesse sentido, alguns autores citam o procedimento amigável como uma forma de auxiliar a solução dos problemas de qualificação, mediante associação com um dos métodos para a qualificação explicados no item anterior, especialmente com o método da Lex Fori. Os adeptos desta linha ${ }^{713}$ defendem que a aplicação do procedimento amigável poderia representar a solução ideal para as questões interpretativas, notadamente o problema das qualificações, já que possibilitaria que ambas as partes chegassem a um acordo sobre a questão interpretativa suscitada.

Não aderimos a esta corrente. Isto porque, apesar da relativa simplicidade e suposta facilidade para a realização de um procedimento amigável, na prática se observa que a dificuldade em implementar tal propósito é bem maior do que está previsto na norma. Especialmente em virtude da ausência de regulamentação detalhada no Direito interno, acreditamos que o procedimento amigável poderia, ao contrário, complicar ainda mais a resolução de um impasse interpretativo.

Em primeiro lugar, como explicado nos parágrafos anteriores, o Modelo da OCDE não estabelece critérios rigorosos a serem obedecidos durante a instalação e realização do procedimento amigável. $\mathrm{Na}$ realidade, o artigo 25 do referido Modelo contém apenas as diretrizes essenciais para a realização do procedimento amigável, e tais disposições são evidentemente amplas e genéricas. Talvez esta ausência de regulamentação mais detalhada seja até mesmo proposital, especialmente considerando a recomendação da própria $\mathrm{OCDE}^{714}$ no sentido de que os países editem normas regulamentando os requisitos e formas de aplicação do procedimento amigável. De fato, alguns países até já possuem normas dedicas à regulamentação deste procedimento, como é o caso da França, Suécia, Japão, Canadá e Estados Unidos. Porém, isto não constitui, nem de longe, a regra geral,

${ }^{712}$ SANTIAGO, Igor Mauler. Direito Tributário Internacional - Métodos de Solução dos Conflitos. São Paulo: Quartier Latin, 2006, p. 181.

713 ROCHA, Sérgio André. Interpretação dos Tratados contra a Bitributação da Renda. Rio de Janeiro: Lumen Juris, 2008, p. 189.

${ }^{714}$ Nesse sentido, vide os Comentários ao artigo 25 do Modelo da OCDE, § 30, alínea c: "30. As regards the mutual agreement procedure in general, the Committee recommended that: (...) c) Competent authorities should, where appropriate, formulate and publicise domestic rules, guidelines and procedures concerning use of the mutual agreement procedure." 
sendo que a maioria dos países, dentre eles o Brasil, não disciplinou ainda a melhor forma de aplicação do dispositivo convencional.

De toda forma, em decorrência do princípio da soberania, sabe-se que qualquer ato material de tributação, em conformidade ou não com a convenção, será realizado apenas por um dos Estados contratantes, conforme a sua Constituição e nos termos do que prescreve a legislação tributária doméstica. Assim, no caso do Brasil, em relação às obrigações tributárias já formalizadas pelo Fisco, ou seja, em relação àqueles tributos para os quais já houve o lançamento e a respectiva notificação ao contribuinte, o próprio princípio da legalidade estrita impediria a realização do procedimento amigável. Isto porque as únicas hipóteses em que pode ocorrer a revisão ou alteração de um lançamento regularmente notificado ao contribuinte são aquelas previstas no artigo $145^{715}$ do Código Tributário Nacional, e dentre elas não se inclui o procedimento amigável.

Ainda que se sustentasse a possibilidade de revisão de ofício, nos termos do artigo $149^{716}$ do mesmo diploma, também não seria possível a realização do procedimento amigável, eis que a lei (para aqueles que consideram que o Tratado internacional possui status equivalente ao de lei ordinária) em questão, ou seja, a própria convenção, não disciplina satisfatoriamente o procedimento de modo a permitir a sua aplicação. E, mesmo se adotássemos a linha interpretativa mais restritiva, que considera que a "lei" mencionada no referido artigo 149 é somente a lei ordinária em sentido estrito, aí é que não haveria qualquer chance de aplicar o procedimento amigável, uma vez que inexiste no ordenamento pátrio dita lei ordinária prevendo e regulamentando o recurso ao procedimento amigável. $^{717}$

Sob outro prisma, ainda que considerássemos a possibilidade de recorrer ao princípio da equidade como fundamento para a realização do procedimento amigável,

\footnotetext{
715 “Art. 145. O lançamento regularmente notificado ao sujeito passivo só pode ser alterado em virtude de: I - impugnação do sujeito passivo; II - recurso de oficio;

III - iniciativa de oficio da autoridade administrativa, nos casos previstos no artigo 149."

716 “Art. 149. O lançamento é efetuado e revisto de ofício pela autoridade administrativa nos seguintes casos:

I - quando a lei assim o determine;

(...)"

${ }^{717}$ Nesse sentido, Santiago ressalta a urgência em editar lei desta natureza: "A necessidade de lei interna sobre o procedimento amigável no Brasil, contemplando outras possibilidades de alteração de ofício do lançamento (como o erro confessado da Administração na exegese do tratado), afigura-nos, assim, premente”. SANTIAGO, Igor Mauler. Direito Tributário Internacional - Métodos de Solução dos Conflitos. São Paulo: Quartier Latin, 2006, p. 203.
} 
como sugerido por Vogel, ainda assim esbarraríamos no artigo $108^{718}$ do Código Tributário Nacional, segundo o qual a equidade somente é admitida com a finalidade de suprir lacuna de lei, sendo proibida a sua aplicação com finalidade de dispensar o pagamento do tributo.

Como se vê, a realização de procedimentos amigáveis no âmbito das convenções brasileiras encontra obstáculos dentro do próprio Direito interno pátrio. Isto porque as normas do referido artigo 25 do Modelo da OCDE são, na maioria das convenções brasileiras, simplesmente reproduzidas, sem a realização dos ajustes necessários para torná-la compatível com a legislação tributária interna e, desta forma, permitir a realização do procedimento. Desta forma, diante dos obstáculos legais acima explicados, entendemos que enquanto não for editada a lei referida no artigo 149 do CTN, dificilmente haverá possibilidade legal de ocorrer um procedimento amigável, já que até mesmo a aplicação do princípio da equidade está restrita pelo artigo 108 do CTN e não se aplica ao caso.

Outro ponto que dificulta a viabilidade prática do procedimento amigável no Brasil consiste na sua reduzida segurança jurídica, uma vez que a norma do próprio tratado é excessivamente ampla e abrangente, além de ser incompatível com o ordenamento tributário interno, o qual, por sua vez, ainda não regulamentou o instituto. Faltaria também uma regulamentação sobre a força vinculante atribuída às decisões tomadas em sede de procedimento amigável. Isso sem mencionar o sempre presente conflito de interesses entre a Administração Tributária brasileira, que visa aumentar a arrecadação a todo custo, e o direito do contribuinte de não ser bitributado internacionalmente e de reduzir, até os limites legalmente permitidos, a exação tributária que lhe é imposta. Em outras palavras, a tendência é de que as autoridades competentes, no caso, as autoridades fiscais federais brasileiras, jamais aceitem uma solicitação feita por um contribuinte para iniciar um procedimento amigável quando os objetivos por ele visados sejam evitar a bitributação ou esclarecer um termo da convenção de forma que isso possa resultar na renúncia de receita tributária por parte do Brasil.

\footnotetext{
718 “Art. 108. Na ausência de disposição expressa, a autoridade competente para aplicar a legislação tributária utilizará sucessivamente, na ordem indicada:

I - a analogia;

II - os princípios gerais de direito tributário;

III - os princípios gerais de direito público;

$I V$ - a eqüidade.

$\S 1^{\circ} \mathrm{O}$ emprego da analogia não poderá resultar na exigência de tributo não previsto em lei.

$\S 2^{\circ} \mathrm{O}$ emprego da eqüidade não poderá resultar na dispensa do pagamento de tributo devido."
} 
Como se vê, a lista de empecilhos e dificuldades para a realização do procedimento amigável, no Brasil, é enorme. Em resumo preciso, Santiago ensina:

"De saida, há a dificuldade em impor-se o cumprimento do dever dos Estados de o iniciarem, mesmo quando verificados os respectivos requisitos.

Depois, a extrema rigidez desses requisitos, que excluem a abertura das negociações em situações como a divergência de percepção dos fatos ou do direito entre o contribuinte e o Fisco (o que retira àquele o direito de contestar as visões deste, possivelmente inspirado pelo compromisso com a arrecadação), ou a acusação de fraude fiscal (que pode não ser procedente e que, ainda que o seja, não deve privar o contribuinte do acesso aos meios de redução do tributo aos limites de direito - entre nós, uma tal justificação para a negativa de seguimento ao pleito do contribuinte não seria possível, por contrariar o art. 3 o do CTN, na parte em que distingue tributo de sanção de ato ilícito.

Em seguida, têm-se as graves limitações ao direito de participação e de acesso aos documentos por parte do contribuinte, bem como a inaptidão para enfrentar casos triangulares.

Merecem ênfase ainda o descompromisso com a aplicação do direito, o possível conflito dos interesses do Estado com os do contribuinte a quem dá proteção (noutras palavras, a parcialidade das autoridades encarregadas da decisão) e a tendência a celebrarem-se package deals. ",719

Em face disso, acreditamos que, especificamente para o problema das qualificações, e especificamente em relação às convenções de bitributação firmadas pelo Brasil, a melhor solução continua sendo a teoria das competências qualificatórias exclusivas defendida pelo Professor Alberto Xavier, já que esta ela evita a necessidade de se recorrer à realização de um procedimento amigável, o qual, como ficou demonstrado, não é passível de realização em face do atual Direito tributário brasileiro ${ }^{720}$.

719 SANTIAGO, Igor Mauler. Direito Tributário Internacional - Métodos de Solução dos Conflitos. São Paulo: Quartier Latin, 2006, pp. 213-214.

${ }^{720}$ A inviabilidade prática do procedimento amigável já foi, há muito tempo, reconhecida e destacada por Ottmar Buhler: "Ciertamente, ese 'procedimiento amistoso', desarrollado hasta ahora casi totalmente a nivel ministerial, resulta para los contribuyentes interesados dificilmente apreciable y no especialmente satisfactorio en tanto el contribuyente no pueda ser parte de él." BUHLER, Ottmar. Principios de Derecho 


\subsubsection{Arbitragem}

Embora já exista e seja utilizada desde a era clássica, na Grécia, para resolver os mais diversos tipos de conflitos, inclusive (e especialmente) no Direito Internacional ${ }^{721}$, no que se refere à solução de disputas no Direito Tributário Internacional a arbitragem constitui uma alternativa vanguardista. Talvez em virtude da estrita legalidade que impera para assuntos tributários, observou-se uma certa relutância da doutrina nacional em aceitar a composição privada $^{722}$ como solução para litígios de natureza fiscal. Esta tendência vem sendo aos poucos superada, especialmente em virtude das boas experiências derivadas da aplicação da arbitragem para a solução de conflitos tributários nos mais diversos países (por exemplo, Estados Unidos, Argentina, Espanha, etc.).

Neste campo, observa-se que a arbitragem vem sendo utilizada sempre após o fracasso da tentativa de composição da disputa por meio de procedimento amigável, qualquer que seja a sua modalidade. Entretanto, não se utiliza a arbitragem como grau recursal, ou seja, não se pode recorrer à arbitragem com a finalidade de rever uma decisão obtida no bojo de um procedimento amigável. Ela só se aplica, portanto, quando não se chega a uma solução satisfatória no procedimento amigável ${ }^{723}$.

A legitimidade para requerer a instauração de um procedimento arbitral é sempre dos Estados, uma vez que as convenções tributárias não estenderam este direito aos contribuintes. Ainda assim, na maioria dos tratados de bitributação ${ }^{724}$ atualmente em vigor, a arbitragem constitui um recurso facultativo, e geralmente as convenções são lacunosas, quando não silentes, em relação ao procedimento para a escolha dos árbitros, não prevendo

Internacional Tributario. Trad. Fernando Cervera Torrejon. Madrid: Editorial de Derecho Financiero, 1968, p. 59.

721 SANTIAGO, Igor Mauler. Direito Tributário Internacional - Métodos de Solução dos Conflitos. São Paulo: Quartier Latin, 2006, p. 138.

${ }^{722} \mathrm{Na}$ arbitragem moderna, o tribunal arbitral não é composto por juízes profissionais, mas indicados para atuar apenas no caso ou grupo de casos em questão, e tem vida fugaz, exinguindo-se com a prolação da decisão final ou, no máximo, com o julgamento do recurso acaso admitido e as normas procedimentais também são definidas pelas partes. SANTIAGO, Igor Mauler. Direito Tributário Internacional - Métodos de Solução dos Conflitos. São Paulo: Quartier Latin, 2006, p. 144.

723 SANTIAGO, Igor Mauler. Direito Tributário Internacional - Métodos de Solução dos Conflitos. São Paulo: Quartier Latin, 2006, p. 220.

724 Diferentemente, a Convenção Européia sobre Transfer Pricing a arbitragem constitui uma forma obrigatória de solução de conflitos, inclusive quando o procedimento amigável fracassa por decurso do prazo prescricional de 2 anos. SANTIAGO, Igor Mauler. Direito Tributário Internacional - Métodos de Solução dos Conflitos. São Paulo: Quartier Latin, 2006, pp. 222-223. 
meios, por exemplo, para suprir a inércia de uma das partes ${ }^{725}$. Outro aspecto interessante notado por Santiago é que os tratados que prevêem a arbitragem, tanto facultativa quanto obrigatória, geralmente determinam também que os contribuintes devem firmar um compromisso de aceitar o laudo arbitral como vinculante, embora eles próprios não detenham legitimidade para requerer o início de um procedimento de arbitragem ${ }^{726}$.

Quanto ao seu desenvolvimento, Santiago observa que as comissões de arbitragem são compostas por representantes dos Estados e também por membros independentes, e o contribuinte não exerce qualquer influência na escolha destes componentes. Este é um aspecto controvertido na doutrina, havendo autores que entendem que a comissão arbitral deveria ser composta por três membros, dois nomeados um por cada Estado e um terceiro indicado pelo contribuinte. Também se recomenda que os árbitros não sejam agentes fiscais, em virtude do dever de sigilo quanto aos fatos e também para assegurar a imparcialidade das decisões ${ }^{727}$.

Neste ponto, seria cabível perguntar: em que medida a arbitragem contribui para a interpretação dos tratados de bitributação? Para respondermos a esta questão, partimos da premissa de que as decisões proferidas por tribunais arbitrais são vinculantes para os Estados envolvidos. E, especialmente nas arbitragens subsequentes a um procedimento amigável malsucedido, principalmente nas modalidades interpretativa e integrativa, fica afastada por expressa determinação convencional a tendência de autocontenção dos tribunais arbitrais que os impediriam de proferir decisões "desligadas de um caso concreto e de editarem sentenças normativas" ${ }^{728}$. Em outras palavras, a previsão de arbitragem, nestes casos, equivale à cláusula de resolução de interesses. E, desta forma, a sentença arbitral proferida não se limita a simplesmente aplicar a convenção, ela também desempenha a importante função de interpretar as normas convencionais. E, não custa lembrar, o resultado da interpretação, assim como a sentença arbitral, serão vinculantes às partes em virtude do princípio pacta sunt servanda.

725 SANTIAGO, Igor Mauler. Direito Tributário Internacional - Métodos de Solução dos Conflitos. São Paulo: Quartier Latin, 2006, p. 225.

${ }^{726}$ SANTIAGO, Igor Mauler. Direito Tributário Internacional - Métodos de Solução dos Conflitos. São Paulo: Quartier Latin, 2006, p. 226.

727 SANTIAGO, Igor Mauler. Direito Tributário Internacional - Métodos de Solução dos Conflitos. São Paulo: Quartier Latin, 2006, p. 228.

${ }^{728}$ SANTIAGO, Igor Mauler. Direito Tributário Internacional - Métodos de Solução dos Conflitos. São Paulo: Quartier Latin, 2006, p. 229. 


\subsection{Demais questões relevantes para a interpretação das convenções contra a bitributação}

5.5.1. A questão da tradução: convenções firmadas em mais de um idioma e as versões traduzidas - a necessidade de uma linguagem fiscal internacional

Interpretação e tradução são dois conceitos essencialmente ligados. O ato de traduzir corresponde a reformular um texto em idioma diverso, utilizando expressões correspondentes aos termos do idioma que se traduz, de modo que os dois textos tenham o mesmo significado, embora escritos em línguas diferentes. Interpretar, por sua vez, consiste em reformular um texto, extraindo o seu sentido, seja no mesmo idioma, seja em idioma distinto. No Direito, a interpretação consiste tipicamente em reformular textos normativos, o que pode ocorrer num mesmo idioma ou de um idioma para outro, como ocorre na tradução. A única diferença é que na interpretação jurídica o intérprete produz um enunciado normativo em seu próprio idioma, enquanto na tradução, produz-se um enunciado diverso, porém com expressões sinônimas ou correspondentes no outro idioma; em ambos os casos, porém, o resultado obtido é fruto da interpretação ${ }^{729}$.

A tradução de textos pode ser um aspecto problemático quando se trata da interpretação de convenções de bitributação. Isto se deve ao fato de que tais convenções geralmente são celebradas em dois ou mais idiomas, podendo ambas as versões serem igualmente vinculantes para os Estados contratantes, ou podendo, alternativamente, haver uma versão que se sobreponha às demais em caso de dúvidas interpretativas.

Até mesmo os modelos de convenções, que não são vinculantes mas possuem grande influência e inegável relevância para a elaboração do texto final destas, geralmente são elaborados em mais de um idioma, e as próprias versões dos modelos podem ser conflitantes entre si, ou mesmo atribuir efeitos jurídicos diversos a uma mesma cláusula, a qual deveria significar exatamente a mesma coisa nos dois idiomas, no sentido de atribuir os mesmos efeitos jurídicos ao que se prescreve.

Observamos, então, que as questões interpretativas decorrentes da pluralidade de idiomas podem ser, basicamente, de dois tipos: (i) relacionadas com o fato de as

${ }^{729}$ GUASTINI, Riccardo. La Interpretación: objetos, conceptos y teorías. In: VÁZQUEZ, Rodolfo (coord.) Interpretación jurídica y decisión judicial. Cidade do Mexico: Fontamara, 2003. p. 23 (Série Doctrina Jurídica Contemporánea). 
diversas versões autênticas do tratado serem equivalentes no que se refere à força vinculante, mas serem redigidas em dois ou mais idiomas, e (ii) relativas à própria tradução do tratado. Estas duas questões principais se desdobram numa extensa lista de outros questionamentos. Por exemplo: a pluralidade de versões do tratado em diferentes idiomas requereria a adoção de diferentes sistemas e métodos de interpretação? Qual a força vinculante que poderia ser atribuída às diversas versões traduzidas? Durante a interpretação de uma convenção firmada em mais de um idioma, seria possível pensar na existência uma obrigação subjacente de comparar as disposições correspondentes constantes das demais versões traduzidas? Quando não estiver expresso no próprio tratado que em caso de dúvidas interpretativas deva prevalecer a versão em determinado idioma, é possível estabelecer uma presunção em favor de algum deles? No silêncio da convenção, havendo uma versão num idioma "diplomático", é possível presumir a prevalência deste sobre os demais ou as partes deverão esforçar-se para conciliar todas as versões em vista dos objetivos e finalidades do acordo $?^{730}$

Vejamos então um primeiro exemplo prático, que envolve a tradução de uma cláusula do Modelo da OCDE, relacionada com à definição da nacionalidade das pessoas jurídicas. Em sua versão francesa, referido Modelo dispõe em seu artigo 3(1)(g) que " $g$ ) le terme 'national', en ce qui concerne un État contractant, désigne: (...) (ii) toute personne morale, société de personnes ou association constituée conformément à la législation en vigueur dans cet État contractant ; (...)”, o que implica que serão consideradas nacionais de um Estado contratante as pessoas jurídicas constituídas (incorporadas) de acordo com a legislação em vigor naquele Estado contratante, revelando a adoção da teoria da teoria da incorporação para a determinação da nacionalidade das pessoas jurídicas. Já a versão inglesa do modelo dispõe que " $g$ ) the term "national", in relation to a Contracting State, means: (...) (ii) any legal person, partnership or association deriving its status as such from the laws in force in that Contracting State; (...)”, ou seja, uma pessoa jurídica será considerada nacional de um Estado contratante na medida em as leis em vigor naquele Estado contratante lhe confiram tal status. De fato, a cláusula escrita em inglês poderia levar à conclusão de que, ao invés de considerar a pessoa jurídica como nacional do Estado onde ocorreu a sua incorporação ou constituição, deveria ser considerado o Estado cujo

\footnotetext{
${ }^{730}$ ENGELEN, Frank. Interpretation of Tax Treaties under International Law. Amsterdam: IBFD, 2004. v. 7 , p. 341 (IBFD Doctoral Series).
} 
Direito lhe confere esta qualidade ${ }^{731}$. Assim, uma companhia que seja regida pelas leis do Estado de sua administração poderia ser considerada nacional deste Estado, embora tenha sido constituída em outro Estado ${ }^{732}$, poderia ser considerada nacional de ambos os Estados ao mesmo tempo, o que poderia acabar inviabilizando a aplicação da convenção. Por outro

\begin{abstract}
731 Especificamente quanto às pessoas jurídicas, há duas teorias principais para a determinação da nacionalidade: (i) a teoria da incorporação, pela qual se considera que a pessoa jurídica é nacional do Estado onde se deram os atos de incorporação (ou de constituição, segundo o Direito brasileiro), e (ii) a teoria do local da administração central, pela qual considera-se que a empresa será nacional do país onde estiver localizada a sede de sua administração central, ou então do país onde forem exercidos os atos de administração vitais para a continuidade da empresa. AVERY JONES, John F. et al. The origins of Concepts and Expressions Used in the OECD Model and their Adoption by States. In: Bulletin - Tax Treaty Monitor. Jun. 2006. Amsterdam: IBFD, p. 227.
\end{abstract}

${ }^{732}$ Avery Jones cita o exemplo do caso Überseering BV (Case C-208/00, 5 November 2002), cuja ementa é seguinte: "Palavras-chave: 1. Tratado CE - Artigo 293. ${ }^{\circ}$, terceiro travessão, CE - Objectivo - Adopção de convenções destinadas a facilitar a realização da liberdade de estabelecimento das sociedades - Adopção que não condiciona o exercício desta liberdade (Artigos $44 .^{\circ}$ CE e 293. ${ }^{\circ}$, terceiro travessão, CE) 2. Livre circulação de pessoas - Liberdade de estabelecimento - Sociedade constituída em conformidade com a legislação de um Estado-Membro e que nele tem a sua sede social - Sociedade que se considera que, segundo o direito de um outro Estado-Membro, transferiu a sua sede efectiva para esse mesmo Estado - Não reconhecimento pelo Estado-Membro de acolhimento da capacidade jurídica - Restrição da liberdade de estabelecimento - Justificação - Inexistência (Artigos 43. ${ }^{\circ}$ CE e 48. ${ }^{\circ}$ CE) 3. Livre circulação de pessoas Liberdade de estabelecimento - Sociedade constituida em conformidade com a legislação de um EstadoMembro e que nele tem a sua sede social - Sociedade que exerce a sua liberdade de estabelecimento noutro Estado-Membro - Obrigação de o Estado-Membro de acolhimento respeitar a capacidade jurídica da sociedade (Artigos 43. ${ }^{\circ} \mathrm{CE}$ e 48. ${ }^{\circ} \mathrm{CE}$ ). Sumário: 1. O artigo 293. ${ }^{\circ} \mathrm{CE}$ não constitui uma reserva de competência legislativa nas mãos dos Estados-Membros. Se esta disposição convida os Estados-Membros a entabular negociações a fim, nomeadamente, de facilitar a solução dos problemas resultantes das disparidades das legislações relativas ao reconhecimento mútuo das sociedades e à manutenção da sua personalidade jurídica em caso de transferência transfronteiriça da sua sede, é unicamente «sempre que necessário», quer dizer, na hipótese de as disposições do Tratado não permitirem realizar os objectivos do Tratado. Mais especificamente, embora as convenções cuja celebração o artigo $293 .{ }^{\circ}$ CE incentiva possam, à semelhança das directivas de harmonização previstas no artigo $44 .^{\circ} \mathrm{CE}$, facilitar a realização da liberdade de estabelecimento, o exercício desta liberdade não pode todavia estar condicionado pela adopção de tais convenções. (cf. n. 54, 55) 2. A recusa, por parte de um Estado-Membro, de reconhecer a capacidade jurídica de uma sociedade constituída em conformidade com o direito de outro Estado-Membro no qual tem a sua sede social com o fundamento, nomeadamente, em que a sociedade transferiu a sua sede efectiva para o seu território na sequência da aquisição da totalidade das quotas por cidadãos deste Estado-Membro que ai residem, o que tem como consequência que a sociedade não pode, no Estado-Membro de acolhimento, estar em juizo para defender os seus direitos resultantes de um contrato, salvo se se reconstituir segundo o direito deste Estado, constitui uma restrição à liberdade de estabelecimento incompativel, em princípio, com os artigos $43{ }^{\circ} \mathrm{CE}$ e $48 .{ }^{\circ} \mathrm{CE}$. A este respeito, não se pode excluir que razóes imperiosas de interesse geral tais como a protecção dos interesses dos credores, dos sócios minoritários, dos assalariados ou mesmo do fisco possam, em determinadas circunstâncias e respeitando determinadas condições, justificar restrições à liberdade de estabelecimento, semelhantes objectivos não podem todavia justificar que sejam negadas a capacidade jurídica e, portanto, a capacidade judiciária a uma sociedade regularmente constituída noutro Estado-Membro onde tem a sua sede social. Com efeito, tal medida equivale à própria negação da liberdade de estabelecimento reconhecida às sociedades pelos artigos $43 .{ }^{\circ} \mathrm{CE}$ e 48. ${ }^{\circ} \mathrm{CE}$. (cf. n.os 82, 92-94, disp. 1 ) 3. Quando uma sociedade constituída em conformidade com a legislação de um Estado-Membro no território do qual tem a sua sede social exerce a sua liberdade de estabelecimento noutro Estado-Membro, os artigos $43 .^{\circ} \mathrm{CE}$ e $48 .^{\circ} \mathrm{CE}$ impõem a este último que respeite a capacidade jurídica e, portanto, a capacidade judiciária que esta sociedade possui nos termos do direito do seu Estado de constituição. (cf. $n{ }^{\circ}$ 95 , disp. 2 )". (íntegra da decisão disponível em<http://eurlex.europa.eu/LexUriServ/LexUriServ.do?uri=CELEX:62000J0208:PT:HTML>- Acesso em 12 jan. 2010) AVERY JONES, John F. et Al. The origins of Concepts and Expressions Used in the OECD Model and their Adoption by States. In: Bulletin - Tax Treaty Monitor. Jun. 2006. Amsterdam: IBFD, p. 227. 
lado, também seria possível que uma pessoa jurídica fosse constituída em diversos países diferentes, mas cujo domicílio fosse estabelecido no país-sede da sua administração central $^{733}$. Este exemplo demonstra, assim, que a diferença na redação da mesma cláusula nos dois idiomas altera consideravelmente os efeitos jurídicos dela decorrentes, e isso pode ser um verdadeiro empecilho à eficácia de uma convenção celebrada nesses moldes e nestes dois idiomas.

Uma outra questão comum concerne à relevância do chamado "idioma de trabalho". Durante a fase de negociação dos tratados, se ambos os Estados não forem falantes do mesmo idioma, é comum que se adote o idioma de um deles, ou então, um terceiro idioma, denominado de "idioma de trabalho". Este idioma, geralmente o inglês, muitas vezes, é o que acompanha os negociantes até a celebração do tratado, o qual efetivamente é celebrado naquele terceiro idioma, e só então traduzido para os idiomas oficiais dos Estados contratantes, atribuindo-se, geralmente, o mesmo poder vinculante às três versões. O problema aqui consistente em determinar se a versão de trabalho poderia ter maior peso durante a interpretação, pelo fato de os intérpretes já estarem acostumados a ela, em detrimento das versões traduzidas, e também em virtude do fato de que grande parte das convenções segue o Modelo da OCDE em inglês. A doutrina tem tentado diminuir a suposta maior importância atribuída ao idioma de trabalho alegando que o próprio Modelo da OCDE também é disponível em francês.

Os problemas não são exclusivamente decorrentes da pluralidade de idiomas. Questões linguísticas podem surgir até mesmo em tratados celebrados em apenas uma lingua, especialmente se durante a interpretação houver o reenvio ao direito interno. Exemplo disso é o caso Gladden Estate ${ }^{734}$, no qual a Corte Federal do Canadá comparou a expressão "venda ou troca", utilizada na cláusula referente aos ganhos de capital do antigo acordo entre o Canadá e os Estados Unidos, com o termo "disposição", conforme utilizado na legislação tributária interna canadense. Neste caso, o litígio envolvia determinar se uma disposição por morte poderia ser considerada isenta por meio da isenção aplicável à "venda

\footnotetext{
${ }^{733}$ Avery Jones cita como exemplo o caso Arab Monetary Fund v. Hashim [1991] 2 W.L.R. 729 (H.L.), no qual o Arab Monetary Fund havia sido constituído em 21 Estados-membros e foi declarado pelo Lord Templeman como possuindo múltipla nacionalidade, mas com domicílio na sede de seu escritório principal. A descrição do caso e a decisão estão disponíveis em: http://www.uniset.ca/other/cs2/213F3d1169.html. Acesso em 12 jan. 2010.

734 Federal Court of Canada. March, 25. 1982. http://scc.lexum.umontreal.ca/en/1995/1995scr2802/1995scr2-802.html. Acesso em 05 dez. 2009.
} 
ou troca", nos termos do tratado. O problema linguístico, neste caso, devia-se ao fato de que o termo em questão estava sendo interpretado sob duas perspectivas, a do direito interno e a do tratado, e possuía significados distintos em cada uma delas. Como demonstra este exemplo, uma parte considerável dos problemas relativos à tradução decorre do reenvio ao Direito interno antes de se buscar interpretar o tratado segundo o seu próprio contexto, ou segundo a linguagem fiscal internacional.

Outros exemplos, desta vez sobre tradução e reenvio ao direito interno de conceitos jurídicos particulares a determinados ordenamentos. O "trust", instituto de Direito privado que tem larga utilização em países anglofônicos, não se encontra definido no Direito interno, por exemplo, do Brasil. Apesar disso, é utilizado nas convenções celebradas pelo Brasil ${ }^{735}$.

Durante a tradução de tratados, uma prática relativamente comum consiste em aplicar conceitos jurídicos do Direito interno para estabelecer a correspondência com o conceito jurídico do Direito estrangeiro que precisa ser traduzido. Quando os conceitos jurídicos em questão são de amplo conhecimento e vastamente utilizados por ambos os Estados contratantes, não costumam surgir maiores problemas. Entretanto, quando apenas um dos Estados habitualmente aplica aquele conceito, o fato de simplesmente traduzi-lo por meio da correspondência a um instituto jurídico do outro país pode não fornecer a melhor tradução, gerando conflitos interpretativos.

As técnicas de tradução utilizadas no Direito interno podem ser aplicáveis para fornecer uma solução quando a situação envolve a interpretação de tratados. Uma primeira técnica consiste em fazer referência ao conceito de Direito tributário ou ao Direito privado que define ou fornece as características do termo que se quer definir no âmbito do tratado.

\footnotetext{
${ }^{735}$ Nessa linha, Maisto cita, ainda, os termos "copyright"e "droit d'auteur", presentes, respectivamente, nas versões inglesa e francesa da cláusula que regulamentava o tratamento dos royalties no tratado entre França e Estados Unidos: "A good example of the issue of the translation of a legal concept is shown by the use of the of the terms "copyright" and "droit d'auteur", that seems to have also influenced the drafting of the current tax treaty concluded by France and the United States. In fact, in departing from the wording of Art. 12 OECD MC, this treaty refers to "payments of any kind received as a consideration for the use of, or the right to use, any copyright of a literary, artistic or scientific work, including payments for the use of, or the right to use any [...] neighboring right" [emphasis added] (in the French version, "droit voisin"). The Technical Explanations to the France-US tax treaty clarifies that the "[...] references to neighboring rights and to software simply confirm that both States share the same interpretation of the term "copyright". They are not intended to suggest that the term "copyright", as used in other US treaties (including the present treaty with France), excludes software or neighboring or similar rights. "This clarification is evidently meant to avoid speculations as to the exact meaning of the concept of "copyright"and that of "droit d'amateur"." MAISTO, Guglielmo. Multilingual texts and interpretation of tax treaties and EC tax law. Amsterdam: IBFD, 2005. pp. xxv-xxvi.
} 
Isto costuma funcionar bem quando o Direito interno de ambos os Estados deriva de uma mesma linha ou segue um mesmo sistema, por exemplo, quando ambos os países seguem o sistema da Civil Law.

A referência expressa a dado conceito do Direito interno possui a vantagem de fornecer uma definição precisa e determinada para o conceito presente no tratado, mas fica sob o risco de excluir daquele conceito as nuances que podem surgir em decorrência do caráter internacional do tratado. Por exemplo, nos Estados Unidos, a Seção 368 (A)(1)(D) do IRS $\operatorname{Code}^{736}$ estabelece um benefício fiscal para as reorganizações societárias qualificáveis sob o conceito de "A Reorganization”, definido na referida Seção. O conceito de "A Reorganization", segundo o dispositivo em comento, refere-se às reorganizações societárias definidas como "statutory mergers" ou "consolidations". Em outras palavras, as reorganizações societárias previstas no artigo 368 do IRS Code permitem que, durante uma fusão, os acionistas americanos da empresa que é comprada ("empresa-alvo") troquem as ações desta por ações da empresa compradora sem o reconhecimento de ganhos. Desta forma, nos termos do artigo 368, uma "reorganização" é definida como uma "fusão estatutária ou consolidação". Anteriormente, o termo "fusão estatutária" tinha seu significado interpretado como correspondente a uma fusão ou consolidação efetuada nos termos do Direito Empresarial de um Estado ou Território ou do Distrito de Columbia. Embora no Direito estrangeiro muitas vezes as normas que regulam fusões operem similarmente às normas norte-americana, uma operação de fusão envolvendo entidades organizadas sob normas jurídicas estrangeiras realizada segundo as normas do Direito empresarial estrangeiro não se qualificam como "Reorganização" para os fins dos benefícios previstos no artigo 368 do IRS Code. ${ }^{737}$. Como se vê, o recurso direto ao Direito interno de um dos Estados, embora possa funcionar em alguns casos, está sob o constante risco de causar uma situação discriminatória, já que o dispositivo da legislação interna de um país pode não ter sido feito com base no critério da nacionalidade, como é o caso do exemplo, e não poder ser aplicado em situações internacionais porque, neste caso, acabaria sendo discriminatório.

\footnotetext{
736 Codificação de normas tributárias do Direito Norte-americano, correspondente ao Código Tributário Nacional brasileiro.

737 PLEWA, David. PAZ, Stacy M. IRS Issues Final Regulations Allowing Foreign Merger Section 368 Reorganizations. 1 FEB 2006. Disponível em http://www.dlapiper.com/section368 reorganizations_article/. Acesso em 06 dez. 2009.
} 
Como demonstramos, os problemas relativos à tradução e às diferenças de idiomas são dos mais diversos tipos, não seria possível pretender esgotá-los aqui. Entretanto, é pacífico o seguinte: seja a questão referente à pluralidade de idiomas ${ }^{738}$, seja ela relativa à estrutura da tradução em si, a sua análise e a eventual solução sempre deverão perpassar o exame dos artigos 31 a 33 da Convenção de Viena, já analisados no capítulo anterior, porque esta é a norma internacional que deve fornecer os parâmetros. Adicionalmente, é necessário aplicar a teoria da argumentação jurídica, que na maioria dos casos pode ser útil para auxiliar na obtenção de um resultado satisfatório para estas questões. Outra opção que vem sendo adotada pelos países como uma solução radical consiste na celebração do tratado em um único idioma, mesmo que não seja o idioma oficial dos países contratantes. Este é o caso dos acordos tributários firmados entre a Bélgica, Israel e a Noruega ${ }^{739}$, que foram celebrados apenas em inglês, idioma este não era o idioma oficial de nenhum dos Estados contratantes.

O ideal seria que houvesse um esforço maior por parte dos países, em conjunto com o Committee of Fiscal Affairs da International Fiscal Association, no sentido de constituir um grupo de especialistas em Direito Tributário internacional com o objetivo de colocar em prática a idéia de uma consolidação da linguagem físcal internacional ${ }^{740}$, reunindo os termos e expressões mais frequentemente utilizados nos acordos internacionais, de modo que os países pudessem recorrer a ela ao invés de socorrer-se ao direito interno, durante a interpretação e aplicação de seus tratados. Na realidade, é possível até mesmo afirmar que uma tal linguagem transnacional já existe. Inclusive, já existem algumas decisões reconhecendo expressamente a existência da linguagem fiscal internacional, como ocorreu no caso SIR v. Downing, julgado na África do Sul. A Corte Federal Alemã e o Hoge Haad (Corte Federal Holandesa) vêm sistematicamente interpretando e aplicando termos como "beneficial owner" e "capital gains" a partir dos conceitos e dos respectivos significados presentes na prática dos tratados de bitributação,

\footnotetext{
${ }^{738}$ MAISTO, Guglielmo. Multilingual texts and interpretation of tax treaties and EC tax law. Amsterdam: IBFD, 2005. SHELTON, Dinah. Reconcilable Differences? The Interpretation of Multilingual Treaties. Disponível em http://www.cisg.law.pace.edu/cisg/biblio/shelton.html. Acesso em 05 dez. 2009.

${ }^{739}$ MAISTO, Guglielmo. Multilingual texts and interpretation of tax treaties and EC tax law. Amsterdam: IBFD, 2005. P. xxi.

${ }^{740}$ RAAD, Kees van. International Coordination of Tax Treaty Interpretation and Application. In: RAAD, Kees van. LEHNER, Moris. KIRCHHOF, Paul. RAUPACH, Arndt. RODI, Michael. International and Comparative Taxation: Essays in honour of Klaus Vogel. London: Kluwer Law International, 2002. pp. 219221.
} 
ou seja, na linguagem fiscal internacional. Desta forma, o único requisito que faltaria para permitir o seu amplo reconhecimento e aplicação é justamente a sistematização ${ }^{741}$.

Entretanto, reconhecemos que se trata de um objetivo razoavelmente difícil de se atingir, embora já exista uma relação de termos e expressões que, mesmo de forma incipiente, podem servir de referência para o que se pretende que seja uma linguagem fiscal internacional. Inclusive, de acordo com $\operatorname{Vogel}^{742}$, seria possível considerar os termos e expressões utilizados nas versões de 1963 e de 1977 do Modelo da OCDE como integrantes da linguagem fiscal internacional ${ }^{743}$. De fato, existem entidades que se esforçam nesse sentido, publicando documentos e obras com a nítida finalidade de orientar os intérpretes das normas das convenções. Talvez o exemplo mais concreto deste esforço seja o glossário de termos fiscais internacionais elaborado e publicado pelo International Bureau of Fiscal Documentation (IBFD International Tax Glossary), que contém uma vasta relação de termos e expressões normalmente utilizadas em tratados internacionais tributários.

\subsubsection{Interpretação das convenções contra a bitributação e a sua} finalidade de prevenção e combate à evasão fiscal ${ }^{74}$

Quando se fala em prevenir ou combater a evasão fiscal internacional e as práticas tributárias abusivas em situações transnacionais necessariamente se fala também em cooperação internacional. E, embora de início possa parecer simples compreender os mecanismos de cooperação internacional, quando aprofundamos a análise percebemos que,

\footnotetext{
${ }^{741}$ VOGEL, Klaus. PROKISCH, Rainer G. General Report. Interpretation of Double Taxation Conventions. Cahiers de Droit Fiscal International. 1993 Florence Congress, International Fiscal Association., vol. LXXVIIIa. p. 63. AMATUCCI, Andrea. GONZÁLEZ, Eusebio. TRZASKALIK, Christoph. International Tax Law. Amsterdam: Kluwer Law International, 2006, p. 163. RAAD, Kees van. International Coordination of Tax Treaty Interpretation and Application. In: RAAD, Kees van. LEHNER, Moris. KIRCHHOF, Paul. RAUPACH, Arndt. RODI, Michael. International and Comparative Taxation: Essays in honour of Klaus Vogel. London: Kluwer Law International, 2002. pp. 219-221.

742 VOGEL, Klaus. On double taxation conventions: a commentary to the OECD, UN and US model conventions for the avoidance of double taxation of income and capital with particular reference to German treaty practice. 3. ed. Germany: Kluwer Law International, 1997, p. 57.

743 VOGEL, Klaus. On double taxation conventions: a commentary to the OECD, UN and US model conventions for the avoidance of double taxation of income and capital with particular reference to German treaty practice. 3. ed. Germany: Kluwer Law International, 1997, p. 57.

${ }^{744} \mathrm{O}$ combate às práticas tributárias abusivas e à evasão fiscal internacional por meio das convenções de bitributação foi tema do $63^{\circ}$. International Congress of the International Fiscal Association - IFA, ocorrido entre os dias 30 ago. 2009 a 04 set. 2009, em Vancouver, no Canadá.
} 
especialmente com relação ao combate à evasão físcal, na prática, isso pode ser bastante complicado. Isto porque, em virtude da imunidade de jurisdição, os Estados têm o direito de rejeitar ou impedir, até mesmo com o uso da força, em último caso, a prática de atos diretamente por outros Estados em seu território, uma vez que isto representaria uma verdadeira violação à sua soberania. Consequentemente, é correto entender que em virtude da imunidade de jurisdição não se admite a exigibilidade nem a execução forçada de créditos tributários em território estrangeiro.

A soberania, deste modo, constitui um dos maiores obstáculos à intensificação da cooperação internacional para evitar a evasão fiscal. Em face disso, rapidamente os Estados compreenderam a necessidade e a importância de flexibilizar ou ceder uma parcela de sua soberania para tornar possível a cooperação internacional no intuito de evitar e combater a evasão físcal. Isso não significa, contudo, que os Estados devam permitir o exercício de poder tributário estrangeiro em seu território. De fato, o princípio da territorialidade é que fornece os limites à cooperação internacional em matéria de combate à evasão fiscal.

Mas, se um Estado não permitirá que um segundo Estado exerça seu poder tributário no território do primeiro, isso não inviabilizaria a cooperação internacional? $\mathrm{Na}$ verdade, veremos que não. Apesar de não poder exercer seu poder tributário em território alheio, um Estado pode requerer que o outro, agindo legitimamente em seu próprio território, lhe forneça as informações e execute os atos necessários para permitir a cobrança de créditos tributários, mediante a garantia da reciprocidade e sob os princípios da boa fé e do pacta sunt servanda. É à luz destes princípios que devem ser interpretadas as cláusulas destinadas à cooperação internacional presentes na maioria dos acordos de bitributação.

Justamente em face destas questões revela-se a importância das cláusulas antiabuso previstas nas convenções contra a bitributação. Isto porque, se tais tratados não contivessem normas contra a evasão fiscal internacional e contra as práticas internacionais abusivas, as leis internas dos países signatários, por si só, não seriam aplicáveis para solucionar o problema, em virtude da já mencionada imunidade de jurisdição, o que 
acarretaria, outrossim, uma violação do princípio pacta sunt servanda e do próprio Direito Internacional $^{745}$.

Como já mencionamos no capítulo anterior, as convenções de bitributação não visam apenas evitar a dupla tributação internacional, elas também possuem o objetivo de auxiliar no combate à evasão fiscal e às práticas tributárias abusivas, e assim, possibilitar maior segurança jurídica aos contribuintes e permitir o fim último de fomentar o desenvolvimento econômico dos países. Já mencionamos também que é justamente em virtude de sua função de combate à evasão é que tais convenções são mais vantajosas do que os métodos unilaterais para evitar a bitributação.

As práticas tributárias internacionais abusivas, ou simplesmente "evasão fiscal internacional", consistem na realização de ações e atitudes ilícitas e/ou fraudulentas por parte do contribuinte após a ocorrência do fato gerador tributário com o propósito ilícito e ilegítimo de evitar o pagamento do tributo devido. Neste ponto, fazemos questão de ressaltar a diferença entre os conceitos de "evasão físcal internacional" e de "planejamento tributário internacional". O planejamento fiscal, tanto nacional quanto internacional, consiste na prática lícita e legítima de atos ou na adoção de determinado comportamento pelo contribuinte com o objetivo de evitar a ocorrência do fato gerador do tributo e, consequentemente, deixar, licitamente, de pagar o tributo. Esclarecemos: não há nenhuma ilicitude em pretender pagar menos tributos (ou mesmo nenhum tributo), desde que isso seja feito mediante ações que impeçam o surgimento do fato gerador tributário. A diferença entre o planejamento fiscal e a evasão, ou seja, a atitude lícita e o comportamento condenável, consiste exatamente no fato de que, na evasão, o sujeito passivo pretende escapar da tributação após já ter sido aperfeiçoado o fato jurídico tributário. Portanto, deve ficar claro que o planejamento tributário não é condenável, pelo contrário, é até bastante salutar, pois pode ser uma forma de alavancar o crescimento econômico das empresas e, desta forma, fomentar o desenvolvimento do próprio Estado.

É importante distinguir, ainda, a evasão fiscal internacional não relacionada com as cláusulas das convenções de bitributação, das práticas denominadas genericamente como treaty-shopping, ou treaty-overriding. Estas constituem uma forma de abuso das próprias cláusulas das convenções com a finalidade de obter benefícios indevidos ou

745 TORRES, Heleno. Direito Tributário Internacional: Planejamento Tributário e Operações Transnacionais. São Paulo: Revista dos Tribunais, 2001, p. 352. 
mesmo de conseguir uma dupla não-tributação. Tanto no treaty-shopping ${ }^{746}$ quanto no treaty-overriding existem operações internacionais geralmente triangulares, envolvendo três países com acordos de bitributação vigentes entre si, estruturadas de modo que, segundo as disposições das referidas convenções, nenhum deles possa tributar os rendimentos resultantes da operação, ou que, se puderem, obtenham benefícios físcais indevidos. Trata-se de uma manipulação intencional da estrutura de um negócio jurídico que não possui causa negocial (causa jurídica), cujo único objetivo consiste na obtenção de tais vantagens indevidas. O treaty-shopping e o treaty-overriding constituem, assim, práticas abusivas decorrentes da própria convenção, e se destacam da generalidade de práticas abusivas que podem ser realizadas tanto no âmbito interno quanto na esfera internacional.

Os modelos de convenções, não apenas o da OCDE, mas praticamente todos eles, contém artigos específicos e dispositivos esparsos inseridos nos demais artigos cuja finalidade é claramente a de evitar ou combater as práticas tributárias abusivas. Exemplos de dispositivos convencionais diretamente voltados ao combate da evasão fiscal seriam a regra geral anti-elisiva ${ }^{747}$, os artigos que tratam do procedimento amigável, bem como as cláusulas de troca de informações e as cláusulas de assistência administrativa e, ainda, o artigo que estabelece a possibilidade de auxílio na cobrança de tributos (este presente apenas no Modelo da OCDE).

Além destes, que se destacam por sua especificidade, há diversos outros que se encontram distribuídos nas demais cláusulas das convenções contra a bitributação. Exemplos destas normas esparsas são aquelas que regulam a exclusão da aplicação dos benefícios decorrentes da convenção a sujeitos situados em países com tributação favorecida ${ }^{748}$, as regras de transparência fiscal, as regras relativas às chamadas "empresascanal" (conduit-companies), as regras referentes às "sociedades-trampolim" (stepping-

\footnotetext{
${ }^{746}$ Para os conceitos de "treaty shopping" and "rule shopping", v. PISTONE, Pasquale. L'abuso delle convensione internazionale in matéria fiscale. In: UCKMAR, Victor (coord.) Corso de Diritto Tributário Internazionale. Padova: Cedam, 1999, p. 492-498. TORRES, Heleno Taveira. Direito Tributário Internacional: Planejamento Tributário e Operações Transnacionais. São Paulo: Revista dos Tribunais, 2001, p. 321-337.

747 A introdução de uma regra geral anti-elusiva constitui uma prática bastante recente no contexto das convenções de bitributação firmadas pelo Brasil. Apenas as convenções firmadas com Israel, Chile, China, Japão e Portugal possuem esta cláusula.

748 Sobre os países com tributação favorecida, v. TORRES, Heleno. Direito Tributário Internacional: Planejamento Tributário e Operações Transnacionais. São Paulo: Revista dos Tribunais, 2001, pp. 75 e seguinqes.
} 
stone-companies), a aplicação do princípio da substância sobre a forma, a aplicação do conceito de "beneficiário efetivo" (presente nas cláusulas referentes aos juros, dividendos e royalties), a regra das empresas de artistas, bem como a previsão de aplicação do princípio “arm's length" às operações envolvendo partes relacionadas, no que se denomina de "regra do relacionamento especial", e, ainda, a aplicação do princípio da "causa negocial" durante a análise das operações que geram rendimentos sujeitos à bitributação.

No caso do Brasil, todos 28 tratados de bitributação atualmente em vigor, e também os 3 que permanecem na pendência da finalização dos procedimentos legislativos para serem aplicáveis internamente, possuem cláusulas antiabuso específicas (todas as mencionadas acima, exceto a cláusula de assistência para a cobrança de tributos), sendo que os mais recentes apresentam também a cláusula geral de prevenção e combate à evasão fiscal, baseada no modelo de cláusula de boa fe $\mathrm{fe}^{749}$. As normas internacionais antiabuso presentes nas convenções brasileiras revestem-se de especial importância se considerarmos que, em virtude da superioridade dos tratados em matéria tributária ${ }^{750}$, bem como pela aplicação do princípio da especialidade (critério lex specialis derrogat generais), elas se sobrepõem às normas infraconstitucionais internas de mesma natureza, em caso de conflitos normativos.

No entanto, apesar da enorme relevância atribuída às normas convencionais de prevenção e combate à evasão fiscal, surpreendentemente não localizamos em nossa pesquisa nenhum acórdão judicial ou administrativo que as aplicasse na prática ou mesmo que fizesse referência a elas. De fato, infelizmente, são bem poucos os acórdãos que tratam da aplicação de acordos de bitributação, os quais serão analisados em outro capítulo mais adiante. Sendo assim, nossa análise, neste ponto, será puramente dogmática. A partir deste ponto, realizaremos uma breve análise das cláusulas antiabuso específicas, e teceremos alguns comentários sobre as disposições antiabuso esparsas.

\footnotetext{
749 O tratado firmado com o Japão, mesmo sendo mais antigo - é de 1963 - já previa a cláusula geral antiabuso.

${ }^{750}$ Sobre a superioridade das normas convencionais internacionais em relação às normas infraconstitucionais internas em matéria tributária, v. Capítulo 4.
} 


\subsubsection{Cláusulas antiabuso específicas}

\section{(a) Norma geral antiabuso (norma da boa fé)}

Não se costuma encontrar frequentemente normas deste tipo nas convenções, uma vez que, devido ao seu vasto campo de aplicação, a sua interpretação pode ser relativamente complicada. Mesmo assim, algumas convenções brasileiras, as mais recentes, já apresentam a cláusula geral de boa fé, ou norma geral antiabuso, mesmo que não o façam em artigo separado. De fato, em todas as convenções que pesquisamos, a cláusula geral antiabuso está localizada ou no artigo dedicado à troca de informações (Brasil-China $^{751}$, Brasil-Japão ${ }^{752}$ e Brasil-e Portugal ${ }^{753}$ ), ou no artigo referente à limitação

\footnotetext{
751 “ARTIGO 26 - Intercâmbio de Informação - 1. As autoridades competentes dos Estados Contratantes trocarão entre si as informações necessárias à aplicação do disposto neste Acordo ou do disposto nas respectivas legislações tributárias que disciplinam o imposto objeto deste Acordo, na medida em que a tributação ali disciplinada não contrariar as disposições deste Acordo, em particular para prevenir a evasão de tais tributos. O intercâmbio de informações não fica limitado pelo que dispõe o artigo 1. Qualquer informação recebida por um Estado Contratante será considerada secreta e será facultada apenas às pessoas ou às autoridades (inclusive tribunais e colegiados administrativos) relacionadas com os tributos abrangidos por este acordo, conforme suas respectivas competências para efetuar o lançamento e a cobrança, aplicar a legislação ou decidir sobre controvérsias. Tais pessoas ou autoridades utilizarão as informações somente para tais finalidades, e poderão revelar as informações em julgamentos públicos ou decisões judiciais."
}

752 “Artigo 24 (...) 3) As autoridades competentes dos Estados Contratantes poderão adotar medidas apropriadas e permutar informações para prevenir a evasão fiscal nos Estados Contratantes relativamente aos impostos aos quais a presente Convenção se aplica."

753 “Artigo $26^{\circ}$ - Troca de Informações - 1. As autoridades competentes dos Estados Contratantes trocarão entre si as informações necessárias para aplicar esta Convenção ou as leis internas dos Estados Contratantes relativas aos impostos abrangidos por esta Convenção, na medida em que a tributação nelas prevista não seja contrária a esta Convenção, em particular para prevenir a fraude ou a evasão desses impostos. A troca de informações não é restringida pelo disposto no Artigo $1^{\circ}$. As informações obtidas por um Estado Contratante serão consideradas secretas, do mesmo modo que as informações obtidas com base na legislação interna desse Estado, e só poderão ser comunicadas às pessoas ou autoridades (incluindo tribunais e autoridades administrativas) encarregadas do lançamento, cobrança ou administração dos impostos abrangidos por esta Convenção, ou dos procedimentos declarativos, executivos ou punitivos relativos a estes impostos, ou da decisão de recursos referentes a estes impostos. Essas pessoas ou autoridades utilizarão as informações assim obtidas apenas para os fins referidos. As autoridades competentes, mediante consultas, determinarão as condições, os métodos e as técnicas apropriadas para as matérias com respeito às quais se efetuarão as trocas de informações, incluídas, quando procedentes, as trocas de informações relativas à evasão fiscal.

2. A autoridade competente de um Estado Contratante poderá enviar à autoridade competente do outro Estado Contratante, independentemente de prévia solicitação, a informação que possua quando:

a) tiver motivos para supor que houve pagamento a menos de imposto resultante da transferência artificial de lucros dentro de um grupo de empresas;

b) do uso de informações anteriormente recebidas do outro Estado Contratante, surgirem novos dados ou antecedentes que sejam de utilidade para a tributação nesse outro Estado Contratante;

c) qualquer outra circunstância leve à suposição de existência de perda de receitas para o outro Estado Contratante.

3. A autoridade competente de um Estado Contratante fornecerá à autoridade competente do outro Estado Contratante, anualmente, mediante prévia identificação dos contribuintes, ou poderá fornecer, mesmo sem a sua prévia identificação, as seguintes informações normalmente prestadas pelos contribuintes: 
de benefícios (Brasil-Israel ${ }^{754}$ ), ou mesmo no protocolo adicional que geralmente acompanha as convenções (Brasil-Chile ${ }^{755}$ ), modificando-lhes algumas cláusulas. Embora as redações e a localização no acordo variem bastante, em todas elas é possível perceber a evidente função de cláusula geral antiabuso.

\section{(b) Procedimento amigável}

Além de ser um dos meios previstos para fornecer soluções para os conflitos interpretativos, o procedimento amigável também pode ser utilizado como meio para permitir a atuação dos Estados para evitar e combater a evasão fiscal internacional. Em geral, as normas que regem o procedimento amigável são bastante semelhantes nos três modelos mais utilizados (OCDE, ONU e US Model), exceto pelo fato de que, no US Model existe a previsão de recurso ao procedimento amigável independentemente da prévia utilização aos remédios fornecidos na legislação interna dos países e independentemente também dos limites temporais impostos pelas leis internas (nos modelos da OCDE e da ONU existe a indicação de um prazo de prescrição). Como já analisamos o procedimento amigável em item anterior, não repetiremos aqui a discussão. Apenas ressaltamos que as mesmas críticas que se aplicam ao procedimento amigável para fins de interpretação também valem para fins de cooperação internacional.

a) informações respeitantes aos lucros obtidos no seu território por pessoas jurídicas ou estabelecimentos estáveis aí situados, a remeter à autoridade competente do Estado Contratante onde esteja domiciliada a pessoa jurídica associada ou a matriz ou sede;

b) informações sobre os lucros declarados por pessoas jurídicas domiciliadas no primeiro Estado Contratante relativos às operações desenvolvidas no outro Estado Contratante por pessoas jurídicas associadas ou estabelecimentos estáveis;

c) qualquer outro tipo de informação que acordem trocar."

754 “ARTIGO 25 Limitação de Beneficios - (...) 2. Uma autoridade competente de um Estado Contratante poderá negar os benefícios da presente Convenção a qualquer pessoa, ou com relação a qualquer transação, se, em sua opinião, a concessão de tais benefícios constituir um abuso da Convenção em conformidade com seus fins. A autoridade competente do Estado Contratante envolvido comunicará a aplicação desta disposição à autoridade competente do outro Estado Contratante."

755 “Protocolo adicional, 8. Disposições Gerais (...) b) Considerando que o objetivo principal desta Convenção é evitar a dupla tributação internacional e prevenir a evasão fiscal, os Estados Contratantes acordam que, no caso em que as disposições da Convenção sejam usadas de forma tal que concedam beneficios não contemplados nem pretendidos por ela, as autoridades competentes dos Estados Contratantes deverão, em conformidade com o procedimento amigável do Artigo 24, recomendar modificações específicas da Convenção. Os Estados Contratantes acordam, ainda, que qualquer das referidas recomendações será considerada e discutida de maneira expedita com vistas a modificar a Convenção na medida em que seja necessário." 


\section{(c) Troca de Informações e Assistência Administrativa}

O instituto da troca de informações destina-se permitir a melhor aplicação das normas tributárias convencionais para promover a maior eficácia dos tratados. São dois os principais motivos que justificariam a inclusão deste artigo nas convenções de bitributação ${ }^{756}$ : (i) para promover a melhor apuração dos fatos em decorrência dos quais devam ser aplicadas as normas da convenção, e (ii) considerando a crescente internacionalização das relações comerciais, seria natural e interessante que os países adotassem uma política de fornecimento recíproco das informações com base nas quais poderiam melhor aplicar a sua legislação tributária interna, mesmo quando não se tratar de uma situação de bitributação.

Uma vez prevista nas convenções, a troca de informações possui caráter compulsório para as partes, em decorrência do princípio pacta sunt servanda. Além disso, ela pode se estender para além dos limites previstos nos artigos $1^{\circ}$ (pessoas visadas) e no artigo $2^{\circ}$ (impostos abrangidos). Em outras palavras, é possível trocar informações sobre pessoas não protegidas pela convenção e sobre tributos que não sejam objeto da convenção, mas sempre dentro do objetivo possibilitar a aplicação de normas da própria convenção ou de normas de Direito tributário interno.

O instituto da trocas de informações possui caráter essencialmente supletivo, ou seja, um Estado contratante somente pode requisitar informações ao outro Estado caso hajam sido esgotados sem êxito os meios pelos quais poderia isoladamente executar sua pretensão. Outra questão importante consiste no sigilo dos dados, que somente podem ser exibidos às autoridades competentes dos Estados.

Os limites aplicáveis à troca de informações entre Estados contratantes são referentes à impossibilidade de fornecer informações em desobediência à legislação interna que impeça a disponibilização de dados. Já o parágrafo $3^{\circ}$ estabelece limitações à aplicação dos parágrafos $1^{\circ}$ e $2^{\circ}$, de modo a evitar que quaisquer dos Estados contratantes venha a exigir que sejam realizadas práticas contrárias às normas tributárias administrativas

\footnotetext{
756 "There are good grounds for including in a convention for the avoidance of double taxation provisions concerning co-operation between the tax administrations of the two Contracting States. In the first place it appears to be desirable to give administrative assistance for the purpose of ascertaining facts in relation to which the rules of the convention are to be applied. Moreover, in view of the increasing internationalisation of economic relations, the Contracting States have a growing interest in the reciprocal supply of information on the basis of which domestic taxation laws has to be administered, even if there is no question of the application of any particular article of the Convention." RAAD, Kees van. Materials on International \& EC Tax Law. Selected and edited by Kees van Raad. 7. ed. Leiden: IBFD, 2007. v. 1, p. 374.
} 
internas, bem como para impedir que os Estados exijam o fornecimento de informações que não possam ser fornecidas de acordo com o direito interno, sendo esta restrição também aplicável quando as informações requisitadas envolvam direitos de propriedade industrial, ou, ainda, informações que estejam protegidas por segredo profissional, industrial ou comercial.

Desde que as solicitações de informações sejam feitas dentro dos limites estatuídos no parágrafo $3^{\circ}$, os Estados contratantes são obrigados a fornecê-las, seja em virtude do acordo firmado entre os países, seja em decorrência do dever de cooperação internacional. Esta obrigação é mantida mesmo se o Estado que estiver fornecendo as informações considerar que elas não são úteis para fins tributários, de acordo com a sua legislação tributária interna. Além disso, o fato de uma informação requisitada não ser útil para o Estado que deva fornecê-la não pode ser justificativa para que este Estado se recuse a colaborar com o outro Estado contratante. Esta é a regra contida no parágrafo $4^{\circ}$ do artigo 26.

Finalmente, a regra do parágrafo $5^{\circ}$ complementa a norma do parágrafo $4^{\circ}$, determinando que um Estado não pode negar o fornecimento de informações apenas em virtude do fato de as informações requisitadas estarem em poder de bancos ou outras instituições financeiras, ou, ainda, porque tais informações sejam correlacionadas aos direitos de propriedade de uma pessoa física ou jurídica.

\section{(d) Assistência na cobrança de tributos}

A assistência na cobrança de tributos está prevista apenas no Modelo da OCDE, mas nenhuma das convenções brasileiras apresenta semelhante dispositivo. A própria OCDE recomenda aos seus membros que somente adotem esta cláusula caso ela não seja conflitante com o seu direito nacional.

Entretanto, uma vez incluído este dispositivo nas convenções de bitributação, os Estados contratantes passam a ser obrigados a prestar auxílio mútuo na cobrança de créditos tributários, mesmo quando tais créditos ultrapassem os limites subjetivos e objetivos previstos nos artigos $1^{\circ}$ (aspecto subjetivo) e $2^{\circ}$ (impostos visados) da Convenção Modelo.

Obviamente, a obrigação de prestar assistência na execução tributária não deve ser interpretada de forma ampla e irrestrita. Ao contrário, ela é sempre pautada pelas 
condições descritas nos demais parágrafos do próprio artigo 27, sendo igualmente possível que os próprios Estados contratantes estabeleçam outras limitações, como, por exemplo, restringir o escopo de aplicação do artigo 27 somente às pessoas e tributos abrangidos pela convenção.

Como fica evidente, trata-se de um artigo de difícil aplicação prática, em virtude da imunidade de jurisdição. Talvez por isso o Brasil siga a política de não incluir este dispositivo em suas convenções.

\subsubsection{Demais dispositivos antiabuso (dispersos nas demais normas das} convenções) ${ }^{757}$

\section{(i) Beneficiário efetivo}

Embora seja um instituto originário do sistema da Common Law, a regra do "beneficiário efetivo" encontrou vasto campo de aplicação nas convenções brasileiras ${ }^{758}$. O conceito de beneficiário efetivo não é precisamente definido ${ }^{759}$. Trata-se de uma construção jurisprudencial que varia de acordo com o sistema jurídico adotado pelo país, mas em geral é utilizado para descrever os direitos de desfrutar de benefícios econômicos de propriedade subjacente, bem como o controle sobre o poder de dispor daquela propriedade. Assim, frequentemente a expressão "beneficiário efetivo" é utilizada em contraposição ao conceito de "proprietário legal", ou "responsável legal". Em outras palavras, o beneficiário efetivo, como o nome diz, é quem efetivamente obtém o proveito econômico a partir de uma relação, mesmo que permaneça oculto por uma terceira pessoa (um agente, um preposto, uma companhia-canal, por exemplo), a qual é interposta na relação exatamente com esta finalidade. É nesse sentido que as convenções contra a

\footnotetext{
757 A relação de normas antielisivas aqui apresentada não é exaustiva, analisamos apenas as que consideramos mais importantes por integrarem as convenções brasileiras.

758 Chile, China, Coréia, Equador, Filipinas, Hungria, Índia, Itália, Noruega, Países Baixos, Portugal, República Theca e República Eslovaca.

${ }^{759}$ De acordo com Black's Law Dictionary ${ }^{208}$, "beneficial owner" is defined as "1. One recognized in equity as the owner of something because use and title belong to that person, even though legal title may belong to someone else; esp., one for whom property is held in trust. - Also termed equitable owner. 2. A corporate shareholder who has the power to buy or sell the shares, but who is not registered on the corporation's books as the owner."
} 
bitributação aplicam o conceito de beneficiário efetivo como uma das exigências para que se possa aplicar os benefícios relativos a juros, royalties e dividendos ${ }^{760}$

Assim, a regra do beneficiário efetivo determina, em resumo, que os benefícios da convenção, sejam eles relativos a juros, dividendos ou royalties, somente se aplicam se o residente que requer a aplicação da convenção for também o beneficiário efetivo dos rendimentos, evitando que pessoas possam se beneficiar excessiva e indevidamente de convenções de bitributação sem serem, de fato, residentes nos países signatários.

Em face disso, atualmente verifica-se uma tendência de interpretar o conceito de beneficiário efetivo de forma bastante ampla como forma de aumentar a eficácia de sua função de norma antiabuso.

\section{(ii) A regra do relacionamento especial - princípio "arm's length"}

Outra cláusula antiabuso bastante comum é a regra do relacionamento especial, que, em resumo, consiste em aplicar o princípio "arm's length",761 nas situações envolvendo partes relacionadas (por exemplo, operações entre matriz e filial, ou entre empresas coligadas, etc.) como forma de evitar a concessão de privilégios que não seriam concedidos se as partes fossem independentes, representando, assim, um compromisso com a garantia dos princípios da isonomia e da não-discriminação. Esta é outra regra que tem aplicação especialmente em relação a juros, dividendos e royalties nas convenções brasileiras.

\section{(iii) Regra das empresas de artistas}

Outro exemplo bastante comum de regra antielisiva consiste na regra das empresas de artistas (ou companhias artísticas), que geralmente vem associada ao artigo que trata dos rendimentos de artistas e desportistas. As "empresas de artistas" constituem uma forma incomum de elisão fiscal na qual o pagamento em razão de uma performance artística ou desportista era feito não ao artista ou atleta em si, mas a uma pessoa jurídica (do tipo "empresa de talentos") situada em outro país, de modo que o rendimento em

\footnotetext{
${ }^{760}$ International Tax Glossary. IBFD, 5. ed. 2005. p. 38.

761 O princípio “arm's length” consiste na prática de uma série de medidas para verificar se as condições da negociação entre partes relacionadas seriam as mesmas caso se tratasse de partes independentes.
} 
questão não era enquadráveis em nenhuma das categorias do acordo, impossibilitando a tributação tanto pelo Estado da fonte quanto pelo de residência. Assim, nas convenções brasileiras, ela determina a tributação no Estado da fonte pagadora dos rendimentos à companhia artística.

\section{(iv) Método da exclusão ("teste da causa negocial")}

Trata-se, aqui, de uma norma antiabuso que se dirige especificamente às pessoas jurídicas que são constituídas com a única finalidade de possibilitar a obtenção de vantagens tributárias para terceiros. Em outras palavras, são pessoas jurídicas destituídas de causa negocial. Como esta verificação é relativamente simples, o método vem se difundindo nas convenções brasileiras, especialmente as mais recentes.

\section{(v) Exclusão de rendimentos que já se beneficiam de regimes tributários preferenciais}

Esta norma antielisiva dirige-se especificamente aos rendimentos derivados de países com tributação favorecida ou que sejam considerados paraísos fiscais, bem como a quaisquer rendimentos que se beneficiem de quaisquer outros regimes tributários favorecidos, excluindo-os do escopo de aplicação da convenção. Como na prática pode ser complicado estabelecer precisamente o que significaria regime de tributação favorecida, as convenções costumam adotar como critério objetivo a exclusão de determinadas modalidades empresariais, como as empresas offshore, do âmbito de sua proteção. Embora isso constitua uma solução radical, não se pode negar que ela seja efetiva, eis que, como a prática já comprovou, na maioria das vezes, as empresas offshore são constituídas com a exclusiva finalidade de reduzir o pagamento de tributos, sem qualquer causa negocial, constituindo, desta forma, nítida prática evasiva.

O teste da "causa negocial" também é aplicável para avaliar se um estabelecimento de uma empresa constitui estabelecimento permanente para os fins da convenção. Mas convenções brasileiras, aplica-se o teste da "causa negocial" para impedir a caracterização de agentes de armazenagem e distribuição como estabelecimentos permanentes. Esta desconsideração não se dá em razão do princípio da substância sobre a forma, o qual, aliás, não é aplicável segundo o Direito Tributário brasileiro, mas, sim, em 
razão da ausência de causa negocial, ou seja, em virtude da falta de substância comercial no negócio jurídico. 


\section{APLICAÇÃO DA TEORIA DA ARGUMENTAÇÃO JURÍDICA À INTERPRETAÇÃO DAS CONVENÇÕES CONTRA A BITRIBUTAÇÃO}

\subsection{A verificação empírica da interpretação da Receita Federal do Brasil acerca dos tratados de dupla tributação}

Como já esclarecemos no primeiro capítulo deste estudo, no Brasil, o órgão que primordialmente detém a competência para interpretar e aplicar os tratados de bitributação é a Receita Federal do Brasil, que, não por acaso, é o órgão máximo da Administração Fazendária nacional. Além da Receita Federal, no âmbito administrativo, a interpretação e aplicação das convenções é realizada pelo Conselho Administrativo de Recursos Fiscais, antigamente denominado de Conselho de Contribuintes. Em virtude de suas próprias competências, a Receita Federal e o Conselho Administrativo de Recursos Fiscais possuem influência direta na eficácia das convenções de bitributação no Brasil, uma vez que sua interpretação é o que determina se os dispositivos da convenção serão ou não aplicados na prática, pelo menos num primeiro momento.

Dizemos "em primeiro momento" porque, caso o contribuinte discorde da decisão proferida pela Receita Federal ou pelo Conselho Administrativo de Recursos Fiscais, sempre existe a possibilidade de levar as suas pretensões diretamente ao Judiciário, que também detém competência para interpretar e aplicar referidas convenções. Inclusive, é possível recorrer a tais órgãos administrativos e judiciais mesmo com finalidade preventiva, mediante, por exemplo, os procedimentos de consulta e os mandados de segurança preventivos, com a finalidade de resguardo contra uma possível autuação fiscal.

Feitas estas considerações iniciais, passamos então à análise do comportamento da Receita Federal em face dos pedidos de aplicação de dispositivos das convenções contra a bitributação.

Após a realização de pesquisa na jurisprudência administrativa, tanto da Receita Federal quanto do Conselho Administrativo de Recursos Fiscais, constatou-se que a interpretação promovida pelas autoridades fiscais brasileiras sobre as cláusulas dos acordos de bitributação tem sido extremamente restritiva. E, embora não concordemos com o argumento, há quem sustente que a interpretação restritiva de dispositivos das 
convenções contra a dupla tributação deve ser seguida porque referidos tratados constituem mecanismos limitadores do exercício da competência tributária dos Estados contratantes, em benefício da liberdade físcal dos Estados. Nesse sentido, o professor Rothmann, citando Van Houtte, explica que:

“a interpretação restritiva dos acordos internacionais freqüentemente tem sido considerada normal, porque eles sempre representam uma limitação ao princípio da soberania dos Estados. 'Expecto est strictissimae interpretationis' seria o princípio de interpretação dos tratados internacionais, especialmente em matéria tributária, na opinião destes autores. Como descreve Pág. Sibille, no relatório belga ao 140 Congresso da IFA em Basiléia, nunca se pode perder de vista que cada linha do acordo interestatal representa uma limitação dos direitos soberanos de um Estado. "762.

Outra possível causa deste comportamento de interpretar restritivamente as cláusulas das convenções de bitributação consiste na premente necessidade de arrecadação por parte do Estado brasileiro. Contudo, segundo entendemos, isto não constitui motivo para uma interpretação tão restritiva e literal como a que se desenvolve atualmente, cerceando os direitos dos contribuintes quase que na totalidade dos casos. Inclusive, este padrão de atitude foi uma das causas que levou à denúncia do acordo Brasil-Alemanha, ocorrida em 2006.

De fato, as autoridades fiscais e o governo brasileiro vivenciam uma situação paradoxal. De um, lado, há a permanente necessidade de arrecadação. Em contraste, existe a constante demanda por incentivos fiscais para as empresas possam se expandir e desenvolver o seu potencial econômico, inclusive no nível internacional, o que, sem dúvida, é uma das formas de se alavancar o desenvolvimento econômico do próprio país. De fato, não é necessário muito esforço para concluir que a existência de um acordo de bitributação entre países pode ser um fator determinante na atração de investimentos estrangeiros, especialmente em países nos quais a carga tributária elevada representa um custo muito significaste na contabilidade das empresas.

Assim, na presença dos acordos de bitributação, os agentes internacionais transacionam considerando que não haverá a tão indesejada dupla tributação dos

\footnotetext{
${ }^{762}$ ROTHMANN, Gerd W. Interpretação e Aplicação dos Acordos Internacionais contra a Bitributação. Tese (doutorado). Faculdade de Direito da Universidade de São Paulo. São Paulo, 1978, pág. 179.
} 
rendimentos auferidos a partir daquele negócio. O problema é que, na prática, quando os rendimentos são disponibilizados e devem ser submetidos à tributação, as autoridades competentes, sempre adotando uma interpretação literal e restritiva das normas convencionais, termina julgando o acordo inaplicável, e, como decorrência direta, permanece a dupla tributação dos rendimentos, restando ineficazes tão importantes tratados.

Com efeito, pelo teor das decisões pesquisadas, observamos que existe um excessivo formalismo e uma interpretação excessivamente literal, sempre remetendo-se ao Direito interno, e, ao mesmo tempo, percebemos que o peso da necessidade de arrecadação parece estar se sobrepondo ao fator de necessidade de desenvolvimento econômico. Assim, concluímos que o comportamento das autoridades fiscais brasileiras (e, em escala um pouco menor, das autoridades judiciárias ${ }^{763}$ ), vem levando a um progressivo e rápido esvaziamento da eficácia de tais tratados.

Apenas a título de exemplo, citamos algumas ementas de decisões proferidas pela Receita Federal do Brasil e pelo Conselho Administrativo de Recursos Fiscais:

“TRATADOS E CONVENÇÕES INTERNACIONAIS. Não obstante o STF tenha se posicionado no sentido de inexistência de primazia hierárquica do tratado internacional, em se tratando de Direito Tributário a prevalência da norma internacional decorre de sua condição de lei especial em relação à norma interna. CONVENÇÃO BRASIL-ARGENTINA PARA EVITAR DUPLA TRIBUTAÇÃO. LUCRO DE SUCURSAL BRASILEIRA NA ARGENTINA. No caso específico, a norma interna prevalecerá sobre a norma internacional, posto que a própria convenção internacional admite a possibilidade de modificação do tratamento aplicável às filiais a empresas brasileiras situadas no exterior por meio de alteração da legislação interna brasileira. (...)" (Recurso Voluntário n. ${ }^{\circ} 138.902-1^{\circ}$ Conselho de Contribuintes - $1^{a}$ Câmara - Rel. Conselheira Sandra Maria Faroni. Julgado em 13/04/2005).$$
* * *
$$$$
\text { "IRF - REMESSA DE JUROS PARA O EXTERIOR - Não se aplica a }
$$$$
\text { Convenção entre o Brasil e o Japão para evitar dupla tributação em matéria }
$$

\footnotetext{
${ }^{763}$ Isto porque o número de casos envolvendo a aplicação de acordos de bitributação que chega a ser discutido judicialmente é menor do que o número de casos discutidos na esfera da administração fazendária.
} 
de impostos sobre rendimentos, na remessa de juros para beneficiário com sede no Panamá, mesmo que esse tenha nacionalidade e seja controlado por empresa japonesa. Recurso negado." (Recurso Voluntário n. ${ }^{\circ} 015.707-1^{o}$ Conselho de Contribuintes - $4^{a}$ Câmara - Rel. Conselheiro Nelson Mallmann. Julgado em 13/04/1999).

\section{“EMENTA: DECADÊNCIA. DATA DE INÍCIO DA CONTAGEM. AUSÊNCIA} DE PAGAMENTO ANTECIPADO. A ausência de pagamento antecipado desloca o início da contagem de prazo para o primeiro dia do exercício seguinte àquele em que o lançamento poderia ter sido efetuado. Preliminar indeferida. TRIBUTAÇÃO EM BASES UNIVERSAIS. TRATADOS INTERNACIONAIS. ALEMANHA. ARGENTINA. Os acordos para evitar a bitributação não impedem que os lucros sejam tributados em ambos os países signatários, mas, sim, apenas admitem a compensação do imposto pago no outro País, desde que obedecidas as restrições da legislação tributária. ACÓRDÃO No 16-6818 de 07 de Abril de 2005,"764

Como se vê, os motivos que se encontram para negar aplicação de um tratado de bitributação são os mais diversos. O mais comum, entretanto, é a interpretação excessivamente restrita e literal dos termos dos tratados internacionais.

O acórdão que será analisado a seguir, referente ao Caso Refratec, constitui um dos leading cases em matéria de interpretação de tratados de bitributação, mas, nem por isso, está livre de equívocos de fundamentação, como demonstraremos. Tais equívocos poderiam ter sido facilmente evitados se, durante a elaboração dos votos, os julgadores atentassem para a necessidade de observar as regras da teoria da argumentação jurídica. É o que demonstraremos no item a seguir.

\section{A) Caso Refratec ${ }^{765}$}

\footnotetext{
${ }^{764}$ Não analisaremos a fundo estas decisões porque não foi possível obter o inteiro teor.

765 “Ementa: LEI 9249/95 - TRATADO INTERNACIONAL - O art. 25 da Lei 9249/95 estabeleceu que o lucro apurado por controlada no exterior devia ser oferecido à tributação do IRPJ pela sócia controladora sediada no Brasil. Contudo, para a pessoa jurídica no Brasil que possuísse controlada com sede em Portugal, essa norma não tinha eficácia por força do Tratado entre Brasil e Portugal para evitar a bitributação (Decreto 69393/71), cujo artigo VII prevê a impossibilidade de um Estado tributar os lucros de
} 
O primeiro caso que analisaremos sob a perspectiva da teoria da argumentação jurídica é o da empresa Refratec Produtos Eletrofundidos Ltda. Em linhas gerais, neste caso, o Conselho Administrativo de Recursos Fiscais (antigo Conselho de Contribuintes) entendeu que a legislação nacional era aplicável em detrimento do tratado de bitributação Brasil-Espanha e, em consequência disso, declarou como legítima a tributação dos lucros obtidos por empresa coligada no exterior (Iliama-Espanha) mesmo antes da sua distribuição para a controladora no Brasil (Refratec).

Para que a análise da fundamentação da decisão seja adequada, é imprescindível conhecer os fatos. Como não tivemos acesso aos autos do processo, tomaremos a descrição dos fatos presente no relatório que integrou o acórdão:

\section{“RELATÓRIO}

Contra a Refratec - Produtos Eletrofundidos Ltda., foi lavrado Auto de Infração, com a conseqüente formalização de créditos tributários relativos ao Imposto de Renda Pessoa Jurídica (IRPJ) e à Contribuição Social sobre o Lucro Líqüido (CSLL), referentes aos anos-calendário de 2001 e 2002.

A autuação em referência decorre de Mandado de Procedimento Fiscal instaurado contra a Recorrente, por meio do qual verificou-se a ausência de adição à base de cálculo do lucro presumido dos valores relativos aos lucros e/ou ganho de capital, auferidos por empresa controlada, sediada no exterior.

\footnotetext{
uma empresa localizada no outro Estado. IRPJ - CONTROLADA EM PORTUGAL - LUCROS A PARTIR DE 1998 - LEI 9532/97 - DISPONIBILIZAÇÃO - EMPREGO DO LUCRO - O art. 1o da Lei 9532/97 alterou a hipótese de incidência para situação de disponibilização dos lucros de controlada no exterior. Dentre as hipóteses de disponibilização, está previsto o emprego dos lucros acumulados, os quais são excluidos enquanto não disponibilizados. A utilização do valor ajustado pela equivalência patrimonial (com lucros) na apuração de ganho de capital na cessão da participação deve ser considerada como a hipótese de emprego do valor do lucro em favor da beneficiária (controladora), situação em que deve ser oferecido à tributação o lucro até então excluído. IRPJ - CONTROLADA NA ESPANHA - LUCROS A PARTIR DE 2001 - MP 2158-34/2001 - TRATADO INTERNACIONAL - O art. 74 da MP 2158-34 estabeleceu a presunção absoluta (ficção) de que o lucro auferido por controlada no exterior deve ser considerado distribuido à controladora no Brasil em 31 de dezembro de cada ano. O Tratado entre Brasil e Espanha não afasta a incidência de tributação por empresa sediada no Brasil relativamente ao lucro de empresa espanhola considerado distribuído. CSL - CONTROLADA NO EXTERIOR - MP 1858-6/99 - INÍCIO DA TRIBUTAÇÃO - O art. 25 da Lei 9249/95 e o art. 1 o da Lei 9532/97 fixaram a tributação de lucro de controlada no exterior apenas pelo IRPJ, não sendo possível alargar a norma jurídica para que se submeta à CSL por falta de amparo legal. Apenas com a edição da MP 1858-6/99 foi introduzida a norma legal que criou a hipótese de incidência. Preliminar de nulidade rejeitada. Recurso parcialmente provido." Processo n. 13603.002794/2003-50, Recurso n. 140.320, Recorrente: Refratec Produtos Eletrofundidos Ltda., Recorrida: 3a Turma/DRJ Belo Horizonte/MG, julgado em 23 de março de 2006, Acórdão n. 108-08.765. Inteiro teor disponível para consulta no site do Conselho de Contribuintes: www.conselhos.fazenda.gov.br. Consulta realizada em 05 fev. 2010.
} 
A bem da verdade, a autuação abrange dois periodos, cuja fundamentação para o lançamento tributário reside em distintas razões. Para o primeiro período, compreendido entre janeiro de 1996 e 11 de dezembro de 2001, os lucros auferidos pela empresa Iliama Investimentos e Serviços Limitada, sediada na Ilha da Madeira, Portugal, foram considerados na apuração do resultado da Recorrente pela D. Fiscalização, em razão da alienação de sua participação societária na empresa estrangeira (ocorrida em 11.12.2001). Tal alienação, de acordo com as Autoridades Fazendárias, teria implicado na disponibilização dos lucros auferidos pela empresa controlada ao longo desses anos.

De outra parte, quanto ao segundo período autuado, compreendido entre 12.12.2001 e 31.12.2002, os valores lançados para a Recorrente referem-se aos lucros auferidos pela empresa Iliama Participações Sociedad Limitada, sediada em Barcelona, Espanha, sendo que a autuação neste ponto teve como supedâneo o disposto no artigo 74, parágrafo único da Medida Provisória $n^{o}$ 2.158-35/2001, cuja redação determina que sejam considerados como disponibilizados, em 31.12.2002, os lucros auferidos por controlada ou coligada no exterior até 31.12.2001.

Intimada acerca da lavratura do Auto de Infração, a ora Recorrente apresentou tempestivamente sua Impugnação, alegando, grosso modo, os seguintes pontos:

h) Nulidade do Auto de Infração por erro de capitulação, haja vista que, no que tange ao periodo compreendido entre janeiro de 1996 a 11 de dezembro de 2001, foi apontando como enquadramento legal, no caso da CSLL, a Instrução Normativa $n^{\circ} 38 / 96$, não sendo esta mesma indicação feita para a autuação relativa ao IRPJ, quando o correto seria o inverso, já que aludida norma seria aplicável apenas à apuração do Imposto sobre a Renda.

i) Nulidade da autuação, porquanto calcada na Instrução Normativa $n^{o}$ 38/1996, tacitamente revogada pela edição da Lei $n^{\circ}$ 9.532/1997.

j) Ainda que admitido que a autuação relativa ao primeiro perído (01.01.1996 a 11.12.2001) apresentasse como fundamentação o artigo 74 
da Medida Provisória $n^{o}$ 2.158-35/2001, o lançamento não poderia subsistir, na medida em que: a) haveria neste fato ofensa ao principio da irretroatividade e da anterioridade; b) ausência de previsão legal para tributação dos lucros formados em 1996 e 1997, c) vedação para tributação dos lucros formados entre 1996 e 1999 em razão da existência de Tratado contra dupla tributação, celebrado entre Brasil e Portugal; d) não sujeição dos lucros formados nos anos de 1996 até outubro de 1999 da incidência da Contribuição Social sobre o Lucro Líqüido - CSLL, dado que tal previsão só foi introduzida no ordenamento jurídico a partir da edição do artigo 19 da Medida Provisória n ${ }^{\circ}$ 1.858-6/1999.

k) Quanto ao segundo período autuado (12.12.2001 a 31.12.2002), o lançamento tributário seria ilegal em face da ofensa ao princípio da anterioridade, bem como em face das disposições trazidas pela Tratado contra dupla tributação celebrado entre Brasil e Espanha.

Em vista do exposto, a $3^{a}$ Turma da DRJ de Belo Horizonte/MG, houve por bem julgar procedente o lançamento tributário, em decisão assim ementada:

'Assunto: Imposto sobre a Renda de Pessoa Jurídica - IRPJ Anocalendário: 2001, 2002 Ementa: LUCROS ORIUNDOS DO EXTERIOR - DEFINIÇÃO DO FATO GERADOR - Entre os anos-calendário de 1996 a 2001, para efeito de tributar os lucros auferidos no exterior, por intermédio de filiais, sucursais, controladas ou coligadas, considera-se ocorrido o fato gerador no ano-calendário em que os lucros tiverem sido disponibilizados para a pessoa jurídica domiciliada no Brasil. A partir do ano-calendário de 2002, tais lucros serão considerados disponibilizados na data do balanço no qual tiverem sido apurados. Quanto aos lucros apurados até 31 de dezembro de 2001 e que até então não tinham sido tributados, serão considerados disponibilizados em 31 de dezembro de 2002, salvo se ocorrida, antes desta data, qualquer das hipóteses de disponibilização previstas na legislação em vigor. LANÇAMENTO DECORRENTE - CSLL - O decidido para o lançamento de IRPJ estende-se ao lançamento que com ele compartilha 
o mesmo fundamento factual quando não há razão de ordem jurídica para lhe conferir julgamento diverso Lançamento procedente.'

No voto condutor da aludida decisão, os Ilmos. Julgadores de Primeira Instância, por entenderem não haver qualquer ilegalidade no lançamento, seja em razão da vigência da Instrução Normativa $n^{\circ}$ 38/1996 à época em que verificados os fatos, seja em virtude da aplicabilidade do artigo 74 da Medida Provisória $n^{o}$ 2.158-35/2001 ao caso concreto, resolveram por manter integralmente o lançamento tributário, inclusive no que se refere à autuação relativa à CSLL.

Intimada acerca da aludida decisão em 24.03.2004, a Recorrente apresentou tempestivamente seu Recurso Voluntário, requerendo a reforma integral da decisão de primeira instância administrativa, alegando, para tanto, as mesmas razões já expostas em sua impugnação.

$$
\text { É o Relatório." }
$$

Tomando apenas os aspectos que interessam ao presente estudo, em resumo, observa-se a empresa Refratec foi autuada pela Receita Federal por não ter adicionado à base de cálculo do lucro presumido os valores relativos aos lucros e/ou ganho de capital auferidos por uma empresa controlada com sede no exterior. A autuação foi feita em duas partes, divididas por período. Relativamente ao primeiro período (janeiro de 1996 a dezembro de 2001), os lucros auferidos pela empresa Iliama Investimentos e Serviços Limitada, sediada na Ilha da Madeira (Portugal), foram considerados na apuração do resultado da Refratec pela na Ilha da Madeira, Portugal, foram considerados na apuração do resultado da Refratec pela fiscalização, uma vez que esta alienou sua participação societária na empresa em 11 de dezembro de 2001, e, segundo as autoridades fazendárias, tal alienação teria implicado a disponibilização dos lucros auferidos pela controlada Iliama-Portugal durante o período. Na segunda parte da autuação, referente ao período entre 12 de dezembro de 2001 e 31 de dezembro de 2002, os valores lançados pela Refratec referiam-se aos lucros auferidos pela controlada Iliama Participações Sociedad Limitada, localizada em Barcelona (doravante denominada de Iliama-Espanha). Esta segunda parte da autuação teve como fundamento legal o artigo 74, parágrafo único, da medida provisória n. 2.158-35/2001, cuja redação é a seguinte: 
“Art. 74. Para fim de determinação da base de cálculo do imposto de renda e da CSLL, nos termos do art. 25 da Lei no 9.249, de 26 de dezembro de 1995, e do art. 21 desta Medida Provisória, os lucros auferidos por controlada ou coligada no exterior serão considerados disponibilizados para a controladora ou coligada no Brasil na data do balanço no qual tiverem sido apurados, na forma do regulamento.

Parágrafo único. Os lucros apurados por controlada ou coligada no exterior até 31 de dezembro de 2001 serão considerados disponibilizados em 31 de dezembro de 2002, salvo se ocorrida, antes desta data, qualquer das hipóteses de disponibilização previstas na legislação em vigor."

Mediante este dispositivo legal, o Fisco considerou como se houvessem sido disponibilizados à Refratec, em 31 de dezembro de 2002, os lucros auferidos pelas controladas Iliama-Portugal e Iliama-Espanha, até o ano calendário de 2001. Vale lembrar que, até então, as autoridades fiscais somente consideravam para fins de tributação o lucro efetivamente distribuído à empresa controladora.

Cumpre então esclarecer algumas particularidades do caso. O tratado BrasilEspanha é considerado pelas empresas que realizam operações transnacionais como um dos mais vantajosos, porque estabelece a tributação de lucros apenas no país de origem, e limita a alíquota incidente sobre os dividendos a $10 \%$, ressalvado o tratamento mais benéfico instituído pela lei interna. É conferir a redação dos dispositivos do tratado:

\section{“ARTIGO 7 - Lucros das empresas}

\section{Os lucros de uma empresa de um Estado Contratante só são tributáveis}

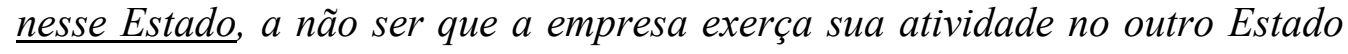
Contratante por meio de um estabelecimento permanente aí situado. No último caso, os lucros da empresa serão tributáveis no outro Estado, mas unicamente na medida em que forem atribuiveis a esse estabelecimento permanente .

2. Quando uma empresa de um Estado Contratante exercer sua atividade no outro Estado Contratante através de um estabelecimento permanente aí situado, serão atribuídos em cada Estado Contratante a esse estabelecimento permanente os lucros que obteria se constituísse uma empresa distinta e separada, exercendo atividades idênticas ou similares. em condições idênticas 
ou similares, e transacionando com absoluta independência com a empresa de que é um estabelecimento permanente.

3. No cálculo dos lucros de um estabelecimento permanente, é permitido deduzir as despesas que tiverem sido feitas para a consecução dos objetivos do estabelecimento permanente, incluindo as despesas de direção e os encargos gerais de administração assim realizados .

4. Nenhum lucro será atribuído a um estabelecimento permanente pelo simples fato de comprar bens ou mercadorias para a empresa.

5. Quando os lucros compreenderem elementos de rendimentos tratados separadamente nos outros artigos da presente Convenção, as disposições desses artigos não serão afetadas pelas disposições do presente Artigo.

$\underline{\text { ARTIGO } 10 \text { - Dividendos }}$

1. Os dividendos pagos por uma sociedade residente de um Estado Contratante a um residente do outro Estado Contratante são tributáveis nesse outro Estado.

2. Todavia, esses dividendos podem ser tributados no Estado Contratante onde reside a sociedade que os paga, e de acordo com a legislação desse Estado, mas o imposto assim estabelecido não poderá exceder $15 \%$ do montante bruto dos dividendos.

Este parágrafo não afetará a tributação da sociedade com referência aos lucros que deram origem aos dividendos pagos.

3. $O$ disposto nos parágrafos 1 e 2 não se aplica quando o beneficiário dos dividendos, residente de um Estado Contratante, tiver, no outro Estado Contratante de que é residente a sociedade que paga os dividendos, um estabelecimento permanente a que estiver ligada a participação geradora dos dividendos. Neste caso, serão aplicáveis as disposições do Artigo 7.

4. O termo "dividendos" usado no presente artigo, designa os rendimentos provenientes de ações, ações ou direitos de fruição, partes de empresas mineradoras, ações de fundador ou outros direitos que permitam participar dos lucros, com exceção de créditos, bem como rendimentos de outras 
participações de capital assemelhados aos rendimentos de ações pela legislação tributária do Estado Contratante em que a sociedade que os distribuir seja residente .

5. Quando uma sociedade residente da Espanha tiver um estabelecimento permanente no Brasil, esse estabelecimento permanente poderá aí [no Brasil] estar sujeito a um imposto retido na fonte de acordo com a legislação fiscal brasileira. Todavia, esse imposto não poderá exceder $15 \%$ do montante bruto dos lucros do estabelecimento permanente determinado após o pagamento do imposto de renda de sociedades referente a esses lucro.

Não obstante, o imposto só será aplicável quando os lucros forem efetivamente transferidos para o exterior. ."

Especificamente relacionado a estes dispositivos, a Receita Federal editou o Ato Declaratório Interpretativo SRF n. 4, de 17/03/2006, em vigor desde 01 de janeiro de $2006^{766}$, que manifesta claramente a forma de interpretação adotada pela Receita Federal sobre os citados dispositivos, e estabelece, quanto aos dividendos, o seguinte:

"Art. $1^{o}$ Ressalvado tratamento mais benéfico estabelecido em lei interna, a tributação na fonte de dividendos será efetuada mediante a aplicação da alíquota máxima de dez por cento, incidente sobre o valor bruto da remessa, sempre que a sociedade residente da Espanha possuir pelo menos vinte e cinco por cento do capital com direito a voto da sociedade residente do Brasil.

Após estes breves esclarecimentos sobre a legislação aplicável, passaremos agora à análise dos votos que compuseram o acórdão, considerando a sua justificação interna e externa, segundo as regras previstas na teoria da argumentação jurídica de Alexy. No intuito de facilitar a compreensão, relembramos os principais pontos da teoria da argumentação jurídica que serão considerados durante o nosso exame:

- As decisões jurídicas devem ser suficientemente fundamentadas, atendendo-se ao requisito da saturação ${ }^{767}$.

- A racionalidade de uma decisão jurídica pode ser mensurada através de três parâmetros: a igualdade das partes, a universalidade dos argumentos e

\footnotetext{
766 Leis estritamente interpretativas podem retroagir. Nesse sentido, v. Capítulo 3. Desta forma, o Ato Declaratório n. 4 já era aplicável ao caso, que foi julgado em 23/03/2006.

${ }^{767}$ Sobre o requisito da saturação, v. Capítulo 2.
} 
o princípio da não coerção. Ou seja, as partes devem ter tido oportunidades iguais para manifestar-se, os argumentos utilizados na justificação da decisão devem ser válidos universalmente e o convencimento pretendido pelo julgador, no caso, deve ser obtido sem a utilização de meios coercivos.

- Qualquer pessoa que rejeita um argumento tem o dever de apresentar as razões que o levam a tal rejeição.

- A justificação interna refere-se à coesão lógica dos argumentos apresentados, bem como das premissas fáticas e normativas. Pelas regras da justificação interna, é necessário que o silogismo normativo tenha caráter universal, ou seja, a regra que se aplica ao caso deve ser também aplicável a qualquer outro caso semelhante; a fundamentação deve conter pelo menos uma norma universal, da qual a decisão deve ser recorrente, mesmo que em conjunto com outras proposições, e cada fato analisado deve ser objeto do maior número de etapas de desenvolvimento possível, com vistas ao atendimento do requisito de saturação da justificação.

- A justificação externa da decisão reporta-se à fundamentação das premissas que o julgador adota para interpretar os fatos e aplicar as normas. Dentre elas incluem-se premissas fáticas, normativas, provas, normas processuais, enunciados empíricos, etc.

- Devem ser considerados os cânones da hermenêutica clássica (interpretação literal, sistemática, histórica, autêntica e teleológica), e,

- Devem ser mencionados, quando possível, precedentes que reforcem os argumentos expostos.

- Quando cabíveis, devem ser utilizadas as formas de argumentos especiais (argumento a contrário, a pari, ad absurdum, dentre outros).

O voto proferido pela relatora do caso, Conselheira Karem Jureidini Dias, embora tenha sido vencido pela maioria, foi extenso e pormenorizadamente fundamentado. Por isso, a análise da justificação desta decisão será realizada por partes.

Iniciaremos pela justificação externa. Já no começo da decisão observa-se que a Relatora estabelece as premissas normativas da decisão por meio de uma abordagem 
cronológico-evolutiva, demonstrando a clara opção pelos métodos hermenêuticos histórico e sistemático para elucidar a legislação aplicável ao caso. Transcrevemos abaixo o trecho do voto onde é possível notar a presença dos argumentos supramencionados:

"Conquanto o caso aborde duas questões distintas, calcadas em diferentes fundamentações, certo é que ambas decorrem da mesma inovação legislativa, trazida pela Lei $n^{\circ}$ 9.249/1995.

Com efeito, até a vigência da Lei $n^{\circ}$ 9.249, editada em 26 de dezembro de 1995, vigorava no Brasil o princípio da territorialidade, segundo o qual, apenas os rendimentos que mantivessem elemento de conexão com o território detentor da pretensão tributária poderiam ser submetidos à tributação. Isto implicava, no campo pragmático, na impossibilidade de incidência de qualquer espécie tributária sobre rendimentos não produzidos no Brasil.

A partir de dezembro de 1995, contudo, o cenário legislativo foi substancialmente alterado pela introdução da referida lei. Desse momento em diante, passou-se a tolerar a tributação sobre rendimentos não produzidos no Brasil, adotando-se, pois, o princípio da universalidade. Veja-se, a propósito, a redação conferida ao artigo 25 da Lei $n^{\circ}$ 9.249/1995.

'Os lucros, rendimentos e ganhos de capital auferidos no exterior serão computados na determinação do lucro real das pessoas jurídicas correspondente ao balanço levantado em 31 de dezembro de cada ano.'

Na esteira da Lei $n^{\circ}$ 9.249/1995, a Secretaria da Receita Federal publicou a Instrução Normativa $n^{\circ} 38 / 1996$, que, para dar cumprimento às novas regras trazidas na referida Lei, acabou por inovar em alguns aspectos, especialmente no que se refere ao momento para reconhecimento das receitas auferidas no exterior. De fato, aludida Instrução Normativa criou verdadeciro diferimento da tributação dos lucros das sociedades estrangeiras, determinando sua disponibilização não mais no fechamento do balanço de cada ano, conforme previsto pela Lei $n^{\circ}$ 9.249/1995, mas, apenas, quando efetivamente pagos ou creditados para empresa controladora.

Trouxe, ainda, a Instrução Normativa $n^{\circ}$ 38/1996, outras hipóteses que caracterizariam a realização do lucro auferido por sociedade estrangeira 
controlada, dentre as quais, a alienação do patrimônio pela empresa brasileira (artigo $2^{\circ}, \S 9^{\circ}$ ), cerne da discussão trazida à baila nesta ocasião.

Posteriormente à edição do diploma normativo referido acima, foi publicada a Lei $n^{\circ}$ 9.532/1997, cujo artigo $1^{\circ}$ revogou as disposições veiculadas na Instrução Normativa $n^{\circ}$ 38/1996, ou seja, estabeleceu que o momento para adição, ao lucro líqüido, dos resultados positivos, auferidos por empresa estrangeira, seria no fechamento do balanço do ano em que pago ou creditado tais valores à sociedade brasileira. Não repetiu, todavia, a hipótese de alienação do patrimônio da empresa controlada como momento para realização dos lucros ainda não distribuidos.

Nova modificação, contudo, veio a atingir o sistema normativo em agosto de 2001. No rastro da alteração promovida pela Lei Complementar $n^{\circ} 104 / 2001$, a qual, dentre outras inovações, inseriu o parágrafo $2^{\circ}$ ao artigo 43 do Código Tributário Nacional, o Poder Executivo editou a Medida Provisória $n^{\circ} 2.158$ 35/2001, cujo artigo 74 trouxe a seguinte redação:

'Art 74 - Para fim de determinação da base de cálculo do imposto de renda e da CSLL, nos termos do art. 25 da Lei no 9.249, de 26 de dezembro de 1995, e do art. 21 desta Medida Provisória, os lucros auferidos por controlada ou coligada no exterior serão considerados disponibilizados para a controladora ou coligada no Brasil na data do balanço no qual tiverem sido apurados, na forma do regulamento.

Parágrafo único Os lucros apurados por controlada ou coligada no exterior até 31 de dezembro de 2001 serão considerados disponibilizados em 31 de dezembro de 2002, salvo se ocorrida, antes desta data, qualquer das hipóteses de disponibilização previstas na legislação em vigor.'

$A$ bem da verdade, referido dispositivo legal praticamente reproduziu a redação conferida ao artigo 25 da Lei $n^{\circ}$ 9.249/1995, dispondo que o lucro auferido por empresa controlada, coligada, filial ou sucursal no exterior será considerado como disponibilizado no momento do fechamento do balanço em que tiverem sido apurados. Mais ainda, determinou que os lucros apurados até 
31.12.2001 ainda não distribuídos, assim deveriam ser considerados ao final de 2002.

Dado este panorama geral do histórico legislativo da matéria tratada no Recurso sob julgamento, passo a análise das alegações levantadas pela Recorrente:"

A regra da carga da fundamentação, ou, do ônus da fundamentação, também pode ser verificada no voto da Relatora, especificamente no trecho em que ela rejeita os argumentos apresentados na decisão de primeira instância administrativa. Isto porque, ao rejeitar as premissas do órgão primário, ela justifica suficientemente seus argumentos. Indicamos no trecho abaixo as passagens que demonstram o ponto de divergência entre o entendimento da Relatora e o entendimento que foi fixado na decisão original, bem como os argumentos por ela expostos para rejeitar as premissas inicialmente estabelecidas:

[Manifestação da discordância:] "De mais a mais, entendo que não deve prevalecer a premissa em que se baseia a decisão de primeira instância administrativa, no sentido de que a sociedade que aliena sua participação em outra, necessariamente dispõe dos lucros incorporados ao seu patrimônio líqüido, razão pela qual estaria subentendido na Lei $n^{\circ}$ 9.532/1997 a hipótese aventada no artigo $2^{\circ}$, $\S 9^{\circ}$ da Instrução Normativa $n^{\circ}$ 38/1996." [Justificação da discordância:] [Argumento 1 - O fundamento da decisão originária não atende ao requisito da generalidade:] "Com efeito, inúmeras são as variáveis que envolvem o processo de compra e venda de uma companhia, não sendo verdade absoluta que os lucros ainda não distribuidos acrescerão o valor das cotas cedidas. [Argumento 2 - A decisão originária viola o princípio da legalidade:] "Esta equiparação entre alienação da participação societária e disponibilização dos lucros incorporados ao patrimônio líqüido, por criar verdadeira presunção, não poderia, sob nenhuma hipótese, ser veiculada por ato infralegal, muito menos quando tal disposição afronta garantia assegurada ao contribuinte por lei."

Em seguida, a Relatora retorna ao método sistemático de interpretação, analisando a legislação aplicável no seu contexto geral, e não tomando as normas isoladamente. Por meio da argumentação sistemática a Relatora percebe que, caso o lançamento fosse mantido, haveria violação ao princípio da anterioridade tributária, e este acaba se tornando o fundamento principal para a exclusão da primeira parte da autuação: 
"Em vista do exposto, considerando, ainda, que a previsão para reconhecimento da disponibilização do lucro auferido no exterior, quando da alienação de participação societária, [Argumentação sistemática:] só foi trazida novamente ao ordenamento jurídico com a edição da Instrução Normativa $n^{\circ}$ 213/2002 - ato este devidamente lastreado pelo disposto no artigo 74 da Medida Provisória $n^{\circ}$ 2.158-35/2001, o qual é posterior ao lançamento objeto da presente - acolho as alegações de mérito expostas pela Recorrente, para cancelar este item da autuação.

Os argumentos que serão analisados a seguir, todos relacionados à aplicação do Tratado Brasil-Espanha, são os mais relevantes para o presente estudo, e apenas com relação a eles examinaremos as regras de justificação interna. No entanto, por não ser possível separar em duas fases sucessivas a justificação interna e a externa, uma vez que os argumentos de uma e de outra se encontram intercalados no corpo da decisão, continuaremos nossa análise seguindo a linha narrativa do voto da Relatora.

2) Do período compreendido entre 12.12.2001 a 31.12.2002

(...)

De outra parte, no que se refere à impossibilidade de tributação dos lucros auferidos por empresa controlada ou coligada na Espanha, em virtude da vedação trazida pelo tratado contra dupla tributação assinado pelo Brasil, internalizado pelo Decreto $n^{\circ} 76.975 / 1976$, vale tecer algumas considerações a respeito.

Em verdade, a questão pode ser vista sob duas óticas, sem que seja, contudo, alterada a conclusão final obtida.

Com efeito, a leitura leiga do disposto no artigo 74 da Medida Provisória $n^{\circ}$ 2.158-35/2001, isto é, despida de qualquer prévia concepção acerca do histórico legislativo que envolve a matéria, torna explícito que a pretensão da referida norma foi, de fato, tributar no Brasil o lucro auferido por empresa estrangeira. Pretende-se, em última análise, a tributação da equivalência patrimonial. Por essa acepção, este lucro propriamente dito não se confunde com o conceito de dividendos. [Premissa n. 1 - Lucros e dividendos são dois conceitos distintos] 
E se essa é a interpretação que se quer fazer do artigo 74 da Medida Provisória $n^{o}$ 2.158-35/2001, certamente que, pelo menos nas relações envolvendo Brasil e Espanha, a eficácia da mencionada regra encontra óbice no Decreto $n^{\circ} 76.975 / 1976$, que promulga a convenção para evitar a dupla tributação entre estes dois países.

Isto porque, de acordo com o artigo $7^{\circ}, \S 1$ do referido Decreto [ou seja, do Tratado], o lucro (resultado contábil) de uma empresa, só é tributável no País em que sediada, salvo se exercer atividade no outro País por meio de estabelecimento permanente, hipótese em que os lucros apurados pelo estabelecimento sofrerão a tributação pelo País em que se encontra fixado. $\underline{\mathrm{Ou}}$ seja, vale a regra estabelecida pelo princípio da fonte, reservando a competência tributária ao país em que produzida a riqueza.

Assim, se a pretensão da Medida Provisória $n^{\circ}$ 2.158-35/2001 foi a tributação deste resultado [ou seja, do lucro], obviamente que esta intenção esbarra no artigo $7^{\circ}$ do disposto no Decreto $n^{\circ} 76.975 / 1976$, aplicável ao caso concreto, não se lhe aplicando o disposto no artigo $10 \mathrm{c} / \mathrm{c}$ artigo 23, ambos do Decreto $n^{\circ} 76.975 / 76$.

De fato, conquanto o $\$ 1^{\circ}$ do artigo 10 do referido tratado estabeleça que os dividendos pagos por uma sociedade residente de um Estado (Espanha) a um residente em outro Estado (Brasil) sejam tributáveis neste Estado (Brasil), no presente caso, o lançamento refere-se à tributação de lucro e não de dividendo pago.

De mais a mais, o $\$ 4^{\circ}$ do artigo 23 do Decreto $n^{\circ} 76.975 / 1976$ é expresso ao estabelecer que os dividendos recebidos por um residente no Brasil, quando tributados na Espanha, não serão aqui tributados, porquanto isentos.

Corrobora esta determinação o disposto no Ato Declaratório Interpretativo SRF $n^{\circ}$ 6/2002, segundo o qual esta regra de isenção não se aplica apenas as Entidad de Tenencia de Valores Extranjeros (ETVE-empresas constituídas na Espanha com determinados beneficios fiscais, entre eles a não tributação dos dividendos distribuídos aos acionistas não residentes), mantendo-se, portanto, a regra de isenção para as demais companhias. 
Por todo o exposto, conheço do Recurso Voluntário, para afastar a preliminar de nulidade suscitada pela Recorrente e, no mérito, Dar Provimento.

Sala das Sessões - DF, em 23 de março de 2006.

\section{KAREM JUREIDINI DIAS”}

Como já mencionamos anteriormente, de acordo com a teoria da argumentação jurídica, a justificação interna deve ter o maior número de etapas de desenvolvimento possível, no intuito de atender ao requisito da saturação da argumentação e permitir que a decisão seja suficientemente justificada. Desta forma, faz-se necessário descrever as etapas deste raciocínio. Para tanto, é razoável e coerente partir dos fatos.

Então, a primeira premissa que se considera é a de que, segundo os fatos narrados no caso, o lançamento em discussão versava sobre lucros, e não sobre dividendos. Efetivamente, tal conclusão é possível mediante a diferenciação dos conceitos de lucros e dividendos. Embora não conste expressamente do acórdão, é possível estabelecer a distinção entre lucros e dividendos sem a necessidade de recorrer ao Direito interno, ou seja, tentando manter, o máximo possível, a discussão no âmbito internacional. Nesse sentido, os lucros são definidos no IBFD International Tax Glossary como o excesso de receita em relação aos custos, enquanto o conceito tributário de dividendo corresponde a qualquer distribuição de bens corporativos (assets) aos acionistas, inclusive sob a forma de distribuições informais e não necessariamente em dinheiro, como ocorre no caso de distribuição de stock dividends ${ }^{768}$.

Uma vez estabelecida a premissa geral fática, torna-se necessário encontrar a regra de validade universal do argumento, requisito este que, segundo Alexy, deve estar presente ao menos em uma das premissas adotadas no raciocínio. Neste caso, a regra de validade universal do argumento será a norma do artigo 98 do CTN, que determina a superioridade dos tratados internacionais em matéria tributária em relação à legislação infraconstitucional interna ${ }^{769}$, em virtude do critério da especialidade. Ilustrativamente, recorrendo à estrutura do raciocínio lógico formal, esta poderia ser tomada como a premissa maior do silogismo.

\footnotetext{
${ }^{768}$ IBFD International Tax Glossary. 5. ed. Amsterdam: IBFD, 2005. pp. 128, 318.

${ }^{769}$ Sobre a superioridade dos tratados internacionais tributários em relação às normas infraconstitucionais internas, v. Capítulo 4.
} 
Consequentemente, tem-se como correta a aplicação do artigo $7 \mathrm{o}$, parágrafo $1^{\circ}$, do Tratado Brasil-Espanha, a qual determina a tributação dos lucros das empresas exclusivamente no país fonte.

Se considerarmos como corretas as duas premissas imediatamente anteriores, o que, de fato, são, a única conclusão racional coerente e, portanto, correta, consiste na exclusão da aplicação da regra do artigo 74, parágrafo único da Medida Provisória n. 2.158-35/2001, uma vez que se trata de legislação infraconstitucional interna, hierarquicamente inferior ao tratado internacional.

E, mesmo se nos fatos houvesse a informação de que o objeto da tributação eram dividendos, e não lucros, ainda assim a tributação somente poderia ocorrer na Espanha, não por força do artigo 7o, mas por decorrência dos artigos 10, parágrafo 1o, conjugado com o artigo 23, parágrafo $4^{0^{770}}$, do Tratado Brasil-Espanha, que dispõe expressamente que os dividendos recebidos por um residente no Brasil serão isentos de tributação em território nacional quando forem tributáveis na Espanha ${ }^{771}$.

Logo, a conclusão correta e coerente em face do ordenamento jurídico brasileiro e em face das normas internacionais convencionais, a qual foi racionalmente elaborada a partir dos argumentos jurídicos acima explicados, é a de que a tributação dos lucros da controlada residente na Espanha somente deveria ser realizada neste país, uma vez que o tratado não atribui ao Brasil qualquer competência para tributar este rendimento, nas condições do caso em questão.

Neste ponto, é importante deixar claro que, apesar de parecer que se adotou a lógica formal e o raciocínio silogístico clássico, a semelhança se restringe apenas à estrutura. $\mathrm{Na}$ verdade, todo o raciocínio desenvolvido e os argumentos que sustentaram a decisão foram encadeados segundo a lógica dialética e de acordo com o raciocínio jurídico.

\footnotetext{
770 “Art. 23 - Métodos para eliminar a dupla tributação. (...) 4. Quando um residente do Brasil receber dividendos que de acordo com as disposições da presente Convenção sejam tributáveis na Espanha, o Brasil isentará de imposto esses dividendos."

${ }^{771}$ De fato, a única exceção à esta regra está prevista no Ato Declamatório Interpretativo SRF n. 6 , de 6 de junho de 2002. que exclui da isenção prevista no artigo 23. $\S 4$ o, os lucros e dividendos recebidos por residentes no Brasil em decorrência de participação em um tipo específico de sociedade espanhola, as chamadas "Entidades de Tenencia de Valores Estrangeiros / ETVEs", que são reguladas pela lei espanhola do imposto sobre sociedades. Este, entretanto, não era o caso dos autos, em que, como já ressaltado, tratavase da tributação de lucros, e não de dividendos, muito menos de dividendos provenientes de ETVEs. E, mesmo assim, questiona-se seriamente a constitucionalidade deste dispositivo, uma vez que trata-se de um ato administrativo interpretativo que sequer tem força de lei modificando o conteúdo de um tratado internacional.
} 
Os critérios aplicáveis são de correção ou adequação em face do ordenamento jurídico e dos princípios que o informam, e não de verdade ou falsidade.

Observa-se, desta forma, que o voto proferido pela Relatora sugeria uma decisão jurídica válida, correta e coerente em termos jurídicos e em termos argumentativos. Apesar disso, este não foi o voto que prevaleceu no acórdão.

O Conselheiro José Henrique Longo, Relator Designado, adotou posicionamento divergente em relação à argumentação exposta pela Relatora. Neste ponto, é interessante retomar o aspecto de que a argumentação jurídica pode se desenvolver até mesmo entre dois julgadores, como ocorreu no presente caso.

Iniciamos a análise do voto vencedor também pela justificação externa, e imediatamente deparamo-nos com a regra da carga da argumentação, na medida em que o Relator Designado diverge do voto inicialmente apresentado, e para sustentar seu posicionamento, apresenta as razões que entende pertinentes. É o que pode ser observado da passagem abaixo, extraída do voto vencedor:

\section{"VOTO VENCEDOR}

\section{Conselheiro JOSÉ HENRIQUE LONGO, Relator Designado}

Os fatos foram muito bem narrados pela eminente Relatora, do mesmo modo que a evolução legislativa a respeito da tributação de lucro de empresa subsidiária, coligada ou controlada com sede no exterior.

Entretanto, em relação ao seu voto, tomo a liberdade de dele discordar em parte pelos fundamentos que vão adiante, o que nem sequer arranha o respeito que merece a Conselheira Karem Jureidini Dias."

$\mathrm{Na}$ realidade, devemos adiantar, para facilitar a compreensão, que a divergência de opinião do Relator Designado é devida a dois aspectos sumamente relevantes. O primeiro deles é relativo à necessidade de observância da regra da superioridade dos tratados internacionais em matéria tributária em relação à legislação infraconstitucional interna, que não parece ter sido considerada relativamente ao caso da empresa espanhola. De fato, relativamente ao caso da empresa portuguesa, o Relator reconhece a superioridade do tratado internacional entre o Brasil e Portugal, mas é obrigado a afastá-lo em virtude do fato de que a empresa portuguesa, sendo residente da Ilha da Madeira, e supostamente já sendo beneficiada pelo regime fiscal da zona franca lá 
existente, estaria excluída do âmbito de proteção da convenção, nos termos do artigo 9o do Protocolo anexo ao tratado ${ }^{772}$. Por isso a sua análise, em relação ao caso da empresa Iliama-Portugal, corretamente, nem chega a considerar a aplicação do acordo.

"Durante a vigência do art. 25 da Lei 9249 (isto é, até o início dos efeitos da Lei 9532/97), época em que se pretendeu exigir IRPJ sobre lucro de controlada no exterior, nada podia se exigir da empresa recorrente, Refratec, pois a sua controlada encontrava-se localizada em território português, cuja situação era protegida à época pelo Tratado entre Brasil e Portugal para evitar a bitributação (Decreto 69393/1971):

“VII - Os lucros de uma empresa de um Estado Contratante só podem ser tributados nesse Estado, a não ser que a empresa exerça a sua atividade no outro Estado Contratante por meio de um estabelecimento estável ai situado. Se a empresa exercer sua atividade deste modo, os seus lucros podem ser tributados no outro Estado, mas unicamente na medida em que forem imputáveis a esse estabelecimento estável."

Por outras palavras, a tributação pelo Brasil de lucro em Portugal somente poderia ocorrer se tal lucro fosse obtido por uma sucursal ou filial lá estabelecida. Mas se o lucro fosse auferido por uma empresa estabelecida em Portugal (como era o caso), seus lucros podiam ser tributados apenas por esse país irmão.

A situação foi alterada com o Tratado introduzido pelo Decreto 4012/2001, cujo item 9 do Protocolo excluiu a Ilha da Madeira (onde se localizava a controlada da recorrente) do tratamento para evitar a bitributação. Porém, a essa altura, a norma brasileira já era outra, a Lei 9532/97, com efeitos a partir de 1998.

Desse modo, e independentemente da IN 38/96 (que aliviou ao contribuinte os comandos da Lei 9249, ainda que contrariando a Lei), não vejo como exigir

\footnotetext{
772 “9. Com referência às Zonas Francas da Ilha da Madeira, da Ilha de Santa Maria e de Manaus, à SUDAM e à SUDENE - Fica entendido que os benefícios desta Convenção não serão atribuídos a qualquer pessoa que tenha direito a beneficios fiscais relativos ao imposto sobre o rendimento de acordo com os dispositivos da legislação e de outras medidas relacionadas com as Zonas Francas da Ilha da Madeira, da Ilha de Santa Maria, de Manaus, a SUDAM e a SUDENE ou a benefícios similares àqueles concedidos, disponíveis ou tornados disponíveis segundo qualquer legislação ou outra medida adotada por qualquer Estado Contratante. As autoridades competentes dos Estados Contratantes notificar-se-ão sobre qualquer legislação ou medida similar e consultar-se-ão sobre a similaridade, ou não, de tais beneficios."
} 
IRPJ da recorrente, Refratec, relativamente aos lucros auferidos pela Iliama Portugal nos anos de 1996 e 1997."

A justificação interna do raciocínio do Relator Designado, neste aspecto, é irretocável e suficientemente fundamentada. A norma de fundamentação geral, que neste caso, também constitui a premissa maior, é igualmente a superioridade dos tratados internacionais em matéria tributária em relação às normas infraconstitucionais internas. Entretanto, a segunda premissa normativa, decorrente do próprio tratado, acaba excluindo a aplicação das normas convencionais ao caso. Assim, uma vez inaplicável o tratado internacional, e existindo normas internas válidas que se aplicam ao caso, a conclusão que se obtém a partir da lógica dos argumentos é a de que devem ser aplicadas as normas internas, com a conseqüente tributação daí decorrente. O raciocínio do julgador, no caso, foi racionalmente fundamentado e os argumentos apresentados atenderam ao requisito da saturação.

Continuando na análise do voto vencedor, encontramos mais argumentos referentes à justificação externa. A passagem a seguir transcrita demonstra a adoção do método sistemático de interpretação da legislação nacional, bem como o recurso ao argumentos empíricos referentes às ciências contábeis, mediante a menção do método de equivalência patrimonial:

\section{“1.2. Anos 1998 a 2001 (vigência da Lei 9532/97)}

Como se disse, a Lei 9532/97 alterou a hipótese de incidência relativa à tributação do rendimento obtido no exterior a partir de 1998:

'Art. $1^{\circ}$ Os lucros auferidos no exterior, por intermédio de filiais, sucursais, controladas ou coligadas serão adicionados ao lucro líquido, para determinação do lucro real correspondente ao balanço levantado no dia 31 de dezembro do ano-calendário em que tiverem sido disponibilizados para a pessoa jurídica domiciliada no Brasil.

$\S 1^{\circ}$ Para efeito do disposto neste artigo, os lucros serão considerados disponibilizados para a empresa no Brasil:

$[\ldots]$

b) no caso de controlada ou coligada, na data do pagamento ou do crédito em conta representativa de obrigação da empresa no exterior. 
$\S 2^{\circ}$ Para efeito do disposto na alínea " $b$ " do parágrafo anterior, considera-se:

a) creditado o lucro, quando ocorrer a transferência do registro de seu valor para qualquer conta representativa de passivo exigível da controlada ou coligada domiciliada no exterior;

b) pago o lucro, quando ocorrer:

1. o crédito do valor em conta bancária, em favor da controladora ou coligada no Brasil;

2. a entrega, a qualquer título, a representante da beneficiária;

3. a remessa, em favor da beneficiária, para o Brasil ou para qualquer outra praça;

4. o emprego do valor, em favor da beneficiária, em qualquer praça, inclusive no aumento de capital da controlada ou coligada, domiciliada no exterior.

$[\ldots]$

Com ela, o fato gerador passou a ser a disponibilização do lucro da subsidiária, sendo que as situações em que se considerava disponibilizado o lucro estavam relacionadas nos parágrafos do art. $1^{\circ}$. Em tais casos, dependia efetivamente de um ato deliberativo de distribuição de dividendos da empresa localizada no exterior para que a empresa sócia sediada no Brasil, beneficiária, submetesse tal rendimento à tributação pelo IRPJ.

Era válido ainda o comando de que os resultados da avaliação, pelo método da equivalência patrimonial, têm o tratamento fixado de modo geral pela legislação tributária. Assim, à medida em que a controlada auferia resultado positivo, a controladora promovia o ajuste no valor do investimento em seu ativo, cuja contrapartida em conta de resultado era neutralizada por exclusão no Lalur. E somente com a disponibilização do lucro - e aqui não se discute a variação cambial - é que o valor correspondente devia ser adicionado para formação do Lucro Real." 
Outra forma de argumento empírico pode ser vista na passagem abaixo, em que o julgador menciona o instituto da presunção legal, que tem o efeito de inverter o ônus da prova sobre os fatos que constituem o objeto da presunção 773 .

"Ocorre que, com a Medida Provisória 2158-34/2001, estabeleceu-se a presunção absoluta (ficção) da disponibilização:

'Art. 74. Para fim de determinação da base de cálculo do imposto de renda e da CSLL, nos termos doart. 25 da Lei no 9.249, de 26 de dezembro de 1995, e do art. 21 desta Medida Provisória, os lucros auferidos por controlada ou coligada no exterior serão considerados disponibilizados para a controladora ou coligada no

Brasil na data do balanço no qual tiverem sido apurados, na forma do regulamento.

Parágrafo único. Os lucros apurados por controlada ou coligada no exterior até 31 de dezembro de 2001 serão considerados disponibilizados em 31 de dezembro de 2002, salvo se ocorrida, antes desta data, qualquer das hipóteses de disponibilização previstas na legislação em vigor.'

Com tal mudança, os lucros auferidos pela controlada (Iliama Portugal) deveriam ser oferecidos à tributação pela controladora no Brasil (Refratec) em 31/12/2001. No caso específico, em função da conclusão do item 1.1 supra, tais lucros referiam-se aos anos de 1998, 1999, 2000 e o próprio ano de 2001. Porém, dias antes da data da disponibilização fixada em lei, ou seja antes de 31/12/2001, a Refratec cedeu sua participação evitando com isso submeter-se à hipótese da presunção absoluta de que os lucros de sua controlada estariam considerados como disponibilizados aos sócios em 31/12/2001.”

O trecho abaixo, por sua vez, demonstra como funcionam, na prática, as regras de transição entre duas modalidades de discurso, mencionadas na teoria de Alexy. No

\footnotetext{
${ }^{773}$ Foi nesse sentido que Perelman afirmou que "a lógica jurídica é uma lógica que permite levar a seu termo uma controvérsia, em que os argumentos são confrontados, em que, em cada etapa, o pró e o contra não são postos em pé de igualdade, pois as presunções intervêm em favor da tese ou da antítese, incumbindo o ônus da prova a quem se propõe derrubar essa presunção." V. Capítulo 1. PERELMAN, Chaïm. Ética e Direito. Trad. Maria Ermantina de Almeida Prado Galvão. 2. ed. São Paulo: Martins Fontes, 2005. p. 504505.
} 
presente caso, os discursos que estão relacionados são o jurídico e o empírico, este relativo às ciências contábeis. Isto pode ser visto mediante a utilização indistinta e conjunta de conceitos pertencentes tanto à ciência jurídica quanto à contabilidade (destacados na transcrição) para fundamentar as proposições normativas. Isto demonstra que as regras de transição efetivamente tem aplicabilidade prática quando apenas uma modalidade de discurso não for capaz de resolver a questão que constitui o seu objeto.

“Uma visão sistemática do comando do art. $1^{\circ}$ da Lei 9532 conjugado com o relativo à equivalência patrimonial permite concluir que não há tributação da $\underline{\text { mais valia do investimento - correspondente apenas ao lucro e não à variação }}$ cambial - enquanto não houver a sua disponibilização efetiva. Ainda que a Lei 9532 trouxesse as hipóteses em que se devia considerar a disponibilização, é evidente que a situação de realização daquele ativo (investimento na Iliama Portugal) - fosse através de distribuição efetiva dos lucros, fosse através da cessão do ativo - provocaria a disponibilidade real e efetiva sobre aquele lucro anterior cuja tributação tinha sido postergada, via exclusão no Lalur.

O valor pelo qual foi promovida a cessão levou em consideração os Lucros Acumulados (correspondentes à parte da equivalência patrimonial), que estavam contabilizados na Refratec, de modo que foram eles empregados em favor da beneficiária. E para essa situação há dispositivo específico dentre as hipóteses de disponibilização estabelecidas pela Lei 9532. Vejamos novamente o disposto no art. $1^{o}, \S 2^{\circ}, b$, item 4 :

'Art. $1^{\circ}$ Os lucros auferidos no exterior, por intermédio de filiais, sucursais, controladas ou coligadas serão adicionados ao lucro líquido, para determinação do lucro real correspondente ao balanço levantado no dia 31 de dezembro do ano-calendário em que tiverem sido disponibilizados para a pessoa jurídica domiciliada no Brasil.

$\S 2^{\circ}$ Para efeito do disposto na alínea " $b$ " do parágrafo anterior, considera-se:

b) pago o lucro, quando ocorrer:

4) o emprego do valor, em favor da beneficiária, em qualquer praça, inclusive no aumento de capital da controlada ou coligada, domiciliada no exterior.' 
Neste outro trecho, ocorre uma transição do discurso teórico para um discurso linguístico, e, concomitantemente, o julgador recorreu ao argumento dos precedentes para fundamentar sua opinião:

"[Discurso linguístico:] Não se pode recusar a denotação do termo emprego do valor para a situação em que o beneficiário tenha transacionado o ativo correspondente e recebido o próprio valor em troca. A Refratec utilizou como custo do seu investimento o valor atualizado pelos lucros da controlada, que haviam sido excluidos por não terem sido, nos respectivos períodos, disponibilizados; ora, o controle no Lalur de tais valores destina-se a apropriar na base de cálculo do IRPJ no período em que houver a disponibilização efetiva, e isso aconteceu com a realização do investimento.

[Precedente:] Em caso semelhante (investimento empregado para pagamento de divida), a $1^{a}$ Câmara decidiu por considerar como disponibilizado o lucro da controlada no exterior (Ac. 101-94.747):

'LUCROS NO EXTERIOR - EMPREGO DO VALOR DISPONIBILIZAÇÃO - A utilização do valor de investimento já reavaliado pela equivalência patrimonial, para pagamento de dívida da empresa, no caso para distrato de adiantamento para futuro aumento de capital, mediante dação em pagamento e entrega das ações, importa em disponibilização do lucro auferido no exterior, por ser forma de emprego do mesmo em favor da beneficiária. Interpretação do disposto no artigo $1^{\circ}, \S 2^{\circ}$, alinea “b”, item 4, da Lei 9.532/97.'

Diante do exposto, entendo que houve disponibilização do lucro auferido no exterior e merece ser mantida a exigência relativa aos lucros dos anos de 1998 a 2001."

Em face de todos estes aspectos, consideramos que a fundamentação apresentada pelo Relator Designado com relação à empresa sediada em Portugal é coerente com o ordenamento jurídico vigente e com as premissas fáticas do caso, e, portanto, não merece reparos.

O mesmo, infelizmente, não se pode afirmar em relação à fundamentação do voto vencedor no que tange à empresa espanhola. O grande equívoco do julgador neste ponto, segundo entendemos, foi considerar que a situação fática da empresa espanhola era 
semelhante à da empresa portuguesa, e a partir disso desconsiderar a aplicação do Tratado Brasil-Espanha, que era plenamente aplicável.

Isto porque a exclusão da aplicação do Tratado Brasil-Portugal no caso da primeira empresa decorreu exclusivamente de uma situação fática, qual seja, o local de residência fiscal da empresa (Ilha da Madeira). Em outras palavras, o Tratado BrasilPortugal só não pode ser aplicado ao caso porque a empresa portuguesa era localizada em território expressamente excluído do âmbito de proteção da convenção. Portanto, afirmamos que o julgador cometeu um sério equívoco lógico-argumentativo ao se esquecer de reavaliar os fatos pertinentes à empresa espanhola. E esse equívoco é justamente o que impede que, nesta parte, a decisão não seja justificável internamente, o silogismo argumentativo não se conclui logicamente.

De fato, se tentássemos estabelecer uma estrutura para a justificação interna desta parte do voto, teríamos a seguinte estrutura:

\section{“2. Espanha}

A situação da controlada Iliama Participações Sociedad Limitada ("Iliama Espanha”), com resultado de parte de 2001 e ano de 2002, é semelhante à da Iliama Portugal a partir da MP 2158.

Com efeito, o art. 74 e $\S$ único da MP 2158-34 estabeleceu a ficção de que o lucro auferido por controlada no exterior estaria disponibilizado à sua controladora no Brasil em 31 de dezembro de cada ano.

Convém observar que não há espaço para o julgador administrativo tecer considerações acerca da inconstitucionalidade de lei nem para afastar sua aplicação, de maneira que há de ser respeitada neste âmbito a ficção mencionada com os seus reflexos de caráter tributário."

Premissa fática (premissa maior): "A situação da controlada Iliama Participações Sociedad Limitada ("Iliama Espanha"), com resultado de parte de 2001 e ano de 2002, é semelhante à da Iliama Portugal a partir da MP 2158”. Logo, por esta premissa, o Tratado Brasil-Espanha seria inaplicável.

Se o tratado Brasil-Espanha é inaplicável, seria possível, em tese, adotar como segunda premissa (premissa normativa) a aplicação da regra prevista no artigo 74, parágrafo único, da Medida Provisória n. 2.158-35. Ocorre que o contribuinte questiona a 
constitucionalidade deste artigo, e, como os membros do Conselho Administrativo de Recursos Fiscais não detém competência para emitir julgamentos que impliquem a declaração de inconstitucionalidade de dispositivos legais (pois isso é competência exclusiva do STF), então faltaria ao raciocínio jurídico a premissa normativa, a norma de fundamentação universal. Por esse motivo o raciocínio deixa de ter fundamentação interna, e, desta forma, a decisão não é legítima e não poderia ser imposta às partes, pois carece de fundamentação.

Em face deste impasse, a saída encontrada pelo julgador foi considerar que os rendimentos em questão caracterizavam dividendos, e não lucros, o que o levaria de volta ao Tratado Brasil-Espanha. É o que se pode inferir a partir do seguinte trecho:

"É de notar também que, diversamente do que dispunha a Lei 9249, a tributação pelo IRPJ e da CSL não incidem sobre o lucro da Iliama Espanha, mas sim sobre os dividendos disponibilizados à Refratec (art. $1^{\circ}$ da Lei 9532 e art. 74 e § ún. da MP 2158-34). Por isso, não há que se cogitar da proteção da cláusula VII do Tratado Brasil e Espanha (Decreto 76975/1976), cuja redação é a mesma que a do Tratado com Portugal e que acima se transcreveu.

É certo que o Tratado Brasil Espanha cuida também da questão da distribuição de dividendos, e que permite a tributação dos dividendos pagos por uma empresa na Espanha (Iliama Espanha) para uma empresa no Brasil (Refratec):

\section{'ARTIGO 10 Dividendos}

1. Os dividendos pagos por uma sociedade residente de um Estado Contratante a um residente do outro Estado Contratante são tributáveis nesse outro Estado.

2. Todavia, esses dividendos podem ser tributados no Estado Contratante onde reside a sociedade que os paga, e de acordo com a legislação desse Estado, mas o imposto assim estabelecido não poderá exceder $15 \%$ do montante bruto dos dividendos. Este parágrafo não afetará a tributação da sociedade com referência aos lucros que deram origem aos dividendos pagos.

3. $O$ disposto nos parágrafos 1 e 2 não se aplica quando o beneficiário dos dividendos, residente de um Estado Contratante, tiver, no outro 
Estado Contratante de que é residente a sociedade que paga os dividendos, um estabelecimento permanente a que estiver ligada a participação geradora dos dividendos. Neste caso, serão aplicáveis as disposições do Artigo 7.

4. O termo "dividendos" usado no presente artigo, designa os rendimentos provenientes de ações, ações ou direitos de fruição, partes de empresas mineradoras, ações de fundador ou outros direitos que permitam participar dos lucros, com exceção de créditos, bem como rendimentos de outras participações de capital assemelhados aos rendimentos de ações pela legislação tributária do Estado Contratante em que a sociedade que os distribuir seja residente.

5. Quando uma sociedade residente da Espanha tiver um estabelecimento permanente no Brasil, esse estabelecimento permanente poderá aí estar sujeito a um imposto retido na fonte de acordo com a legislação fiscal brasileira. Todavia, esse imposto não poderá exceder $15 \%$ do montante bruto dos lucros do estabelecimento permanente determinado após o pagamento do imposto de renda de sociedades referente a esses lucro. Não obstante, o imposto só será aplicável quando os lucros forem efetivamente transferidos para o exterior."

(http://www.receita.fazenda.gov.br/Legislacao/AcordosInternacionais /Espanha/Dec769751976.htm)'

Entendo que deva ser considerado como "dividendo pago" (item 1 do Artigo 10) como o dividendo que o sócio tiver direito, que tiver sido disponibilizado ao sócio. Caso contrário, qualquer emprego do dividendo que não fosse a transferência para uma conta de titularidade do sócio estaria à margem da incidência do tributo, e, à evidência, não é esse o conteúdo dessa norma jurídica.

Vale advertir ainda que algumas restrições previstas no texto reproduzido referem-se a situações específicas. Explico. A restrição da alíquota máxima de $15 \%$ de imposto sobre o dividendo é aplicável apenas ao país em que a empresa geradora do lucro tiver sede, no caso a restrição é para a Espanha (item 2). A limitação de que a tributação sobre os dividendos só será aplicável 
quango forem efetivamente distribuidos ao exterior refere-se ao caso em que uma empresa da Espanha tiver um estabelecimento permanente no Brasil (item $5)$.

Assim, em relação aos lucros da Iliama Espanha, devem ser tidos como disponibilizados à sócia brasileira, Refratec, levando em conta que não cabe ao julgador administrativo apreciar a legalidade ou constitucionalidade do art. 74 da MP 2158-34 (Regimento Interno CC, art. 22-A). Desse modo, deve ser mantida a exigência.

Em face do exposto, dou parcial provimento para afastar a exigência de IRPJ relativamente aos lucros dos periodos de 1996 e 1997 (valor de $R \$ 5.018 .226,03)$, e a de CSL relativamente aos lucros dos periodos de 1996, 1997 e 1998 (valor de $R \$ 6.604 .487,68$ ).

Sala das Sessões - DF, em 23 de março de 2006.

JOSÉ HENRIQUE LONGO”

Mais uma vez, percebemos um erro quanto aos fatos que conduziu a um erro quanto às normas aplicáveis, impedindo a justificação interna da decisão. Isto porque, segundo constava do relatório do acórdão, os rendimentos em questão não caracterizavam dividendos, mas, sim, lucros, de forma que o artigo do tratado aplicável era o artigo $7^{\circ}$, e não o artigo 10. Neste ponto, imaginamos que o julgador talvez não tenha tomado em consideração a diferença entre os conceitos de lucro e de dividendos, que explicamos anteriormente.

Entretanto, mesmo que fosse possível classificar os rendimentos em questão como dividendos, ainda assim não poderia haver a tributação no Brasil, em virtude da conjugação do artigo 10 , parágrafo $1^{\circ}$, com o artigo 23 , parágrafo $4^{\circ}$ do mesmo tratado, que prevê expressamente a isenção dos dividendos.

E, mesmo se nos fatos houvesse a informação de que o objeto da tributação fossem mesmo dividendos, e não lucros, ainda assim a tributação somente poderia ocorrer na Espanha, por decorrência direta dos artigos 10, parágrafo $1^{\circ}$, e 23 , parágrafo $4 \mathrm{o}$, do Tratado Brasil-Espanha, que dispõe expressamente que "4. Quando um residente do Brasil receber dividendos que de acordo com as disposições da presente Convenção sejam tributáveis na Espanha, o Brasil isentará de imposto esses dividendos." 
Portanto, observa-se que o voto vencedor continha um grave erro lógicoargumentativo, que impedia a sua justificação interna e, por isso, impossibilitava que ele fosse imposto ao contribuinte da forma como efetivamente ocorreu. $\mathrm{O}$ acórdão em questão, embora aparentemente coerente, carecia de fundamento legal, e essa percepção somente foi possível mediante a aplicação das regras que compõem a teoria da argumentação jurídica.

\section{B) Caso $\mathrm{CBPO}^{774}$}

Este é outro caso em que a interpretação de uma convenção de bitributação pelo método clássico, especificamente pelo equivocado reenvio ao direito interno, levou a um resultado totalmente ilógico. Aplicaremos a teoria da argumentação jurídica para demonstrar o equívoco e provar que, se houvessem sido seguidas as regras propostas por Alexy, a decisão, que apesar de ter sido favorável em parte ao contribuinte, poderia ser racional e coerente, o que, de fato, não foi.

O caso em questão envolve a empresa CBPO Engenharia Ltda., que foi autuada pela fiscalização federal por não ter incluído na apuração do lucro real da matriz no Brasil os lucros auferidos por sua sucursal localizada na Argentina, no período de 1996 e 1997. Em sua defesa, a empresa afirmou que o lucro da sucursal argentina já havia sido tributado naquele país, e que, segundo o artigo VII, parágrafo $1^{\circ}$ da Convenção BrasilArgentina, só poderia ser tributado na Argentina. Alternativamente, requereu que, caso a fiscalização assim não entendesse, que fosse autorizada a compensação do "Impuesto sobre las Ganancias" pago na Argentina no período em questão. Esta pretensão era baseada na Convenção Brasil-Argentina, artigo VII, parágrafo $1^{\circ}$.

A decisão de primeira instância entendeu, com razão, que a referida convenção não vedou, em momento algum, que os lucros da sucursal argentina fossem tributados também no Brasil, afinal, o Brasil adota o princípio worldwide income taxation desde 1996 A decisão reconheceu também que havia o direito à compensação, mas negou à empresa

\footnotetext{
774 Processo n. 16327.000619/2001-61, Recurso n. 38.932. Recorrente: CBPO ENGENHARIA LTDA. Recorrida : $10^{\mathrm{a}}$ Turma/DRJ em São Paulo- SP - I. Sessão de : 13 de abril de 2005 Acórdão no . : 101-94.910. Disponível em: http://161.148.1.141/domino/Conselhos/SinconWeb.nsf/b51ea9ebd0dcdaee032566f7006e567c/53cfcb69ca73 411603256fe80003eaf4/\$FILE/Ac.101-94.910-138932.pdf. Acesso em 08 jan. 2010.
} 
em questão o seu exercício, mediante o argumento de que ela não teria apresentado o documento comprobatório do pagamento do imposto argentino ${ }^{775}$.

Em face desta decisão, a empresa CBPO recorreu da decisão ao Conselho Administrativo de Recursos Fiscais, cuja decisão foi assim ementada:

“TRATADOS E CONVENÇÕES INTERNACIONAIS. Não obstante o STF tenha se posicionado no sentido de inexistência de primazia hierárquica do tratado internacional, em se tratando de Direito Tributário a prevalência da norma internacional decorre de sua condição de lei especial em relação à norma interna. CONVENÇÃO BRASIL-ARGENTINA PARA EVITAR DUPLA TRIBUTAÇÃO. LUCRO DE SUCURSAL BRASILEIRA NA ARGENTINA. No caso específico, a norma interna prevalecerá sobre a norma internacional, posto que a própria convenção internacional admite a possibilidade de modificação do tratamento aplicável às filiais a empresas brasileiras situadas no exterior por meio de alteração da legislação interna brasileira. IMPOSTO PAGO NO EXTERIOR. COMPENSAÇÃO. Para fins de compensação do imposto de renda incidente no exterior, a comprovação pode ser feita na forma do art. 16 da Lei 9.430/96. COMPENSAÇÃO DE PREJUÍZOS ACUMULADOS DE PERÍODOS -BASE ANTERIORES A 1995. Comprovado nos autos o trânsito em julgado de decisão judicial admitindo a compensação integral dos prejuízos anteriores a 1995, deve ser atendido o pleito do contribuinte de utilizar os saldos dos prejuizos compensáveis com os lucros tributáveis apurados no procedimento em litígio. Recurso provido em parte.”

O Conselho Administrativo de Recursos Fiscais, apesar de reconhecer a primazia do tratado internacional sobre a legislação tributária interna, negou a aplicação do acordo Brasil-Argentina por entender que o próprio acordo autorizava a aplicação da

775 “'Assunto: Imposto sobre a Renda de Pessoa Jurídica - IRPJ

Ano-calendário: 1996-1997

Ementa: LUCRO DE SUCURSAL NO EXTERIOR. TRIBUTAÇÃO. Os lucros auferidos por filiais, sucursais ou controladas, no exterior, de pessoas jurídicas domiciliadas no Brasil serão computados na apuração do lucro real.

IMPOSTO PAGO NO EXTERIOR. COMPENSAÇÃO.

Para fins de compensação, o documento relativo ao imposto de renda incidente no exterior deverá ser reconhecido pelo respectivo órgão arrecadador e pelo Consulado da Embaixada no país em que for devido o imposto.

INEXISTENNCIA DE MEDIDA JUDICIAL. MULTA DE OFÍCIO.

Não havendo medida judicial favorável à impugnante, com o mesmo objeto da autuação, há que se manter o lançamento da multa de oficio." 
legislação interna em detrimento das normas convencionais. E o fundamento para tanto, segundo a Relatora, foi a norma contida na Nota 3 do Protocolo anexo ao tratado. Vale conferir nas palavras da própria Relatora:

"Tendo em vista o princípio do pacta sunt servanda, a norma a prevalecer deveria ser a norma internacionalmente acordada, de tributação pelo país onde se situa o estabelecimento permanente. Ocorre que, no caso específico, a Nota 3 do Protocolo que integra a Convenção, dispõe:

\section{'3. Com referência ao Artigo VII, parágrafo 1:}

Fica estabelecido que, no caso de alterações da legislação brasileira do imposto sobre a renda que impliquem na modificação do tratamento aplicável às filiais situadas no exterior de empresas brasileiras, vigente na data da assinatura do presente Protocolo, a Argentina poderá solicitar a revisão do Artigo VII, parágrafo 1, da Convenção.'

Assim, não obstante a norma internacional dever, em regra,prevalecer sobre a norma interna, no caso específico, prevalece o artigo 25 da Lei 9.249/95, eis que admitida pela própria convenção a alteração, pela legislação interna brasileira, da tributação dos lucros na forma prevista na convenção."

Entendemos que a interpretação realizada pela Relatora acerca desta norma foi bastante equivocada. Realmente, a citada Nota 3 apresenta redação bastante confusa, cujo significado é difícil de ser apreendido. Mas, segundo entendemos, não há nessa norma qualquer autorização para que se deixe de aplicar o tratado internacional. Nem mesmo há autorização para que o Brasil sequer solicite a revisão do acordo. Independente da redação ruim, é possível perceber claramente que a norma da referida Nota 3 prevê a possibilidade de apenas a Argentina requerer a revisão do artigo $7^{\circ}$, parágrafo 1.

$\mathrm{Na}$ realidade, percebemos que a norma contida neste dispositivo nada mais é do que a materialização da cláusula rebus sic stantibus, segundo a qual, havendo modificações nas condições originais em que o acordo foi celebrado, as partes podem requerer a revisão. E, no caso específico, estabeleceu-se que se o Brasil modificar a sua legislação interna sobre o imposto de renda, alterando, assim, a situação original em que o acordo foi celebrado, a Argentina poderia solicitar a revisão do artigo $7^{\circ}$, parágrafo $1^{\circ}$, da convenção, em virtude da quebra do equilíbrio contratual, princípio que também se aplica aos tratados internacionais. Além disso, a referida Nota 3 do Protocolo estabelece, pelo que 
entendemos, que a alteração na legislação do imposto de renda brasileiro deve ser em relação às leis vigentes na época da assinatura do protocolo. Mas este argumento nem precisa ser justificado, porque a interpretação foi tão equivocada que nem se chegou a discutir este requisito no texto da decisão.

Assim, para o caso em análise, interessa apenas que a autorização conferida pela Nota 3 do Protocolo permite tão-somente que a Argentina peça a revisão do acordo, e mesmo assim, desde que atendidas as condições nela estabelecidas. Não há no dispositivo em comento qualquer autorização para o Brasil aplicar a sua legislação interna em detrimento do tratado.

Então, aplicando-se as regras da Teoria da Argumentação Jurídica, teríamos que a justificação externa para a aplicação desta norma seria a própria ocorrência da bitributação internacional, que se verificava concretamente mediante a apresentação de argumentos empíricos (provas documentais) e ensejava a aplicação do tratado.

A regra da justificação externa estava, portanto, atendida na decisão.

O grande problema foi a justificação interna, na qual deveriam ser observadas a lógica e a coerência entre os fatos e as normas jurídicas aplicadas. Na realidade, um simples exercício de lógica argumentativa comprova que a conclusão da Relatora não faz o menor sentido, ou seja, não tem lógica argumentativa, a partir das premissas que ela mesma adota, não podendo, desta forma, ser considerada racional. Isto porque as premissas que ela adota não são corretas, já que o fundamento legal que ela apresenta (a Nota 3 do Protocolo), não prevê a regra (de aplicação da legislação interna em detrimento do tratado) que ela equivocadamente aplicou ao caso. Em outras palavras, a partir da redação da citada Nota 3 do Protocolo, a norma jurídica que se extrai é a de que a Argentina poderia requerer a revisão do acordo atendidas as condições especificadas, e isto não serve para fundamentar a pretensão (ou seja, a conclusão da Relatora) de aplicar as normas tributárias internas brasileiras em detrimento do tratado. Não se estabelece, nesse caso, o vínculo lógico entre os fundamentos normativos e a decisão.

Com isso, observa-se que o voto da Relatora, que conduziu a decisão, carecia de justificação interna, ou seja, faltava-lhe o requisito do encadeamento entre as proposições e as normas que lhes conferem validade, faltava-lhe coerência legal. E, em virtude disso, faltou-lhe racionalidade. 
De fato, se aplicássemos a Teoria da Argumentação Jurídica, veríamos que a conclusão correta seria aplicar o tratado, e não a legislação interna brasileira. Aplicando as regras da justificação interna, teríamos o seguinte:

[Norma de validade universal n. 1] - Princípio da tributação em bases universais no Brasil.

[Norma de validade universal n. 2] - Artigo $7^{\circ}$, parágrafo $1^{\circ}$ - permite a tributação dos lucros da sucursal na Argentina.

[Normas que fundamentam as demais etapas do desenvolvimento] - Artigo 23, $1^{\mathrm{o}}$ - autoriza a dedução no imposto a pagar no Brasil do montante do imposto pago na Argentina. Aqui não entraremos no mérito da documentação necessária para a compensação, pois, para os fins da presente discussão, ou seja, para demonstrar que o raciocínio da relatora não estava logicamente correto, podemos presumir que as obrigações acessórias necessárias para a compensação foram cumpridas.

[Argumentos empíricos] - Fatos comprovados - a empresa possuía uma sucursal, que é considerada estabelecimento permanente nos termos do artigo $5^{\circ}$, II, b, do Tratado.

[Conclusão] - A empresa brasileira poderia ser tributada na Argentina, como efetivamente foi, mas o montante do imposto pago na argentina poderia ser deduzido do imposto a pagar no Brasil.

Ao final, a decisão foi parcialmente favorável à empresa recorrente, tendo sidolhe permitida a dedução do imposto pago na Argentina relativamente ao período de 1996. Porém, esta conclusão decorreu de premissas equivocadas (decorreu da legislação interna, quando deveria decorrer da aplicação do tratado. Se o tratado houvesse sido devidamente aplicado, muito provavelmente (aqui estamos presumindo que as obrigações acessórias para tanto foram cumpridas) o contribuinte poderia ter se beneficiado com a dedução do montante total do imposto pago na Argentina.

Portanto, considerando o exercício de aplicação da Teoria da Argumentação Jurídica que fizemos acima, demonstramos que a decisão em questão não pode ser considerada racional, primeiro porque a conclusão da relatora não é coerente com as premissas expostas, ou seja, não faz sentido em face dos pressupostos adotados, e segundo porque a decisão final, embora tenha sido parcialmente favorável ao contribuinte, baseou- 
se em premissas totalmente equivocadas, e se houvessem sido adotados os pressupostos corretos.

\subsection{A Ação Direta de Inconstitucionalidade n. 2.588}

Paralelamente às discussões em torno da tributação de lucros e dividendos através de acordos de bitributação, os recursos permanecem aguardando a tão esperada decisão do Supremo Tribunal Federal sobre a Ação Direta de Inconstitucionalidade n. 2.588, ajuizada pela Confederação Nacional da Indústria - CNI contra o Presidente da República e o Congresso Nacional, na qual se questiona precisamente o artigo 74 da Medida Provisória $\mathrm{n}^{\mathrm{o}} 2.158-32 / 2001^{776}$, artigo este que, como vimos acima, determina a cobrança de Imposto de Renda e de Contribuição Social sobre o Lucro Líquido sobre os lucros auferidos por controladas e coligadas no exterior, mesmo que estes ainda não tenham sido distribuídos às controladoras no Brasil, por meio de uma presunção de distribuição na data do fechamento do balanço anual (31 de dezembro de cada ano), e também o artigo 43, parágrafo 20 , do $\mathrm{CTN}^{777}$.

A relatora do processo é a Ministra Ellen Gracie, e o caso será julgado pelo Pleno do Supremo Tribunal Federal. Os dispositivos constitucionais que se reportam como violados pelos artigos acima indicados são os artigos 62; 150, III, "a" e 153, III, todos da Constituição Federal de 1988.

A Confederação Nacional da Indústria, na posição de Requerente, aponta as seguintes inconstitucionalidades:

- Inobservância do requisito de urgência - a edição da MP 2.158-35/01 atendeu ao requisito de relevância, mas não atendeu ao requisito de urgência (violação do art. 62 da $\mathrm{CF} / 88$ ).

\footnotetext{
776 Art. 74. Para fim de determinação da base de cálculo do imposto de renda e da CSLL, nos termos do art. 25 da Lei n. 9.249, de 26 de dezembro de 1995, e do art. 21 desta Medida Provisória, os lucros auferidos por controlada ou coligada no exterior serão considerados disponibilizados para a controladora ou coligada no Brasil na data do balanço no qual tiverem sido apurados, na forma do regulamento. Parágrafo único. Os lucros apurados por controlada ou coligada no exterior até 31 de dezembro de 2001 serão considerados disponibilizados em 31 de dezembro de 2002, salvo se ocorrida, antes desta data, qualquer das hipóteses de disponibilização previstas na legislação em vigor

${ }^{777}$ Art. 43. O imposto, de competência da União sobre a renda e proventos de qualquer natureza tem como fato gerador a aquisição da disponibilidade econômica ou jurídica: (...) $\S 2^{\circ} \mathrm{Na}$ hipótese de receita ou de rendimento oriundos do exterior, a lei estabelecerá as condições e o momento em que se dará sua disponibilidade, para fins de incidência do imposto referido neste artigo. (Incluído pela LC 104/01)
} 
- Violação dos princípios da anterioridade e irretroatividade (violação ao art. 150, III, "a" e "b" da CF/88) - o parágrafo único do art. 74 da MP 2.158$35 / 01$ viola os princípios da anterioridade e irretroatividade ao pretender tributar, em 31/12/2002, todos os lucros apurados por controladora ou coligada no exterior até 31/12/2001.

- Violação do conceito constitucional de renda (violação ao art. 153, III, da $\mathrm{CF} / 88$ ). O caput do art. 74 da MP 2.158-35/01 viola o conceito constitucional de renda ao considerar disponibilizados pela controladora ou coligada no Brasil os lucros auferidos por controladora ou coligada no exterior, na data do balanço no qual tiverem sido apurados, pois não houve, ainda, o acréscimo patrimonial, não sendo possível considerar disponibilizados para a controladora ou controlada no Brasil os lucros que foram apenas apurados pela controladora ou coligada no exterior. Além disso, o art. 43, parágrafo $2^{\circ}$, do CTN viola o conceito constitucional de renda ao permitir ao legislador ordinário fixar o momento da ocorrência do fato gerador.

Em contrapartida, os argumentos apresentados pelos Requeridos (Presidente da República e Congresso Nacional, foram os seguintes:

- Presunção de atendimento aos requisitos de relevância e urgência: pelo art. $2^{\circ}$ da Emenda Constitucional n. 32/2001, as medidas provisórias editadas anteriormente à sua publicação continuam em vigor até a sua revogação por norma posterior ou sua rejeição pelo Congresso Nacional.

- A disponibilidade econômica e jurídica da renda ocorreria no momento da realização do balanço da pessoa jurídica controlada ou coligada no exterior, e, uma vez verificada a existência de lucro, estes já estariam na esfera de disponibilidade da controladora ou coligada no Brasil. Deste modo, os dispositivos atacados (art. 74, caput e parágrafo único da MP 2.158-35/01 e art. 43, parágrafo 20 , do $\mathrm{CTN}$ ) não violavam o conceito constitucional de renda, sendo, portanto, constitucionais.

- Os lucros apurados no exterior configurariam renda desde o momento de sua apuração. 
- Inexistência de ofensa aos princípios da anterioridade e da irretroatividade tributária, haja vista que não houve a criação de tributo novo nem a majoração de tributo pré-existente.

- O parágrafo $2^{\circ}$ do art. 43 do CTN não teria alterado o conceito de renda, mas apenas definido o aspecto temporal da disponibilidade econômica dos lucros auferidos no exterior ${ }^{778}$.

Em face dos argumentos expostos pelas duas partes, a Relatora, Ministra Ellen Gracie, proferiu seu voto opinando pela procedência parcial da ação, em virtude dos seguintes argumentos:

- Inconstitucionalidade da expressão "ou coligadas", contida no caput do art. 74 da Medida Provisória 2.158-35/01. No caso das controladas, a apuração em balanço já configura a disponibilidade da renda para fins de IRPJ (fato gerador). No entendimento da Ministra, a relação ente empresa controladora e controlada é de subordinação, de modo que a disponibilidade dos lucros da empresa controlada depende exclusivamente da empresa controladora, que detém o poder decisório sobre o destino dos lucros, ainda que não remetidos para o Brasil. Desta forma, no que tange às controladas no exterior, o art. 74 da medida provisória 2.158-35/01 seria constitucional. Em conseqüência, a apuração de tais lucros caracterizaria perfeitamente o fato gerador do imposto de renda. Este raciocínio, no entanto, não é aplicável às empresas coligadas, uma vez que, de acordo com a Lei das Sociedades Anônimas, não a empresa coligada residente no Brasil não detém uma posição de controle sobre a sua coligada no exterior. A relação é de paridade, implicando que a coligada residente no Brasil não detém a disponibilidade dos lucros auferidos pela coligada estrangeira antes da efetiva remessa desses lucros o Brasil, ou, pelo menos, antes da deliberação dos diretores da coligada residente no exterior a respeito do destino dos lucros do exercício. Desta forma, com relação às coligadas, o art. 74 é inconstitucional, na medida em que o seu caput violaria o art. 146, III, "a" da $\mathrm{CF} / 88$, que reservou à lei complementar a definição do fato gerador, definição esta que não pode ser alterada por meio de lei ordinária.

\footnotetext{
${ }^{778}$ Nesse sentido, citam como precedente o acórdão do Recurso Extraordinário n.192.711.
} 
Portanto, para a tributação dos lucros das empresas coligadas no exterior pelo IRPJ e pela CSLL permaneceria vigente o disposto na Lei 9.532/97.

- Disponibilidade econômica x disponibilidade jurídica: o STF adota entendimento no sentido de que a aquisição de disponibilidade econômica de renda consiste na percepção efetiva pelo contribuinte do rendimento em dinheiro, ou seja, em receita realizada, ao passo que a disponibilidade jurídica consiste no direito de o contribuinte receber um crédito mediante a existência de um título hábil para recebê-lo. Assim, o fato gerador do imposto de renda depende da disponibilidade econômica da renda, não apenas da disponibilidade jurídica.

Já o Ministro Marco Aurélio votou pela procedência total da ação, declarando a inconstitucionalidade de ambos os dispositivos em virtude dos seguintes argumentos:

- $\mathrm{O}$ artigo 62 da $\mathrm{CF} / 88$ teria sido violado em face da absoluta falta de urgência para justificar a edição da medida provisória em questão;

- Os artigos 153, III, e 195, I, “c”, da CF/88 também teriam sido violados em decorrência da exigência de imposto e contribuição sobre situação que não configura renda ou lucro. Neste aspecto, o Ministro entendeu que a Medida Provisória n. 2.158-35/01 criou um novo fato gerador, discrepante do conceito constitucional de renda, daí a violação aos preceitos constitucionais supracitados.

- Desrespeito aos princípios da anterioridade e irretroatividade, mediante a violação do artigo 150, III, da CF/88: o artigo 74, caput e parágrafo único, da MP, editada em julho de 2001, diz que os lucros apurados por controlada ou coligada no exterior até 31 de dezembro daquele ano serão considerados disponibilizados em 31 de dezembro de 2002, salvo algumas exceções previstas em lei. Houve, desta forma, um alargamento da ficção jurídica, imprimindo-lhe eficácia retroativa incompatível com o princípio constitucional da anterioridade. Assim, a violação do artigo 150, III, da CF/88 decorreu da pretensão veiculada por meio do artigo 74 , caput e parágrafo único da Medida Provisória n. 2.158-35/01 de pretender tributar lucros acumulados relativos a períodos anteriores à sua edição e também relativos ao mesmo exercício financeiro em que foi a mesma foi publicada. 
De fato, o Ministro Marco Aurélio entendeu que os dispositivos atacados criaram uma extravagância ao pretenderem tributar o lucro da coligada ou controlada no exterior sem ter ocorrido a disponibilidade econômica do lucro em questão. Em seu voto, o Ministro entendeu que enquanto inexistente o ingresso da participação da empresa brasileira no território nacional, ou seja, enquanto não distribuídos os lucros pela empresa estrangeira com a qual se mantenha laços sob o ângulo da coligação ou do controle, não é possível cogitar do fato gerador do imposto sobre a renda, porque a renda é inexistente e porque não passou a disponibilidade, em si, sob tal ângulo, e não do patrimônio, da empresa coligada ou controlada para a brasileira.

Além disso, especialmente no caso das coligadas (como já mencionado, inclusive pela Conselheira Karem Jureidini, no Caso Refratec), o destino a ser dado ao lucro de determinada empresa pode ficar sujeito à deliberação da assembléia, não é possível simplesmente presumir que ele seja disponibilizado automaticamente. E, especialmente nos casos de empresas residentes no exterior, por exemplo, pode ocorrer, com a manutenção do artigo 74, parágrafo único, da Medida Provisória 2.158-35/01, a bitributação - o que, efetivamente já ocorreu, conforme ficou demonstrado pela decisão proferida pelo Conselho Administrativo de Recursos Fiscais no caso Refratec, analisado no item anterior.

Os Ministros Sepúlveda Pertence e Ricardo Lewandowski acompanharam o voto do Ministro Marco Aurélio pela procedência total da ação. Entretanto, o fundamento do voto do ministro Ricardo Lewandowski foi a violação do princípio da proporcionalidade. Embora ele pondere que seja louvável o evidente caráter anti-evasivo presente na norma do artigo 74 da referida medida provisória, o dispositivo acabou invadindo a competência reservada à lei complementar e, dessa forma, deu nova definição ao fato gerador do imposto de renda.

Em posição oposta, o atual ex-Ministro Nelson Jobim votou pela improcedência total da ação, entendendo que os dispositivos que são objeto da Adi são constitucionais, devendo ser interpretados conforme a Constituição. O entendimento do Ministro Nelson Jobim foi baseado no argumento de que as empresas que utilizam o método de equivalência patrimonial estariam sujeitas à legislação introduzida pela Medida Provisória. Nesse mesmo sentido votou o Ministro Eros Grau, empatando a votação em três votos a favor da procedência da ação, declarando a inconstitucionalidade dos 
dispositivos atacados, e três votos contra, nos quais se entende que os dispositivos são constitucionais.

Atualmente o processo encontra-se novamente paralisado, com pedido de vistas para o Ministro Carlos Britto, desde 29/11/2007. Desta forma, o quadro da votação encontra-se no seguinte estado:

1 - Ellen Gracie (Relatora) - Procedência parcial

2 - Nelson Jobim - Improcedência total. Sua sucessora, a Ministra Cármen Lúcia, ficou impedida de votar porque o Ministro Nelson Jobim já havia proferido seu voto no caso.

3. Gilmar Mendes - * Impedido *

4. Sepúlveda Pertence - Procedência total. O ministro Dias Toffoli, sucessor do falecido ministro Menezes Direito, encontra-se impedido de votar porque o Ministro Sepúlveda Pertence, a quem o Ministro Menezes Direito sucedeu, já havia proferido seu voto.

5. Celso de Mello - Ainda não votou

6. Marco Aurélio - Procedência total

7. Cezar Peluso - Ainda não votou

8. Carlos Brito - Ainda não votou - pedido de vista desde 29/11/2007.

9. Joaquim Barbosa - Ainda não votou

10. Eros Grau - improcedência total

11. Ricardo Lewandowski - procedência total

Enquanto não se chega ao veredicto final deste caso, as empresas que possuem controladas ou coligadas no exterior permanecem sujeitas à dupla tributação, especialmente se considerarmos o comportamento das autoridades fiscais responsáveis pela interpretação e aplicação de tais tratados.

\subsection{A denúncia do Acordo Brasil-Alemanha}

O exemplo mais recente e talvez o que mais sérias consequências teve relacionado à interpretação restritiva dos tratados de bitributação foi a denúncia do tratado 
Brasil-Alemanha ${ }^{779}$, ocorrida em $07 / 04 / 2005^{780}$, cujos efeitos se operaram a partir de $01 / 01 / 2006^{781}$.

Diversos foram os motivos que levaram à denúncia do acordo, mas provavelmente a gota d'água tenha sido a inflexibilidade e a reiterada violação de dispositivos do acordo por parte da Receita Federal do Brasil, que insistia em adotar sempre a interpretação, principalmente no que concerne ao art. $7^{\circ}$, que tratava dos lucros das empresas ${ }^{782}$, mais favorável à arrecadação brasileira. De fato, por reiteradas vezes, a Receita Federal deixava de aplicar o artigo $7^{\circ}$ (lucros de empresas, que são tributáveis no país de residência) para aplicar o artigo 22 do tratado (outros rendimentos, que são tributáveis na fonte, ou seja, no Brasil), indevidamente qualificando os lucros na categoria de outros rendimentos $^{783}$, com o nítido objetivo de manter a sua tributação no Brasil ${ }^{784}$. E,

\footnotetext{
${ }^{779}$ Antigo Decreto n. ${ }^{\circ} 76.988 / 76$.

${ }^{780}$ No Brasil, a revogação ocorreu por meio do Decreto n. ${ }^{\circ} 5.654 / 05$.

${ }^{781}$ FUCK, Luciano Felício. A denúncia da convenção entre Brasil e Alemanha e os métodos para evitar a dupla tributação internacional. In: Revista de Direito Internacional Econômico e Tributário. Jul. dez. 2006. Brasília: Fortium, 2006, v. 1, n. 2. pp. 254-266.
}

${ }^{782}$ A redação do art. $7^{\circ}$ do Decreto n. ${ }^{\circ} 76.988 / 76$ - Tratado Brasil-Alemanha, era a seguinte: ARTIGO $7^{\circ}$ Lucros das Empresas 1. Os lucros de uma empresa de um Estado Contratante só são tributáveis nesse Estado, a não ser que a empresa exerça sua atividade no outro Estado Contratante por meio de um estabelecimento permanente aí situado. Se a empresa exercer sua atividade na forma indicada, seus lucros serão tributáveis no outro Estado, mas unicamente na medida em que forem atribuíveis a esse estabelecimento permanente. 2. Quando uma empresa de um Estado Contratante exercer sua atividade no outro Estado Contratante através de um estabelecimento permanente aí situado, serão atribuídos em cada Estado Contratante a esse estabelecimento permanente os lucros que obteria, se constitú́sse uma empresa distinta e separada, exercendo atividade idênticas ou similares, em condições idênticas ou similares, e transacionando com absoluta independência com a empresa de que é um estabelecimento permanente. 3 . No cálculo dos lucros de um estabelecimento permanente, é permitido deduzir as despesas que tiverem sido feitas para a consecução dos objetivos do estabelecimento permanente, incluindo as despesas de direção e os encargos gerais de administração assim realizados. 4. Nenhum lucro será atribuído a um estabelecimento permanente pelo simples fato de comprar bens ou mercadorias para a empresa. 5. Quando os lucros compreenderem elementos de rendimentos tratados separadamente nos outros artigos do presente acordo, as disposições desses artigos não serão afetadas pelo presente artigo.

${ }^{783}$ A redação do art. 22 do Decreto n. ${ }^{0}$ 76.988/76 - Tratado Brasil-Alemanha, era a seguinte: ARTIGO 22 Rendimentos não Expressamente Mencionados. Os rendimentos de um residente de um Estado Contratante não expressamente mencionados nos artigos precedentes do presente acordo são tributáveis em ambos os Estados Contratantes.

${ }^{784}$ Nesse sentido, vale mencionar trecho de palestra proferida pelo prof. Luís Eduardo Schoueri, em palestra proferida no IBDT, em 11/08/2005, ocasião em que se discutiram os motivos que levaram à denúncia do tratado: “(...) houve o problema do Artigo $7^{\circ}$ contra o Artigo 21 - não sei se vale a pena lembrar isso, mas basicamente o Brasil adotou uma posição curiosíssima dizendo que os lucros da empresas não são, que as empresas que tenham lucros no exterior, que em princípio não seriam tributadas nos termos do acordo, já não têm mais lucro, têm rendimentos não identificados do acordo do Artigo 21. É um tema mais técnico, mas, para resumir, a posição brasileira desse Ato Declaratório Interpretativo Número 1 que inventava que o Brasil poderia tributar remessas para os serviços que não fossem inseridos no Artigo 12. Essa foi uma posição 
assim, a Receita sempre encontrava uma "brecha" na qual fosse possível enquadrar as situações apresentadas pelos contribuintes no campo das exceções, fazendo delas, muitas vezes, a regra geral.

Quando o acordo de bitributação Brasil-Alemanha ainda era vigente, a tributação de remessas para o pagamento de serviços que não envolvessem transferência de tecnologia estariam perfeitamente dentro do escopo da proteção do tratado. Deste modo, nos termos do seu art. $7^{\circ}$, os lucros auferidos por empresa oriundos do outro Estadocontratante somente poderiam ser tributados no Estado de origem da empresa, salvo se esta empresa possuísse, no outro Estado-contratante, um estabelecimento permanente. Em termos práticos, significava que os lucros de uma empresa alemã auferidos no Brasil somente seriam tributáveis na Alemanha, salvo se esta empresa alemã tivesse um estabelecimento permanente situado no Brasil, hipótese em que tais lucros também poderiam ser tributados no Brasil.

Ocorre que o órgão fazendário sempre entendeu que os lucros decorrentes de prestação de serviços não se encaixariam na hipótese de lucros prevista no artigo $7^{\circ}$, mas sim, na hipótese do art. 22, o que ensejaria a tributação pelo Brasil em virtude de se tratar de rendimentos diversos, e não de lucros. Este entendimento convenientemente distorcido em função da urgência arrecadaria do Estado brasileiro, decorre do fato de que no artigo $7^{\circ}$ não existe uma referência expressa ao termo prestação de serviços. Com isso, sempre prevalece a interpretação que permite maior arrecadação ao fisco brasileiro.

O mesmo problema ocorre quando se trata da tributação de remessas decorrentes de prestações de serviço de assistência técnica, as quais deveriam ser tributadas na categoria de royalties, nos termos do art. $12^{785}$ da Convenção e de acordo

também contrária, no meu ponto de vista contrária ao acordo. O Brasil não negociou. (...)”. A íntegra da palestra pode ser conferida em http://www.ibdt.com.br/integra_11082005.htm.

${ }^{785}$ A redação do art. 12 do Decreto n. ${ }^{\text {7 }}$ 76.988/76 - Tratado Brasil-Alemanha, era a seguinte: ARTIGO 12 Royalties. 1. Os royalties provenientes de um Estado Contratante e pagos a um residente do outro Estado Contratante são tributáveis nesse outro Estado. 2. Todavia, esses royalties podem ser tributados no Estado Contratante de que provêm, de acordo com a legislação desse Estado, mas o imposto assim estabelecido não poderá exceder: a) $25 \%$ do montante bruto dos royalties, provenientes do uso ou da concessão do uso de marcas de indústria ou comércio; b) $15 \%$ em todos os demais casos. 3. O termo "royalties" empregado neste artigo designa as remunerações de qualquer natureza pagas pelo uso ou pela concessão do uso de um direito de autor sobre uma obra literária, artística ou científica (inclusive os filmes cinematográficos, filmes ou fitas de gravação de programas de televisão ou radiodifusão), qualquer patente, marcas de indústria ou comércio desenho ou modelo, plano, fórmula ou processos secretos, bem como pelo uso ou pela concessão do uso de um equipamento industrial, comercial ou científico e por informações correspondentes à experiência adquirida no setor industrial, comercial ou científico. 4. Os royalties serão considerados provenientes de um Estado Contratante quando o devedor for o próprio Estado, uma sua subdivisão política, uma autoridade local 
com as práticas correntes em Direito Tributário Internacional. Nos termos do referido art. 12, tais remessas somente poderiam ser tributadas na Alemanha, mas o fisco brasileiro entende que não se trata de royalties, mas sim de rendimentos não especificados ${ }^{786}$, enquadráveis no art. 22, e, portanto, passíveis da incidência dos tributos brasileiros, no caso, imposto de renda e CIDE-royalties, instituída pela Lei n. 10.332/01.

Assim, apesar de, na prática, no curto prazo, a denúncia do tratado não provocar significativas alterações para as empresas, tendo em vista que o Brasil já não vinha cumprindo as suas disposições há bastante tempo, a denúncia do acordo pelos motivos acima explicados pode ter efeitos danosos a longo prazo para o Brasil, em virtude de dois motivos principais. Primeiro, porque o Brasil adota, para todas as suas convenções de dupla tributação, o Modelo OCDE, que serviu de base para o tratado com a Alemanha. Logo, a interpretação dada pela autoridade fiscal brasileira, bem como as críticas a ela

ou um residente desse Estado. Todavia, quando o devedor dos royalties, seja ou não residente de um estado contratante, tiver num Estado Contratante um estabelecimento permanente em relação com o qual haja sido contraída a obrigação de pagar os royalties e caiba a esse estabelecimento permanente o pagamento desses royalties, serão eles considerados provenientes do Estado Contratante em que o estabelecimento permanente estiver situado. 5. As disposições dos parágrafos $1^{\circ}$ e $2^{\circ}$ não se aplicam, quando o beneficiário dos royalties, residente de um Estado Contratante, tiver, no outro Estado Contratante que de provêm os royalties, um estabelecimento permanente ao qual estão ligados efetivamente o direito ou bem que deu origem aos royalties. Nesse caso, aplicar-se-á o disposto no artigo $7^{\circ}$. 6. Se, em conseqüência de relações especiais, existentes entre o devedor e o credor, ou entre ambos e terceiros, o montante dos royalties pagos, tendo em conta o uso, direito ou informação pelo qual é pago, exceder àquele que seria acordado entre o devedor e o credor na ausência de tais relações, as disposições deste artigo são aplicáveis apenas a este último montante. Neste caso, a parte excedente dos pagamentos será tributável conforme a legislação de cada Estado Contratante, e tendo em conta as outras disposições do presente acordo. 7. A limitação da alíquota do imposto prevista no parágrafo $2^{\circ}$, b, não se aplicará aos royalties pagos antes de primeiro de Janeiro de 1977, quando tais royalties forem pagos a um residente de um Estado Contratante que possua, direta ou indiretamente, no mínimo $50 \%$ do capital com direito a voto da sociedade que paga esses royalties.

786،REMESSAS AO EXTERIOR. TRATADO INTERNACIONAL. SERVIÇOS TÉCNICOS SEM TRANSFERENCIA DE TECNOLOGIA. ENQUADRAMENTO. Segundo entendimento administrativo dominante, as remessas como contraprestação por serviços técnicos sem transferência de tecnologia, feitas a beneficiária domiciliada em país com o qual o Brasil mantenha tratado para evitar a dupla tributação, enquadram-se na rubrica "outras rendas", submetendo-se à tributação firmada pela legislação doméstica. O raciocínio vale ainda nas hipóteses em que o respectivo acordo internacional ostentar Protocolo equiparando a remuneração por serviços técnicos a royalties. As remessas da natureza aludida, feitas a beneficiária domiciliada na Alemanha, submetem-se à tributação pela alíquota de 25\%". (Solução de Consulta n. 34 de 04/03/3002, Superintendência Regional da Receita Federal - $7^{\mathrm{a}}$ Região Fiscal).

***

REMESSAS AO EXTERIOR. TRATADO INTERNACIONAL. SERVIÇOS TÉCNICOS SEM TRANSFERENCIA DE TECNOLOGIA. ENQUADRAMENTO. Segundo entendimento administrativo dominante, as remessas como contraprestação por serviços técnicos sem transferência de tecnologia, feitas a beneficiária domiciliada em país com o qual o Brasil mantenha tratado para evitar a dupla tributação, enquadram-se na rubrica "outras rendas", submetendo-se à tributação firmada pela legislação doméstica. O raciocínio vale ainda nas hipóteses em que o respectivo acordo internacional ostentar Protocolo equiparando a remuneração por serviços técnicos a royalties. As remessas da natureza aludida, feitas a beneficiária domiciliada na Holanda, submetem-se à tributação pela alíquota de 25\%. (Solução de Consulta n. ${ }^{\circ} 150$, de 21/02/2001, Superintendência Regional da Receita Federal $-7^{\text {a }}$ Região Fiscal). 
aplicáveis e os motivos que ensejaram a denúncia deste tratado são, em tese, perfeitamente válidos para todos os demais. Em segundo lugar, porque, com a denúncia do tratado BrasilAlemanha, tornou-se público e notório o fato de que o Brasil decididamente não é capaz de renunciar à qualquer parcela de sua arrecadação tributária, por menor que ela seja, nem mesmo para cumprir os dispositivos de acordo internacional que ele mesmo negociou e celebrou.

Isto certamente serve como desestímulo para empresas alemãs e também para empresas de outras nacionalidades que estariam dispostas a realizar investimentos no Brasil, já que, evidentemente, qualquer empresa que busque o lucro preferiria a proteção de um tratado internacional, o que pode ser considerado um fator decisivo quando se trata de um país com uma carga tributária tão elevada, como é o caso do Brasil. 


\section{CONCLUSÕES}

Interpretação e aplicação são duas atividades distintas, embora na maioria das vezes sejam realizadas em conjunto. Para fins didáticos, é útil separá-las como etapas sucessivas, principalmente porque no campo da Dogmática é possível interpretar uma norma jurídica abstratamente, ou seja, sem aplicá-la imediatamente a um caso concreto.

A interpretação e a aplicação do direito não obedecem às regras da lógica formal, mas, sim, da lógica jurídica (ou lógica argumentativa). Isto se deve ao fato de que a aplicação do Direito pressupõe a realização de juízos de valor. Desta forma, o direito se sujeita à lógica dialética, cujos critérios são de correção ou de adequação face a um referencial (no caso, o ordenamento jurídico). Assim, enquanto a lógica formal opera por meio de critérios de exclusão (uma conclusão correta exclui todas as demais), a lógica jurídica se funda em argumentos cuja força de convencimento é variável, de forma que não se pode afirmar que a argumentação em um dado sentido exclui a argumentação em outro.

Assim, a lógica jurídica, por seu caráter argumentativo, é o que fornece a coerência necessária para que uma decisão jurídica seja dotada de racionalidade à luz do direito vigente.

O raciocínio jurídico é baseado no jogo argumentativo, e está presente em todas as proposições que se fazem a respeito do direito. Entretanto, é mais fácil visualizar a evolução do raciocínio jurídico nas decisões judiciais (sentenças e acórdãos).

A estrutura do raciocínio jurídico se assemelha à estrutura do raciocínio prático. Uma sentença judicial, por exemplo, compreenderá, necessariamente, duas partes: a primeira, na qual o juiz expõe as razões e fundamentos que motivaram e justificaram sua decisão, e a segunda, que conterá a decisão propriamente dita. A estrutura do raciocínio jurídico assemelha-se a um silogismo formal, mas vai além deste justamente por conter o juízo de valor, o fator “decisão" do juiz. É precisamente isso que diferencia o raciocínio prático geral do raciocínio jurídico. No raciocínio jurídico, sempre haverá a presença da variável do juízo de valor, que deve obedecer ao princípio da razoabilidade e da equidade.

Este mesmo juízo de valor constitui, ainda, o motivo pelo qual uma decisão judicial nunca pode ser considerada absolutamente isenta, uma vez que o raciocínio do juiz para adotar as premissas que fundamentarão sua decisão é influenciado por fatores externos ao Direito. 
O Brasil ainda se encontra num estágio muito incipiente no que se refere à interpretação e aplicação das convenções de bitributação, especialmente quando em comparação aos países europeus, que já possuem uma longa tradição de utilização de tratados desta natureza. As autoridades brasileiras responsáveis pela aplicação destes acordos, os juízes e até mesmo os advogados, em sua maioria, quando não desconhecem por completo o tema, possuem pouca experiência no assunto. E, infelizmente, no meio acadêmico a doutrina nacional é igualmente reduzida.

Considerando isso, não é de causar surpresa o fato de que a jurisprudência brasileira sobre o tema ainda seja muito escassa: são pouquíssimos os acórdãos que versam sobre as convenções de bitributação, e mais raros ainda são aqueles que tratam especificamente das questões relacionadas à sua interpretação. A maioria das decisões limita-se a afirmar ora a superioridade, ora a paridade hierárquica destes acordos em relação às normas infraconstitucionais internas, mas, na maioria das vezes, não chega a aplicar o tratado, talvez em virtude da ausência dos argumentos adequados.

Na realidade, a aplicação do Direito é realizada, no mais das vezes, de forma instintiva pelos operadores. Não estamos afirmando, de forma alguma, que os operadores do direito atuem de forma leviana, mas a prática jurídica demonstra que, em geral, não existe uma preocupação com processo de interpretar e aplicar as normas; a preocupação é sempre relacionada com o resultado em si, e quase nunca com o caminho a se percorrer para atingi-lo.

No entanto, acreditamos que a preocupação com a correção e com a adequação dos procedimentos de interpretação aplicação do direito pode garantir, ou, na pior das hipóteses, aumentar as chances de êxito dos resultados, e é exatamente isso que propomos mediante a aplicação da Teoria da Argumentação Jurídica à interpretação das convenções contra a bitributação.

De fato, grande parte dos juízes e julgadores administrativos sequer desconfia da necessidade de se justificar uma decisão mediante a concatenação lógica dos argumentos jurídicos. $\mathrm{Na}$ realidade, analisando-se a jurisprudência nacional é possível perceber que quando o julgador fundamenta a sua decisão, existe sempre uma excessiva preocupação com a legalidade dos fundamentos, mas não se verifica o mesmo cuidado em relação à estrutura por meio da qual a argumentação deverá ser desenvolvida para que a decisão ao final proferida seja lógica e coerente. 
Como demonstramos no Capítulo 5, os critérios tradicionais propostos pela Convenção de Viena e pelos Comentários ao Modelo da OCDE, apesar de serem bastante difundidos, e de terem grande utilidade, não são aptos a resolver problemas importantes relacionados à interpretação das convenções de bitributação. Isto porque, na maioria das vezes, eles se baseiam em parâmetros que podem variar. O exemplo mais claro é o reenvio da interpretação ao direito interno, que na maioria das vezes, só traz mais problemas, já que os países não são obrigados a aceitar o significado atribuído ao termo ou expressão a partir do direito interno alheio.

Assim, nossa proposta consiste precisamente na aplicação da teoria da argumentação jurídica desde o momento em que se realiza a subsunção dos fatos às normas, organizando o raciocínio a partir da lógica argumentativa, até o momento da construção da decisão que aplica a norma internacional, garantindo-se assim a justificação interna e externa que assegura a sua racionalidade.

Especificamente quanto ao problema das qualificações, entendemos que a solução perpassa a eliminação, ou, pelo menos, a redução ao mínimo possível, do reenvio ao direito interno. Acreditamos que esta deveria ser a última alternativa para fornecer o significado de termos e expressões não definidos ou cujo significado no tratado seja obscuro ou confuso. Ao invés disso, as autoridades responsáveis pela aplicação das convenções de bitributação deveriam priorizar o contexto do tratado e os significados estabelecidos na linguagem fiscal internacional, a qual, apesar de ainda não estar sistematizada, pode ser conhecida mediante análise das decisões.

Os dois acórdãos que foram examinados no Capítulo 6 demonstram a possibilidade e a viabilidade da aplicação da Teoria da Argumentação Jurídica como método de interpretação das convenções contra a bitributação.

No Caso Refratec, demonstramos, mediante aplicação das regras da fundamentação interna e externa, que a decisão final não era coerente com os fatos apresentados, resultando na indevida exclusão da aplicação do tratado Brasil-Espanha e em evidente prejuízo ao contribuinte, que teve que arcar com os custos da bitributação.

Por fim, o exame do Caso CBPO demonstrou que, apesar de a decisão ter sido parcialmente favorável ao contribuinte, faltavam-lhe os pressupostos lógicos que garantiriam a sua racionalidade. De fato, se houvesse sido aplicada a Teoria da Argumentação Jurídica, teria sido identificado o erro no raciocínio da relatora e poderia ter 
ocorrido a devida correção e a consequente aplicação do tratado ao invés das normas internas, como demonstramos ser possível.

Enfim, é importante esclarecer que não estamos a sugerir que se deixe de aplicar a Convenção de Viena, até porque, como se trata de jus cogens, isso não seria possível, muito menos sugerimos que se deixe de seguir as recomendações da OCDE, já que, como ressaltamos, trata-se de um conjunto importante de opiniões de especialistas.

Nossa proposta, cuja correção e viabilidade prática foram demonstradas nos capítulos anteriores, consiste em aplicar a teoria da argumentação jurídica como um método viável para a interpretação dos tratados internacionais contra a bitributação, o que certamente poderia lhes permitir maior grau de eficácia. Considerando isso, entendemos que a Teoria da Argumentação Jurídica deveria ser utilizada em todas as situações envolvendo a interpretação e aplicação de tratados de bitributação, e não apenas para suprir as falhas do método clássico. 


\section{BIBLIOGRAFIA}

ALBUQUERQUE, Simone Gasperin. Isenção por meio de tratados internacionais \& autonomia tributária. Curitiba: Juruá, 2005.

ALEXY, Robert. Teoria da Argumentação Jurídica: A Teoria do Discurso Racional como Teoria da Justificação Jurídica. Trad. Zilda Hutchinson Schild Silva. Introd. à ed. brasileira Claudia Toledo. São Paulo: Landy, 2005.

ALEXY, Robert. Teoria de Los Derechos Fundamentales. Trad. para espanhol Ernesto Garzón Valdés. Madrid: Centro de Estudios Constitucionales, 1993.

ALMEIDA JR. Fernando Osório de. Considerações sobre o princípio da interpretação conforme à Constituição e sobre sua aplicação na jurisprudência do STF em matéria tributária. In: Revista de Direito Tributário. São Paulo: Malheiros, 2000, n. 77.

ALVES, Taciana Stanislau Afonso Bradley. O Princípio da Renda Mundial no Direito Brasileiro. In: TORRES, Heleno Taveira (coord.). Direito Tributário Internacional Aplicado. São Paulo: Quartier Latin, 2003, v. 1.

AMADO, Juan Antonio García. Sobre el argumento a contrario en la aplicación del Derecho.

Disponível

em:

http://www.cervantesvirtual.com/servlet/SirveObras/01372719768028837422802/do xa24/doxa24_05.pdf. Acesso em 29 dez. 2009.

AMARO, Luciano da Silva. O imposto de renda e os princípios da irretroatividade e da anterioridade. São Paulo: RDT n. 25/6.

AMATUCCI, Andrea. GONZÁLEZ, Eusebio. TRZASKALIK, Christoph. International Tax Law. Amsterdam: Kluwer Law International, 2006.

ANTÓN, Fernando Serrano. Hacia la Unificación del Decrecho Tributario para Residentes y no Residentes? In: TORRES, Heleno Taveira (Coord.). Direito Tributário Internacional Aplicado. São Paulo: Quartier Latin, 2005, v. 3.

ANTÓN, Fernando Serrano. Las Medidas Antiabuso en los Convênios para Evitar la Doble Imposición Internacional y su Compatibilidad con las Medidas Antiabuso de Carácter Interno y el Derecho Comunitario. In: TORRES, Heleno Taveira. Directo Tributário Internacional Aplicado. São Paulo: Quartier Latin, 2003. 
ANZILOTTI, Dionísio. Il diritto Internazionale nel giudizi interni. Bologna: Ditta Nicola Zanichelli, 1905.

ARESPACOCHAGA, Joaquín de. Planificación Fiscal Internacional: Convenios doble imposición, Estructuras fiscales, Tributación no residentes. Madrid: Marcial Pons, 1996.

ARTEAGA, Juan Rafael Bravo. Nociones Fundamentales de Derecho Tributario. $2^{\mathrm{a}}$ edición. Ediciones Rosaristas: Santa Fé de Bogotá-DC. 1997.

ATIENZA, Manuel. As razões do Direito: teorias da argumentação jurídica. Trad. Maria Cristina Gumarães Cupertino. 3. ed. São Paulo: Landy, 2006.

ATIENZA, Manuel. Los Límites de la Interpretación Constitucional: De Nuevo sobre los Casos Trágicos. In: VÁZQUEZ, Rodolfo (coord.) Interpretación jurídica y decisión judicial. Cidade do México: Fontamara, 2003. (Série Doctrina Jurídica Contemporánea).

AULT, H. J. The Role of the OECD Commentaries in the Interpretation of Tax Treaties. Intertax 4. 1994.

AUSTIN, John Langshaw. How to do Things with Words. 2. ed. United States: Harvard University Press, 1975.

AVERY JONES, John F. Brittish Report. In: Interpretation of Double Taxation Conventions. Cahiers de Droit Fiscal International. 1993 Florence Congress, International Fiscal Association., vol. LXXVIIIa.

AVERY JONES, John F. Conflicts of qualification: comment on Prof. Vogel's and Alexander Rust's Articles. In: Bulletin - Tax Treaty Monitor. Amsterdam: IBFD. mai. 2003.

AVERY JONES, John F. et al. The Interpretation of Tax Treaties with Particular Reference to Article 3(2) of the OECD Model - I. In: British Tax Review n. 1, 1984.

AVERY JONES, John F. et al. The Interpretation of Tax Treaties with Particular Reference to Article 3(2) of the OECD Model - II. In: British Tax Review, n. 2, 1984.

AVERY JONES, John F. The one true meaning of a Tax Treaty. In: Bulletin - Tax Treaty Monitor. Amsterdam: IBFD, jun.2004. pp. 220-224. 
AVERY JONES, John F. et al. The origins of Concepts and Expressions Used in the OECD Model and their Adoption by States. In: Bulletin - Tax Treaty Monitor. Jun. 2006. Amsterdam: IBFD.

AVERY JONES, John F. SINCLAIR, Ian, Sir. RAAD, Kees van. VOGEL, Klaus. WARD, David. Interpretation of Tax Treaties. In: Bulletin - IBFD. Amsterdam: IBFD, fev. 1986.

AVERY JONES, John F. The "One True Meaning” of a Tax Treaty. In: Bulletin - Tax Treaty Monitor. Amsterdam: IBFD, jun. 2001.

AVERY JONES, John F. The effect of changes in the OECD Commentaries after a treaty is concluded. In: Bulletin - Tax Treaty Monitor. Amsterdam: IBFD, mar. 2002.

AVERY JONES, John F. The relationship between Domestic Tax Systems and Tax Treaties. In: Bulletin - Tax Treaty Monitor. Amsterdam: IBFD, jun. 2002.

ÁVILA, Humberto. Teoria dos Princípios: da definição à aplicação dos princípios jurídicos. São Paulo: Malheiros, 2003, p. 121.

BAIER, K. The Moral Point of View. Londres: Ithaca, 1958, p. 197 e seguintes.

BAIER, Kurt. The Moral Point of View. Ithaca/NY: Cornell University Press, 1958, p. 85.

BAKER, Philip N. Double Taxation Conventions and International Tax Law. 2. ed. London: Sweet \& Maxwell, 1994.

BALEEIRO, Aliomar, Limitações Constitucionais ao Poder de Tributar, 7. ed. rev. e compl. Misabel Abreu Machado Derzi. Rio de Janeiro: Forense, 2006.

BALEEIRO, Aliomar. Direito Tributário Brasileiro. 11. ed. atual. Misabel Abreu Machado Derzi. Rio de Janeiro: Forense, 2005.

BARROSO, Luiz Roberto. Os princípios da razoabilidade e da proporcionalidade no direito constitucional. In: Revista Forense. Out. Nov. dez. 1996, ano 92, pp. 125-136, Rio de Janeiro: Forense, v. 336.

BASSANEZE, João Marcello Tramujas. Pluritributação Internacional: Origem, Conceito e Medidas Unilaterais Destinadas à sua Eliminação. In: TORRES, Heleno Taveira (coord.). Direito Tributário Internacional Aplicado. São Paulo: Quartier Latin, 2003. v. 1. 
BECKER, Alfredo Augusto. Teoria Geral do Direito Tributário. 2. ed. São Paulo: Saraiva, 1972.

BELLAN, Daniel Vitor. Algumas Considerações sobre a Tributação dos Royalties pagos a Beneficiários Residentes ou Domiciliados no Exterior. In: TORRES, Heleno Taveira (coord.). Direito Tributário Internacional Aplicado. São Paulo: Quartier Latin, 2003. v. 1.

BELLAN, Daniel Vítor. Interpretação dos Tratados Internacionais em Matéria Tributária. In: TORRES, Heleno Taveira (coord.). Direito Tributário Internacional Aplicado. São Paulo: Quartier Latin, 2005. v. 3.

BIANCO, João Francisco. Transparência Fiscal Internacional. São Paulo: Dialética, 2007.

Black's Law Dictionary

BOBBETT, Catherine. JONES, John Avery. Tax Treaty Definition of Royalties. In: Bulletin - Tax Treaty Monitor. Amsterdam: IBFD, jan. 2006.

BOBBIO, Norberto. Teoria do Ordenamento Jurídico. Trad. Maria Celeste Cordeiro Leite dos Santos. Rev. Claudio de Cicco. 6. ed. Brasília: Editora Universidade de Brasília, 1995.

BOITEUX, Elza Antônia Pereira Cunha. O significado perdido da função de julgar. São Paulo, 1990. Tese (Doutorado em Direito). Universidade de São Paulo.

BORGES, José Souto Maior. Direitos Humanos e Tributação. In: Revista Tributária e de Finanças Públicas. Set. out. 2001. São Paulo: Editora Revista dos Tribunais, 2001. v. 40.

BRACEWELL-MILNES, Barry. Summary of proceedings of the seminar 'Double Taxation Treaties between Industrialized and Developing Countries: OECD and UN Models, a comparison. In: Double taxation treaties between industrialized and developing countries: OECD and UN Models, a comparison. Proceedings of a seminar held in Stockholm in 1990 during the $44^{\text {th }}$ Congress of the International Fiscal Association. Deventer/Boston: Kluxer Law and Taxation Publishers, v. 15.

BRUNSCHOT, Frank van. The Judiciary and the OECD Model Tax Convention and its Commentaries. In: Bulletin - Tax Traty Monitor. Amsterdam: IBFD, jan. 2005. 
BUHLER, Ottmar. Principios de Derecho Internacional Tributario. Trad. Fernando Cervera Torrejon. Madrid: Editorial de Derecho Financiero, 1968.

BUJANDA, Fernando Sainz de. Hacienda y Derecho, Estudios de Derecho Financeiro, Madrid: Editorial de Estudios Políticos, 1966, Tomo 4.

CALIENDO, Paulo. Estabelecimentos Permanentes em Direito Tributário Internacional. São Paulo: Revista dos Tribunais, 2005.

CALIENDO, Paulo. Princípio da Igualdade de Tratamento entre Nacionais e Estrangeiros em Direito Tributário, In: TORRES, Heleno Taveira (Coord.). Direito Tributário Internacional Aplicado, São Paulo: Quartier Latin, 2005. v. 3.

CAMARGO, Maria Margarida Lacombe. Hermenêutica Jurídica e Argumentação: uma Contribuição ao Estudo do Direito. Rio de Janeiro: Renovar, 2001.

CAMINHA, Maria do Carmo Puccini. Os Tratados Internacionais Tributários e a eficácia de suas Normas no Ordenamento Jurídico Brasileiro. In: Revista Tributária e de Finanças Públicas. Nov. dez. 2001. Ano 9. São Paulo: Malheiros, 2001. v. 41.

CARraZZA, Roque Antônio. Curso de Direito Constitucional Tributário. 20. ed. São Paulo: Malheiros, 2004.

CARRAZZA, Roque Antônio. Imposto de renda-pessoa física. In: Revista de Direito Tributário $\mathrm{n}^{\circ}$ 74. São Paulo: Malheiros, 1999.

CARRERO, José M. Calderón. La doble imposición internacional y los métodos para su eliminación. Madrid: McGraw-Hill, 1997.

CARVALHO, André de Souza. Acordo Brasil-EUA: O que ainda falta para a sua conclusão? In: PANZARINI FILHO, Clóvis (Coord.) et. al. Revista de Direito Tributário Internacional. São Paulo: Quartier Latin, 2006, v. 4.

CARVAlHO, Paulo de Barros. Curso de Direito Tributário. 16. ed. São Paulo: Saraiva, 2004, p. 104.

CARVALHO, Paulo de Barros. Direito Tributário: Fundamentos Jurídicos da Incidência. 3. ed., rev. e atual. São Paulo: Saraiva, 2004.

CARVALHO, Paulo de Barros. Tratados internacionais em matéria tributária: estudo de um caso concreto. In: AMARAL, Antônio Carlos Rodrigues do (coord.). Tratados Internacionais na Ordem Jurídica Brasileira. São Paulo: Aduaneiras, 2005. 
CELLA, José Renato Gaziero. A Teoria da Argumentação Jurídica como proposta de uma racionalidade possivel frente à postura cética do positivismo jurídico contemporâneo. Universidade Federal do Estado do Paraná. (Disserção de mestrado). 2001.

COÊLHO, Sacha Calmon Navarro. Curso de Direito Tributário Brasileiro. 8. ed., rev. e atual. de acordo com o Código Civil de 2002. Rio de Janeiro: Forense, 2005.

COÊLHO, Sacha Calmon Navarro. Noções da Fiscalidade Interancional. Belo Horizonte: Movimento Editorial Faculdade de Direito da UFMG, 1998.

COÊLHO, Sacha Calmon Navarro. Teoria Geral do Tributo e da Exoneração Tributária. 3. ed. Belo Horizonte: Del Rey, 2000.

Commentaries to the OECD Model Tax Convention, In: RAAD, Kees van. Materials on International e EC Tax Law, selected and edited by Kees van Raad. Leiden: IBFD, 2007/2008, v. 1.

COURT, J. F. Some reflections on the experience of the UN Model in tax treaties between developed and developing countries. In: Double taxation treaties between industrialized and developing countries: OECD and UN Models, a comparison. Proceedings of a seminar held in Stockholm in 1990 during the $44^{\text {th }}$ Congress of the International Fiscal Association. Deventer/Boston: Kluxer Law and Taxation Publishers, v. 15, pp. 15-19.

DAMARCO, Jorge Hector. El Principio de Capacidad Contributiva como Fundamento y Medida de Los Impuestos. Disponível em: www.econ.uba.err/www/institutos/epistemology/marco_archivos/potencies/Actas\%2 0XIII/Trabajos\%20Episte/Damarco trabajo.pfd.. Acesso em 29 out. 2009.

DE MITA, Enrico. O princípio da Capacidade Contributiva. In: FERRAZ, Roberto. (Coord.). Princípios e Limites da Tributação. São Paulo: Quartier Latin, 2005.

DERZI, Misabel Abreu Machado. COÊLHO, Sacha Calmon Navarro. Do Imposto sobre a Propriedade Predial e Territorial Urbana. São Paulo: Saraiva, 1982.

DINIZ, Maria Helena. Compêndio de introdução à ciência do direito. São Paulo: Saraiva, 1991. 
DOLINGER, Jacob. As soluções da Suprema Corte brasileira para os conflitos entre o direito interno e o direito internacional: um exercício de ecletismo. In: Revista Forense. Rio de Janeiro, v. 334, abr. jun. 1996. pp. 71-107.

DÓRIA, Antônio Roberto Sampaio. Direito Constitucional Tributário e Due Process of Law. 2. ed. Rio de Janeiro: Forense, 1986.

DORNELLES, Francisco Neves. A Dupla Tributação Internacional da Renda. Rio de Janeiro: Editora da Fundação Getúlio Vargas, 1979.

DOUMA, Sjoerd. The principle of legal certainty enforcing international norms under community law. In: ENGELEN, Frank. DOUMA, Sjoerd (coord.). The Legal Status of the OECD Commentaries. Amsterdam: IBFD, 2008, v. 1, pp. 224-225 (Conflict of Norms in Internetional Tax Law Series).

DOURADO, Ana Paula. Do caso "Saint-Gobain" ao caso "Metallgeselschaft": o âmbito do princípio da não-discriminação do estabelecimento estável no tratado da comunidade européia e a cláusula da nação mais favorecida. In: Revista de Direito Tributário. São Paulo: Malheiros, (ano). v. 86.

DWORKIN, Ronald. Levando os direitos a sério. Trad. Nelson Boeira. 2. ed. São Paulo: Martins Fontes, 2007.

ELLIS, Maarten J. The influence of the OECD Commentaries on Treaty Interpretation Response to Prof. Dr. Klaus Vogel. In: Bulletin - Tax Treaty Monitor. Amsterdam: IBFD, dec. 2000.

ELLIS, Maarten J. The Role of the Commentaries no the OECD Model in the Tax Treaty Interpretation Process - Response to David Ward. In: Bulletin - Tax Treaty Monitor, Amsterdam: IBFD, mar. 2006.

ENGELEN, Frank. Interpretation of Tax Treaties under International Law. Amsterdam: IBFD, 2004, v. 7 (IBFD Doctoral Series).

ENGELEN, Frank. PÖTGENS, F. P. Report on "The Application of the OECD Model Tax Convention to Partnerships" and the Interpretation of Tax Treaties. In: Bulletin IBFD. Amsterdam: IBFD, 2000. v. 54.

ENGELEN, Frank. Some observations no the Legal Status of the Commentaries on the OECD Model. In: Bulletin - Tax Treaty Monitor. Ámsterdam: IBFD, Mar. 2006. 
ENTERRIA, Eduardo Garcia. Hermenêutica e Supremacia Constitucional: El principio de la interpretación conforme a la Constitución de todo el Ordenamiento. In: Revista de Direito Público. n. 77, jan. fev. mar. 1986. Ano XIX. São Paulo: Revista dos Tribunais, 1986.

EZQUIAGA, Francisco Javier. Argumentos Interpretativos y Postulado del Legislador Racional. In: VÁZQUEZ, Rodolfo (coord.) Interpretación jurídica y decisión judicial. Cidade do México: Fontamara, 2003. (Série Doctrina Jurídica Contemporánea).

FANTOZZI, Augusto. Il principio comunitario di non-discriminazione nell'imposizione sul reddito. In: Revista de Direito Tributário. São Paulo: Malheiros, (ano). v. 86.

FASSBENDER, Bardo. UN security council reform and the right of veto: a constitutional perspective. The Hague/Netherlands: Kluwer Law International, 1998.

FAZZALARI, Elio. Conoscenza e Valori: Saggi. 2. ed. Torino: G. Giappichelli Editore, 2004.

FERNANDES, Edison Carlos. Acordos Multilaterais do Comercio, não-discriminação tributária e controle fiscal dos preços de transferência. In: PANZARINI FILHO, Clóvis (coord.). Revista de Direito Tributário Internacional. São Paulo: Quartier Latin, 2006. v. 4.

FERRAZ JR., Tércio Sampaio. A ciência do direito. São Paulo: Atlas, 1977.

FIÚZA, Cezar. Direito Civil - Atualidades. Belo Horizonte: Del Rey, 2003.

FUCK, Luciano Felício. A denúncia da convenção entre Brasil e Alemanha e os métodos para evitar a dupla tributação internacional. In: Revista de Direito Internacional Econômico e Tributário. Jul. dez. 2006. Brasília: Fortium, 2006. n. 2, v. 1.

GADAMER, Hans-Georg. Verdade e Método I: Traços de uma hermenêutica filosófica. Trad. Flávio Paulo Meurer. 10. ed. Petrópolis: Ed. Vozes, 2008.

GANUZAS, Francisco Javier Ezquiaga. Tipos de argumentos jurídicos. Disponível em http://www.tedf.org.mx/ccje/investigacion/pdf/TIPOS\%20DE\%20ARGUMENTOS \%20JUR\%CDDICOS.Pdf. Acesso em 29 dez.2009.

GARBARINO, Carlo. La tassazione dei redditi transnazionale. Padova: CEDAM, 1990. 
GIULIANI, Federico Maria. La Interpretación de Los Convenios Internacionales para Evitar La Doble Imposición sobre las Rentas In: UCKMAR, Victor (coord.). Curso de Derecho Tributario Internacional. Tomo I, 2003.

GIULIANI, Federico Maria. La interpretazione delle convenzioni internazionali contro le doppie imposizioni sui redditi. In: UCKMAR, Victor (coord.). Corso di Diritto Tributário Internacional. 2. ed. Padova: CEDAM, 2000.

GOLDSCHMIDT, Fabio Brun. O Princípio do não-confisco no Direito Tributário. São Paulo: Editora Revista dos Tribunais, 2004.

GRAU, Eros Roberto. Ensaio e Discurso sobre a Interpretação/Aplicação do Direito. São Paulo: Malheiros, 2002.

GRAU, Eros Roberto. O direito posto e o direito pressuposto. São Paulo: Malheiros, 2002.

GRUPENMACHER, Betina Treiger. Tratados internacionais em matéria Tributária e a Ordem Interna. São Paulo: Dialética, 1999.

GUASTINI, Riccardo. La Interpretación: objetos, conceptos y teorías. In: VÁZQUEZ, Rodolfo (coord.) Interpretación jurídica y decisión judicial. Cidade do México: Fontamara, 2003, (Série Doctrina Jurídica Contemporánea)

GUASTINI, Riccardo. Das Fontes às Normas. São Paulo: Quartier Latin, 2005.

GUERRA FILHO, Willis Santiago. Sobre Princípios Constitucionais Gerais: Isonomia e Proporcionalidade. In: Revista dos Tribunais v. 719. Ano 84, set. 1995.

HABERMAS, Jürgen. Agir Comunicativo e Razão Descentralizada. Trad. Lucia Aragão. Rio de Janeiro: Tempo Brasileiro, 2002.

HACCIUS, Charles. Ireland in International Tax Planning. 2. ed. Amsterdam: IBFD, 2004.

HAMAEKERS, Hubert. The source principle versus the residence principle. In: Revista dos Tribunais. abr. mai. jun. 1993. São Paulo: Malheiros, 1993.

HARE, Richard M. A Linguagem da Moral. São Paulo: Martins Fontes, 1996.

HART, Herbert L. A. O Conceito de Direito. Trad. Antônio de Oliveira Sette-Câmara. São Paulo: Martins Fontes, 2009.

HELMINEM, Marjaana. Tax Treaty Interpretation in Finland. In: LANG, Michael (org.). Tax Treaty Interpretation. Viena: Linde Werlag, 2001. 
HENRIQUES JR., Fernando do Couto. Conflito entre norma interna e norma de tratado internacional. In: AMARAL, Antônio Carlos Rodrigues do (coord.). Tratados Internacionais na Ordem Jurídica Brasileira. São Paulo: Aduaneiras, 2005.

HOLMES, Kevin. International Tax Policy and Double Tax Treaties: An Introduction to Principles and Application. Amsterdam: IBFD, 2007.

IATAROLA, Ana Cristina Silva. Capacidade Contributiva - Princípio norteador de justiça tributária e sua limitação pelos direitos fundamentais: mínimo existencial versus não confisco tributário. Dissertacao de mestrado. Rio de Janeiro: Universidade Gama Filho. 2005. Disponível em $<$ http://www.dominiopublico.gov.br/download/texto/cp000807.pdf $>$. Acesso em 05 jun. 2009.

IBFD International Tax Glossary. $5^{\text {th }}$ Edition. Completely revised. IBFD: Amsterdam, 2005.

JARACH, Dino. Hermenêutica no Direito Tributário. In: MORAES, Bernardo Ribeiro de. et al. Interpretação no Direito Tributário. São Paulo: Saraiva, 1975.

JARACH, Dino. O Fato Imponível, Teoria geral do Direito Tributário Substantivo. 2. ed. Rev. da trad. Dejalma de Campos, São Paulo: Revista dos Tribunais, 2004.

KEILY, Troy. Good Faith \& the Vienna Convention on Contracts for the International Sale of Goods (CISG), VJ 1999/1, at 15 et seq. Disponível em <www.TransLex.org/131400>. Acesso em 18 out.2009.

KELSEN, Hans. Teoria Pura do Direito. Trad. João Baptista Machado. São Paulo: Martins Fontes, 1999.

KOSTERS, Bart. The UN Model Tax Convention and Its Recent Developments. Disponível em

$<$ http://www.adb.org/Documents/Events/2003/Tax_Conference/text_kosters.pdf $>$. Acesso em 13 out. 2009.

LA CUADRA, Enrique Evans de. ESPIÑEIRA, Eugenio Evans. Los Tributos Ante la Constitución. Editorial Jurídica de Chile: Santiago, 1997.

LANG, Michael. BRUGGER, Florian. O papel dos Comentários da OCDE na Interpretacao dos Acordos de Bitributação. Trad. Gustavo Gonçalves Vettori. In: 
PANZARINI FILHO, Clóvis. Revista de Direito Tributário Internacional. São Paulo: Quartier Latin, 2008. v. 3.

LAPATZA, José Juan Ferrero. La interpretación en el derecho financiero: especial referencia al derecho tributario. In: Revista de Direito Tributário. São Paulo: Malheiros, 1990, ano 14, v. 51.

LAPATZA, José Juan Ferreiro. Curso de Derecho Financiero Español, 19. ed., Madrid: Marcial Pons, 1997.

LEHNER, Moris. The influence of EU Law on Tax Treaties from a German Perspective. In: Bulletin - IBFD. Aug. Sep. 2000 Amsterdam: IBFD, 2000.

LEHNER, Moris. The National Power of Taxation and the Fundamental Freedoms and Non-Discrimination Clause of the EC Treaty. In: Revista de Direito Tributário. São Paulo: Malheiros, 2002, v. 83.

MACCORMICK, Neil. Argumentação Jurídica e Teoria do Direito. Trad. Waldéa Barcellos. São Paulo: Martins Fontes, 2006.

MACHADO, Hugo de Brito. Curso de Direito Tributário. 12. ed. São Paulo: Malheiros, 1997.

MACHADO, João Baptista. Lições de Direito Internacional Privado, 4. ed., Coimbra: Almedina, 1990.

MAGALHÃES, José Carlos de. O Supremo Tribunal Federal e o Direito Internacional: uma análise critica. Porto Alegre: Livraria do Advogado, 2000.

MAISTO, Guglielmo. Multilingual texts and interpretation of tax treaties and EC tax law. Amsterdam: IBFD, 2005.

MARTINS, Ives Gandra da Silva. Teoria da imposição tributária. 2. ed., rev. e atual., São Paulo: LTr, 1998.

MAXIMILIANO, Carlos. Hermenêutica e Aplicação do Direito. 18 ed. Rio de Janeiro: Forense, 1999, p. 09.

MEDEIROS, Antônio Paulo Cachapuz. O poder de celebrar tratados. Porto Alegre: Sérgio Antônio Fabris. 1995. 
MELIS, Giuseppe. Vincoli internazionali e norma tributaria interna. In: TORRES, Heleno Taveira (Coord.). Direito Tributário Internacional Aplicado, São Paulo: Quartier Latin, 2005, v. 3.

MELlO, Celso Albuquerque. Direito Constitucional Internacional, Rio de Janeiro: Renovar, 2000.

MELlo, Osvaldo Aranha Bandeira de. Princípios Gerais de Direito Administrativo. 3. ed., Introdução. São Paulo: Malheiros, 2007, v. 1.

MICHELSEN, Aage. Tax Treaty Interpretation in Denmark. In: LANG, Michael (Coord.). Tax Treaty Interpretation. Vienna: Linde Verlag, 2001.

MOLINA, Pedro M. Herrera. CARRETERO, Belén García. Imposición Directa, no Discriminación y Libertades Comunitarias. In: TORRES, Heleno Taveira (coord.). Direito Tributário Internacional Aplicado. São Paulo: Quartier Latin, 2003. v. 1.

MONTÚfAR, Lorenzo. Nociones de Derecho de Gentes Y Leyes de La Guerra. Bibliolife, 2009.

NABAIS, José Casalta. O dever fundamental de pagar impostos: contributo para a compreensão constitucional do estado fiscal contemporâneo. Coimbra: Almedina, 1998.

NABAIS, José Casalta. Por um Estado Fiscal Suportável: Estudos de Direito Fiscal. Coimbra: Almedina, 2005.

NEVES, Antônio Castanheira. O Actual Problema Metodológico da Interpretação Jurídica - I. Coimbra: Coimbra Editora, 2003.

NIARADI, George Augusto. O 'iter’ de elaboração dos tratados internacionais no Brasil. In: AMARAL, Antônio Carlos Rodrigues do (coord.). Tratados Internacionais na Ordem Jurídica Brasileira. São Paulo: Aduaneiras, 2005.

NOGUEIRA, Ruy Barbosa. Interpretação e Integração da Legislação Tributária. In: NASCIMENTO, Carlos Valder do. NOGUEIRA, Ruy Barbosa. MACHADO, Hugo de Brito. COÊLHO, Sacha Calmon Navarro. São Paulo: Revista dos Tribunais, 1989. pp. 7-24. 
NOVAK, Fabián. PARDO, Fernando. Derecho Diplomático - Comentários a la Convención sobre Relaciones Diplomáticas. Lima: El Fondo Editorial de La Pontifícia Universidad Católica del Peru, 2003.

NOVOA, César Garcia. Interpretación de los convenios de doble imposición internacional. In: FAJARDO, Juan Pablo Godoy. (coord.). Estudios de Derecho Internacional Tributário - Los convenios de doble imposición. Bogotá: Legis, 2006.

OKUMA, Alessandra. Tributação dos Dividendos Remetidos aos Não-residentes. Comentários à decisão do Superior Tribunal de Justiça no Recurso Especial $n$. 602.725/PR. In: TORRES, Heleno Taveira (Coord.). Direito Tributário Internacional Aplicado, São Paulo: Quartier Latin, 2005. v. 3.

PAULSEN, Leandro. Direito Tributário - Constituição e Código Tributário à Luz da Doutrina e da Jurisprudência. 9. ed. Porto Alegre: Livraria do Advogado/ESMAFE, 2007.

PERELMAN, Chaïm. Ética e Direito. Trad. Maria Ermantina de Almeida Prado Galvão. 2. ed. São Paulo: Martins Fontes, 2005.

PERELMAN, Chaïm. OLBRECHTS-TYTECA, Lucie. Tratado da Argumentação: A nova Retórica. Trad. Maria Ermantina de Almeida Prado Galvão. 2. ed. São Paulo: Martins Fontes, 2005.

PIJL, Hans. Os comentários da OCDE como fonte do Direito Internacional e o papel do Poder Judiciário. In: PANZARINI FILHO, Clóvis (Coord.). Revista de Direito Tributário Internacional. São Paulo: Quartier Latin, 2006. v.1.

PIOVESAN, Flávia. Direitos Humanos e o Direito Constitucional Internacional. São Paulo: Max Limonad, 1996.

PIRES, Manuel. Da Dupla Tributação Jurídica Internacional sobre o Rendimento. Lisboa: Centro de Estudos Fiscais, Ministério das Finanças, 1984.

PISTONE, Pasquale. L'abuso delle convensione internazionale in matéria fiscale. In: UCKMAR, Victor (coord.) Corso de Diritto Tributário Internazionale. Padova: Cedam, 1999.

PLEWA, David. PAZ, Stacy M. IRS Issues Final Regulations Allowing Foreign Merger Section 368 Reorganizations. 1 FEB 2006. Disponível em 
$<$ http://www.dlapiper.com/section368 reorganizations article/> . Acesso em $06 \mathrm{dez}$. 2009.

PROKISCH, Rainer. Does it make sense if we speak of an "international tax language"? In: VOGEL, Klaus. Interpretation of Tax Law and Treaties and Transfer Pricing in Japan and Germany. The Hague: Kluwer Law International, 1998. (Series on International Taxation n. 20).

RAAD, Kees van (org.). Introduction to the Commentaries. Integrated texts of the OECD Commentaries of 1977 and 1992 (incorporating the changes of 1994, 1995, 1997, 2000, 2003 and 2005) in: Materials on International \& EC Tax Law. Selected and edited by Kees van Raad. 7. ed. Leiden: IBFD, 2007. v. 1.

RAAD, Kees van. Cinco regras fundamentais para a aplicação de tratados para evitar a dupla tributação. Trad. Helena de Rezende Grabenweger. In: PANZARINI FILHO, Clóvis (coord.). Revista de Direito Tributário Internacional, São Paulo: Quartier Latin, 2005. v. 1.

RAAD, Kees van. International Coordination of Tax Treaty Interpretation and Application. In: RAAD, Kees van. LEHNER, Moris. KIRCHHOF, Paul. RAUPACH, Arndt. RODI, Michael. International and Comparative Taxation: Essays in honour of Klaus Vogel. London: Kluwer Law International, 2002.

RAAD, Kees van. Materials on International \& EC Tax Law. Selected and edited by Kees van Raad. 7. ed. Leiden: IBFD, 2007. v. 1.

RAZ, Joseph. Por qué interpretar? In: VÁZQUEZ, Rodolfo (coord.) Interpretación jurídica y decisión judicial. Cidade do México: Fontamara, 2003. (Série Doctrina Jurídica Contemporánea).

REALE, Miguel. Filosofia do Direito. São Paulo: Saraiva, 2002.

REIMER, Ekkehart. Tax Treaty Interpretation in Germany. In: LANG, Michael (org.). Tax Treaty Interpretation. Viena: Linde Verlag, 2001.

RIBES, Aurora Ribes. Convenios para evitar la doble imposición internacional: interpretación, procedimiento amistoso y arbitraje. Madrid: Editoriales de Derecho Reunidas, 2003. 
ROCHA, Sérgio André. A Hermenêutica Jurídica sob o Influxo da Hermenêutica Filosófica de Hans-Georg Gadamer. In: Revista Tributária e de Finanças Públicas n. 64. Set. out. 2005. Ano 13. São Paulo: Revista dos Tribunais, 2005.

ROCHA, Sérgio André. Interpretação dos Tratados contra a Bitributação da Renda. Rio de Janeiro: Lumen Juris, 2008.

RONCATI, Eduardo Jara. La Función Diplomática. Santiago: RIL Editores, 2000.

ROSAS, Roberto. Devido Processo Legal: Proporcionalidade e Razoabilidade. In: Revista dos Tribunais. Jan. 2001, ano 90. v. 783.

ROTHMANN, Gerd W. Interpretação e Aplicação dos Acordos Internacionais contra a Bitributação. São Paulo: USP, 1978. Tese (doutorado).

ROTHMANN, Gerd W. Tributação Internacional sem Sujeito Passivo: uma nova modalidade do imposto de renda sobre ganhos de capital? In: Grandes questões atuais de Direito Tributário. São Paulo: Dialética, 2006. v. 10.

RUBINSTEIN, Flávio. Interpretazione e Aplicazione delgli Accordo contro la Doppia Imposizione: il ruolo della buona fede oggetiva. In: Diritto i Pratica Tributaria Internazionale $\quad$ n. 01/2006., Disponível em $<$ http://www.dpti.it:80/documenti/528624.asp?linkparam=Preleva\%201a\%20rivista $>$ Acesso em 26 jul. 2006.

RUBINSTEIN, Flávio. Interpretazione ed Applicazione degli Accordi Contro la Doppia Imposizione: Il Ruolo della Buona Fede Oggetiva. In: Diritto e Pratica Tributaria Internazionale. Padova: CEDAM, 2005. v. 1.

RUST, Alexander. The New Approach to Qualification Conflicts Has its Limits. In: Bulletin - Tax Treaty Monitor. Amsterdam: IBFD, fev. 2003.

SACCHETTO, Claudio. Territorialità - diritto tributario. Enciclopédia del Diritto. Milano: Giuffrè, 1999.

SANTIAGO, Igor Mauler. Direito Tributário Internacional:- Métodos de Solução dos Conflitos. São Paulo: Quartier Latin, 2006.

SARAIVA FILHO, Oswaldo Othon de Pontes. IRPJ e os tráfegos entrante e sainte de telecomunicações internacionais. In: PIRES, Adilson Rodrigues, et Al. Tributação, 
Justiça e Liberdade: homenagem da Associação Paulista de Estudos Tributários a Ives Gandra da Silva Martins. Curitiba: Juruá, 2005.

SCHIMILL, Ulises. COSSÍO, José Ramón. Interpretation del derecho y conceptions del mundo. In: VÁZQUEZ, Rodolfo (coord.) Interpretación jurídica y decisión judicial. Cidade do México: Fontamara, 2003. (Série Doctrina Jurídica Contemporánea).

SCHOUERI, Luís Eduardo. Direito Tributário Internacional: Qualificação e Substituição Tributação, no Brasil, de Rendimentos Provenientes de Sociedade de Pessoas Residente na Alemanha. In: Revista Dialética de Direito Tributário .São Paulo: Dialética, n.54, 2000.

SCHOUERI, Luís Eduardo. Planejamento Fiscal através de Acordos de Bitributação: Treaty Shopping. São Paulo: Revista dos Tribunais, 1995.

SCHOUERI, Luís Eduardo. The residence of the employer In the '183-day clause' (articule 15 of the OECDs Model Double Taxation Convention). In: Internacional Tax Review - Intertax. Amsterdam: Intertax, 1993.

SHELTON, Dinah. Reconcilable Differences? The Interpretation of Multilingual Treaties.

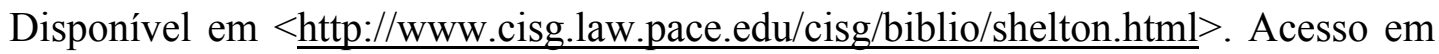
05 dez. 2009.

SILVA, Ênio Moraes da. Limites Constitucionais Tributários no Direito Norte-Americano. Curitiba: Juruá, 2001.

SILVEIRA, Rodrigo Maitto da. Aplicação de Tratados Internacionais contra a Bitributação: Qualificação de Partnership Joint Ventures. São Paulo: Quartier Latin, 2006.

SINCLAIR, I. The Vienna Convention on the Law of Treaties, 2. ed., Manchester: Manchester University Press, 1984, n. 404.

SOUZA, Carlos Affonso Pereira de. SAMPAIO, Patrícia Regina Pinheiro. O princípio da razoabilidade e o princípio da proporcionalidade: uma abordagem constitucional. In: Revista Forense. Jan. fev. mar. 2000. ano 96. Rio de Janeiro: Forense, v. 349.

STRUCHINER, Noel. Uma Análise da Textura Aberta da Linguagem e sua Aplicação ao Direito. Extrato da dissertação. Revista CEJ, Brasília, n.17,abr. jun.2002 p. 120. Disponível em <http://daleth.cjf.jus.br/revista/numero17/prodacad2.pfd> Acesso em 10 dez.2009 
TABORY, Mala. Multilingualism in international law and institutions. Amsterdam: Sijthoff \& Noordhoff International Publishers, 1980.

TÁCITO, Caio. A razoabilidade das leis. In: Revista Forense. Jul. ago. set. 1996, ano 92.

TAMAYO Y SALMORÁN, Rolando. Interpretación Constitucional - La falacia de la interpretación cualitativa. In: VÁZQUEZ, Rodolfo (coord.) Interpretación jurídica y decisión judicial. Cidade do México: Fontamara, 2003, (Série Doctrina Jurídica Contemporánea).

TAVOLARO, Agostinho Toffoli. Globalização, Soberania e Tributação. In: Revista Tributária e de Finanças Públicas n. 60, jan. fev. 2005, Ano 13, São Paulo: Revista dos Tribunais, 2005.

TORRES, Heleno Taveira. A interpretação dos Tratados Internacionais em Matéria Tributária sobre a Renda e o Capital. In: Estudios en Memoria de Ramón Valdés Costa. Montevideo: Fundación de Cultura Universitária. 1999. v. 1.

TORRES, Heleno Taveira. Capital Estrangeiro e Princípio da Não-Discriminação Tributária no Direito Interno e nas Convenções Internacionais. In: Revista Dialética de Direito Tributário n. 87, dez. 2002, São Paulo: Dialética, 2002.

TORRES, Heleno Taveira. Direito Tributário Internacional: Planejamento Tributário e Operações Transnacionais. São Paulo: Editora Revista dos Tribunais, 2001.

TORRES, Heleno Taveira. Dupla (Múltipla) Tributação Internacional. Rendas de Empresas: 'Dupla tributação Jurídica Internacional' e 'Dupla Tributação Econômica Internacional'. In: Revista de Direito Tributário .São Paulo: Malheiros, 1995. n. 65.

TORRES, Heleno Taveira. Juros sobre o capital próprio - autonomia privada nos investimentos societários e suas implicações em matéria tributária. In: Revista Internacional de Direito Tributário. Associação Brasileira de Direito Tributário. Belo Horizonte: Del Rey, 2006. v. 4.

TORRES, Heleno Taveira. Aplicação dos tratados internacionais em matéria tributária: o procedimento de interpretação. In: Revista da Associação Brasileira de Direito Tributário. Belo Horizonte: Del Rey, 1998, pp. 109-136.

TORRES, Heleno Taveira. Lucros auferidos por meio de controladas e coligadas no exterior. In: TORRES, Heleno Taveira. (Coord.). Direito Tributário Internacional Aplicado, São Paulo: Quartier Latin, 2005. v. 3. 
TORRES, Heleno Taveira. O princípio da não-discriminação tributária na Constituição e no GATT e a prevalência dos tratados internacionais em matéria tributária. In: Construindo o Direito Tributário na Constituição: Uma análise da Obra do Ministro Carlos Mário Velloso. Belo Horizonte: Del Rey, 2004.

TORRES, Heleno Taveira. Pluritributação Internacional sobre as Rendas de Empresas. 2. ed. rev., ampl. e atual. São Paulo: Revista dos Tribunais, 2001.

TÔRRES, Heleno. Direito Tributário e Direito Privado: autonomia privada, simulação, elusão tributária. São Paulo: Editora Revista dos Tribunais, 2003.

TORRES, Ricardo Lobo. A idéia de liberdade no Estado Patrimonial e no Estado Fiscal. Rio de Janeiro: Renovar, 1991.

TORRES, Ricardo Lobo. Curso de Direito Financeiro e Tributário. 7. ed. Renovar, 2000.

TORRES, Ricardo Lobo. Normas de Interpretação e Integração do Direito Tributário. Rio de Janeiro: Renovar, 2006, pp. 309-310.

TORRES, Ricardo Lobo. Tratado de Direito Constitucional Financeiro e Tributário (Os Direitos Humanos e a Tributação: Imunidades e Isonomia). Rio de Janeiro: Renovar, 1999, v. III.

TORRES, Ricardo Lobo. Considerações sobre o futuro da hermenêutica tributária à luz dos princípios da liberdade e da justiça tributária. In: Revista de Direito Tributário. São Paulo: Malheiros, v. 88.

TOULMIN, Stephen Edelston. Os Usos do Argumento. Trad. Reinaldo Guarany e Marcelo Brandão Cipolla. 2. ed. São Paulo: Martins Fontes, 2006.

TRINDADE, Otávio Augusto Drummond Cançado. O Mercosul no Direito Brasileiro: Incorporação de Normas e Seguranca Juridica. Belo Horizonte: Del Rey, 2006.

UCKMAR, Victor. Princípios comuns de Direito Constitucional tributário, trad. Marco Aurélio Greco, São Paulo: Editora Revista dos Tribunais, 1976.

UCKMAR, Victor. Los tratados internacionales en materia tributaria. In: UCKMAR, Victor (Coord.). Curso de Derecho Tributário Internacional. Bogotá: Temis, 2003.

VELlOSO, Carlos Mário da Silva. Tratados internacionais na jurisprudência do Supremo Tribunal Federal. In: AMARAL, Antônio Carlos Rodrigues do (coord.). Tratados Internacionais na Ordem Jurídica Brasileira. São Paulo: Aduaneiras, 2005. 
VIEHWEG, Theodor. Tópica e Jurisprudência. Trad. da 5. ed., alemã, rev. e ampl. Kelly Susane Alflen da Silva. Porto Alegre: Sergio Antonio Fabris Editor, 2008.

VOGEL, Klaus. Conflicts of Qualification - The Discussion is not finished. In: Bulletin Tax Treaty Monitor. Amsterdam: IBFD, fev. 2003.

VOGEL, Klaus. Problemas na Interpretação de Acordos de Bitributação. Trad. Luís Eduardo Schoueri. In: SCHOUERI, Luís Eduardo (Coord.). Direito Tributário: Homenagem a Alcides Jorge Costa, São Paulo: Quartier Latin, 2003. v. II.

VOGEL, Klaus. The influence of the OECD Commentaries on Treaty Interpretation. In: Bulletin - Tax Treaty Monitor, Amsterdam: IBFD, dez. 2000.

VOGEL, Klaus. On double taxation conventions: a commentary to the OECD, UN and US model conventions for the avoidance of double taxation of income and capital with particular reference to German treaty practice. 3. ed. Germany: Kluwer Law International, 1997.

VOGEL, Klaus. PROKISCH, Rainer G. General Report. Interpretation of Double Taxation Conventions. Cahiers de Droit Fiscal International. 1993. Florence Congress, International Fiscal Association., v. LXXVIIIa.

WALD, Arnoldo. Obrigações e Contratos. 14. ed., rev., atual. e ampl. com a colaboração do prof. Semy Glanz. São Paulo: Editora Revista dos Tribunais, 2000.

WARD, David A. The role of the Commentaries no the OECD Model In the Tax Treaty Interpretation Process. In: Bulletin - Tax Treaty Monitor, Amsterdam: IBFD, mar. 2006.

WATTS, Arthur. The International Law Commission, 1949-1998, New York: Oxford University Press. 2000. v. 2.

WEISS, Friedl. Interpretation of tax treaties in accordance with the commentaries on the OECD Model Tax Convention under the Vienna Convention on the Law of Treaties. In: ENGELEN, Frank. DOUMA, Sjoerd (coord.). The Legal Status of the OECD Commentaries. Amsterdam: IBFD, 2008, v. 1 (Conflict of Norms in Internetional Tax Law Series).

XAVIER, Alberto, Os Princípios da Legalidade e da Tipicidade da Tributação. São Paulo: Editora Revista dos Tribunais, 1978. 
XAVIER, Alberto. Direito Tributário Internacional do Brasil. 6. ed. reform. e atual.,Rio de Janeiro:Forense, 2007.

YAMAMOTO, Toru. Direito Internacional e Direito Interno. Porto Alegre: Sérgio Antônio Fabris, 2000.

YAMASHITA, Douglas. Evolução da Convenção-Modelo da OCDE e a influência de suas alterações na interpretação de tratados para evitar a bitributação. In: AMARAL, Antônio Carlos Rodrigues do (coord.). Tratados Internacionais na Ordem Jurídica Brasileira. São Paulo: Aduaneiras, 2005.

ZANCANER, Weida. Razoabilidade e moralidade na Constituição de 1988. In: Revista Trimestral de Direito Público. n. 2, São Paulo: Malheiros, 1993. 


\section{RESUMO}

O fenômeno jurídico denominado "dupla tributação internacional” ocorre quando dois ou mais Estados soberanos submetem uma mesma pessoa (física ou jurídica), num mesmo período de tempo, ao pagamento de tributos comparáveis, em razão de um mesmo fato gerador. Embora não seja proibida expressamente por qualquer princípio geral de Direito Internacional, a dupla tributação é altamente indesejável em virtude de seus efeitos danosos à economia e, indiretamente, à sociedade em geral. Em vista disso, desde o século XIX os Estados nacionais vêm tentando implementar soluções para o problema, dentre as quais se incluem as chamadas "convenções de bitributação", cujo objetivo consiste exatamente em evitar ou, ao menos, minimizar este pernicioso fenômeno. As normas contidas nestas convenções atuam atribuindo a competência tributária ora a um, ora a outro Estado, dependendo do tipo de rendimento, e, desta forma, limitam a soberania fiscal dos Estados contratantes.

Considerando a enorme diversidade de ordenamentos jurídicos, bem como a grande facilidade com que são estruturadas novas operações comerciais e, até mesmo, a diversidade de idiomas, conclui-se que a eficácia das normas destas convenções é essencialmente dependente das formas e métodos de interpretação e aplicação de suas cláusulas. As entidades dedicadas ao estudo do tema, notadamente a Organização para a Cooperação e Desenvolvimento Econômico - OCDE, a Organização das Nações Unidas ONU e também a International Fiscal Association - IFA constantemente elaboram estudos que contém recomendações de critérios a serem seguidos pelos países para a interpretação e aplicação das convenções.

Contudo, em face das incompatibilidade entre os ordenamentos, em virtude dos frequentes reenvios ao direito interno dos países, e, muitas vezes, em decorrência dos próprios conflitos de interesses econômicos entre os países, nem sempre os critérios de interpretação tradicionais, ou seja, aqueles já propostos pela OCDE, ONU e mesmo pela IFA, são capazes de resolver os conflitos interpretativos e/ou de qualificação de forma a possibilitar o maior grau de eficácia de tais acordos. Assim, surge a necessidade de uma solução alternativa para o problema. Propomos, desta forma, a aplicação da teoria da argumentação jurídica com o objetivo de facilitar o raciocínio e manter a discussão sobre a interpretação das cláusulas, termos e expressões o máximo possível na esfera internacional, evitando o reenvio ao direito interno e preenchendo as lacunas deixadas pelos critérios tradicionais, possibilitando, assim, maior eficácia das normas convencionais. 


\begin{abstract}
International double taxation occurs when to or more sovereign states impose comparable taxes to the same person or legal entity within the same period of time. Although it is not expressly forbidden by any International Law rule or principle, international double taxation is highly undesirable as a result of it harmful effects to the countries' economy and society in general. In view of this, since the $19^{\text {th }}$ century countries have been trying to provide solutions for the problem, and among these possible solutions the double taxation conventions stand out as a way to avoid or at least minimize this harmful phenomenon. The rules provided in these conventions work by allocating the taxing power either to one or to the other contracting state, depending on the type of income, and, therefore, double taxation conventions do represent a limitation to the tax sovereignty of the contracting states.

Considering the enormous diversity of legal systems, as well as the profusion of structures that may be used for commercial transactions, and even due to the variety of languages, it is possible to conclude that the efficiency level of double taxation conventions considerably depends on the way and on the methods pursuant to which their clauses are interpreted and applied. The international entities dedicated to analyze and suggest solutions for these issues, especially the Organization for Economic Cooperation and Development - OECD, the United Nations - UN and also the International Fiscal Association - IFA are constantly searching for solutions and also recommending some criteria to the interpretation and application of these conventions. These criteria compose the traditional, also called "classical", method of interpretation.

Nevertheless, due to the incompatibilities between legal systems, as well as in virtue of the frequent recourse to national law, and sometimes due to the conflicts of economical interests between the countries, the traditional criteria already proposed by the OECD, UN and IFA for the interpretation and application of double tax conventions become quite inefficient, and, as a result of this, double taxation remains a problem. Therefore, there is an urging need for an alternative solution. Thence, we propose the application of the Theory of Legal Argumentation in order to facilitate the process of interpretation and legal reasoning regarding clauses, terms and expressions, avoiding, thus, the recourse to national law and also filling the gaps existing in the traditional criteria, for the purpose of allowing larger efficiency of conventional rules.
\end{abstract}




\section{RIASSUNTO}

Il fenomeno giuridico chiamato "doppia tributazione internazionale" avviene quando due o più Stati sovrani sottopongono una stessa persona (fisica o giuridica), in uno stesso intervallo di tempo, al pagamento di tributi comparabili, in forza di uno stesso fatto generatore. Malgrado non sia proibita da qualsiasi principio generale del Diritto Internazionale, la doppia tributazione è altamente indesiderabile in ragione dei suoi effetti dannosi all'economia e, indirettamente, alla società in genere. In vista di ciò, fin dal secolo XIX gli Stati nazionali si sforzano di introdurre soluzioni per tale problema, tra le quali si annoverano le cosiddette "convenzioni di tributazione", il cui obbiettivo consiste esattamente nell'evitare o, quanto meno, minimizzare questo pernicioso fenomeno. Le norme contenute in queste convenzioni operano attribuendo la competenza tributaria ora ad uno, ora ad altro Stato, dipendendo dal tipo di reddito, e, così, limitano la sovranità fiscale degli Stati contraenti.

Considerando l'enorme diversità tra gli ordinamenti giuridici, come anche la grande facilità con la quale sono strutturate le nuove operazioni commerciali e, così pure, la diversità delle lingue, si conclude che l'efficacia delle norme di queste convenzioni è essenzialmente dipendente dalle forme e dai metodi di interpretazione applicati a tali clausole. Le entità che si dedicano allo studio del tema, specificamente L'Organizzazione per la Cooperazione e lo Sviluppo Economico - OCSE, l'Organizzazione delle Nazioni Unite, ONU, e anche 1'International Fiscal Association - IFA costantemente elaborano studi che contengono raccomandazioni sui criteri che dovono essere seguiti dai paesi nell'interpretazione e applicazione delle convenzioni.

Tuttavia, tenuto conto dell'incompatibilità tra gli ordinamenti, in virtù del frequente rinvio all'ordinamento interno dei paesi e, spesso, in ragione degli stessi conflitti di interessi economici tra i paesi, non sempre i criteri di interpretazione tradizionali, ossia quelli già proposti dalla OCSE, ONU ed anche dalla IFA, sono capaci di risolvere i conflitti di interpretazione e/o di qualificazione, così da rendere possibile un maggiore grado di efficacia di tali accordi. Proponiamo, pertanto, l'applicazione della teoria dell'argomentazione giuridica al fine di falilitare il ragionamento e mantenere la discussione sull'iterpretazione, termini ed espressioni, quanto più possibile nella sfera internazionale, evitando il rinvio al diritto interno e colmando le lacune lasciate dai criteri tradizionali, rendendo possibile, così, una maggiore efficacia delle norme convenzionali. 